\title{
THE CENOZOIC DEEP SEA MICROFOSSIL RECORD: EXPLORATIONS OF THE DSDP/ODP SAMPLE SET USING THE NEPTUNE DATABASE
}

\section{Cinzia Spencer-Cervato}

\section{ABSTRACT}

For 30 years the Deep Sea Drilling Project (DSDP) and the Ocean Drilling Program (ODP) have been drilling the ocean floors and retrieving sediment cores. This study presents a relational micropaleontological and stratigraphic database, Neptune, where a selection of the published studies made on these sediments is available. The selected sites and their stratigraphic extent represent a statistically reproducible subset of the whole DSDP and ODP data set as of 1995 (up to Leg 135). Cenozoic sediments from 165 globally distributed holes were dated with age/depth plots using biochronology of four marine plankton groups (diatoms, nannofossils, foraminifera, and radiolarians). Each hole's location is available with paleogeographic coordinates. A taxonomic revision of the $8000+$ reported species names was also made. The database is searchable and a variety of routines are available. Data can be exported to produce age range charts, geographic distribution maps, and occurrence charts.

A rigorous evaluation of the database potentials and limitations is presented together with a summary of the published studies that have been carried on with the data. These include stratigraphic studies (diachrony of Neogene plankton, hiati distribution in Cenozoic sediments) and evolution studies (cladogenesis and evolution of one foraminiferal lineage). Unpublished data on macroevolutionary patterns (species longevity and richness, speciation and extinction rates) are presented as example of Neptune's potential for paleobiological research. Finally, some suggestions are presented as to how Neptune can be more fully exploited through the addition of sedimentologic and isotopic data. A variety of critical sedimentologic and paleoceanographic questions could be addressed with this extended database.

Cinzia Spencer-Cervato, Eidgenössische Technische Hochschule, Geologisches

Institut, ETH Zentrum, 8092 Zurich, Switzerland

[Mailing address: P.O. Box 23, 1312 Slependen, Norway]

KEY WORDS: Cenozoic, relational database, plankton, evolution, age models

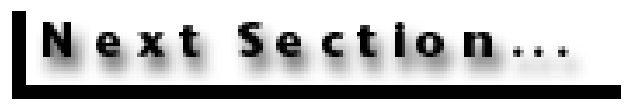

Copyright: Paleontological Society, 22 October 1999

Submission: 5 April 1999, Acceptance: 7 October 1999 


\section{Iose W indow}

\section{THE CENOZOIC DEEP SEA MICROFOSSIL RECORD: EXPLORATIONS OF THE DSDP/ODP SAMPLE SET USING THE NEPTUNE DATABASE}

\section{PLAIN LANGUAGE SUMMARY:}

Marine sediments contain the most complete record of the evolution of life on Earth. After the mass extinction event of the Cretaceous/Tertiary boundary, 65 million years' worth of sediments have accumulated on the sea floor. The Deep Sea Drilling Project and its successor, the Ocean Drilling Program, have drilled, retrieved and analysed kilometers of cores, as well as described their paleontological content. The Neptune database was established to compile the most valuable and significant data, and to use them to study the evolution of marine plankton. The global geographic coverage (165 holes), the high number of species described (1400+) from four marine plankton groups, the improved age control on the sediments, and the relatively high sample resolution (a few hundred thousand years) make this relational database the most complete paleontological data set currently available.

The analysis of these data has shown different evolutionary patterns in different plankton groups. On average a plankton species 'survives' 7 to 10 millions of years. Siliceous plankton (diatoms and radiolarians) tend to speciate and become extinct at distinct climatic and oceanographic boundaries independently from their nutritional habits (photosynthetic algae or plankton feeders). On the other hand, calcareous plankton seems to be more independent from these conditions. The results also show that the total number of species preserved in the sediments as fossils (a subset of the total number of species that existed at each given time and location) has gradually increased through time, but has also fluctuated strongly in the last 65 million years perhaps in response to climatic changes. This database has the potential to allow paleontologists to study the complex interactions between marine life and environment at a geological scale.

Cinzia Spencer-Cervato, Eidgenössische Technische Hochschule, Geologisches Institut, ETH Zentrum, 8092 Zurich, Switzerland [Mailing address: P.O. Box 23, 1312 Slependen, Norway] 


\section{INTRODUCTION: THE SCOPE OF THE DATABASE AND ORIGINAL PLANNING}

Last year (1998) marked the 30th anniversary of the first Deep Sea Drilling Project (DSDP) cruise and the collection of the first cores. The handful of scientists who conceived and initiated this gigantic enterprise in the early 1960s probably did not expect this international project to spur as many controversies and theories on the history of the Earth as it indeed did. At that time, Plate Tectonics, the fundamental theory that unifies most if not all of our geological (and not only geological) knowledge, was still just a controversial hypothesis accepted by only a few scientists. JOIDES (Joint Oceanographic Institute for Deep Earth Science), the program that initiated the DSDP and later the Ocean Drilling Program (ODP), deserves a lot of the credit for the collection and study of the evidence that today practically makes plate tectonics a widely accepted 'truth'.

As a side effect of the wealth of knowledge acquired in these 30 years, scientists have produced an enormous amount of data, so large that I am not aware of any recent estimate after the one done for the first ten years of research (Revelle 1981). Up to recently, all results were first published in reports (also known as 'blue books'). This procedure made most of the raw data available from a centralized and easily accessible printed source. In addition, JOIDES published a CD-ROM containing much of the data produced from the some 1000 holes during the progress of DSDP in electronic format. However, this multitude of data makes sense only to a limited number of scientists that have been involved in their production, and nobody has a concrete overview of what is available. Moreover, the competitiveness of the recent research climate does not encourage the re-evaluation of older data, but leads instead to the production of more new data.

With this background, a group of biostratigraphers at the ETH Zürich initiated the Neptune project in 1990. The group included some veterans from DSDP (Jean-Pierre Beckmann, Katharina von Salis Perch-Nielsen, Hans Thierstein), one participant of the more recent ODP cruises (Dave Lazarus), and some newcomers (Milena Biolzi, Jörg Bollmann, Heinz Hilbrecht, and myself). The project was funded by the Swiss National Science Foundation. The project was, in its initial stages, conceived and led by Dave Lazarus (Lazarus 1994; Lazarus et al. 1995a), while in the later, scientific analysis phase, the effort was carried out by this author (Spencer-Cervato et al. 1993, 1994; Spencer-Cervato and Thierstein 1997; Spencer-Cervato 1998).

The scope of the Neptune project was to evaluate and organize the existing DSDP and ODP data into a relational database that would be accessible to the research community. First, we planned to 'rescue' and compile the micropaleontological information. This information could be used first to establish an updated chronology for selected sites. The micropaleontological data themselves were then to be used for various studies of evolution. The established chronology would also be used to obtain age control on sedimentological and geochemical data. 
This database would be substantially different from a mere compilation of existing data, as was assembled in the DSDP CD-ROM. The main difference would be in the 'quality control' of the data to be included. Suitable sites would be selected, based on criteria dictated by our experience in biostratigraphy and deep-sea drilling. We decided to limit the number of sites in the database to give preference to an accurate selection and analysis of the data available for each site. We initially planned to include some 100 holes, but this number has been substantially increased in a later phase of the project. The second innovative approach was represented by the search options. The data in the DSDP CD-ROM are not searchable, but are available as a series of gigantic tables with listings of data. As potential end users, we recognized the necessity to create links between the different data sets (e.g., by hole, by age, by geographic location, by fossil group) to optimize the research applications of the database.

In the next chapters, I will provide a description of what is in the Neptune database and how it got there. I will also discuss what we would have liked to do, and why we did not get to it. Some of the published (and in progress) applications of Neptune will be discussed in a separate chapter. I will conclude with some suggestions on possible additions and how Neptune can be used as a tool available to the research community.

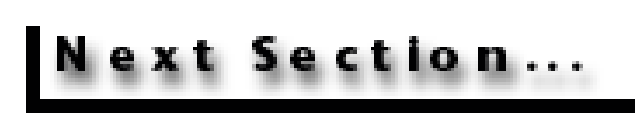




\section{THE CONCEPTION OF NEPTUNE AS A STEPPING STONE TOWARD THE MICROPALEONTOLOGIST'S DREAM OF THE IDEAL WORLD}

\subsection{Stratigraphic and geographic coverage}

Marine sediments provide more or less continuous, laterally extensive and correlatable geological archives. The first choice that we made was to limit the database to deep-sea sediments, thereby excluding land sections. Hence the name given by D. Lazarus to the database: Neptune, the Roman god of the sea. The largest amount of data on deep-sea sediments come from ocean drilling, and we began our work by systematically searching through the Initial Reports of the Deep Sea Drilling Project (DSDP) and the Initial and the Proceedings of the Ocean Drilling Program, Scientific Results. Based on a variety of criteria, we rated the holes drilled by DSDP and by ODP up to Leg 135 (the latest leg available in 1995, when I expanded the database to the whole Cenozoic). Ratings were given for each fossil group separately. No rating meant that biostratigraphy was not available, a rating of ' $\mathrm{M}$ ' (medium) indicated the presence of biostratigraphy limited to a few markers and often the absence of detailed range charts. A rating of ' $H$ ' (high) was used for detailed biostratigraphic reports with extensive range charts. Comments on core recovery, preservation, etc. were also added at this point. Given our long-range goal of using the data for a micropaleontological database, we selected to include in Neptune mainly holes that were marked as high or medium priority for more than one biostratigraphic group. Other hole selection criteria included good core recovery, relatively continuous coring, the length of the stratigraphic interval covered, as well as good microfossil preservation. The recognition of magnetostratigraphy, which could be used for further age control, was also determinant in the selection.

To date, Neptune includes stratigraphic data for the whole Cenozoic (last 65 million years). Several reports are available on Cretaceous sediments and some on Jurassic sediments. However, the $\mathrm{K} / \mathrm{T}$ boundary represents a major stratigraphic boundary that marks a dramatic faunal and floral assemblage turnover. I feel, therefore, justified in the choice of limiting the coverage to the Cenozoic. At the other end of the spectrum, upper Pleistocene and Holocene sediments are not well represented in DSDP and ODP reports and, therefore, in Neptune. This is mainly due to the limited resolution of marine biostratigraphy for recent sediments, the relatively coarse sampling used in most reports and to loss of the upper few meters of sediments in early coring work.

Final additions or changes to the list of holes were done after plotting the geographic location of the selected holes. We aimed to have a broad geographic coverage and at least one complete section for each biogeographic province (Figure 2.1). The coverage of shelf to abyssal sediments was equally considered: the range of water depths

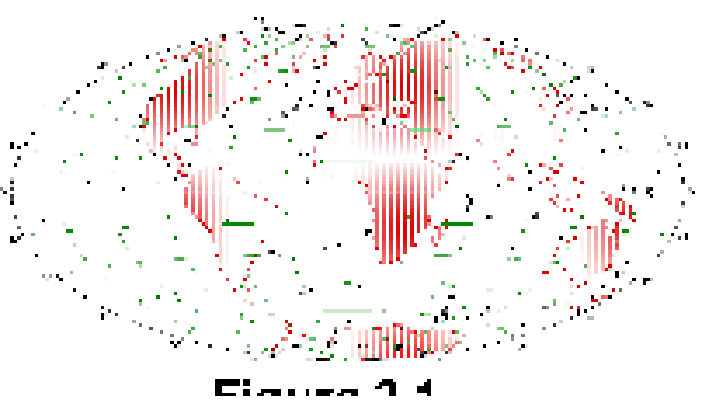


of the sediment/water interface represents a

rIyUI E. 4. statistically representative subset of all the holes drilled by DSDP and ODP as of 1995 (Spencer-Cervato 1998). However, shallow water (shallower than $1000 \mathrm{~m}$ ) sediments are underrepresented in the DSDP and ODP collection and are, therefore, underrepresented also in Neptune. In total, we did include 165 holes (Table 2.1). More holes would have been desirable and we have possibly excluded holes of considerable importance. This was due to time limitations and the project's goals of creating a 'micropaleontological database'.

\subsection{Chronology}

The next step consisted in establishing an internally consistent chronology for the selected holes. Because magnetostratigraphic data were available only for some of the holes, biochronology represented the best and often the only way to provide an age model for the holes. Biochronology provides a series of 'calibrated events' which essentially mark the first and last appearance of biostratigraphic markers (taxa). Ideally, these events have been correlated in several locations to an independent stratigraphic method, like magnetostratigraphy or oxygen isotope stratigraphy. These scales have in turn been calibrated to absolute chronology in millions of years through complex procedures. The magnetostratigraphic scale used initially for Neptune was Berggren et al. (1985). We subsequently updated our chronology to Berggren et al. (1995b), which is based on Cande and Kent's magnetostratigraphy $(1992,1995)$. Berggren et al.'s chronology was chosen because it is the most updated and most comprehensive time scale published to date - it includes biochronological data for several hundred Cenozoic events. Oxygen isotope stratigraphy (in turn calibrated to a magnetostratigraphic scale) was used for only a few of the calibrated events used in Neptune.

Through this two-step approach, numerical ages in million of years (Ma) are given to biostratigraphic events. We assumed that these events are geologically instantaneous and occur simultaneously throughout a given region of the globe (i.e., are globally synchronous and at least regionally widespread, and not dependent on local environment or sediment facies). Berggren et al. (1985) and its recent updates (Berggren et al., 1995a, b) were the source of biochronological events for planktic foraminifera and calcareous nannoplankton. Various regional calibrations were used for siliceous plankton (for radiolarians: Hays and Opdyke 1967; Hays 1970; Theyer et al. 1978; Johnson and Nigrini 1985; Sanfilippo et al. 1985; Goll and Bjørklund 1989; Nigrini 1991; Harwood et al. 1992; Caulet 1991; for diatoms: Barron 1981, 1985a, b; Berggren et al. 1985; Fenner 1984; Koizumi and Tanimura 1985; Gersonde and Burckle 1990; Mikkelsen 1990; and Harwood and Maruyama 1992). Paleogene siliceous plankton biochronology is less well established than the one for the Neogene, so most of the events used were biozonation boundary markers.

Published biochronological events were used to construct the chronology of each 
hole. Templates were assembled with all the events that we found in the cited references (Table 2.2). These templates (ASCIl files to be used in MS Excel) contained the description of the event, an identification code, and the age interval of the calibration. An excerpt from one of these files is shown in Table 2.3.

\subsection{Taxonomy}

The articles published in the DSDP and ODP reports are an immense source of evolutionary and biostratigraphic data. Although we were aware of many discrepancies in the subjective nature of taxa and taxonomic names (e.g., Gradstein et al. 1985), we assumed that these factors would be manageable by use of simple synonymy lists in our study. A very extensive taxonomic literature is available for marine plankton, and taxa and nomenclature are quite well defined among the most common microfossil groups. This can be used to reasonably standardize taxonomic usage. Thus if taxon $\mathbf{A b}$ is called $\mathbf{A b}$ by one author but $\mathbf{B b}$ by another, we could standardize the data by creating an equivalence $\mathbf{B b}=\mathbf{A b}$ in the database. Moreover, the holes that we selected had been extensively studied for biostratigraphy and some of them represented classical micropaleontological studies. We, however, had to assume that taxon names in all the selected holes were uniformly used, in other words, that taxon $\mathbf{A b}$ described in Hole 289 was identical to taxon $\mathbf{A b}$ described in Hole 747A. More than 8800 taxon names have been used in the selected holes.

\subsection{Biostratigraphy}

Most micropaleontological studies are limited to one or perhaps two fossil groups. Biostratigraphic studies in DSDP and ODP reports include diatoms, radiolarians, calcareous nannoplankton, planktic and benthic foraminifera, dinoflagellates, silicoflagellates. We decided to consider only planktic organisms and out of the several groups described in the Reports, we selected the four groups that are most abundant in deep-sea sediments, most regularly described in the biostratigraphic literature, and for which extensive event calibration is available: diatoms, radiolarians, calcareous nannoplankton and planktic foraminifera. This selection includes two siliceous (diatoms and radiolarians) and two calcareous (nannoplankton and foraminifera) plankton groups, and at the same time two phytoplankton (diatoms and nannoplankton) and two zooplankton (radiolarians and foraminifera) groups. This approach has several advantages: it would allow us to compare evolutionary trends in multiple groups, but mainly it allowed us to have a better biochronological control on the age models. Planktic foraminifera are probably the most used microfossils for biostratigraphy, and with this approach we were able to compare their resolution and accuracy to the other groups.

The templates were filled in with actual occurrences of the events for each hole. We went through the published range charts or lists of markers and located the events present in the templates. The list of references to the individual reports is given in Table 2.4. Each event was normally recorded as occurring between two samples 
within the stratigraphic section. Samples were either recorded as meters below seafloor (mbsf) or as actual sample names, in core-section-interval within section in centimeter format. The sample names were then automatically translated into mbsf by the plotting software. No systematic attempt was made to search the general literature for additional stratigraphic data, although biostratigraphic data for some critical holes (e.g., DSDP 558 and 563) were extracted from charts published outside the DSDP reports. The creation of biostratigraphic files from the templates was initially subdivided among the project participants. In the later phase of the project, I was solely responsible for this task. This eliminated some of the discrepancies in the event identification due to subjective interpretations of range charts in terms of First Occurrence (FO) and Last Occurrence (LO).

The first and last occurrence of a taxon were identified when the taxon was not recorded in two or more samples above or below the first or last recorded occurrence. Because the precision of the actual FO or LO depends on the sample spacing, we recorded each event as the stratigraphic interval between the two samples bracketing the event.

Paleomagnetic stratigraphy was recorded as a set of paleomagnetic polarity interval identifications, as given by the original author. In some cases, it became necessary to revise the original identification scheme to achieve an optimal fit between biostratigraphy and paleomagnetic polarity patterns. However, this was usually apparent only when the events were plotted.

The biostratigraphic files prepared for each group were pasted together and used in the construction of age models. There is a varietyare several of methods available to process stratigraphic event data, including Shaw's plots (Shaw 1964) and Probabilistic Stratigraphy (Hay 1972). However, the most used method of stratigraphic correlation for deep-sea sediments is the age vs. depth plot method. A plot is made of the depth occurrences of previously age-calibrated events in each hole and a line is drawn to correlate depth to age. Although various curve-fitting methods can be used, we have chosen to manually fit a series of straight line segments of varying slopes to the data.

To handle the large volume of data plotting and analysis we used a special-purpose, age-depth plotting program written by Lazarus (1992). The program, written for Macintosh computers, reads the stratigraphic data files and produces an age- vs. versus-depth scatter plot of the data points. The program allows us to draw a line of correlation through the points interactively on the computer screen. Automatic correlation methods were attempted but proven unreliable because they were too easily affected by data outliersdata outliers too easily affected them. The manual construction of the line of correlation allows us to take into consideration recovery gaps and changes in preservation or lithology that may affect the reliability of the age vs. depth plot. The age models are thus subjective and, with a few exceptions, the scatter of data allows for two or more possible interpretations. The use of two or more biostratigraphic groups was intended to minimize the bias introduced by an a priori selection of 'good' or 'bad' events. 
Age models were initially constructed by several project participants. To eliminate discrepancies in the selection of the line of correlation due to subjective preferences, all Neogene DSDP age models were subsequently revised by Dave Lazarus (Lazarus et al. 1995a) and later by myself (after the addition of Paleogene data and ODP holes, and the update of the chronology). A personal rating of the quality of the age models is given in Table 2.1. Although the results of all these efforts still do not guarantee that the age models are optimally reliable, I hope that they represent a far more consistent and updated data set than available prior to the beginning of the project.

The established chronology provided age control on the 30,000 samples described in the DSDP and ODP reports for the selected holes. Information on the micropaleontological content of these samples is available as range charts. These charts give information on the presence or absence of a taxon, and usually describe its abundance. Properly formatted MS Excel range charts were either extracted from the DSDP CD-ROM by the Neptune database program, typed by us, or provided directly from ODP (Table 2.4). These were then imported into Neptune and represent the bulk of data available. We planned to use this information for various studies (species occurrence patterns, longevity and diversity, identification of temporal distribution of biogeographic provinces) which are described in Chapter 4.

The age/depth plots and the age models (text files) are given in the Appendix A. The stratigraphic data files used to construct the age vs. depth plots, are not published here because of space considerations and the complexity of having such a large number of files and links. They are, however, available from the author.

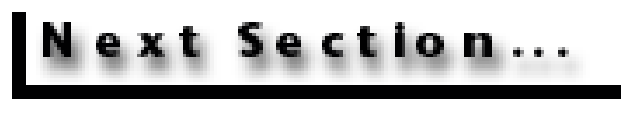




\section{Close Window}

Figure 2.1. Location of DSDP and ODP holes in the Neptune database. Dots mark holes with one or more hiati, squares holes with a continuous stratigraphy, within the resolution of the chronology.

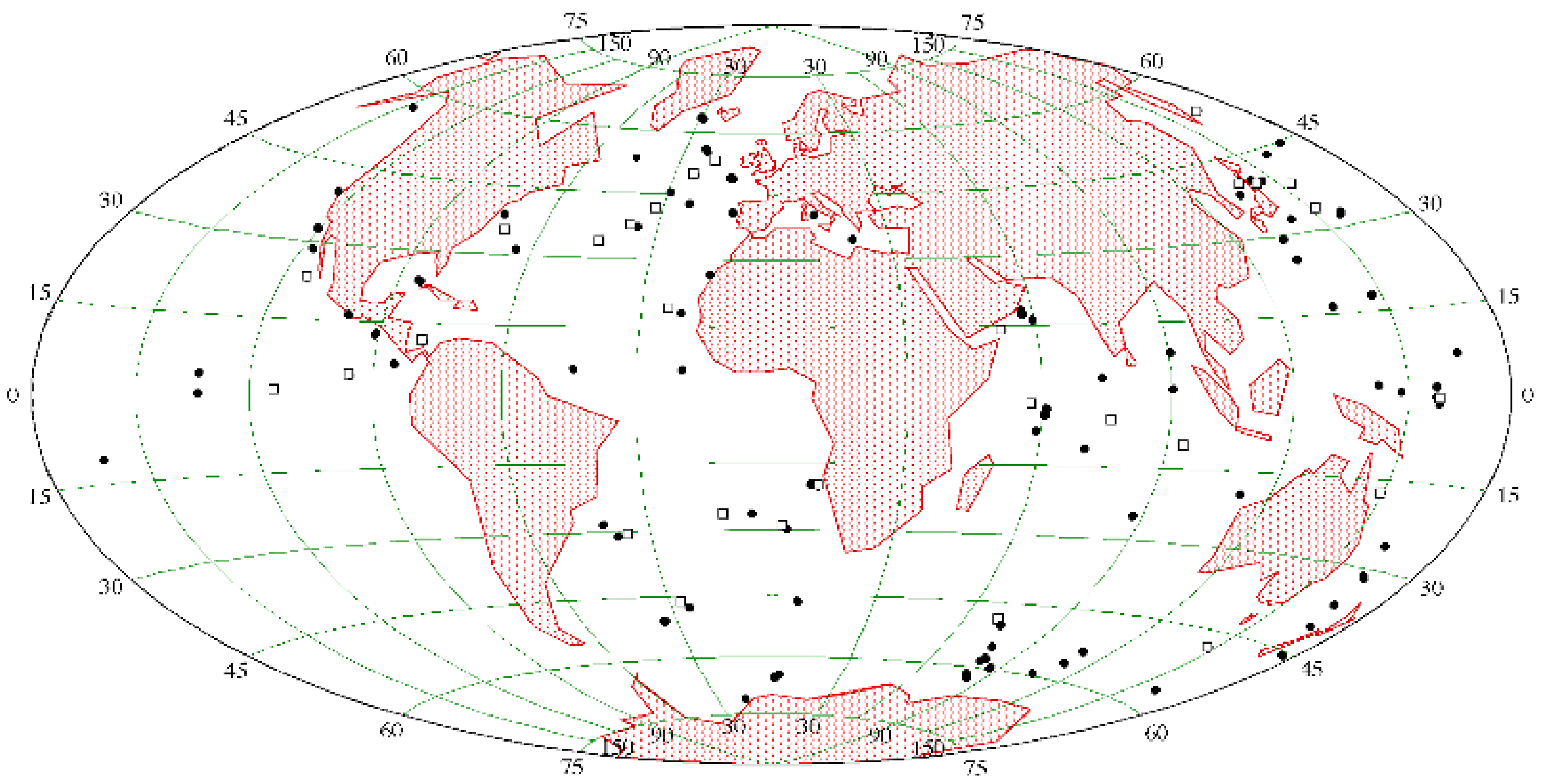




\section{Close Window}

\section{Table 2.1.}

\begin{tabular}{|c|c|c|c|c|c|c|c|c|c|c|c|c|c|}
\hline \multirow[b]{2}{*}{ Leg } & \multirow[b]{2}{*}{ Hole } & \multirow[b]{2}{*}{ Latitude } & \multirow[b]{2}{*}{ Longitude } & \multirow[b]{2}{*}{ Pmaq } & \multicolumn{4}{|c|}{ Priority } & & \multicolumn{4}{|c|}{ RCs exist: } \\
\hline & & & & & D & $\mathrm{N}$ & $\mathrm{R}$ & $\mathrm{F}$ & \begin{tabular}{|c|} 
Loc \\
Quality
\end{tabular} & D & $\mathrm{N}$ & $\mathrm{R}$ & $\mathrm{F}$ \\
\hline 7 & 62 & 1.9 & 141.9 & $\mathrm{~N}$ & & & $\mathrm{H}$ & & $\mathrm{P}$ & - & Y & $\bar{Y}$ & $\mathrm{Y}$ \\
\hline 7 & $62 \mathrm{~A}$ & 1.9 & 141.9 & $\mathrm{~N}$ & & & $\mathrm{H}$ & & $\mathrm{P}$ & 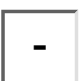 & $\mathrm{Y}$ & $\bar{Y}$ & $Y$ \\
\hline 7 & 63 & 0.8 & 147.9 & $N$ & & & M & & P & 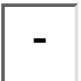 & $\bar{Y}$ & $\bar{Y}$ & - \\
\hline 7 & $63 \mathrm{~A}$ & 0.8 & 147.9 & $\mathrm{~N}$ & & & $M$ & & $\mathrm{P}$ & - & $\bar{Y}$ & $\bar{Y}$ & - \\
\hline 7 & 63B & 0.8 & 147.9 & $\mathrm{~N}$ & & & $M$ & & $P$ & 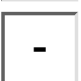 & Y & $\bar{Y}$ & - \\
\hline 7 & 64 & -1.7 & 158.6 & $\mathrm{~N}$ & & & $M$ & & M & 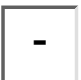 & $\bar{Y}$ & $\bar{Y}$ & $\bar{Y}$ \\
\hline 7 & $64 \mathrm{~A}$ & 1.5 & 158.4 & $\mathrm{~N}$ & & & $M$ & $\mathrm{H}$ & $M$ & 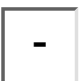 & $\bar{Y}$ & $\bar{Y}$ & $\mathrm{Y}$ \\
\hline 13 & 125 & 34.6 & 20.4 & $\mathrm{~N}$ & & & & $\mathrm{H}$ & $P$ & 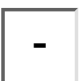 & $\bar{Y}$ & - & $\mathrm{Y}$ \\
\hline 13 & 132 & 40.3 & 11.4 & $\mathrm{~N}$ & & & & $\mathrm{H}$ & G & 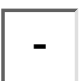 & $\bar{Y}$ & - & $\mathrm{Y}$ \\
\hline 14 & 141 & 19.4 & -24.0 & $\mathrm{~N}$ & & & & $\mathrm{H}$ & & & & & \\
\hline
\end{tabular}


Close Window

Table 2.2. (Continued next 4 pages.)

\begin{tabular}{|c|c|c|c|c|c|c|c|c|c|}
\hline \begin{tabular}{|l} 
Planktic \\
Foraminifera
\end{tabular} & & & \begin{tabular}{|l|} 
Berggren \\
et al. \\
$1995 a, b$
\end{tabular} & & & & & & \\
\hline Group & Event Name & Plotcode & Young Age & $\begin{array}{l}\text { Old } \\
\text { Age }\end{array}$ & Group & Event Name & Plotcode & $\begin{array}{r}\text { Young } \\
\text { Age }\end{array}$ & $\begin{array}{l}\text { Old } \\
\text { Age }\end{array}$ \\
\hline $\mathrm{F}$ & $\begin{array}{l}\text { TOP Globoquadrina } \\
\text { pseudofoliata }\end{array}$ & Tpft & 0.22 & & $\mathrm{~F}$ & $\begin{array}{l}\text { TOP Globorotalia } \\
\text { miozea }\end{array}$ & Tmza & 15.9 & \\
\hline $\mathrm{F}$ & BT G. hirsuta & Bhir & 0.45 & & $\mathrm{~F}$ & $\begin{array}{l}\text { BT Praeorbulina } \\
\text { circularis }\end{array}$ & BPcr & 16 & \\
\hline $\mathrm{F}$ & BT G. flexuosa & Bflx & 0.4 & & $\mathrm{~F}$ & $\begin{array}{l}\text { BT Praeorbulina } \\
\text { glomerosa }\end{array}$ & $\mathrm{BPgl}$ & 16.1 & \\
\hline $\mathrm{F}$ & BT Bolliella calida & BBca & 0.22 & & $\mathrm{~F}$ & $\begin{array}{l}\text { BT Globigerinoides } \\
\text { diminutus }\end{array}$ & Bdim & 16.1 & \\
\hline$F$ & TOP G. flexuosa & Bflx & 0.068 & & $\mathrm{~F}$ & $\begin{array}{l}\text { BT Praeorbulina } \\
\text { curva }\end{array}$ & BPcv & 16.3 & \\
\hline $\mathrm{F}$ & $\begin{array}{l}\text { TOP Globorotalia } \\
\text { tosaensis }\end{array}$ & Ttos & 0.65 & 1 & $\mathrm{~F}$ & $\begin{array}{l}\text { BT Praeorbulina } \\
\text { sicana (= G.es } \\
\text { bispher.) }\end{array}$ & BPsc & 16.4 & \\
\hline $\mathrm{F}$ & BT Pulleniatina finalis & BPfn & 1.4 & & $\mathrm{~F}$ & $\begin{array}{l}\text { BT Globorotalia } \\
\text { miozea }\end{array}$ & Bmza & 16.7 & \\
\hline $\mathrm{F}$ & $\begin{array}{l}\text { TOP Globigerinoides } \\
\text { fistulosus }\end{array}$ & Tfst & 1.6 & & $\mathrm{~F}$ & $\begin{array}{l}\text { TOP Globorotalia } \\
\text { zealandica }\end{array}$ & Tzld & 17.3 & \\
\hline $\mathrm{F}$ & $\begin{array}{l}\text { TOP Globigerinoides } \\
\text { obliquus extremus }\end{array}$ & Tobe & 1.7 & & $\mathrm{~F}$ & $\begin{array}{l}\text { TOP Globorotalia } \\
\text { pseudomiozea }\end{array}$ & Tpmz & 16.6 & \\
\hline $\mathrm{F}$ & $\begin{array}{l}\text { BT Globorotalia } \\
\text { truncatulinoides }\end{array}$ & Btrc & 2 & & $F$ & $\begin{array}{l}\text { BT Globorotalia } \\
\text { birnageae }\end{array}$ & Bbng & \begin{tabular}{|c|}
16.7 \\
\end{tabular} & \\
\hline $\mathrm{F}$ & $\begin{array}{l}\text { TOP Globorotalia } \\
\text { exilis }\end{array}$ & Texl & 2.15 & & $\mathrm{~F}$ & $\begin{array}{l}\text { TOP Catapsydrax } \\
\text { stainforthi }\end{array}$ & TCst & 17.2 & \\
\hline $\mathrm{F}$ & $\begin{array}{l}\text { reappear.Pulleniatina } \\
\text { (local) }\end{array}$ & RAPu & 2.3 & & $\mathrm{~F}$ & $\begin{array}{l}\text { BT Globorotalia } \\
\text { zealandica }\end{array}$ & Bzld & 17.3 & \\
\hline $\mathrm{F}$ & $\begin{array}{l}\text { TOP Globorotalia } \\
\text { miocenica }\end{array}$ & Tmio & 2.3 & & $\mathrm{~F}$ & $\begin{array}{l}\text { BT Globorotalia } \\
\text { pseudomiozea }\end{array}$ & Bpmz & 17.3 & \\
\hline $\mathrm{F}$ & $\begin{array}{l}\text { TOP } \\
\text { Neogloboquadrina } \\
\text { atlantica }\end{array}$ & Tatl & 2.41 & & $\mathrm{~F}$ & $\begin{array}{l}\text { TOP Globorotalia } \\
\text { semivera }\end{array}$ & Tsmv & 17.3 & \\
\hline $\mathrm{F}$ & TOP G. puncticulata & Tpun & 2.41 & & $\mathrm{~F}$ & $\begin{array}{l}\text { TOP Globorotalia } \\
\text { incognita }\end{array}$ & Tigt & 16.4 & \\
\hline $\mathrm{F}$ & $\begin{array}{l}\text { TOP Globorotalia } \\
\text { pertenuis }\end{array}$ & Tprt & 2.6 & & $\mathrm{~F}$ & $\begin{array}{l}\text { TOP Catapsydrax } \\
\text { dissimilis }\end{array}$ & TCds & 17.3 & \\
\hline $\mathrm{F}$ & $\begin{array}{l}\text { TOP Globorotalia } \\
\text { multicamerata }\end{array}$ & Tmtc & 3.09 & & $\mathrm{~F}$ & $\begin{array}{l}\text { BT Globorotalia } \\
\text { praescitula }\end{array}$ & Bpsc & 18.5 & \\
\hline $\mathrm{F}$ & $\begin{array}{l}\text { TOP Globoquadrina } \\
\text { altispira }\end{array}$ & Talp & 3.09 & & $\mathrm{~F}$ & $\begin{array}{l}\text { TOP } \\
\text { Globoquadrina } \\
\text { dehiscens } \\
\text { f.spinosa }\end{array}$ & TGqds & 17.9 & \\
\hline
\end{tabular}


Table 2.1: THE CENOZOIC DEEP SEA MICROFOSSIL RECORD:...F THE DSDP/ODP SAMPLE SET USING THE NEPTUNE DATABASE

\begin{tabular}{|c|c|c|c|c|c|c|c|}
\hline $\mathrm{F}$ & $\begin{array}{l}\text { TOP } \\
\text { Sphaeroidinellopsis } \\
\text { seminulina }\end{array}$ & Tsem & 3.12 & $F$ & $\begin{array}{l}\text { BT Globigerinoides } \\
\text { altiaperturus }\end{array}$ & Batp & 20.5 \\
\hline $\mathrm{F}$ & $\begin{array}{l}\text { BT Globigerinoides } \\
\text { fistulosus }\end{array}$ & Bfst & 3.33 & $F$ & $\begin{array}{l}\text { BT Tenuitella } \\
\text { munda }\end{array}$ & Bmun & 21.4 \\
\hline $\mathrm{F}$ & $\begin{array}{l}\text { TOP } \\
\text { Spheroidinellopsis spp }\end{array}$ & TSdp & 3.25 & $F$ & $\begin{array}{l}\text { TOP Globorotalia } \\
\text { kugleri }\end{array}$ & Tkgl & 21.5 \\
\hline $\mathrm{F}$ & $\begin{array}{l}\text { BT Spheroidinella } \\
\text { dehiscens s.s. }\end{array}$ & BSdd & 3.25 & $F$ & $\begin{array}{l}\text { BT Globoquadrina } \\
\text { dehiscens } \\
\text { f.spinosa }\end{array}$ & BGqds & 22.2 \\
\hline $\mathrm{F}$ & BT Globorotalia inflata & Bifl & 3.25 & $F$ & \begin{tabular}{|l|} 
TOP \\
Globoquadrina \\
globularis
\end{tabular} & TGqg & 22.8 \\
\hline $\mathrm{F}$ & $\begin{array}{l}\text { TOP Globorotalia } \\
\text { conomiozea }\end{array}$ & Tcmz & 3.25 & $\mathrm{~F}$ & $\begin{array}{l}\text { BT Globoquadrina } \\
\text { dehiscens }\end{array}$ & BGqd & 23.2 \\
\hline$F$ & $\begin{array}{l}\text { BT Globorotalia } \\
\text { tosaensis }\end{array}$ & Btos & 3.35 & $F$ & $\begin{array}{l}\text { BT Globorotalia } \\
\text { incognita }\end{array}$ & Bigt & 21.6 \\
\hline $\mathrm{F}$ & $\begin{array}{l}\text { BT Globorotalia } \\
\text { crassula }\end{array}$ & Bcrl & 3.3 & $F$ & \begin{tabular}{|l} 
TOP \\
Globoturborotalita \\
angulisuturalis
\end{tabular} & Tags & 21.6 \\
\hline $\mathrm{F}$ & $\begin{array}{l}\text { TOP Pulleniatina } \\
\text { (local) }\end{array}$ & TPIt & 3.45 & $\mathrm{~F}$ & $\begin{array}{l}\text { TOP Globorotalia } \\
\text { pseudokugleri }\end{array}$ & Tpkg & 21.6 \\
\hline $\mathrm{F}$ & $\begin{array}{l}\text { BT Globorotalia } \\
\text { pertenuis }\end{array}$ & Bprt & 3.45 & $\mathrm{~F}$ & $\begin{array}{l}\text { BT Globigerina } \\
\text { euapertura }\end{array}$ & Beua & 23.8 \\
\hline $\mathrm{F}$ & $\begin{array}{l}\text { BT Globorotalia } \\
\text { miocenica }\end{array}$ & Bmio & 3.55 & $F$ & $\begin{array}{l}\text { B Globorotalia } \\
\text { kugleri }\end{array}$ & bGku & 23.8 \\
\hline $\mathrm{F}$ & $\begin{array}{l}\text { TOP Globorotalia } \\
\text { margaritae }\end{array}$ & Tmgt & 3.58 & $F$ & $\begin{array}{l}\text { T Globorotalia } \\
\text { mendacis }\end{array}$ & tGme & 23.8 \\
\hline $\mathrm{F}$ & $\begin{array}{l}\text { TOP Pulleniatina } \\
\text { primalis }\end{array}$ & TPpr & 3.65 & $\mathrm{~F}$ & $\begin{array}{l}\text { B Globigerinoides } \\
\text { primordius } \\
\text { (common) }\end{array}$ & bGpr-c & 24.3 \\
\hline $\mathrm{F}$ & Pulleniatina s->d & sdP & 3.95 & $F$ & $\begin{array}{l}\text { B Globigerinoides } \\
\text { primordius (rare) }\end{array}$ & bGpr-r & 26.7 \\
\hline $\mathrm{F}$ & $\begin{array}{l}\text { TOP Globigerina } \\
\text { nepentes }\end{array}$ & Tnep & 4.2 & $\mathrm{~F}$ & $\begin{array}{l}\text { T Globorotalia } \\
\text { opima }\end{array}$ & tGop & 27.1 \\
\hline$F$ & $\begin{array}{l}\text { TOP Pulleniatina } \\
\text { spectabilis }\end{array}$ & TPsp & 4.2 & $F$ & $\begin{array}{l}\text { B Globigerina } \\
\text { angulisuturalis }\end{array}$ & bGas & 29.4 \\
\hline$F$ & $\begin{array}{l}\text { BT Globorotalia } \\
\text { crassaformis s.s. }\end{array}$ & Bcrs & 4.5 & $\mathrm{~F}$ & $\begin{array}{l}\text { T Globigerina } \\
\text { angiporoides }\end{array}$ & tGap & 30 \\
\hline$F$ & $\begin{array}{l}\text { TOP Globigerinoides } \\
\text { seiglei }\end{array}$ & Tsgl & 4.7 & $\mathrm{~F}$ & $\begin{array}{l}\text { T Globigerina } \\
\text { ampliapertura }\end{array}$ & tGam & 30.3 \\
\hline$F$ & $\begin{array}{l}\text { BT Globorotalia } \\
\text { puncticulata }\end{array}$ & Bptc & 4.5 & $F$ & $\begin{array}{l}\text { T Globorotalia } \\
\text { cerroazulensis }\end{array}$ & tGce & 33.8 \\
\hline$F$ & $\begin{array}{l}\text { TOP Globorotalia } \\
\text { cibaoensis }\end{array}$ & Tcbn & 4.4 & $F$ & T Hantkenina & tHan & 33.7 \\
\hline $\mathrm{F}$ & $\begin{array}{l}\text { BT Spheroidinella } \\
\text { dehiscens }\end{array}$ & BSdd & 5.2 & $F$ & $\begin{array}{l}\text { T Porticulasphaera } \\
\text { semiinvoluta }\end{array}$ & tPsi & 35.3 \\
\hline $\mathrm{F}$ & $\begin{array}{l}\text { BT Globorotalia } \\
\text { sphericomiozea }\end{array}$ & Bsphc & 5.6 & $\mathrm{~F}$ & $\begin{array}{l}\text { T Morozovella } \\
\text { spinulosa }\end{array}$ & tMsp & 38.1 \\
\hline$F$ & $\begin{array}{l}\text { BT Globorotalia } \\
\text { pliozea }\end{array}$ & Bpli & 5.6 & $F$ & $\begin{array}{l}\text { B Porticulasphaera } \\
\text { semiinvoluta }\end{array}$ & bPsi & 38.4 \\
\hline
\end{tabular}


Table 2.1: THE CENOZOIC DEEP SEA MICROFOSSIL RECORD:...F THE DSDP/ODP SAMPLE SET USING THE NEPTUNE DATABASE

\begin{tabular}{|c|c|c|c|c|c|c|c|}
\hline $\mathrm{F}$ & $\begin{array}{l}\text { BT Globorotalia } \\
\text { tumida }\end{array}$ & Btum & 5.6 & $F$ & $\begin{array}{l}\text { T Subbotina } \\
\text { frontosa }\end{array}$ & tSfr & 39.3 \\
\hline$F$ & $\begin{array}{l}\text { BT Pulleniatina } \\
\text { spectabilis }\end{array}$ & BPsp & 5.6 & $F$ & $\begin{array}{l}\text { T Globigerapsis } \\
\text { beckmanni }\end{array}$ & tGbe & 40.1 \\
\hline$F$ & $\begin{array}{l}\text { BT Globigerinoides } \\
\text { conglobatus }\end{array}$ & Bcgb & 5.8 & $F$ & $\begin{array}{l}\text { B Globigerapsis } \\
\text { beckmanni }\end{array}$ & bGbe & 40.5 \\
\hline $\mathrm{F}$ & $\begin{array}{l}\text { BT Globorotalia } \\
\text { cibaoensis }\end{array}$ & Bcbn & 7.8 & $F$ & $\begin{array}{l}\text { T Acarinina } \\
\text { bullbrooki }\end{array}$ & tAbu & 40.5 \\
\hline$F$ & $\begin{array}{l}\text { TOP Globoquadrina } \\
\text { dehiscens }\end{array}$ & TGqd & 5.8 & $F$ & $\begin{array}{l}\text { B Globorotalia } \\
\text { pomeroli }\end{array}$ & bGpo & 42.4 \\
\hline$F$ & $\begin{array}{l}\text { TOP Globorotalia } \\
\text { lenguaensis }\end{array}$ & TIng & 6 & $F$ & $\begin{array}{l}\text { B Globigerapsis } \\
\text { index }\end{array}$ & bGin & 42.9 \\
\hline$F$ & $\begin{array}{l}\text { BT Globorotalia } \\
\text { margaritae }\end{array}$ & Bmgt & 6 & $F$ & $\begin{array}{l}\text { B Morozovella } \\
\text { lehneri }\end{array}$ & bMle & 43.5 \\
\hline$F$ & $\begin{array}{l}\text { BT Pulleniatina } \\
\text { primalis }\end{array}$ & BPpr & 6.4 & $F$ & $\begin{array}{l}\text { T Morozovella } \\
\text { aragonensis }\end{array}$ & tMar & 43.6 \\
\hline$F$ & $\begin{array}{l}\text { Neogloboquadrina } \\
\text { acostaensis s->d }\end{array}$ & acsd & 6.2 & $F$ & $\begin{array}{l}\text { B Globorotalia } \\
\text { possagnoensis }\end{array}$ & bGpg & 46 \\
\hline$F$ & $\begin{array}{l}\text { BT Globorotalia } \\
\text { menardii form } 5 \text { (dext.) }\end{array}$ & Bmn5 & 6.4 & $F$ & $\begin{array}{l}\text { B Planorotalites } \\
\text { palmerae }\end{array}$ & bPpa & 50.4 \\
\hline$F$ & $\begin{array}{l}\text { Neogloboquadrina } \\
\text { acostaensis } d->s\end{array}$ & acds & 6.6 & $F$ & $\begin{array}{l}\text { B Morozovella } \\
\text { aragonensis }\end{array}$ & bMar & 52.3 \\
\hline$F$ & $\begin{array}{l}\text { Neogloboquadrina } \\
\text { atlantica } d->s\end{array}$ & atds & 6.8 & $F$ & $\begin{array}{l}\text { B Morozovella } \\
\text { formosa }\end{array}$ & bMfo & 54 \\
\hline$F$ & $\begin{array}{l}\text { BT Globorotalia } \\
\text { conomiozea }\end{array}$ & Bcmz & 7.12 & $F$ & $\begin{array}{l}\text { T Morozovella } \\
\text { velascoensis }\end{array}$ & tMve & 54.7 \\
\hline$F$ & $\begin{array}{l}\text { TOP Globorotalia } \\
\text { menardii form } 4 \text { (sin.) }\end{array}$ & Tmn4 & 7.4 & $F$ & $\begin{array}{l}\text { T Planorotalites } \\
\text { pseudomenardii }\end{array}$ & tPps & $\begin{array}{r}55.9 \\
(?)\end{array}$ \\
\hline $\mathrm{F}$ & $\begin{array}{l}\text { BT Globorotalia } \\
\text { suterae }\end{array}$ & Bsut & 7.8 & $F$ & $\begin{array}{l}\text { B Morozovella } \\
\text { velascoensis }\end{array}$ & bMve & 60 \\
\hline$F$ & BT Globorotalia juanai & Bjua & 8.1 & $F$ & $\begin{array}{l}\text { B Morozovella } \\
\text { pusilla }\end{array}$ & bMpu & $61(?)$ \\
\hline$F$ & BT Candeina nitida & Bcnit & 8.1 & $F$ & $\begin{array}{l}\text { B Morozovella } \\
\text { conicotruncata }\end{array}$ & bMco & 60.9 \\
\hline$F$ & $\begin{array}{l}\text { BT Globigerinoides } \\
\text { extremus }\end{array}$ & BGex & 8.3 & $F$ & $\begin{array}{l}\text { B Morozovella } \\
\text { angulata }\end{array}$ & bMan & 61 \\
\hline $\mathrm{F}$ & $\begin{array}{l}\text { BT Globorotalia } \\
\text { plesiotumida }\end{array}$ & Bplt & 8.3 & $F$ & $\begin{array}{l}\text { B Morozovella } \\
\text { uncinata }\end{array}$ & bMun & $\begin{array}{r}61.2 \\
(?)\end{array}$ \\
\hline $\mathrm{F}$ & $\begin{array}{l}\text { BT Neogloborotalia } \\
\text { humerosa }\end{array}$ & Bhum & 8.5 & $F$ & $\begin{array}{l}\text { B Planorotalites } \\
\text { compressus }\end{array}$ & bPco & $63(?)$ \\
\hline $\mathrm{F}$ & \begin{tabular}{|l} 
TOP \\
Neogloboquadrina \\
nympha
\end{tabular} & Tnym & 10.1 & $F$ & T Globotruncana & tGtc & 65 \\
\hline$F$ & $\begin{array}{l}\text { BT Neogloboquadrina } \\
\text { acostaensis }\end{array}$ & Bac & 10.9 & & & & \\
\hline
\end{tabular}




\section{Close Window}

Table 2.3: Example of format used in the biostratigraphic templates. 'Young age' and 'Old age' allow entering two different values and obtain an age range for the event. The last two columns to the right are left blank and will be filled with depth information from each hole. $B$ represents the first appearance datum (FAD), $T$ the last appearance datum (LAD).

\begin{tabular}{|c|c|c|c|c|c|c|}
\hline Hole & 2.00 & $d d / m m / y y$ & $\begin{array}{c}\text { Author of } \\
\text { file }\end{array}$ & \multicolumn{3}{|c|}{ Comments } \\
\hline Group & Event name & Code & $\begin{array}{l}\text { Young } \\
\text { age }\end{array}$ & $\begin{array}{l}\text { Old } \\
\text { age }\end{array}$ & $\begin{array}{c}\text { Top } \\
\text { Depth }\end{array}$ & $\begin{array}{l}\text { Bottom } \\
\text { Depth }\end{array}$ \\
\hline $\mathrm{N}$ & B D. tamalis & B Dta & 3.8 & & & \\
\hline $\mathrm{N}$ & $\begin{array}{l}\text { B D. } \\
\text { asymmetricus }\end{array}$ & B Das & 4.2 & & & \\
\hline $\mathrm{N}$ & T A. primus & T Apr & 4.8 & & & \\
\hline $\mathrm{N}$ & B C. rugosus & B Cru & 5 & 5.23 & & \\
\hline
\end{tabular}




\section{Close Window}

Table 2.4. References to biostratigraphic files present in Neptune. The 'Group' column indicates the plankton group (D: diatoms; F: foraminifera; N: nannofossils; R: radiolarians) stratigraphy or magnetostratigraphic data $(\mathrm{M})$ presented in the reference.

Vol. Author(s) Group

7 Brönnimann, P.; Resig, J., $1971 \mathrm{~F}$

7 Martini, E.; Worsley, T., $1971 \mathrm{~N}$

7 Riedel. W.R.; Sanfilippo, A., 1971 R

13 Gartner, S., Jr., 1973 N

13 Bukry, D., $1973 \mathrm{~N}$

13 Ryan, W. B. F.; Hsü, K. J., 1973 F

14 Beckmann, J. P., $1972 \mathrm{~F}$

14 Roth, P. H.; Thierstein, H. R., 1972 N

16 Kaneps, A. G., 1973 F

16 Dinkelman, M.G., 1973 R

16 Bukry, D.; Foster, J.H., 1973 D

18 Ingle, J. C., Jr., 1973 F

18 Kling, S. A., 1973 R

18 Schrader, H. J., 1973 D

18 Wise, S. W., $1973 \mathrm{~N}$

19 Koizumi, I., $1973 \mathrm{D}$

19 Ling, H. Y., 1973 R

19 Worsley, T. R., $1973 \mathrm{~N}$

19 Echols, R. J., $1973 \mathrm{~F}$

19 Akiba, F., 1986 (vol. 87) D

22 Johnson, D. A., $1974 \mathrm{R}$

22 Gartner, S., Jr., 1974 N

22 McGowran, B., $1974 \mathrm{~F}$

22 Berggren, W.A.; et al., $1974 \mathrm{~F}$

22 Schrader, H.-J., 1974 (vol. 24) D

24 Sanfilippo, A.; Riedel, W. R., 1974 R

24 Roth, P. H., 1974 N

24 Schrader, H. J., 1974 D

24 Vincent, E.; et al., $1974 \mathrm{~F}$

24 Heiman, M.E.; et al., $1974 \mathrm{~F}$

26 Boltovskoy, E., $1974 \mathrm{~F}$

26 Thierstein, H. R., $1974 \mathrm{~N}$

28 McCollum, D. W., 1975 D

28 Chen, P. H., 1975 R

28 Burns, D. A., $1975 \mathrm{~N}$

28 Kaneps, A. G., $1975 \mathrm{~F}$

29 Edwards, A. R.; Perch-Nielsen, K., 1975 N 
29 Petrushevskaya, M. G., 1975 R

29 Jenkins, D. G., $1975 \mathrm{~F}$

29 Schrader, H. J., 1976 (vol. 35) D

30 Holdsworth, B. K., 1975 R

30 Shafik, S., $1975 \mathrm{~N}$

31 Koizumi, I., 1975 D

31 Ellis, C. H., $1975 \mathrm{~N}$

31 Ling, H.Y., 1975 R

33 Johnson, D. A., 1976 R

33 Martini, E., $1976 \mathrm{~N}$

33 Takayanagi, Y.; Oda, M., $1976 \mathrm{~F}$

39 Boersma, A., $1977 \mathrm{~F}$

39 Perch-Nielsen, K., $1977 \mathrm{~N}$

39 Sanfilippo, A.; Nigrini, C., 1995 R $^{\star}$

39 Fenner, J., 1978 (supplement) D

40 Jenkins, D. G., 1978 F

40 Proto Decima, F.; et al., $1978 \mathrm{~N}$

40 Toumarkine, M., $1978 \mathrm{~F}$

40 Pisias, N.G.; Moore, T.C. Jr., 1978 R

41 Bukry, D., $1978 \mathrm{~N}$

41 Krasheninnikov, V. A.; Pflaumann, U., $1978 \mathrm{~F}$

41 Krasheninnikov, V. A.; Pflaumann, U., $1978 \mathrm{~F}$

41 Johnson, D. A., 1978 R

41 Schrader, $1978 \mathrm{D}$

43 Okada, H.; Thierstein, H.R., 1979 N

47 Blechschmidt, G., $1979 \mathrm{~N}$

48 Murray, J.W., $1979 \mathrm{~F}$

48 Müller, C., 1979 N

49 Poore, R. Z., $1979 \mathrm{~F}$

49 Ling, H. Y., 1979 R

49 Steinmetz, J. C., $1979 \mathrm{~N}$

49 Martini, E., $1979 \mathrm{~N}$

49 Schrader, H. J., 1979 D

55 Takayama, T., $1980 \mathrm{~N}$

55 Ling, H. Y., 1980 R

55 Koizumi, I., $1980 \mathrm{D}$

56/7 Thompson, P. R., $1980 \mathrm{~F}$

56/7 Reynolds, R. A., 1980 R

$56 / 7$ Shaffer, B. L., $1980 \mathrm{~N}$

56/7 Keller, G., $1980 \mathrm{~F}$

56/7 Harper, H. E., Jr., 1980 D

56/7 Sakai, T., 1980 R

56/7 Barron, J. A., 1980 D

58 Okada, H., $1980 \mathrm{~N}$

58 Sloan, J., 1980 R 
59 Martini, E., $1981 \mathrm{~N}$

59 Theyer, F.; Lineberger, P., 1981 R

59 Heiman, M.E., $1981 \mathrm{~F}$

60 Ellis, C. H., $1982 \mathrm{~N}$

60 Kling, S. A., 1982 R

61 Premoli Silva, I.; Violanti, D., $1981 \mathrm{~F}$

61 Thierstein, H.R.; Manivit, H., $1981 \mathrm{~N}$

61 Sanfilippo, A.; et al., $1981 \mathrm{R}$

63 Barron, J. A., 1981 D

63 Wolfart, R., $1981 \mathrm{R}$

63 Poore, R. Z., $1981 \mathrm{~F}$

66 Stradner, H.; Allram, F., 1982 N

66 McMillen, K.J., 1982 R

67 Thompson, P. R., 1982 F

67 Muzylöv, N., 1982 N

67 Westberg, M. J.; Riedel, W. R., 1982 R

67 Harper, H. E., Jr.; et al., 1982 D

67 Jousé, A.P.; et al., 1982 D

68 Kent, D. V.; Spariosu, D. J., 1982 M

68 Riedel, W. R.; Westberg, M. J., 1982 R

68 Keigwin, L. D., Jr., 1982 F

68 Sancetta, C., 1982 D

68 Kent, D. V.; Spariosu, D. J., 1982 M

71 Krasheninnikov, V. A.; Basov, I. A., 1983 F

71 Salloway, J. C., $1983 \mathrm{M}$

71 Wise, S. W., $1983 \mathrm{~N}$

71 Gombos, A.M.; Ciesielski, P.F., 1983 D

71 Weaver, F. M., 1983 R

71 Ciesielski, P. F., 1983 D

72 Berggren, W.A.; et al., $1983 \mathrm{M}$

72 Pujol, C., $1983 \mathrm{~F}$

72 Berggren, W.A.; et al., $1983 \mathrm{~F}$

72 Gombos, A.M., Jr., 1983 D

72 Pujol, C.; Duprat, J., 1983 F

73 Percival, S. F., Jr., 1984 N

73 Poore, R. Z., 1984 F

73 Smith, C.C.; Poore, R.Z., 1984 F

73 Tauxe, L.; et al., $1984 \mathrm{M}$

73 Gombos, A.M., Jr., 1984 D

74 Boersma, A., $1984 \mathrm{~F}$

74 Jiang, M.-J.; Gartner, S., 1984 N

77 Lang, T.H.; Watkins, D.K., 1984 N

80 Snyder, S. W.; Waters, V. J., 1985 F

80 Müller, C., $1985 \mathrm{~N}$

80 Townsend, H. A., 1985 M 
80 Pujol, C.; Duprat, J., 1985 F

80 Pujos, A., $1985 \mathrm{~N}$

80 Labracherie, M., 1985 R

81 Krumsiek, K.; Roberts, D. G., 1984 M

81 Backman, J., $1984 \mathrm{~N}$

81 Huddlestun, P. F., 1984 F

81 Baldauf, J.G., 1984 D

81 Westberg-Smith, M.J.; Riedel, W.R., 1984 R

82 Parker, M.E.; et al., $1985 \mathrm{~N}$

82 Bukry, D., $1985 \mathrm{~N}$

82 Miller, K.G.; et al., 1985 N,F*

82 Miller, K.G.; et al., 1994 N,F,M*

85 Weinreich, N.; Theyer, F., 1985 M

85 Saito, T., $1985 \mathrm{~F}$

85 Labracherie, M., 1985 R

85 Baldauf, J. G., 1985 D

85 Barron, J. A., 1985 D

85 Gartner, S.; Chow, J., 1985 N

85 Nigrini, C. A., 1985 R

85 Pujos, A., $1985 \mathrm{~N}$

86 Koizumi, I.; Tanimura, Y., 1985 D

86 Heath, G. R.; et al., 1985 M

86 Bleil, U., $1985 \mathrm{M}$

86 Monechi, S., $1985 \mathrm{~N}$

86 Morley, J. J., 1985 R

90 Martini, E., $1986 \mathrm{~N}$

89/90 Lohman, W. H., $1986 \mathrm{~N}$

90 Ciesielski, P. F., 1986 D

89/90 Jenkins, D. G.; Srinivasan, M. S., 1986 F

90 Barton, C. E.; Bloemendal, J., 1986 M

89/90 Caulet, J. P., 1986 R

92 Romine, K., $1986 \mathrm{~F}$

92 Knüttel, S., $1986 \mathrm{~N}$

93 Muza, J. P.; et al., 1987 N

93 Lang, T.H.; Wise, S.W., Jr., 1987 N

93 Applegate, J.L.; Wise, S.W., Jr., 1987 N

93 Ma'alouleh, K.; Moullade, M., 1987 F

93 Saint-Marc, P., $1987 \mathrm{~F}$

93 Nishimura, A., 1987 R

93 Gombos, A.M., Jr., 1987 D

93 Canninga, G.; et al., 1987 M

94 Jenkins, D.G., $1987 \mathrm{~F}$

94 Weaver, P. P. E., $1987 \mathrm{~F}$

94 Clement, B. M.; Robinson, F., 1987 M

94 Baldauf, J. G., 1987 D 
94 Takayama, T.; Sato, T., $1987 \mathrm{~N}$

94 Westberg-Smith, M.J.; et al., 1987 R

95 Miller, K.G.; Hart, M.B., 1987 F*

95 Palmer, A.A., 1987 R

95 Valentine, P.C., $1987 \mathrm{~N}$

95 Abbott, W.H., 1987 D

105 Knüttel, S.; et al., $1989 \mathrm{~N}$

105 Firth, J.V., $1989 \mathrm{~N}$

105 Aksu, A.E.; Kaminski, M.A., 1989 F

105 Baldauf, J.G.; Monjanel, A.-L., 1989 D

105 Lazarus, D.; Pallant, A., 1989 R

105 Clement, B.M.; et al., 1989 M

108 Manivit, H., 1989 N

108 Weaver, P.P.E.; Raymo, M.E., 1989 F

108 Tauxe, L.; et al., 1989 M

113 Spiess, V., 1990 M

113 Pospichal, J.J.; Wise, S.W., 1990 N

113 Wei, W.; Wise, S.W., $1990 \mathrm{~N}$

113 Abelmann, A., $1990 \mathrm{R}$

113 Lazarus, D.B., $1990 \mathrm{R}$

113 Gersonde, R.; Burckle, L.H., 1990 D

113 Stott, L.D.; Kennett, J.P., 1990 F

114 Fenner, J., $1991 \mathrm{D}$

114 Crux, J.A., $1991 \mathrm{~N}$

114 Madile, M.; Monechi, S., $1991 \mathrm{~N}$

114 Nocchi, M.; et al., $1991 \mathrm{~F}$

114 Hailwood, E.A.; Clement, B.M., 1991 M

114 Hailwood, E.A.; Clement, B.M., 1991 M

115 Okada, H., $1990 \mathrm{~N}$

115 Rio, D.; et al., $1990 \mathrm{~N}$

115 Premoli Silva, I.; Spezzaferri, S., 1990 F

115 Johnson, D.A., $1990 \mathrm{R}$

115 Fenner, J.; Mikkelsen, N., 1990 D

115 Vincent, E.; Toumarkine, M., $1990 \mathrm{~F}$

115 Schneider, D.A.; Kent, D.V., 1990 M

117 Spaulding, S., $1991 \mathrm{~N}$

117 Sato. T.; et al., $1991 \mathrm{~N}$

117 Nigrini, C., $1991 \mathrm{R}$

117 Spaulding, S.A.; et al., $1991 \mathrm{~F}^{\star}$

117 Hayashida, A.; Bloemendal, J., 1991 M

119 Huber, B.T., 1991 F

119 Wei, W.; Thierstein, H.R., $1991 \mathrm{~N}$

119 Wei, W.; Pospichal, J.J., $1991 \mathrm{~N}$

119 Caulet, J.P., $1991 \mathrm{R}$

119 Lazarus, D.B., 1992 (vol. 120) R 
119 Baldauf, J.G.; Barron, J.A., 1991 D

119 Sakai, H.; Keating, B.H., 1991 M

119 Keating, B.H.; Sakai, H., 1991 M

120 Heider, F.; et al., 1992 M

120 Inokuchi, H.; Heider, F., 1992 M

120 Aubry, M.-P., $1992 \mathrm{~N}$

120 Wei, W.; Wise, S.W., $1992 \mathrm{~N}$

120 Berggren, W.A., $1992 \mathrm{~F}$

120 Berggren, W.A., $1992 \mathrm{~F}$

120 Harwood, D.M.; Maruyama, T., 1992 D

120 Takemura, A., $1992 \mathrm{R}$

120 Abelmann, A., $1992 \mathrm{R}$

120 Lazarus, D.B., $1992 \mathrm{R}$

122 Siesser, W.G.; Bralower, T.J., 1992 N

122 Galbrun, B., 1992 M

122 Zachariasse, W.J., $1992 \mathrm{~F}^{*}$

122 Tang, C., $1992 \mathrm{M}$

125 Ciampo, G., $1992 \mathrm{~N}$

125 Xu, Y.; Wise, S.W., Jr., $1992 \mathrm{~N}$

125 Milner, G.J., 1992 F

127 Rahman, A., $1992 \mathrm{~N}$

127 Brunner, C.A., $1992 \mathrm{~F}$

127 Alexandrovich, J.M., 1992 R* $^{*}$

127 Koizumi, I., 1992 D

127 Hamano, Y.; et al., $1992 \mathrm{M}$

130 Leckie, R.M.; et al., $1993 \mathrm{~F}^{*}$

130 Chaisson, W.P; Leckie, R.M., $1993 \mathrm{~F}$

130 Takayama, T., $1993 \mathrm{~N}$

132 Premoli Silva, I.; et al., 1993 N,F

132 Sager, W.W.; et al., $1993 \mathrm{M}$

133 Gartner, S.; et al., $1993 \mathrm{~N}$

133 Kroon, D., $1993 \mathrm{~F}^{*}$

134 Zhao, X.; et al., $1994 \mathrm{M}$

134 Staerker, T.S., $1994 \mathrm{~N}$

134 Perembo, R.C.B., $1994 \mathrm{~F}$

134 Weinheimer, A.L.; et al., $1994 \mathrm{R}$

135 Nishi, H.; Chaproniere, G.C.H., 1994 F*

135 Quinterno, P.J., $1994 \mathrm{~N}^{*}$

* used only in biostratigraphy files, not available in Neptune 


\section{THE REALISATION OF NEPTUNE - THE REAL WORLD IS WORSE THAN WE THOUGHT}

\subsection{Stratigraphic and geographic coverage}

The geographic distribution of the 165 holes included in Neptune is uneven. In some areas there is a very detailed coverage, like for example in some parts of the Antarctic Ocean (Fig. 2.1). On the other hand, no holes from the central north and southeastern Pacific Ocean are present in Neptune. (Holes from ODP Leg 145 now provide a transect across the north Pacific.) The mid- and high latitudes in the southern hemisphere and the tropical regions of the Atlantic Ocean are also not well represented. This is due in part to the uneven coverage of DSDP and ODP cruises and in part to the selection made for Neptune, which preferentially included holes with good biostratigraphy.

Each year, ODP organizes five to six drilling cruises which result in as many published Scientific Results. Although not all cruises retrieve micropaleontologically significant material, many of them provide a detailed biostratigraphy and data relevant to the scopes of Neptune. The present geographic coverage of holes in Neptune has been last updated in 1995 (Leg 135). Since then more than twenty-five volumes of Scientific Results have been published. From the beginning of the project, we were faced with the need to maintain a balance between keeping up with the new data produced by ODP and the need to analyze the data already in Neptune for biostratigraphic or micropaleontological studies. At present, I have decided to keep Neptune at its current, acceptable but not optimal, size in order to complete some of the studies that we had planned. If it will be decided to update Neptune in the future, it will be necessary to:

- select suitable holes from Leg 136 onward, and for the selected holes:

- compile biostratigraphic files and construct age models;

- import the core depth file and the age model file for each hole;

- download from ODP the available range charts;

- format the range chart files to make them compatible with Neptune;

- import the range chart file;

- update the species name list with the new names eventually present in the range charts.

Another limitation of the database is given by the often incomplete often-incomplete recovery of sediments (Fig. 3.1). Before the advent of hydraulic piston coring, few continuously recovered sections were available. Core recovery has drastically improved in the more recent ODP holes but

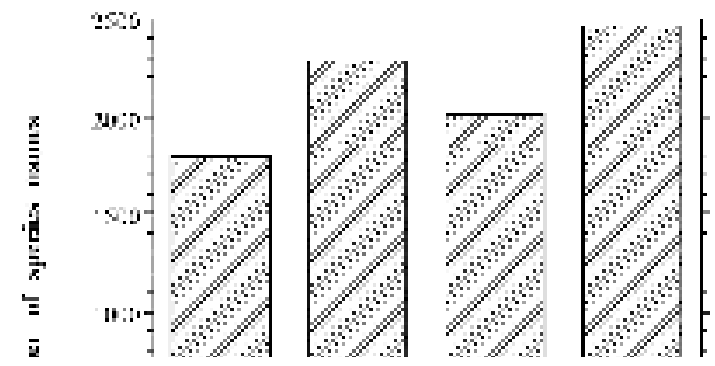


sediment loss at core breaks is still common even in continuously cored sections (Farrell and Janecek 1991).

In addition, there is an uneven distribution in the temporal coverage of the sections. Whilst

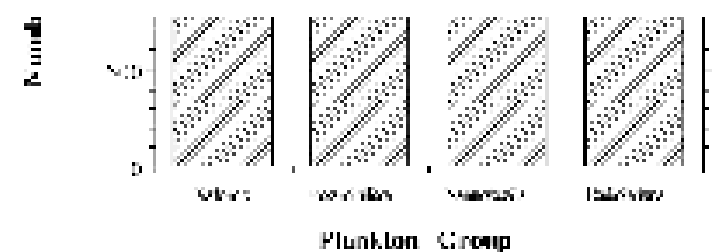

Figure 3.1. Plio-Pleistocene sections are very well represented in Neptune (as they are in ODP holes overall), the detail of stratigraphic coverage decreases for older time periods, as naturally expected from the drilling procedure (Fig. 3.2, Spencer-Cervato 1998). This might be interpreted as a need to recover more Miocene and older sections, but this pattern actually reflects the number of studied sections and not simply the recovered sections. Therefore, I believe that the

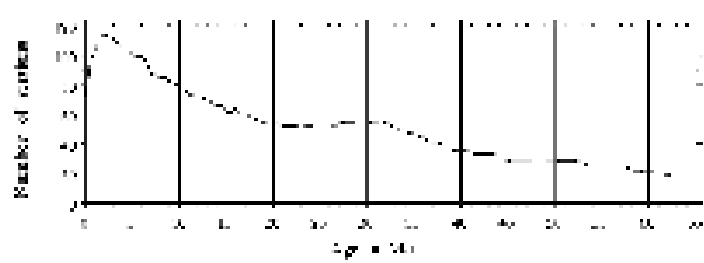

Figure 3.2. problem does not lie only in the 'quantity' of older sections drilled, but also in the 'quality' of their stratigraphy. The reliability of the stratigraphy provided for a section depends strongly on the availability of good calibrations, and these are currently available mainly for Neogene sediments. Figure 3.2 also shows that the number of

well-studied sections does not decrease gradually and regularly with age, but shows peaks (around $2 \mathrm{Ma}$ ) and plateaus (e.g., between 20 and $32 \mathrm{Ma}$ ). This likely reflects the relative, unequal attention given to the Cenozoic stratigraphy through the history of DSDP and ODP.

\subsection{Chronology}

For the database, we have chosen to use a comprehensive biochronology based on deep-sea sections, therefore not considering land sections, which represent the type localities where stratigraphic series were first described. This may represent a limitation in the achieved biochronological calibration. The precision of the ages determined with the age models depends on various factors, some subjective and nonquantifiable, and some, like sample spacing, accuracy of biostratigraphic calibration, or core recovery, that can be quantified. A conservative estimate of the age model precision of $0.36 \mathrm{~m}$.y. was determined for Neogene sediments (Spencer-Cervato et al. 1994). For Paleogene sediments it is about 0.66 m.y. (twice the average sample spacing).

Another important factor is the quality of the age model. The Neogene DSDP age/depth plots that we have published so far (Spencer-Cervato et al. 1993; Lazarus et al. 1995a) are a good example of the range of reliability of the line of correlation. The subjective ranking given in Table 2.2 varies from very poor or poor (wide scatter of events, straight line of correlation drawn across the middle of the cloud), to moderate (some scatter of a limited number of events, various possible lines of correlation), to good or excellent (40\% of the holes: very good agreement of the event ages, abundant events to constrain the line of correlation, good agreement between 
magnetostratigraphy and biostratigraphy). Several factors can cause the scatter of events observed in most age/depth plots: reworking, downhole contamination, incorrect entry in the biostratigraphy file, typos in the range charts, diachrony of the calibrated event, , and sample spacing. Whilst most of these causes can be easily double-checked, diachrony is quite difficult to assess. The assumption of 'globally synchronous events' which is at the base of biochronology is validly established only for some selected, well documented events (e.g., Hays and Shackleton 1976;

Thierstein et al. 1977; Backman and Shackleton 1983; Wei 1993; Spencer-Cervato et al. 1994). It is likely that more complete data collection and documentation would lead to the identification of more globally synchronous events. But in most cases, a calibration is valid only for the more or less restricted biogeographic province where it is done, and only a few events are truly globally synchronous, within the precision of the method adopted for calibration. The need for localized calibrations has long been known for siliceous plankton stratigraphy, but it is not widely accepted by biostratigraphers using calcareous plankton. To minimize this factor, we intentionally used multiple regional calibrations for diatoms and radiolarians. Even with this approach, the scatter is sometimes too large to provide a reliable line of correlation. For nannofossils and foraminifera only one general (low latitude) calibration is available (Berggren et al. 1985, 1995a, $\underline{b}$ ). The advantage of this calibration is that it is based on several sites, while most of the regional calibrations are based only on one hole. An estimate of the diachrony/synchrony of Neogene events was done with a subset of the holes currently present in Neptune (Spencer-Cervato et al. 1994). This study indicated that calcareous nannofossils provide the most reliable biostratigraphic events, as they are mostly cosmopolitan and, if diachronous, the age margin is relatively small.

Very few sections are actually continuous, and long stratigraphic gaps are common (Spencer-Cervato 1998) (Fig. 3.3). Two-thirds of the selected holes contain at least one hiatus, and on average they each contain three hiati of various lengths (Fig. 2.1). The presence of these hiati results in

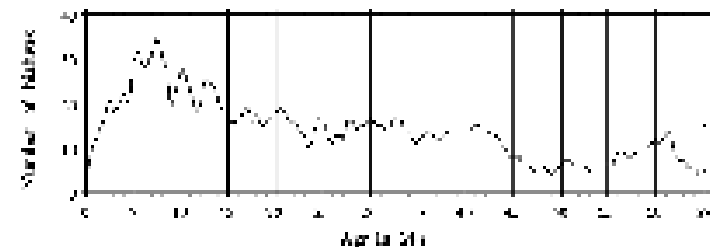

Figure 3.3. artificially older or younger ages for the samples adjacent to the gap. This does not allow one to automatically ('blindly') search the database for e.g.,such information as species ages, but requires that every output is be checked and compared with the age models.

The final and probably most necessary improvement of the chronology of Neptune is given by the life-timelifetime of the biochronology selected for the age model calibration. We initially based the age models on Berggren et al. (1985). An updated magnetostratigraphy was published later (Cande and Kent 1992) but it did not provide the combination of biochronology and magnetostratigraphy available from Berggren et al.'s (1985) work. We thus decided to continue using Berggren et al. (1985) throughout the first phase of the project (DSDP Neogene sediments). However, ten 
years after the first biochronology compilation, a new updated biochronology was published (Berggren et al. 1995b) and the chronology of Neptune became suddenly outdated. The iterations to update Neptune's chronology were greatly helped by additional programming of Neptune by Dave Lazarus and an auxiliary computer program (not part of Neptune and written ad hoc by Bernhard Brabec) which created a correlation function between the old and the new master biochronology. This function was applied to all age model files and new revised age models were created. . Then, all biostratigraphy files were updated using a 'find - replace' routine with lookup tables (i.e.: if code in column 3 is equal to $X Y w z$, replace age in column 4 with corresponding value in lookup table). While we could directly use the new calibrations for calcareous plankton as lookup tables, it was necessary to recalibrate to the new time scale all regional templates used for siliceous plankton events. Finally, before the new age models could be imported into Neptune, all the age/depth plots were redone by myself and eventually adjusted to fit the new event ages.

\subsection{Taxonomy}

Among the other reasons mentioned above, if a bio-event recorded in a specific hole plots far outside the area where the line of correlation can be drawn, it could be due to its taxonomic identification. Many authors have put together the hundreds of range charts that were used for Neptune and not all agree in the detailed taxonomic identification of all the 8800+ taxa included in Neptune. Indeed, taxonomic identification is subjective. The time pressure under which biostratigraphers are during a leg is also an important limiting factor in the number of species described in a range chart, which is often limited to biostratigraphic markers. The extent to which this taxonomic problem has affected the data in Neptune can be judged by experts in particular cases but cannot be easily quantified.

Starting from the biostratigraphy filesbiostratigraphic records assembled for the chronology, we assumed that the taxon associated with one event and described in the range chart was the one we were looking for. Further, we needed to consider the occurrence of synonyms. It sometimes happens that the name used by one author for a taxon corresponds either to a different taxon according to another author, or that a different name is used by a second author for this specific taxon (synonymy). For example, the foraminifer species Globorotalia truncatulinoides has been also called Truncorotalia truncatulinoides. To account for this, we have used the literature, personal experience and extensive consultation with taxonomic experts to identify valid taxon names. Three thousand of the 8810 names listed in Neptune (Fig. 3.4) are 
considered valid (i.e., are legal names in the framework of the ICZN and ICBN, and are known to be real to at least one of the experts). Synonyms to these valid names were then identified (with the corresponding valid name). They constitute $31 \%$ of the total number of names. In several cases we could not unequivocally identify a specific name and marked it as 'unknown' (15\% of all names). Only 43 names $(0.5 \%)$ were considered invalid. This information is available in the 'Species Names' table of Neptune. The synonymizsation is subjective (the initials of the person who identified each species name is also given in the 'Species

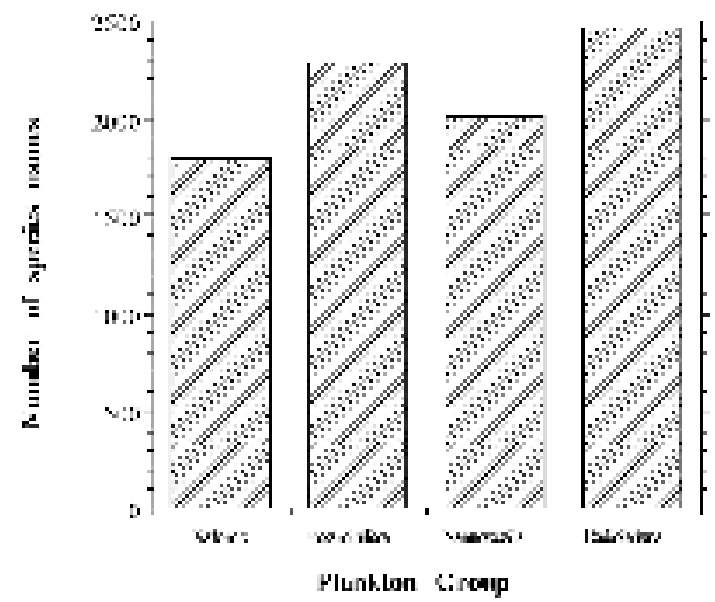

Figure 3.4. Names' table) and the names list does not at all pretend to be a thorough or complete taxonomic revision of marine plankton. It merely represents a working table that gives us a first approximation of plankton taxonomy. A 'real' taxonomic database would need complete taxonomic descriptions (with history) for each taxon and a series of images to illustrate them. Cathy Nigrini, Jean-Pierre Caulet, and Dave Lazarus are currently working on a detailed taxonomic database for radiolarians, but it is well beyond the scopes of Neptune to even attempt anything like this for all groups. The taxonomic list also needs continuous update: every time a new hole is added to Neptune, the biostratigraphic range charts carry with them new names, sometimes several ones. These need to be added to the 'Species Names' list and identified as valid or not.

\subsection{Biostratigraphy}

There is an uneven distribution in the number of reports by plankton group in Neptune. Over $60 \%$ of the 225 articles from which data for Neptune have been extracted (Table 2.4) are on calcareous plankton, almost equally distributed between nannofossils and foraminifera. Radiolarians follow with about $21 \%$ and diatoms trail with only $16 \%$. At the same time, biostratigraphic work on siliceous plankton is underrepresented in Paleogene sections, and most often limited to the Oligocene and younger sections (Fig. 3.5). This unevenness represents a bias for evolution studies where we would like to compare calcareous and siliceous plankton occurrences. Whether this distribution represents the average abundance of fossil plankton in deep-sea deposits or is instead the reflection of staffing decisions by DSDP and ODP is yet to be determined.

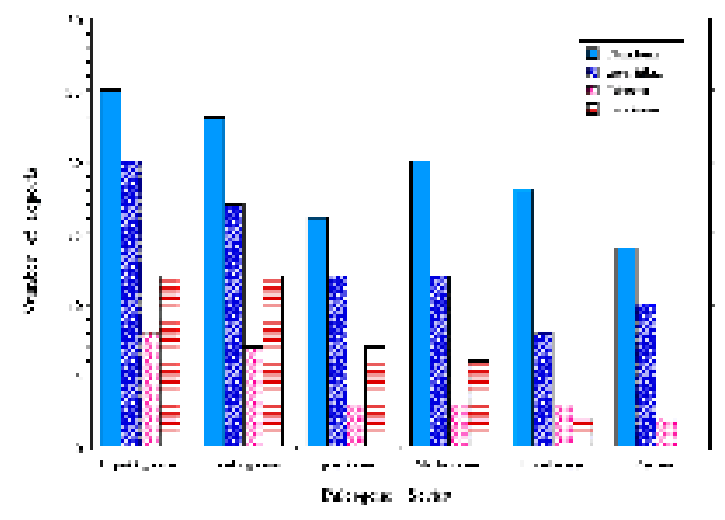

Figure 3.5.

One of the limitations of Neptune as a comprehensive micropaleontological database is given by our decision to include only four plankton groups. The DSDP and ODP 
Reports include many articles on benthic foraminifera, silicoflagellates, dinoflagellates as well as palynology. At the moment, there are no plans to include their occurrence data in the database, which in itself would not be a huge task.

Next Section... 
Figure 3.1: THE CENOZOIC DEEP SEA MICROFOSSIL RECORD...F THE DSDP/ODP SAMPLE SET USING THE NEPTUNE DATABASE

\section{Close W indow}

Figure 3.1. Total core recovery in percentage in the holes included in Neptune.

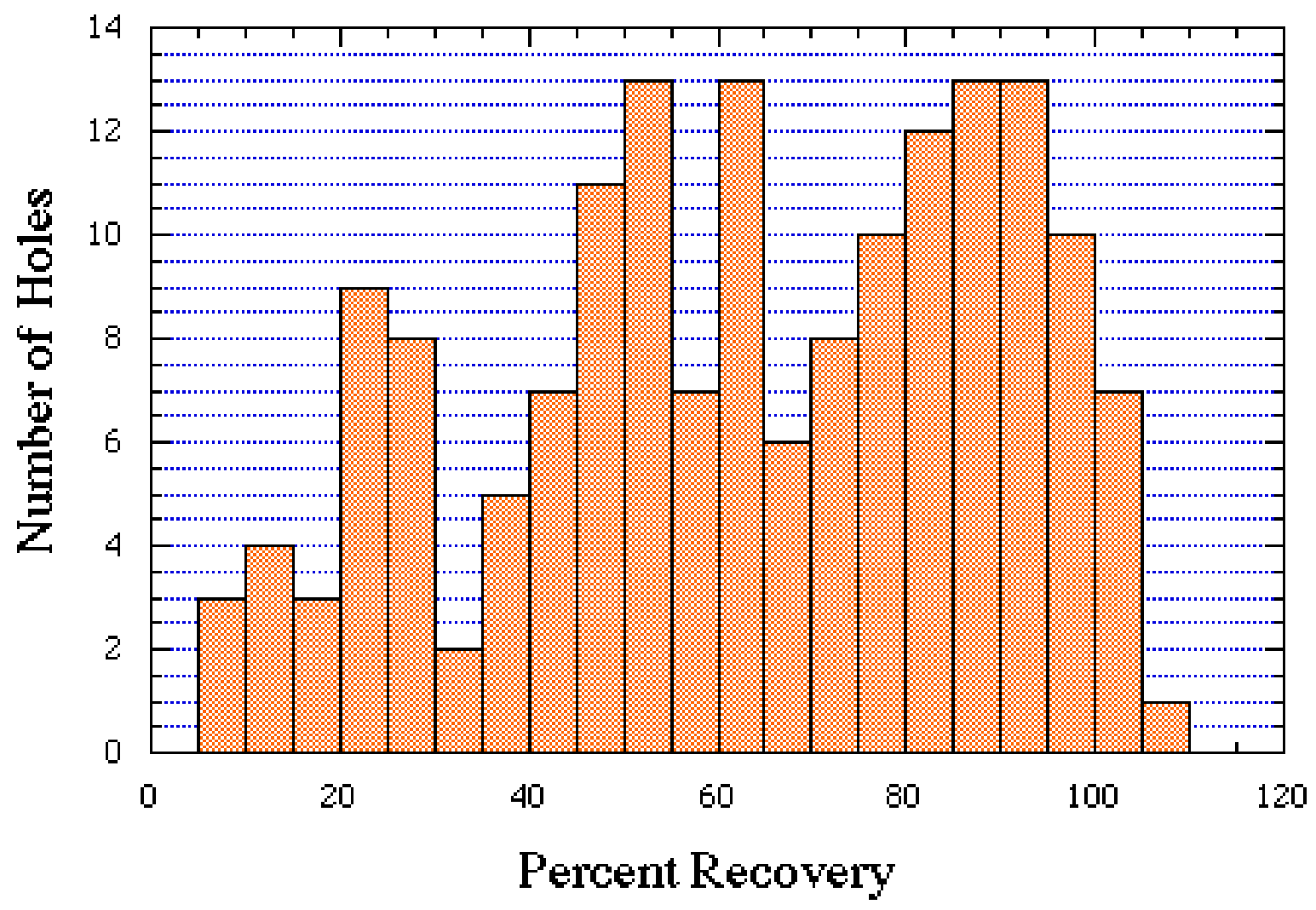


Figure 3.2: THE CENOZOIC DEEP SEA MICROFOSSIL RECORD: EXPLORATIONS OF THE DSDP/ODP SAMPLE SET USING THE NEPTUNE DATABASE

\section{Close W indow}

Figure 3.2. Age distribution of the sections included in Neptune.

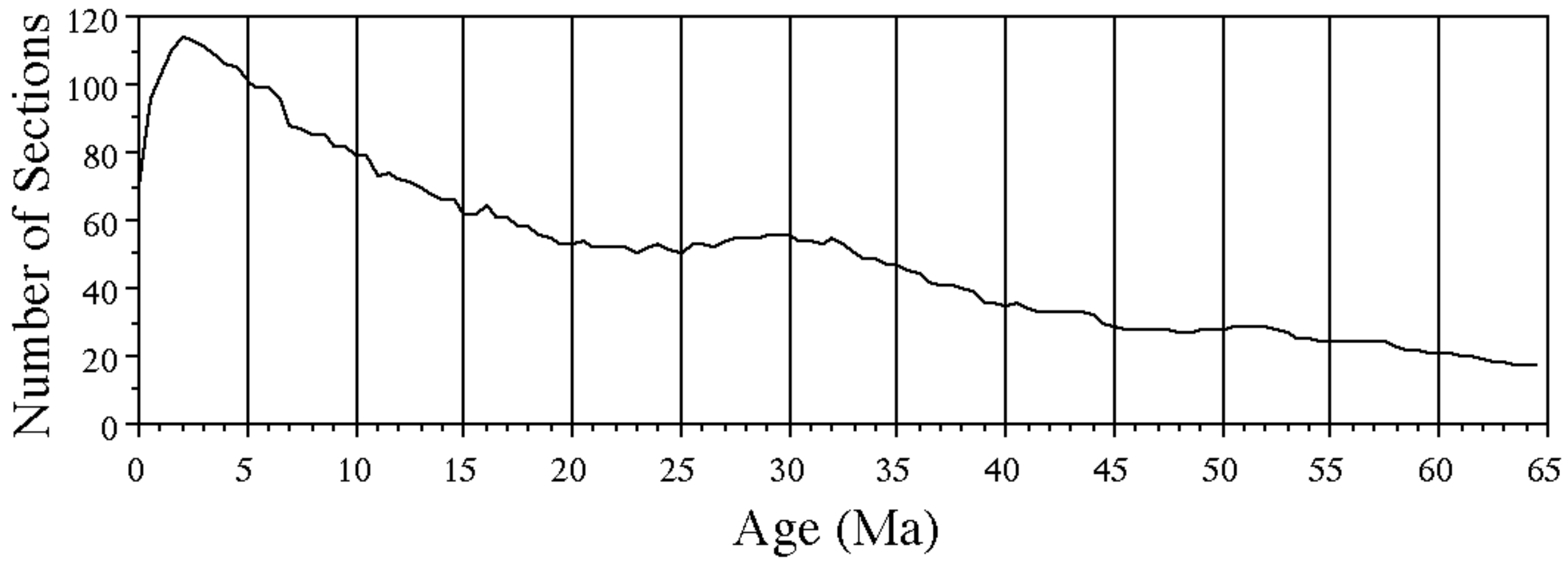


Figure 3.3: THE CENOZOIC DEEP SEA MICROFOSSIL RECORD: EXPLORATIONS OF THE DSDP/ODP SAMPLE SET USING THE NEPTUNE DATABASE

\section{Close Window}

Figure 3.3. Age distribution of hiati in the sections included in Neptune.

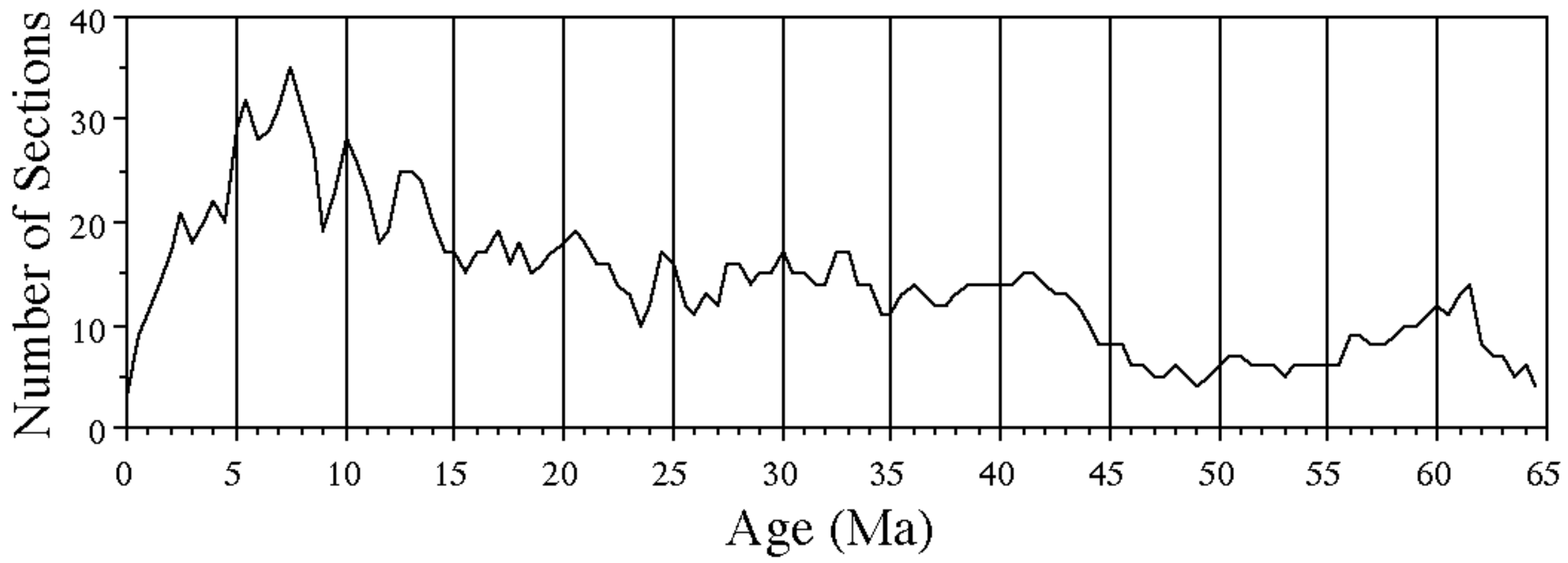




\section{Close Window}

Figure 3.4. Number of species names in each plankton group included in Neptune.

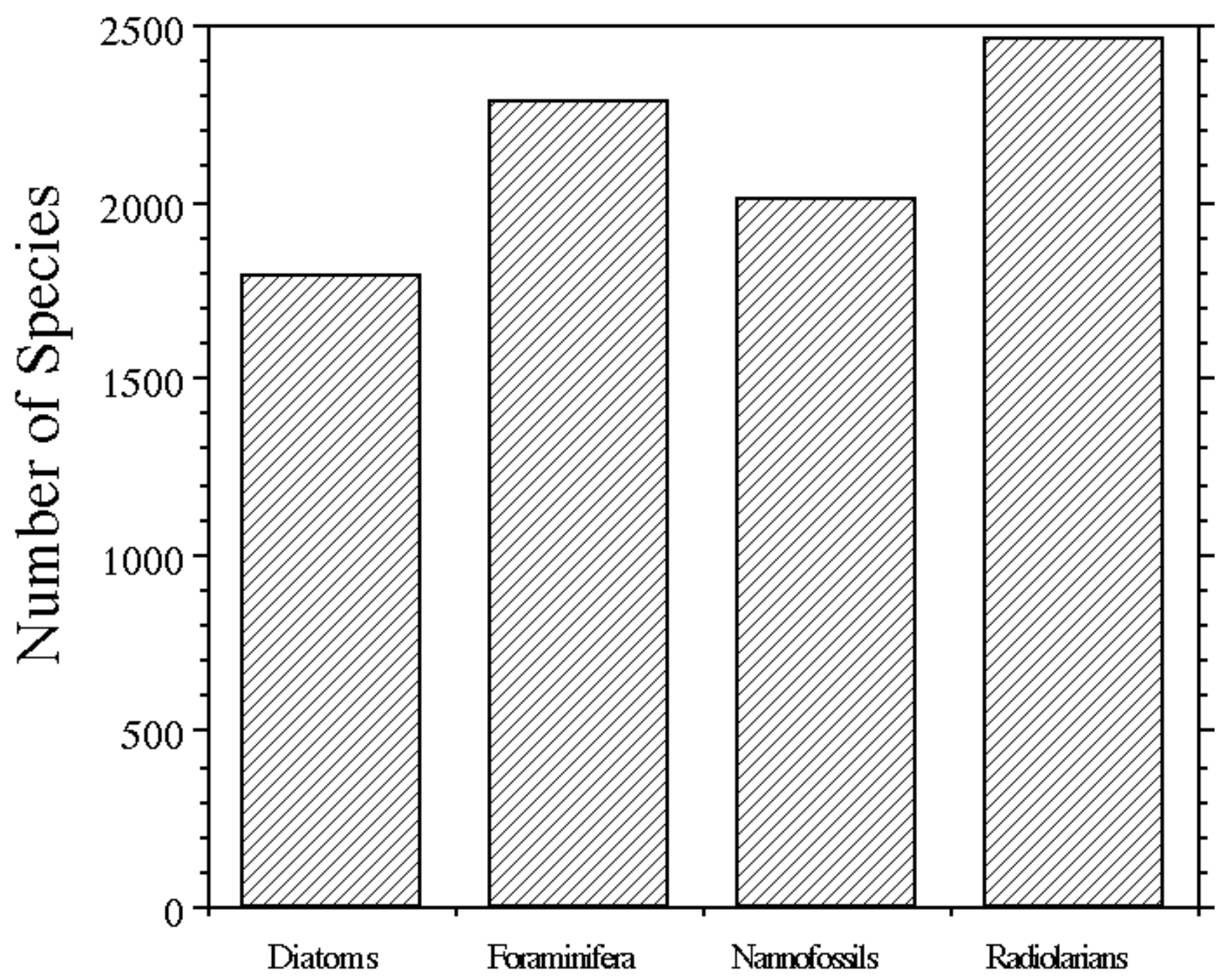




\section{Close window}

Figure 3.5. Number of reports on Paleogene biostratigraphy in Neptune by plankton group.

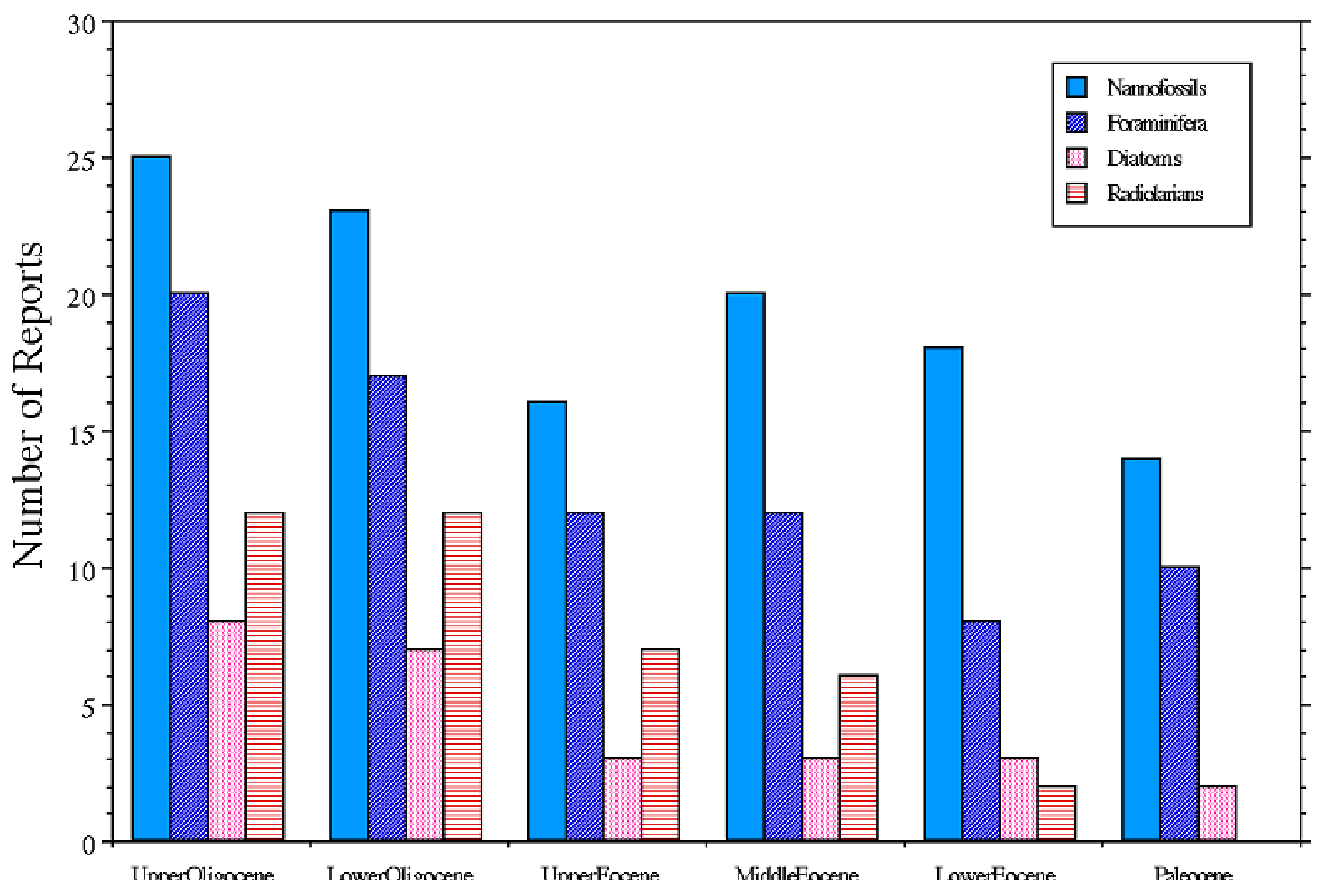


Figure 3.5: THE CENOZOIC DEEP SEA MICROFOSSIL RECORD: EXPLORATIONS OF THE DSDP/ODP SAMPLE SET USING THE NEPTUNE DATABASE

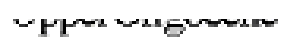

oprosantar

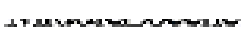

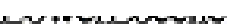

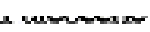




\section{RESEARCH PROJECTS CARRIED OUT WITH NEPTUNE, WHAT THEY TOLD US, AND RECOMMENDATIONS FOR THE FUTURE}

\subsection{The database structure and search capabilities: a tool to find out what we do or don't know}

The Neptune database currently provides rapid retrieval of age information on 165 DSDP and ODP holes; taxonomically corrected species lists and other taxonomic information for calcareous nannofossils, planktic foraminifera, diatoms and radiolarians for the entire Cenozoic; paleogeographic location of the 165 holes (paleolatitude and paleolongitude); extensive distributional data for these fossil groups (e.g., biogeographic occurrence information, computerized microfossil range charts) (Fig. 4.1). The design and implementation of the database software have been described in Lazarus (1994)

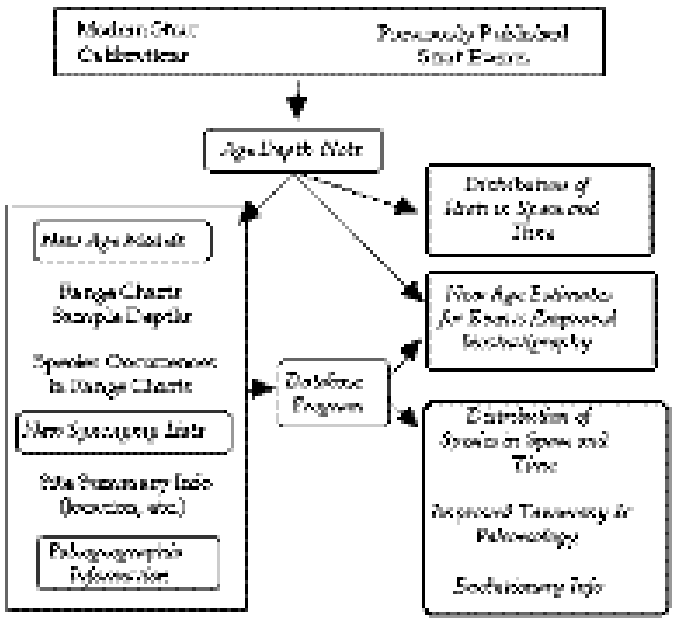

Figure 4.1. and in an unpublished guide (Lazarus, personal commun., 1996). These will be used for this description, with the updates of the data tables based on the present status of the database (after the most recent upgrade).

4.1.1. Overview of database structure. Neptune is designed as a relational database. Macintosh computers and 4th Dimension ${ }^{\mathrm{TM}}$ database software (4D) are used to run the database (Lazarus 1994). The database is implemented as several relational tables that contain (as of February 1998) close to 500,000 records.

Import procedures for range chart data as well as search procedures are available. The search procedures can locate all reported occurrences of any taxon or combination of taxa, automatically identifying occurrences recorded under synonymous names. Searches can also be used to locate other relevant information, such as general hole information, sample age, species occurrences, etc. Commercial mapping software (e.g., Atlas ${ }^{\mathrm{TM}}$ ) is used to plot locations of species occurrences, using a Neptune-generated plotting data file with latitude and longitude. A 'composite age range chart' program can also be used with an appropriately formatted file generated by a Neptune search (Lazarus 1994).

Neptune was created as a relational database where the data are separated into simple tables, with relational links between the tables. The structure of the database is shown in Figure 4.2. Five data tables hold the primary data: stratigraphic occurrence data for taxa ('Bug Data' table);

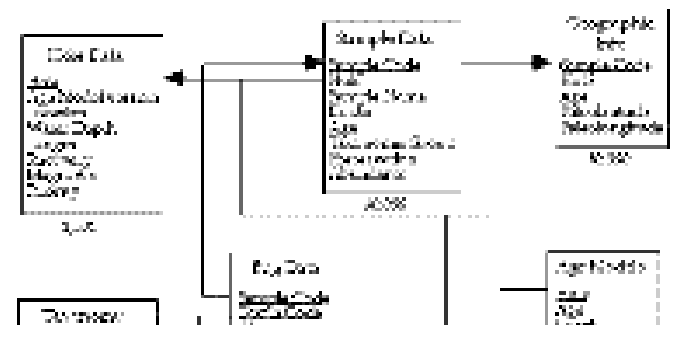


taxonomic data on species' names ('Taxonomy'); biogeographic data on species' occurrences ('Taxa by Hole'); geologic age information ('Age Models'); and paleogeographic information ('Geographic Info'). Paleo-water depths are available for selected

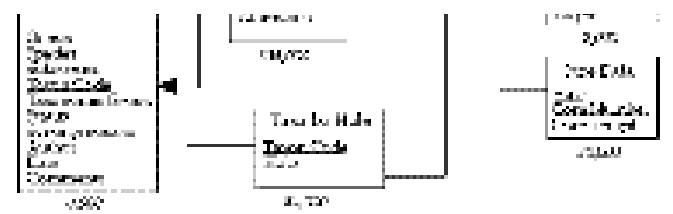

Figure 4.2. samples and have been published

(Spencer-Cervato 1998). As this information is not available for all samples, it is not currently included in Neptune.

The database maintains a strict separation between the primary observational data (occurrences of named taxa at specific depths in holes) and the interpreted meaning of the data (i.e., the species to which the name belongs - 'Taxonomy' - or the age of the section at a specific depth - 'Age Models'). These tables can be in fact modified repeatedly, but the observations remain constant (Lazarus 1994).

The stratigraphic occurrence data form the core of the database (over 380,000 records of 'Bug Data'). A typical range chart is decomposed into a minimum of one species occurrence in one sample. Further data separation is achieved by putting all information about samples and species into separate tables ('Sample Data' and 'Taxonomy'). Samples and species are represented in the 'Bug Data' table only by internal codes, linked to the more detailed records in other tables.

4.1.1.1. Species names ('Taxonomy' table). All names in the database are identified by a separate entry in this table. Each occurrence, including misspellings and questionable names (e.g., A. deflandrei?), is given as a separate entry. Each is identified by up to three words (genus, species, subspecies or qualifier). The qualifier is generally used to identify questionable entries, marked with the letter ' $Q$ '. Each entry is uniquely identified by a 'Taxon code', a combination of nine characters originally given by DSDP. This code is central to the functioning of the database, as it provides links to the other tables. The first five characters are letters, all upper case. The first letter identifies the fossil group ( $D$ for Diatoms, $N$ for Nannofossils, etc.). The next four letters are characteristic of the genus. The last four characters are numbers and give the species number in the genus. DSDP started with 0010 and incremented by units of 10 for each new species name. ODP does not use codes to identify species names. Thus, we created new codes for new species names that occur in ODP range charts. To avoid any overlap, we have used the same 5 letters to identify the group and the genus, but started with 5010 to number the new species (DSDP never had numbers higher than 2500).

Every entry has other information attached to it. The Status (or validity) field is a single uppercase letter which states that the name is V-alid, a S-ynonym to another name (with corresponding taxon code entered in the 'synonymous to' field), I-nvalid, Q-uestionable, or U-nknown. A G is used to indicate a genus-level name. Every name has also an author code (initials of person responsible for the entries in the Status field) and a date ( $\mathrm{mm} / \mathrm{dd} / \mathrm{yy})$. Comments of any length are also entered in the 'Comments' field. 
Additional species' records are available in the 'Species by Hole' table which comes directly from the DSDP data set. The current table, reformatted from the original data set to save space, contains simply a Taxon Code and a Hole field.

\subsubsection{Age Models and Hole summary data ('Age Models' and 'Hole Data'} tables). The 'Age Models' table contains the age model developed for each hole with range chart available in the database. The age model was constructed by a broken line composed of straight segments, which can be horizontal in the case of hiati. The extremes of the segments are identified by age and depth and entered in the corresponding field, next to the 'Hole' field. To keep track of which age model is being used in the database, each age model's time of creation date stamp is entered automatically in the 'Hole Data' table ('Age model version'). This latter table contains a variety of information, including latitude and longitude, water depth, ocean basin, hole length and recovery, etc. Holes that have an age model (and therefore range chart data) have an entry in the 'Age Model version' field and a ranking for each fossil group (originally used to select holes).

\subsubsection{Sample Info ('Sample Data' table). Most of the fields in this table are} created directly from computer files or by Neptune. Each sample described in each range chart is identified by a unique digital code and is specific for one fossil group. This means that, if in one sample (identified as depth in a hole (mbsf), but also in three separate fields as core-section-depth interval format - grouped in Figure 4.2 under 'Sample Name') both diatoms and radiolarians ('Taxonomic Group' field) were described, this sample would be described twice in Neptune, each time with a different 'Sample Code'. The age of the sample is derived from the 'Age Model' table through a relational link. If available, information on the preservation and abundance of the specific fossil group in that sample is also given.

4.1.1.4. Paleogeographic data ('Geographic Info' table). With the addition of Paleogene range charts, I considered it necessary to locate species occurrences in their appropriate paleogeographic position. For this purpose, I used a PC-based program kindly provided by Alan Smith (Cambridge University) which uses finite rotations. The program is based on published reconstruction data (Euler rotations and their ages) used to move a given site relative to Africa and then reposition that site in paleomagnetic coordinates (Smith, personal commun., 1997). The input file contained present latitude and longitude: paleolatitudes and paleolongitudes were determined for each hole at $5 \mathrm{~m}$.y. intervals. This approximation was necessary to simplify the entry of these data into Neptune, but I believe that it does not significantly affect the already approximated estimate of paleolatitude and paleolongitude made by the finite rotations program. These paleogeographic data, with hole and age, were imported into a separate table ('Geographic Info') and the Sample Code used to link it to other tables.

\subsubsection{Importing data into Neptune (range charts and age models). Data can be} imported into Neptune by the 'administrator' (this function is not available in the 'user' 
mode or with the runtime version of 4D). Most of the DSDP range charts were imported directly from the DSDP CD-ROM data, but ODP data need to be imported as individual spreadsheet format files. Each procedure creates automatically new sample records for each sample in the range chart data ('Sample Data') and new 'Bug Data' records for each non blank cell of occurrence data in the range chart. No ages are assigned in this procedure and all sample ages are set at zero. Only when the age model is imported, a corresponding age is recorded in the age field of the 'Sample Data'.

Each range chart file needs to hold data for one hole and one fossil group only. Each sample must be entered in one row in a 'leg-hole-core-section-first depth-second depth' format (e.g., 113-689-B-2H-1-115-116). These data are automatically entered in the corresponding fields in the 'Sample Data' table. The depth in mbsf is derived from the 'Core Data' table, where the core depth files for each hole are imported as soon as a hole is selected. Species names must be entered as Species Codes (9 characters, e.g., DACTI0020). Every species code present in the spreadsheet must be already available in the 'Taxonomy' table. The 'import from spreadsheet' procedure in Neptune automatically checks each DSDP Code in the spreadsheet and if it encounters a code that is not present in the 'Taxonomy' table, the procedure aborts.

Age information is present in Neptune in two forms. The 'Age Model' table actually holds all the line of correlations (age models) for each hole. Age for samples are calculated from the line of correlations and stored as calculated fields in the 'Sample Data' table. This calculation is done only once, when the age model is read into the database, and is automatic. Only one age model can be imported at a time. To update an existing age model, it is sufficient to read in the new file and the old ages will be automatically replaced by ages based on the new line of correlation.

4.1.3. Report capabilities and external graphics. Data can be extracted from the database in a variety of ways. The results can be then saved as export files, that can eventually be used with other programs. Procedures that search for taxa, in either the 'Bug Data' table of stratigraphic occurrence information, or in the 'Taxa by Hole' table of biogeographic information, create lists of Taxon Codes (from 'Taxonomy') to search for. These lists include the taxonomic name/s requested by the user, but are supplemented by lists of synonyms to these names. Users can edit these lists to fine-tune searches.

In addition to export formats for statistics and spreadsheet packages (usually in ASCII format), the database exports data in formats specific for two types of graphic data display. Data on the location of specific DSDP/ODP sites can be plotted in a map form using Atlas ${ }^{\text {TM }}$ (WTC Scientific). The most recent version of this program for Macintosh computers does not run reliably on PowerPCs and the use of the PC IBM-compatible version (which

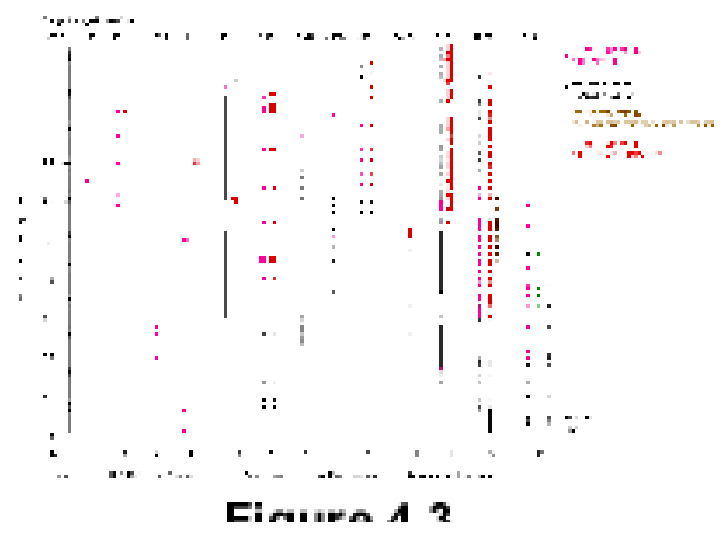


can use the same cross-platform file) is recommended. A custom application creates graphic displays of occurrence data for taxa, plotted by age and hole ('Age Range Charts', Lazarus 1994) (Fig. 4.3).

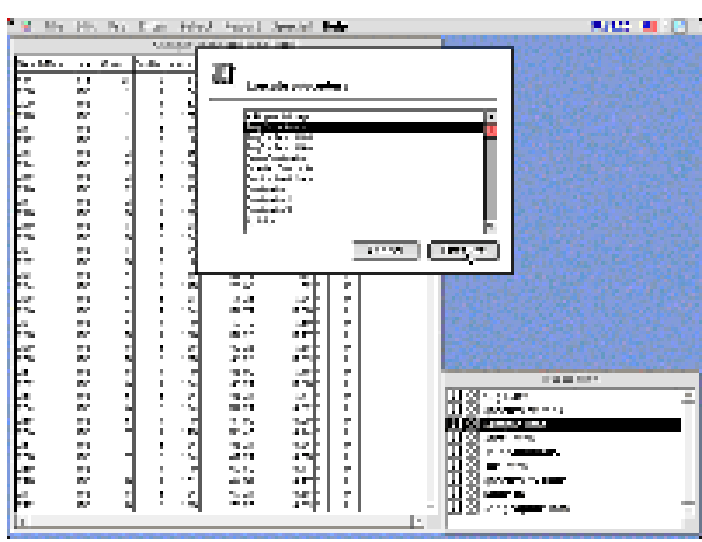

Figure 4.5.

4.1.4. Searching the database. The simplest way to search Neptune is by using the built-in 4D 'Search Editor' (under the 'Select' menu). Any of the tables previously described (Species Names, Hole Info etc.) can be selected from the list in the small window that automatically appears when Neptune is started. This shows a window with all the records in that table. The 'Search Editor' function displays a dialogue window which shows the fields available in the table. Only fields in bold can be selected and additional search criteria (equal to, contains, less than etc.) added. The results of the search are displayed in a few seconds (Fig. 4.4).

More complex procedures, such as a 'Bug Data' search, allow to locate range chart data about one or more taxa. These predetermined procedures can be selected with the 'Execute Procedure' function under the 'Special' menu (Fig. 4.5). The 'Bug Data Search' procedure first shows a search editor window for 'Species Names' and waits for a taxon entry. This can be formulated as 'Species - is equal to - name' or done directly with DSDP codes (Fig. 4.6). This procedure locates all taxa matching the entered criteria, as well as other taxa identified in

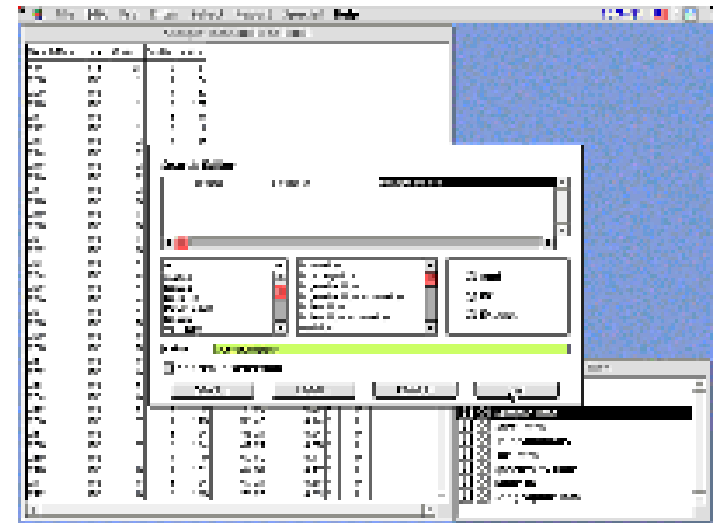

Figure 4.6. the database as synonyms for any of these. The user can then select one or all of the identified taxon names and click the 'done' button at the bottom of the window (Fig. 4.7). The procedure then searches the 'Bug Data' table to locate all records for this list of taxa. This search is done using indices, and only takes a few seconds (Fig. 4.8). 


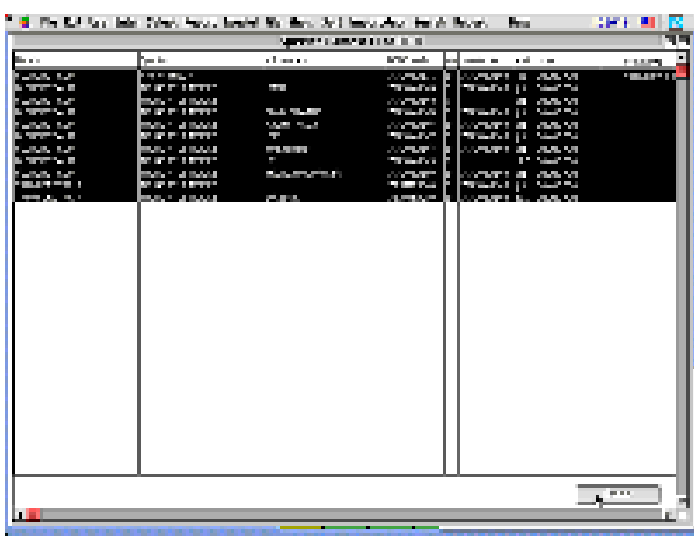

Figure 4.7.
The procedure informs the user via a dialogue box how many records have been found, and then presents the search editor window a second time. At this point the user can enter any other

criteria, such as only samples with ages greater than 0 (i.e., holes with age models), or from holes from a specific geographic location (Fig. 4.9). The 'search in selection' box (lower left corner) is automatically marked allowing to search only among the already identified occurrences (and not the whole database!). The user should then click 'ok' to proceed. The procedure will refine the selection according to these secondary criteria, and present the user with a list (Fig. 4.10). This list can also be edited to refine the selection. Lastly, the user clicks 'done' to exit the procedure. The selected records can then be printed, exported to disc, or summarized in a report.

A search procedure is also available to the automatic search for the ages of all samples recording several taxa given in a list (and their synonyms). This 'Batch Search'

('BugDataSearchBat') allows for the automatic operation of the series of procedures described above (Species name selection, identification of synonyms, bug data search, restriction to holes with age models, sorting of samples by age). It produces one separate output file for each name, as well as a cumulative file. This procedure was used to obtain

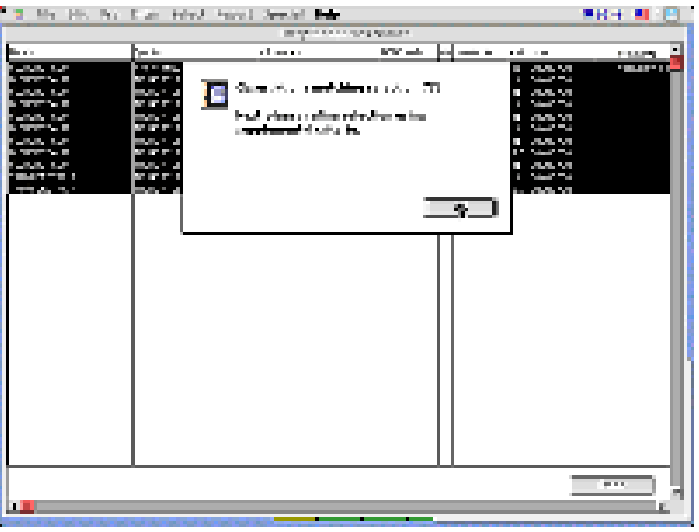

Figure 4.8. species longevity data (described below). Alternatively, samples can be sorted by latitude and longitude to obtain ranges of geographic distribution of taxa through time (e.g., to identify cosmopolitan or endemic taxa).

\subsection{Paleontological research based on Neptune: plankton evolution}

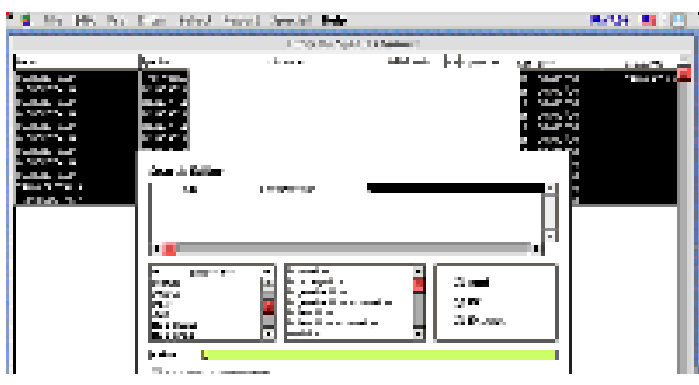

In this and in the next section (4.3), I am presenting a summary of published paleontological and stratigraphic research conducted with Neptune, as well as some unpublished data on macroevolution. Neptune's potential for paleontological research has been, so far, only marginally exploited. In spite 


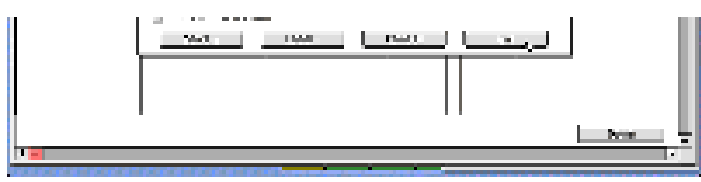

Figure 4.9. of the limitations outlined in Chapter 3, the database provides the opportunity for large-scale macroevolutionary studies that could go well beyond presently available studies (e.g., Jablonski 1993; Kammer et al. 1997). The age control and time resolution, combined with the taxonomic information at species level on four distinct plankton groups, make Neptune a high quality data set.

Currently, the two studies we published on evolution were focused on the evolution of one foraminifer species and were based on Plio-Pleistocene sediments, which are represented in a large number of holes in Neptune (Lazarus et al. 1995b;

Spencer-Cervato and Thierstein 1997). The goal of these studies was to document patterns of evolution of a new species (the planktic foraminifer, Globorotalia truncatulinoides) from its ancestors and to identify speciation and migration in distinct biogeographic provinces by using the tests' morphometry. In addition, we attempted to determine the environmental conditions (water depth, thermal structure of water column) at the time of speciation or immigration with stable isotope geochemistry. Whether changes in these environmental conditions were a determinant factor in the speciation or migration,

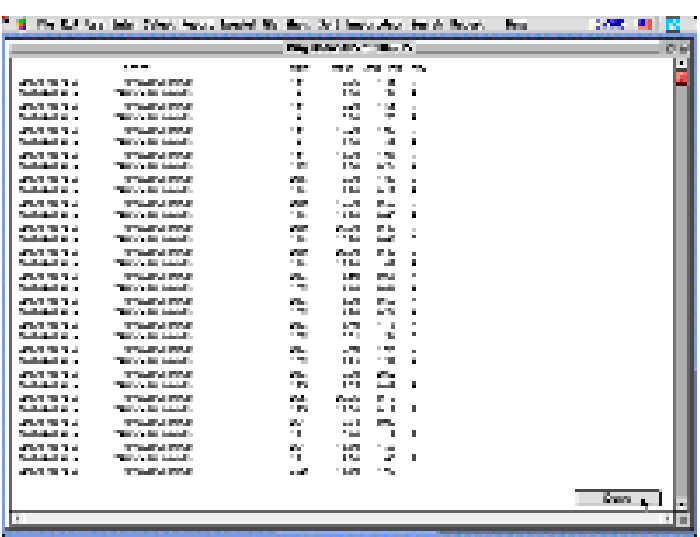

Figure 4.10. even after these detailed studies, remains still speculative.

For these studies, Neptune was used in the selection of sites by identifying the occurrences by hole and FADs/LADs (first appearance datum/last appearance datum) of the species and its ancestors. An age range chart was produced from the search for all G. truncatulinoides and related species occurrences (Fig. 4.3). This was used

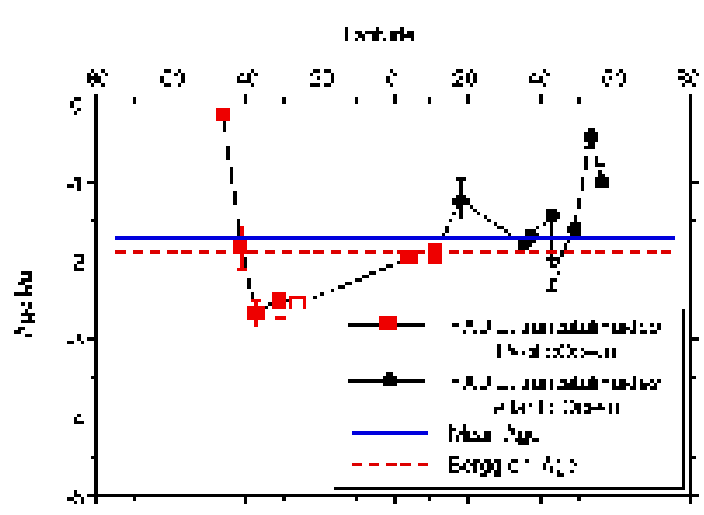

Figure 4.11. to identify the oldest first occurrences and to have an overview of the age distribution, which shows a distinct diachrony (Fig. 4.11). This search lead to the selection of suitable DSDP and ODP sites from which samples were requested. The samples were then analyzed morphometrically and isotopically to determine patterns of evolution (in this case, cladogenesis or phylogenetic branching) and species migration (Lazarus et al. 1995b;

Spencer-Cervato and Thierstein 1997).

The earliest first occurrences are found in several sites in the southwest Pacific. Gradual cladogenesis was documented in this region during the late Pliocene in sympatric or parapatric populations (Lazarus et al. 1995b). Based on qualitative 
observations, similar but younger, gradual transitions had been reported from other areas of the world's oceans. Therefore, the hypothesis arose that this gradual evolutionary branching might have occurred in response to changing environments at different times in different ocean areas. To evaluate this hypothesis, we studied the morphological transitions of the three taxa, using image analytical techniques, in several deep-sea sections from various areas, identified with Neptune (Spencer-Cervato and Thierstein 1997). The morphometric analyses showed that $\mathbf{G}$. truncatulinoides evolved between 2.8-2.3 Ma sympatrically in large populations from its ancestor G. crassaformis in the southwest Pacific. Differentiated morphotypes of G. truncatulinoides subsequently immigrated into the Indian and Atlantic Oceans between 2.3 and 1.9 Ma. Our morphometric data show these younger appearances outside the southwest Pacific to be punctuated, and representing migration events (Spencer-Cervato and Thierstein 1997).

One of the most crucial, yet elusive issues in evolution is the role played by the environment in the appearance of a new species or its extinction. Planktic foraminifera are ideally suited for these studies because of the large populations, widespread occurrence of tests in marine sediments, relatively large size that allows for detailed identification with traditional microscopic techniques, abundance of information on living populations and their habitats, conceivably rapid colonization of biogeographic provinces under suitable conditions, and the possibility to reconstruct these conditions (e.g., water depth, temperature, nutrients) with stable isotope geochemistry.

Globorotalia truncatulinoides is an ideal species for the study of the environmental conditions at the time of speciation. We hypothesized that the global cooling of surface waters, coinciding with the northern hemisphere glaciation, led to the formation of oceanographic barriers that could have retarded the expansion of $\mathbf{G}$. truncatulinoides up to $2.3 \mathrm{Ma}$. At this time, a relative warming and subsequent transgression could have spurred the migration from the southwest Pacific into the Indian Ocean, possibly through the Indonesian passage. A direct link between the speciation and surface water changes linked to the northern hemisphere glaciation has not been proven so far and seems unlikely. In fact, stable isotope data in G. truncatulinoides and its ancestors indicate that the three species' depth habitat preferences remained unchanged through the speciation and migration of $\mathbf{G}$. truncatulinoides and that all three species were dominantly deep-dwellers, in agreement with their present environmental preferences (Spencer-Cervato and Thierstein 1997).

One of the original goals of the Neptune project was to perform macroevolutionary studies. Macroevolution is a major area of paleontology that developed during the 1970s and 1980s, inspired by the apparent success of the taxic approach to evolutionary patterns (Smith 1994). Macroevolution covers various concepts and processes. These studies differ from the previously described, 'microevolutionary' ones - which concentrated on the heritable variations of a population composed of one species and its immediate ancestors - mainly in the scale. Macroevolution studies 
large-scale patterns of diversification and extinction arising from processes active at or above the species level (Smith 1994 and citations therein). Some workers have instead defined macroevolution as the extrapolation of microevolutionary processes into geological time (e.g., Levinton 1988). Smith (1994, Chapter 4) presents a comprehensive review of macroevolutionary concepts and theories.

Existing studies mainly consider fossil records of marine invertebrates in high hierarchical groupings (orders, families) with low stratigraphic age resolution (e.g., Jablonski 1993) from punctual, geographically restricted sources. Amongst the various causes of artifacts in macroevolutionary patterns, sampling resolution seems to be an important biasing factor (e.g., Alroy 1998). The chronological control of Neptune and its large amount of paleontological data with taxonomic accuracy at species level, combined with its comparably high sampling resolution (on average, 185 k.y. for the Neogene (Spencer-Cervato et al. 1994) and 330 k.y. for the Paleogene) holds promise for potentially significant contributions to this field of paleontology. Because the quality of the results of macroevolutionary studies is strongly dependent on a sound basis of chronology and taxonomy, we have first exploited the stratigraphic data set (see Section 4.3) and revised the taxonomy of the paleontological records (Section 3.3). We have thus left the study of macroevolutionary patterns in marine plankton to the final phase of the project.

I am presenting here some examples of data searches conducted with Neptune to answer some typical paleobiological questions. They cover the overall longevity and speciation/extinction distribution of Cenozoic marine plankton. I am purposely leaving the discussion and interpretation of these data to an absolute minimum. My goal is in fact to show what type of data can be obtained from the database and the potential of Neptune for paleobiological research.

To optimize the diverse paleontological data set in Neptune, the analyses have been conducted separately for the four plankton groups and the results interpreted in terms of similarities or differences among the groups. The data presented here are based on more than 1400 valid species names (Table 4.1), and include the occurrences of their synonyms. The output of every species' search consisted of their oldest first appearance and their youngest last appearance. Every result was checked to eliminate false entries caused by, for example, occurrences near hiati, typos, occurrences reported in one single sample, etc. Species that were reported only in one hole were not considered to eliminate the bias of single geographic data points. Finally, one table was produced for each group including the species name, the number of times it had been reported in a sample, the location (paleolatitude and paleolongitude) and age of its first appearance, and the location and age of its last occurrence. From these ages, the species' longevity was calculated.

- What is the distribution of the longevity of plankton species? Are there substantial differences or similarities among the four plankton groups?

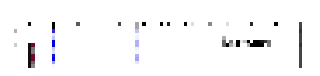


distribution of the four groups with a 1 m.y. resolution. Comparing the four groups, three simple observations can be made: (1) all groups show an asymmetric, unimodal distribution, with a mode around 7 m.y. (diatoms and radiolarians), 14 m.y. (foraminifera) and 19 m.y. (nannofossils), and a tail towards higher longevity values; (2) the median for all distributions is around 10 m.y., except for diatoms, where it is around $7 \mathrm{~m}$.y. - comparing

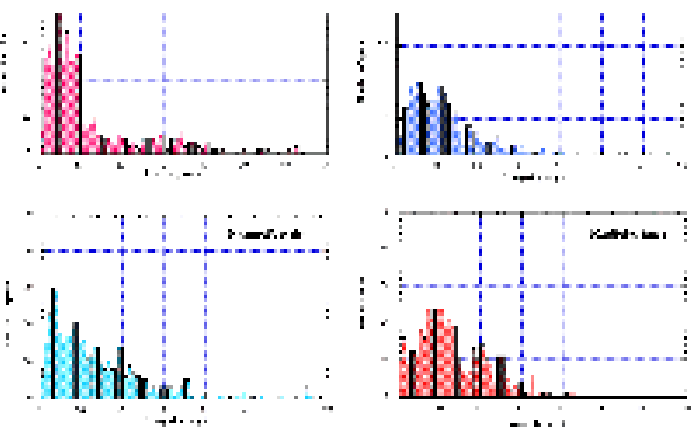

Figure 4.12. these values with the mode, the peak of the distribution of diatoms is narrower and has a higher symmetry than the other groups; (3) a few phytoplankton species (diatoms and nannofossils) are very longevous (more than 40 m.y.), whilst zooplankton species (foraminifera and radiolarians) live all less than 43 m.y. These observations point to similarities between phyto- or zooplankton in one case, and between siliceous or calcareous plankton in another. However, they also show that diatoms are quite distinct from the other groups.

- What is the average species' longevity? Are there substantial differences between extinct and extant species' longevities?

Table 4.2 shows the average longevity (and standard deviations) of both extant and extinct plankton species. It is noticeable that the longevity of extinct species is consistently shorter than the one of extant species. This could be due to the different sizes of the populations considered (less than 30\% of the species are extant), which might also explain the larger standard deviations of extant species' longevity.

Alternatively, this could be the effect of differential preservation. Or it could be caused by the artificial boundary set at the beginning of the Cenozoic - the data might include species originated in the Mesozoic, giving them a shorter-than-real longevity. However, only a very small number of species (e.g., the extant nannofossils Braarudosphera bigelowii and Scapholithus fossilis, the extinct nannofossil Placozygus sigmoides; Perch-Nielsen 1985) are reported also from the Mesozoic. Statistically, they should not significantly affect the data set.

For demographic reasons, one would expect a gradually decreasing longevity instead of the asymmetrical peaks shown in Fig. 4.12. Is this lower-than-expected number of short-lived species an artifact of the analysis or a real signal? On the other hand, the differences seen in the longevity data could be real, suggesting for example that species which evolved in the Neogene (the majority of the extant species) are more likely to live longer. One can only speculate on the cause of this, such as larger surface water temperature gradients linked to growth of ice caps in polar regions? However, the Neogene climate mode, characterized by abrupt shifts from glacials to interglacials and vice versa, would seem to provide stressful environmental conditions that intuitively should increase species turnover, i.e., shorter longevities. This question requires further analyses (e.g., longevity plots at selected critical times) before a viable hypothesis can be formulated. 
To help answer the various open hypotheses on species' longevities, an important factor that should be considered is the geographic distribution of species throughout their duration. This parameter allows to identify endemic versus cosmopolitan species and is an important factor in ecological studies. By comparing this parameter with species longevity, one would test if a species restricted to a narrow geographic region is more likely to survive longer than a globally widespread species, or vice versa.

- Are there periods in the Cenozoic with a high concentration of species' appearances or extinctions? Are there geographically defined speciation centers or survival refugia?

Appearance and extinction rates were calculated for the four groups to eliminate the bias of the sample size (Wei and Kennett 1983). The rates are calculated as the ratio between the number of extinctions or appearances and the total diversity (number of species) in each $1 \mathrm{~m}$.y. time slice. The Cenozoic appearance rates are shown in Fig. 4.13. Appearances are widespread throughout the Cenozoic and no specific time interval is characterized by anomalously high appearance rates, with the exception of the Paleocene. The graphs show that diatom, radiolarian and foraminifer species appeared all during the Cenozoic, with $100 \%$ peaks in the Paleocene, while only $50 \%$ of the nannofossil species present in the first million year of the Cenozoic appeared then the remaining 50\% existed already in the Mesozoic (see above for some examples). The apparent late appearance of radiolarians in the early Cenozoic is probably an artifact of the data set: no radiolarian reports are available for the Paleocene (Fig. 3.5). Average appearance rates are less than $10 \%$ and
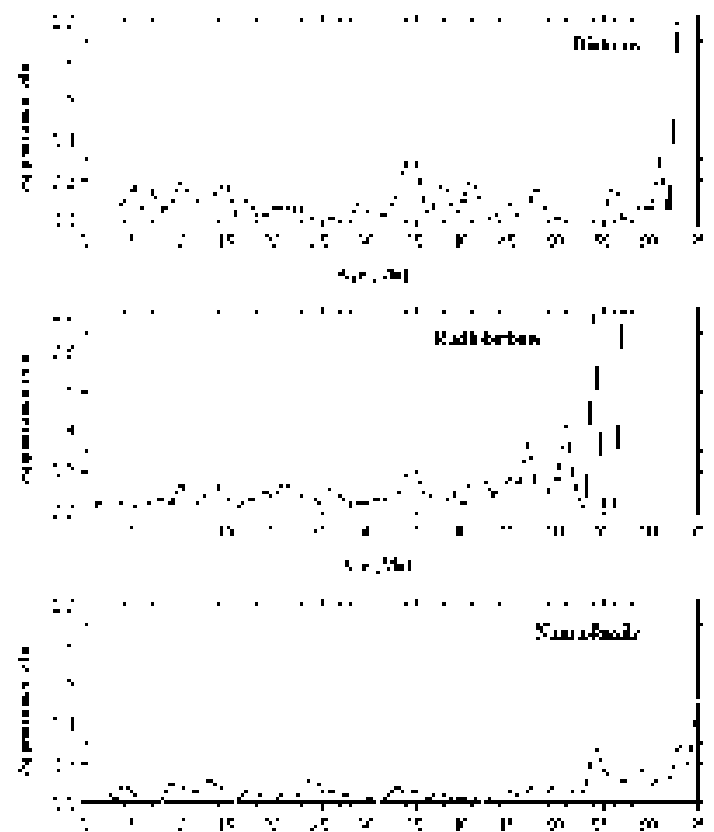

$\Delta \mathrm{g}$ |н :

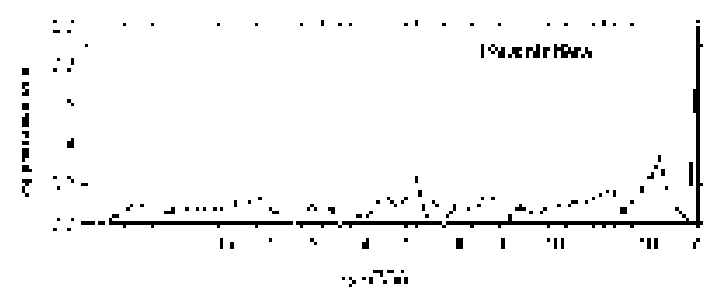

Figure 4.13. only rarely reach $30 \%$, and are characterized by short fluctuations with a somewhat random frequency. In some instances (e.g., at 61 $\mathrm{Ma}, 35 \mathrm{Ma}, 10 \mathrm{Ma}$ ), peaks of appearances in one group correspond to peaks in other groups, but no consistent pattern is apparent.

Extinction rate values are much lower than appearance rates and show a more random distribution (Fig. 4.14). Diatoms show a distinct peak in extinctions at the Paleocene/Eocene boundary which is not clearly reproduced in the other groups. On the other hand, radiolarians, nannofossils and foraminifera show a minor peak around the Oligocene/Miocene boundary (25-22 Ma), while all groups (with the exception of radiolarians) show exceptionally high extinctions in the past 3 m.y.

It is interesting to notice that these trends do not 


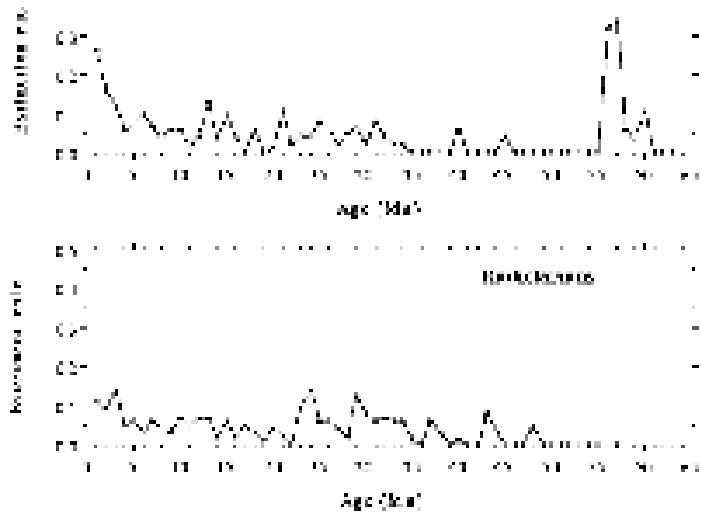

correspond to peaks in appearances (Fig. 4.13), but there seems to be a time lapse of a couple of million years between the peaks in extinctions and appearances as the two curves are mostly out of phase. The increase in extinctions in the last 5-7 Ma might be related to the onset of highly variable environmental conditions, which apparently did not cause a corresponding increase in the rate of species' appearances.

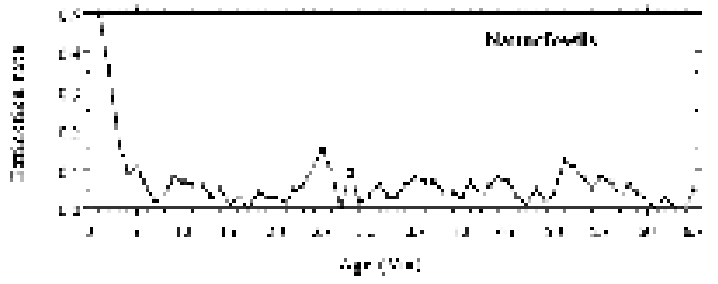

Speciation centers and survival refugia are discrete geographic regions with high concentrations of appearances or extinctions. These are often associated with particularly favorable or stressed environmental conditions and may be limited by

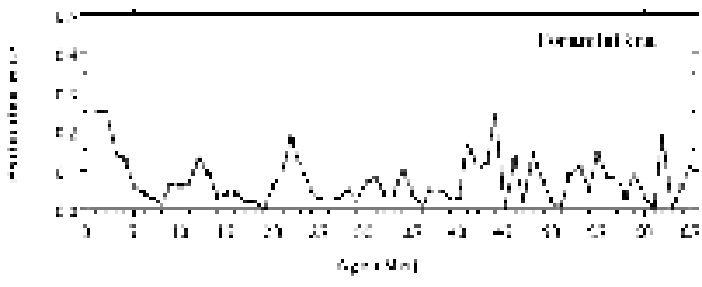
biogeographic or oceanographic boundaries (e.g., Jablonski 1993). One simple way to identify these regions is by plotting the latitude of the location of the earliest first appearance or the latest last appearance (Fig. 4.15). The latitudinal distribution

Figure 4.14. of FADs (and of LADs, not shown here, but with an identical pattern to FADs) is clearly different in siliceous and calcareous plankton. Appearances and extinctions of diatom and radiolarian species are concentrated in three belts, around the equator and at mid- to high northern and southern latitudes respectively. These belts are bound by well established nutrient boundaries, like e.g., the polar front. This pattern
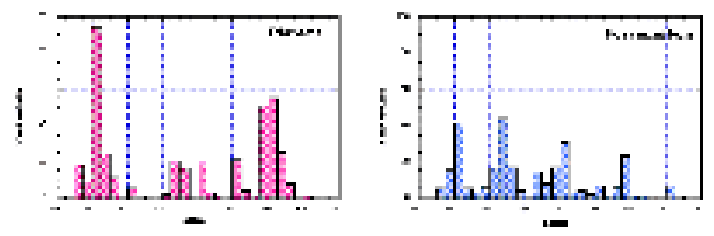

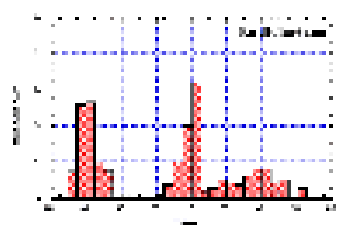

Figure 4.15. also reflects the present distribution of siliceous plankton in marine sediments (e.g., Leinen et al. 1986), suggesting that the environmental preferences of these organisms did not change through time. A different scenario is presented by calcareous plankton groups, whose appearances (and extinctions) are more uniformly distributed throughout the latitudinal range.

- How did plankton diversity change through time? How do the patterns for the four plankton groups compare?

Even with the limitations summarized in Chapter 3, I attempted to estimate the distribution of plankton species' diversity during the Cenozoic. This 'partial' diversity, limited mainly to occurrences of biostratigraphic markers and biased by the low number of extensive range charts published for DSDP and ODP holes, is still a very comprehensive estimate, even though not a 'real' diversity. I present here some preliminary results based on the data included in Neptune. 
The total species richness for the four plankton groups was calculated at one million-year intervals. To eliminate the bias of the uneven distribution of the number of sections in Neptune (progressively more sections in younger times, Fig. 3.2), I have normalized the diversity by dividing it by the total number of sections in each

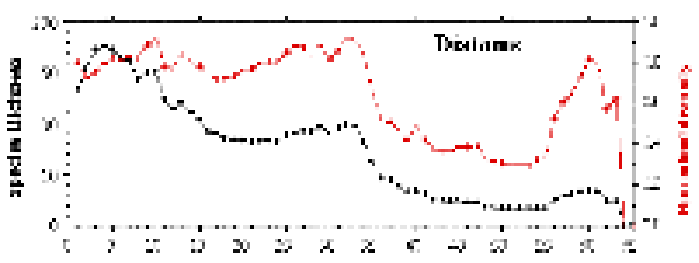

sornhi
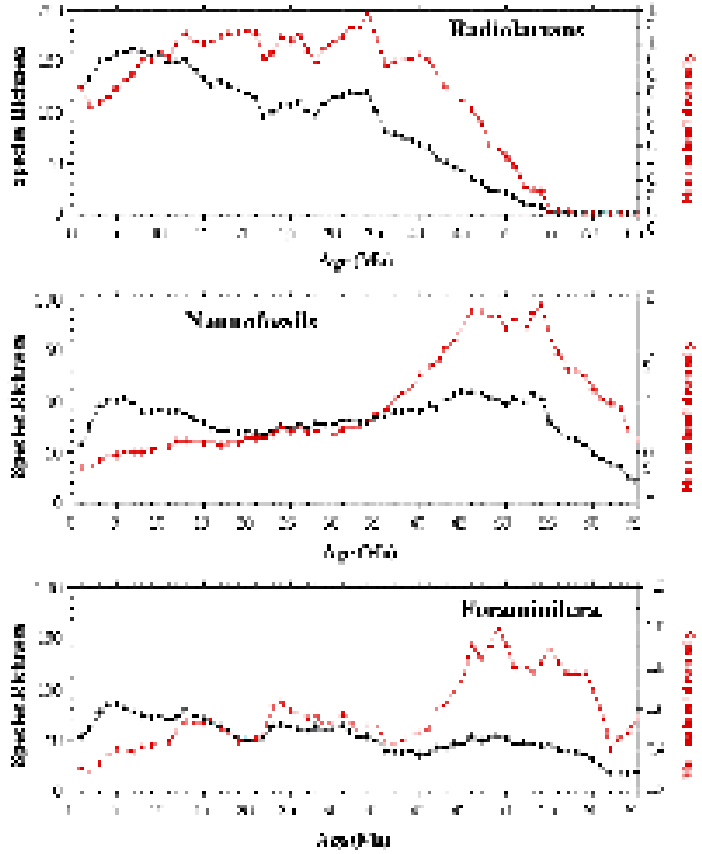

Figure 4.16.

time interval. The results are shown in Figure 4.16. The normalized diversity patterns shown by siliceous plankton are quite similar and clearly distinct from what is shown by calcareous plankton. The two distinct patterns shown by the siliceous and calcareous plankton groups are exactly out of phase, with diatoms and radiolarians showing maximum diversity in the Oligocene to Recent, when nannofossils and foraminifera show their minimum values. Both diatoms and radiolarians show a gradual increase in diversity peaking around the Eocene/Oligocene boundary, followed by a relatively stable plateau during the Neogene. Diatoms also show a peak of diversity in the late Paleocene, when radiolarians are not reported. Diversity of nannofossils and foraminifera, instead, peaked during the early to middle Eocene, decreased in the late Eocene, and has remained more of less constant since the Oligocene.

While it is possible that much of the general variability is due to taphonomy, several further speculations could be made on these patterns. However, potential biases would have to be examined first. For example, what is the lithology of the sections in Neptune through time? Are siliceous sediments more common in the Neogene, thereby explaining the higher siliceous plankton diversity? And how do the absolute normalized values compare? The highest values are recorded in nannofossils while the lowest ones are given for diatoms. The number of valid species names in the two groups is almost identical (Table 4.1), but nannofossil names (valid and non valid) are overall slightly more abundant than diatom names in Neptune (Fig. 3.4). However, 


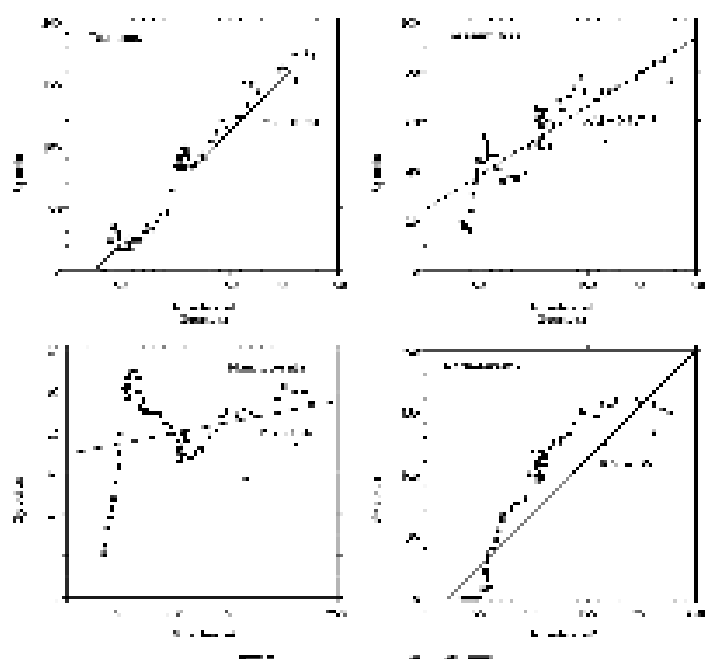

Figure 4.17.

foraminifera and radiolarian names are the most abundant ones of the four groups, while their normalized diversity is intermediate between diatoms' and nannofossils' diversity. Is there a consistent bias in the published range charts, with more reports available on siliceous plankton than on calcareous plankton in the Neogene? The number of reports on Paleogene sections (Fig. 3.5) shows a relatively lower number of reports on siliceous groups than on calcareous groups. The high correlation shown between diatoms' and radiolarians' species richness (and to a lesser extent foraminifera) and the total number of sections available for each time interval (Fig. 4.17)

suggests that absolute values of species diversity are strongly biased by the size of the data set (i.e., more species are described when more sections, and therefore reports, are available). On the other hand, the species richness of nannofossils shows a complex polynomial correlation with the number of sections but a completely random linear correlation $(\mathrm{R} 2=0.07)$. This may be due to the fact that the correlation is made with the total number of sections and not with the number of sections that contain nannofossil stratigraphy. For nannofossils and foraminifera the latter may be the significant parameter which would perhaps show a higher correlation with the species richness, similarly to the one shown for siliceous plankton.

Finally, how strong is the bias caused by the dominant presence of stratigraphic markers in the reports? Siliceous plankton biostratigraphy is better developed for Neogene sediments than it is for the Paleogene, while it is more uniform for calcareous plankton groups. One approach to this question would be to separate the species included in the distribution into stratigraphic markers, other common taxa and rare taxa, and see if the diversity patterns remain the same or change substantially.

These are only some of the factors that one must consider before a feasible interpretation of these trends can be formulated, and some of these require the addition of data to Neptune which are not currently available (e.g., distribution of siliceous versus calcareous sediments). But however preliminary and partial, these results are still quite encouraging and represent a more detailed data set than what is available from the paleobiological literature.

\subsubsection{Availability of relational databases for the paleontological community: the} ODP database JANUS versus Neptune. At present, the ODP database, JANUS, which is currently available onboard the JOIDES Resolution and through the WWW, does not represent a viable substitute for Neptune. I must point out, however, that JANUS is very new and that the import of data has just begun. My experience with JANUS is limited to a superficial browsing through ODP's database WWW site, which provided me with the following information. Site data (water depth, coordinates, length 
drilled, length recovered, etc.), physical properties (e.g., GRAPE, magnetic susceptibility), and chemical results (e.g., carbonate content) represent the bulk of the database and are available for most ODP Legs. Age model and paleontological information are part of the database structure, but (as of March 1998) are given only for a handful of sites. There is one general grouping ('Paleontology') which is divided into four searchable tables: Age Model, Paleontological Investigation, Range Table, and Species Information. Age Model information is currently (as of March 1998) available only for one hole in Leg 105 and consists of two points, the top of the drilled section and the bottom. ODP is probably planning to progressively add more detailed age model data for all ODP sites.

I used a simple, predetermined query to search the database for paleontological information and I only obtained very preliminary information, such as the name/s of the paleontologist/s who did the shipboard study, the depth in meters below seafloor of the samples analyzed, their relative stratigraphic position (e.g., middle Eocene), and the abundance and preservation of the microfossil group. As this information was available only from Leg 171 onward, legs for which no reports are published as yet, I do not know if it is planned to add more detailed paleontological information (e.g., the range charts that are available in Neptune) from the Scientific Results, once they become available.

Very basic taxonomic information is also available. For example, the search for 'Globorotalia truncatulinoides' resulted in the name of the author who named the species (d'Orbigny), when the species was first described (1839), and the stratigraphic interval it is found in (Neogene).

I finally attempted to develop a customized 'Power Query' to search JANUS but I did not succeed. No instructions were given on how to select the various items present in the relational tables and the query routine was neither user-friendly nor intuitive.

While JANUS is undoubtedly a very valuable resource for site information and shipboard results (mainly physical properties), the preliminary search of the paleontological content of JANUS suggests that Neptune is still clearly a more valuable source of paleontological information. Although I do not see how JANUS and Neptune could be easily integrated, the two databases certainly complement each other. As shown in the studies outlined above (Lazarus et al. 1995b; Spencer-Cervato and Thierstein 1997), Neptune can be extremely helpful to biostratigraphers during ODP cruises, for example for the identification of the taxa previously recorded in a specific region during a certain time interval, thereby restricting the field of species identification to likely occurrences.

4.3. Stratigraphic research with Neptune: diachrony and hiati distribution. The field where Neptune's potential has been already quite thoroughly exploited is stratigraphy. The chronology of Neptune's holes has been revised several times and even if the quality of age models is quite varied (Table 2.1), it still represents the most complete and reliable data set available for stratigraphic studies. Two major groups of 
information have been derived from this data set, the first directly applicable to biostratigraphy, the second of a stratigraphic and paleoceanographic significance.

The goal for the first group of studies (Spencer-Cervato et al. 1993; 1994) was to determine the reliability of biostratigraphic markers, in terms of their regional versus global significance and of their synchrony or diachrony. As mentioned in Chapter 3 , siliceous biostratigraphy is based on several regional calibrations of events, whilst calcareous biostratigraphy relies on a single, mainly low-latitude calibration (Berggren et al. 1995a, $\underline{b}$ ). The use of the latter approach (one calibration for all holes, irrelative of their biogeographic location) implies a global synchrony of biostratigraphic events, that has actually been demonstrated only in very few cases. The first study (Spencer-Cervato et

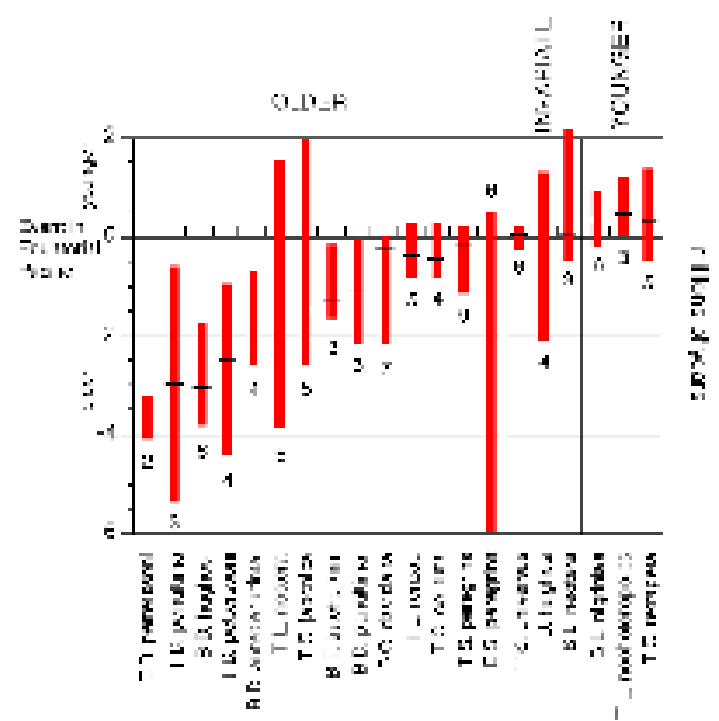

Figure 4.18. al. 1993) was aimed to calibrate several Neogene radiolarian events in the north Pacific and to study the degree of diachrony within this biogeographic region (Fig. 4.18). The projected ages of radiolarian first and last occurrences derived from the line of correlation of age/depth plots from the North Pacific have been computed from twelve North Pacific sites, and 28 radiolarian events have thereby been newly cross-calibrated to North Pacific diatom and other stratigraphy. Several of the North Pacific radiolarian events are older than in previously published equatorial Pacific calibrations (Johnson and Nigrini 1985) (Fig. $\underline{4.18}$ ), and some may be diachronous within the North Pacific. We hypothesized that these patterns may be due to complex latitudinal patterns of clinal variation in morphotypes within lineages, or to migration events from the North Pacific towards the Equator.

The second, more comprehensive study (Spencer-Cervato et al. 1994) evaluated the synchrony and diachrony of 124 commonly used Neogene biostratigraphic events in 35 globally distributed DSDP and ODP holes. Global mean age estimates based on combined biostratigraphy and magnetostratigraphy were calculated for each event. The ages' standard deviations were used as an estimate of synchrony/diachrony. Average standard deviations for event ages by fossil group are: calcareous nannofossil first appearance

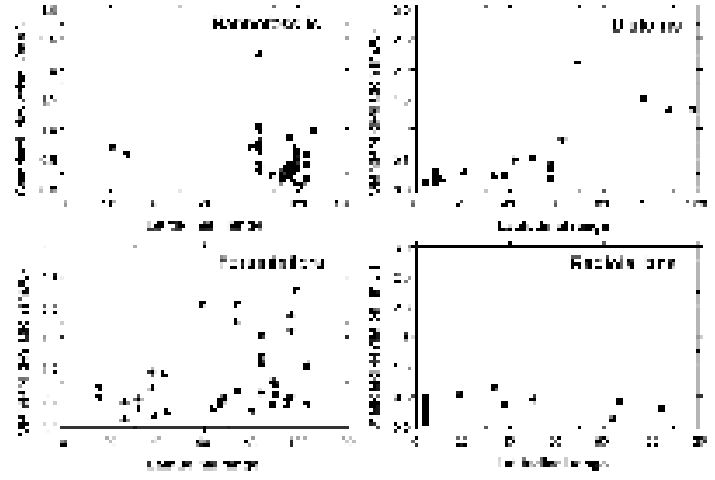

Figure 4.19. datums (FADs): 0.57 m.y. (21 events), calcareous nannofossil last appearance datums (LADs): 0.60 m.y. (25 events), diatom FADs: 0.57 m.y. (7 events), diatom LADs: 0.85 m.y. (14 events), planktic foraminifera FADs: 0.88 m.y. (22 events), 
foraminifera LADs: 0.68 m.y. (16 events), radiolarian FADs: 0.30 m.y. (9 events), radiolarian LADs: 0.31 m.y. (10 events). 53 of the 124 events can be considered synchronous, within the resolution of the method ( \pm two average sample spacings, i.e., 360 k.y.). The remaining diachronous events were analyzed for true patterns of diachrony and other biases. Generally, diachrony is more frequent among cosmopolitan than among endemic taxa (Fig. 4.19). Also, the precision of age calibrations decreases with increasing age. Some diachrony patterns may be due to investigator bias (see examples shown in Spencer-Cervato et al. 1994), but in general they appear to be, at least in part, real phenomena. Thus, they could provide opportunities for exploration of paleobiological processes (see for example the study on G. truncatulinoides described above, Spencer-Cervato and Thierstein 1997).

A similar study of diachrony was not attempted for Paleogene events and is not recommended either. The age control on the chronology of Paleogene sediments is poorer than what is available for Neogene sediments. Moreover, fewer sections were analyzed for magnetostratigraphy, which provides the independent control on the age models selected for the Neogene study described above. I expect that the patterns of diachrony that could be obtained for Paleogene events would be largely biased by the data set and, therefore, would not provide a scientifically sound basis for further studies.

The chronology of the 165 holes in Neptune was the subject of the third stratigraphic study originated from Neptune. It was mentioned in Chapter 3 that continuous stratigraphic sequences were very rare and that most age models were characterized by hiati. Hiati are commonly recognized in shelf sediments, but regional deep-sea hiati have also been extensively studied (e.g., Keller and Barron 1983). The reason for the interest in the timing and geographic distribution of hiati lies in the processes that cause them. A hiatus is a stratigraphic gap caused by erosion, dissolution, corrosion, nondeposition, rate of sediment supply versus dissolution (corrosion) of sediments (controlled by fluctuations in the calcite compensation depth - CCD), or shallow to deep water sediment fractionation (Berger 1970). Several studies have interpreted the occurrence of deep-water hiati in terms of changes in deep water circulation and corrosiveness (e.g., Keller and Barron 1987). Other studies have focused on the occurrence of hiati in continental shelf sediments and some authors have interpreted them within a framework of sea-level fluctuations (e.g., Vail et al. 1977; 1987).

For this study (Spencer-Cervato 1998) I have identified 'hiatus events' during the Cenozoic, based on the occurrence of individual hiati both in shelf and deep-sea sediments. The goal of the study was to test if there is a causal link between sea-level fluctuations (and climate change) and global occurrences of hiati, which are linked to oceanic circulation through a variety of complex processes. I initially attempted to reproduce the 'global eustatic sea-level curve' of Haq et al. (1987) with a curve of hiati distribution. This sea-level curve was constructed by the Exxon Exploration Group and 
is based on proprietary seismic data collected mainly on the eastern Atlantic passive continental margin. This curve has been a source of controversy since its publication, mainly because scientists had failed to reproduce it and because it was difficult to find physical mechanisms that could cause rapid sea-level fluctuations of more than 250 $m$, such as the ones implied in the curve. Drilling off New Jersey during ODP Leg 150X has recovered stratigraphic sequences which contain gaps that can be correlated to the ones used to construct the sea-level curve. These results (e.g., Miller et al., 1996) seem to have sedated the debates on the reliability of the sea-level curve, but the dispute on the magnitude of the fluctuations is still unresolved.

Compared to previous compilations of hiatus distribution in the DSDP stratigraphic record (e.g., Moore et al., 1978), the curve that I have obtained (Fig. $4.20 \mathrm{c}$ ) has a better resolution (0.5 m.y.), contains more recent holes with better recovery, and is based on a more reliable and updated biochronology. Other studies (e.g., Keller and Barron 1983; Ramsay et al. 1994) instead focused on specific regions, e.g., the Indian or the Atlantic

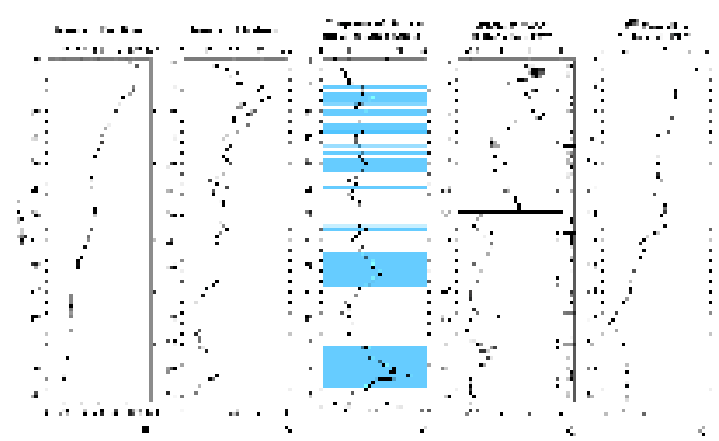

Figure 4.20. Ocean, while my study (Spencer-Cervato 1998) is of global extent.

To help in the interpretation of the record of hiati, I have estimated the paleo-water depth at which the hiati occurred and constructed three individual curves for shallow $(0-2000 \mathrm{~m})$, intermediate $(2000-3000 \mathrm{~m})$ and deep (> $3000 \mathrm{~m})$ water (Fig. 4.21). The curves show that the Paleogene is characterized by few, several million-years long hiati, while the Neogene is punctuated by short, frequent hiati events (Fig. 4.20), occurring nearly synchronously in shallow and deep water sediments. The most significant Cenozoic hiatus event spans most of the Paleocene. Epoch boundaries are characterized by peaks in deepwater hiati possibly caused by an increased circulation of corrosive bottom water and sediment dissolution. The Plio-Pleistocene is characterized by a gradual decrease in the frequency of hiati. This could be caused by several factors, including the better recovery of younger sediments and therefore a lower chance of recording artificial hiati. Alternatively, this can indicate that sediment erosion and corrosion is time dependent and thus that there has been insufficient time to create hiati in the youngest sections. However, this smooth drop can also be an artifact of the time interval chosen for this analysis, which masks the high-frequency cycles of Quaternary glacio-eustatic sea level change possibly characterized by short (<0.5 m.y.) hiati, not recorded in this study.

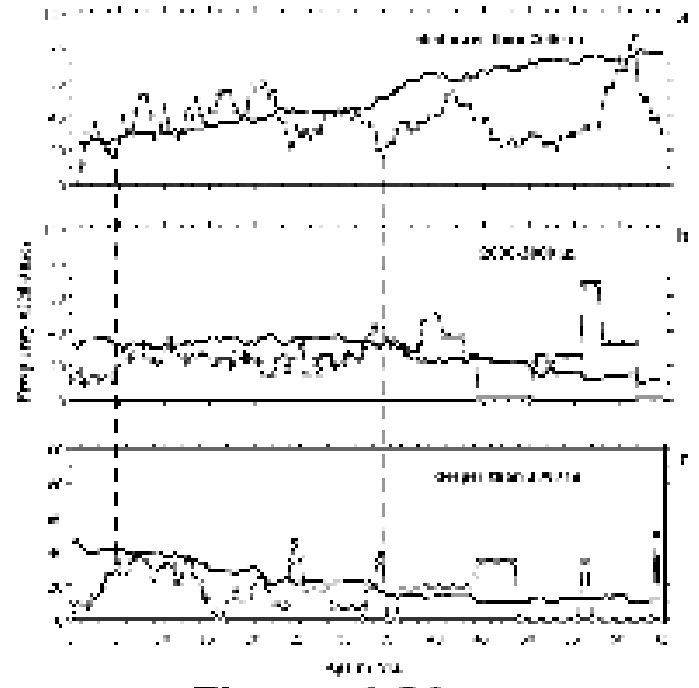

Figure 4.21. 
Although some speculations were advanced on the causes of these hiatus events, their regional significance and possible causes will be the topic of future, more detailed studies. Among these, of particular interest would be the geographic distribution of hiati within ocean basins (e.g., latitudinal distribution of hiati versus latitudinal distribution of DSDP and ODP holes in the database and western versus eastern margins to identify the temporal evolution of oceanic gyre circulation) and their comparison to detailed isotopic records of deepwater circulation (e.g., Wright and Miller 1993). The depth distribution of hiati in mid-ocean and aseismic ridge sites versus continental shelf and slope sites must be also analyzed separately. These areas should be affected differently by sea level changes.

In summary, Neptune's data have been used for five published studies of plankton evolution and stratigraphy. While the stratigraphic studies provide a quite complete overview of the potential of Neptune, the study of plankton evolution has so far been limited to biostratigraphic applications. The analysis of plankton longevity and diversity has been shown here as raw data. This is the field where Neptune's data still have much to offer to the paleontological community. In the following section, I will explore the possibility of expanding Neptune beyond the paleontological field and will suggest possible future avenues of research based on this database.

\subsection{Potential additional data for Neptune for sedimentological and paleoceanographic research}

In my opinion, the potential of Neptune for future research extends considerably beyond analyses of micropaleontological data. Neptune's chronology and relatively large number of holes are its greatest assets and they should be properly exploited. A significant step forward would be represented by the addition of sedimentological data, which would open up a whole new range of research possibilities. The expansion of Neptune would benefit the research community by providing interdisciplinary links and correlations that are at present rarely possible to scientists working on ODP material. Time pressure and poor funding force ODP-participating scientists to limit their post-cruise research to very limited, mainly isolated goals (James D. Wright, personal commun., 1998). Once their duty as sedimentologists or micropaleontologists is fulfilled and their report is submitted, scientists move quickly to the next 'hot' research topic, and the potential for correlations between data sets and large-scale research studies is left largely untouched. In this scenario, the opportunities provided by Neptune's chronology and paleontological data would be greatly enhanced by other data that would allow to make large-scale, interdisciplinary (e.g., modeling) studies, or at least would provide an easily accessible source of a large amount of quality data from which to start such studies. Only very few of these studies based on deep-sea sediments are available at present (e.g., Delaney and Boyle 1988).

Among the data that should be included in Neptune, and that are consistently available at least for the more recent ODP holes, are: lithology (percentage carbonate, percentage silica); organic carbon content; physical properties (e.g., bulk density, 
grain density, porosity); and grain-size distribution. The field of paleoceanography would be the primary beneficiary of the combination of the existing paleontological and chronological data in Neptune with sedimentological information and physical properties data. I will mention here only a couple of the several, current research questions that are debated in the paleoceanographic community and that could be addressed with these additional data.

During the middle Miocene, important changes occurred in the climate of the Earth, an important step toward the establishment of cold polar climates and the modern climate mode characterized by glacial and interglacial cycles. These changes are documented in the oxygen isotope records (e.g., Miller et al. 1987; Fig. 4.20e), and indicate the onset of a progressive global cooling. It is not yet known what causes the abrupt shifts in climate mode that the Earth has experienced in the last million years, even though some recent evidence (Zachos et al. 1997) suggest that these shifts might have characterized the earth's climate already since the Oligocene. It is, therefore, obvious why so many studies have focused on middle Miocene sediments and have led to the formulation of various hypotheses. Several hypotheses have linked climate changes to large-scale deepwater circulation (e.g., Shackleton et al. 1983), but the causal relationship between middle Miocene changes in deepwater circulation and the establishment of a permanent ice sheet in eastern Antarctica, is still uncertain (e.g., Kennett and Barker 1990).

Keller and Barron (1983) proposed that a "silica switch" occurred between the Atlantic and Pacific Ocean in the middle Miocene, around $15 \mathrm{Ma}$ and contemporary to the $\delta 180$ increase. Based on the relative abundance of siliceous sediments in nine tropical Atlantic sites, they suggested that prior to $15 \mathrm{Ma}$, Atlantic sediments were silica-rich, but that after that time, silica sedimentation switched to the Pacific Ocean. Predominantly carbonatic sediments have apparently been accumulating in the Atlantic since then. This switch would have been caused by the initiation of the Northern Component Water (NCW) circulation in the north Atlantic. However, Wright et al. (1992) have raised some concerns on the selection of data on which Keller and Barron (1983) based their hypothesis, and argue that NCW's production began earlier (around $19 \mathrm{Ma}$ ) and had actually shut down during the $15 \mathrm{Ma} \delta 18 \mathrm{O}$ event. Wright et al. (1992) propose that the middle Miocene $\delta 180$ increase does not correlate with deepwater circulation changes and does not represent the transition from an ice-free to an ice-house world, but is part of two or three glacial/interglacial cycles.

How could Neptune help solve this controversy? The cause of disagreement in the interpretations is the data on which Keller and Barron (1983) based their hypothesis.

The possibility of modeling the results of a larger number of chronologically well constrained holes in the Atlantic and Pacific Oceans would give the 'middle Miocene controversy' a strong, potentially unbiased basis of data. The data that would be needed are the concentrations of carbonate and opal. These data have not been incorporated in Neptune yet, because data from different holes are potentially 
incompatible, due to the different methods used in their collection.

Since the beginning of the DSDP project, carbonate concentration has been a routine analysis performed on the sediments. Biogenic opal data are also available for DSDP holes, but only in the more recent ODP holes has it been estimated analytically. It would be conceptually simple to add a new table to Neptune, which would include the sample number, percentage carbonate and percentage opal. This table would be linked to the Sample Data table, which would provide an age estimate for each sample. In reality, this task is far from being trivial. The main reason for this is due to the analytical methodology used to determine the concentration of carbonate and opal. During DSDP, several different methods were used, giving results that are not comparable to each other. Routinely, percentage carbonate and opal have been estimated from smear slides, a method that has a maximum accuracy of $\pm 10 \%$ (Hsü, Montadert et al. 1978). These data are highly subjective and not useful for rigorous quantitative studies. Keller and Barron (1983) used these counts for their "silica switch" hypothesis, on sites where the biosiliceous component was actually minimal and easily affected by dissolution of diatoms, the primary components of siliceous productivity (Wright et al. 1992). Quantitative analytical measurements of carbonate and opal would be required to map the distribution of these carbonatic and siliceous sediments in the entire ocean basins and to test the "silica switch" hypothesis.

The shipboard-based 'carbonate bomb' method (Müller and Gastner 1971) has been used relatively early in the DSDP on a few selected samples to provide a control on the smear slide estimates. The accuracy of this method, the most common analytical method used during DSDP cruises, is between 1 and $5 \%$, lower for carbonate-rich sediments. In some instances, other shorebase methods (e.g., the LECO method; Hsü, Montadert et al. 1978) were compared to the results of the 'carbonate bomb' method and systematic differences observed. In more recent ODP Legs, a shipboard Coulometer is used to determine percent carbonate (and percent organic carbon)(e.g., Leg 121), with a precision of approx. 1\%. I am not aware of a study that compares this method to the previous methods. The silica content has been quantitatively analyzed only for some ODP holes, using X-Rayx-ray fluorescence and the normative equation of Leinen (1977) (e.g., Littke et al. 1991) or, more recently, a single-step alkaline extraction method (Mortlock and Froelich 1989). The precision of the latter method is $\pm 4 \%$. The carbonate bomb, LECO and Coulometer estimates for carbonate and the X-ray fluorescence and alkaline extraction estimates of opal content from holes where sampling frequency is sufficient (e.g., one sample every 0.5 m.y.), could be selectively incorporated into Neptune. Some of these data are available for ODP holes from the JANUS database, but they would probably need to be added manually for the DSDP holes.

These same lithological data, combined with the paleo-water depth estimates of Spencer-Cervato (1998) (not yet included in Neptune but available at the NOAA-WDCA for Paleoclimatology Data Contr. Series \#97-030: ftp://ftp.ngdc.noaa.gov/paleo/paleocean/by_contributor/spencer-cervato1998/) could 
be used to reconstruct the depth fluctuations of the Calcite Compensation Depth (CCD) during the Cenozoic, for which the curve by van Andel (1975) is still being used. The very smooth fluctuations of the CCD curve of van Andel (1975) do not agree with the abrupt changes that have been recently shown to characterize the earth's climate and ocean systems in the Cenozoic. This is probably caused by the low resolution of stratigraphic studies in the 1970s. The better resolution (around 0.5 m.y. or better) of the Neptune data would allow us to refine the curve and to make it more compatible with, for example, the isotopic data currently being produced.

I briefly mentioned earlier the importance of deepwater circulation reconstruction for the understanding of the climate/ocean systems. Sediment accumulation rates and dissolution profiles can be reconstructed from physical property data and grain-size distributions, all data that are routinely produced onboard ship and that could be quite easily added to Neptune. Recent studies (Zachos et al. 1997) use a record of percent coarse fraction to demonstrate that glacial/interglacial cycles existed as far back as the late Oligocene. This parameter, combined with a high resolution $\delta 180$ record from ODP Leg 154 (Ceara Rise - south Atlantic), shows a 40-k.y. periodicity, indicating a high-latitude orbital control on ice volume and temperature. This isotopic record suggests that there is an orbital control on deepwater circulation, which had not yet been shown so early probably because of the low resolution of previous studies and the paucity of deep-sea sections with high sedimentation rates and a long stratigraphic record, like the ones recovered by Leg 154 on the Ceara Rise.

The trend for future paleoceanographic studies is toward high (tens of thousands of years) resolution studies. Is Neptune ready for these studies? The answer is: not yet. The chronology of Neptune, its biggest strength and the most updated record available, is based on biostratigraphy and magnetostratigraphy, which provide an accuracy on the order of hundreds of thousands of years, at best. Oxygen isotope stratigraphy is currently the only means to obtain a better age resolution than this for Neogene sediments. Results from ODP Leg 154 provide the longest and most complete isotopic record for the whole Neogene which extends into the Oligocene (Weedon et al. 1997). A calibration of the sporadic isotopic records available for DSDP holes and the more common records from ODP holes to this recent isotopic calibration would allow us to refine the (mainly) late Neogene chronological resolution for some of the sites in Neptune. My biggest concern about this calibration is that correlations with standard isotopic records are still done by 'wiggle matching'. Because the absolute isotopic values vary depending on the foraminifer species or sediment fraction used to obtain the record, the shape of the curve (which remains substantially the same) is used for the correlation. I am not aware of any comprehensive study that has carefully pinpointed and tabulated some of the ages of the 200+ (the total number is actually unknown: some 140 are recognized only in the Plio-Pleistocene) isotopic stages to magnetostratigraphy beyond the late Miocene (Hodell et al. 1994). This would provide fixed reference points for stratigraphic interpretations. 'Eye-balled' graphic correlation is, in my opinion, too inaccurate for the type of studies that it is used for (unless one can actually count back all stages 
starting from the Holocene) and greatly reduces the potential resolution of isotope stratigraphy.

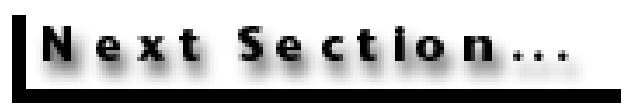




\section{Close Window}

Figure 4.1. Overview of database project (modified after Lazarus, 1994). Combining existing data (boxes with thin outlines) with new information generated by project members (rounded boxes with italic text), we have produced new information (bold outline boxes).

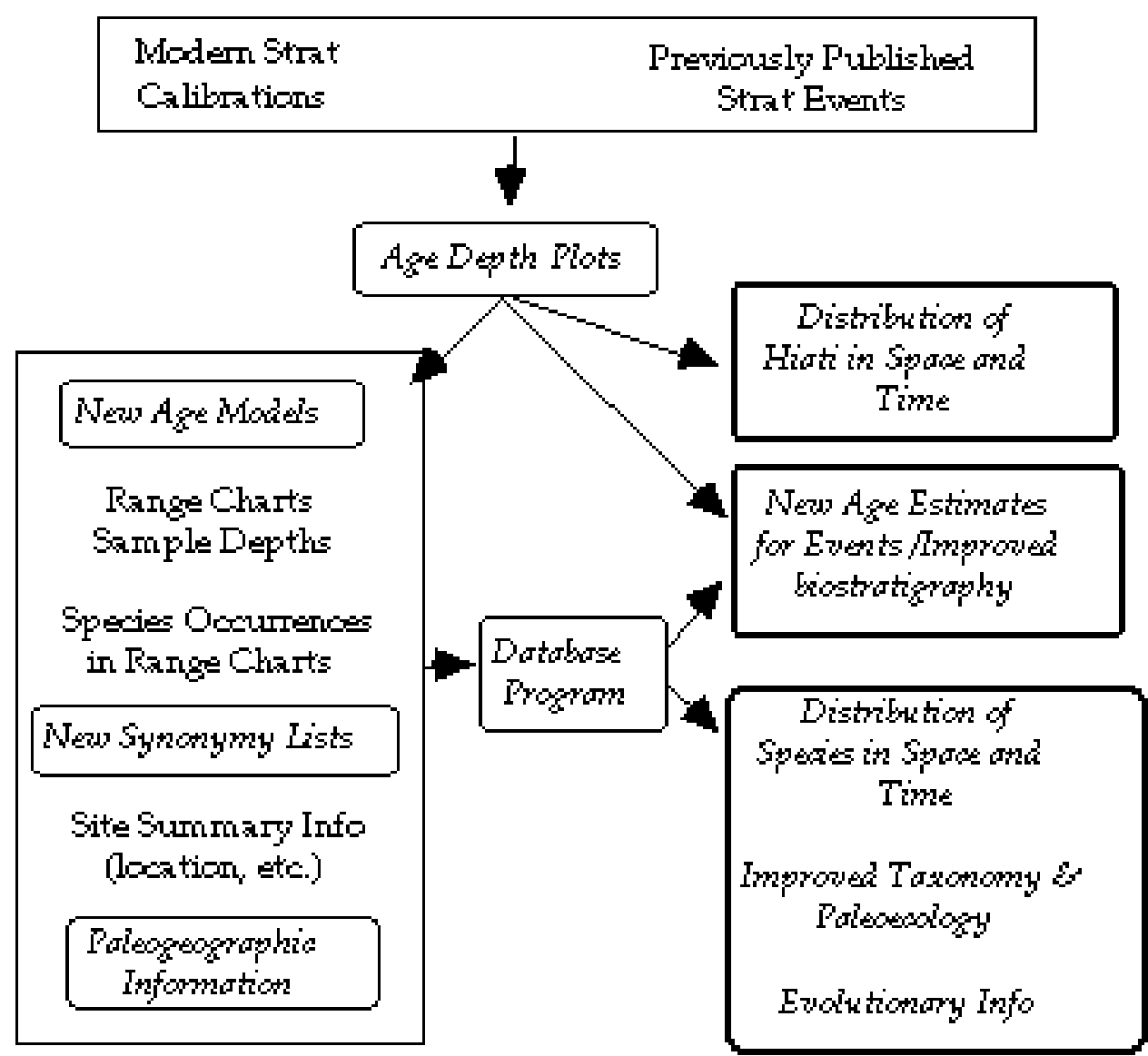




\section{close Window}

Figure 4.2. Simplified sketch of the database structure (modified after Lazarus 1994). Each box represents one relational table, with field names listed in the box. Relational links between tables are shown by thin lines. Arrows point from a table with many records with the same value for the relating field, to a table with unique values for each record in this field. The primary key for each table (the combination of one or more fields which makes each record in the table unique) is underlined. The approximate number of records (as of February, 1998) is shown below each box. The records in the 'Taxa by Hole' table were extracted from the DSDP CD-ROM. The other tables were created by Neptune.

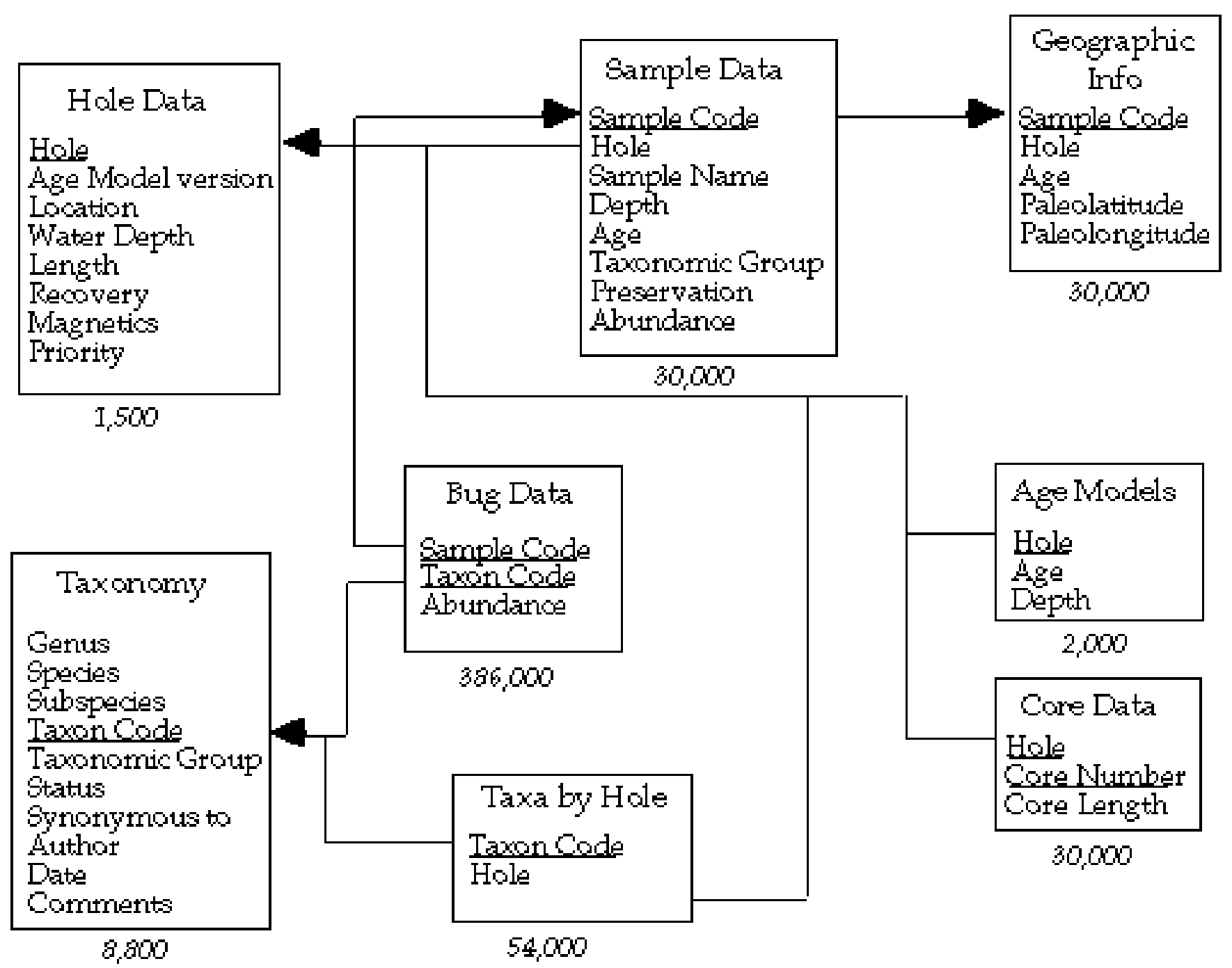




\section{close window}

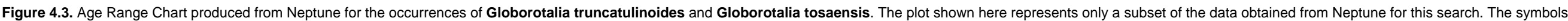

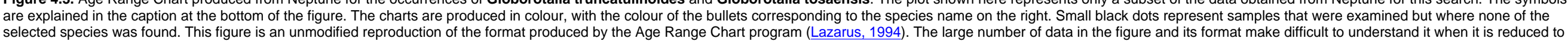
a one-page size and does not clearly show the differences between the different species' occurrences.

Composite Age-Range Chart

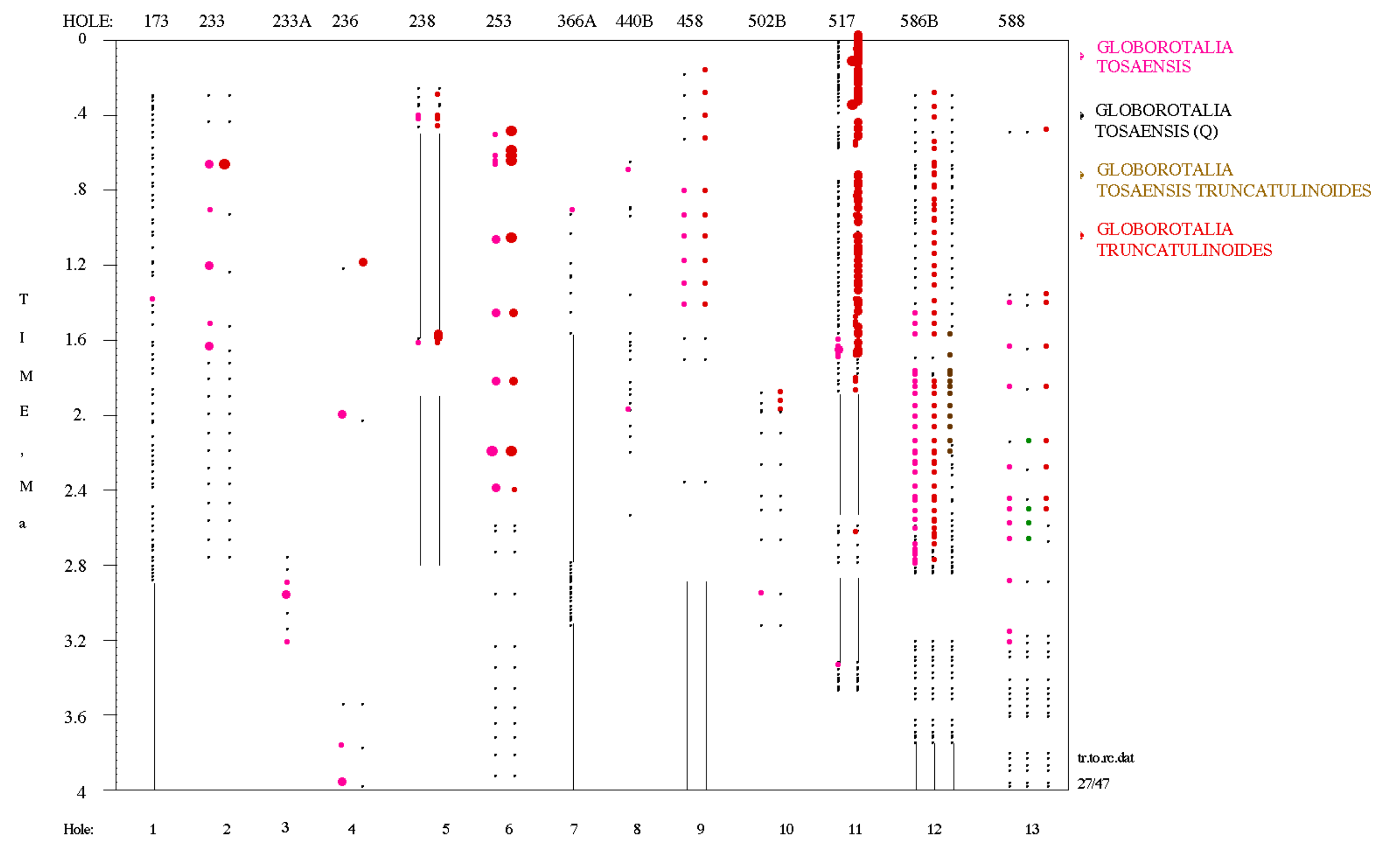


Figure 4.3: THE CENOZOIC DEEP SEA MICROFOSSIL RECORD: EXPLORATIONS OF THE DSDP/ODP SAMPLE SET USING THE NEPTUNE DATABASE

KEY:

$$
\text { I HIATUS - Absent }
$$

- Trace-Rare

- Few-Common
- Abundant-Dominant 


\section{Close W indow}

Figure 4.4. Screen snapshot of a simple query in Neptune. The table in the lower right corner is the list of tables in Neptune that are directly searchable with a 'Search Editor' window (under the 'Select' menu). Selecting one of the tables shows the records included in it and their number (in the heading). The larger table in the background is the 'Sample Info' table, which contains 30800 records.

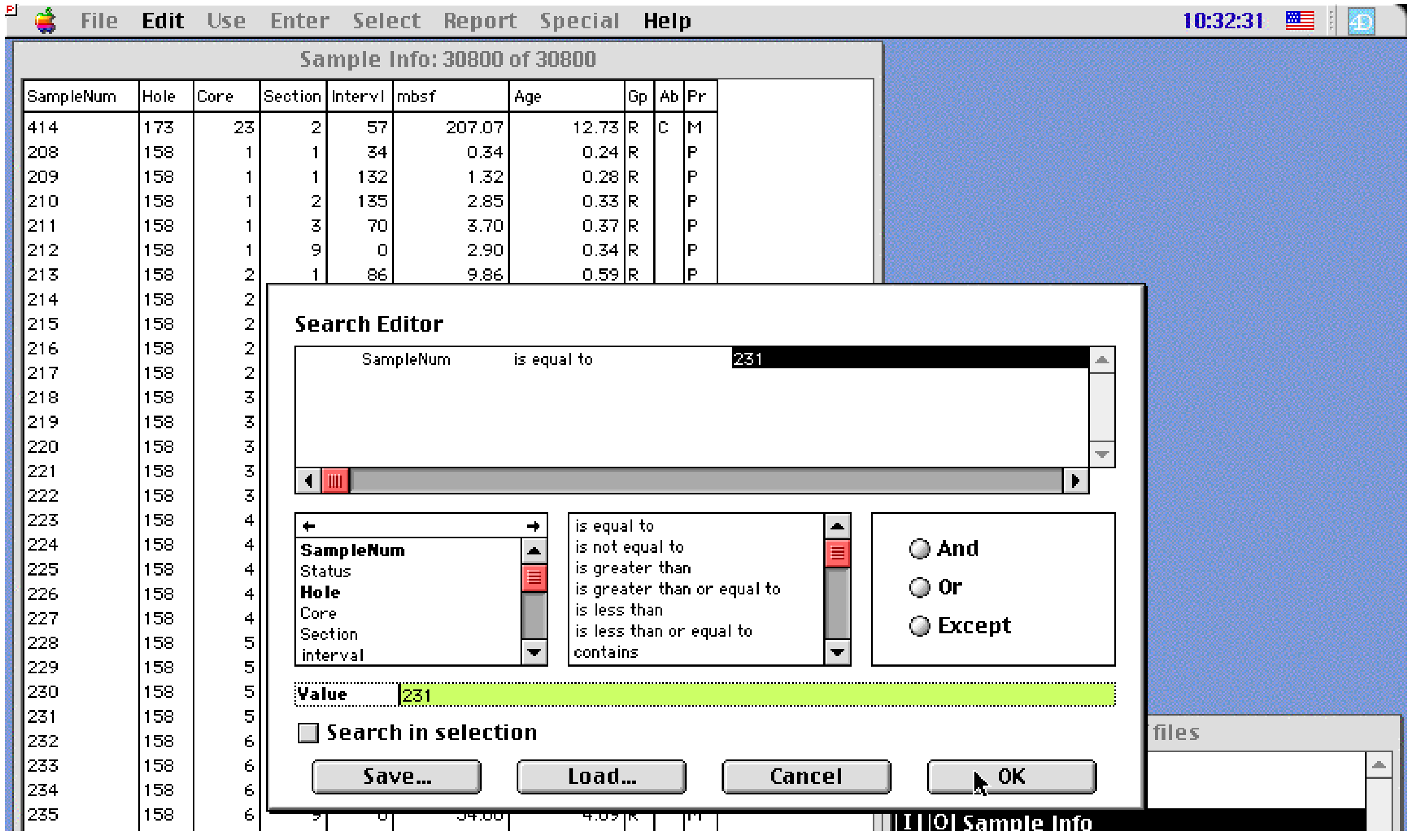


Figure 4.4: THE CENOZOIC DEEP SEA MICROFOSSIL RECORD: EXPLORATIONS OF THE DSDP/ODP SAMPLE SET USING THE NEPTUNE DATABASE

\begin{tabular}{|c|c|c|c|c|c|c|c|c|c|}
\hline 236 & |158 & 7 & 1 & 143 & 55.43 & $4.14 \mid \mathrm{R}$ & $M$ & I 0 Core Data & \\
\hline 237 & 158 & 7 & 3 & 124 & 58.24 & $4.24 \mathrm{R}$ & $M$ & I & \\
\hline 238 & 158 & 7 & 5 & 124 & 61.24 & $4.35 \mid R$ & $M$ & Dore summary & \\
\hline 239 & 158 & 7 & 9 & 0 & 62.80 & $4.41 \mathrm{R}$ & $M$ & I0 Loc Data & \\
\hline 240 & 158 & 8 & 1 & 131 & 64.31 & $4.47 R$ & $M$ & I 0 Species by Hole & \\
\hline 241 & 158 & 8 & 3 & 124 & 67.24 & $4.58 \mid R$ & $M$ & I 0 Table I0 & \\
\hline 242 & 158 & 8 & 5 & 123 & 70.23 & $4.69 \mid \mathrm{R}$ & $M$ & $\overline{\mathrm{I}} \overline{0}$ Geographic Info & $\nabla$ \\
\hline
\end{tabular}




\section{Close Window}

Figure 4.5. Screen snapshot of the 'Execute Procedure' window (under the 'Special' menu). This allows to search a combination of tables using one of the predefined procedures. The following figures show the progression of a 'Bug Data Search' procedure for the occurrence of the planktic foraminifer Globorotalia truncatulinoides in the Neptune holes. A 'Bug Data Search Batch' (described in Section 4.1.4) is one of the other procedures shown on the list.

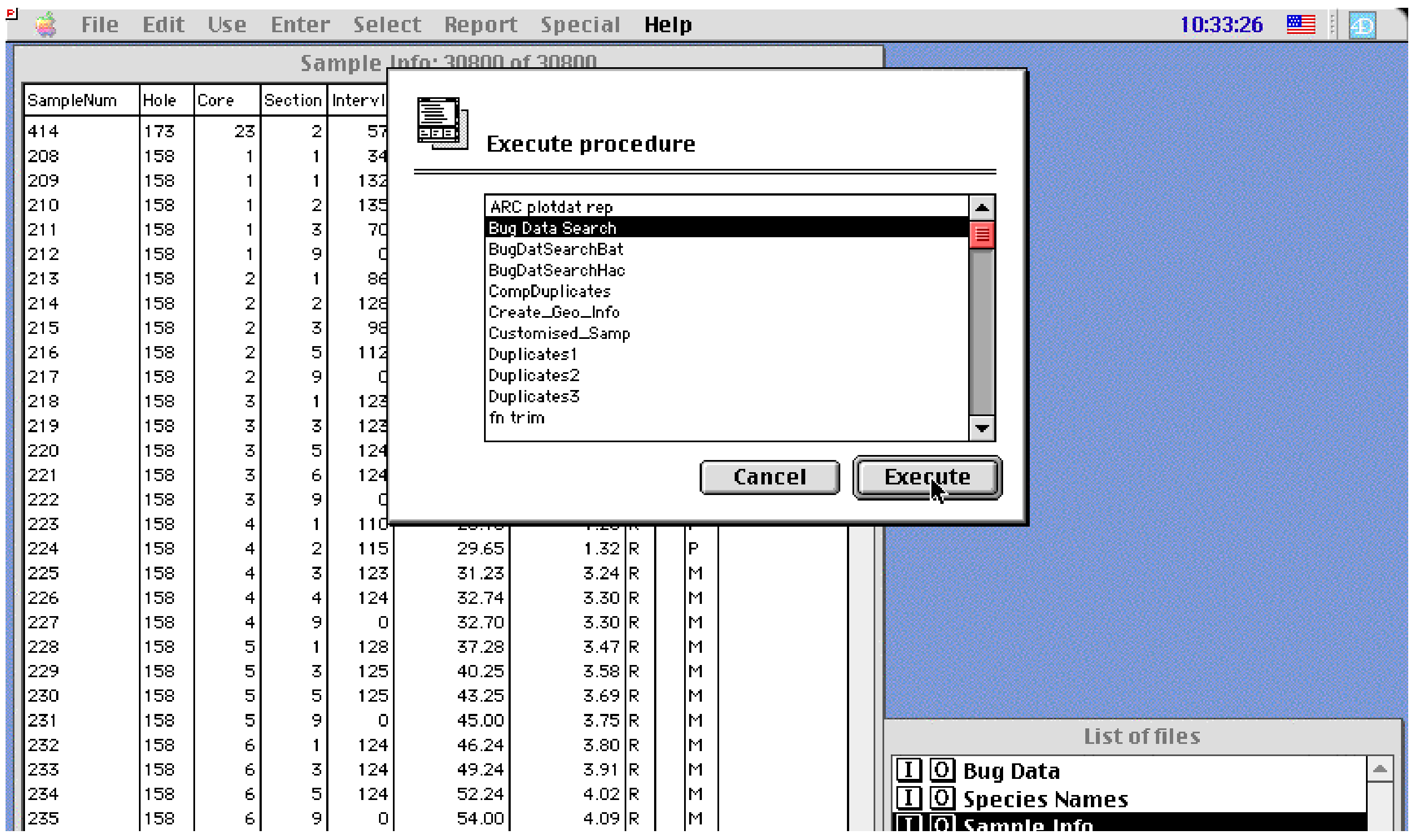


Figure 4.5: THE CENOZOIC DEEP SEA MICROFOSSIL RECORD: EXPLORATIONS OF THE DSDP/ODP SAMPLE SET USING THE NEPTUNE DATABASE

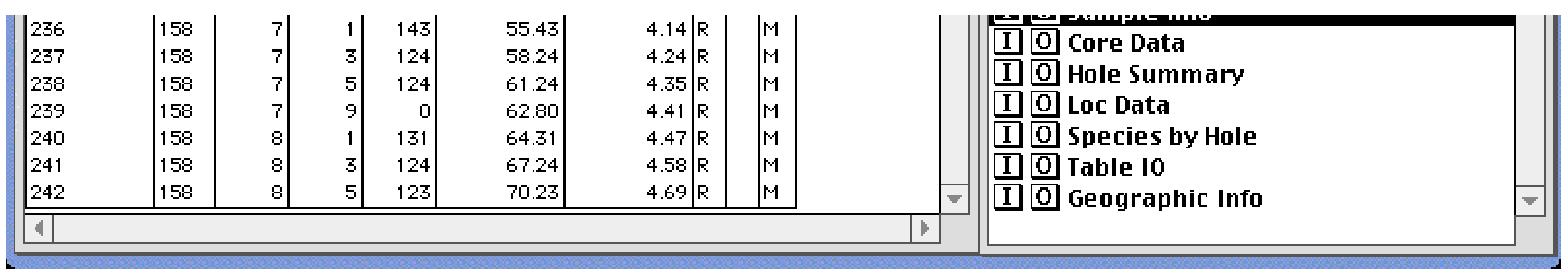




\section{Close window}

Figure 4.6. Once the type of procedure is chosen, a 'Search Editor' window is shown. In this example, a search is made for the species' name - 'Species' 'is equal to' 'truncatulinoides'.

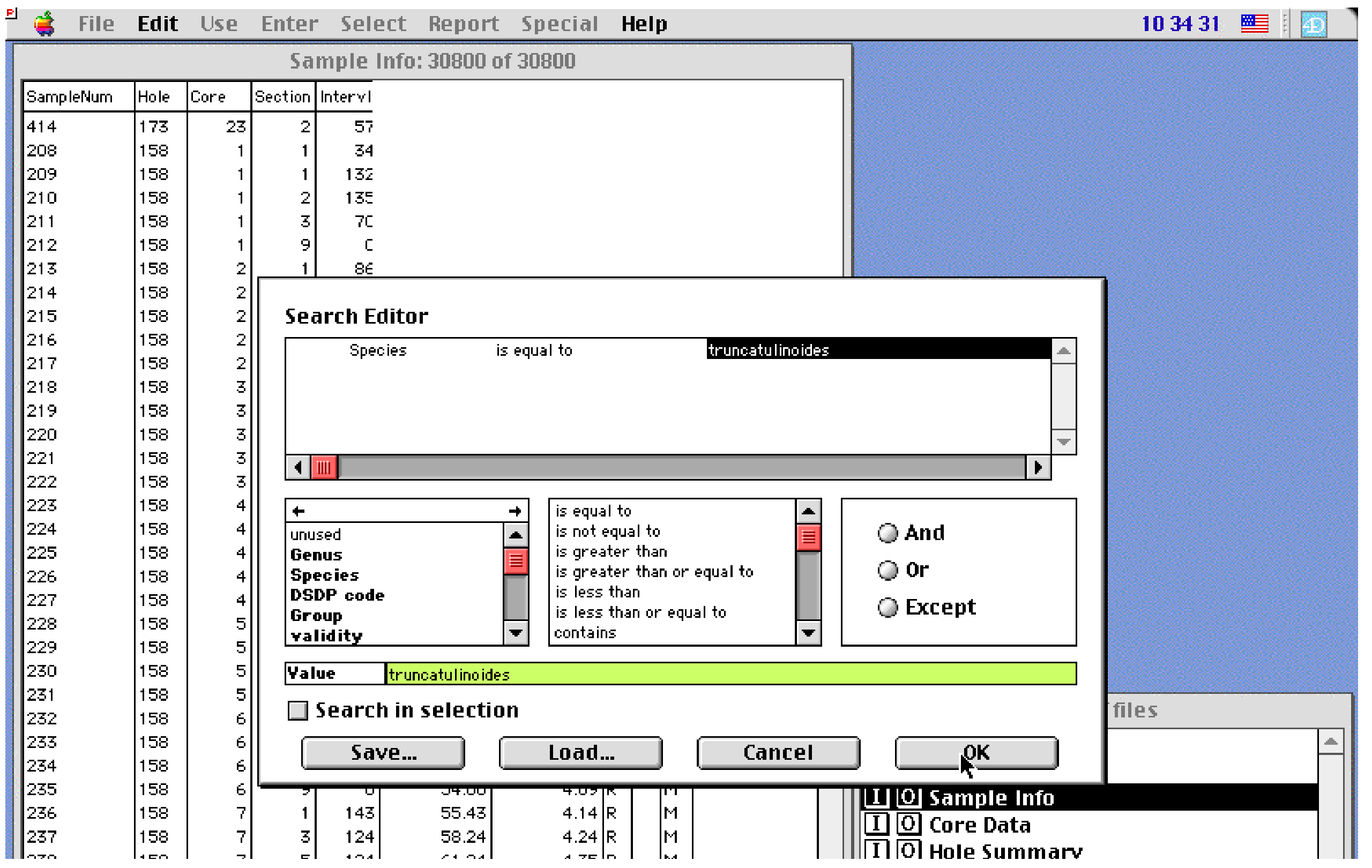


Figure 4.6: THE CENOZOIC DEEP SEA MICROFOSSIL RECORD: EXPLORATIONS OF THE DSDP/ODP SAMPLE SET USING THE NEPTUNE DATABASE

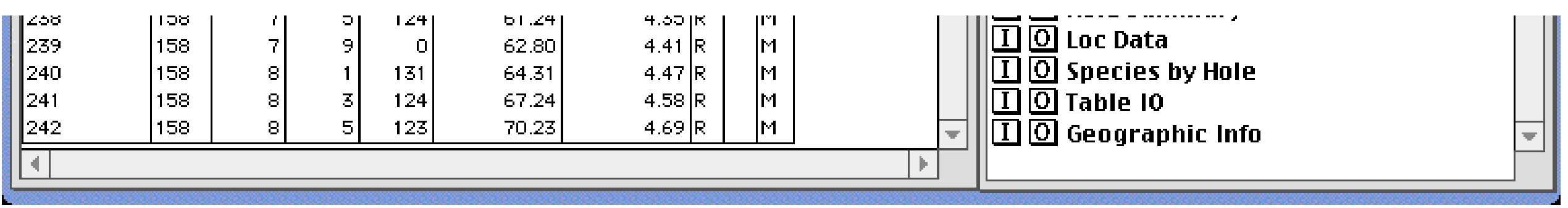




\section{Close window}

Figure 4.7. The selected species' name is found in the 'Species Names' table together with linked synonyms. After one has highlighted the names that should be used, one can proceed with the Search. Note the format of the data in the 'Species Names' table, described in Section 3.3 and characteristic of Neptune.

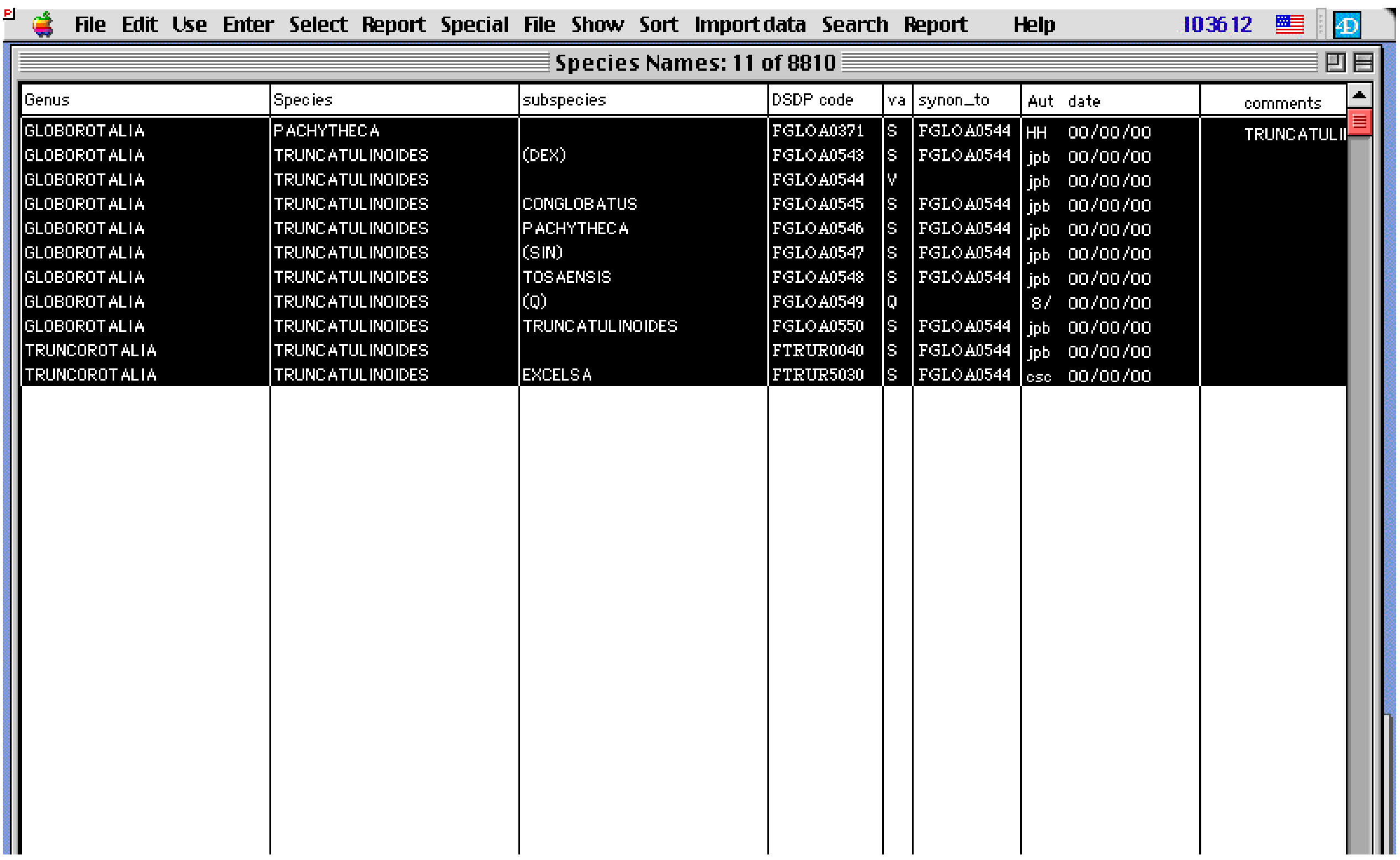


Figure 4.7: THE CENOZOIC DEEP SEA MICROFOSSIL RECORD: EXPLORATIONS OF THE DSDP/ODP SAMPLE SET USING THE NEPTUNE DATABASE

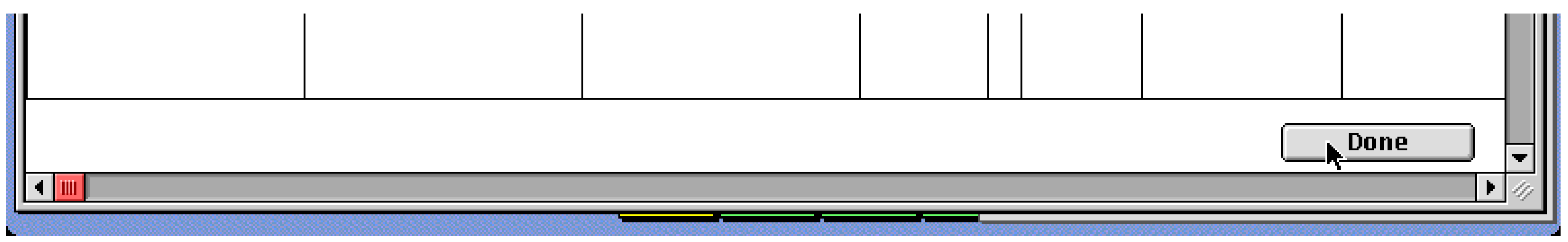




\section{Close Window}

Figure 4.8. The result of the search is shown in a window that gives the number of occurrences in all the holes present in Neptune (779 in this example). The next step allows to refine the selection with additional criteria.

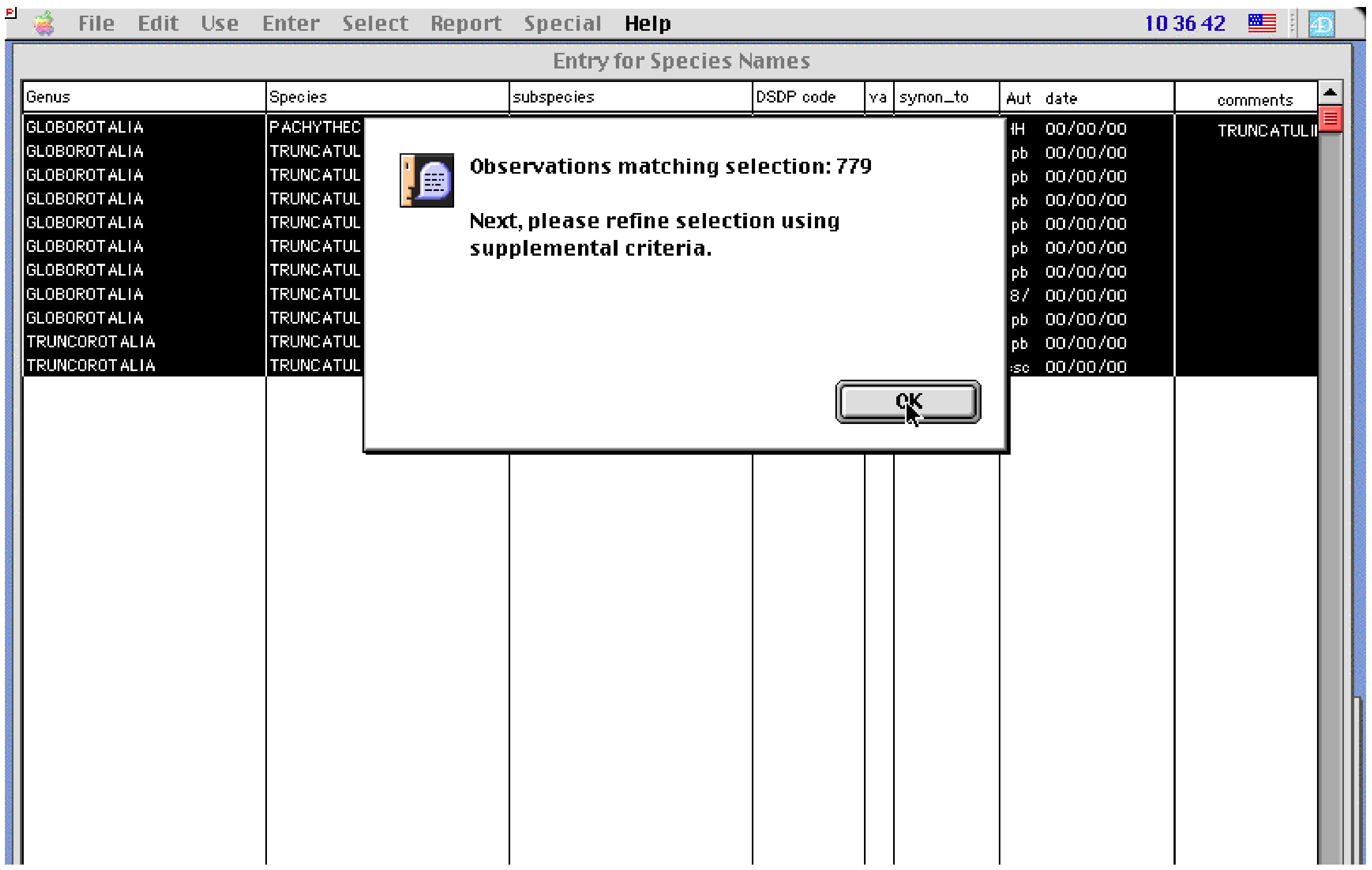


Figure 4.8: THE CENOZOIC DEEP SEA MICROFOSSIL RECORD: EXPLORATIONS OF THE DSDP/ODP SAMPLE SET USING THE NEPTUNE DATABASE

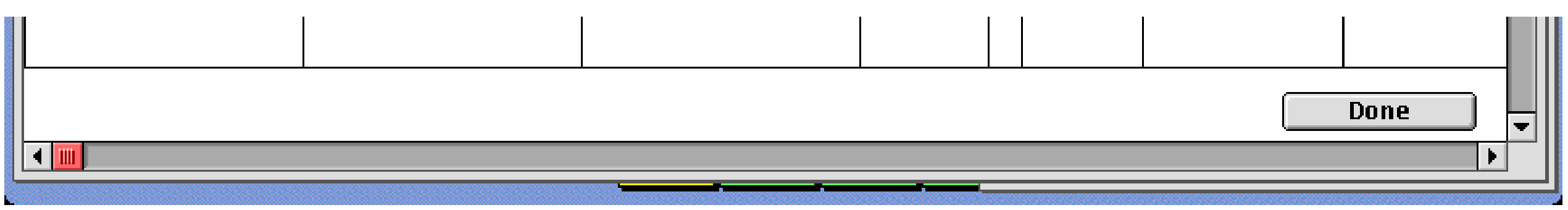




\section{Close Window}

Figure 4.9. In this example I have chosen to refine the search to obtain only data from holes for which we have age models. To do this, I have selected 'Age' in the 'Sample Info' table (left) and specified that it has to be greater than 0 (all samples from holes without age models have ages set to 0). The 'Search in selection' box, which allows to search only in the selection found through the previous queries, is automatically marked.

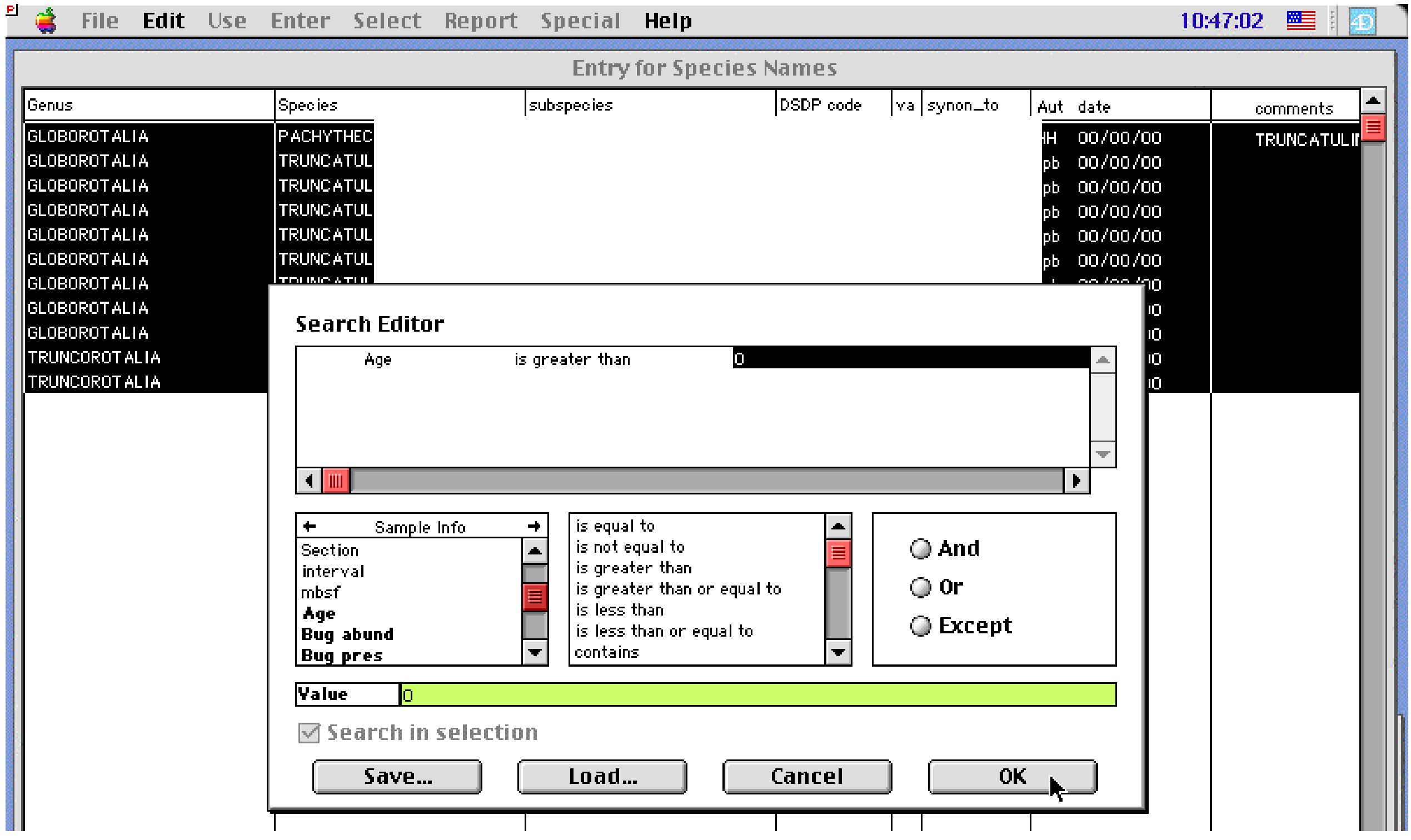


Figure 4.9: THE CENOZOIC DEEP SEA MICROFOSSIL RECORD: EXPLORATIONS OF THE DSDP/ODP SAMPLE SET USING THE NEPTUNE DATABASE

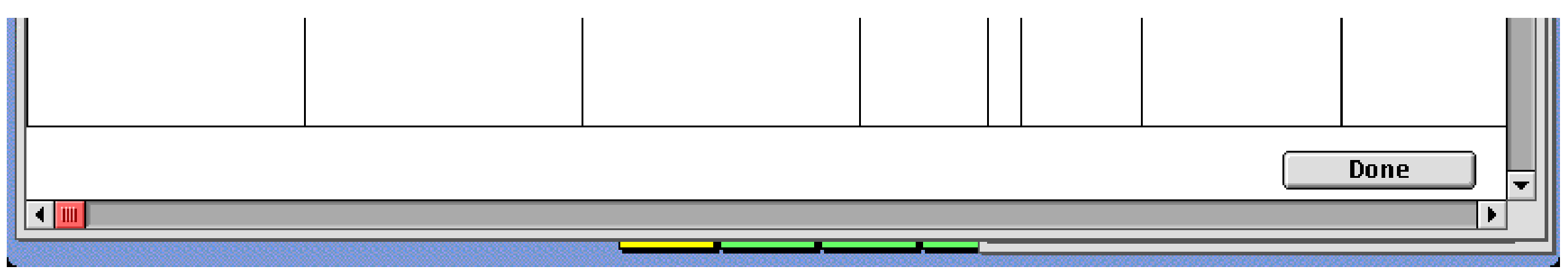




\section{Close Window}

Figure 4.10. The results of this procedure are shown in a table containing 485 records (of the 779 found earlier in the search). This table and related data can be sorted, printed out, exported, or saved in various formats.

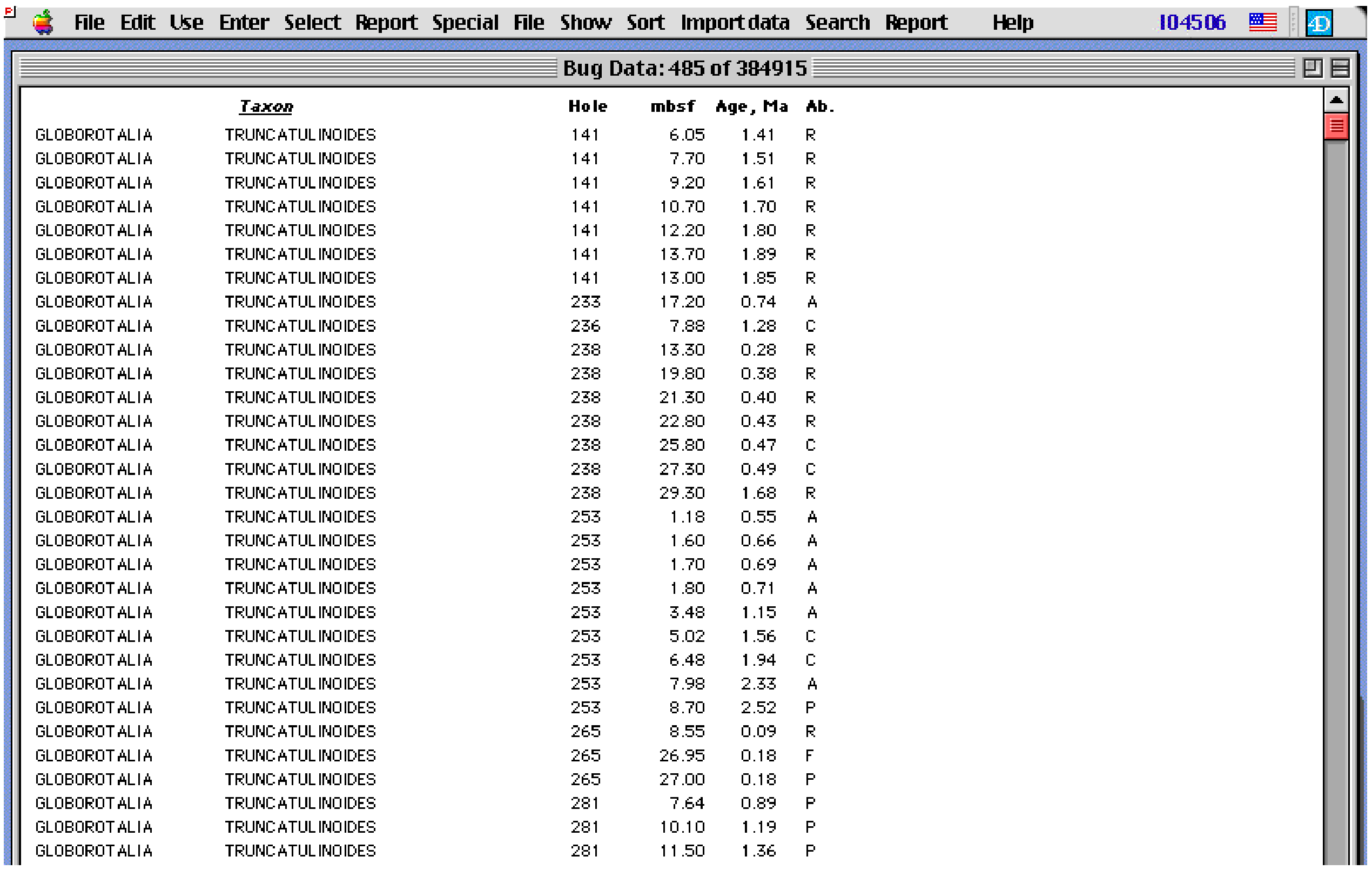


Figure 4.10: THE CENOZOIC DEEP SEA MICROFOSSIL RECORD: EXPLORATIONS OF THE DSDP/ODP SAMPLE SET USING THE NEPTUNE DATABASE

GLOBOROT ALIA

GLOBOROTALIA
TRUNCATULINOIDES

TRUNCATULINOIDES
281

362
12.20

45.50 


\section{Close Window}

Figure 4.11. Age versus latitude plot of the first occurrences of G. truncatulinoides in selected Neptune sites (from Spencer-Cervato and Thierstein 1997).

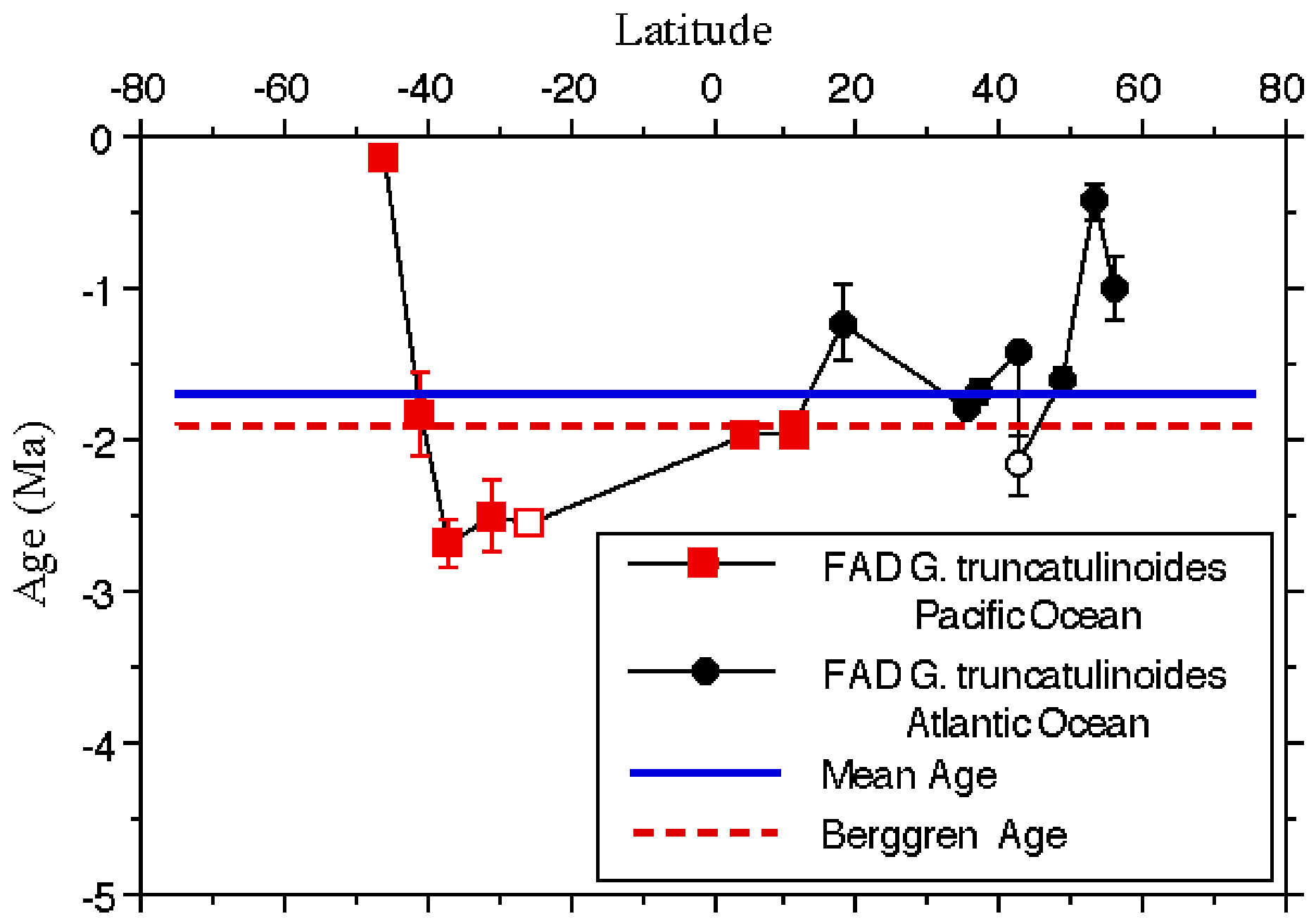




\section{Close window}

Figure 4.12. Distribution of diatom, foraminifera, nannofossil and radiolarian longevity by species (in m.y.), including both extant and extinct species. Note that, while most phytoplankton species are less longevous than zooplankton species, extreme longevity values are exclusively found in phytoplankton species.
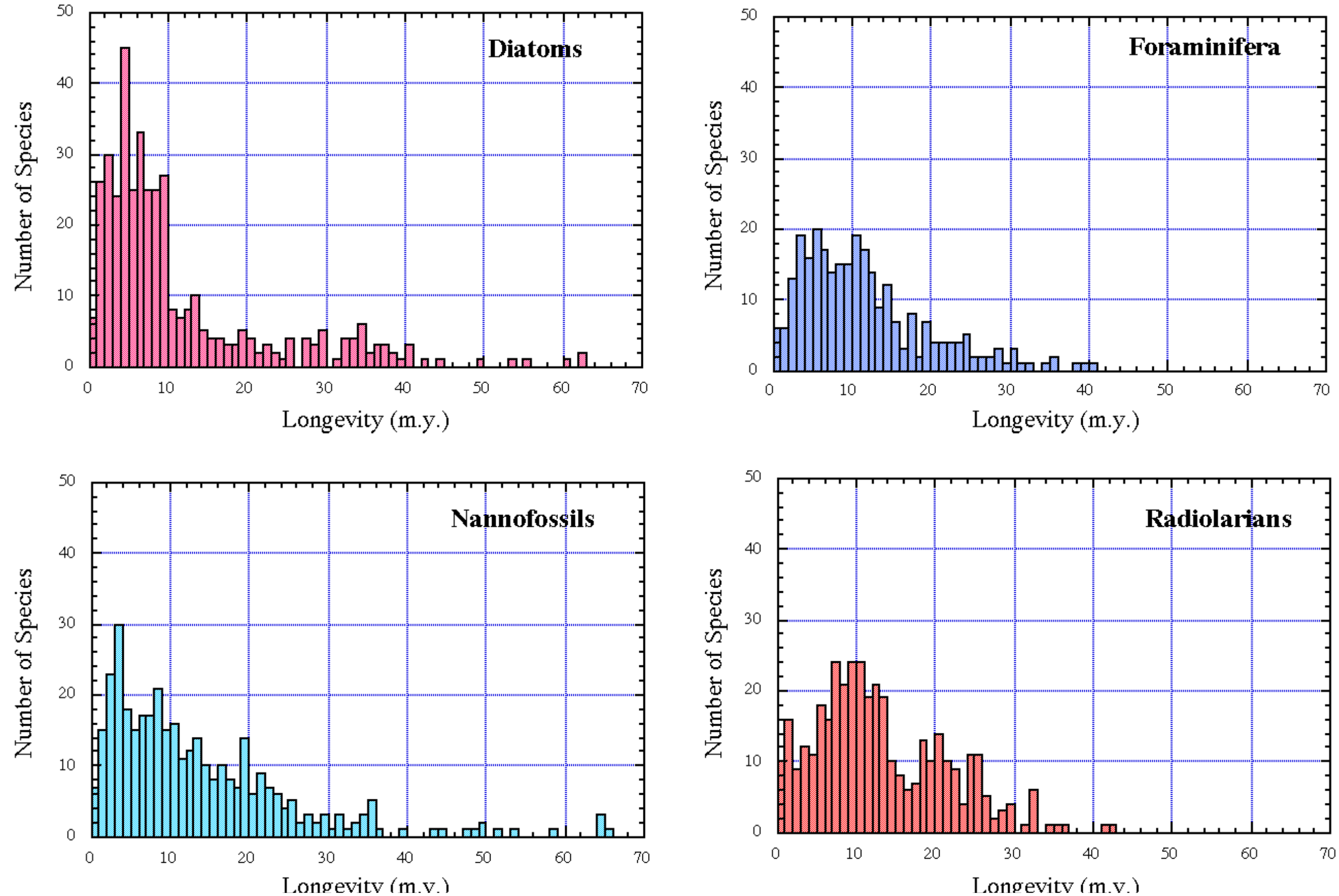

http://www-odp.tamu.edu/paleo/1999_2/neptune/fig4_12.htm (1 of 2) [10/26/1999 10:02:45 AM] 
Figure 4.12: THE CENOZOIC DEEP SEA MICROFOSSIL RECORD: EXPLORATIONS OF THE DSDP/ODP SAMPLE SET USING THE NEPTUNE DATABASE

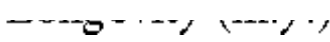




\section{Close Window}

Figure 4.13. Appearance rates (calculated as the ratio between number of FADs versus number of species) of the four groups during the Cenozoic Note that the rates are biased by species richness in low diversity intervals (see Fig. 4.9).
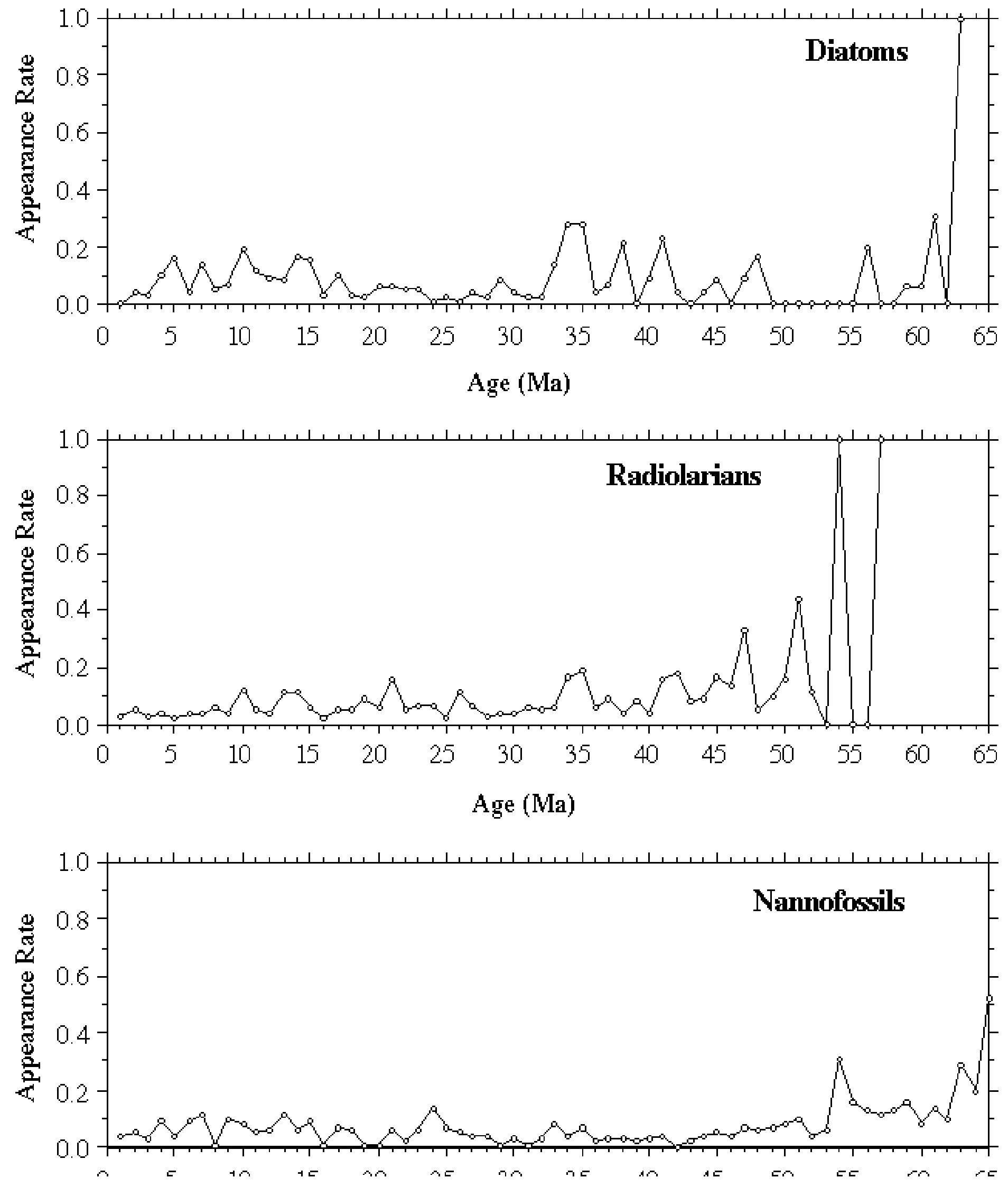
Figure 4.13: THE CENOZOIC DEEP SEA MICROFOSSIL RECOR...F THE DSDP/ODP SAMPLE SET USING THE NEPTUNE DATABASE

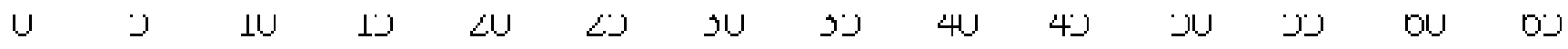

Age (Ma)

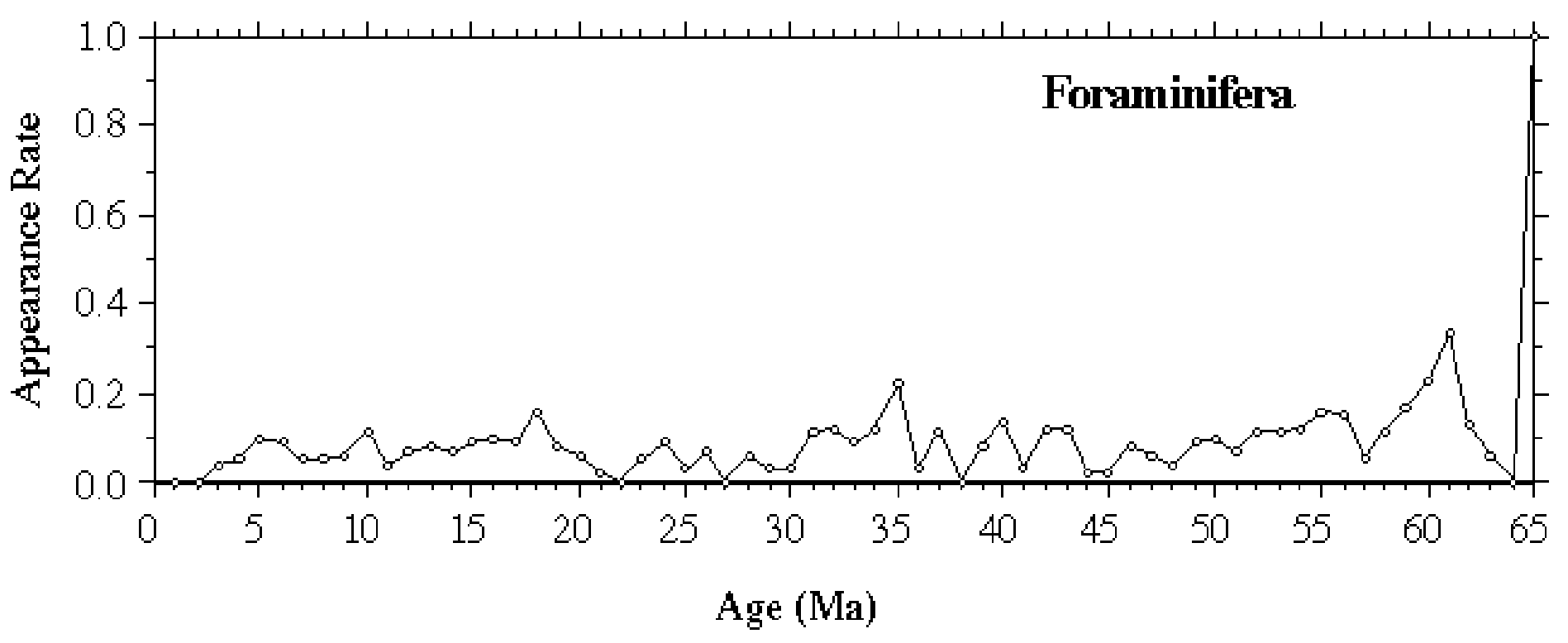




\section{Close Window}

Figure 4.14. Extinction rates (calculated as the ratio between number of LADs versus number of species) of the four groups during the Cenozoic.
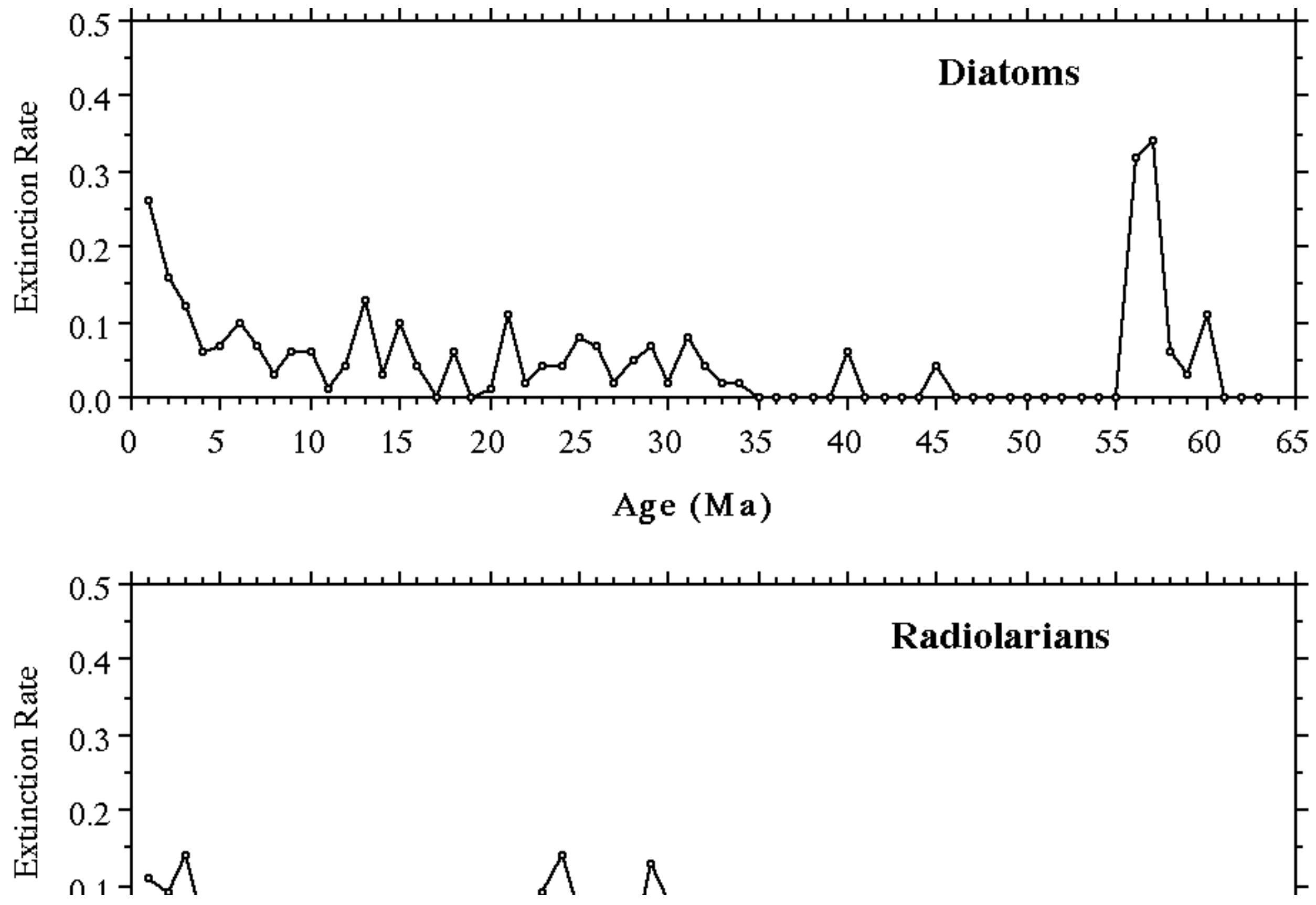
Figure 4.14: THE CENOZOIC DEEP SEA MICROFOSSIL RECORD: EXPLORATIONS OF THE DSDP/ODP SAMPLE SET USING THE NEPTUNE DATABASE
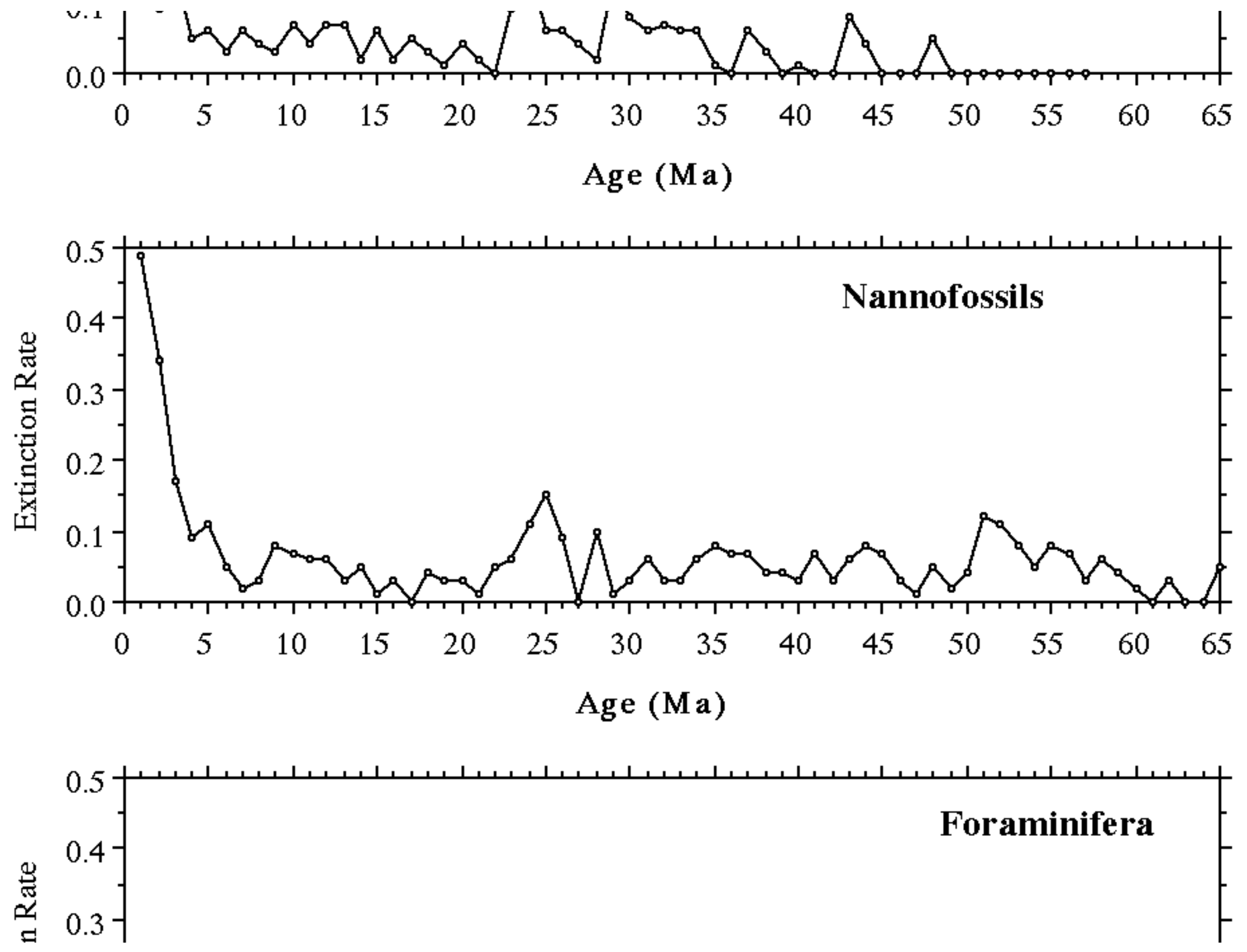
Figure 4.14: THE CENOZOIC DEEP SEA MICROFOSSIL RECORD: EXPLORATIONS OF THE DSDP/ODP SAMPLE SET USING THE NEPTUNE DATABASE

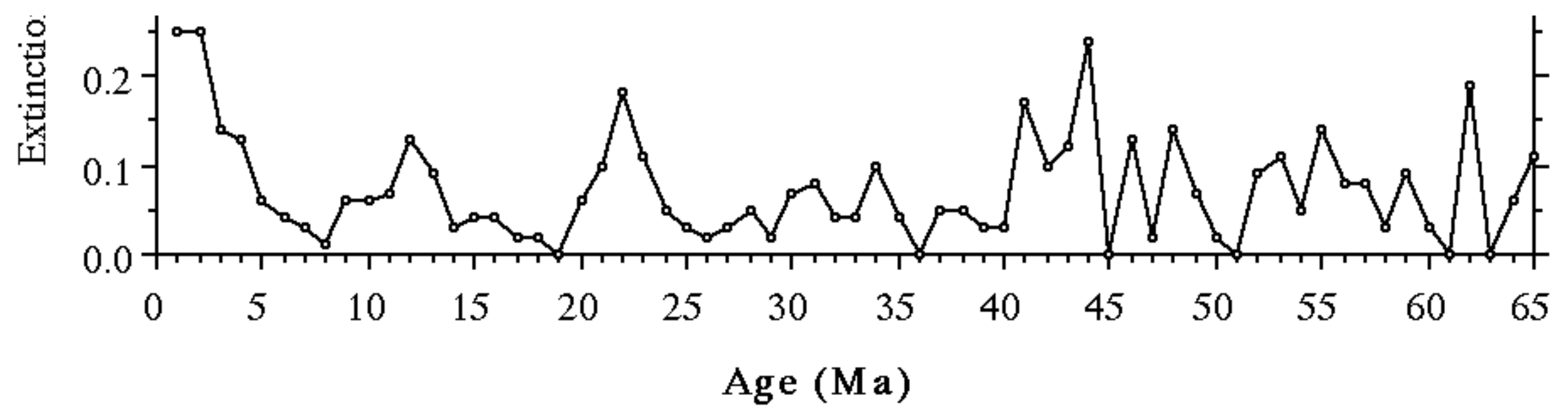




\section{Close Window}

Figure 4.15. Geographic distribution of species FADs for the four groups. Southern latitudes are given as negative numbers. The latitude given for each FAD is a calculated paleolatitude at the time of the appearance (see 4.1.1.4 for details on the method).
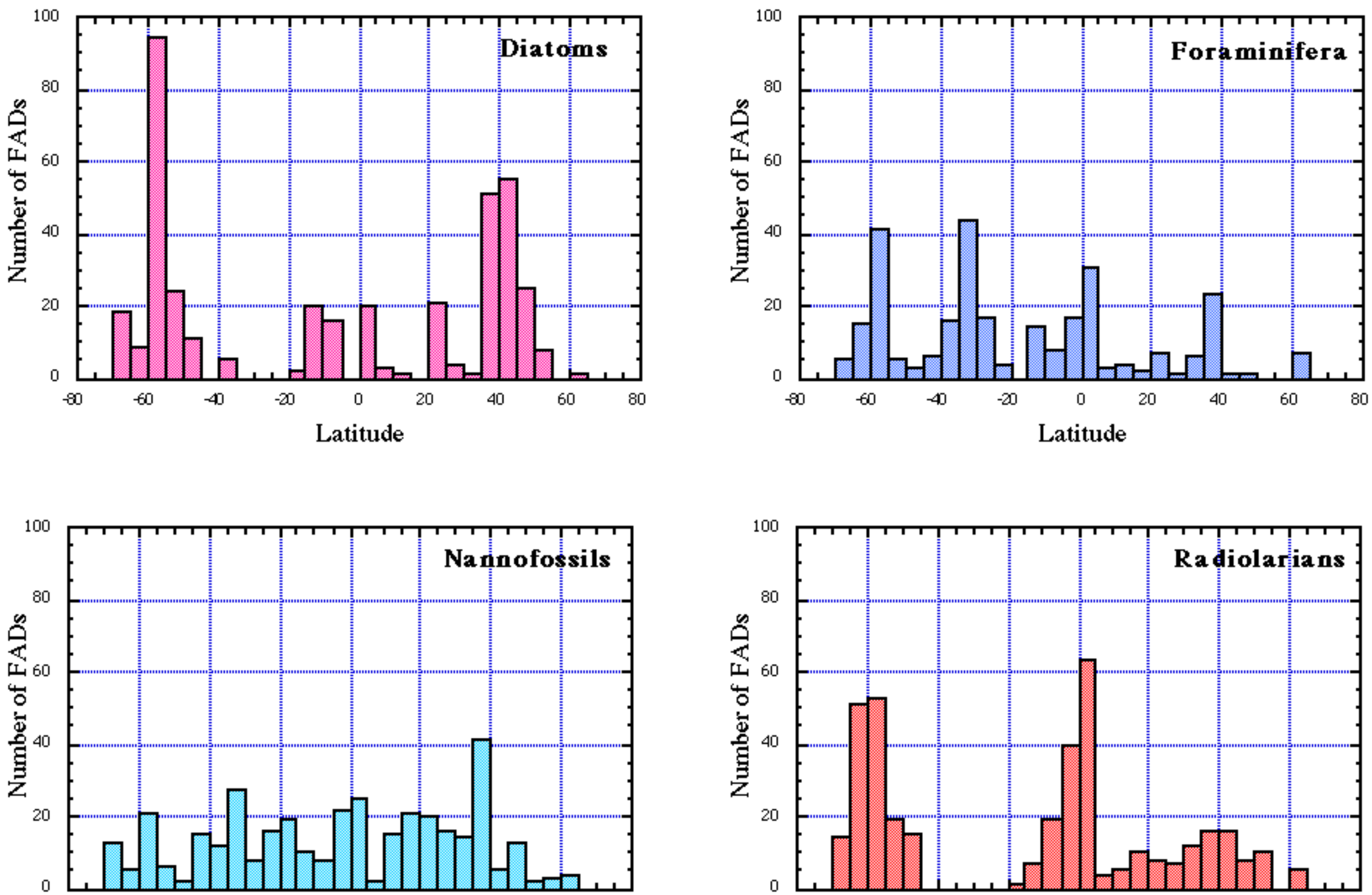
Figure 4.15: THE CENOZOIC DEEP SEA MICROFOSSIL RECORD: EXPLORATIONS OF THE DSDP/ODP SAMPLE SET USING THE NEPTUNE DATABASE

$-\infty$

60

$-40$

$-20$

\section{Latitude}

60

80

$-80$

$-60$

$-40$

40

$-20$

\section{Latitude}




\section{C lose $W$ indo w}

Figure 4.16. Species richness (total number of species - diamond symbols and black line) and diversity normalised on the number of sections in Neptune (ratios between diversity and number of sections - crosses and grey line) for the four plankton groups during the Cenozoic. Species richness is calculated at $1 \mathrm{~m} . \mathrm{y}$. intervals. Note that the scale of the normalised diversity is different in the four graphs.

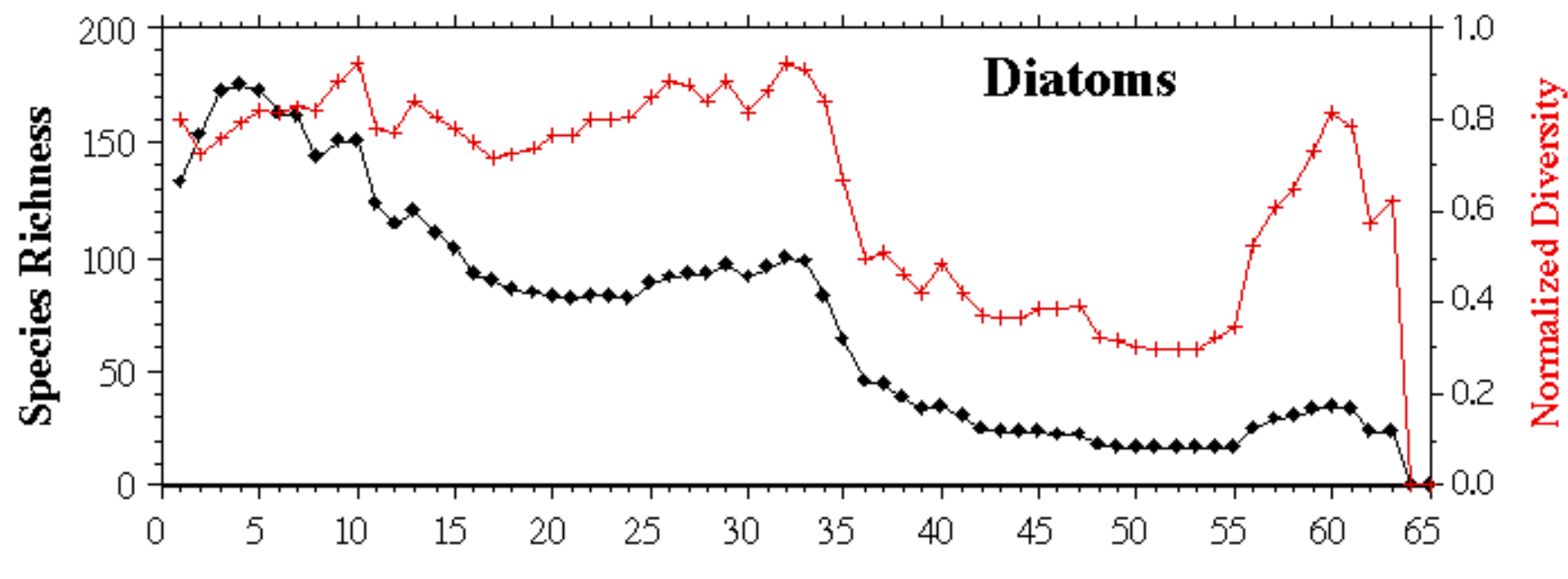

Age (Ma)
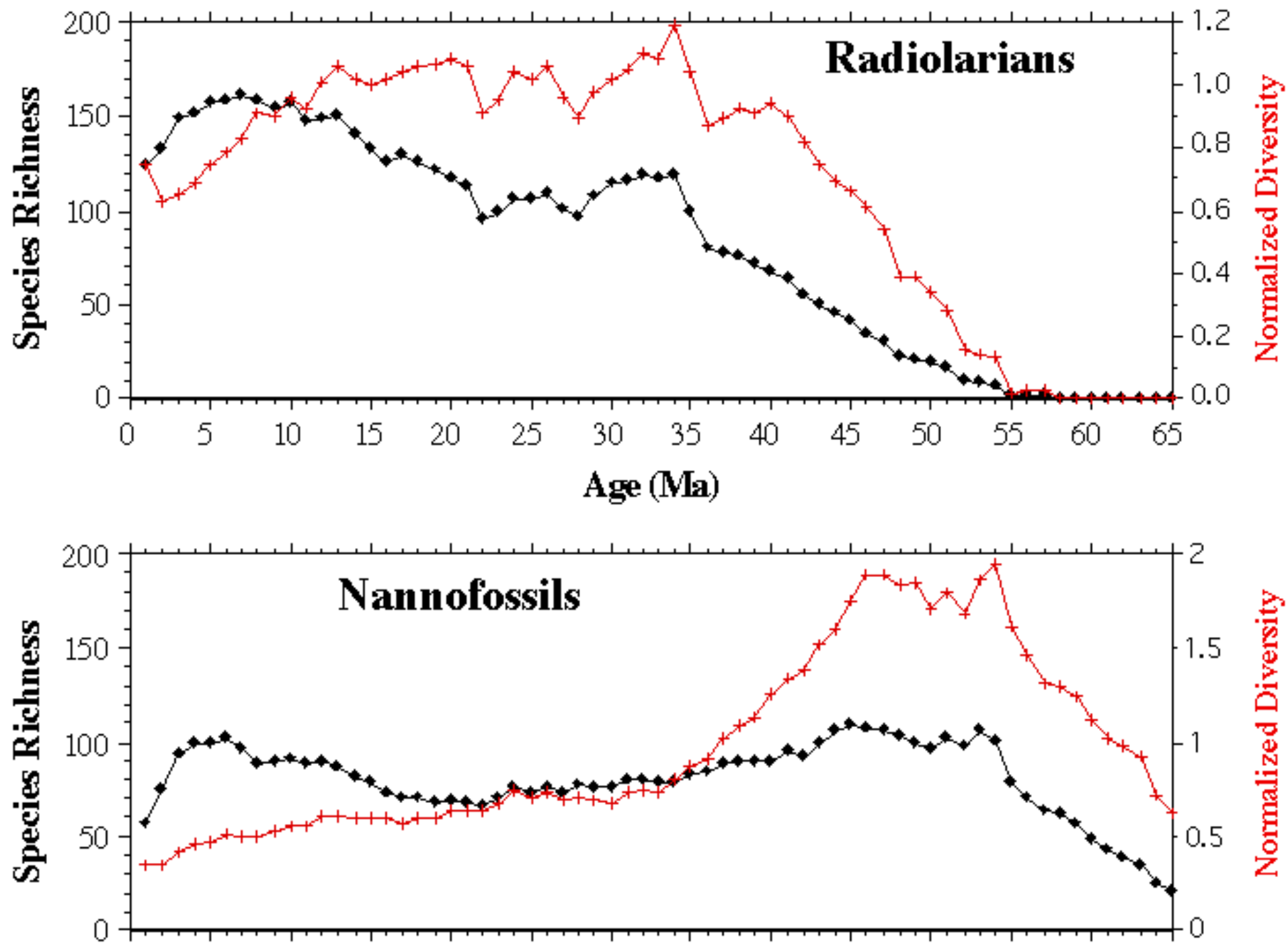
Figure 4.16: THE CENOZOIC DEEP SEA MICROFOSSIL RECOR...F THE DSDP/ODP SAMPLE SET USING THE NEPTUNE DATABASE

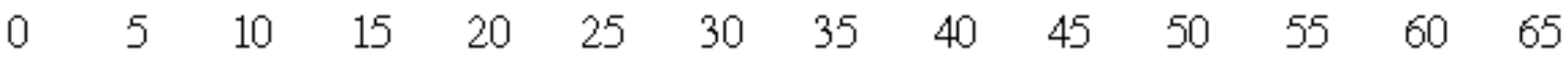

Age (Ma)

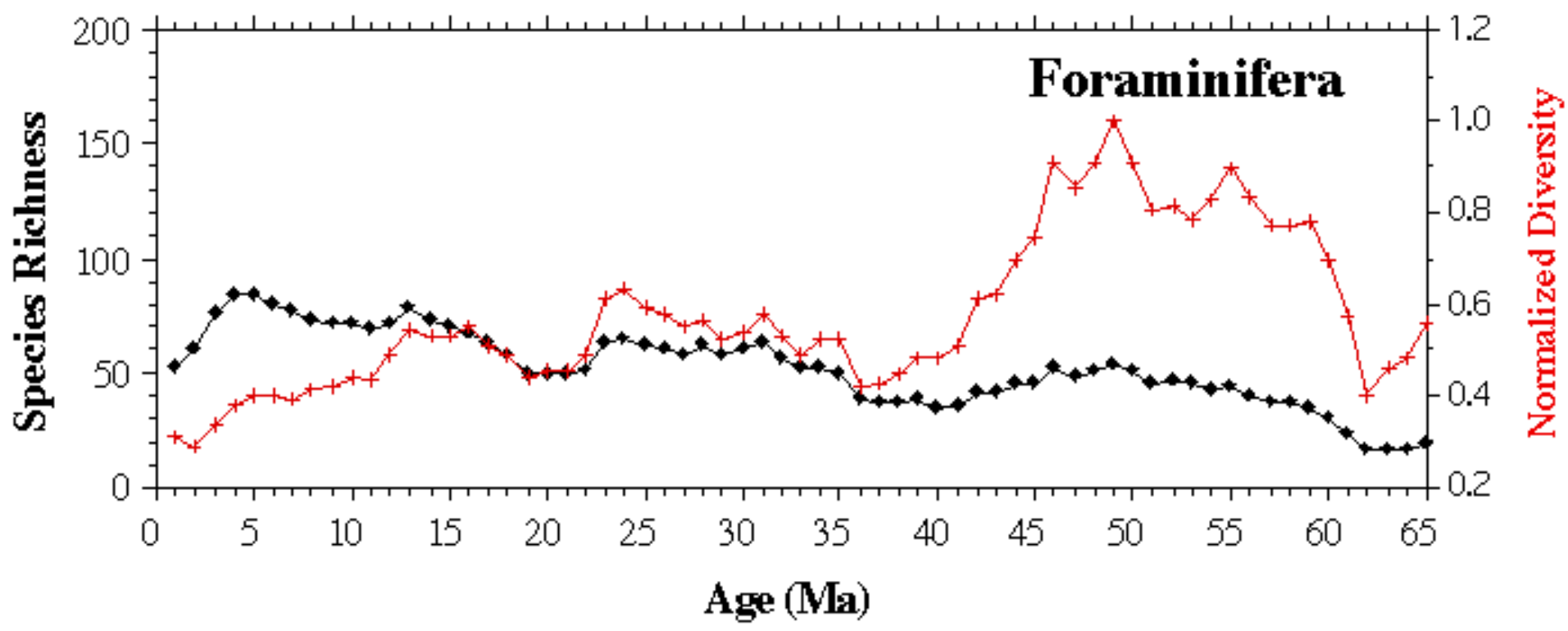




\section{Close window}

Figure 4.17. Species richness versus the total number of sections in Neptune. The R2 refers to the simple linear correlation shown in the graphs.
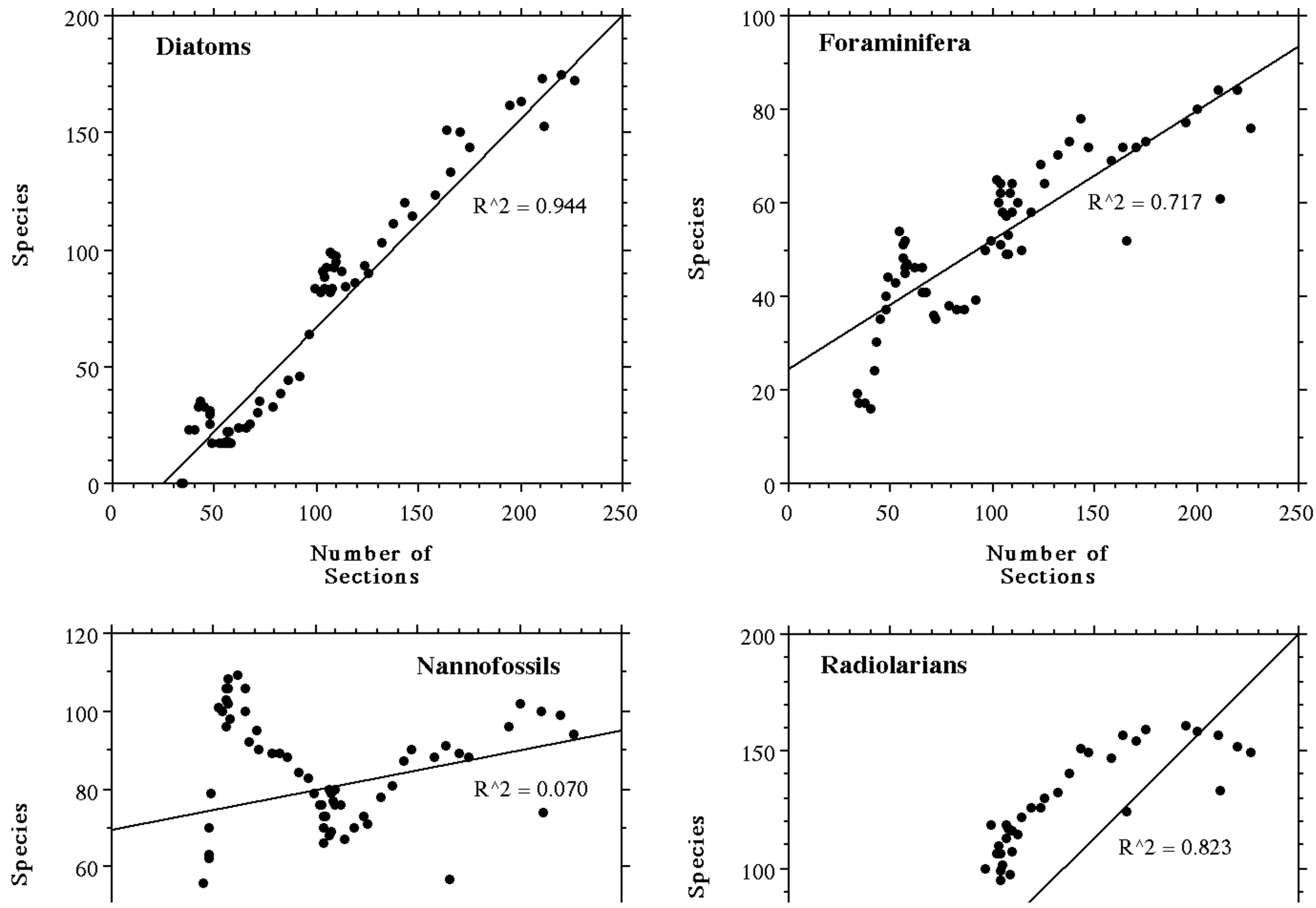
Figure 4.17: THE CENOZOIC DEEP SEA MICROFOSSIL RECORD: EXPLORATIONS OF THE DSDP/ODP SAMPLE SET USING THE NEPTUNE DATABASE
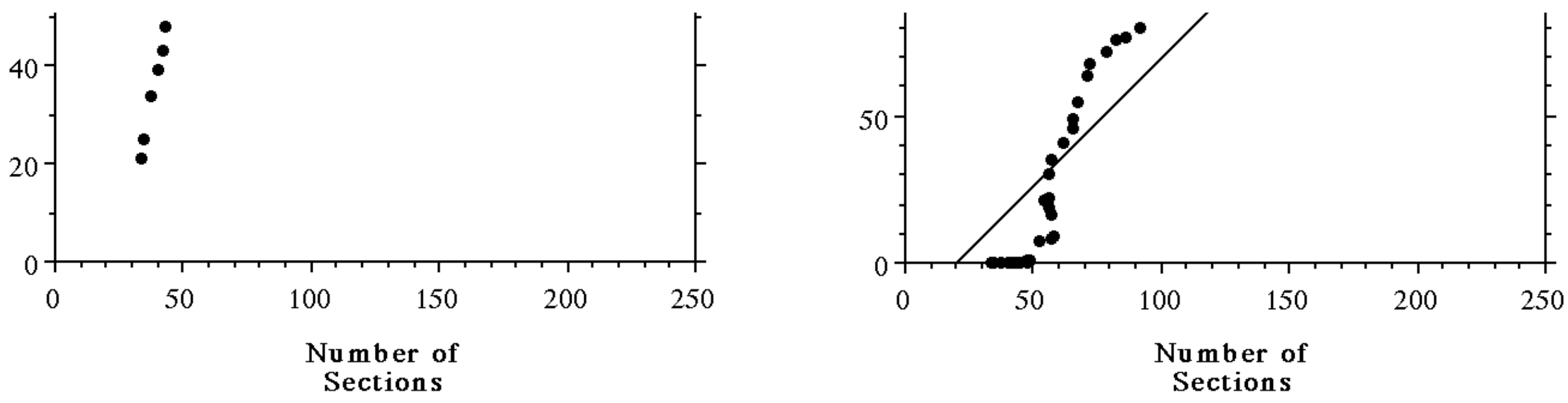


\section{Close $W$ indo w}

Figure 4.18. Age differences between equatorial Pacific calibration (defined as 0 ) and North Pacific age ranges. The horizontal bar represents the suggested calibration for the single events. The events are divided into three groups, from left to right: the first, largest group includes events that are older in the North Pacific than they are in the Equatorial Pacific, the second group of events is synchronous in the equatorial and North Pacific, the third group includes events that are younger in the North Pacific. The number of sites included in the age range is written below the bar (from Spencer-Cervato et al. 1993).

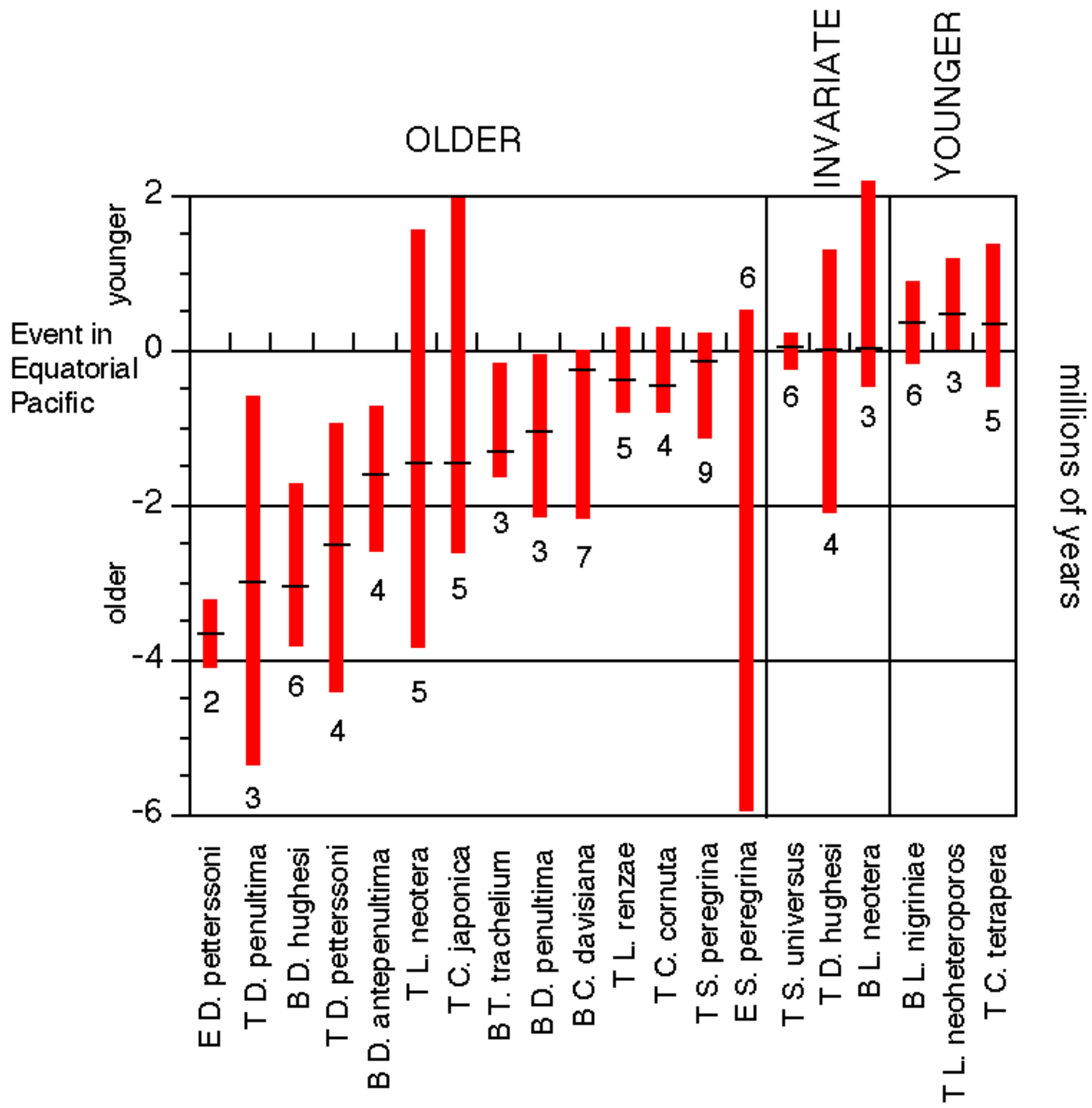




\section{Close window}

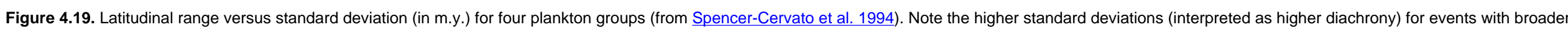

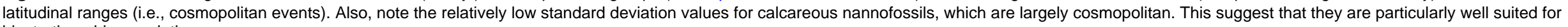
biostratigraphic correlations.
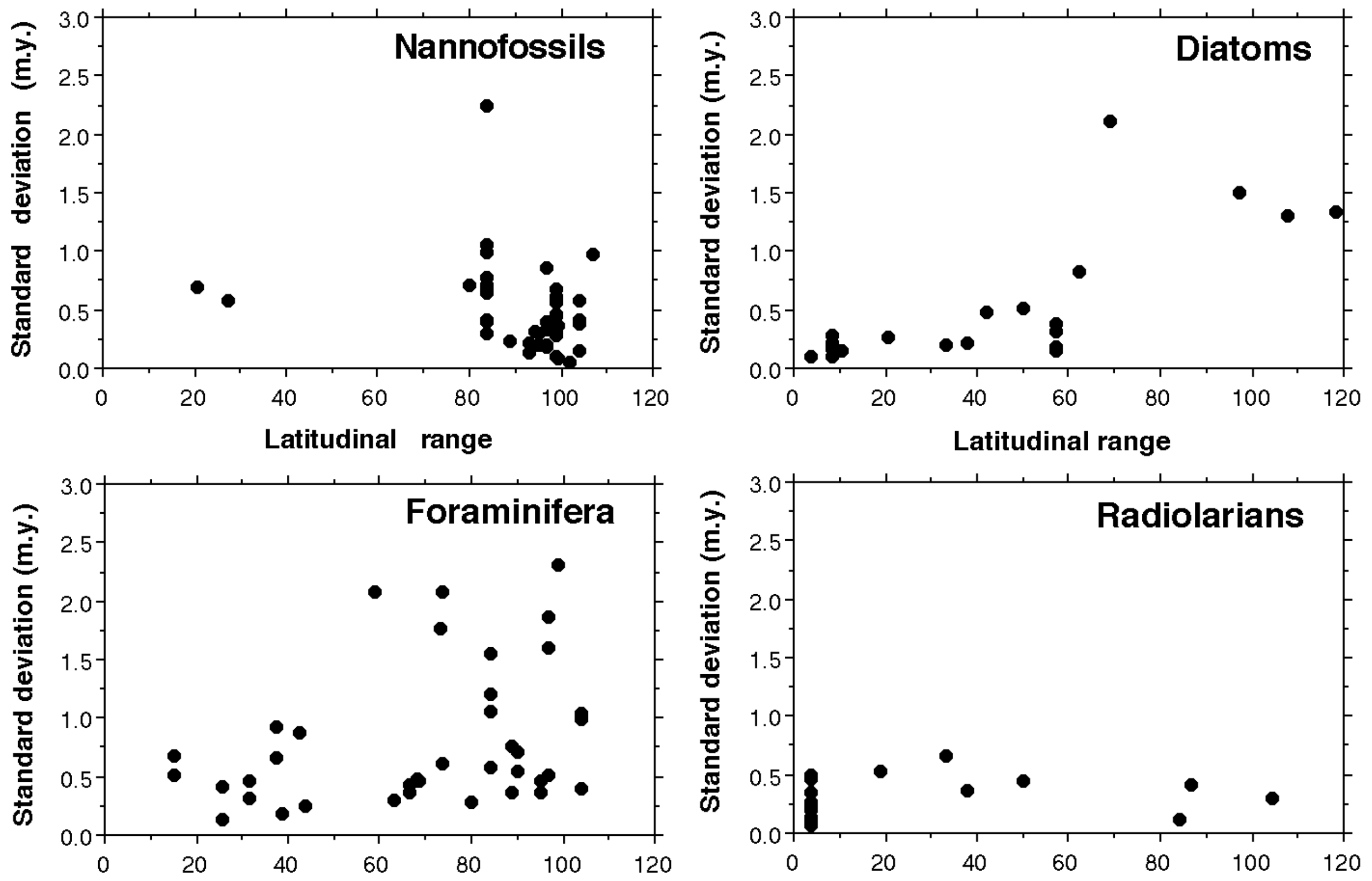
Figure 4.19: THE CENOZOIC DEEP SEA MICROFOSSIL RECORD: EXPLORATIONS OF THE DSDP/ODP SAMPLE SET USING THE NEPTUNE DATABASE

\section{Latitudinal range}

Latitudinal range 


\section{Close window}

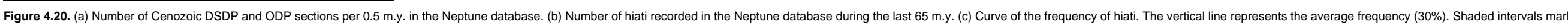

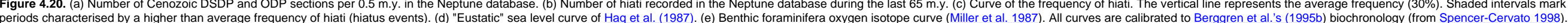

\section{Number of sections}

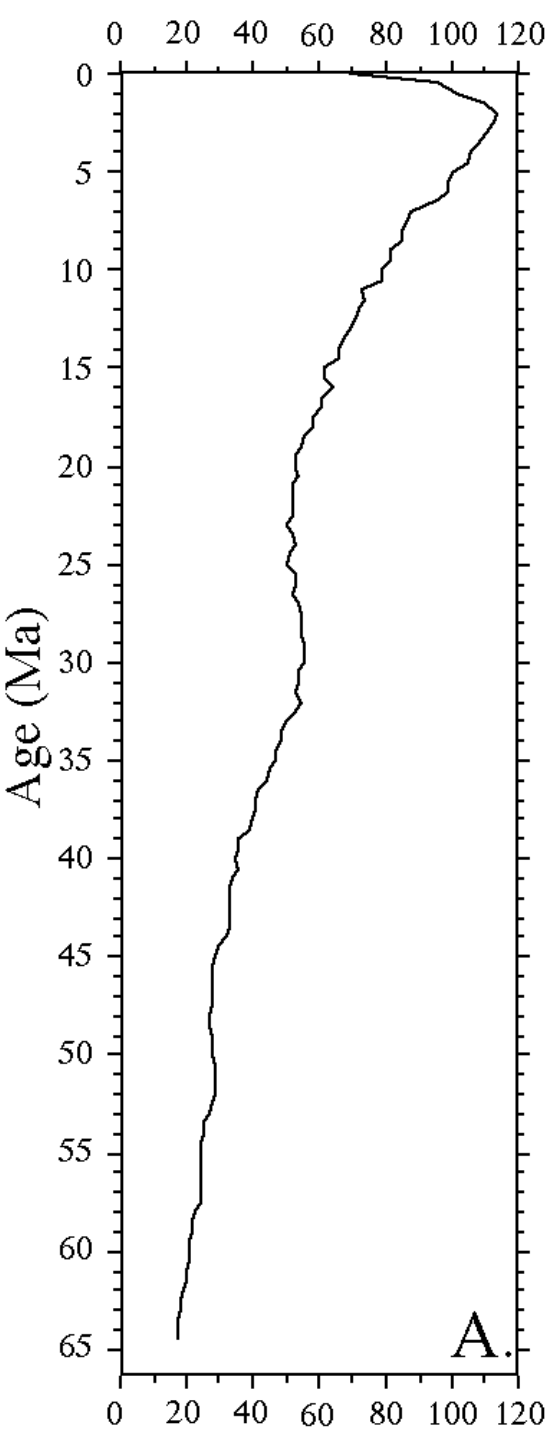

Number of hiatuses

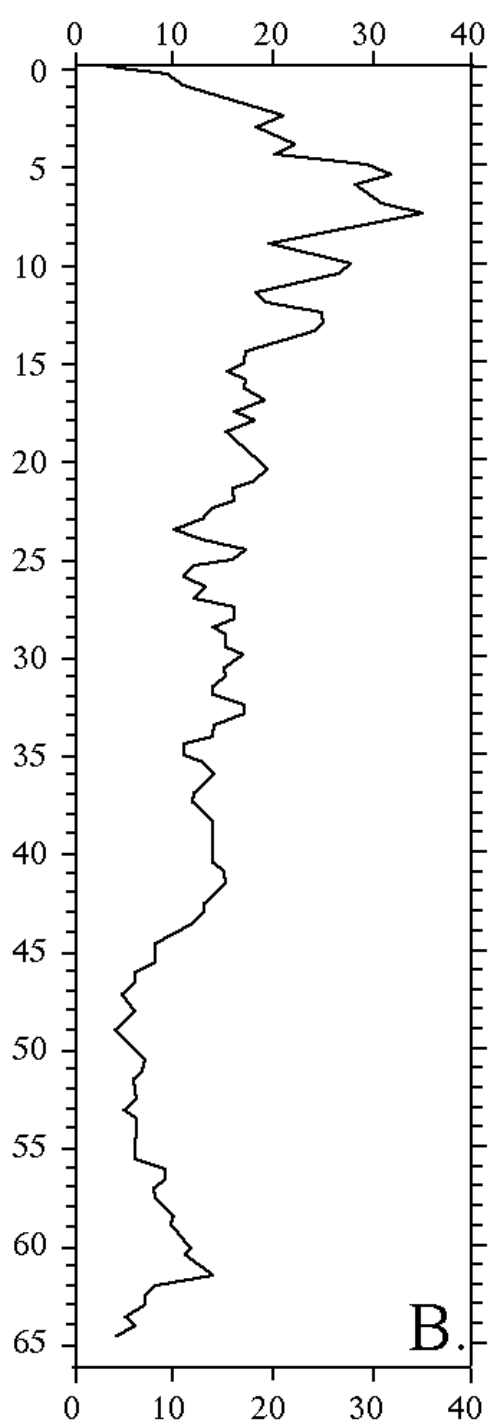

Frequency of hiatuses (in \% of total sections)
"Eustatic" curve

\section{of Haq et al., 1987}

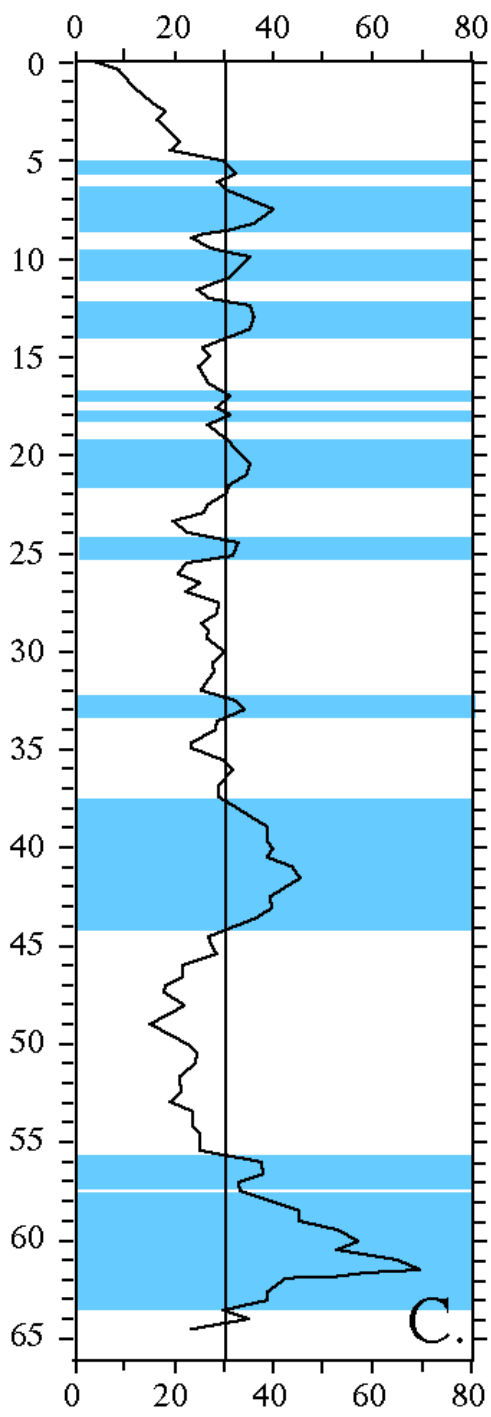

\begin{abstract}
$\begin{array}{llll}200 & 100 & 0 & -100\end{array}$
\end{abstract}

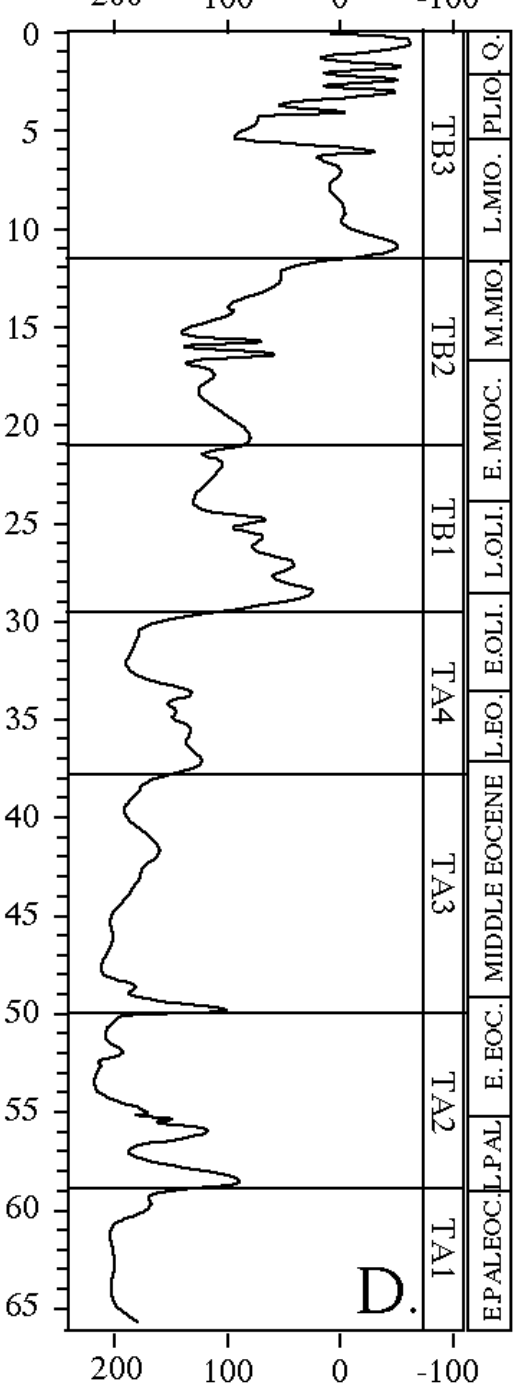

$\delta 18$ O\%denthic

Miller et al., 1987

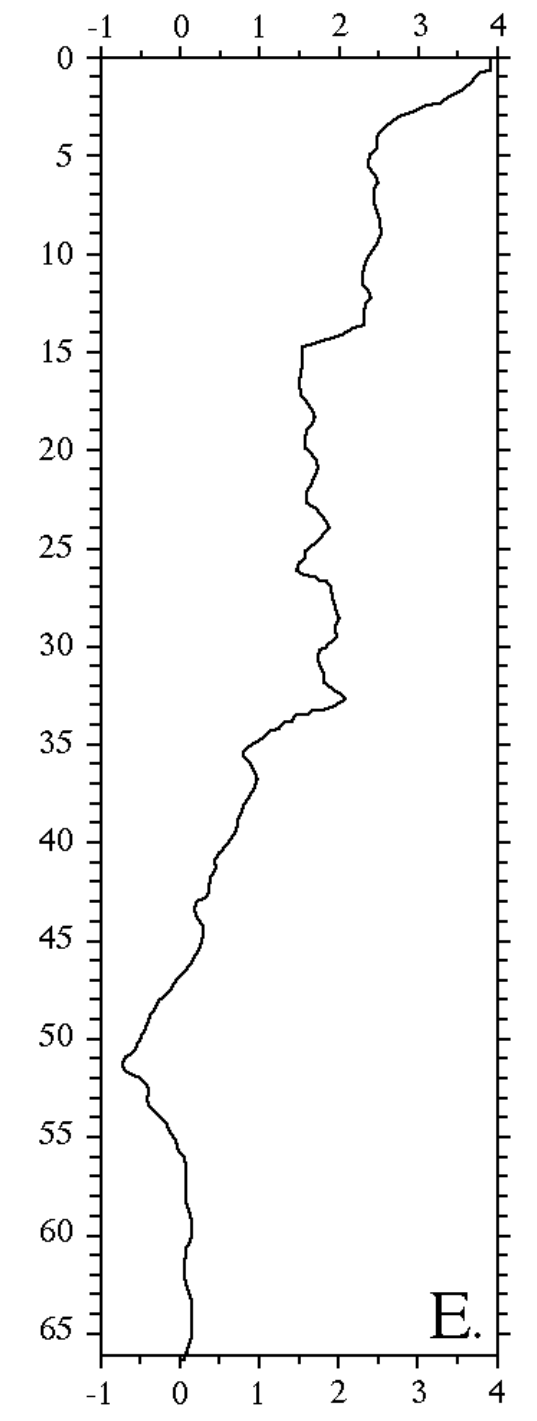




\section{Close Window}

Figure 4.21. The lines with symbols represent the frequency of hiati recorded at various paleodepth intervals: (a) shallower than $2000 \mathrm{~m}$, (b) between 2000 and $3000 \mathrm{~m}$, and (c) deeper than $3000 \mathrm{~m}$. The continuous lines represent the percentage of sections in the Neptune database in that interval of paleo-water depth (from Spencer-Cervato 1998).

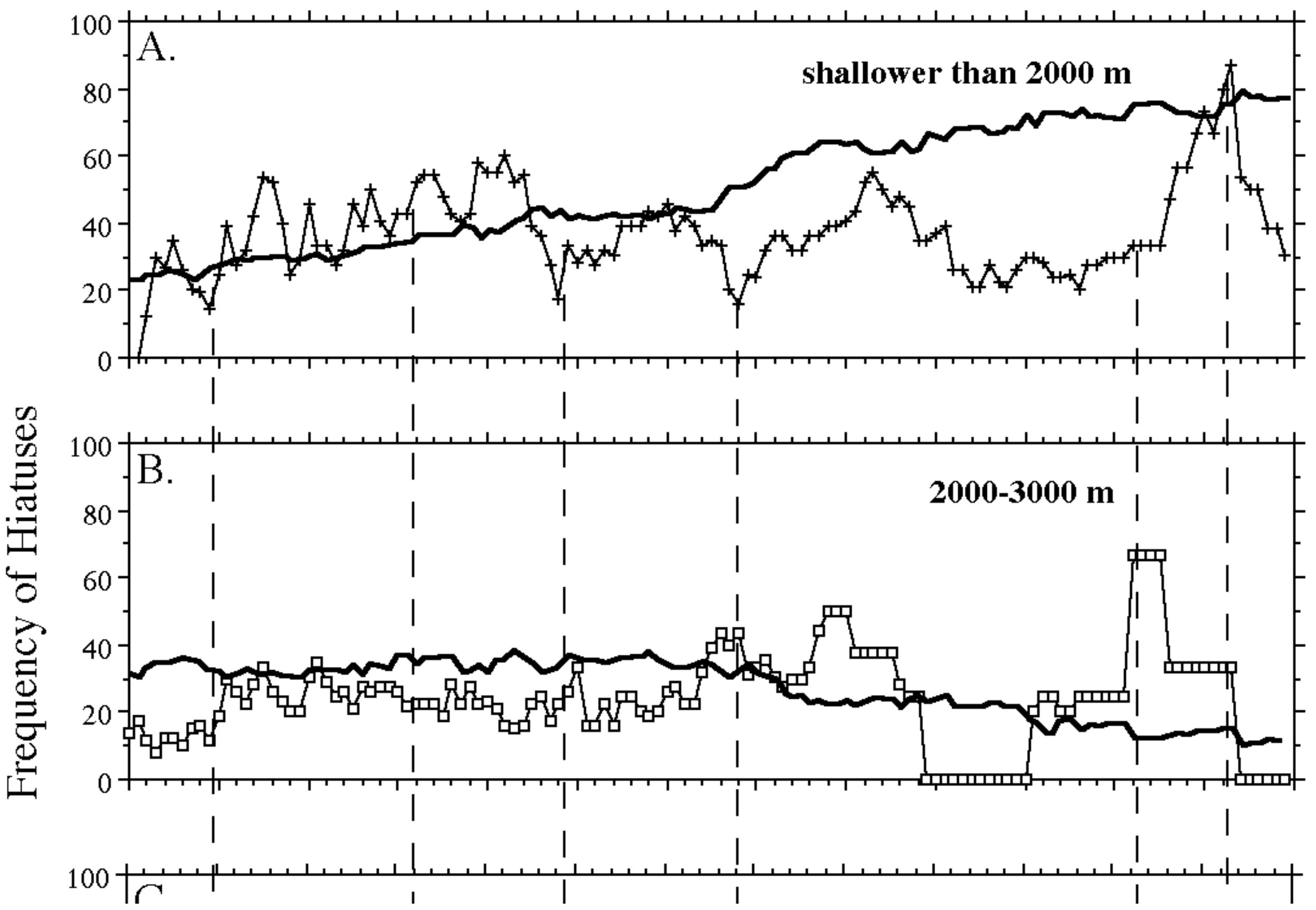


Figure 4.21: THE CENOZOIC DEEP SEA MICROFOSSIL RECORD: EXPLORATIONS OF THE DSDP/ODP SAMPLE SET USING THE NEPTUNE DATABASE

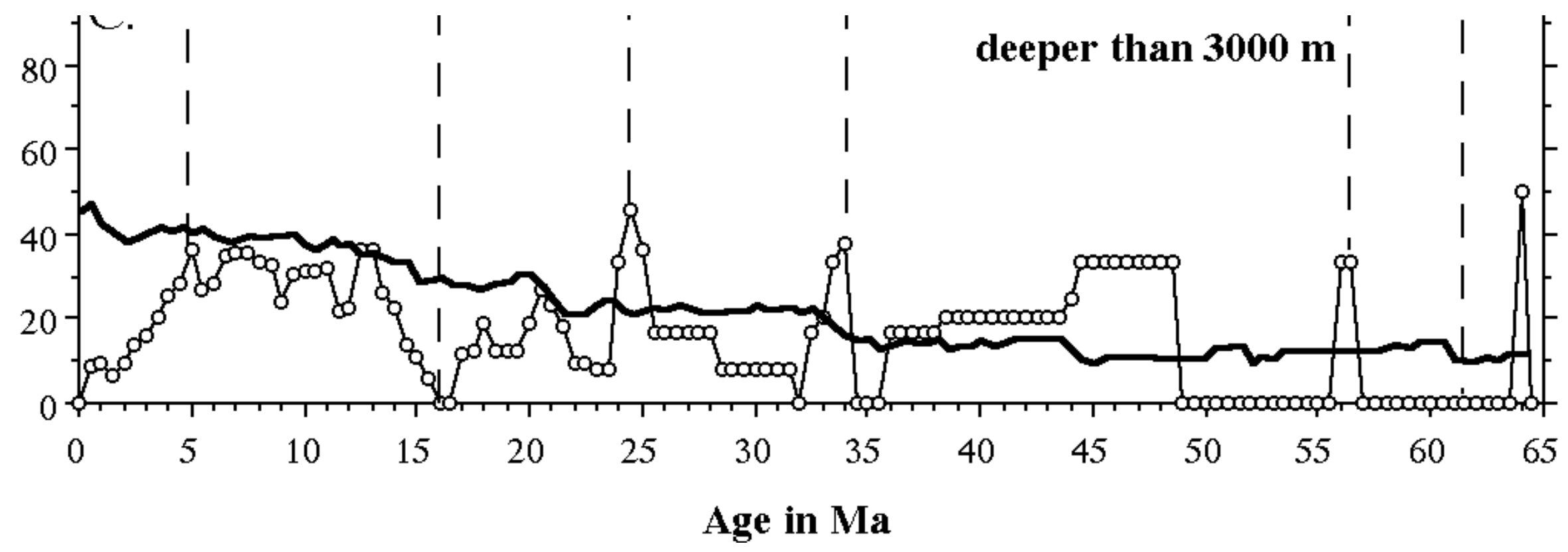




\section{Close Window}

Table 4.1. Names of 1418 species included in the macroevolution analyses.

Diatoms

ABAS WITTII

ACHTINOPTYCHUS BIPUNCTATUS

ACHTINOPTYCHUS SENARIUS

ACHTINOPTYCHUS SPLENDENS

ACTINOCYCLUS CURVATULUS

ACTINOCYCLUS ELLIPTICUS

ACTINOCYCLUS ELONGATUS

ACTINOCYCLUS INGENS

ACTINOCYCLUS LANCEOLATUS

ACTINOCYCLUS MORONENSIS

ACTINOCYCLUS OCHOTENSIS

ACTINOCYCLUS OCTONARIUS

ACTINOCYCLUS OCULATUS

ACTINOCYCLUS TSUGARUENSIS

ACTINOCYCLUS ACTINOCHILUS

ACTINOCYCLUS FASCICULATUS

ACTINOCYCLUS FRYXELLAE

ACTINOCYCLUS KARSTENII

ANNELLUS CALIFORNICUS

ASTEROLAMPRA ACUTILOBA

ASTEROLAMPRA AFFINIS

ASTEROLAMPRA GREVILLEI

ASTEROLAMPRA INSIGNIS

ASTEROLAMPRA MARYLANDICA 
ASTEROLAMPRA PUNCTIFERA

ASTEROLAMPRA VULGARIS

ASTEROLAMPRA SCHMIDTII

ASTEROMPHALUS ARACHNE

ASTEROMPHALUS DARWINII

ASTEROMPHALUS FLABELLATUS

ASTEROMPHALUS HEPTACTIS

ASTEROMPHALUS HOOKERI

ASTEROMPHALUS IMBRICATUS

ASTEROMPHALUS OLIGOCENICUS

ASTEROMPHALUS PARVULUS

ASTEROMPHALUS PETERSONII

ASTEROMPHALUS ROBUSTUS

ASTEROMPHALUS SYMMETRICUS

ASTEROMPHALUS KENNETTII

AZPEITIA NODULIFER

AZPEITIA ENDOI

AZPEITIA TABULARIS

AZPEITIA GOMBOSI

AZPEITIA OLIGOCENICA

AZPEITIA PRAENODULIFER

AZPEITIA VETUSTISSIMA

BACTERIOSIRA FRAGILIS

BACTERIASTRUM HYALINUM

BAXTERIA BRUNII

BOGOROVIA VENIAMINI

BOGOROVIA PALEACEA

BOGOROVIA PRAEPALEACEA 
CESTODISCUS CONVEXUS CESTODISCUS MUKHINAE CESTODISCUS PEPLUM CESTODISCUS PULCHELLUS CESTODISCUS RETICULATUS CESTODISCUS ROBUSTUS CESTODISCUS STOKESIASUS CESTODISCUS TROCHUS CESTODISCUS ANTARCTICUS CESTODISCUS DEMERGITUS CESTODISCUS PARMULA CHAETOCEROS FURCELLATUS CHAETOCEROS ASYMMETRICUS CHAETOCEROS BULBOSUM CLADOGRAMMA DUBIUM COCCONEIS CALIFORNICA COCCONEIS COSTATA COCCONEIS PSEUDOMARGINATA COCCONEIS SCUTELLUM CORETHRON CRIOPHILUM COSCINODISCUS AFRICANUS COSCINODISCUS APICULATUS COSCINODISCUS ASTEROMPHALUS COSCINODISCUS BLYSMOS COSCINODISCUS CENTRALIS COSCINODISCUS CRENULATUS COSCINODISCUS DEFORMANS 
COSCINODISCUS ELEGANS

COSCINODISCUS EXCAVATUS

COSCINODISCUS FLEXUOSUS

COSCINODISCUS GIGAS

COSCINODISCUS KOLBEI

COSCINODISCUS LEWISIANUS

COSCINODISCUS MARGINATUS

COSCINODISCUS NODULIFER

COSCINODISCUS OCCULUS-IRIDIS

COSCINODISCUS PLICATUS

COSCINODISCUS PRAEYABEI

COSCINODISCUS PUSTULATUS

COSCINODISCUS RADIATUS

COSCINODISCUS RHOMBICUS

COSCINODISCUS STELLARIS

COSCINODISCUS SUPERBUS

COSCINODISCUS TEMPEREI

COSCINODISCUS TUBERCULATUS

COSCINODISCUS YABEI

COSCINODISCUS CRUXII

COSCINODISCUS HAJOSIAE

COSCINODISCUS VULNIFICUS

COSMIODISCUS INSIGNIS

CRASPEDODISCUS COSCINODISCUS

CRASPEDODISCUS UMBONATUS

CRUCIDENTICULA NICOBARICA

CRUCIDENTICULA PUNCTATA

CRUCIDENTICULA KANAYAE 
CUSSIA LANCETTULA

CYCLOTELLA STRIATA

CYMATOGONIA AMBLYOCERAS

CYMATOSIRA COMPACTA

CYMATOSIRA DEBYI

CYMATOTHECA WEISSFLOGII

DACTYLIOSOLEN ANTARCTICUS

DELPHINEIS SURIRELLA

DELPHINEIS ISCHABOENSIS

DENTICULOPSIS DIMORPHA

DENTICULOPSIS HUSTEDTII

DENTICULOPSIS HYALINA

DENTICULOPSIS LAUTA

DENTICULOPSIS MACCOLLUMII

DENTICULOPSIS MIOCENICA

DENTICULOPSIS NORWEGICA

DENTICULOPSIS PRAEDIMORPHA

DENTICULOPSIS PUNCTATA

DENTICULOPSIS SEMINAE

DENTICULOPSIS KATAYAMAE

DENTICULOPSIS MERIDIONALIS

DIMEROGRAMMA FOSSILE

DIPLONEIS BOMBUS

DIPLONEIS COFFAEIFORMIS

DIPLONEIS SMITHII

DIPLONEIS WEISSFLOGII

ETHMODISCUS REX 
EUCAMPIA ANTARCTICA

GONIOTHECIUM DECORATUM

GONIOTHECIUM ODONTELLA

GRUNOWIELLA GEMMATA

GRUNOWIELLA PALAEOCAENICA

HEMIDISCUS CUNEIFORMIS

HEMIDISCUS KARSTENII

HEMIDISCUS OVALIS

HEMIDISCUS SIMPLICISSIMUS

HEMIDISCUS TRIANGULARUS

HEMIAULUS ALTAR

HEMIAULUS BARBADENSIS

HEMIAULUS CARACTERISTICUS

HEMIAULUS EXIGUUS

HEMIAULUS INCISUS

HEMIAULUS POLYMORPHUS

HEMIAULUS PUNGENS

HEMIAULUS SUBACUTUS

HEMIAULUS TAURUS

HEMIAULUS FRAGILIS

HEMIAULUS GRACILIS

HEMIAULUS KRISTOFFERSENII

HEMIAULUS NOCCHIAE

HEMIAULUS PERIPTERUS

HEMIAULUS POLYCYSTINORUM

HEMIAULUS RECTUS

HEMIAULUS ROSSICUS

HYALODISCUS OBSOLETUS 
HYALODISCUS AMBIGUUS

IKEBEA TENUIS

KATATHIRAIA ASPERA

KISSELEVIELLA CARINA

KOZLOVIELLA MINOR

LISITZINIA ORNATA

LITHODESMIUM CORNIGERUM

LITHODESMIUM MINUSCULUM

LITHODESMIUM REYNOLDSII

LITHODESMIUM UNDULATUM

MACRORA STELLA

MEDIARIA SPLENDIDA

MELOSIRA ALBICANS

MELOSIRA SOL

NAVICULA LYRA

NAVICULA UDENTSEVII

NAVICULA WISEI

NEOBRUNIA MIRABILIS

NEODENTICULA KAMTSCHATICA

NEODENTICULA KOIZUMII

NITZSCHIA AEQUATORIALIS

NITZSCHIA ANGULATA

NITZSCHIA BICAPITATA

NITZSCHIA BRAARUDII

NITZSCHIA CHALLENGERI

NITZSCHIA CLAVICEPS

NITZSCHIA CURTA 
NITZSCHIA CYLINDRICA

NITZSCHIA GRANULATA

NITZSCHIA GROSSEPUNCTATA

NITZSCHIA GRUNOWII

NITZSCHIA INFLATULA

NITZSCHIA INTERFRIGIDARIA

NITZSCHIA INTERRUPTESTRIATA

NITZSCHIA JANUARIA

NITZSCHIA JOUSEAE

NITZSCHIA KERGUELENSIS

NITZSCHIA KOLACZECKII

NITZSCHIA MARINA

NITZSCHIA MIOCENICA

NITZSCHIA PANDURIFORMIS

NITZSCHIA PORTERI

NITZSCHIA PRAEINTERFRIGIDARIA

NITZSCHIA PRAEREINHOLDII

NITZSCHIA PSEUDOKERGUELENSIS

NITZSCHIA PUNCTATA

NITZSCHIA PUSILLA

NITZSCHIA REINHOLDII

NITZSCHIA RITSCHERII

NITZSCHIA ROLANDII

NITZSCHIA SEPARANDA

NITZSCHIA SERIATA

NITZSCHIA SICULA

NITZSCHIA SUIKOENSIS

NITZSCHIA UMAOIENSIS 
NITZSCHIA WEAVERI

NITZSCHIA CYLINDRUS

NITZSCHIA DENTICULOIDES

NITZSCHIA DIETRICHII

NITZSCHIA DONAHUENSIS

NITZSCHIA EFFERANS

NITZSCHIA EVENESCENS

NITZSCHIA EXTINCTA

NITZSCHIA FOSSILIS

NITZSCHIA MALEINTERPRETARIA

ODONTELLA AURITA

ODONTELLA TUOMEYI

PARALIA SULCATA

PARALIA ARCHITECTURALIS

PARALIA CLAVIGERA

PLAGIOGRAMMA STAUROPHORUM

PLANKTIONELLA SOL

POROSIRA GLACIALIS

PSEUDOEUNOTIA DOLIOLUS

PSEUDOPODOSIRA ELEGANS

PSEUDOPODOSIRA SIMPLEX

PSEUDOPYXILLA AMERICANA

PSEUDOPYXILLA RUSSICA

PSEUDOTRICERATIUM CHENEVIERI

PSEUDOTRICERATIUM RADIOSORETICULATUM

PTEROTHECA ACULEIFERA

PTEROTHECA CLAVATA 
PTEROTHECA EVERMANNI

PTEROTHECA KITTONIANA

PYXILLA RETICULATA

RHABDONEMA ARCUATUM

RHABDONEMA JAPONICUM

RHAPHIDODISCUS MARYLANDICUS

RHAPHONEIS AMPHICEROS

RHAPHONEIS ANGUSTATA

RHAPHONEIS MARGARITALIMBATA

RHIZOSOLENIA ALATA

RHIZOSOLENIA BERGONII

RHIZOSOLENIA CRETACEA

RHIZOSOLENIA CURVIROSTRIS

RHIZOSOLENIA HEBETATA

RHIZOSOLENIA INTERPOSITA

RHIZOSOLENIA MATUYAMAI

RHIZOSOLENIA MIOCENICA

RHIZOSOLENIA PRAEBERGONII

RHIZOSOLENIA STYLIFORMIS

RHIZOSOLENIA ANTARCTICA

RHIZOSOLENIA OLIGOCENICA

RHIZOSOLENIA SETIGERA

RIEDELIA CLAVIGER

ROCELLA GELIDA

ROCELLA VIGILANS

ROCELLA PRAENITIDA

ROPERIA PRAETESSELATA

ROPERIA TESSELATA 
ROSSIELLA PALEACEA

ROSSIELLA PRAEPALEACEA

ROSSIELLA TATSUNOKUCHIENSIS

ROSSIELLA SYMMETRICA

ROUXIA CALIFORNICA

ROUXIA GRANDA

ROUXIA HETEROPOLARA

ROUXIA ISOPOLICA

ROUXIA NAVICULOIDES

ROUXIA OBESA

ROUXIA PERAGALLI

ROUXIA YABEI

SCEPTRONEIS GRUNOWII

SCEPTRONEIS HUMUNCIA

SCEPTRONEIS PESPLANUS

SCEPTRONEIS TENUE

SCEPTRONEIS LINGULATUS

SIMONSENIELLA BARBOI

SIMONSENIELLA PRAEBARBOI

SKELETONEMA BARBADENSE

SPHYNCTOLETHUS HEMIAULOIDES

STEPHANOPYXIS DIMORPHA

STEPHANOPYXIS GRUNOWII

STEPHANOPYXIS HORRIDUS

STEPHANOPYXIS MARGINATA

STEPHANOPYXIS SPINOSISSIMA

STEPHANOPYXIS TURRIS 
STEPHANOPYXIS ORNATA

STEPHANOGONIA HANZAWAE

STELLARIMA MICROTRIAS

STELLARIMA PRIMALABIATA

SYNEDRA INDICA

SYNEDRA JOUSEANA

SYNEDRA MIOCENICA

THALASSIOSIRA ANTARCTICA

THALASSIOSIRA ANTIQUA

THALASSIOSIRA BURCKLIANA

THALASSIOSIRA CONVEXA

THALASSIOSIRA DECIPIENS

THALASSIOSIRA DELICATULA

THALASSIOSIRA ECCENTRICA

THALASSIOSIRA FRAGA

THALASSIOSIRA GRACILIS

THALASSIOSIRA GRAVIDA

THALASSIOSIRA HYALINA

THALASSIOSIRA JACKSONII

THALASSIOSIRA KRYOPHILA

THALASSIOSIRA LACUSTRIS

THALASSIOSIRA LEPTOPUS

THALASSIOSIRA LINEATA

THALASSIOSIRA NIDULUS

THALASSIOSIRA NODULOLINEATA

THALASSIOSIRA NORDENSKIOELDII

THALASSIOSIRA OESTRUPII

THALASSIOSIRA OPPOSITA 
THALASSIOSIRA PACIFICA

THALASSIOSIRA PLICATA

THALASSIOSIRA PRAECONVEXA

THALASSIOSIRA PUNCTATA

THALASSIOSIRA SINGULARIS

THALASSIOSIRA SPINOSA

THALASSIOSIRA SPUMELLAROIDES

THALASSIOSIRA SYMBOLOPHORA

THALASSIOSIRA SYMMETRICA

THALASSIOSIRA TEMPEREI

THALASSIOSIRA TAPPANES

THALASSIOSIRA TRIFULTA

THALASSIOSIRA TUMIDA

THALASSIOSIRA USATSCHEVII

THALASSIOSIRA YABEI

THALASSIOSIRA ZABELINAE

THALASSIOSIRA BUKRYI

THALASSIOSIRA ELLIPTIPORA

THALASSIOSIRA GERSONDEI

THALASSIOSIRA LENTIGINOSA

THALASSIOSIRA MANIFESTA

THALASSIOSIRA MARUJAMICA

THALASSIOSIRA MIOCENICA

THALASSIOSIRA NATIVA

THALASSIOSIRA OLIVERANA

THALASSIOSIRA STRIATA

THALASSIOSIRA WEBBI 
THALASSIONEMA BACILLARIS

THALASSIONEMA HIROSAKIENSIS

THALASSIONEMA NITZSCHIOIDES

THALASSIONEMA ROBUSTA

THALASSIONEMA SCHRADERI

THALASSIOTHRIX FRAUENFELDII

THALASSIOTHRIX LONGISSIMA

THALASSIOTHRIX MIOCENICA

TRACHYNEIS ASPERA

TRICERATIUM ACUTANGULUM

TRICERATIUM BARBADENSE

TRICERATIUM CINNAMOMEUM

TRICERATIUM CONDECORUM

TRICERATIUM GRONINGENSIS

TRICERATIUM SCHULZII

TRICERATIUM CELLULOSUM

TRICERATIUM GOMBOSII

TRICERATIUM MIRABILE

TRICERATIUM UNGUICULATUM

TRINACRIA EXCAVATA

TRINACRIA PILEOLUS

TRINACRIA REGINA

TRINACRIA SIMULACRUM

TRINACRIA SUBCAPITATA

TRINACRIA CONIFERA

TRINACRIA DECIUSII

TRINACRIA SENTA

TRINACRIA SIMULACROIDES 
TROCHOSIRA CONCAVA

TROCHOSIRA SPINOSA

TROCHOSIRA GRACILLIMA

TROCHOSIRA MARGINATA

TROCHOSIRA RADIATA

XANTHIOPYXIS OBLONGA

XANTHIOPYXIS ACROLOPHA

Foraminifera

ACARININA ASPENSIS

ACARININA BROEDERMANNI

ACARININA BULLBROOKI

ACARININA CONVEXA

ACARININA DECEPTA

ACARININA ESNAENSIS

ACARININA INTERMEDIA

ACARININA MATHEWSAE

ACARININA MCKANNAI

ACARININA PENTACAMERATA

ACARININA PRIMITIVA

ACARININA ROTUNDIMARGINATA

ACARININA RUGOSOACULEATA

ACARININA SOLDADOENSIS

ACARININA SPINULOINFLATA

ACARININA SPIRALIS

ACARININA TRIPLEX

ACARININA WILCOXENSIS

ACARININA APPRESSOCAMERATA 
ACARININA CUNEICAMERATA

ACARININA ECHINATA

ACARININA PRAEPENTACAMERATA

ACARININA PRAETOPILENSIS

BEELLA DIGITATA

CANDEINA NITIDA

CASSIGERINELLOITA AMEKIENSIS

CASSIGERINELLA CHIPOLENSIS

CATAPSYDRAX DISSIMILIS

CATAPSYDRAX PARVULUS

CATAPSYDRAX STAINFORTHI

CHILOGUEMBELINA CUBENSIS

CHILOGUEMBELINA MIDWAYENSIS

CHILOGUEMBELINA WILCOXENSIS

CHILOGUEMBELINA CRINITA

CRIBROHANTKENINA INFLATA

DENTOGLOBIGERINA GALAVISI

EOGLOBIGERINA EOBULLOIDES

EOGLOBIGERINA TAURICA

EOGLOBIGERINA FRINGA

GLOBOROTALIA AEMILIANA

GLOBOROTALIA ACROSTOMA

GLOBOROTALIA ANFRACTA

GLOBOROTALIA ARCHAEOMENARDII

GLOBOROTALIA BIRNAGAE

GLOBOROTALIA BONONIENSIS

GLOBOROTALIA CIBAOENSIS

GLOBOROTALIA COLLACTEA 


\section{GLOBOROTALIA CONICA}

GLOBOROTALIA CONOIDEA

GLOBOROTALIA CONOMIOZEA

GLOBOROTALIA CONTINUOSA

GLOBOROTALIA CRASSAFORMIS

GLOBOROTALIA CRASSATA

GLOBOROTALIA EXILIS

GLOBOROTALIA FOHSI

GLOBOROTALIA GEMMA

GLOBOROTALIA HIRSUTA

GLOBOROTALIA INCONSTANS

GLOBOROTALIA INCREBESCENS

GLOBOROTALIA INFLATA

GLOBOROTALIA INSOLITA

GLOBOROTALIA JUANAI

GLOBOROTALIA KUGLERI

GLOBOROTALIA ICHINOSEKIENSIS

GLOBOROTALIA LENGUAENSIS

GLOBOROTALIA MARGARITAE

GLOBOROTALIA MARGINODENTATA

GLOBOROTALIA MAYERI

GLOBOROTALIA MENARDII

GLOBOROTALIA MENDACIS

GLOBOROTALIA MEROTUMIDA

GLOBOROTALIA MINIMA

GLOBOROTALIA MINUTISSIMA

GLOBOROTALIA MIOCENICA 
GLOBOROTALIA MIOTUMIDA

GLOBOROTALIA MIOZEA

GLOBOROTALIA MULTICAMERATA

GLOBOROTALIA NANA

GLOBOROTALIA OBESA

GLOBOROTALIA OPIMA

GLOBOROTALIA NYMPHA

GLOBOROTALIA PANDA

GLOBOROTALIA PERIPHEROACUTA

GLOBOROTALIA PERIPHERORONDA

GLOBOROTALIA PERMICRA

GLOBOROTALIA PERTENUIS

GLOBOROTALIA PLESIOTUMIDA

GLOBOROTALIA PLIOZEA

GLOBOROTALIA POSTCRETACEA

GLOBOROTALIA PRAEMENARDII

GLOBOROTALIA PSEUDOMENARDII

GLOBOROTALIA PSEUDOMIOCENICA

GLOBOROTALIA PSEUDOPUMILIO

GLOBOROTALIA PUNCTICULATA

GLOBOROTALIA QUADRATA

GLOBOROTALIA QUETRA

GLOBOROTALIA REISSI

GLOBOROTALIA SCITULA

GLOBOROTALIA SEMIVERA

GLOBOROTALIA SIAKENSIS

GLOBOROTALIA SUTERAE

GLOBOROTALIA TADJIKITANENSIS 
GLOBOROTALIA THEYERI

GLOBOROTALIA TOSAENSIS

GLOBOROTALIA TRINIDADENSIS

GLOBOROTALIA TRUNCATULINOIDES

GLOBOROTALIA TUMIDA

GLOBOROTALIA UNCINATA

GLOBOROTALIA UNGULATA

GLOBOROTALIA WHITEI

GLOBOROTALIA ZEALANDICA

GLOBOROTALIA SHERICOMIOZEA

GLOBOCONUSA DAUBJERGENSIS

GLOBIGERINOIDES ALTIAPERTURUS

GLOBIGERINOIDES BISPHERICUS

GLOBIGERINOIDES BOLLII

GLOBIGERINOIDES CONGLOBATUS

GLOBIGERINOIDES DIMINUTUS

GLOBIGERINOIDES FISTULOSUS

GLOBIGERINOIDES HIGGINSI

GLOBIGERINOIDES MITRA

GLOBIGERINOIDES PRIMORDIUS

GLOBIGERINOIDES RUBER

GLOBIGERINOIDES SACCULIFER

GLOBIGERINOIDES SICANUS

GLOBIGERINOIDES SUBQUADRATUS

GLOBIGERINOIDES TYRRHENICUS

GLOBIGERINOIDES OBLIQUUS

GLOBIGERINATELLA INSUETA 
GLOBIGERINA AMPLIAPERTURA

GLOBIGERINA ANGULIOFFICINALIS

GLOBIGERINA ANGULISUTURALIS

GLOBIGERINA APERTURA

GLOBIGERINA ATLANTICA

GLOBIGERINA BINAIENSIS

GLOBIGERINA BRAZIERI

GLOBIGERINA BREVIS

GLOBIGERINA BULBOSA

GLOBIGERINA BULLOIDES

GLOBIGERINA CARIACOENSIS

GLOBIGERINA CIPEROENSIS

GLOBIGERINA CORPULENTA

GLOBIGERINA CRYPTOMPHA

GLOBIGERINA DRURYI

GLOBIGERINA EAMESI

GLOBIGERINA EUAPERTA

GLOBIGERINA FALCONENSIS

GLOBIGERINA FOLIATA

GLOBIGERINA GLOBULARIS

GLOBIGERINA GORTANII

GLOBIGERINA HAGNI

GLOBIGERINA INAEQUISPIRA

GLOBIGERINA JUVENILIS

GLOBIGERINA LABIACRASSATA

GLOBIGERINA LINAPERTA

GLOBIGERINA MEGASTOMA

GLOBIGERINA MUNDA 
GLOBIGERINA NEPENTHES

GLOBIGERINA OFFICINALIS

GLOBIGERINA OUACHITAENSIS

GLOBIGERINA PATAGONICA

GLOBIGERINA PRAEBULLOIDES

GLOBIGERINA PRAEDIGITATA

GLOBIGERINA PRAETURRITILINA

GLOBIGERINA PRASAEPIS

GLOBIGERINA PSEUDOAMPLIAPERTURA

GLOBIGERINA PSEUDOCIPEROENSIS

GLOBIGERINA PSEUDOBULLOIDES

GLOBIGERINA PSEUDOVENEZUELANA

GLOBIGERINA RUBESCENS

GLOBIGERINA SELLII

GLOBIGERINA SENNI

GLOBIGERINA TAPURIENSIS

GLOBIGERINA TENELLA

GLOBIGERINA TRILOCULINOIDES

GLOBIGERINA TRIPARTITA

GLOBIGERINA TRIVIALIS

GLOBIGERINA UTILISINDEX

GLOBIGERINA VARIANTA

GLOBIGERINA WINKLERI

GLOBIGERINA WOODI

GLOBIGERINA YEGUAENSIS

GLOBIGERINELLOIDES SUBCARINATUS

GLOBIGERINELLOIDES MULTISPINATUS 
GLOBIGERINELLA CALIDA

GLOBIGERINELLA SIPHONIFERA

GLOBOQUADRINA ALTISPIRA

GLOBOQUADRINA BAROEMOENENSIS

GLOBOQUADRINA CONGLOMERATA

GLOBOQUADRINA DEHISCENS

GLOBOQUADRINA LARMEUI

GLOBOQUADRINA PSEUDOFOLIATA

GLOBOQUADRINA VENEZUELANA

GLOBIGERINATHEKA BARRI

GLOBIGERINATHEKA INDEX

GLOBIGERINATHEKA MEXICANA

GLOBIGERINATHEKA SEMIINVOLUTA

GLOBIGERINATHEKA SUBCONGLOBATA

GLOBOROTALOIDES SUTERI

GLOBOROTALOIDES TESTARUGOSUS

GLOBOROTALOIDES TREMA

GLOBOROTALOIDES VARIABILIS

GLOBOROTALOIDES HEXAGONA

GLOBOROTALOIDES OREGONENSIS

GLOBIGERINITA GLUTINATA

GLOBIGERINITA HOWEI

GLOBIGERINITA PERA

GLOBIGERINITA UVULA

HANTKENINA ALABAMENSIS

HANTKENINA PRIMITIVA

HASTIGERINA PELAGICA

IGORINA PUSILLA 
MOROZOVELLA ACUTA

MOROZOVELLA ACUTISPIRA

MOROZOVELLA AEQUA

MOROZOVELLA ANGULATA

MOROZOVELLA ARAGONENSIS

MOROZOVELLA CONICOTRUNCATA

MOROZOVELLA FORMOSA

MOROZOVELLA LEHNERI

MOROZOVELLA LENSIFORMIS

MOROZOVELLA OCCLUSA

MOROZOVELLA SPINULOSA

MOROZOVELLA SUBBOTINAE

MOROZOVELLA VELASCOENSIS

MOROZOVELLA CRATER

MOROZOVELLA EDITA

MOROZOVELLA NICOLI

MOROZOVELLA PRAECURSORIA

MURICOGLOBIGERINA AQUIENSIS

MURICOGLOBIGERINA CHASCANONA

NEOGLOBOQUADRINA ACOSTAENSIS

NEOGLOBOQUADRINA ASANOI

NEOGLOBOQUADRINA DUTERTREI

NEOGLOBOQUADRINA HUMEROSA

NEOGLOBOQUADRINA PACHYDERMA

NEOGLOBOQUADRINA PSEUDOPIMA

ORBULINA SUTURALIS

ORBULINA UNIVERSA 
PLANOROTALITES AUSTRALIFORMIS

PLANOROTALITES CHAPMANI

PRAEORBULINA GLOMEROSA

PRAEORBULINA TRANSITORIA

PROTENTELLA CLAVATICAMERATA

PROTENTELLA NAVAZUELENSIS

PSEUDOHASTIGERINA BARBADOENSIS

PSEUDOHASTIGERINA MICRA

PSEUDOHASTIGERINA NAGUEWICHIENSIS

PSEUDOHASTIGERINA WILCOXENSIS

PSEUDOHASTIGERINA DANVILLENSIS

PULLENIATINA OBLIQUILOCULATA

PULLENIATINA PRAECURSOR

PULLENIATINA PRIMALIS

PULLENIATINA SPECTABILIS

SPHAEROIDINELLA DEHISCENS

SPHAEROIDINELLOPSIS DISJUNCTA

SPHAEROIDINELLOPSIS SEMINULINA

SPHAEROIDINELLOPSIS MULTILOBA

STREPTOCHILUS GLOBIGERUM

SUBBOTINA ANGIPOROIDES

SUBBOTINA EOCAENA

SUBBOTINA EOCAENICA

SUBBOTINA TRIANGULARIS

SUBBOTINA TRILOCULARIS

SUBBOTINA TURGIDA

SUBBOTINA BAKERI

SUBBOTINA CROCIAPERTURA 
SUBBOTINA EUAPERTURA

SUBBOTINA PSEUDOEOCAENA

TENUITELLINATA IOTA

TENUITELLA ANGUSTIUMBILICATA

TRUNCOROTALOIDES PSEUDOTOPILENSIS

TRUNCOROTALOIDES ROHRI

TRUNCOROTALOIDES TOPILENSIS

TURBOROTALIA CERROAZULENSIS

TURBOROTALIA COMPRESSA

TURBOROTALITA HUMILIS

TURBOROTALITA QUINQUELOBA

ZEAGLOBIGERINA INCISA

ZEAGLOBIGERINA MICROSTOMA

EOGLOBIGERINA EOBULLOIDES

Nannofossils

AMAUROLITHUS AMPLIFICUS

AMAUROLITHUS BIZZARUS

AMAUROLITHUS DELICATUS

AMAUROLITHUS PRIMUS

AMAUROLITHUS TRICORNICULATUS

AMAUROLITHUS SIGMUNDII

ANGULOLITHINA ARCA

BIANTHOLITHUS SPARSUS

BICOLUMNUS OVATUS

BIRKELUNDIA STAURION

BRAARUDOSPHAERA BIGELOWII

BRAARUDOSPHAERA DISCULA 
BRAMLETTEIUS SERRACULOIDES

CALCIDISCUS LEPTOPORUS

CALCIDISCUS MACINTYREI

CALCIDISCUS PREMACINTYREI

CALCIDISCUS PROTOANNULUS

CAMPYLOSPHAERA DELA

CAMPYLOSPHAERA EODELA

CATINASTER CALYCULUS

CATINASTER COALITUS

CERATOLITHUS ACUTUS

CERATOLITHUS ARMATUS

CERATOLITHUS CRISTATUS

CERATOLITHUS RUGOSUS

CERATOLITHUS TELESMUS

CHIASMOLITHUS ALTUS

CHIASMOLITHUS BIDENS

CHIASMOLITHUS CALIFORNICUS

CHIASMOLITHUS CONSUETUS

CHIASMOLITHUS DANICUS

CHIASMOLITHUS EOGRANDIS

CHIASMOLITHUS EXPANSUS

CHIASMOLITHUS FREQUENS

CHIASMOLITHUS GIGAS

CHIASMOLITHUS GRANDIS

CHIASMOLITHUS OAMARUENSIS

CHIASMOLITHUS SOLITUS

CHIASMOLITHUS TITUS

CHIPHRAGMALITHUS ACANTHODES 
CHIPHRAGMALITHUS AUSTRIACUS

CHIPHRAGMALITHUS CALATHUS

CLAUSICOCCUS CRIBELLUM

CLAUSICOCCUS FENESTRATUS

COCCOLITHUS EOPELAGICUS

COCCOLITHUS MIOPELAGICUS

COCCOLITHUS PELAGICUS

COCCOLITHUS TENUISTRIATUS

COCCOLITHUS CRASSIPONS

COCCOLITHUS FUSCUS

CORANNULUS GERMANICUS

CORONOCYCLAS PRIONION

CORONOCYCLUS NITESCENS

CORONOCYCLUS SERRATUS

CRASSIDISCUS BACKMANII

CRASPEDOLITHUS DECLIVUS

CRENALITHUS PRODUCTELLUS

CRIBROCENTRUM RETICULATUM

CRUCIPLACOLITHUS EDWARDSII

CRUCIPLACOLITHUS PRIMUS

CRUCIPLACOLITHUS SUBROTUNDUS

CRUCIPLACOLITHUS TENUIS

CRUCIPLACOLITHUS NOTUS

CRUCIPLACOLITHUS CRIBELLUM

CRUCIPLACOLITHUS CRUCIFORMIS

CRUCIPLACOLITHUS LATIPONS

CRUCIPLACOLITHUS TARQUINIUS 
CRUCIPLACOLITHUS VANHECKAE

CYCLICARGOLITHUS ABISECTUS

CYCLICARGOLITHUS FLORIDANUS

CYCLICARGOLITHUS PSEUDOGAMMATON

CYCLICARGOLITHUS LUMINIS

CYCLOCOCCOLITHINA KINGII

DICTYOCOCCITES ANTARCTICUS

DICTYOCOCCITES BISECTUS

DICTYOCOCCITES CALLIDUS

DICTYOCOCCITES HESSLANDII

DICTYOCOCCITES ONUSTUS

DICTYOCOCCITES PRODUCTUS

DICTYOCOCCITES SCRIPPSAE

DICTYOCOCCITES DAVIESII

DISCOASTER ADAMANTEUS

DISCOASTER ASYMMETRICUS

DISCOASTER AULAKOS

DISCOASTER BARBADIENSIS

DISCOASTER BELLUS

DISCOASTER BERGGRENII

DISCOASTER BIFAX

DISCOASTER BINODOSUS

DISCOASTER BLACKSTOCKAE

DISCOASTER BOLLII

DISCOASTER BRAARUDII

DISCOASTER BRAMLETTEI

DISCOASTER BROUWERI

DISCOASTER CALCARIS 


\section{DISCOASTER CRUCIFORMIS}

DISCOASTER DECORUS

DISCOASTER DEFLANDREI

DISCOASTER DELICATUS

DISCOASTER DIASTYPUS

DISCOASTER DISTINCTUS

DISCOASTER DIVARICATUS

DISCOASTER DRUGGII

DISCOASTER ELEGANS

DISCOASTER EXILIS

DISCOASTER EXTENSUS

DISCOASTER FALCATUS

DISCOASTER FORMOSUS

DISCOASTER GEMMIFER

DISCOASTER GERMANICUS

DISCOASTER HAMATUS

DISCOASTER INTERCALARIS

DISCOASTER KUEPPERI

DISCOASTER KUGLERI

DISCOASTER LENTICULARIS

DISCOASTER LIDZII

DISCOASTER LODOENSIS

DISCOASTER LOEBLICHII

DISCOASTER MEDIOSUS

DISCOASTER MIRUS

DISCOASTER MISCONCEPTUS

DISCOASTER MOHLERI 
DISCOASTER MOOREI

DISCOASTER MULTIRADIATUS

DISCOASTER NEOHAMATUS

DISCOASTER NEORECTUS

DISCOASTER NEPHADOS

DISCOASTER NOBILIS

DISCOASTER NODIFER

DISCOASTER NONARADIATUS

DISCOASTER PANSUS

DISCOASTER PENTARADIATUS

DISCOASTER PREPENTARADIATUS

DISCOASTER PSEUDOVARIABILIS

DISCOASTER QUADRAMUS

DISCOASTER QUINQUERAMUS

DISCOASTER ROBUSTUS

DISCOASTER SAIPANENSIS

DISCOASTER SALISBURGENSIS

DISCOASTER SANMIGUELENSIS

DISCOASTER SAUNDERSI

DISCOASTER SEPTEMRADIATUS

DISCOASTER SIGNUS

DISCOASTER STELLULUS

DISCOASTER STRICTUS

DISCOASTER SUBLODOENSIS

DISCOASTER SUBSURCULUS

DISCOASTER SURCULUS

DISCOASTER TAMALIS

DISCOASTER TANII 
DISCOASTER TRIDENUS

DISCOASTER TRINIDADENSIS

DISCOASTER TRIRADIATUS

DISCOASTER TRISTELLIFER

DISCOASTER VARIABILIS

DISCOASTER WEMMELENSIS

DISCOASTER CHALLENGERI

DISCOASTEROIDES MEGASTYPUS

DISCOSPHAERA TUBIFERA

ELLIPSOLITHUS DISTICHUS

ELLIPSOLITHUS LAJOLLAENSIS

ELLIPSOLITHUS MACELLUS

EMILIANIA ANNULA

EMILIANIA HUXLEYI

ERICSONIA CAVA

ERICSONIA FORMOSA

ERICSONIA OBRUTA

ERICSONIA OVALIS

ERICSONIA ROBUSTA

ERICSONIA SUBDISTICHA

ERICSONIA SUBPERTUSA

FASCICULITHUS BILLII

FASCICULITHUS INVOLUTUS

FASCICULITHUS MITREUS

FASCICULITHUS PILEATUS

FASCICULITHUS SCHAUBII

FASCICULITHUS TYMPANIFORMIS 
FASCICULITHUS ULII

GEMINILITHELLA ROTULA

GEPHYROCAPSA APERTA

GEPHYROCAPSA CARIBBEANICA

GEPHYROCAPSA ERICSONIA

GEPHYROCAPSA OCEANICA

GEPHYROCAPSA PROTOHUXLEYI

GEPHYROCAPSA SINUOSA

HAYASTER PERPLEXUS

HAYELLA SITULIFORMIS

HELICOSPHAERA AMPLIAPERTA

HELICOSPHAERA BRAMLETTEI

HELICOSPHAERA CARTERI

HELICOSPHAERA COMPACTA

HELICOSPHAERA DINESENII

HELICOSPHAERA EUPHRATIS

HELICOSPHAERA GRANULATA

HELICOSPHAERA HEEZENI

HELICOSPHAERA INTERMEDIA

HELICOSPHAERA INVERSA

HELICOSPHAERA KAMPTNERI

HELICOSPHAERA LOPHOTA

HELICOSPHAERA NEOGRANULATA

HELICOSPHAERA OBLIQUA

HELICOSPHAERA RECTA

HELICOSPHAERA RETICULATA

HELICOSPHAERA SELLII

HELICOSPHAERA SEMINULUM 
HELICOSPHAERA OMANICA

HELICOSPHAERA PERCH-NIELSENIAE

HELICOSPHAERA WILCOXONII

HELIOLITHUS CANTABRIAE

HELIOLITHUS CONICUS

HELIOLITHUS KLEINPELLII

HELIOLITHUS RIEDELII

HOLODISCOLITHUS MACROPORUS

HORNIBROOKINA AUSTRALIS

HORNIBROOKINA TEURIENSIS

ILSELITHINA FUSA

ISTHMOLITHUS RECURVUS

LANTERNITHUS MINUTUS

LITHOSTROMATION PERDURUM

LOPHODOLITHUS ACUTUS

LOPHODOLITHUS NASCENS

LOPHODOLITHUS MOCHLOPORUS

MARKALIUS INVERSUS

MICRANTHOLITHUS FLOS

MICRANTHOLITHUS ALTUS

MINYLITHA CONVALLIS

NANNOTETRINA ALATA

NANNOTETRINA CRISTATA

NANNOTETRINA FULGENS

NANNOTETRINA QUADRATA

NEOCHIASTOZYGUS CEARAE

NEOCHIASTOZYGUS CONCINNUS 
NEOCHIASTOZYGUS CHIASTUS

NEOCHIASTOZYGUS DISTENTUS

NEOCHIASTOZYGUS JUNCTUS

NEOCHIASTOZYGUS MODESTUS

NEOCHIASTOZYGUS PERFECTUS

NEOCOCCOLITHES DUBIUS

NEOCOCCOLITHES PROTENUS

OOLITHOTUS FRAGILIS

ORTHORHABDUS SERRATUS

ORTHOZYGUS AUREUS

PEDINOCYCLUS LARVALIS

PERITRACHELINA JOIDESA

PLACOZYGUS SIGMOIDES

PONTOSPHAERA ANISOTREMA

PONTOSPHAERA DISCOPORA

PONTOSPHAERA DISTINCTA

PONTOSPHAERA JAPONICA

PONTOSPHAERA JONESII

PONTOSPHAERA MULTIPORA

PONTOSPHAERA OVATA

PONTOSPHAERA PECTINATA

PONTOSPHAERA PACIFICA

PONTOSPHAERA PLANA

PONTOSPHAERA RIMOSA

PONTOSPHAERA SCUTELLUM

PONTOSPHAERA SEGMENTA

PONTOSPHAERA FORMOSA

PONTOSPHAERA SCISSURA 
PRINSIUS BISULCUS

PRINSIUS DIMORPHOSUS

PRINSIUS MARTINII

PSEUDOEMILIANIA LACUNOSA

PSEUDOTRIQUETRORHABDULUS INVERSUS

PYROCYCLUS INVERSUS

PYROCYCLUS ORANGENSIS

RETICULOFENESTRA DICTYODA

RETICULOFENESTRA HAMPDENENSIS

RETICULOFENESTRA HAQII

RETICULOFENESTRA HILLAE

RETICULOFENESTRA INSIGNATA

RETICULOFENESTRA LOCKERI

RETICULOFENESTRA MINUTA

RETICULOFENESTRA MINUTULUS

RETICULOFENESTRA OAMARUENSIS

RETICULOFENESTRA PSEUDOUMBILICA

RETICULOFENESTRA SAMODUROVII

RETICULOFENESTRA UMBILICA

RETICULOFENESTRA AMPLA

RETICULOFENESTRA ASANOI

RETICULOFENESTRA GELIDA

RETICULOFENESTRA LONGISTYLIS

RHABDOLITHUS STYLIFER

RHABDOLITHUS TENUIS

RHADBOSPHAERA CLAVIGERA

RHADBOSPHAERA INFLATA 
RHADBOSPHAERA PROCERA

RHADBOSPHAERA VITREA

RHOMBOASTER CUSPIS

SCAPHOLITHUS FOSSILIS

SCAPHOLITHUS RHOMBIFORMIS

SCYPHOSPHAERA AMPHORA

SCYPHOSPHAERA APSTEINII

SCYPHOSPHAERA CAMPANULA

SCYPHOSPHAERA CANTHARELLA

SCYPHOSPHAERA CONICA

SCYPHOSPHAERA CYLINDRICA

SCYPHOSPHAERA EXPANSA

SCYPHOSPHAERA GLADSTONENSIS

SCYPHOSPHAERA GLOBULATA

SCYPHOSPHAERA INTERMEDIA

SCYPHOSPHAERA MAGNA

SCYPHOSPHAERA PROCERA

SCYPHOSPHAERA PULCHERRIMA

SCYPHOSPHAERA RECTA

SCYPHOSPHAERA RECURVATA

SEMIHOLOLITHUS KERABYI

SPHENOLITHUS ABIES

SPHENOLITHUS ANARRHOPUS

SPHENOLITHUS BELEMNOS

SPHENOLITHUS CIPEROENSIS

SPHENOLITHUS CONICUS

SPHENOLITHUS DELPHIX

SPHENOLITHUS DISSIMILIS 
SPHENOLITHUS DISTENTUS

SPHENOLITHUS EDITUS

SPHENOLITHUS FURCATOLITHOIDES

SPHENOLITHUS HETEROMORPHUS

SPHENOLITHUS INTERCALARIS

SPHENOLITHUS MORIFORMIS

SPHENOLITHUS NEOABIES

SPHENOLITHUS OBTUSUS

SPHENOLITHUS ORPHANKNOLLI

SPHENOLITHUS PREDISTENTUS

SPHENOLITHUS PRIMUS

SPHENOLITHUS PSEUDORADIANS

SPHENOLITHUS RADIANS

SPHENOLITHUS SPINIGER

SPHENOLITHUS CAPRICORNUTUS

STRIATOCOCCOLITHIS PACIFICANUS

SYRACOSPHAERA HISTRICA

SYRACOSPHAERA PULCHRA

THORACOSPHAERA ALBATROSSIANA

THORACOSPHAERA DEFLANDREI

THORACOSPHAERA HEIMII

THORACOSPHAERA OPERCULATA

THORACOSPHAERA SAXEA

TOWEIUS CALLOSUS

TOWEIUS CRATICULUS

TOWEIUS EMINENS

TOWEIUS MAGNICRASSUS 
TOWEIUS GAMMATION

TOWEIUS TOVAE

TOWEIUS OCCULTATUS

TOWEIUS PERTUSUS

TOWEIUS CRASSUS

TRANSVERSOPONTIS FIMBRIATUS

TRANSVERSOPONTIS OBLIQUIPONS

TRANSVERSOPONTIS PULCHER

TRIBRACHIATUS CONTORTUS

TRIBRACHIATUS NUNNII

TRIBRACHIATUS ORTHOSTYLUS

TRIQUETRORHABDULUS CARINATUS

TRIQUETRORHABDULUS MILOWII

TRIQUETRORHABDULUS RUGOSUS

UMBELLOSPHAERA IRREGULARIS

UMBILICOSPHAERA JAFARII

UMBILICOSPHAERA MIRABILIS

UMBILICOSPHAERA SIBOGAE

ZYGODISCUS ADAMAS

ZYGODISCUS PLACTOPONS

ZYGODISCUS SPIRALIS

ZYGODISCUS HERLYNII

ZYGRHABLITHUS BIJUGATUS

Radiolarians

ACROCUBUS OCTOPYLUS

ACROBOTRYS TRITUBUS

ACROSPHAERA MURRAYANA 
ACROSPHAERA SPINOSA

ACROSPHAERA AUSTRALIS

ACROSPHAERA LABRATA

ACROSPHAERA MERCURIUS

ACTINOMMA BEROES

ACTINOMMA GOLOWNINI

ACTINOMMA HOLTEDAHLI

ACTINOMMA MEDIANUM

ACTINOMMA MEDUSA

ACTINOMMA DELICATULUM

ACTINOMMA KERGUELENSIS

ACTINOMMA LEPTODERMUM

ACTINOMMA POPOFSKII

ACTINOMMA MAGNIFENESTRA

AMPHYMENIUM CHALLENGERAE

AMPHYMENIUM SPLENDIARMATUM

AMPHICRASPEDUM PROLIXUM

AMPHISTYLUS ANGELINUS

AMPHIRHOPALUM YPSILON

AMPHIRHOPALUM VIRCHOWII

AMPHISPYRIS ROGGENTHENI

ANDROSPYRIS ANTHROPISCUS

ANOMALACANTHA DENTATA

ANTARCTISSA CYLINDRICA

ANTARCTISSA DENTICULATA

ANTARCTISSA LONGA

ANTARCTISSA ROBUSTA 
ANTARCTISSA STRELKOVI

ANTARCTISSA DEFLANDREI

ANTHOCYRTELLA CALLOPISMA

ANTHOCYRTIDIUM EURYCLATHRUM

ANTHOCYRTIDIUM JENGHISI

ANTHOCYRTIDIUM PLIOCENICA

ANTHOCYRTIDIUM ANGULARE

ANTHOCYRTIDIUM EHRENBERGII

ANTHOCYRTIDIUM OPHIRENSE

ANTHOCYRTIDIUM MICHELINAE

ANTHOCYRTIDIUM NOSICAAE

ARTOPHORMIS BARBADENSIS

ARTOPHORMIS GRACILIS

ARTOSTROBUS ANNULATUS

AXOPRUNUM ANGELINUM

AXOPRUNUM PIERINAE

BATHROPYRAMIS WOODRINGI

BEKOMIFORMA MYNX

BOTRYOPYLE DICTYOCEPHALUS

BOTRYOPYLE DIONISI

BOTRYOPERA TRILOBA

BOTRYOSTROBUS AQUILONARIS

BOTRYOSTROBUS AURITUS-AUSTRALIS

BOTRYOSTROBUS MIRALESTENSIS

BOTRYOSTROBUS TUMIDULUS

BOTRYOSTROBUS BRAMLETTEI

BOTRYOSTROBUS KERGUELENSIS

BOTRYOSTROBUS REDNOSUS 


\section{BUCCINOSPHAERA INVAGINATA}

BURYELLA CLINATA

CALOCYCLETTA ACANTHOCEPHALA

CALOCYCLETTA CAEPA

CALOCYCLETTA COSTATA

CALOCYCLETTA ROBUSTA

CALOCYCLETTA SERRATA

CALOCYCLETTA VIRGINIS

CALOCYCLAS ASPERUM

CALOCYCLAS DISPARIDENS

CALOCYCLAS HISPIDA

CALOCYCLAS TURRIS

CALOCYCLAS BANDYCA

CALOCYCLOMA AMPULLA

CARPOCANOPSIS BRAMLETTEI

CARPOCANOPSIS CINGULATA

CARPOCANOPSIS FAVOSA

CARPOCANOPSIS CRISTATA

CENOSPHAERA CRISTATA

CENOSPHAERA OCEANICA

CENTROBOTRYS GRAVIDA

CENTROBOTRYS PETRUSHEVSKAYAE

CENTROBOTRYS THERMOPHILA

CERATOCYRTIS AMPLUS

CERATOCYRTIS MASHAE

CERATOCYRTIS HISTRICOSA

CERATOCYRTIS STIGI 
CERATOSPYRIS PENTAGONA

CIRCODISCUS ELLIPTICUS

CLATHROCANIUM SPHAEROCEPHALUM

CLATHROCYCLAS BICORNIS

CLATHROCYCLAS UNIVERSA

COLLOSPHAERA ORTHOCONUS

COLLOSPHAERA TUBEROSA

CORYTHOSPYRIS FISCELLA

CORYTHOMELISSA HORRIDA

CORNUTELLA PROFUNDA

CRYPTOCARPIUM AZYX

CRYPTOCARPIUM ORNATUM

CYCLADOPHORA GOLLI

CYCLADOPHORA DAVISIANA

CYCLADOPHORA HUMERUS

CYCLADOPHORA SPONGOTHORAX

CYCLADOPHORA PLIOCENICA

CYCLADOPHORA BICORNIS

CYCLADOPHORA ANTIQUA

CYCLADOPHORA CABRILLOENSIS

CYCLADOPHORA CONICA

CYMAETRON SINOLAMPAS

CYRTOCAPSELLA CORNUTA

CYRTOCAPSELLA ELDHOLMI

CYRTOCAPSELLA ELONGATA

CYRTOCAPSELLA JAPONICA

CYRTOCAPSELLA TETRAPERA

CYRTOCAPSELLA ROBUSTA 
CYRTOCAPSELLA LONGITHORAX

CYRTOLAGENA LAGUNCULA

DENDROSPYRIS BURSA

DENDROSPYRIS DAMAECORNIS

DENDROSPYRIS MEGALOCEPHALIS

DENDROSPYRIS STABILIS

DENDROSPYRIS RHODOSPYROIDES

DESMOSPYRIS SPONGIOSA

DIARTUS HUGHESI

DIARTUS PETTERSSONI

DICTYOPRORA AMPHORA

DICTYOPRORA ARMADILLO

DICTYOPRORA MONGOLFIERI

DICTYOPRORA OVATA

DICTYOPRORA PIRUM

DICTYOPRORA URCEOLUS

DICTYOPRORA PHYSOTHORAX

DICTYOPHIMUS CALLOSUS

DICTYOPHIMUS INFABRICATUS

DICTYOPHIMUS ARCHIPILIUM

DICTYOPHIMUS CRATICULA

DICTYOPHIMUS CRISIAE

DICTYOPHIMUS HIRUNDO

DICTYOPHIMUS POCILLUM

DICTYOPHIMUS SPLENDENS

DICTYOCORYNE ONTONGENSIS

DIDYMOCYRTIS ANTEPENULTIMA 
DIDYMOCYRTIS AVITA

DIDYMOCYRTIS DIDYMUS

DIDYMOCYRTIS LATICONUS

DIDYMOCYRTIS MAMMIFERA

DIDYMOCYRTIS PENULTIMA

DIDYMOCYRTIS PRISMATICA

DIDYMOCYRTIS TETRATHALAMUS

DIDYMOCYRTIS TUBARIA

DIDYMOCYRTIS VIOLINA

DIDYMOCYRTIS BASSANII

DORCADOSPYRIS ALATA

DORCADOSPYRIS ARGISCA

DORCADOSPYRIS ATEUCHUS

DORCADOSPYRIS CIRCULUS

DORCADOSPYRIS CONFLUENS

DORCADOSPYRIS DENTATA

DORCADOSPYRIS FORCIPATA

DORCADOSPYRIS PAPILIO

DORCADOSPYRIS PENTAGONA

DORCADOSPYRIS PLATYACANTHA

DORCADOSPYRIS QUADRIPES

DORCADOSPYRIS RIEDILI

DORCADOSPYRIS SIMPLEX

DORCADOSPYRIS SPINOSA

DORCADOSPYRIS TRICEROS

DRUPPATRACTUS HASTATUS

EUCECRYPHALUS CRASPEDOTA

EUCHITONIA FURCATA 
EUCYRTIDIUM ACUMINATUM

EUCYRTIDIUM ANOMALUM

EUCYRTIDIUM CALVERTENSE

EUCYRTIDIUM CIENKOWSKII

EUCYRTIDIUM DIAPHANES

EUCYRTIDIUM HEXAGONATUM

EUCYRTIDIUM INFLATUM

EUCYRTIDIUM MATUYAMAI

EUCYRTIDIUM PSEUDOINFLATUM

EUCYRTIDIUM BICONICUM

EUCYRTIDIUM ANTIQUUM

EUCYRTIDIUM CHENI

EUCYRTIDIUM INFUNDIBULUM

EUCYRTIDIUM MARIAE

EUCYRTIDIUM TEUSCHERI

EUSYRINGIUM FISTULIGERUM

EUSYRINGIUM LAGENA

GONDWANARIA DEFLANDREI

GONDWANARIA DOGELI

GONDWANARIA HISTER

GONDWANARIA JAPONICA

HAECKELIELLA INCONSTANS

HALIOMMETTA MIOCENICA

HELODISCUS ASTERISCUS

HELOTHOLUS PRAEVEMA

HISTIASTRUM MARTINIANUM

LAMPROMITRA CORONATA 
LAMPROCYCLAS AEGLES

LAMPROCYCLAS HANNAI

LAMPROCYCLAS JUNONIS

LAMPROCYCLAS MARGATENSIS

LAMPROCYCLAS MARITALIS

LAMPROCYRTIS DANIELLAE

LAMPROCYRTIS HETEROPOROS

LAMPROCYRTIS NEOHETEROPOROS

LAMPROCYRTIS NIGRINIAE

LARCOSPIRA QUADRANGULA

LARCOPYLE BUTSCHLII

LIPMANELLA DICTYOCERAS

LIRIOSPYRIS ELEVATA

LIRIOSPYRIS GENICULOSA

LIRIOSPYRIS MUTUARIA

LIRIOSPYRIS OVALIS

LIRIOSPYRIS PARKERAE

LIRIOSPYRIS STAUROPORA

LITHELIUS MINOR

LITHELIUS NAUTILOIDES

LITHATRACTUS TIMMSI

LITHOCIRCUS TOXARIA

LITHOMITRELLA MINUTA

LITHOCYCLIA ANGUSTA

LITHOCYCLIA ARISTOTELIS

LITHOCYCLIA CRUX

LITHOCYCLIA OCELLUS

LITHOCARPIUM FRAGILIS 


\section{LITHOMELISSA CHALLENGERAE}

LITHOMELISSA EHRENBERGII

LITHOMELISSA ROBUSTA

LITHOMELISSA SPHAEROCEPHALIS

LITHOMELISSA TRICORNIS

LITHOMELISSA CHENI

LITHOMELISSA DUPLIPHYSA

LITHOPERA BACCA

LITHOPERA BAUERI

LITHOPERA NEOTERA

LITHOPERA RENZAE

LITHOPERA THORNBURGI

LITHOCHYTRIS VESPERTILIO

LOPHOCYRTIS BIAURITA

LOPHOCYRTIS JACCHIA

LOPHOCYRTIS BRACHYTORAX

LOPHOCYRTIS LEPTETRUM

LOPHOCYRTIS LONGIVENTER

LOPHOCYRTIS MILOWI

LOPHOCYRTIS NEATUM

LOPHOCYRTIS PEGETRUM

LOPHOCYRTIS TANYTHORAX

LYCHNOCANOMA AMPHITRITE

LYCHNOCANOMA BELLUM

LYCHNOCANOMA ELONGATA

LYCHNOCANOMA GRANDE

LYCHNOCANOMA TRIFOLIUM 
LYCHNOCANOMA CONICA

MITROCALPIS ARANEAFERA

OTOSPHAERA AURICULATA

PENTAPYLONIUM IMPLICATUM

PERIPHAENA DECORA

PERIPHAENA HELIASTERISCUS

PERIPHAENA TRIPYRAMIS

PERIPHAENA CIRCUMTEXTA

PHORMOCYRTIS EMBOLUM

PHORMOCYRTIS STRIATA

PHORMOSTICHOARTUS CORBULA

PHORMOSTICHOARTUS DOLIOLUM

PHORMOSTICHOARTUS MULTISERIATUS

PHORMOSTICHOARTUS FISTULA

PHORMOSTICHOARTUS FURCASPICULATA

PHORMOSTICHOARTUS MARYLANDICUS

PHORMOSTICHOARTUS PLATYCEPHALA

PHORMOSTICHOARTUS PITOMORPHUS

PHORMOSTICHOARTUS CRUSTULA

PHORTICIUM CLEVEI

PHORTICIUM PYLONIUM

PODOCYRTIS AMPLA

PODOCYRTIS CHALARA

PODOCYRTIS DIAMESA

PODOCYRTIS DORUS

PODOCYRTIS FASCIOLATA

PODOCYRTIS GOETHEANA

PODOCYRTIS MITRA 
PODOCYRTIS PAPALIS

PODOCYRTIS SINUOSA

PODOCYRTIS TRACHODES

PRUNOPYLE ANTARCTICA

PRUNOPYLE FRAKESI

PRUNOPYLE HAYESI

PRUNOPYLE TETRAPILA

PRUNOPYLE TYTAN

PRUNOPYLE MONIKAE

PRUNOPYLE POLYACANTHA

PRUNOPYLE TRYPOPYRENA

PERICHLAMYDIUM PRAETEXTUM

PSEUDOCUBUS VEMA

PSEUDODICTYOPHIMUS GRACILIPES

PSEUDODICTYOPHIMUS GALEATUS

PTEROCORYS CAMPANULA

PTEROCORYS CLAUSUS

PTEROCORYS HERTWIGII

PTEROCORYS ZANCLEUS

PTEROCANIUM CHARYBDEUM

PTEROCANIUM KOROTNEVI

PTEROCANIUM PRAETEXTUM

PTEROCANIUM PRISMATIUM

PTEROCANIUM AUDAX

RHABDOLITHIS PIPA

RHIZOSPHAERA ANTARCTICA

RHOPALOCANIUM ORNATUM 
SACCOSPYRIS ANTARCTICA

SACCOSPYRIS CONITHORAX

SACCOSPYRIS PREANTARCTICA

SATURNALIS CIRCULARIS

SETHOCHYTRIS BABYLONIS

SETHOCHYTRIS TRICONISCUS

SIPHOCAMPE ACEPHALA

SIPHOCAMPE ARACHNEA

SIPHOCAMPE LINEATA

SIPHOCAMPE NODOSARIA

SIPHOCAMPE IMBRICATA

SIPHOCAMPE PACHYDERMA

SIPHONOSPHAERA VESUVIUS

SIPHONOSPHAERA MAGNISPHAERA

SIPHOSTICHARTUS CORONA

SOLENOSPHAERA OMNITUBUS

SPHAEROPYLE LANGII

SPHAEROPYLE ROBUSTA

SPIROCYRTIS GYROSCALARIS

SPIROCYRTIS SCALARIS

SPIROCYRTIS SUBSCALARIS

SPIROCYRTIS SUBTILIS

SPONGODISCUS AMBUS

SPONGODISCUS CRATICULATUS

SPONGODISCUS OSCULOSUS

SPONGODISCUS KLINGI

SPONGOMELISSA DILLI

SPONGASTER BERMINGHAMI 
SPONGASTER PENTAS

SPONGASTER TETRAS

SPONGOCORE PUELLA

SPONGOTROCHUS GLACIALIS

SPONGOTROCHUS VENUSTUM

SPONGURUS PYLOMATICUS

STAUROXIPHOS COMMUNIS

STICHOCORYS ARMATA

STICHOCORYS DELMONTENSIS

STICHOCORYS PEREGRINA

STICHOCORYS JOHNSONI

STICHOCORYS WOLFII

STYLATRACTUS CORONATUS

STYLATRACTUS NEPTUNUS

STYLATRACTUS SANTANNAE

STYLATRACTUS UNIVERSUS

STYLODICTYA TARGAEFORMIS

STYLODICTYA VALIDISPINA

STYLODICTYA HASTATA

STYLODICTYA OCELLATA

STYLOSPHAERA ANGELINA

STYLOSPHAERA HISPIDA

STYLOSPHAERA RADIOSA

STYLACONTARIUM ACQUILONIUM

STYLACONTARIUM BISPICULUM

THEOCOTYLISSA FICUS

THEOCYRTIS ANNOSA 
THEOCYRTIS DIABLOENSIS

THEOCYRTIS TUBEROSA

THEOCYRTIS ROBUSTA

THEOCORYS REDONDENSIS

THEOCORYS SPONGOCONUS

THEOCOTYLE CONICA

THEOCOTYLE CRYPTOCEPHALA

THEOCORYTHIUM TRACHELIUM

THEOCORYTHIUM VETULUM

THOLOSPYRIS RHOMBUS

THYRSOCYRTIS BROMIA

THYRSOCYRTIS CLAUSA

THYRSOCYRTIS RHIZODON

THYRSOCYRTIS TENSA

THYRSOCYRTIS TETRACANTHA

THYRSOCYRTIS TRICANTHA

TRICERASPYRIS ANTARCTICA

TRICERASPYRIS CORONATA

TRICOLOCAPSA PAPILLOSA

TRIPILIDIUM CLAVIPES

TRISTYLOSPYRIS TRICEROS

VELICUCULLUS ALTUS

ZYGOCIRCUS BUTSCHLII 


\section{Close W indow}

Table 4.2: Average species longevities for 1418 Cenozoic marine plankton species contained in Neptune. Longevities and standard deviations are in million years.

\begin{tabular}{|l|r|r|r|r|r|r|}
\hline $\begin{array}{c}\text { Plankton } \\
\text { Group }\end{array}$ & $\begin{array}{c}\text { Number } \\
\text { of } \\
\text { species }\end{array}$ & $\begin{array}{c}\text { Extant } \\
\text { species } \\
\text { (in \%) }\end{array}$ & $\begin{array}{c}\text { Mean } \\
\text { Longevity } \\
\text { of Extant } \\
\text { Species }\end{array}$ & $\begin{array}{r}\text { Mean } \\
\text { Standard } \\
\text { Deviation }\end{array}$ & $\begin{array}{c}\text { Longevity } \\
\text { of Extinct } \\
\text { Species }\end{array}$ & $\begin{array}{r}\text { Standard } \\
\text { Deviation }\end{array}$ \\
\hline Diatoms & 389 & 26.5 & 14.4 & 13.7 & 10.2 & 10.3 \\
\hline Foraminifera & 281 & 13.9 & 13.9 & 9.2 & 11.1 & 7.8 \\
\hline Radiolarians & 383 & 29.8 & 13.4 & 9.2 & 12.9 & 7.8 \\
\hline Nannofossils & 365 & 8.5 & 17.8 & 19.8 & 13.1 & 10.6 \\
\hline All groups & 1418 & 20.2 & 14.3 & 12.4 & 11.9 & 9.4 \\
\hline
\end{tabular}




\section{A MORE REALISTIC ASSESSMENT: NEPTUNE AS A TOOL IN SUPPORT OF DATA IMPROVEMENT}

Eight years after the first planning meetings at the ETH, I have finally achieved a balance between the initial expectations/dreams and the realization of what Neptune really is and its limitations. I have described the scopes, accomplishments, and drawbacks of this project in the previous chapters and now it is time to answer the question: what next? What is the future of Neptune? In the previous chapters, I tried to convey that Neptune is not a sufficient data set to base several (biostratigraphic) publications on, but mainly a tool to make collecting new data more focused and more efficient. And this is the legacy of this project to the research community.

The chronology of the Neogene sediments of some 100 DSDP holes was published as an Ocean Drilling Program Technical Note (Lazarus et al. 1995a) and is currently available through the WWW site of the NOAA- National Geographic Data Center (NGDC) (http://www.ngdc.noaa.gov/mgg/geology/ lazarus.html). The age models for these sites were based on Berggren et al. (1985). The updated models (to Berggren et al. 1995a, b) extended to the whole Cenozoic, as well as additional ODP holes, are published here in graphic form and as text files in the Appendix A. At the same time, a link to them will be deposited at the widely used archival site of the NGDC.

At present, the database is accessible through the author, at the ETH Zürich, and at the Natural History Museum in Basel, Switzerland. It is still unclear how the whole database with its search options will be made accessible to the community. Among the options discussed are a CD-ROM (which would, however, require the relatively expensive 4th Dimension ${ }^{\circledR}$ program to run) and a server at the Micropaleontological Reference Center (MRC) in Basel. The optimal solution for this second option would be an interactive WWW site that could be remotely accessible world-wide. Recently, the program NetLink/4D TM has been made available on the market. This program apparently makes databases searchable through the Internet (Lazarus, personal commun., 1998). However, I have not seen nor tried the program yet and do not know how user-friendly it is. However, I suspect that the large size of Neptune would make even the simplest searches very slow and time consuming through the Internet. A more modest, but immediately feasible alternative, would be to have one person at the MRC in charge of the use of Neptune. Requests for searches could be e-mailed to 
the MRC and the results (in print or as computer files) mailed to the requester. Among the various possibilities, searches for presence/absence and location or number of occurrence of single or multiple taxa would require only a few minutes. This search would also provide information on the taxonomic validity of the taxa and the lists of synonyms. A more extensive search would distinguish between stratigraphically and thematically well and poorly covered intervals. The identification of significant gaps in the biostratigraphic record (e.g., Paleogene

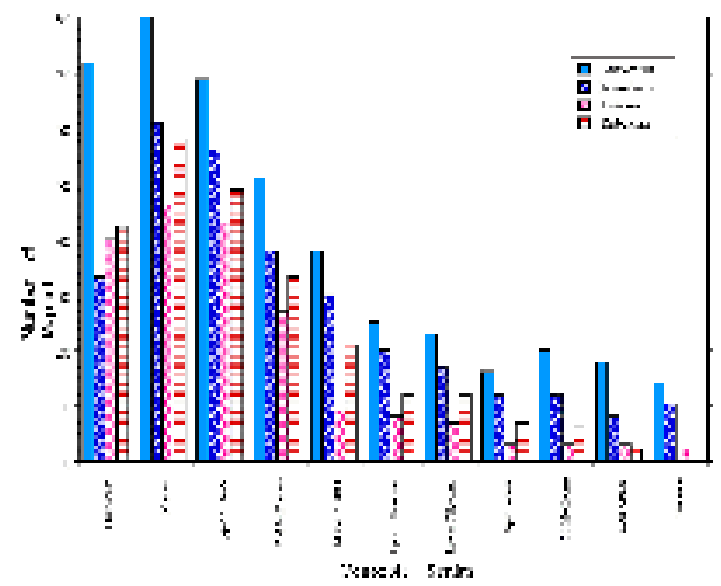

Figure 5.1. biochronology of siliceous microfossils and revisitation of suitable Paleogene sediments for detailed biostratigraphy) (Fig. 5.1) would be the basis for the logical, objective planning of future research. It could spur clearly aimed detailed micropaleontological studies, instead of random studies that generate a lot of repetition and overlap (e.g., Moore 1972).

Considering that Neptune contains selected, good quality holes, it is still notable how small the number of useful holes (well cored, well analyzed and well documented with modern biochronological methods and modern taxonomy) has remained. An enormous amount of re-analysis of older sections could be quite profitable. Fig. 5.1 indicates that a lot can still be done on sections older than the late Miocene, especially on siliceous plankton groups. New coring needed to fill the existing coverage gaps could be identified with three dimensional (latitude vs. longitude vs. time) maps of the oceans produced with Neptune. Another way to identify stratigraphic coverage gaps is given by the rate of success in recovering drilled sections (Fig. 5.2). This curve indicates that the early and middle Eocene, as well as large parts of the Miocene, have

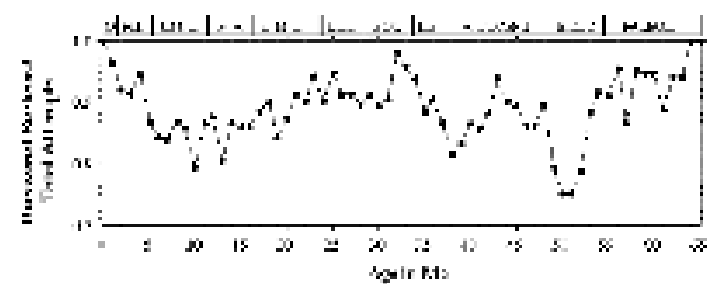

Figure 5.2. been less well recovered than e.g., the Plio-Pleistocene or the Eocene/Oligocene boundary. This might be one of the causes of the poor Eocene biochronology for certain plankton groups. Recent ODP Legs (e.g., 171B) have recovered long Eocene sections: these should be studied in detail to cover this recovery gap.

These are just a couple of examples of the utility of Neptune in designing goal-oriented studies aimed to obtain a complete picture of the oceans' history during the Cenozoic, necessary for a better understanding of the complex processes that control the Earth systems. This approach would, however, require the change in nature of the DSDP and ODP projects from 'leg oriented' to 'overview oriented', which in my opinion is a more effective investment of resources. This step would certainly represent the most valuable contribution of Neptune to the geological community. 
Next Section... 


\section{Close Window}

Figure 5.1. Number of reports on Cenozoic biostratigraphy in Neptune by plankton group. Reports that cover the whole or only a part of the series are included. No selection based on the detail or the quality of the reports was made. Note the overall better availability of nannofossil biostratigraphy in comparison with the other plankton groups. The anomalously low number of reports for foraminifera, diatoms and radiolarians may be in part due to the lower number of Pleistocene sections available in Neptune (Fig. 3.2). However, it likely represents also an artifact of the analysis caused by the scarcity of biostratigraphic events of these three groups calibrated for the Pleistocene.

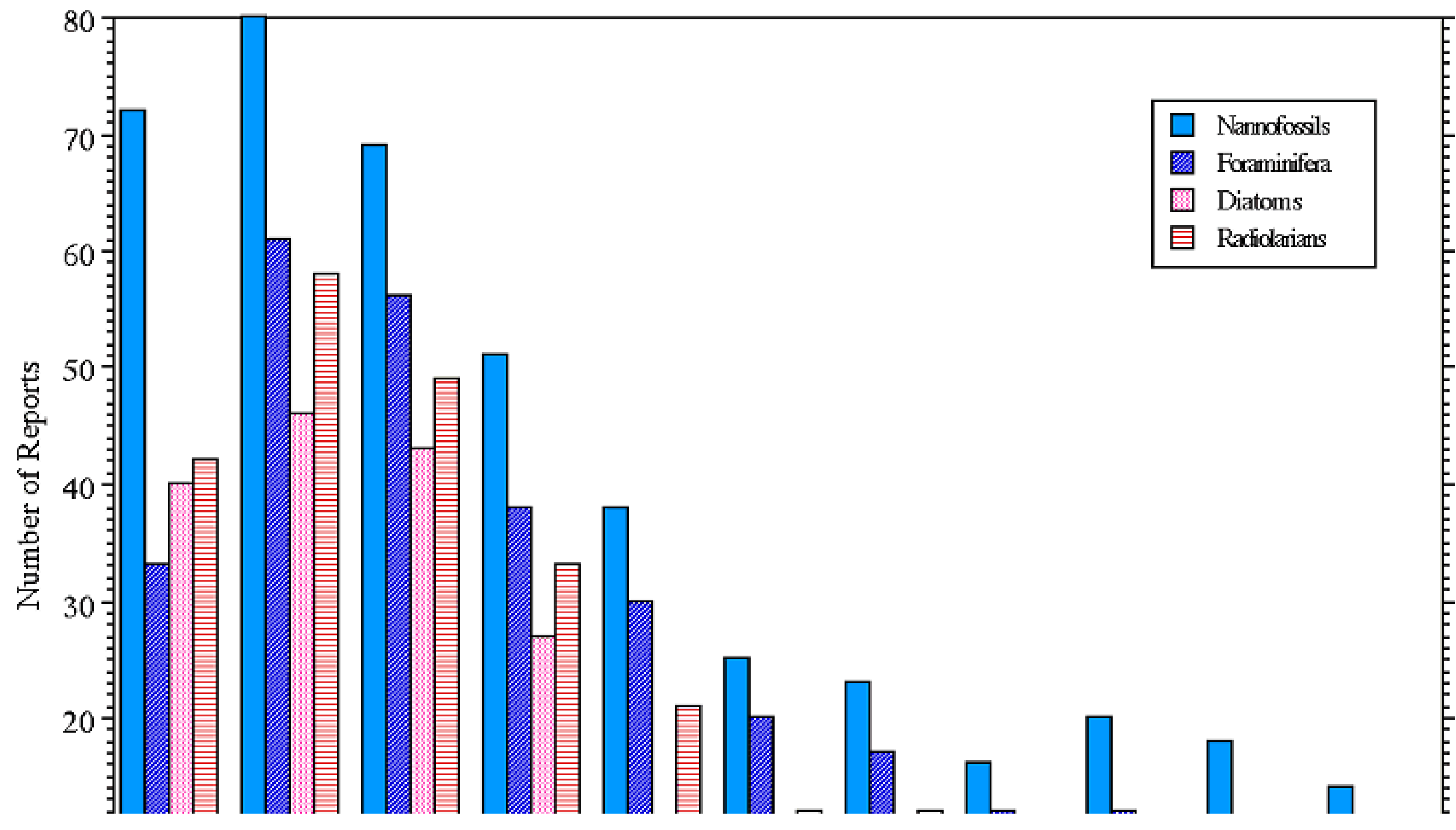


Figure 5.1: THE CENOZOIC DEEP SEA MICROFOSSIL RECORD: EXPLORATIONS OF THE DSDP/ODP SAMPLE SET USING THE NEPTUNE DATABASE

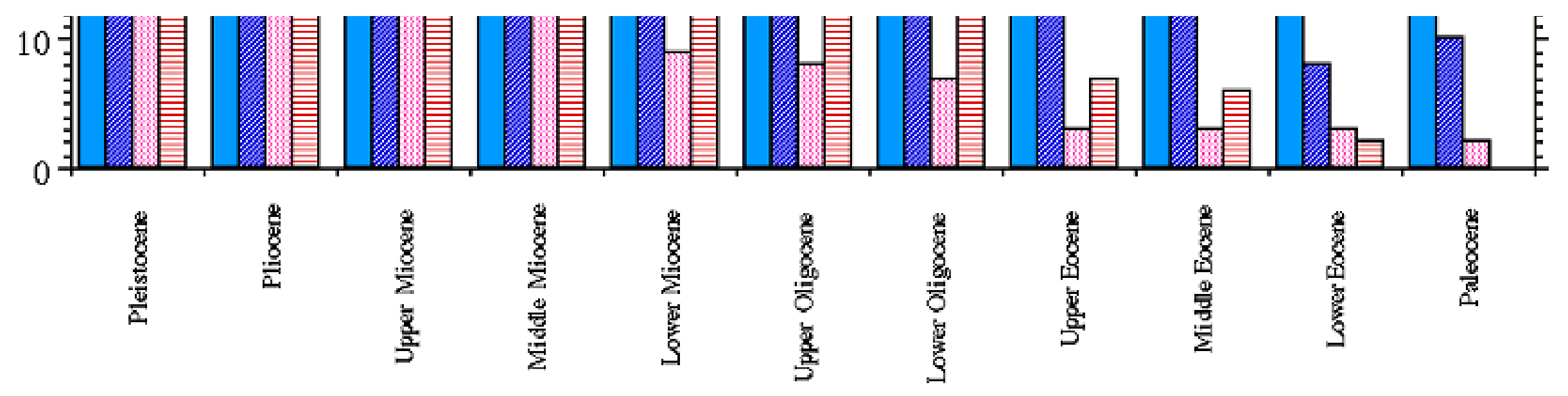




\section{Close Window}

Figure 5.2. Ratio between the number of recovered sections and the total number of times recovery was attempted at 1-m.y. resolution. Sections that recovered sediments containing at least $5 \%$ of the one m.y. interval are included. The horizontal line represents the average recovery ratio for all the sections analysed $(0.89)$. The data are limited to the sections included in Neptune and for which we have age control. This means that in some instances, deeper sediments were also recovered, but no biostratigraphic study done on them to provide us with an age model. This graph does not reflect the 'true' availability of sediments but only the time interval that was recovered in each section - it includes also intervals that are represented by hiati (see Fig. 3.3), which are e.g., quite frequent in Miocene sediments. Note that Paleocene sediments are overall quite well recovered even though scarce (Fig. 3.2), an improvement from the early study by Moore (1972) which identified this interval as the least well represented in the Cenozoic sediments recovered by the early DSDP legs.

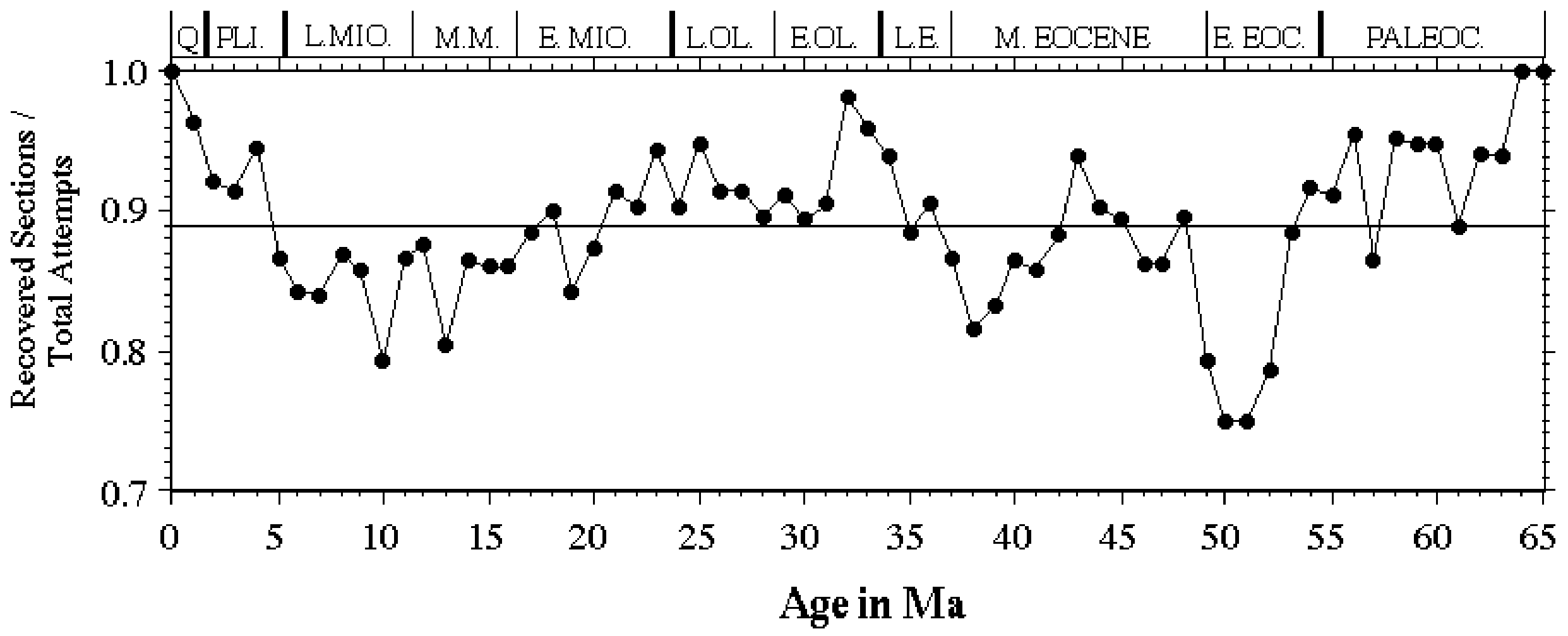




\section{ACKNOWLEDGEMENTS}

I would like to thank J.-P. Beckmann, M. Biolzi, J. Bollmann, H. Hilbrecht, and K. von Salis Perch-Nielsen for their contribution to the Neptune project, and H.R. Thierstein for his continuous support to this project and years of encouragement. D.B. Lazarus, who initiated the project, designed and programmed the database, taught me much of what I know about ODP and biostratigraphy. Reviews and comments by H.R. Thierstein, J.A. McKenzie and two anonymous reviewers have greatly improved the manuscript. A special thanks goes to D.A. Spencer, who never ceased to remind me to write this work and for his constant support. Several other people have been involved in the taxonomic part of this project: J.-P. Caulet, J. Fenner, C. Nigrini, and C. Sancetta worked on preparing synonymy lists. C. Nigrini and A. Sanfilippo kindly provided their unpublished radiolarian range charts and revised Paleogene biozonations. A. Smith's help and suggestions with the paleogeographic reconstruction is gratefully acknowledged. He kindly made available the unpublished program that was used for the paleoposition calculations. B. Brabec and K. Ragoonaden generously provided me with their computational expertise. A. Vit helped in the compilation of biostratigraphic files. M. Rakesh and the ODP Paleontological Archive staff made available the spreadsheet files of ODP range charts. The editors of Palaeontologia Electronica, Tim Patterson and Norm MacLeod, and three anonymous reviewers are gratefully acknowledged for their comments. Jennifer Rumford, PE's technical editor, has been a great help in sorting out the challenge presented by the formatting the $200+$ figures and tables. Finally, I would like to acknowledge my baby daughter, Francesca Louise Spencer, for patiently letting me spend long hours in front of the computer writing this synthesis when I was supposed to rest while expecting her. This work is dedicated to you and to your dad. 


\section{lose Window}

\section{REFERENCES}

Abbott, W. H. 1987. Diatom Occurrences, Deep Sea Drilling Project Sites 612 and 613. In: Poag, C. W., Watts, A. B. (Eds.). Initial Reports of the Deep Sea Drilling Project, 95:417-418. Washington: U. S. Government Printing Office.

Abelmann, A. 1990. Oligocene to Middle Miocene Radiolarian Stratigraphy of Southern High Latitudes from Leg 113, Sites 689 and 690, Maud Rise. In: Barker, P. F., Kennett, J. P. (Eds.). Proceedings of the Ocean Drilling Program, Scientific Results, 113:675-708. College Station, TX: Ocean Drilling Program.

Abelmann, A. 1992. Early to mid-Miocene radiolarian stratigraphy of the Kerguelen Plateau (ODP Leg 120). In S. W. Wise \& R. Schlich (Eds.), Proceedings of the Ocean Drilling Program, Scientific Results, 120:757-784. College Station, TX: Ocean Drilling Program.

Aksu, A. E., and Kaminski, M.A. 1989. Neogene and Quaternary Planktonic Foraminifer Biostratigraphy and Biochronology in Baffin Bay and the Labrador Sea. In: Srivastava, S. P., Arthur, M.A., Clement, B. (Eds.). Proceedings of the Ocean Drilling Program, Scientific Results, 105:287-304. College Station, TX: Ocean Drilling Program.

Alexandrovich, J. M. 1992. Radiolarians from Sites 794, 795, 796, and 797, Japan Sea. In: Pisciotto, K. A., Ingle, J. C. (Eds.). Proceedings of the Ocean Drilling Program, Scientific Results, 127:291-307. College Station, TX: Ocean Drilling Program.

Alroy, J. 1998. Diachrony of mammalian appearance events: Implications for biochronology. Geology, 26:23-26.

Applegate, J. L., and Wise, S. W., Jr. 1987. Eocene Calcareous Nannofossils, Deep Sea Drilling Project Site 605, Upper Continental Rise off New Jersey, U.S.A. In: van Hinte, J. E., Wise, S. W., Jr. (Eds.). Initial Reports of the Deep Sea Drilling Project, 93:685-698. Washington: U.S.

Government Printing Office.

Aubry, M.-P. 1992. Paleogene Calcareous Nannofossils from the Kerguelen Plateau, Leg 120. In: Wise, S. W., Schlich, R. (Eds.). Proceedings of the Ocean Drilling Program, Scientific Results, 120:471-491. College Station, TX: Ocean Drilling Program.

Backman, J. 1984. Cenozoic calcareous nannofossil biostratigraphy from the northeastern Atlantic Ocean - Deep Sea Drilling Project Leg 81. In D. G. Roberts \& D. Schnitker (Eds.), Initial Reports of the Deep Sea Drilling Project, 81:403-428. Washington: U. S. Government Printing Office.

Baldauf, J. G. 1985. A high resolution Late Miocene-Pliocene diatom biostratigraphy for the eastern Equatorial Pacific. In L. Mayer \& F. Theyer (Eds.), Initial Reports of the Deep Sea Drilling Project, 85:457-476. Washington: U. S. Government Printing Office.

Baldauf, J. G. 1987. Diatom biostratigraphy of the middle- and high-latitude North Atlantic Ocean, Deep Sea Drilling Project Leg 94. In W. F. Ruddiman \& R. B. Kidd (Eds.), Initial Reports of the Deep Sea Drilling Project, 94:729-762. Washington: U. S. Government Printing Office.

Baldauf, J. G., and Barron, J. A. 1991. Diatom Biostratigraphy: Kerguelen Plateau and Prydz Bay Regions of the Southern Ocean. In: Barron, J., Larsen, B. (Eds.). Proceedings of the Ocean Drilling Program, Scientific Results, 119:547-598. College Station, TX: Ocean Drilling Program. 
Baldauf, J. G., and Monjanel, A. -L. 1989. An Oligocene Diatom Biostratigraphy for the Labrador Sea: DSDP Site 112 and Hole 647A. In: Srivastava, S. P., Arthur, M.A., Clement, B. (Eds.).

Proceedings of the Ocean Drilling Program, Scientific Results, 105:323-347. College Station, TX: Ocean Drilling Program.

Baldauf, J.G. 1984. Cenozoic diatom biostratigraphy and paleoceanography of the Rockall Plateau region, north Atlantic, Deep Sea Drilling Project Leg 81. In D. G. Roberts \& D. Schnitker (Eds.), Initial Reports of the Deep Sea Drilling Project, 81:439-478. Washington: U. S. Government Printing Office.

Barron, J. A. 1980. Lower Miocene to Quaternary diatom biostratigraphy of Leg 57, off northeastern Japan, Deep Sea Drilling Project. In Scientific Party, Initial Reports of the Deep Sea Drilling Project, 56,57:641-685. Washington: U.S. Government Printing Office.

Barron, J. A. 1981. Late Cenozoic diatom biostratigraphy and paleoceanography of the middle-latitude eastern North Pacific, Deep Sea Drilling Project Leg 63. In R. S. Yeats \& B. U. Haq (Eds.), Initial Reports of the Deep Sea Drilling Project, 63:507-538. Washington: U. S. Government Printing Office.

Barron, J. A. 1985a. Late Eocene to Holocene diatom biostratigraphy of the equatorial Pacific Ocean, Deep Sea Drilling Project Leg 85. In L. Mayer \& F. Theyer (Eds.), Initial Reports of the Deep Sea Drilling Project, 85:413-457. Washington: U. S. Government Printing Office.

Barron, J. A. 1985b. Miocene to Holocene planktic diatoms. In H. M. Bolli,J. B. Saunders, \& K. Perch-Nielsen (Eds.), Plankton Stratigraphy, 763-809. Cambridge University Press.

Barton, C. E., and Bloemendal, J. 1986. Paleomagnetism of sediments collected during Leg 90, Southwest Pacific. In J. P. Kennett \& C. C. von der Borch (Eds.), Intitial Reports of the Deep Sea Drilling Project, 90:1273-1316. Washington: U. S. Government Printing Office.

Backmann, J. and N.J. Shackleton 1983. Quantitative biochronology of Pliocene and early Pleistocene calcareous nannoplankton from the Atlantic, Indian and Pacific Oceans, Mar. Micropaleont, 8:141-170.

Beckmann, J. P. 1972. The Foraminifera and some associated microfossils of Sites 135 to 144. In D. E. Hayes \& A. C. Pimm (Eds.), Initial Reports of the Deep Sea Drilling Project, 14:389-420. Washington: U. S. Government Printing Office.

Berger, W.H. 1970. Biogenous deep-sea sediments: fractionation by deep-sea circulation. Geol. Soc. Am. Bull., 81:1385-1402.

Berggren, W. A. 1992. Neogene Planktonic Foraminifer Magnetobiostratigraphy of the Southern Kerguelen Plateau ( Sites 747, 748, and 751). In: Wise, S. W., Schlich, R. (Eds.). Proceedings of the Ocean Drilling Program, Scientific Results, 120:631-647. College Station, TX: Ocean Drilling Program.

Berggren, W. A. 1992. Paleogene Planktonic Foraminifer Magnetobiostratigraphy of the Southern Kerguelen Plateau (Sites 747-749). In: Wise, S. W., Schlich, R. (Eds.). Proceedings of the Ocean Drilling Program, Scientific Results, 120:551-568. College Station, TX: Ocean Drilling Program.

Berggren, W. A., Aubry, M. P., and Hamilton, N. 1983. Neogene Magnetobiostratigraphy of the Deep Sea Drilling Project Site 516 ( Rio Grande Rise, South Atlantic). In: Barker, P. F., Carlson, R. L., Johnson, D. A. (Eds.). Initial Reports of the Deep Sea Drilling Project, 72:675-713. Washington: U. S. Government Printing Office.

Berggren, W. A., Hamilton, N., Johnson, D. A., Pujol, C., Weiss, W., Cepek, P., and Gombos, A. M. 
Jr. 1983. Magnetobiostratigraphy of the Deep Sea Drilling Project Leg 72, Sites 515-518, Rio Grande Rise (South Atlantic). In: Barker, P. F., Carlson, R. L., Johnson, D. A. (Eds.). Initial Reports of the Deep Sea Drilling Project, 72:939-948. Washington: U. S. Government Printing Office.

Berggren, W. A., Kent, D. V., Flynn, J. J., and Van Couvering, J. A. 1985. Cenozoic geochronology. Geological Society of America Bulletin, 96:1407-1418.

Berggren, W.A., Lohmann, G.P., Poore, R.P. 1974. Shore Laboratory Report on Cenozoic Planktonic Foraminifera: Leg 22. In: von der Borch, C. C., Sclater, J. G. (Eds.). Initial Reports of the Deep Sea Drilling Project, 22:635-655. Washington: U. S. Government Printing Office.

Berggren, W.A., F.J. Hilgen, C.C. Langereis, D.V. Kent, J.D. Obradovich, I. Raffi, M. Raymo, and N.J. Shackleton 1995a. Late Neogene chronology: New perspectives in high-resolution stratigraphy. Geol. Soc. Am. Bulletin, 107:1272-1287.

Berggren, W.A., D.V. Kent, C.C. Swisher, and M.P. Aubry 1995b. A revised Cenozoic geochronology and chronostratigraphy, In: Geochronology, Time Scales and Global Stratigraphic Correlations: A unified temporal framework for an historical geology, edited by Berggren, W.A., Kent, D.V., and Hardenbol, J., SEPM Special Volume, 54:129-212.

Blechshmidt, G. 1979. Biostratigraphy of Calcareous Nannofossils: Leg 47B, Deep Sea Drilling Project. In: Sibuet, J.-C., Ryan, W.B.F. (Eds.). Initial Reports of the Deep Sea Drilling Project, 47:327-360. Washington: U. S. Government Printing Office.

Bleil, U. 1985. The magnetostratigraphy of northwest Pacific sediments, Deep Sea Drilling Project Leg 86. In G. R. Heath \& L. H. Burkle (Eds.), Initial Reports of the Deep Sea Drilling Project, 86:441-458. Washington: U. S. Government Printing Office.

Boersma, A. 1977. Cenozoic Planktonic Foraminifera- DSDP Leg 39 (South Atlantic). In: Supko, P.R., Perch-Nielsen, K. (Eds.). Initial Reports of the Deep Sea Drilling Project, 39:567-590. Washington: U. S. Government Printing Office.

Boersma, A. 1984. Cretaceous-Tertiary planktonic foraminifers from the southeastern Atlantic, Walvis Ridge area, Deep Sea Drilling Project Leg 74. In T. C. Moore Jr. \& P. D. Rabinowitz (Eds.), Initial Reports of the Deep Sea Drilling Project, 74:501-523. Washington: U. S. Government Printing Office.

Boltovskoy, E. 1974. Neogene planktonic foraminifera of the Indian Ocean (DSDP, Leg 26). In T. A. Davies \& B. P. Luyendyk (Eds.), Initial Reports of the Deep Sea Drilling Project, 26:675-742. Washington: U. S. Government Printing Office.

Brönnimann, P., and Resig, J. 1971. A Neogene globigerinacean biochronologic time-scale of the southwestern Pacific. In E. L. Winterer (Ed.), Initial Reports of the Deep Sea Drilling Project, 7:1235-1470. Washington: U. S. Government Printing Office.

Brunner, C. A. 1992. Paleoenvironment and Biostratigraphy of Foraminifers at Sites 794, 795, 796, and 797 in the Japan Sea. In: Pisciotto, K. A., Ingle, J. C. (Eds.). Proceedings of the Ocean Drilling Program, Scientific Results, 127:187-224. College Station, TX: Ocean Drilling Program.

Bukry, D. 1973. Low-latitude coccolith biostratigraphic zonation. In N. T. Edgar \& J. B. Saunders (Eds.), Initial Reports of the Deep Sea Drilling Project, 13:685-704. Washington: U. S. Government Printing Office.

Bukry, D. 1978. Cenozoic coccolith and silicoflagellate stratigraphy, offshore northwest Africa, Deep Sea Drilling Project, Leg 41. In Y. Lancelot \& E. Seibold (Eds.), Initial Reports of the Deep Sea Drilling Project, 41:689-708. Washington: U. S. Government Printing Office. 
Bukry, D. 1985. Mid-Atlantic Ridge Coccolith and Silicoflagellate Biostratigraphy, Deep Sea Drilling Project Sites 558 and 563. In: Bougault, H., Cande, S. C. (Eds.). Initial Reports of the Deep Sea Drilling Project, 82:591-603. Washington: U. S. Government Printing Office.

Bukry, D., and Foster, J.H. 1973. Silicoflagellate and Diatom Stratigraphy, Leg 16, Deep Sea Drilling Project. In: van Andel, T.H. \& Heath, G.R. (Eds.).Initial Reports of the Deep Sea Drilling Project, 16:747-813. Washington: U. S. Government Printing Office.

Burns, D. A. 1975. Nannofossil biostratigraphy for Antarctic sediments, Leg 28, Deep Sea Drilling Project. In D. E. Hayes \& L. A. Frakes (Eds.), Initial Reports of the Deep Sea Drilling Project, 28:589-598. Washington: U. S. Government Printing Office.

Cande, S. C., and Kent, D. V. 1992. A new geomagnetic polarity time scale for the Late Cretaceous and Cenozoic. Journal of Geophysical Research, 97:13,917-13,951.

Cande, S.C. and Kent, D.V. 1995. Revised calibration of the geomagnetic polarity timescale for the Late Cretaceous and Cenozoic. Journal of Geophysical Research, 100:6093-6095.

Canninga, G., Zijderveld, J. D. A., and van Hinte, J. E. 1987. Late Cenozoic magnetostratigraphy of Deep Sea Drilling Project Hole 603C, Leg 93, on the North American continental rise off Cape Hatteras. In J. E. van Hinte \& S. W. Wise (Eds.), Initial Reports of the Deep Sea Drilling Project, 93:839-848. Washington: U. S. Government Printing Office.

Caulet, J. P. 1986. Radiolarians from the southwest Pacific. In J. P. Kennett \& C. C. von der Borch (Eds.), Initial Reports of the Deep Sea Drilling Project, 90:835-861. Washington: U. S. Government Printing Office.

Caulet, J. P. 1991. Radiolarians from the Kerguelen Plateau, Leg 119. In: Barron, J., Larsen, B. (Eds.). Proceedings of the Ocean Drilling Program, Scientific Results, 119:513-542. College Station, TX: Ocean Drilling Program.

Chaisson, W. P., and Leckie, R. M. 1993. High-resolution Neogene Planktonic Foraminifer Biostratigraphy of Site 806, Ontong Java Plateau (Western Equatorial Pacific). In: Berger, W. H., Kroenke, L. W. (Eds.). Proceedings of the Ocean Drilling Program, Scientific Results, 130:137-178. College Station, TX: Ocean Drilling Program.

Chen, P. H. 1975. Antarctic radiolaria. In Initial Reports of the Deep Sea Drilling Project, 28:437-513. Washington: U. S. Government Printing Office.

Ciampo, G. 1992. Late Miocene (CN9B subzone) to Holocene calcareous nannofossils from the western and northwestern Pacific Ocean, Leg 125. In: P. Fryer, J.A. Pearce, \& Stokking, L.B. (Eds.) Proceedings of the Ocean Drilling Program Scientific Results, 125:15-41. College Station, TX: Ocean Drilling Program.

Ciesielski, P. F. 1983. The Neogene and Quaternary diatom biostratigraphy of subantarctic sediments, Deep Sea Drilling Project Leg 71. In W. J. Ludwig \& V. A. Krasheninnikov (Eds.), Initial Reports of the Deep Sea Drilling Project, 71:635-666. Washington: U. S. Government Printing Office.

Ciesielski, P. F. 1986. Middle Miocene to Quaternary diatom biostratigraphy of Deep Sea Drilling Project Site 594, Chatham Rise, southwest Pacific. In J. P. Kennett \& C. C. von der Borch (Eds.), Initial Reports of the Deep Sea Drilling Project, 90:863-886. Washington: U. S. Government Printing Office.

Clement, B. M., and Robinson, F. 1987. The magnetostratigraphy of Leg 94 sediments. In W. F. Ruddiman \& R. B. Kidd (Eds.), Initial Reports of the Deep Sea Drilling Project, 94:635-650. 
Washington: U. S. Government Printing Office.

Clement, B. M., Hall, F. J., and Jarrard, R. D. 1989. The Magnetostratigraphy of Ocean Drilling Program Leg 105 Sediments. In: Srivastava, S. P., Arthur, M.A., Clement, B. (Eds.). Proceedings of the Ocean Drilling Program, Scientific Results, 105:583-595. College Station, TX: Ocean Drilling Program.

Crux, J.A. 1991. Calcareous nannofossils recovered by Leg 114 in the subantarctic South Atlantic Ocean. In P.F. Ciesielski, Y. Kristoffersen, et al. (Eds.), Proceedings of the Ocean Drilling Program, Scientific Results, 114:155-177. College Station, TX: Ocean Drilling Program.

Delaney, M.L., and Boyle, E.A. 1988. Tertiary paleoceanic chemical variability: unintended consequences of simple geochemical models. Paleoceanography, 3:137-156.

Dinkelmann, M.G. 1973. Radiolarian Straitigraphy: Leg 16., Deep Sea Drilling Project. In: van Andel, T.H. \& Heath, G.R. (Eds.).Initial Reports of the Deep Sea Drilling Project, 16:747-813. Washington: U. S. Government Printing Office.

Echols, R. J. 1973. Foraminifera, Leg 19 Deep Sea Drilling Project. In J. S. Creager \& D. W. Scholl (Eds.), Initial Reports of the Deep Sea Drilling Project, 19:721-737. Washington: U. S. Government Printing Office.

Edwards, A. R., and Perch-Nielsen, K. 1975. Calcareous nannofossils from the southern southwest Pacific, Deep Sea Drilling Project, Leg 29. In J. P. Kennett \& R. E. Houtz (Eds.), Initial Reports of the Deep Sea Drilling Project, 29:469-540. Washington: U. S. Government Printing Office.

Ellis, C. H. 1975. Calcareous nannofossil biostratigraphy - Leg 31, DSDP. In D. E. Karig \& J. C. Ingle Jr. (Eds.), Initial Reports of the Deep Sea Drilling Project, 31:655-676. Washington: U. S. Government Printing Office.

Ellis, C. H. 1982. Calcareous nannoplankton biostratigraphy - Deep Sea Drilling Project Leg 60. In D. M. Hussong \& S. Uyeda (Eds.), Initial Reports of the Deep Sea Drilling Project, 60:507-536. Washington: U. S. Government Printing Office.

Farrell, J.W. and T.R. Janecek 1991. Late Neogene paleoceanography and paleoclimatology of the northeast Indian Ocean (Site 758). Proceedings of the Ocean Drilling Program, Scientific Results, 121:297-355, College Station TX.

Fenner, J. 1978. Cenozoic Diatom Biostratigraphy of the Equatorial and Southern Atlantic Ocean. In: Supko, P.R., Perch-Nielsen, K. (Eds.). Initial Reports of the Deep Sea Drilling Project, 39 supplement: 491-624. Washington: U. S. Government Printing Office.

Fenner, J. 1984. Eocene-Oligocene planktic diatom stratigraphy in the low latitudes and the high southern latitudes. Micropaleontology, 30:319-342.

Fenner, J. 1991. Taxonomy, stratigraphy, and paleoceanographic implications of Paleocene diatoms. In P.F. Ciesielski, Y. Kristoffersen, et al. (Eds.), Proceedings of the Ocean Drilling Program, Scientific Results, 114:123-154. College Station, TX: Ocean Drilling Program.

Fenner, J., and Mikkelsen, N. 1990. Eocene-Oligocene Diatoms in the Western Indian Ocean: Taxonomy, Stratigraphy, and Paleoecology. In: Duncan, R. A., Backman, J., Peterson, L. C. (Eds.). Proceedings of the Ocean Drilling Program, Scientific Results, 115:395-409. College Station, TX: Ocean Drilling Program.

Firth, J. V. 1989. Eocene and Oligocene Calcareous Nannofossils from the Labrador Sea, ODP Leg 105. In: Srivastava, S. P., Arthur, M.A., Clement, B. (Eds.). Proceedings of the Ocean Drilling Program, Scientific Results, 105:263-286. College Station, TX: Ocean Drilling Program. 
Galbrun, B. 1992. Magnetostratigraphy of Upper Cretaceous and Lower Tertiary Sediments, Sites 761 and 762, Exmouth Plateau, Northwest Australia. In: von Rad, U., Haq, B. U. (Eds.).

Proceedings of the Ocean Drilling Program, Scientific Results, 122:699-716. College Station, TX: Ocean Drilling Program.

Gartner, S., and Chow, J. 1985. Calcareous nannofossil biostratigraphy, Deep Sea Drilling Project Leg 85, eastern Equatorial Pacific. In L. Mayer \& F. Theyer (Eds.), Initial Reports of the Deep Sea Drilling Project, 85:609-620. Washington: U. S. Government Printing Office.

Gartner, S., Jr. 1973. Calcareous nannofossil age determinations, Deep Sea Drilling Project, Leg 13. In W. B. F. Ryan \& K. J. Hsü (Eds.), Initial Reports of the Deep Sea Drilling Project, 13:822-828. Washington: U. S. Government Printing Office.

Gartner, S., Jr. 1974. Nannofossil Biostratigraphy, Leg 22, Deep Sea Drilling Project. In: von der Borch, C. C., Sclater, J. G. (Eds.). Initial Reports of the Deep Sea Drilling Project, 22:577-599. Washington: U. S. Government Printing Office.

Gartner, S., Wei, W., and Shyu, J. P. 1994. Neogene Calcareous Nannofossil Biostratigraphy at ODP Sites 812 through 818. In: McKenzie, J. A., Davies, J. A. (Eds.). Proceedings of the Ocean Drilling Program, Scientific Results, 133:3-18. College Station, TX: Ocean Drilling Program.

Gersonde, R., and Burckle, L. 1990. Neogene diatom biostratigraphy of ODP Leg 113, Weddell Sea (Antarctic Ocean). In P. Barker, J. P. Kennett, et al. (Eds.), Proceedings of the Ocean Drilling Program, Scientific Results, 113:761-790. College Station, TX: Ocean Drilling Program.

Gersonde, R., and Burckle, L. H., 1990. Neogene Diatom Biostratigraphy of ODP Leg 113, Weddell Sea (Antartic Ocean). In: Barker, P. F., Kennett, J. P. (Eds.). Proceedings of the Ocean Drilling Program, Scientific Results, 113:761-789. College Station, TX: Ocean Drilling Program.

Goll, R. M., and Bjørklund, K. R. 1989. A new radiolarian biostratigraphy of Norwegian Sea sediments: ODP Leg 104. In O. Eldholm,J. Thiede, \& E. Taylor (Eds.), Proceedings of the Ocean Drilling Program, Scientific Results, 104:697-738. College Station, TX: Ocean Drilling Program.

Gombos, A. M. Jr. 1983. Survey of Diatoms in the Upper Oligocene and Lower Miocene in Holes 515B and 516F. In: Barker, P. F., Carlson, R. L., Johnson, D. A. (Eds.). Initial Reports of the Deep Sea Drilling Project, 72:793-804. Washington: U. S. Government Printing Office.

Gombos, A. M. Jr., and Ciesielski, P. F. 1983. Late Eocene to Early Miocene Diatoms from the Southwest Atlantic. In: Ludwig, W. J., Krasheninnikov, V. A. (Eds.). Initial Reports of the Deep Sea Drilling Project, 71:583-634. Washington: U. S. Government Printing Office.

Gombos, A. M., Jr. 1987. Middle Eocene Diatoms from the North Atlantic, Deep Sea Drilling Project Site 605. In: van Hinte, J. E., Wise, S. W., Jr. (Eds.). Initial Reports of the Deep Sea Drilling Project, 93:793-814. Washington: U. S. Government Printing Office.

Gombos, A.M., Jr. 1984. Late Paleocene diatoms in the Cape Basin. In K. J. Hsü \& J. L. LaBrecque (Eds.), Initial Reports of the Deep Sea Drilling Project, 73:495-511. Washington: U. S. Government Printing Office.

Gradstein, F.,, Agterberg, F.P., Brower, and Schwarzacher, W. 1985. Quantitative Stratigraphy, Reidel-Unesco Publ.

Hailwood, E.A., and Clement, B.M. 1991. Magnetostrtatigraphy of Sites 699 and 700, East Georgia Basin. In P.F. Ciesielski, Y. Kristoffersen, et al. (Eds.), Proceedings of the Ocean Drilling

Program, Scientific Results, 114:337-357. College Station, TX: Ocean Drilling Program. 
Hailwood, E.A., and Clement, B.M. 1991. Magnetostrtatigraphy of Sites 703 and 704, Meteor Rise, southeastern South Atlantic. In P.F. Ciesielski, Y. Kristoffersen, et al. (Eds.), Proceedings of the Ocean Drilling Program, Scientific Results, 114:367-386. College Station, TX: Ocean Drilling Program.

Hamano, Y., Krumsiek, K. A. O., Vigliotti, L., and Wippern, J. J. M. 1992. Pliocene-Pleistocene Magnetostratigraphy of Sediment Cores from the Japan Sea. In: Pisciotto, K. A., Ingle, J. C. (Eds.). Proceedings of the Ocean Drilling Program, Scientific Results, 127:969-982. College Station, TX: Ocean Drilling Program.

Haq, B.U., J. Hardenbol, and P.R. Vail 1987. Chronology of fluctuating sea levels since the Triassic (250 million years ago to present). Science, 235:1156-1167.

Harper, H. E., Jr. 1980. Diatom biostratigraphy of Sites 434, 435, and 436, northwestern Pacific, Leg 56, Deep Sea Drilling Project. In Scientific Party, Initial Reports of the Deep Sea Drilling Project, 56, 57 pt. 2:633-640. Washington: U. S. Government Printing Office.

Harper, H. E., Jr. 1982. Diatom biostratigraphy of Sites 495, 496, and 497, Deep Sea Drilling Project Leg 67. In J. Aubouin \& R. von Huene (Eds.), Initial Reports of the Deep Sea Drilling Project, 67:447-454. Washington: U. S. Government Printing Office.

Harwood, D. M., and Maruyama, T. 1992. Middle Eocene to PeistocenePleistocene diatom biostratigraphy of Southern Ocean sediments from the Kerguelen Plateau, Leg 120. In S. W. Wise \& R. Schlich (Eds.), Proceedings of the Ocean Drilling Program, Scientific Results, 120:683-733. College Station, TX: Ocean Drilling Program.

Harwood, D., Lazarus, D. B., Aubry, M., Berggren, W. A., Heider, F., Inokuchi, H., and Maruyama, T. 1992. Neogene stratigraphic synthesis, ODP Leg 120. In W. Wise, R. Schlich,S. O'Connell, et al. (Eds.), Proceedings of the Ocean Drilling Program, Scientific Results, 120:1031-1052. College Station, TX: Ocean Drilling Program.

Hay, W.W. 1972. Probabilistic stratigraphy, Eclogae Geol. Helv., 65:255-266.

Hayashida, A. and Bloemendal, J. 1991. Magnetostratigraphy of ODP Leg 117 sediments from the Owen Ridge and the Oman Margin, western Arabian Sea. In: W.L. Prell and N. Niitsuma (Eds.), Proceedings of the Ocean Drilling Program Scientific Results, 117:161-179. College Station, TX: Ocean Drilling Program.

Hays, J. D. 1970. Stratigraphy and evolutionary trends of radiolaria in North Pacific deep-sea sediments. In Geological Society of America Memoirs, 126:185-218. Geological Society of America.

Hays, J. D., and Opdyke, N. D. 1967. Antarctic radiolaria, magnetic reversals, and climate change. Science, 158:1001-1011.

Hays, J.D., and N.J. Shackleton 1976. Globally synchronous extinction of the radiolarian Stylatractus universus, Geology, 4:649-652.

Heath, G. R., Rea, D. H., and Levi, S. 1985. Paleomagnetism and accumulation rates of sediments at Sites 576 and 578, Deep Sea Drilling Project Leg 86, Western North Pacific. In G. R. Heath \& L. H. Burkle (Eds.), Initial Reports of the Deep Sea Drilling Project, 86:459-502. Washington: U. S. Government Printing Office.

Heider, F., Leitner, B., and Inokuchi, H. 1992. High Southern Latitude Magnetostratigraphy and Rock Magnetic Properties of Sediments from Sites 748 and 750, Leg 120. In: Wise, S. W., Schlich, R. (Eds.). Proceedings of the Ocean Drilling Program, Scientific Results, 120:225-245. College Station, TX: Ocean Drilling Program. 
Heiman, M.E. 1981. Oligocene to Quaternary Foraminifers from the Philippine Sea, Deep Sea Drilling Project Leg 59. In: Kroenke, L., Scott, R. (Eds.). Initial Reports of the Deep Sea Drilling Project, 59:567-579. Washington: U. S. Government Printing Office.

Heiman, M.E., Frerichs, W.E., Vincent, E. 1974. Paleogene Planktonic Foraminifera from the Western Tropical Indian Ocean, Deep Sea Drilling Project, Leg 24. In: Fisher, R.L., Bruce, E.T. (Eds.). Initial Reports of the Deep Sea Drilling Project, 22:851-857. Washington: U. S. Government Printing Office.

Hodell, D.A., Benson, R.H., Kent, D.V., Boersma, A., and Rakic-El Bied, K. 1994.

Magnetostratigraphic, biostratigraphic, and stable isotope biostratigraphy of an upper Miocene drill core from the Salé Briqueterie (northwestern Morocco): A high-resolution chronology for the Messinian stage. Paleoceanography, 9:835-856.

Holdsworth, B. K. 1975. Cenozoic Radiolaria biostratigraphy: Leg 30: tropical and equatorial Pacific. In J. E. Andrews \& G. Packham (Eds.), Initial Reports of the Deep Sea Drilling Project, 30:499-538. Washington: U. S. Government Printing Office.

Hsü, K.J., Montadert, L., et al. 1978. Introduction and explanatory notes. Initial Reports of the Deep Sea Drilling Project, 42/1:3-26. Washington: U. S. Government Printing Office.

Huber, B. T. 1991. Paleogene and Early Neogene Planktonic Foaraminifer Biostratigraphy of Sites 738 and 744, Kerguelen Plateau ( Southern Indian Ocean). In: Barron, J., Larsen, B. (Eds.).

Proceedings of the Ocean Drilling Program, Scientific Results, 119:427-449. College Station, TX: Ocean Drilling Program.

Huddlestun, P. F. 1984. Planktonic foraminiferal biostratigraphy, Deep Sea Drilling Project Leg 81 . In D. G. Roberts \& D. Schnitker (Eds.), Initial Reports of the Deep Sea Drilling Project, 81:429-438. Washington: U. S. Government Printing Office.

Ingle, J. C., Jr. 1973. Neogene foraminifera from the northeastern Pacific Ocean, Leg 18, Deep Sea Drilling Project. In L. D. Kulm \& R. von Huene (Eds.), Initial Reports of the Deep Sea Drilling Project, 18:517-567. Washington: U. S. Government Printing Office.

Inokuchi, H., and Heider, F. 1992. Magnetostratigraphy of sediments from Sites 748 and 750, Leg 120. In: Wise, S. W., Schlich, R. (Eds.). Proceedings of the Ocean Drilling Program, Scientific Results, 120:247-253. College Station, TX: Ocean Drilling Program.

Jablonski, D. 1993. The tropics as a source of evolutionary novelty through geological time. Nature, 364:142-144.

Jenkins, D. G. 1975. Cenozoic planktonic foraminiferal biostratigraphy of the southwestern Pacific and Tasman Sea - DSDP Leg 29. In J. P. Kennett \& R. E. Houtz (Eds.), Initial Reports of the Deep Sea Drilling Project, 29:449-468. Washington: U. S. Government Printing Office.

Jenkins, D. G. 1978. Neogene planktonic foraminifers from DSDP Leg 40 Sites 360 and 362 in the southeastern Atlantic. In H. M. Bolli \& W. B. F. Ryan (Eds.), Initial Reports of the Deep Sea Drilling Project, 40:723-740. Washington: U. S. Government Printing Office.

Jenkins, D. G. 1987. Middle Eocene to Miocene Planktonic Foraminifers from Deep Sea Drilling Project Sites 608 and 610, Northeastern Atlantic. In: Ruddiman, W. F., Kidd, R. B., Thomas, E. (Eds.). Initial Reports of the Deep Sea Drilling Project, 94:605-611. Washington: U. S. Government Printing Office.

Jenkins, D. G., and Srinivasan, M. S. 1986. Cenozoic planktonic foraminifers from the Equator to the Sub-Antarctic of the Southwest Pacific. In J. P. Kennett \& C. C. von der Borch (Eds.), Initial 
Reports of the Deep Sea Drilling Project, 90:795-834. Washington: U. S. Government Printing Office.

Jiang, M.-J., and Gartner, S. 1984. Neogene and Quaternary calcareous nannofossil biostratigraphy of the Walvis Ridge. In T. C. Moore Jr. \& P. D. Rabinowitz (Eds.), Initial Reports of the Deep Sea Drilling Project, 74:561-598. Washington: U. S. Government Printing Office.

Johnson, D. A. 1974. Radiolaria from the eastern Indian Ocean, DSDP Leg 22. In C. C. von der Borch \& J. G. Sclater (Eds.), Initial Reports of the Deep Sea Drilling Project, 22:521-576. Washington: U. S. Government Printing Office.

Johnson, D. A. 1976. Cenozoic radiolarians from the central Pacific, DSDP Leg 33. In S. O. Schlanger \& E. D. Jackson (Eds.), Initial Reports of the Deep Sea Drilling Project, 33:425-438. Washington: U. S. Government Printing Office.

Johnson, D. A. 1978. Cenozoic radiolaria from the eastern tropical Atlantic, DSDP, Leg 41. In Y. Lancelot \& E. Seibold (Eds.), Initial Reports of the Deep Sea Drilling Project, 41:763-790. Washington: U. S. Government Printing Office.

Johnson, D. A. 1990. Radiolarian Biostratigraphy in the Central Indian Ocean, Leg 115. In: Duncan, R. A., Backman, J., Peterson, L. C. (Eds.). Proceedings of the Ocean Drilling Program, Scientific Results, 115:395-409. College Station, TX: Ocean Drilling Program.

Johnson, D. A., and Nigrini, C. A. 1985. Synchronous and time-transgressive Neogene radiolarian datum levels in the equatorial Indian and Pacific Oceans. Marine Micropaleontology, 9:489-523.

Jousé, A. P., Kazarina, G. K., and Mukhina, V. V. 1982. Distribution of Diatoms in Pliocene and Pleistocene Deposits from the Middle America Trench Off Guatemala. In: Aubouin, J., von Huene, R. (Eds.). Initial Reports of the Deep Sea Drilling Project, 67:455- 471. Washington: U. S. Government Printing Office.

Kammer, Baumiller, and Ausich 1997. Species longevity as a function of niche breadth: Evidence from fossil crinoids. Geology, 25:219-222.

Kaneps, A. G. 1973. Cenozoic planktonic Foraminifera from the eastern equatorial Pacific, Leg 16, Deep Sea Drilling Project. In T. H. van Andel \& G. R. Heath (Eds.), Initial Reports of the Deep Sea Drilling Project, 16:713-746. Washington: U. S. Government Printing Office.

Kaneps, A. G. 1975. Cenozoic planktonic foraminifera from Antarctic deep-sea sediments. In D. E. Hayes \& L. A. Frakes (Eds.), Initial Reports of the Deep Sea Drilling Project, 28:573-584. Washington: U. S. Government Printing Office.

Keating, B. H., and Sakai, H. 1991. Magnetostratigraphic Studies of Sediments from Site 744, Southern Kerguelen Plateau. In: Barron, J., Larsen, B. (Eds.). Proceedings of the Ocean Drilling Program, Scientific Results, 119:771-794. College Station, TX: Ocean Drilling Program.

Keigwin, L. D., Jr. 1982. Neogene planktonic foraminifers from Deep Sea Drilling Project Sites 502 and 503. In W. L. Prell \& J. V. Gardner (Eds.), Initial Reports of the Deep Sea Drilling Project, 68:269-288. Washington: U. S. Government Printing Office.

Keller, G. 1980. Planktonic foraminiferal biostratigraphy and paleoceanography of the Japan Trench, Leg 57, Deep Sea Drilling Project. In Scientific Party, Initial Reports of the Deep Sea Drilling Project, 56, 57 pt. 2:809-834. Washington: U. S. Government Printing Office.

Keller, G. and J.A. Barron 1983. Paleoceanographic implications of Miocene deep-sea hiatuses. Geological Society of America Bulletin, 94:590-613. 
Keller, G. and J.A. Barron 1987. Paleodepth distribution of Neogene deep-sea hiatuses. Paleoceanography, 2:697-713.

Kennett, J.P., and Barker, P.F. 1990. Latest Cretaceous to Cenozoic climate and oceanographic developments in the Weddell Sea, Antarctica: An ocean-drilling perspective. Proc. Ocean Drill. Program, Sci. Results, 113:937-960.

Kent, D. V., and Spariosu, D. J. 1982. Magnetostratigraphy of Caribbian Site 502 hydraulic piston cores. In W. L. Prell \& J. V. Gardner (Eds.), Initial Reports of the Deep Sea Drilling Project, 68:419-434. Washington: U. S. Government Printing Office.

Kent, D. V., and Spariosu, D. J. 1982. Magnetostratigraphy of equatorial Pacific Site 503 hydraulic piston cores. In W. L. Prell \& J. V. Gardner (Eds.), Initial Reports of the Deep Sea Drilling Project, 68:435-440. Washington: U. S. Government Printing Office.

Kling, S. A. 1973. Radiolaria from the eastern North Pacific, Deep Sea Drilling Project, Leg 18. In L. D. Kulm \& R. von Huene (Eds.), Initial Reports of the Deep Sea Drilling Project, 18:617-672. Washington: U. S. Government Printing Office.

Kling, S. A. 1982. Radiolarians from the Mariana Trough and Trench region: Deep Sea Drilling Project Leg 60. In D. M. Hussong \& S. Uyeda (Eds.), Initial Reports of the Deep Sea Drilling Project, 60:537-556. Washington: U. S. Government Printing Office.

Knuttel, S., Russell, M. D., Jr., and Firth, J. V. 1989. Neogene Calcareous Nannofossils from ODP Leg 105: Implications for Pleistocene Paleoceanographic Trends. In: Srivastava, S. P., Arthur, M.A., Clement, B. (Eds.). Proceedings of the Ocean Drilling Program, Scientific Results, 105:245-262. College Station, TX: Ocean Drilling Program.

Knüttel, S. 1986. Calcareous nannofossil biostratigraphy of the central East Pacific Rise, Deep Sea Drilling Project Leg 92: evidence for downslope transport of sediments. In M. Leinen \& D. K. Rea (Eds.), Initial Reports of the Deep Sea Drilling Project, 92:255-290. Washington: U. S. Government Printing Office.

Koizumi, I. 1973. The late Cenozoic diatoms of Sites 183-193, Leg 19 Deep Sea Drilling Project. In J. S. Creager \& D. W. Scholl (Eds.), Initial Reports of the Deep Sea Drilling Project, 19:805-856. Washington: U. S. Government Printing Office.

Koizumi, I. 1975. Neogene diatoms from the western margin of the Pacific Ocean, Leg 31, Deep Sea Drilling Project. In D. E. Karig \& J. C. Ingle Jr. (Eds.), Initial Reports of the Deep Sea Drilling Project, 31:779-820. Washington: U. S. Government Printing Office.

Koizumi, I. 1980. Neogene diatoms from the Emperor Seamount chain, Leg 55, Deep Sea Drilling Project. In E. D. Jackson \& I. Koizumi (Eds.), Initial Reports of the Deep Sea Drilling Project, 55:387-408. Washington: U. S. Government Printing Office.

Koizumi, I. 1992. Diatom Biostratigraphy of the Japan Sea: Leg 127. In: Pisciotto, K. A., Ingle, J. C. (Eds.). Proceedings of the Ocean Drilling Program, Scientific Results, 127:249-289. College Station, TX: Ocean Drilling Program.

Koizumi, I., and Tanimura, Y. 1985. Neogene diatom biostratigraphy of the middle latitude western North Pacific, Deep Sea Drilling Project Leg 86. In G. R. Heath \& L. H. Burkle (Eds.), Initial Reports of the Deep Sea Drilling Project, 86:269-300. Washington: U. S. Government Printing Office.

Krasheninnikov, V. A., and Basov, I. A. 1983. Cenozoic planktonic foraminifers of the Falkland Plateau and Argentine Basin, Deep Sea Drilling Project Leg 71. In W. J. Ludwig \& V. A.

Krasheninnikov (Eds.), Initial Reports of the Deep Sea Drilling Project, 71:821-858. Washington: 


\section{U. S. Government Printing Office.}

Krasheninnikov, V. A., and Pflaumann, U. 1978. Zonal stratigraphy and planktonic foraminifers of Paleogene deposits of the Atlantic Ocean to the west off Africa (Deep Sea Drlling Project, Leg 41). In Y. Lancelot \& E. Seibold (Eds.), Initial Reports of the Deep Sea Drilling Project, 41:581-611. Washington: U. S. Government Printing Office.

Krasheninnikov, V. A., and Pflaumann, U. 1978. Zonal stratigraphy of Neogene deposits of the eastern part of the Atlantic Ocean by means of planktonic foraminifers, Leg 41, Deep Sea Drilling Project. In Y. Lancelot \& E. Seibold (Eds.), Initial Reports of the Deep Sea Drilling Project, 41:613-658. Washington: U. S. Government Printing Office.

Kroon, D. 1994. Some Planktonic Foraminiferal Datum Levels During the Last $10.4 \mathrm{Ma}$, Leg 133. In: McKenzie, J. A., Davies, J. A. (Eds.). Proceedings of the Ocean Drilling Program, Scientific Results, 133:787-790. College Station, TX: Ocean Drilling Program.

Krumsiek, K., and Roberts, D. G. 1984. Paleomagnetics of Tertiary sediments from the southwest Rockall Plateau, Deep Sea Drilling Project Leg 81. In D. G. Roberts \& D. Schnitker (Eds.), Initial Reports of the Deep Sea Drilling Project, 81:837-854. Washington: U. S. Government Printing Office.

Labracherie, M. 1985. Quaternary radiolarians from the Equatorial Pacific, Deep Sea Drilling Project Leg 85. In L. Mayer \& F. Theyer (Eds.), Initial Reports of the Deep Sea Drilling Project, 85:499-510. Washington: U. S. Government Printing Office.

Lang, T. H., and Watkins, D. K. 1984. Cenozoic Calcareous Nannofossils from the Deep Sea Drilling Project Leg 77, Southeast Gulf of Mexico. In: Buffler, R. T., Schlager, W. (Eds.). Initial Reports of the Deep Sea Drilling Project, 77:629-648. Washington: U. S. Government Printing Office.

Lang, T.H., and Wise, S. W., Jr. 1987. Neogene and Paleocene-Maestrichtian Calcareous Nannofossil Stratigraphy, Deep Sea Drilling Project Sites 604 and 605, Upper Continental Rise off New Jersey: Sedimentation Rates, Hiatuses, and Correlations with Seismic Stratigraphy. In: van Hinte, J. E., Wise, S. W., Jr. (Eds.). Initial Reports of the Deep Sea Drilling Project, 93:661-683. Washington: U. S. Government Printing Office.

Lazarus, D. B. 1990. Middle Miocene to Recent Radiolarians from the Weddell Sea, AntarticaAntarctica, ODP Leg 113. In: Barker, P. F., Kennett, J. P. (Eds.). Proceedings of the Ocean Drilling Program, Scientific Results, 113:709-728. College Station, TX: Ocean Drilling Program.

Lazarus, D. B. 1992. Age Depth Plot and Age Maker: age depth modelling [stet] on the Macintosh series of computers. Geobyte, 71:7-13.

Lazarus, D. B. 1992b. Antarctic Neogene radiolarians from the Kerguelen Plateau, ODP Legs 119 and 120. In S. W. Wise \& R. Schlich (Eds.), Proceedings of the Ocean Drilling Program, Scientific Results, 120:785-810. College Station, TX: Ocean Drilling Program.

Lazarus, D. B. 1994. The Neptune Project - developing a large relational database of marine microfossil data on a personal computer. Mathematical Geology 26:817-832.

Lazarus, D., C. Spencer-Cervato, M. Pika-Biolzi, J.P. Beckmann, K. von Salis, K., H. Hilbrecht, and H.R. Thierstein 1995a. Revised chronology of Neogene DSDP Holes from the World Ocean. Ocean Drilling Program Technical Note No. 24, 312 pp.

Lazarus, D. B., Hilbrecht, H., and Spencer-Cervato, C. 1995b. Speciation and phyletic change in Globorotalia truncatulinoides (planktonic foraminifera). Paleobiology 21:28-51. 
Lazarus, D., and Pallant, A. 1989. Oligocene and Neogene Radiolarians from the Labrador Sea: ODP Leg 105. In: Srivastava, S. P., Arthur, M.A., Clement, B. (Eds.). Proceedings of the Ocean Drilling Program, Scientific Results, 105:349-380. College Station, TX: Ocean Drilling Program.

Leckie, R. M., Farnham, C., and Schmidt, M. G. 1993. Oligocene Planktonic Foraminifer Biostratigraphy of Hole 803D (Ontong Java Plateau) and Hole 628A (Little Bahama Bank), and Comparison with the Southern High Latitudes. In: Berger, W. H., Kroenke, L. W. (Eds.).

Proceedings of the Ocean Drilling Program, Scientific Results, 130:113-136. College Station, TX: Ocean Drilling Program.

Leinen, M. 1977. A normative calculation technique for determining opal in deep-sea sediments. Geoch. Cosmoch. Acta, 41:671-676.

Leinen, M., Cwienk, D., Heath, G.R., Biscaye, P.E., Kolla, V., Thiede, J., and Dauphin, J.P. 1986. Distribution of biogenic silica and quartz in recent deep-sea sediments. Geology, 14:199-203.

Levinton, J. 1988. Genetics, Paleontology and Macroevolution. Cambridge University Press, Cambridge.

Ling, H. Y. 1973. Radiolaria: Leg 19 of the Deep Sea Drilling Project. In J. S. Creager \& D. W. Scholl (Eds.), Initial Reports of the Deep Sea Drilling Project, 19:777-798. Washington: U. S. Government Printing Office.

Ling, H. Y. 1979. Radiolarians from the west flank of the Reykjanes Ridge, Deep Sea Drilling Project Leg 49. In B. P. Luyendyk \& J. R. Cann (Eds.), Initial Reports of the Deep Sea Drilling Project, 49:583-588. Washington: U. S. Government Printing Office.

Ling, H. Y. 1980. Radiolarians from the Emperor Seamounts of the northwest Pacific: Leg 55 of the Deep Sea Drilling Project. In E. D. Jackson \& I. Koizumi (Eds.), Initial Reports of the Deep Sea Drilling Project, 55:365-374. Washington: U. S. Government Printing Office.

Ling, H.Y. 1975 . Radiolaria: Leg 31 of the Deep Sea Drilling Project. In: Karig, D.E., Ingle, J.C., Jr. (Eds.) Initial Reports of the Deep Sea Drilling Project, 31:703-761. Washington: U. S. Government Printing Office.

Littke, R., Fourtanier, E., Thurow, J., and Taylor, E. 1991. Silica diagenesis and its effects on lithification of Broken Ridge deposits, central Indian Ocean. In J. Weissel, J. Peirce, et al. (Eds.), Proceedings of the Ocean Drilling Program, Scientific Results, 121:261-272. College Station, TX: Ocean Drilling Program.

Lohman, W. H. 1986. Calcareous nannoplankton biostratigraphy of the southern Coral Sea, Tasman Sea, and southwestern Pacific Ocean, Deep Sea Drilling Project Leg 90: Neogene and Quaternary. In J. P. Kennett \& C. C. von der Borch (Eds.), Initial Reports of the Deep Sea Drilling Project, Leg 90, 90:763-793. Washington: U. S. Government Printing Office.

Ma'alouleh, K., and Moullade, M. 1987. Biostratigraphic and paleoenvironmental study of Neogene and Quaternary planktonic foraminifers from the lower continental rise of the New Jersey margin (western North Atlantic), Deep Sea Drilling Project Leg 93, Site 603. In J. E. van Hinte \& S. W. Wise (Eds.), Initial Reports of the Deep Sea Drilling Project, 93:481-492. Washington: U. S. Government Printing Office.

Madile, M., and Monechi, S. 1991. Late Eocene to early Oligocene calcareous nannofossil assemblages from Sites 699 and 703, subantarctic South Atlantic Ocean. In P.F. Ciesielski, Y. Kristoffersen, et al. (Eds.), Proceedings of the Ocean Drilling Program, Scientific Results, 114:179-192. College Station, TX: Ocean Drilling Program.

Manivit, H. 1989. Calcareous nannofossil biostratigraphy of Leg 108 sediments. In: W. Ruddiman \& 
M. Sarnthein (Eds.). Proceedings of the Ocean Drilling Program Scientific Results, 108:35-69. College Station, TX: Ocean Drilling Program.

Martini, E. 1976. Cretaceous to Recent calcareous nannoplankton from the central Pacific Ocean (DSDP Leg 33). In S. O. Schlanger \& E. D. Jackson (Eds.), Initial Reports of the Deep Sea Drilling Project, 33:439-450. Washington: U. S. Government Printing Office.

Martini, E. 1979. Calcareous nannoplankton and silicoflagellate biostratigraphy at Reykjanes Ridge, northeastern North Atlantic (DSDP Leg 49, Sites 407 and 409). In B. P. Luyendyk \& J. R. Cann (Eds.), Initial Reports of the Deep Sea Drilling Project, 49:533-549. Washington: U. S. Government Printing Office.

Martini, E. 1981. OligocenetoOligocene to Recent Calcareous Nannoplankton from the Philippine Sea, Deep Sea Drilling Project Leg 59. In: Kroenke, L., Scott, R. (Eds.). Initial Reports of the Deep Sea Drilling Project, 59:547-565. Washington: U. S. Government Printing Office.

Martini, E. 1986. Paleogene Calcareous Nannoplankton from the Southwest Pacific Ocean, Deep Sea Drilling Project Leg 90. In: Kennett, J. P., von der Borch, C. C. (Eds.). Initial Reports of the Deep Sea Drilling Project, 90:747-761. Washington: U. S. Government Printing Office.

Martini, E., and Worsley, T. 1971. Tertiary calcareous nannoplankton from the western equatorial Pacific. In E. L. Winterer (Ed.), Initial Reports of the Deep Sea Drilling Project, 7:1471-1508. Washington: U. S. Government Printing Office.

McCollum, D. W. 1975. Diatom stratigraphy of the Southern Ocean. In D. E. Hayes \& L. A. Frakes (Eds.), Initial Reports of the Deep Sea Drilling Project, 28:515-572. Washington: U. S. Government Printing Office.

McGowran, B. 1974. Foraminifera. In: von der Borch, C. C., Sclater, J. G. (Eds.). Initial Reports of the Deep Sea Drilling Project, 22:609-627. Washington: U. S. Government Printing Office.

McMillan, K.J. 1982. Radiolarians from the Southern Mexico Active Margin, Deep Sea Drilling Project Leg 66. In: Watkins, J. S., Moore, J. C. (Eds.) Initial Reports ofod the Deep Sea Drilling Project, 66:643-651. Washington: U. S. Government Printing Office.

Mikkelsen, N. 1990. Cenozoic diatom biostratigraphy and paleoceanography of the western equatorial Indian Ocean. In R. A. Duncan, J. Backman, \& L. C. Peterson (Eds.), Proceedings of the Ocean Drilling Program, Scientific Results, 115:411-432. College Station, TX: Ocean Drilling Program.

Miller, K. G., and Hart, M. B. 1987. Cenozoic Planktonic Foraminifers and Hiatuses on the New Jersey Slope and Rise: Deep Sea Drilling Project Leg 95, Northwest Atlantic. In: Poag, C. W., Watts, A. B. (Eds.). Initial Reports of the Deep Sea Drilling Project, 95:253-265. Washington: U. S. Government Printing Office.

Miller, K.G., Aubry, M.P., Khan, Melillo, Kent, D.V., and Berggren, W.A. 1985. Oligocene-Miocene biostratigraphy, magnetostratigraphy, and isotopic stratigraphy of the western North Atlantic.

Geology, 13:257-261.

Miller, K.G., R.G. Fairbanks, and G.S. Mountain 1987. Tertiary oxygen isotope synthesis, sea level history, and continental margin erosion. Paleoceanography, 2:1-19.

Miller, K.G., Wright, J.D., Van Fossen, and Kent, D.V. 1994. Miocene stable isotopic stratigraphy and magnetostratigraphy of Buff Bay, Jamaica. Geol. Soc. Am. Bull., 106:1605-1620.

Miller, K.G., G.S. Mountain, the Leg 150 Shipboard Party and Members of the New Jersey Coastal Plain Drilling Project 1996. Drilling and dating New Jersey Oligocene-Miocene sequences: ice 
volume, global sea level and Exxon records. Science, 271:1092-1095.

Milner, G.J. 1992. Middle Eocene to early Oligocene foraminifers from the Izu-Bonin forearc, Hole 786A. In: P. Fryer, J.A. Pearce, \& Stokking, L.B. (Eds.) Proceedings of the Ocean Drilling Program Scientific Results, 125:71-90. College Station, TX: Ocean Drilling Program.

Monechi, S. 1985. Campanian to Pleistocene calcareous nannofossil stratigraphy from the northwest Pacific Ocean, Deep Sea Drilling Project Leg 86. In G. R. Heath \& L. H. Burkle (Eds.), Initial Reports of the Deep Sea Drilling Project, 86:301-336. Washington: U. S. Government Printing Office.

Moore, T.C., Jr. 1972. DSDP: successes, failures, proposals. Geotimes, 17 (July):27-31.

Moore, T.C. Jr, T.H. Van Andel, C. Sancetta, and N. Pisias 1978. Cenozoic hiatuses in pelagic sediments. Micropaleontology, 24:113-138.

Morley, J. J. 1985. Radiolarians from the Northwest Pacific, Deep Sea Drilling Project Leg 86. In G. R. Heath \& L. H. Burckle (Eds.), Initial Reports of the Deep Sea Drilling Project, 86:399-421. Washington: U. S. Government Printing Office.

Mortlock, R.A., and Froelich, P.N. 1989. A simple method for the rapid determination of biogenic opal in pelagic marine sediments. Deep-Sea Res., Part A, 36, 1415-1426.

Müller, C. 1979. Calcareous Nannofossils from the North Atlantic (Leg 48). In: Montadert, L., Roberts, D.G. (Eds.). Initial Reports of the Deep Sea Drilling Project, 48:589-620. Washington: U. S. Government Printing Office.

Müller, C. 1985. Biostratigraphic and paleoenvironmental interpretation of the Goban Spur region based on a study of calcareous nannoplankton. In P. C. Graciansky \& C. W. Poag (Eds.), Initial Reports of the Deep Sea Drilling Project, 80:573-600. Washington: U. S. Government Printing Office.

Müller, G., and Gastner, M. 1971. The "Karbonat Bombe", a simple device for the determination of the carbonate content in sediments, soils and other materials. Neues Jahrb. Mineral. Monatsch., 10:466-469.

Muza, J. P., Wise, S. W., and Covington, J. M. 1987. Neogene calcareous nannofossils from Deep Sea Drilling Project Site 603, lower continental rise, western North Atlantic: biostratigraphy and correlations with magnetic and seismic stratigraphy. In J. E. van Hinte \& S. W. Wise (Eds.), Initial Reports of the Deep Sea Drilling Project, 93:593-616. Washington: U. S. Government Printing Office.

Muzylöv, N. 1982. Nannoplankton stratigraphy of Leg 67 drill sites. In J. Aubouin \& R. von Huene (Eds.), Initial Reports of the Deep Sea Drilling Project, 67:401-425. Washington: U. S. Government Printing Office.

Nigrini, C. 1991. Composition and biostratigraphy of radiolarian assemblages from an area of upwelling (northwestern Arabian Sea, Leg 117). In W. L. Prell \& N. Niitsuma (Eds.), Proceedings of the Ocean Drilling Program, Scientific Results, 117:89-126. College Station, TX: Ocean Drilling Program.

Nigrini, C. 1991. Composition and biostratigraphy of radiolarian assemblages from an area of upwelling (northwestern Arabian Sea, Leg 117). In: W.L. Prell and N. Niitsuma (Eds.), Proceedings of the Ocean Drilling Program Scientific Results, 117:89-126. College Station, TX: Ocean Drilling Program.

Nigrini, C. A. 1985. Radiolarian biostratigraphy in the central Equatorial Pacific, Deep Sea Drilling 
Project Leg 85. In L. Mayer \& F. Theyer (Eds.), Initial Reports of the Deep Sea Drilling Project, 85:511-553. Washington: U. S. Government Printing Office.

Nishi, H. and Chaproniere G.C.H. 1994. Eocene-Oligocene subtropical planktonic foraminifera at Site 841. In: J. Hawkins, L. Parson, \& J. Allan (Eds.), Proceedings of the Ocean Drilling Program Scientific Results, 135:245-266. College Station, TX: Ocean Drilling Program.

Nishimura, A. 1987. Cenozoic radiolaria in the western North Atlantic, Site 603, Leg 93 of the Deep Sea Drilling Project. In J. E. van Hinte \& S. W. Wise (Eds.), Initial Reports of the Deep Sea Drilling Project, 93:685-698. Washington: U. S. Government Printing Office.

Nocchi, M., Amici, E., and Premoli Silva, I. 1991. Planktonic foraminiferal biostratigraphy and paleoenvironmental interpretation of Paleogene faunas from the subantarctic transect, Leg 114. In P.F. Ciesielski, Y. Kristoffersen, et al. (Eds.), Proceedings of the Ocean Drilling Program, Scientific Results, 114:233-279. College Station, TX: Ocean Drilling Program.

Okada, H. 1980. Calcareous Nannofossils from the Deep Sea Drilling Project Sites 442 through 446, Philippine Sea. In: deVries Klein, G., Kobayashi, K. (Eds.). Initial Reports of the Deep Sea Drilling Project, 58:549-585. Washington: U. S. Government Printing Office.

Okada, H. 1990. Quaternary and Paleogene Calcareous Nannofossils, Leg 115. In: Duncan, R. A., Backman, J., Peterson, L. C. (Eds.). Proceedings of the Ocean Drilling Program, Scientific Results, 115:129-174. College Station, TX: Ocean Drilling Program.

Okada, H., and Thierstein, H.R. 1979. Calcareous Nannoplankton- Leg 43, Deep Sea Drilling Project. In: Tucholke, B.E., Vogt, P.R. (Eds.). Initial Reports of the Deep Sea Drilling Project, 43:507-573. Washington: U. S. Government Printing Office.

Palmer, A. A. 1987. Cenozoic Radiolarians from the Deep Sea Drilling Project Sites 612 and 613 (Leg 95, New Jersey Transect) and Atlantic Slope Site ASP 15. In: Poag, C. W., Watts, A. B. (Eds.). Initial Reports of the Deep Sea Drilling Project, 95:339-357. Washington: U. S. Government Printing Office.

Parker, M. E., Clark, M., and Wise, S. W., Jr. 1985. Calcareous Nannofossils of the Deep Sea Drilling Project Sites 558 and 563, North Atlantic Ocean: Biostratigraphy and the Distribution of Oligocene Braarudosphaerids. In: Bougault, H., Cande, S. C. (Eds.). Initial Reports of the Deep Sea Drilling Project, 82:559-589. Washington: U. S. Government Printing Office.

Perch-Nielsen, K. 1977. Albian to Pleistocene Calcareous Nannofossils from the Western South Atlantic, DSDP Leg 39. In: Supko, P.R., Perch-Nielsen, K. (Eds.). Initial Reports of the Deep Sea Drilling Project, 39:699-823. Washington: U. S. Government Printing Office.

Perch-Nielsen, K. 1985. Mesozoic calcareous nannofossils. In: Plankton stratigraphy, edited by Bolli, H.M., Saunders, J.B. \& Perch-Nielsen, K., 329-426.

Percival, S. F., Jr. 1984. Late Cretaceous to Pleistocene calcareous nannofossils from the South Atlantic, Deep Sea Drilling Project Leg 73. In K. J. Hsü \& J. L. LaBrecque (Eds.), Initial Reports of the Deep Sea Drilling Project, 73:391-424. Washington: U. S. Government Printing Office.

Perembo, R. C. B. 1994. Miocene to Pliocene Planktonic Foraminifers from the North Aoba Basin, Site 832. In: Green, H. G., Collot, J.-Y. (Eds.). Proceedings of the Ocean Drilling Program, Scientific Results, 134:247-263. College Station, TX: Ocean Drilling Program.

Petrushevskaya, M. G. 1975. Cenozoic radiolarians of the Antarctic Deep Sea Drilling Project Leg 29. In J. P. Kennett \& R. E. Houtz (Eds.), Initial Reports of the Deep Sea Drilling Project, 29:541-676. Washington: U. S. Government Printing Office. 
Pisias, N.G., and Moore, T.C. Jr. 1978. Cenozoic Radiolarians from Deep Sea Drilling Project Leg 40. In: Bolli, H.M., Ryan, W.B.F.(Eds.). Initial Reports of the Deep Sea Drilling Project, 40:845-856. Washington: U. S. Government Printing Office.

Poore, R. Z. 1979. Oligocene through Quaternary planktonic foraminiferal biostratigraphy of the North Atlantic. In B. P. Luyendyk \& J. R. Cann (Eds.), Initial Reports of the Deep Sea Drilling Project, 49:447-518. Washington: U. S. Government Printing Office.

Poore, R. Z. 1981. Miocene through Quaternary planktonic foraminifers from offshore Southern California and Baja California. In R. S. Yeats \& B. U. Haq (Eds.), Initial Reports of the Deep Sea Drilling Project, 63:415-436. Washington: U. S. Government Printing Office.

Poore, R. Z. 1984. Middle Eocene through Quaternary planktonic foraminifers from the southern Angola Basin, Deep Sea Drilling Project Leg 73. In K. J. Hsü \& J. L. LaBrecque (Eds.), Initial Reports of the Deep Sea Drilling Project, 73:429-448. Washington: U. S. Government Printing Office.

Pospichal, J. J., and Wise, S. W. 1990. Paleocene to Middle Eocene Calcareous Nannofossils of ODP Sites 689 and 690, Maud Rise, Weddell Sea. In: Barker, P. F., Kennett, J. P. (Eds.).

Proceedings of the Ocean Drilling Program, Scientific Results, 113:613-638. College Station, TX: Ocean Drilling Program.

Premoli Silva, I., and Violanti, D. 1981. Cenozoic Planktonic Foraminifer Biostratigraphy of the Deep Sea Drilling Project Hole 462, Nauru Basin (Western Equatorial Pacific), and Distribution of the Pelagic Components. In: Larson, R.L, Schlanger, S.O. (Eds.). Initial Reports of the Deep Sea Drilling Project, 61:397-422. Washington: U. S. Government Printing Office.

Premoli-Silva, I., and Spezzaferri, S. 1990. Paleogene Planktonic Foraminifer Biostratigraphy and Paleoenvironmental Remarks on Paleogene Sediments from Indian Ocean Sites, Leg 115. In: Duncan, R. A., Backman, J., Peterson, L. C. (Eds.). Proceedings of the Ocean Drilling Program, Scientific Results, 115:277-314. College Station, TX: Ocean Drilling Program.

Premoli-Silva, I., Castradori, D., and Spezzaferri, S. 1993. Calcareous Nannofossil and Planktonic Foraminifer Biostratigraphy of Hole 810C (Shatsky Rise, Northwestern Pacific). In: Natland, J. H., Storms, M. A. (Eds.). Proceedings of the Ocean Drilling Program, Scientific Results, 132:15-36. College Station, TX: Ocean Drilling Program.

Proto Decima, F., Medizza, F., and Todesco, L. 1978. SotheasternSoutheastern Atlantic Leg 40 calcareous nannofossils. In H. M. Bolli \& W. B. F. Ryan (Eds.), Initial Reports of the Deep Sea Drilling Project, 40:571-634. Washington: U. S. Government Printing Office.

Pujol, C. 1983. Cenozoic planktonic foraminiferal biostratigraphy of the southwestern Atlantic (Rio Grande Rise): Deep Sea Drilling Project Leg 72. In P. F. Barker, R. L. Carlson, \& D. A. Johnson (Eds.), Initial Reports of the Deep Sea Drilling Project, 72:623-675. Washington: U. S. Government Printing Office.

Pujol, C., and Duprat, J. 1983. Quaternary Planktonic Foraminifers of the Southwestern Atlantic (Rio Grande Rise), Deep Sea Drilling Project Leg 72. In: Barker, P. F., Carlson, R. L., Johnson, D. A. (Eds.). Initial Reports of the Deep Sea Drilling Project, 72:601-622. Washington: U. S. Government Printing Office.

Pujol, C., and Duprat, J. 1985. Quaternary and Pliocene Planktonic Foraminifers of the North Eastern Atlantic (Goban Spur), Deep Sea Drilling Project Leg 80. In: Graciansky, P. C. de, Poag, C. W. (Eds.). Initial Reports of the Deep Sea Drilling Project, 80:683-723. Washington: U. S. Government Printing Office. 
Pujos, A. 1985. Cenozoic nannofossils, central Equatorial Pacific, Deep Sea Drilling Project Leg 85. In L. Mayer \& F. Theyer (Eds.), Initial Reports of the Deep Sea Drilling Project, 85:581-608. Washington: U. S. Government Printing Office.

Pujos, A. 1985. Quaternary Nannofossils from Goban Spur, EastrenEastern North Atlantic Ocean, Deep Sea Drilling Project Holes 548 and 549A. In: Graciansky, P. C. de, Poag, C. W. (Eds.). Initial Reports of the Deep Sea Drilling Project, 80:767-792. Washington: U. S. Government Printing Office.

Quinterno, P.J. 1994. Calcareous nannofossil biostratigraphy: Sites 840 (Tonga Ridge) and 841 (Tonga Trench). In: J. Hawkins, L. Parson, \& J. Allan (Eds.), Proceedings of the Ocean Drilling Program Scientific Results, 135:267-284. College Station, TX: Ocean Drilling Program.

Rahman, A. 1992. Calcareous Nannofossil Biostratigraphy of Leg 127 in the Japan Sea. In: Pisciotto, K. A., Ingle, J. C. (Eds.). Proceedings of the Ocean Drilling Program, Scientific Results, 127:171-186. College Station, TX: Ocean Drilling Program.

Ramsay, A.T.S., T.J.S. Sykes, and R.B. Kidd 1994. Waxing (and waning) lyrical on hiatuses: Eocene-Quaternary Indian Ocean hiatuses as proxy indicators of water mass production.

Paleoceanography, 9:857-877.

Revelle, R. 1981. The past and future of ocean drilling. In 'The Deep Sea Drilling Project: A decade of progress', Warme, J.E. et al. (Eds.), SEPM Spec. Publ. 32:1-4.

Reynolds, R. A. 1980. Radiolarians from the western North Pacific, Leg 57, Deep Sea Drilling Project. In Scientific Party, Initial Reports of the Deep Sea Drilling Project, 56, 57 pt. 2:735-770. Washington: U. S. Government Printing Office.

Riedel, W. R., and Sanfilippo, A. 1971. Cenozoic radiolaria from the western tropical Pacific, Leg 7. In E. L. Winterer (Ed.), Initial Reports of the Deep Sea Drilling Project, 7:1529-1672. Washington: U. S. Government Printing Office.

Riedel, W. R., and Westberg, M. J. 1982. Neogene radiolarians from the eastern tropical Pacific and Caribbean, Deep Sea Drilling Project Leg 68. In W. L. Prell \& J. V. Gardner (Eds.), Initial Reports of the Deep Sea Drilling Project, 68:289-300. Washington: U. S. Government Printing Office.

Rio, D., Fornaciari, E., and Raffi, I. 1990. Late Oligocene through Early Pleistocene Calcareous Nannofossils from Western Equatorial Indian Ocean (Leg 115). In: Duncan, R. A., Backman, J., Peterson, L. C. (Eds.). Proceedings of the Ocean Drilling Program, Scientific Results, 115:175-235. College Station, TX: Ocean Drilling Program.

Romine, K. 1986. Planktonic foraminifers from Oligocene to Pleistocene sediments, Deep Sea Drilling Project Leg 92. In M. Leinen \& D. K. Rea (Eds.), Initial Reports of the Deep Sea Drilling Project, 92:291-298. Washington: U. S. Government Printing Office.

Roth, P. H. 1974. Calcareous nannofossils from the northwestern Indian Ocean, Leg 24. In R. L. Fisher \& E. T. Bunce (Eds.), Initial Reports of the Deep Sea Drilling Project, 24:969-994. Washington: U. S. Government Printing Office.

Roth, P. H., and Thierstein, H. R. 1972. Calcareous nannoplankton: Leg XIV of the Deep Sea Drilling Project. In D. E. Hayes \& A. C. Pimm (Eds.), Initial Reports of the Deep Sea Drilling Project, 14:421-486. Washington: U. S. Government Printing Office.

Ryan, W. B. F., and Hsü, K. J. (Eds.) 1973. Initial Reports of the Deep Sea Drilling Project. , Leg 13, Washington, D. C.: U. S. Government Printing Office.

Sager, W. W., Polgreen, E., and Rack, F. 1993. Magnetic Polarity Reversal Stratigraphy of Hole 
810C, Shatsky Rise, Western Pacific Ocean. In: Natland, J. H., Storms, M. A. (Eds.). Proceedings of the Ocean Drilling Program, Scientific Results, 132:47-55. College Station, TX: Ocean Drilling Program.

Saint-Marc, P. 1987. Biostratigraphic and Paleocene Benthic and Planktonic Foraminifers, Site 605, Deep Sea Drilling Project Leg 93. In: van Hinte, J. E., Wise, S. W., Jr. (Eds.). Initial Reports of the Deep Sea Drilling Project, 93:539-547. Washington: U. S. Government Printing Office.

Saito, T. 1985. Planktonic foraminiferal biostratigraphy of eastern Equatorial Pacific sediments, Deep Sea Drilling Project Leg 85. In L. Mayer \& F. Theyer (Eds.), Initial Reports of the Deep Sea Drilling Project, 85:621-654. Washington: U. S. Government Printing Office.

Sakai, H., and Keating, B. H. 1991. Paleomagnetism of Leg 119-Holes 737A, 738C, 742A, 745B, and 746A. In: Barron, J., Larsen, B. (Eds.). Proceedings of the Ocean Drilling Program, Scientific Results, 119:751-770. College Station, TX: Ocean Drilling Program.

Sakai, T. 1980. Radiolarians from Sites 434, 435, and 436, Northwest Pacific, Leg 56, Deep Sea Drilling Project. In Scientific Party, Initial Reports of the Deep Sea Drilling Project, 56, 57, part 2:695-734. Washington: U. S. Government Printing Office.

Salloway, J. C. 1983. Paleomagnetism of sediments from Deep Sea Drilling Project Leg 71. In W. J. Ludwig \& V. A. Krasheninnikov (Eds.), Initial Reports of the Deep Sea Drilling Project,

71:1073-1092. Washington: U. S. Government Printing Office.

Sancetta, C. 1982. Diatom biostratigraphy and paleoceanography, Deep Sea Drilling Project Leg 68. In W. L. Prell \& J. V. Gardner (Eds.), Initial Reports of the Deep Sea Drilling Project, 68:301-310. Washington: U. S. Government Printing Office.

Sanfilippo, A. and C. Nigrini 1995. Radiolarian stratigraphy across the Oligocene/ Miocene transition. Marine Micropaleontology, 24:239-285.

Sanfilippo, A., and Riedel, W. R. 1974. Radiolaria from the west-central Indian Ocean and Arabian Sea, DSDP Leg 24. In R. L. Fisher \& E. T. Bunce (Eds.), Initial Reports of the Deep Sea Drilling Project, 24:997-1037. Washington: U. S. Government Printing Office.

Sanfilippo, A., Westberg, M.J., and Riedel, W.R. 1981. Cenozoic Radiolarians at Site 462, Deep Sea Drilling Project Leg 61, Western Tropical Pacific. In: Larson, R.L, Schlanger, S.O. (Eds.). Initial Reports of the Deep Sea Drilling Project, 61:495-505. Washington: U. S. Government Printing Office.

Sanfilippo, A., M.J. Westberg-Smith, and W.R. Riedel, 1985. Cenozoic radiolaria. In: Plankton stratigraphy, edited by Bolli, H.M., Saunders, J.B. \& Perch-Nielsen, K., 631-712.

Sato, T., Kameo, K., and Takayama, T. 1991. Coccolith biostratigraphy of the Arabian Sea. In: W.L. Prell and N. Niitsuma (Eds.), Proceedings of the Ocean Drilling Program Scientific Results, 117:37-54. College Station, TX: Ocean Drilling Program.

Schneider, D. A., and Kent, D. V. 1990. Paleomagnetism of Leg 115 Sediments: Implications for Neogene Magnetostratigraphy and Paleolatitude of the Reunion Hotspot. In: Duncan, R. A., Backman, J., Peterson, L. C. (Eds.). Proceedings of the Ocean Drilling Program, Scientific Results, 115:717-736. College Station, TX: Ocean Drilling Program.

Schrader, H. J. 1973. Cenozoic diatoms from the Northeast Pacific, Leg 18. In L. D. Kulm \& R. von Huene (Eds.), Initial Reports of the Deep Sea Drilling Project, 18:673-798. Washington: U. S. Government Printing Office.

Schrader, H. J. 1974. Cenozoic marine planktonic diatom stratigraphy of the tropical Indian Ocean. 
In R. L. Fisher \& E. T. Bunce (Eds.), Initial Reports of the Deep Sea Drilling Project, 24:887-968. Washington: U. S. Government Printing Office.

Schrader, H. J. 1976. Cenozoic planktonic diatom biostratigraphy of the southern Pacific Ocean. In C. D. Hollister \& C. Craddock (Eds.), Initial Reports of the Deep Sea Drilling Project, 35:605-672. Washington: U. S. Government Printing Office.

Schrader, H. J. 1979. Opal phytoplankton in DSDP Leg 49 samples. In B. P. Luyendyk \& J. R. Cann (Eds.), Initial Reports of the Deep Sea Drilling Project, 49:589-594. Washington: U. S. Government Printing Office.

Schrader, H.J. 1978. Diatoms in DSDP Leg 41 sites. In Y. Lancelot \& E. Seibold (Eds.), Initial Reports of the Deep Sea Drilling Project, 41:791-812. Washington: U. S. Government Printing Office.

Shackleton, N.J., Hall, M.A., Line, J., and Chuxi, C. 1983. Carbon isotope data in core V19-30 confirm reduced carbon dioxide in the ice age atmosphere. Nature, 306:319-322.

Shaw, A.B. 1964. Time in stratigraphy. McGraw-Hill, New York.

Shaffer, B. L. 1980. Calcareous-nannofossil biostratigraphy of Japan Trench transect, Deep Sea Drilling Project Leg 57. In Scientific Party, Initial Reports of the Deep Sea Drilling Project, 56, 57 pt. 2:875-886. Washington: U. S. Government Printing Office.

Shafik, S. 1975. Nannofossil biostratigraphy of the southwest Pacific, Deep Sea Drilling Project, Leg 30. In J. E. Andrews \& G. Packham (Eds.), Initial Reports of the Deep Sea Drilling Project, 30:549-598. Washington: U. S. Government Printing Office.

Siesser, W. G., and Bralower, T. J. 1992. Cenozoic Calcareous Nannofossil Biostratigraphy on the Exmouth Plateau, Eastern Indian Ocean. In: von Rad, U., Haq, B. U. (Eds.). Proceedings of the Ocean Drilling Program, Scientific Results, 122:601-631. College Station, TX: Ocean Drilling Program.

Sloan, J. 1980. Radiolarians from Sediments of the Philippine Sea, Deep Sea Drilling Project Leg 58. In: deVries Klein, G., Kobayashi, K. (Eds.). Initial Reports of the Deep Sea Drilling Project, 58:587-595. Washington: U. S. Government Printing Office.

Smith, A.B. 1994. Systematics and the fossil record - documenting evoltuionaryevolutionary patterns. Blackwell Scientific Publications, Oxford.

Smith, C.C. and Poore, R.Z. 1984. Upper Maestrichtian and Paleocene planktonic foraminiferal biostratigraphy of the northern Cape Basin, Deep Sea Drilling Project Hole 524. In K. J. Hsü \& J. L. LaBrecque (Eds.), Initial Reports of the Deep Sea Drilling Project, 73:449-457. Washington: U. S. Government Printing Office.

Snyder, S. W., and Waters, V. J. 1985. Cenozoic planktonic foraminiferal biostratigraphy of the Goban Spur region, Deep Sea Drilling Project Leg 80. In P. C. Graciansky \& C. W. Poag (Eds.), Initial Reports of the Deep Sea Drilling Project, 80:439-472. Washington: U. S. Government Printing Office.

Spaulding, S. 1991. Neogene nannofossil biostratigraphy of Sites 723 through 730, Oman Continental Margin, northwestern Arabian Sea. In: W.L. Prell and N. Niitsuma (Eds.), Proceedings of the Ocean Drilling Program Scientific Results, 117:5-36. College Station, TX: Ocean Drilling Program.

Spaulding, S.A., Bloemendal, J., Hayashida, A., Hermelin, J.O.R., Kameo, K., Kroon, D., Nigrini, C.A., Sato, T., Steens, T.N.F., Takayama, T., and Troelstra, S.R. 1991. Magnetostratigraphic and 
biostratigraphic synthesis, Leg 117, Arabian Sea. In: W.L. Prell and N. Niitsuma (Eds.), Proceedings of the Ocean Drilling Program Scientific Results, 117:127-145. College Station, TX: Ocean Drilling Program.

Spencer-Cervato, C. 1998. Changing depth distribution of hiatuses during the Cenozoic. Paleoceanography, 13:178-182.

Spencer-Cervato, C., Lazarus, D. B., Beckmann, J. P., Perch-Nielsen, K. v. S., and Biolzi, M. 1993. New calibration of Neogene radiolarian events in the North Pacific. Marine Micropaleontology, 21:261-294.

Spencer-Cervato, C., Thierstein, H. R., Lazarus, D. B., and Beckmann, J. P. 1994. How synchronous are Neogene marine plankton events? Paleoceanography 9:739-763.

Spencer-Cervato, C. and Thierstein, H.R. 1997. First appearance of Globorotalia truncatulinoides: Cladogenesis and immigration. Marine Micropaleontology, 30:267-291.

Spiess, V. 1990. Cenozoic Magnetostratigraphy of Leg 113 Drill Sites, Maud Rise, Weddell Sea, AntarticaAntarctica. In: Barker, P. F., Kennet, J. P. (Eds.). Proceedings of the Ocean Drilling Program, Scientific Results, 113:261-315. College Station, TX: Ocean Drilling Program.

Staerker, T. S. 1994. Calcareous Nannofossil Biostratigraphy: Evidence for Thrust Faulting and Sediment Mixing in the Accretionary Complex of the Central New Hebrides Island Arc. In: Green, $\mathrm{H}$. G., Collot, J.-Y. (Eds.). Proceedings of the Ocean Drilling Program, Scientific Results, 134:179-245. College Station, TX: Ocean Drilling Program.

Steinmetz, J. C. 1979. Calcareous nannofossils from the North Atlantic Ocean, Leg 49, Deep Sea Drilling Project. In B. P. Luyendyk \& J. R. Cann (Eds.), Initial Reports of the Deep Sea Drilling Project, 49:519-532. Washington: U. S. Government Printing Office.

Stott, L. D., and Kennett, J. P. 1990. The Paleoceanographic and Paleoclimatic Signature of the Cretaceous/Paleogene Boundary in the Antartic: Stable Isotopic Results from ODP Leg 113. In: Barker, P. F., Kennett, J. P. (Eds.). Proceedings of the Ocean Drilling Program, Scientific Results, 113:829-848. College Station, TX: Ocean Drilling Program.

Stradner, H., and Alram, F. 1982. The Nannofossil Assemblages of the Deep Sea Drilling Project Leg 66, Middle America Trench. In: Watkins, J. S., Moore, J. C. (Eds.) Initial Reports ofd the Deep Sea Drilling Project, 66:589-639. Washington: U. S. Government Printing Office.

Takayama, T. 1980. Calcareous nannofossil biostratigraphy, Leg 55 of the Deep Sea Drilling Project. In E. D. Jackson \& I. Koizumi (Eds.), Initial Reports of the Deep Sea Drilling Project, 55:349-364. Washington: U. S. Government Printing Office.

Takayama, T. 1993. Notes on the Neogene Calcareous Nannofossil Biostratigraphy of the Ontong Java Plateau and Size Variation of Reticulofenestra Coccoliths. In: Berger, W. H., Kroenke, L. W. (Eds.). Proceedings of the Ocean Drilling Program, Scientific Results, 130:179-229. College Station, TX: Ocean Drilling Program.

Takayama, T., and Sato, T. 1987. Coccolith biostratigraphy of the North Atlantic Ocean, Deep Sea Drilling Project Leg 94. In W. F. Ruddiman \& R. B. Kidd (Eds.), Initial Reports of the Deep Sea Drilling Project, 94:651-702. Washington: U. S. Government Printing Office.

Takayanagi, Y., and Oda, M. 1976. Shore laboratory report on Cenozoic planktonic foraminifera, Leg 33. In S. O. Schlanger \& E. D. Jackson (Eds.), Initial Reports of the Deep Sea Drilling Project, 33:451-466. Washington: U. S. Government Printing Office.

Takemura, A. 1992. Radiolarian Paleogene Biostratigraphy in the Southern Indian Ocean, Leg 120. 
In: Wise, S. W., Schlich, R. (Eds.). Proceedings of the Ocean Drilling Program, Scientific Results, 120:735-756. College Station, TX: Ocean Drilling Program.

Tang, C. 1992. Paleomagnetism of Cenozoic Sediments in Holes 762B and 763A, Central Exmouth Plateau, Northwest Australia. In: von Rad, U., Haq, B. U. (Eds.). Proceedings of the Ocean Drilling Program, Scientific Results, 122:717-733. College Station, TX: Ocean Drilling Program.

Tauxe, L., Tucker, P., Petersen, N. P., and LaBrecque, J. L. 1984. Magnetostratigraphy of Leg 73 sediments. In K. J. Hsü \& J. L. LaBrecque (Eds.), Initial Reports of the Deep Sea Drilling Project, 73:609-622. Washington: U. S. Government Printing Office.

Tauxe, L., Valet, J.-P., and Bloemendal, J. 1989. Magnetostratigraphy of Leg 108 advanced hydraulic piston cores. In: W. Ruddiman \& M. Sarnthein (Eds.). Proceedings of the Ocean Drilling Program Scientific Results, 108:429-439. College Station, TX: Ocean Drilling Program.

Theyer, F., and Lineberger, P. 1981. Radiolarian Biostratigraphy of the Philippine Sea, Deep Sea DrilingDrilling Project Leg 59. In: Kroenke, L., Scott, R. (Eds.). Initial Reports of the Deep Sea Drilling Project, 59:581-585. Washington: U. S. Government Printing Office.

Theyer, F., Mato, C. Y., and Hammond, S. R. 1978. Paleomagnetic and geochronologic calibration of latest Oligocene to Pliocene radiolarian events, equatorial Pacific. Marine Micropaleontology, 3:377-395.

Thierstein, H. R. 1974. Calcareous nannoplankton - Leg 26, Deep Sea Drilling Project. In T. A. Davies \& B. P. Luyendyk (Eds.), Initial Reports of the Deep Sea Drilling Project, 26:619-668. Washington: U. S. Government Printing Office.

Thierstein, H.R., and Manivit, H. 1981. Calcareous-Nannofossil Biostratigraphy, Nauru Basin, Deep Sea Drilling Project Site 462, and Upper Cretaceous Nannofacies. In: Larson, R.L, Schlanger, S.O. (Eds.). Initial Reports of the Deep Sea Drilling Project, 61:475-494. Washington: U. S. Government Printing Office.

Thierstein, H.R., K. Geitzenauer, B. Molfino, and N.J. Shackleton 1977. Global synchroneity of Late Quaternary coccolith datums: Validation by oxygen isotopes, Geology, 5:400-404.

Thompson, P. R. 1980. Foraminifers from Deep Sea Drilling Project Sites 434, 435, and 436, Japan Trench. In Scientific Party, Initial Reports of the Deep Sea Drilling Project, 56, 57 pt. 2:775-808. Washington: U. S. Government Printing Office.

Thompson, P. R. 1982. Foraminifers of the Middle America Trench. In J. Aubouin \& R. von Huene (Eds.), Initial Reports of the Deep Sea Drilling Project, 67:351-383. Washington: U. S. Government Printing Office.

Toumarkine, M. 1978. Planktonic Foraminifera Biostratigraphy of the Paleogene of Sites 360 to 364 and the Neogene of Sites 362A, 363, and 364 Leg 40. In: Bolli, H.M., Ryan, W.B.F.(Eds.). Initial Reports of the Deep Sea Drilling Project, 40:679-721. Washington: U. S. Government Printing Office.

Townsend, H. A. 1985. The paleomagnetism of sediments acquired from the Goban Spur on Deep Sea Drilling Project Leg 80. In P. C. Graciansky \& C. W. Poag (Eds.), Initial Reports of the Deep Sea Drilling Project, 80:389-414. Washington: U. S. Government Printing Office.

Vail, P.R., R.M. Jr. Mitchum, R.G. Todd, J.M. Widmier, S. Thompson III, J.B. Sangree, J.N. Bubb, and W.G. Hatlelid 1977. Seismic stratigraphy and global sea-level changes. In: Seismic stratigraphy - applications to hydrocarbon exploration, edited by Payton, C.E., Tulsa, American Association of Petroleum Geologists Memoir, 26:49-212. 
Valentine, P. C. 1987. Lower Eocene Calcareous Nannofossil Biostratigraphy beneath the Atlantic Slope and Upper Rise off New Jersey- New Zonation based on Deep Sea Drilling Project Sites 612 and 613. In: Poag, C. W., Watts, A. B. (Eds.). Initial Reports of the Deep Sea Drilling Project, 95:359-394. Washington: U. S. Government Printing Office.

van Andel, T.H. 1975. Mesozoic/Cenozoic Calcite Compensation Depth and the global distribution of calcareous sediments. Earth and Planet. Sci. Letters, 26:187-195.

Vincent, E., and Toumarkine, M. 1990. Neogene Planktonic Foraminifers from the Western Tropical Indian Ocean, Leg 115. In: Duncan, R. A., Backman, J., Peterson, L. C. (Eds.). Proceedings of the Ocean Drilling Program, Scientific Results, 115:795-836. College Station, TX: Ocean Drilling Program.

Vincent, E., Frerichs, W. E., and Heiman, M. E. 1974. Neogene planktonic foraminifera from the Gulf of Aden and the western tropical Indian Ocean, Deep Sea Drilling Project, Leg 24. In R. L. Fisher \& E. T. Bunce (Eds.), Initial Reports of the Deep Sea Drilling Project, 24:827-850. Washington: U. S. Government Printing Office.

Weaver, F. M. 1983. Cenozoic radiolarians from the Southwest Atlantic, Falkland Plateau region, Deep Sea Drilling Project Leg 71. In W. J. Ludwig \& V. A. Krasheninnikov (Eds.), Initial Reports of the Deep Sea Drilling Project, 71:667-686. Washington: U. S. Government Printing Office.

Weaver, F. M. 1983. Cenozoic radiolarians from the southwest Atlantic, Falkland Plateau region, Deep Sea Drilling Project Leg 71. In W. J. Ludwig \& V. A. Krasheninnikov (Eds.), Initial Reports of the Deep Sea Drilling Project, 71:667-686. Washington: U. S. Government Printing Office.

Weaver, P. P. E. 1987. Late Miocene to Recent planktonic foraminifers from the North Atlantic: Deep Sea Drilling Project Leg 94. In W. F. Ruddiman \& R. B. Kidd (Eds.), Initial Reports of the Deep Sea Drilling Project, 94:703-728. Washington: U. S. Government Printing Office.

Weaver, P.P.E. and Raymo, M.E. 1989. Late Miocene to Holocene planktonic foraminifers from the equatorial Atlantic, Leg 108. Proceedings of the Ocean Drilling Program Scientific Results, 108:71-91. College Station, TX: Ocean Drilling Program.

Weedon, G.P., Shackleton, N.J., and Pearson, P.N. 1997. The Oligocene time scale and cyclostratigraphy on the Ceara Rise, western equatorial Atlantic. In: Shackleton, N.J., Curry, W.B., Richter, C., and Bralower, T.J. (Eds.) Proceedings of the Ocean Drilling Program Scientific Results, 154:101-114. College Station, TX: Ocean Drilling Program.

Wei, K.-Y. and Kennett, J. 1983. Nonconstant extinction rates of Neogene planktonic foraminifera. Nature, 305:218-220.

Wei, W. 1993. Calibration of Upper Pliocene-Lower Pleistocene nannofossil events with oxygen isotope stratigraphy, Paleoceanography, 8, 85-99.

Wei, W., and Pospichal, J. J. 1991. Danian Calcareous Nannofossil Succession at Site 738 in the Southern Indian Ocean. In: Barron, J., Larsen, B. (Eds.). Proceedings of the Ocean Drilling Program, Scientific Results, 119:495-512. College Station, TX: Ocean Drilling Program.

Wei, W., and Thierstein, H. R. 1991. Upper Cretaceous and Cenozoic Calcareous Nannofossils of the Kerguelen Plateau ( Southern Indian Ocean) and Prydz Bay (East America). In: Barron, J., Larsen, B. (Eds.). Proceedings of the Ocean Drilling Program, Scientific Results, 119:467-493. College Station, TX: Ocean Drilling Program.

Wei, W., and Wise, S. W. 1990. Middle Eocene to Pleistocene Calcareous Nannofossils Recovered by Ocean Drilling Program Leg 113 in the Weddell Sea. In: Barker, P. F., Kennet, J. P. (Eds.). 
Proceedings of the Ocean Drilling Program, Scientific Results, 113:639-666. College Station, TX: Ocean Drilling Program.

Wei, W., and Wise, S. W. 1992. Oligocene-Pleistocene Calcareous Nannofossils from Southern Ocean Sites. In: Wise, S. W., Schlich, R. (Eds.). Proceedings of the Ocean Drilling Program, Scientific Results, 120:509-521. College Station, TX: Ocean Drilling Program.

Weinheimer, A. L., Sanfilippo, A., and Riedel, W. R. 1994. Radiolarians from Leg 134, Vanuatu Region, Southwestern Tropical Pacific. In: Green, H. G., Collot, J.-Y. (Eds.). Proceedings of the Ocean Drilling Program, Scientific Results, 134:309-318. College Station, TX: Ocean Drilling Program.

Weinreich, N., and Theyer, F. 1985. Paleomagnetism of Deep Sea Drilling Project Leg 85 sediments: Neogene magnetostratigraphy and tectonic history of the central Equatorial Pacific. In L. Mayer \& F. Theyer (Eds.), Initial Reports of the Deep Sea Drilling Project, 85:849-904. Washington: U. S. Government Printing Office.

Westberg, M. J., and Riedel, W. R. 1982. Radiolarians from the Middle America Trench off Guatemala, Deep Sea Drilling Project Leg 67. In J. Aubouin \& R. von Huene (Eds.), Initial Reports of the Deep Sea Drilling Project, 67:401-424. Washington: U. S. Government Printing Office.

Westberg-Smith, M. J., Tway, L. E., and Riedel, W. R. 1987. Radiolarians from the North Atlantic Ocean, Deep Sea Drilling Project Leg 94. In: Ruddiman, W. F., Kidd, R. B., Thomas, E. (Eds.). Initial Reports of the Deep Sea Drilling Project, 94:763-777. Washington: U. S. Government Printing Office.

Westberg-Smith, M.J.; Riedel, W.R., 1984. Radiolarians from the western margin of the Rockall Plateau: Deep Sea Drilling Project Leg 81. In D. G. Roberts \& D. Schnitker (Eds.), Initial Reports of the Deep Sea Drilling Project, 81:479-501. Washington: U. S. Government Printing Office.

Wise, S. W. 1973. Calcareous nannofossils from cores recovered during Leg 18, Deep Sea Drilling Project: biostratigraphy and observations of diagenesis. In L. D. Kulm \& R. von Huene (Eds.), Initial Reports of the Deep Sea Drilling Project, 18:569-616. Washington: U. S. Government Printing Office.

Wise, S. W. 1983. Mesozoic and Cenozoic calcareous nannofossils recovered by Deep Sea Drilling Project Leg 71 in the Falkland Plateau region, southwest Atlantic Ocean. In W. J. Ludwig \& V. A. Krasheninnikov (Eds.), Initial Reports of the Deep Sea Drilling Project, 71:481-550. Washington: U. S. Government Printing Office.

Wolfart, R. 1981. Neogene radiolarians from the eastern North Pacific (off Alta and Baja California), Deep Sea Drilling Project, Leg 63. In R. S. Yeats \& B. U. Haq (Eds.), Initial Reports of the Deep Sea Drilling Project, 63:473-506. Washington: U. S. Government Printing Office.

Worsley, T. R. 1973. Calcareous nannofossils: Leg 19 of the Deep Sea Drilling Project. In J. S. Creager \& D. W. Scholl (Eds.), Initial Reports of the Deep Sea Drilling Project, 19:741-750. Washington: U. S. Government Printing Office.

Wright, A.A. 1985. Introduction, cruise summary, and explanatory notes: Deep Sea Drilling Project Leg 86, western North Pacific. In G.R. Heath and L.H. Burckle (Eds.), Initial Reports of the Deep Sea Drilling Project, 86:5-21. Washington: U. S. Government Printing Office.

Wright, J.D. and K.G. Miller 1993. Southern Ocean influences on late Eocene to Miocene deepwater circulation. In: 'The Antarctic paleoenvironment: a perspective on global change'. AGU Antarctic Research Series, 60:1-25. 
Wright, J.D., Miller, K.G., and Fairbanks, R.G. 1992. Early and middle Miocene stable isotopes: implications for deepwater circulation and climate. Paleoceanography, 7:357-389.

$\mathrm{Xu}, \mathrm{Y}$. and Wise, S.W., Jr. 1992. Middle Eocene to Miocene calcareous nannofossils of Leg 125 from the western Pacific Ocean. In: P. Fryer, J.A. Pearce, \& Stokking, L.B. (Eds.) Proceedings of the Ocean Drilling Program Scientific Results, 125:43-70. College Station, TX: Ocean Drilling Program.

Zachariasse, W. J. 1992. Neogene Planktonic Foraminifers from Sites 761 and 762 off Northwest Australia. In: von Rad, U., Haq, B. U. (Eds.). Proceedings of the Ocean Drilling Program, Scientific Results, 122:665-675. College Station, TX: Ocean Drilling Program.

Zachos, J.C., Flower, B.P., and Paul, H. 1997. Orbitally paced climate oscillations across the Oligocene/Miocene boundary. Nature, 388:567-570.

Zhao, X., Roperch, P., and Stokking, L. 1994. Magnetostratigraphy of the North Aoba Basin. In: Green, H. G., Collot, J.-Y. (Eds.). Proceedings of the Ocean Drilling Program, Scientific Results, 134:457-474. College Station, TX: Ocean Drilling Program. 


\section{Appendix A. Age/Depth Plots and Age Model files}

One or two plots are given for each hole analysed. Where two plots are available, they cover the Neogene ( $N$ in the file name) and the Paleogene ( $P$ in the file name) sections, respectively.

All plots were created with the ADP program described in Lazarus (1992), which gives additional details on plotting procedures, conventions, and usage. The $x$-axis represents the age in million years. There is also a reproduction at the bottom of the plot of the Berggren et al. (1995b) magnetostratigraphic scale. On the left y-axis is the depth in meters below sea floor, on the right a representation of the cores (numbered boxes, with heights proportional to actual recovery) and (short lines on right side of boxes) $1.5 \mathrm{~m}$ section breaks. The symbols corresponding to the microfossil groups are on the top of the plot: $\mathrm{D}=$ diatoms, $\mathrm{F}=$ foraminifera, $\mathrm{M}=$ magnetostratigraphy, $\mathrm{N}=$ nannofossils, $\mathrm{R}=$ radiolarians. Each event is labelled only with a short plotcode to reduce visual clutter in the figure. Translations for the plotcodes are given in Table 2.2. Error bars for the depth level of each event are represented as vertical lines crossing the symbols, but sometimes the error bars are not visible because they are smaller than the symbol itself.

ASCII files of the age models are also given. Only one file is given for each hole. The files consist of two columns. The first row shows the hole name (e.g. 62A) on the left and the date the age model was created on the right (in the format YYMMDD, e.g., 19950725). The second row gives the headings of the data columns, age to the left and depth to the right. The third row gives the number of points in the age model. The coordinates of the age model points follow from the fourth row. The files are exactly in the format generated by Lazarus's (1994) ADP program. This format is required by the ADP program and can, therefore, be used directly to create an age/depth plot with this software. Alternatively, the age and depth coordinates can be used to construct a simple xy line graph. The files can be opened with any word processing or spreadsheet program.

To download full-size diagrams, open the following directory and choose the file (named by hole number). File naming convention is 62A_PICT.GIF (62A = hole number).

DIRECTORY: adps app

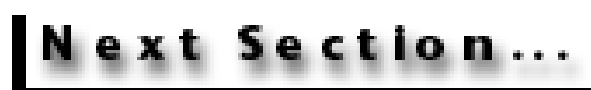




\section{Holes 62A-192}

To download full-size diagrams, open the following directory and choose the file (named by hole number). File naming convention is 62A_PICT.GIF (62A = hole number).

DIRECTORY: adps app

\section{A 19950725}

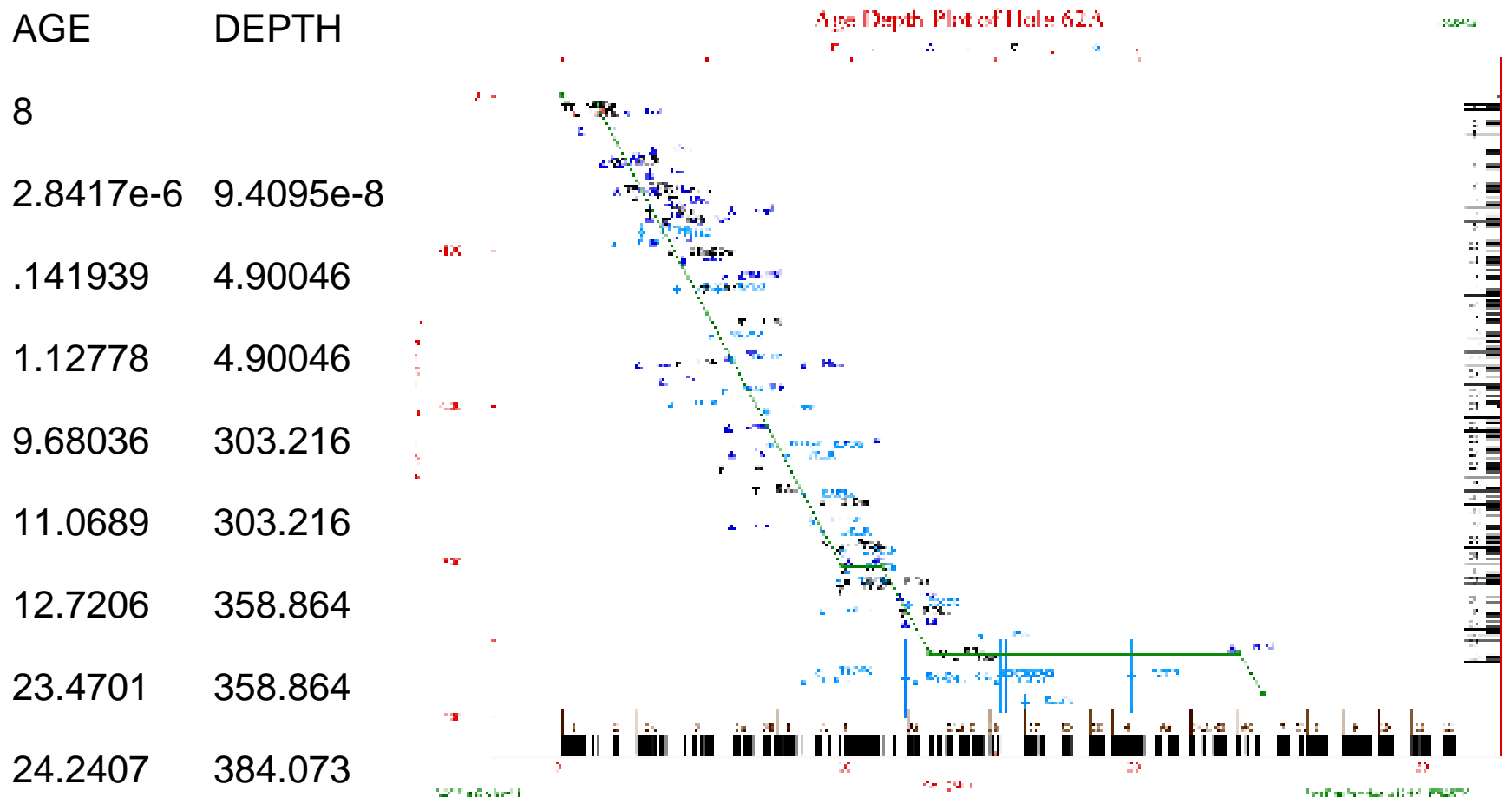

6319950725

AGE DEPTH

8

.2350682 .25

$1.41768 \quad 21.7458$

$4.52453 \quad 21.7458$

$5.58455 \quad 33.5375$

8.7952298 .3155

$14.5641 \quad 141.439$

$16.1099 \quad 172.741$

30.7299551

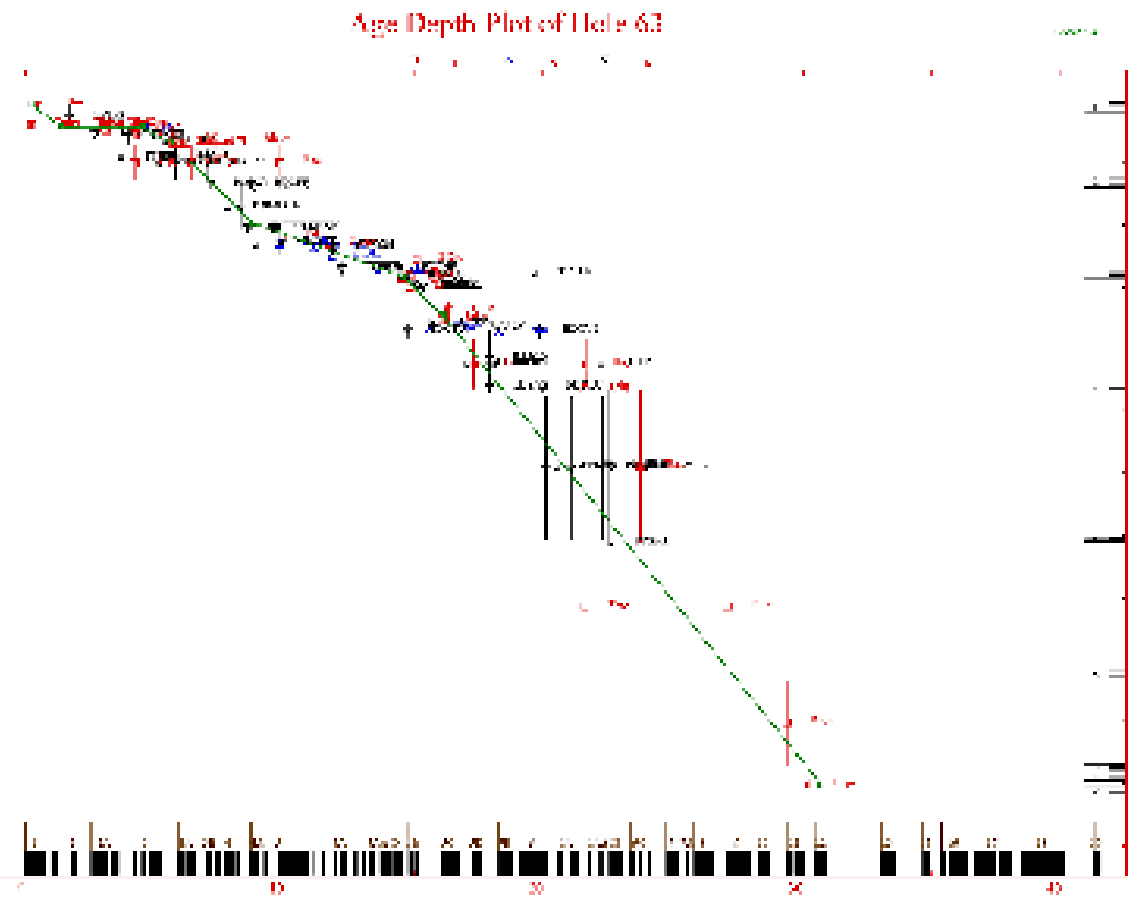

6419950725 


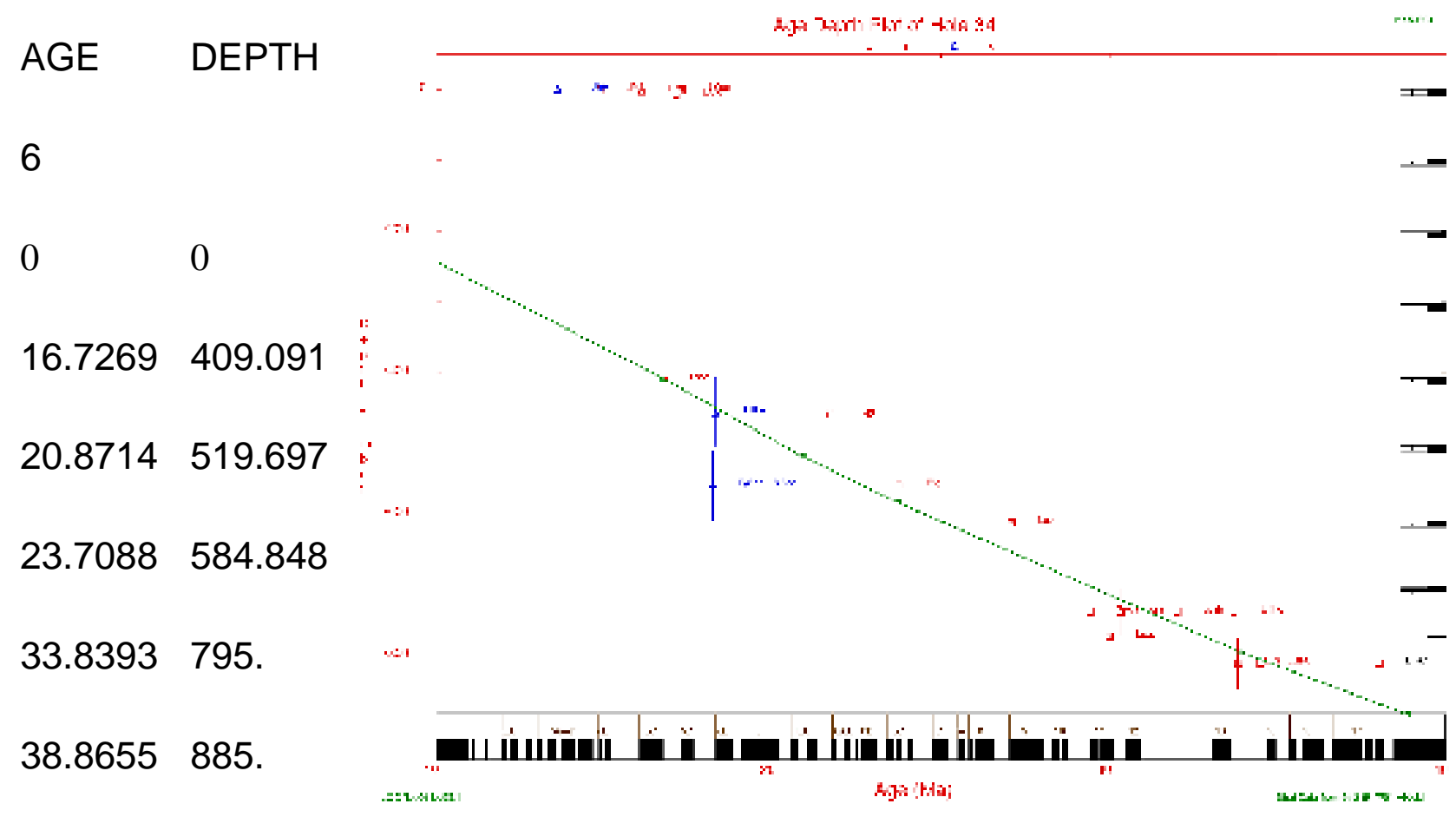

\section{7}

AGE DEPTH

9

$0 \quad 0$

$0.50725644 \quad 7.68817$

1.9398545533 .9247

$2.50595378 \quad 36.9355$

$2.8905904 \quad 41.0215$

3.1222222247 .9032

$3.281479 \quad 60.5914$

$4.70278875 \quad 60.5914$

$4.932678 \quad 65.7527$

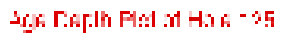

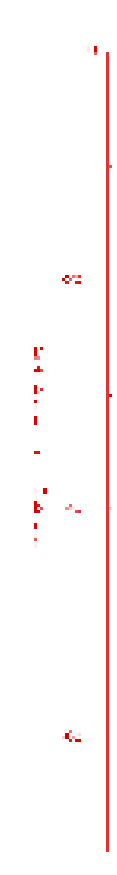
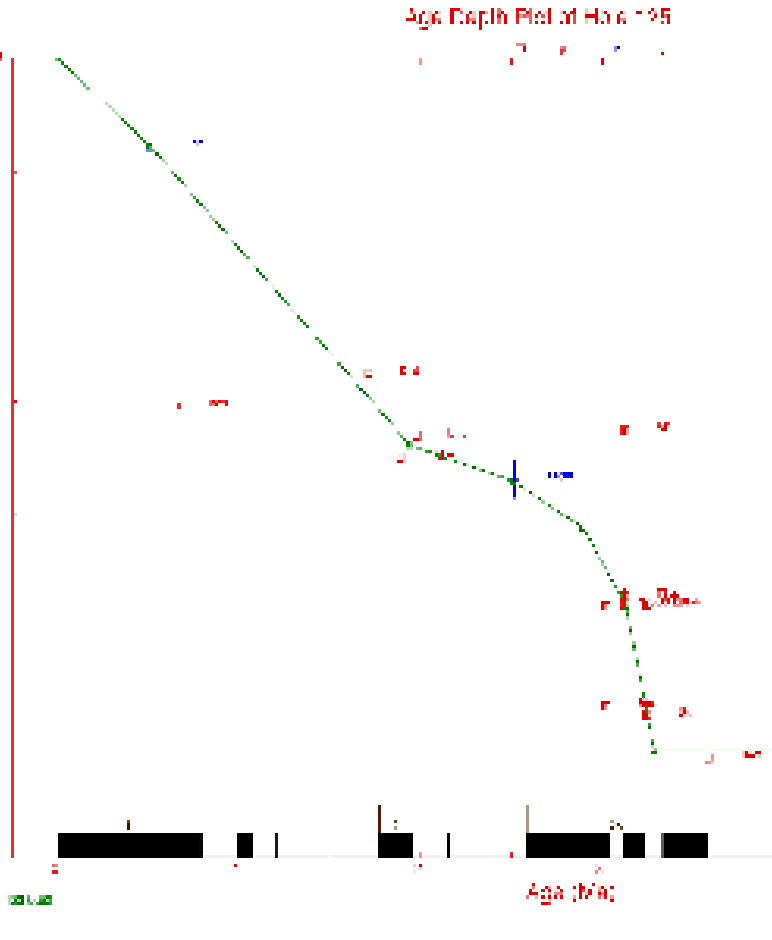

13219952507

AGE DEPTH

15

$0 \quad 0$

$0.26997723 \quad 3.89784$

$0.50953233 \quad 9.27418$ 


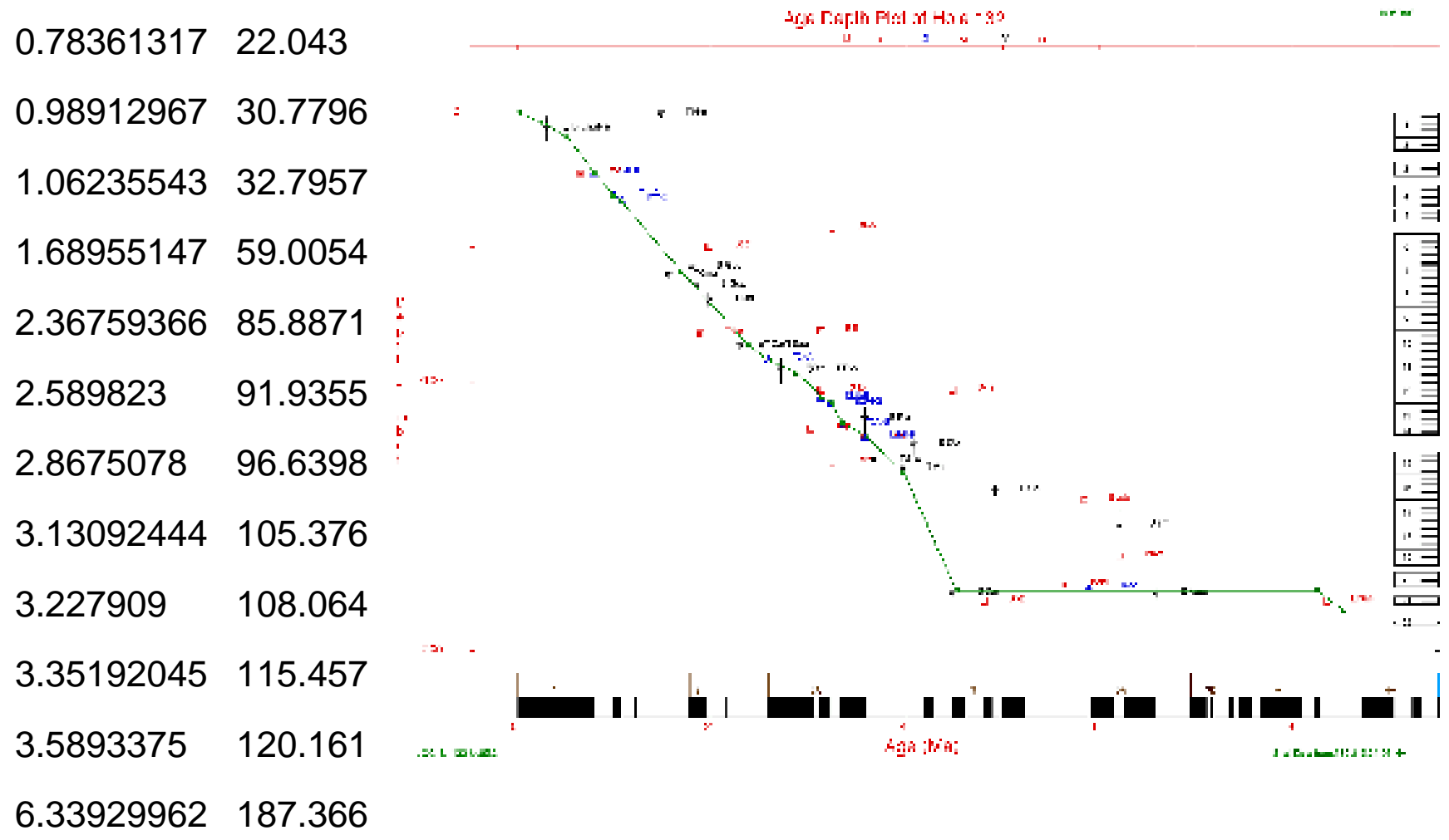

14119950803

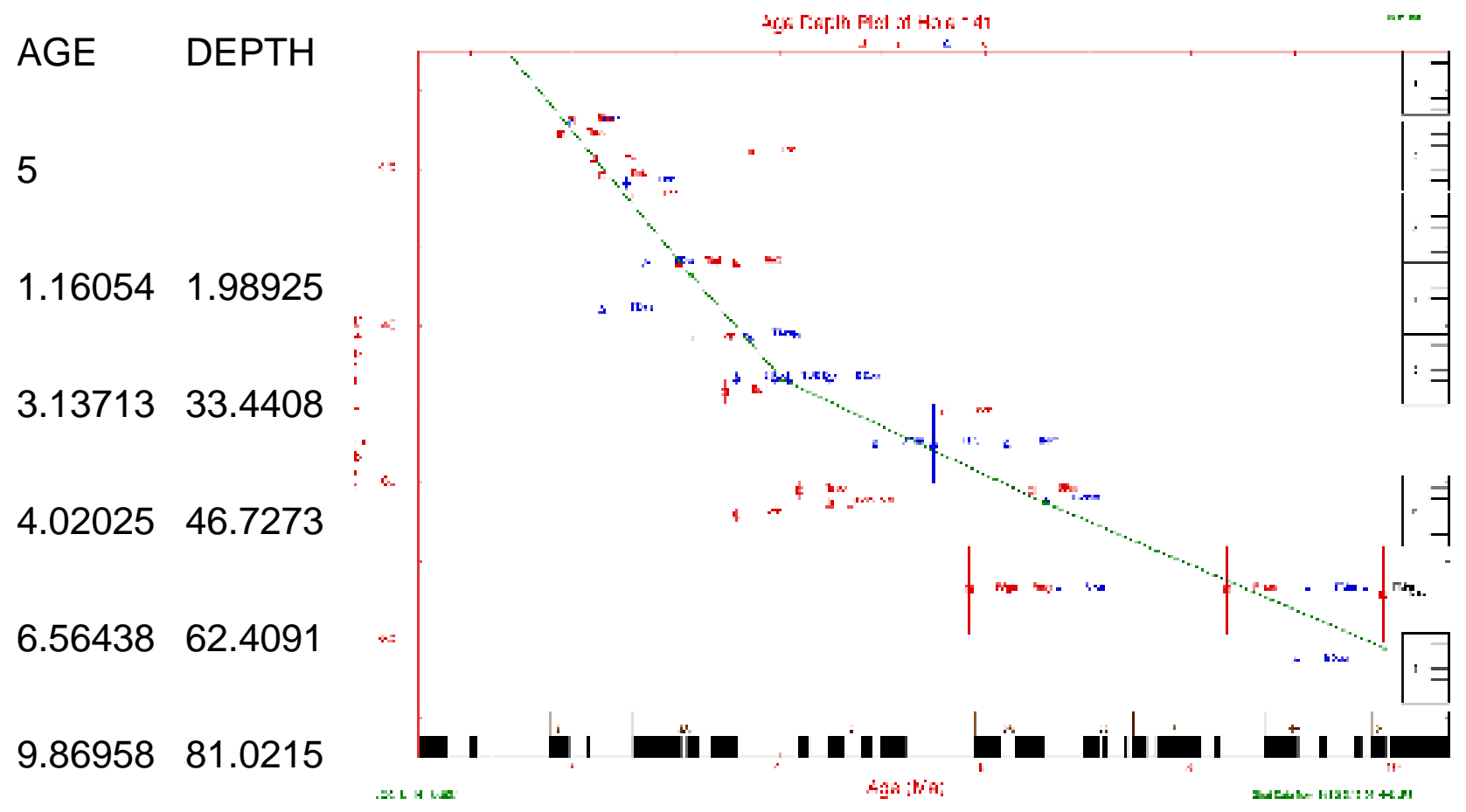

15819952507

AGE DEPTH

6

$0.23538477 \quad 1.55 \mathrm{E}-07$ 


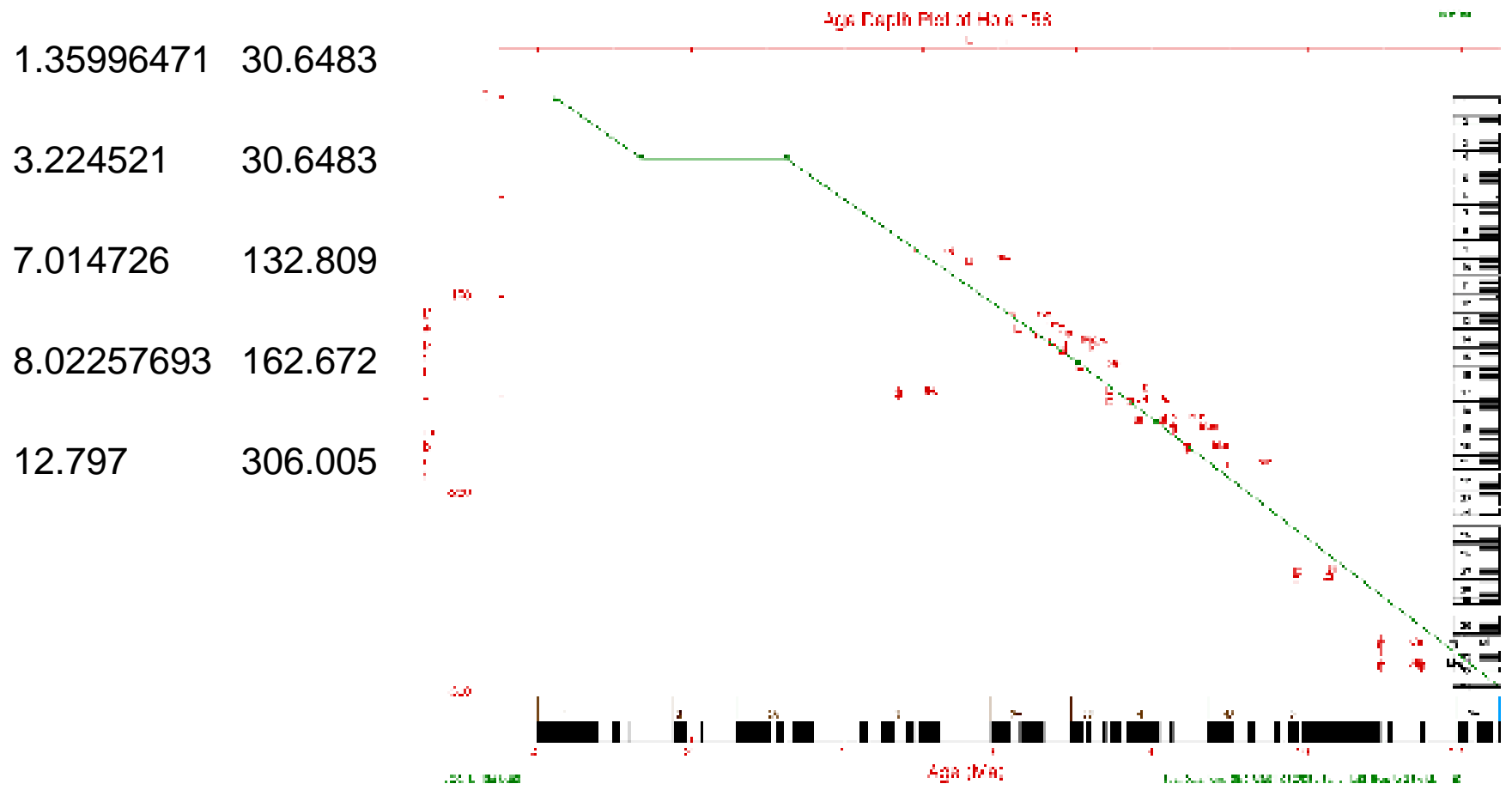

17319950726

AGE DEPTH

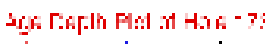

10

.328114 .71513

$2.9078 \quad 122.888 \quad$ 1.0

$4.63826 \quad 122.888$

$4.89237 \quad 135.077$

$8.44733 \quad 135.077$

9.78273180 .814

$12.3588 \quad 180.814$

$13.7132 \quad 276.364$

18.2511276 .364

|

18.5347288 .636

17819952507

AGE

DEPTH

5 


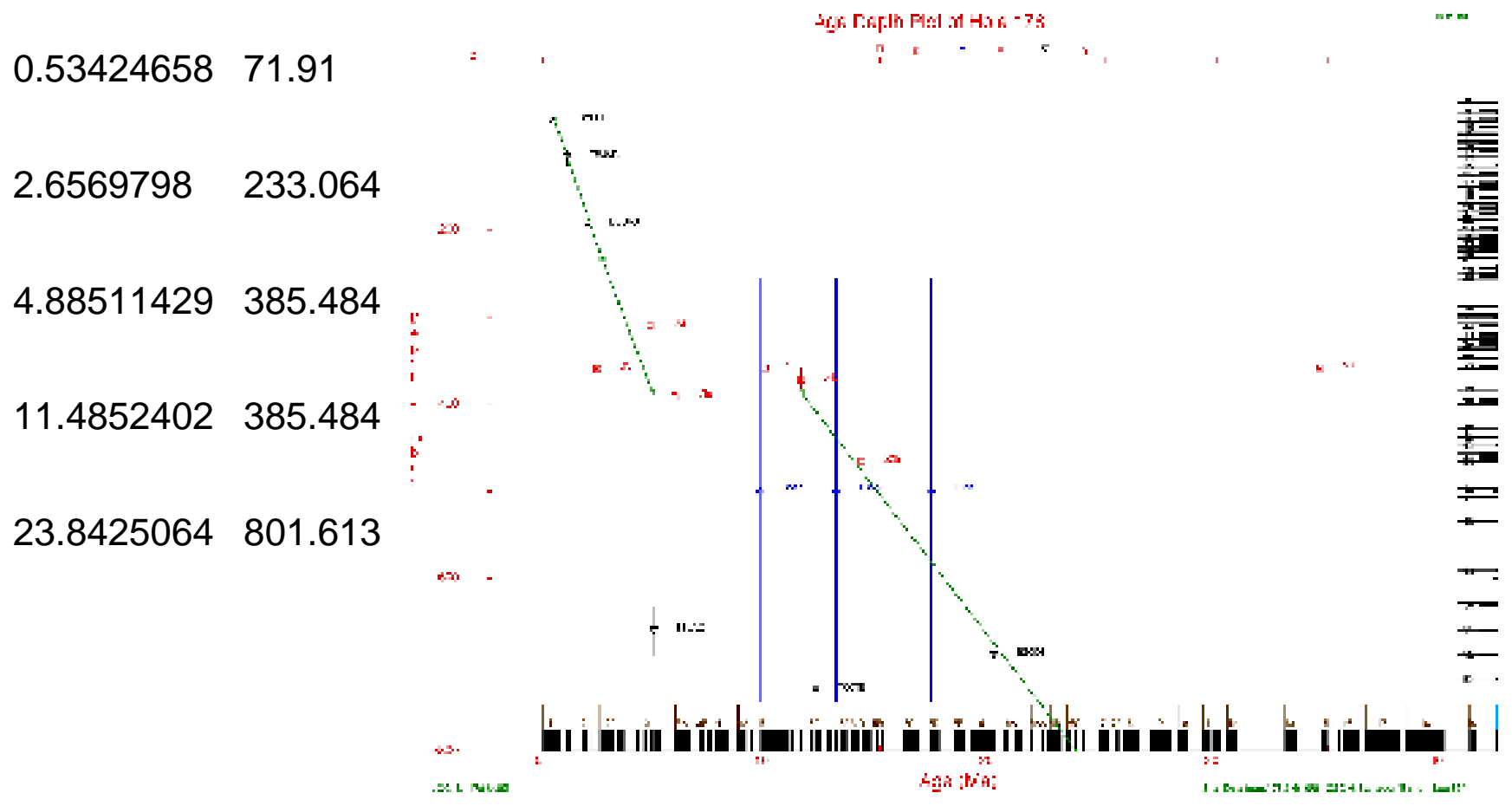

19219960802

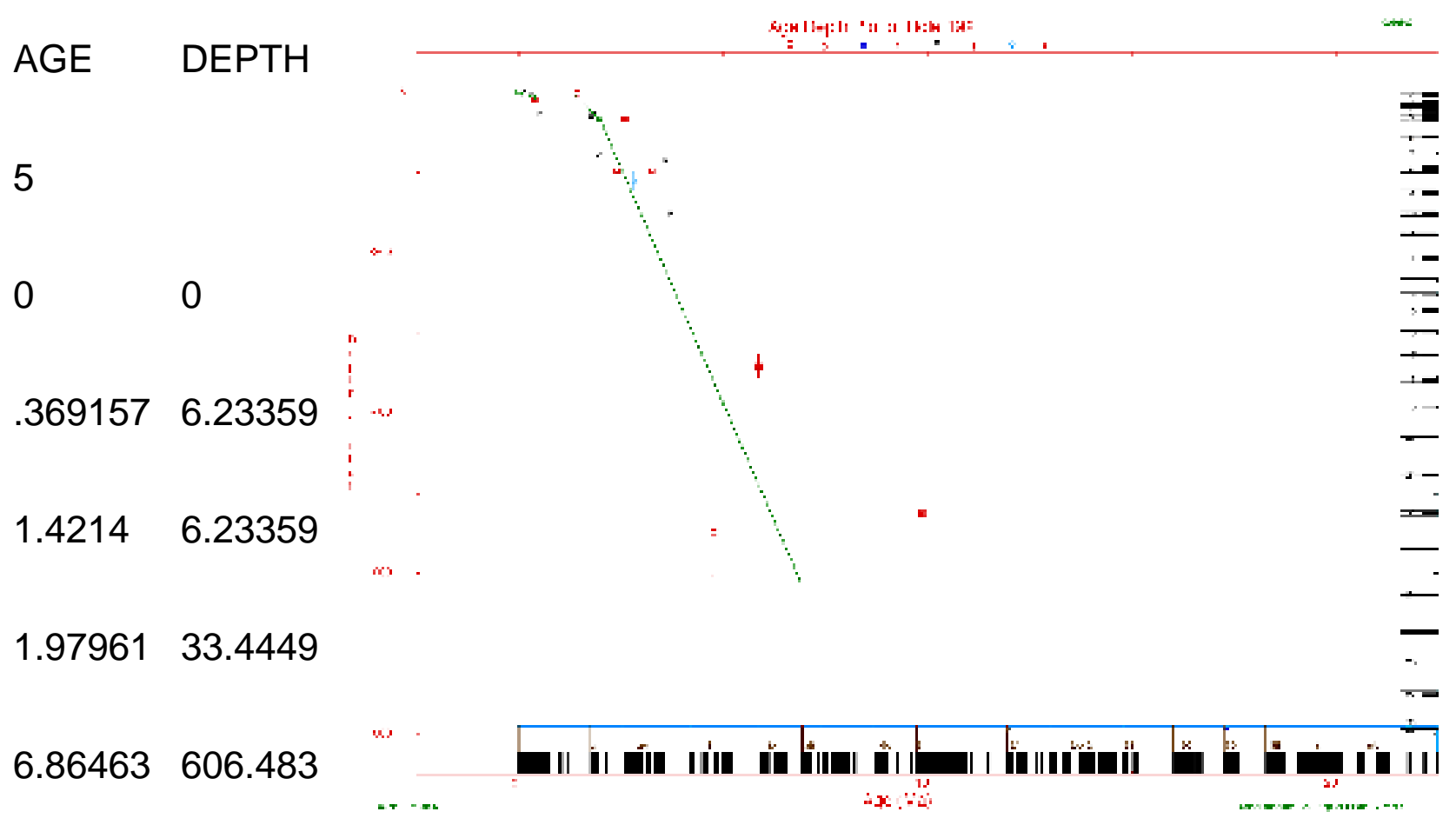


To download full-size diagrams, open the following directory and choose the file (named by hole number). File naming convention is $62 \mathrm{~A}$ _PICT.GIF (62A $=$ hole number).

DIRECTORY: adps app

\section{Holes 213-289}

\section{7}

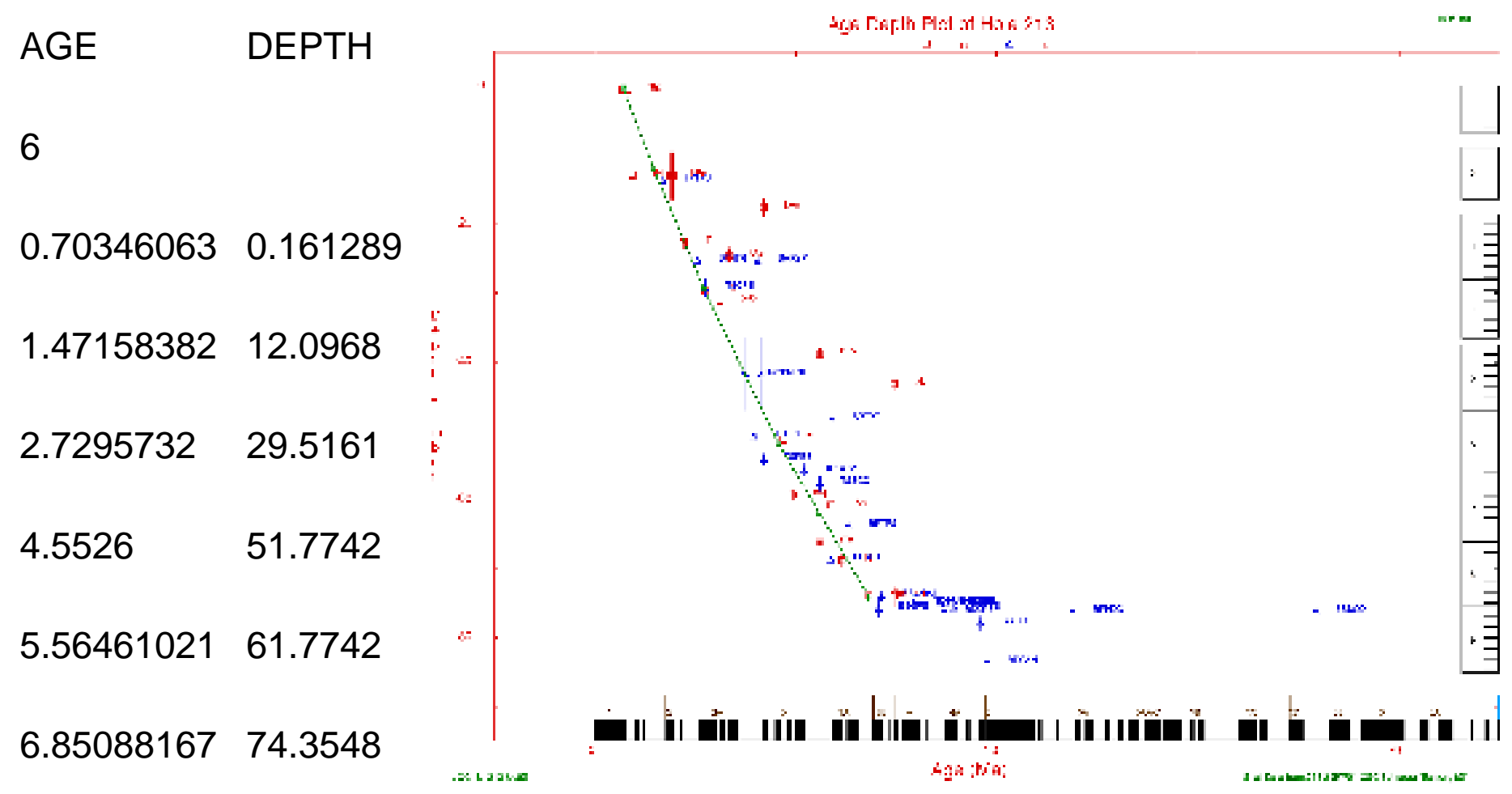

\section{1}

AGE DEPTH

13

24.5483188 .636

$27.5525 \quad 213.553$

$29.9212 \quad 234.848$

$32.2847 \quad 250.909$

$34.333 \quad 260.242$

$35.6408 \quad 271.97$

$40.5515 \quad 271.97$

$43.7868 \quad 282.466$

$55.9191 \quad 310.031$

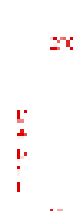

track
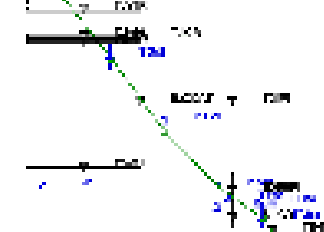

in
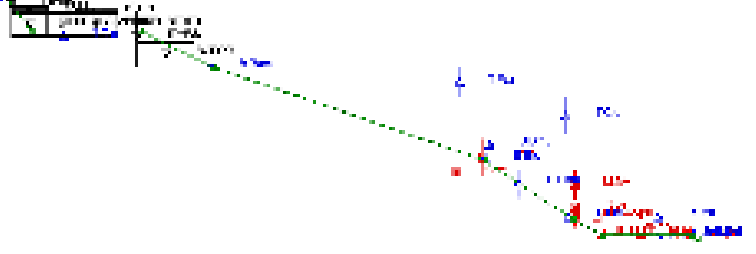

:寻

ग

$5=$

兰

"न

ت

프

II.

n

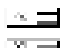

ग्य

$n \exists$
$n \exists$

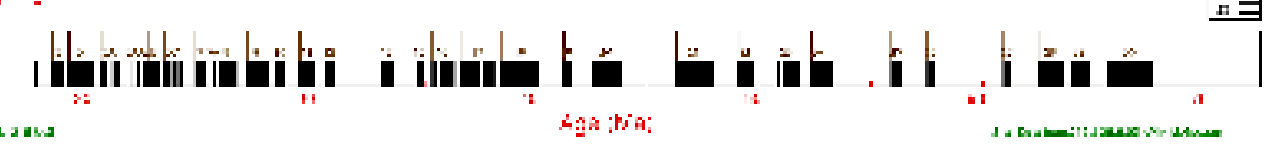


$60.021 \quad 327.642$

$61.292 \quad 331.853$

$65.2206 \quad 331.853$

65.5095333 .002

\section{1}

AGE DEPTH

11

$25.526 \quad 211.591$

$29.9362 \quad 269.924$

32.2742307 .576

$34.2402 \quad 314.47$

43.6982346 .288

$54.8565 \quad 374.394$

58.188402.

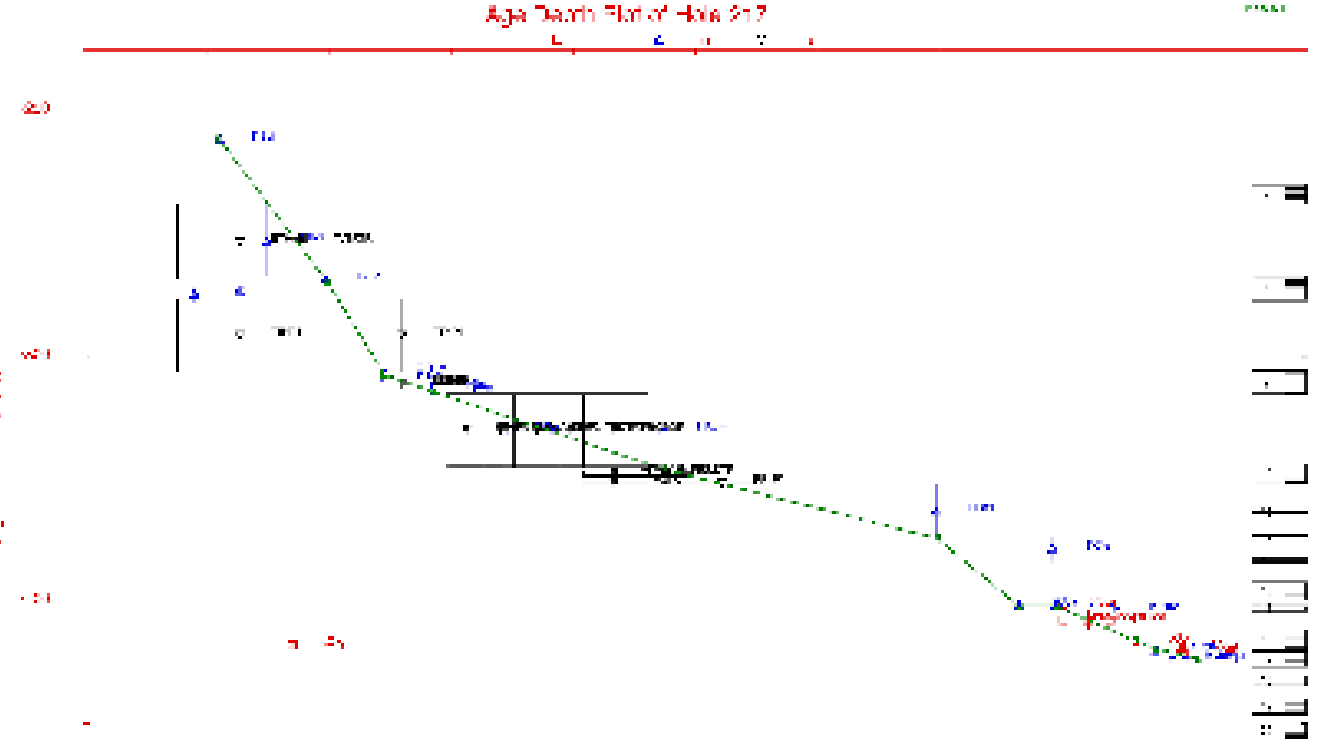

59.7059402.

$62.9674 \quad 416.167$

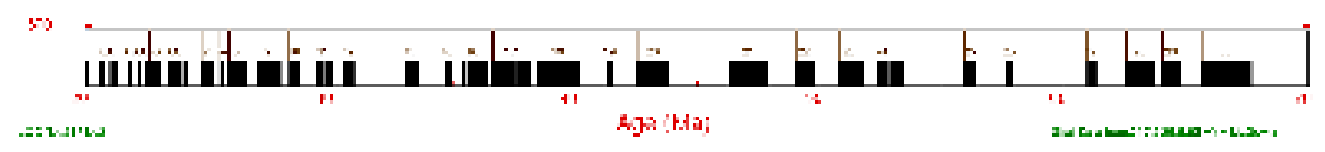

$63.8078 \quad 419.667$

65.5672423 .833

\section{A 19952507}
AGE
DEPTH

3

0

0

$2.7295732 \quad 155.484$ 
3.48132955237 .742

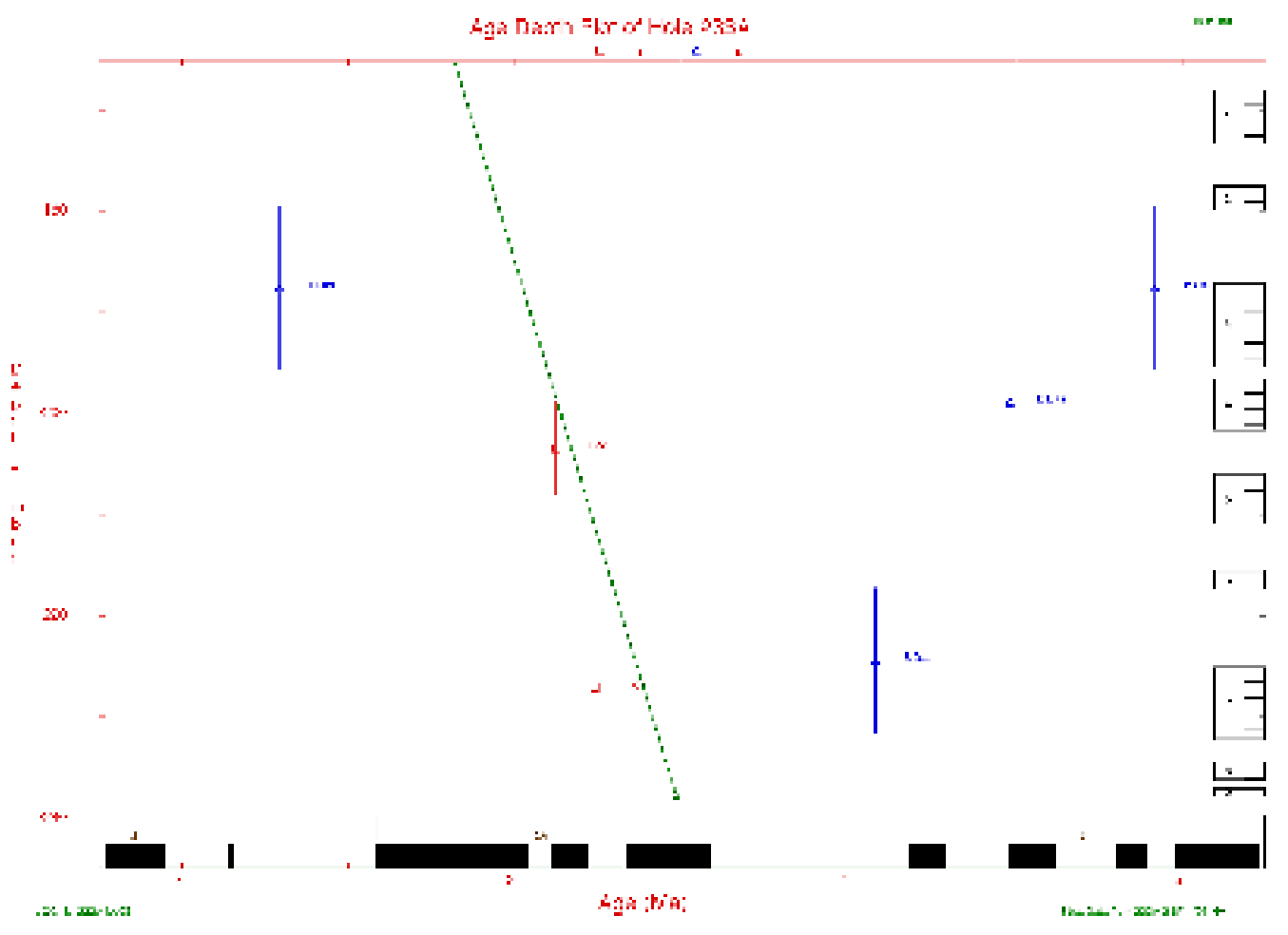

23319952507

AGE

DEPTH

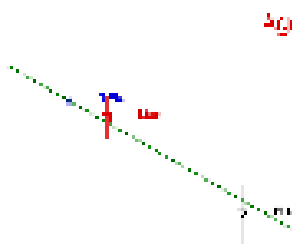

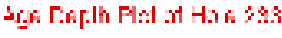

$m+m$
4

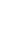

0.28043244

0.134415

1.7078647152 .957

$2.7386512 \quad 155.78$

3.05683

188.038

\section{7}

AGE

DEPTH

12

$0.50646575 \quad 1.75$

1.8822218212 .6344 
$2.32763746 \quad 22.9839$

$3.7561625 \quad 28.629$

$4.894581 \quad 43.6828$

$6.058079 \quad 88.8441$

$7.2096275 \quad 117.07$

$8.70997 \quad 134.005$

$9.85409067 \quad 140.591$

17.1451336163 .172

$23.6537636 \quad 182.93$

24.6236353194 .22

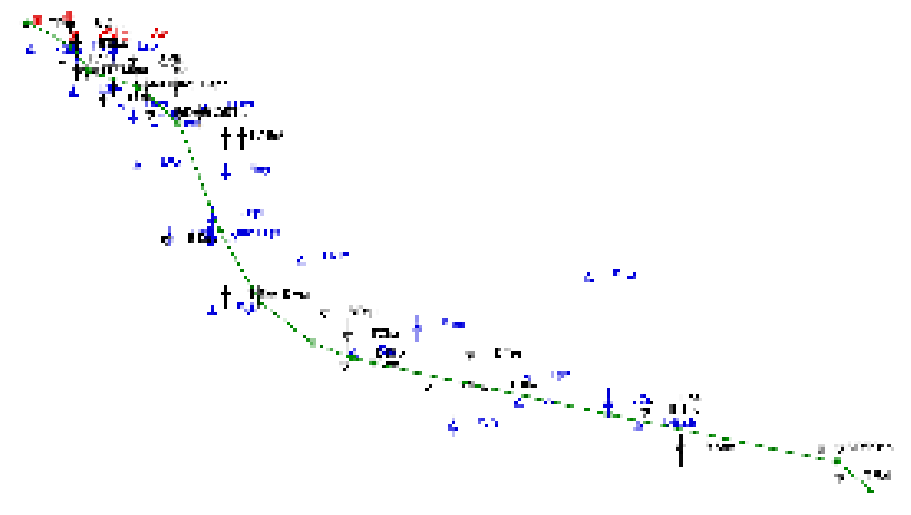

|

\section{5}

AGE DEPTH

15

$9.08219 \mathrm{e}-2.6$

$.503739 \quad 27.5581$

$1.6675 \quad 27.5581$

$1.9704 \quad 64.7674$

$2.92014 \quad 64.7674$

$4.30004 \quad 103.629$

$5.53405 \quad 139.113$

$7.83913 \quad 217.976$

$9.03281 \quad 250.982$

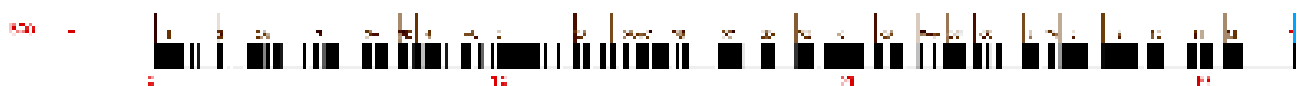

$10.4839 \quad 294.99$

$13.4466 \quad 294.99$

$14.9224 \quad 344.624$

$18.8235 \quad 393.333$

$23.7132 \quad 393.333$ 
$24.9632 \quad 420.833$

\section{5}

AGE DEPTH

10

.5064661

3.3357511 .7742

5.3328322 .0039

$6.20518 \quad 34.1847$

8.9863544 .1667

$11.7006 \quad 66.0118$

$14.0429 \quad 66.0118$

15.019875 .6385

$22.303 \quad 75.6385$
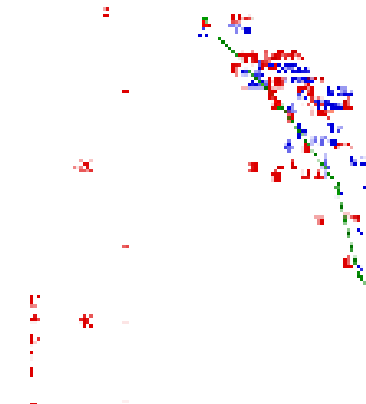

23.732587 .6228

26519952507

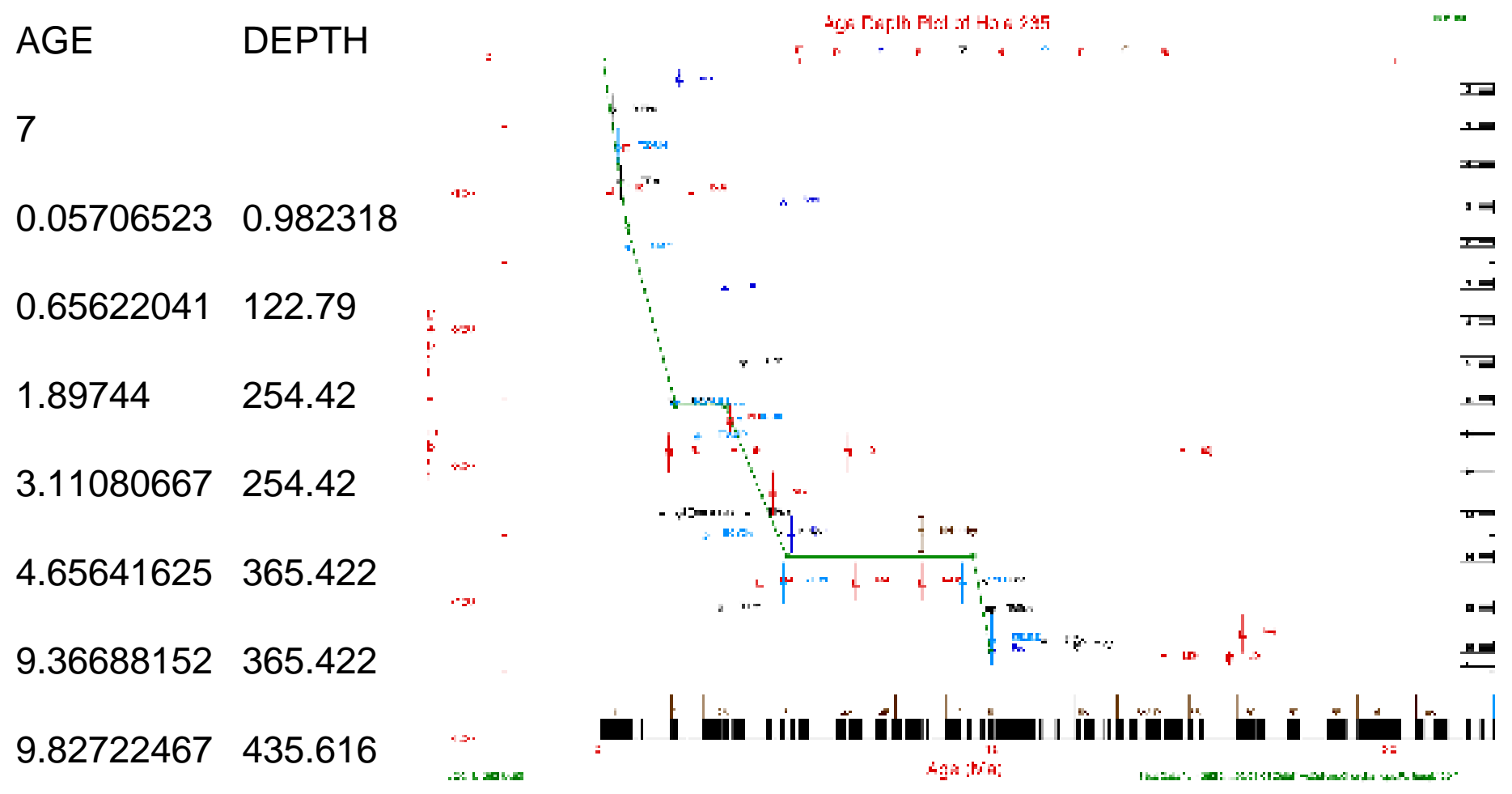

26619952407 
AGE DEPTH

7

0.17119184 1.55E-07

$4.671435 \quad 146.169$

$12.0819954 \quad 146.169$

$12.7419467 \quad 184.274$

$15.182488 \quad 184.274$

17.4549109290 .766

$20.6570596 \quad 368.566$

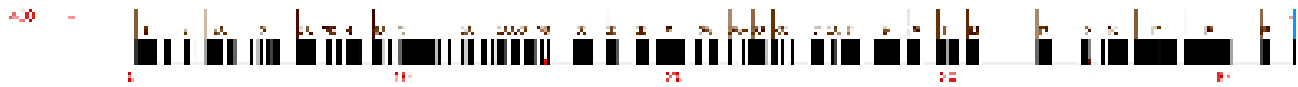
$\therefore$ ance
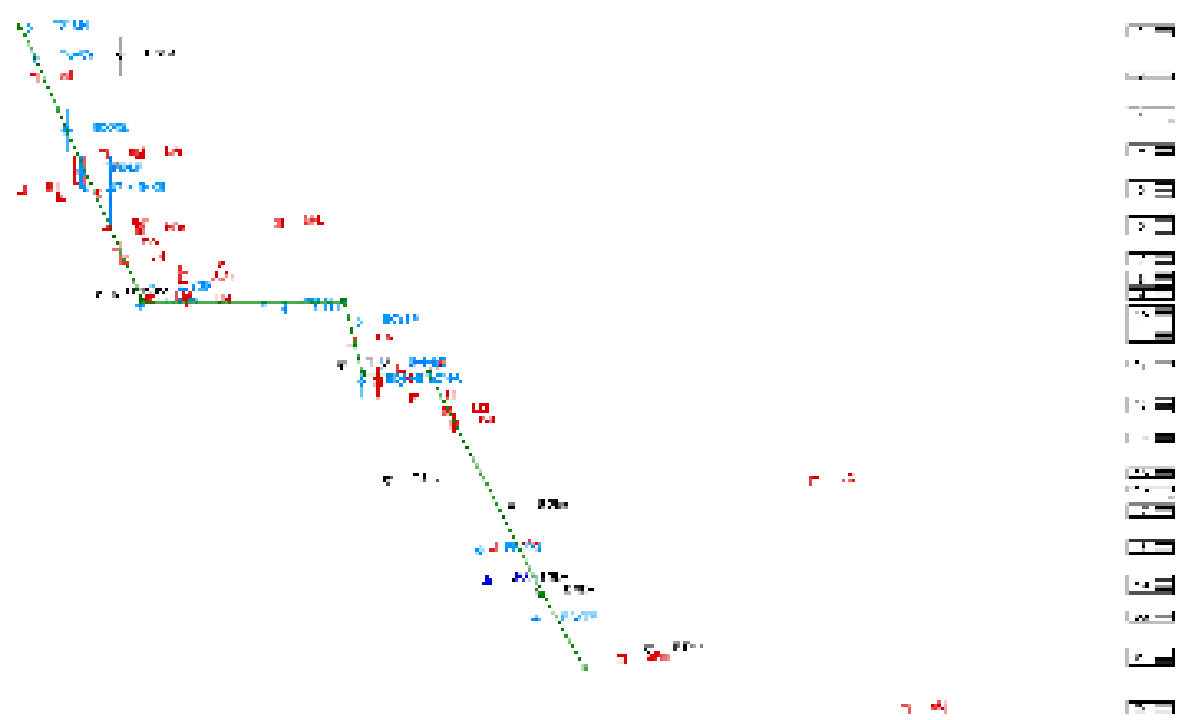

267B 19952507

AGE DEPTH

5

$1.57300147 \quad 100$

$\begin{array}{ll}2.7307564 & 150.098 \\ 8.15160371 & 150.098\end{array}$

$\begin{array}{ll}2.7307564 & 150.098 \\ 8.15160371 & 150.098\end{array}$

12.3394888216 .935

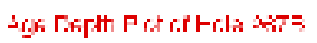
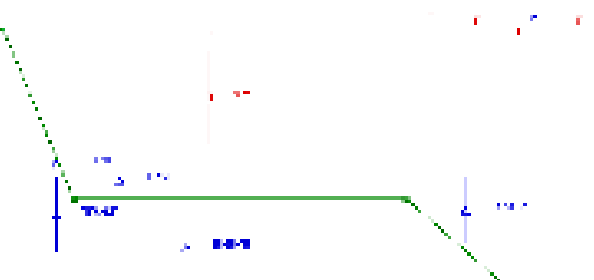

$1: 20$

i.

$14.160065 \quad 290.963$

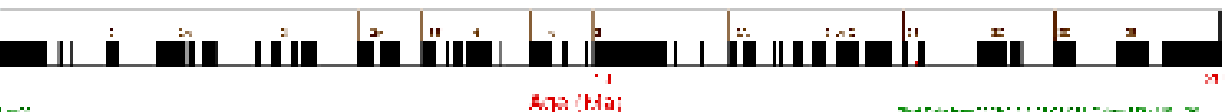

27819960813

AGE DEPTH

11

$9.08219 \mathrm{e}-2 \quad .755$ 


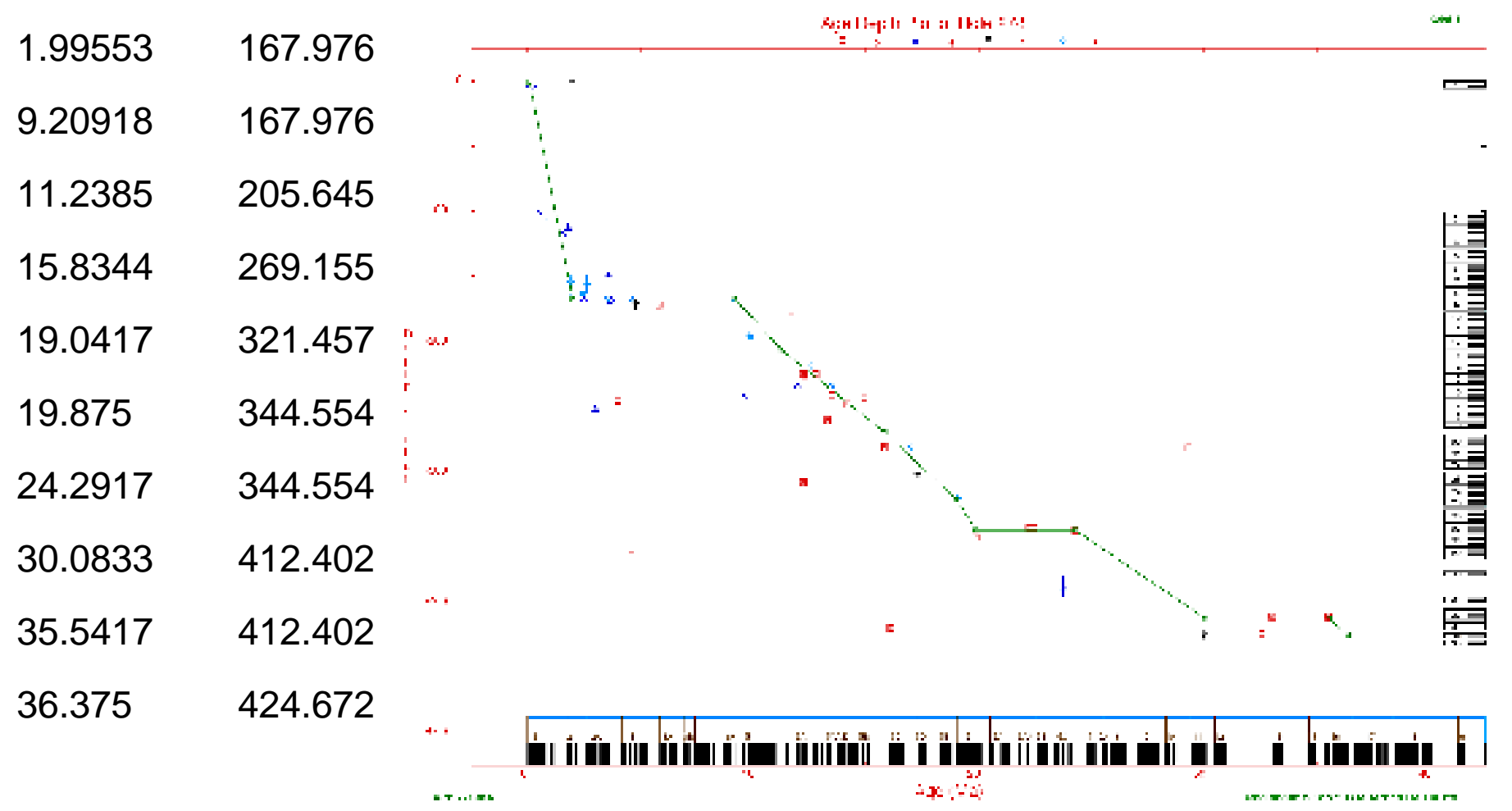

\section{5}

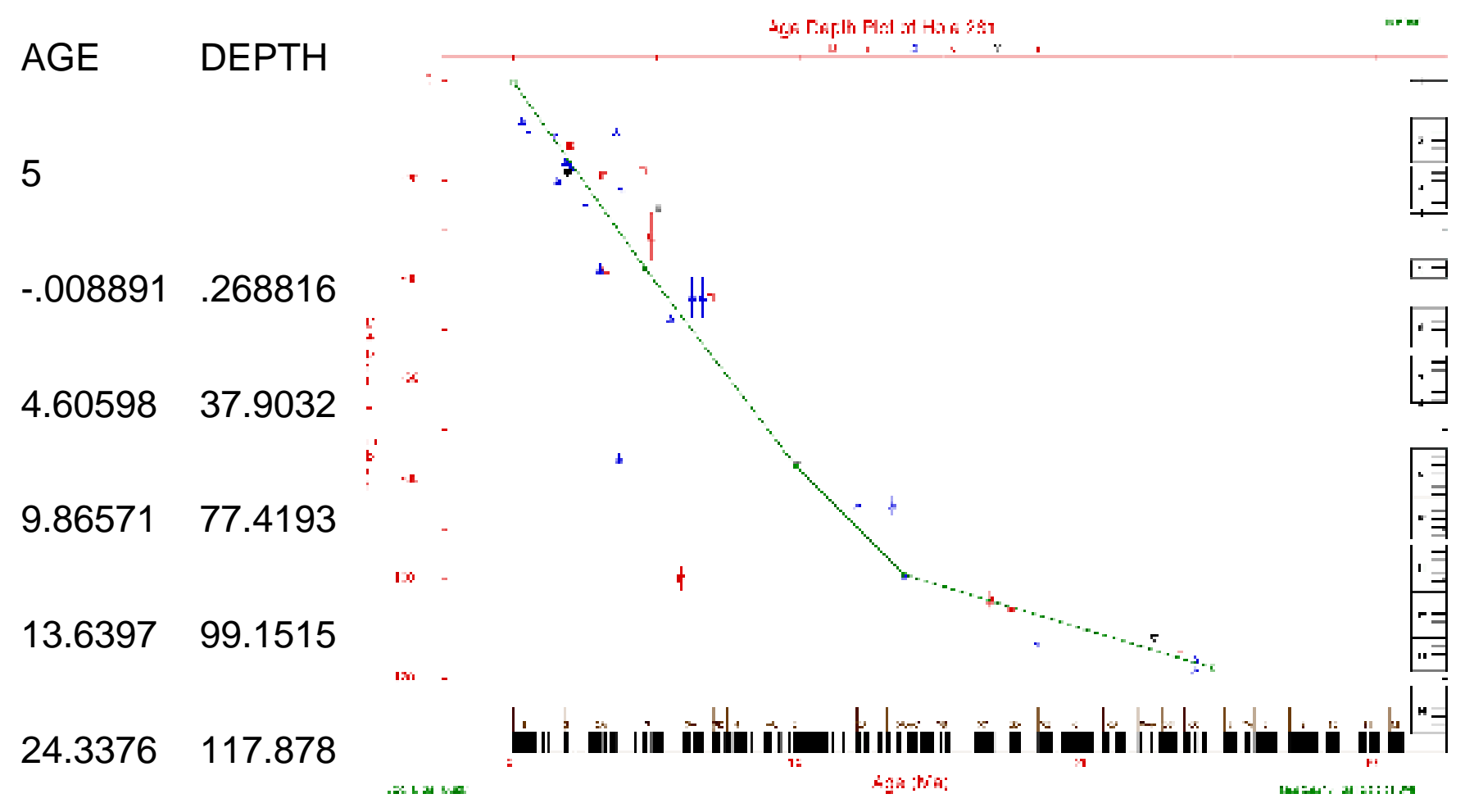

\section{5}

AGE DEPTH

22

$.98226 \quad 1.51514$ 
$5.17537 \quad 138.507$

$7.09866 \quad 221.212$

8.32915275 .049

9.42646305 .501

$9.7598 \quad 335.953$

$9.87195 \quad 335.953$

$11.8377 \quad 362.475$

$12.3424 \quad 401.515$

$13.855 \quad 401.515$

$14.9395 \quad 476.621$

18.2511545 .454

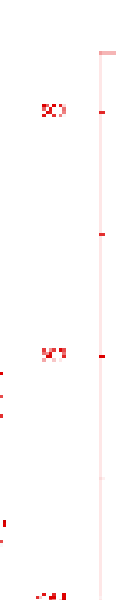

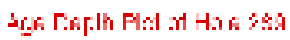

$22.1728 \quad 666.208$

$24.2542 \quad 742.424$

27.5425795

$27.5806 \quad 798.333$

$28.839 \quad 819.167$

31.0016940.

34.1936968 .333

$37.314 \quad 1014.17$

$40.3587 \quad 1035.83$

$59.6 \quad 1126.3$

Next Section... 
To download full-size diagrams, open the following directory and choose the file (named by hole number). File naming convention is $62 \mathrm{~A}$ _PICT.GIF (62A = hole number).

DIRECTORY: adps app

\section{Holes 317-398D}

317B 19952407

AGE DEPTH

11

0.085597840 .589391

1.8209727310 .0196

$3.78595 \quad 25.3438$

$4.940436 \quad 56.5815$

$7.88500493 \quad 87.2298$

9.74485053113 .752

11.8377352131 .434

$12.8819848 \quad 147.348$

16.7658775173 .87

19.0025073195 .678

$23.72128 \quad 237.397$

35419950709

AGE DEPTH

16

-7.35239e-3 .378792

$2.20589 \quad 94.3182$

$3.08351 \quad 142.424$

$5.59244 \quad 142.424$

6.60294239 . 


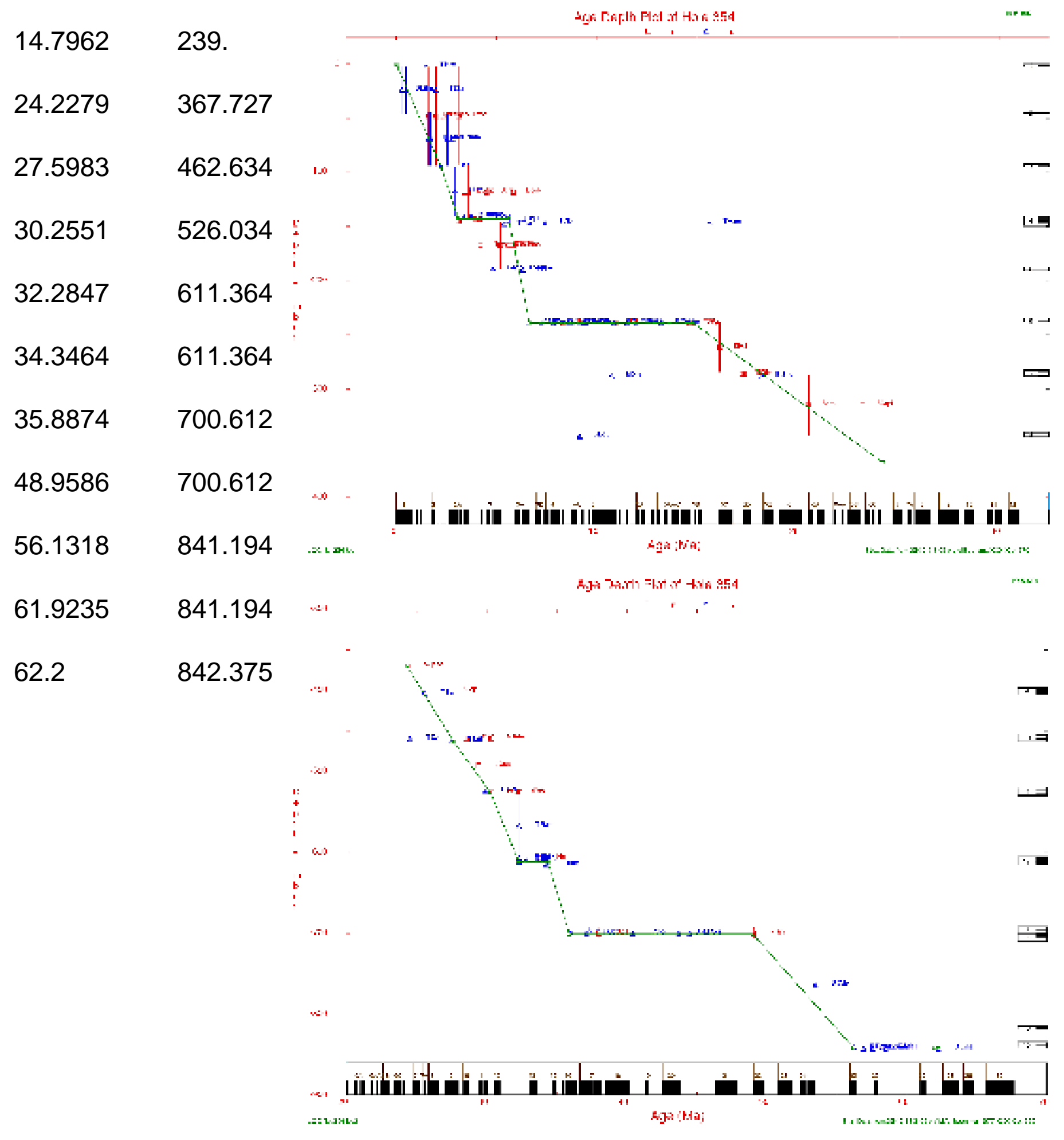

35619950807

AGE DEPTH

13

7.79154e-3 .159091

$4.84164 \quad 17.9848$

$23.6765 \quad 39.9697$ 


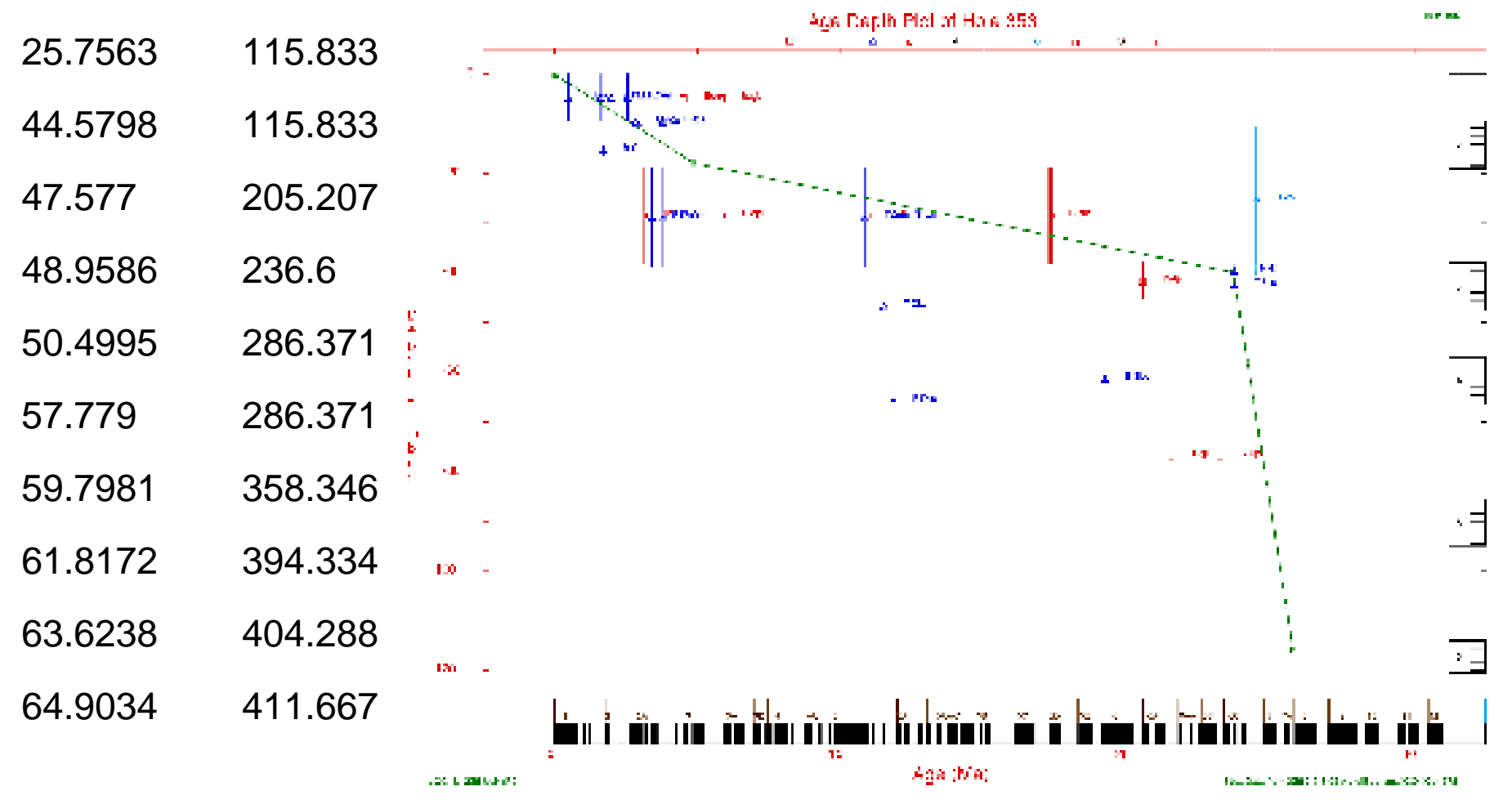

\section{5}

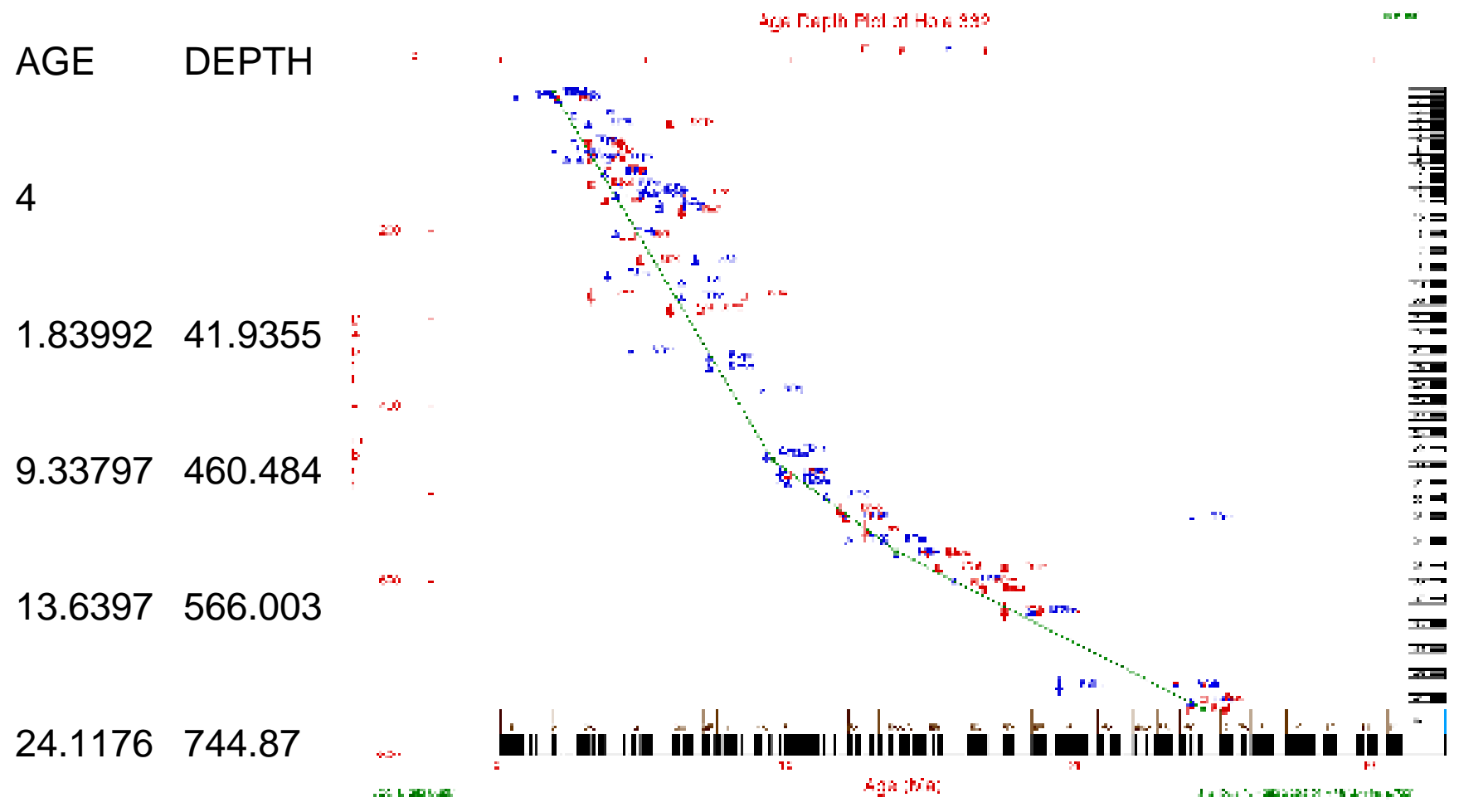

36319950710

AGE DEPTH

15

$24.5165 \quad 36.7534$

$27.4389 \quad 72.2818$ 
31.6544129 .25

$34.187 \quad 185.605$

35.9405203 .982

37.2157203 .982

$40.3507 \quad 221.746$

$43.6982 \quad 221.746$

$47.3109 \quad 234.609$

$50.6057 \quad 259.724$

$53.5504 \quad 280.551$

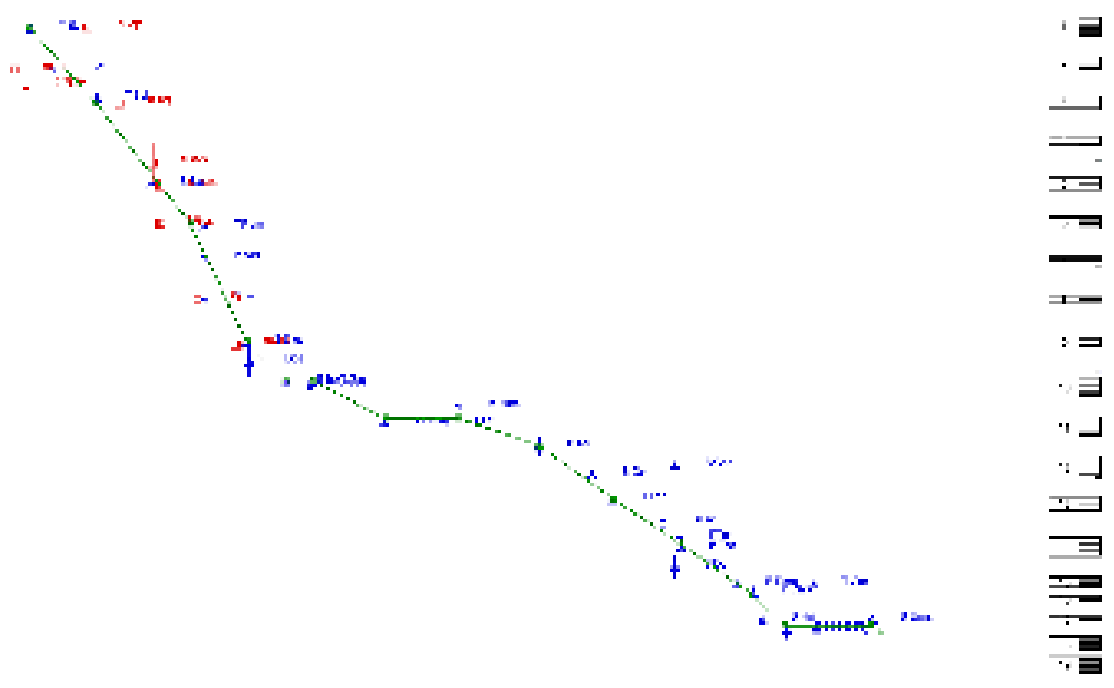

56.9288305 .666

58.3634320 .367

| $\therefore$ sous

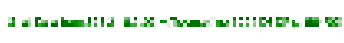

$62.1892 \quad 320.367$

$62.6142 \quad 322.818$

366A 19950710

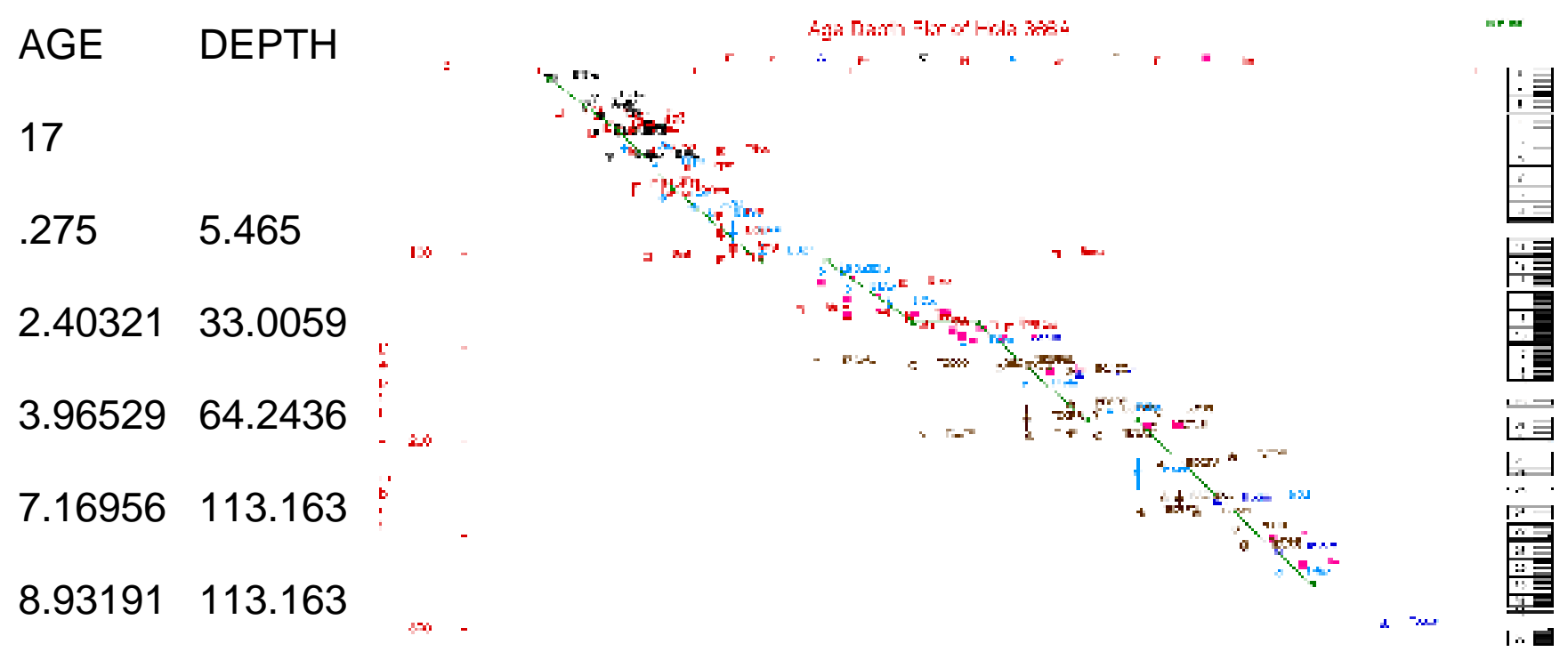

$10.8545 \quad 131.434$

$11.7757 \quad 131.434$

$12.8571 \quad 138.507$

|

$13.9386 \quad 146.758$ 
$14.8598 \quad 146.758$

$16.4219 \quad 164.44$

$18.2243 \quad 188.016$

19.4259188 .016

$21.9493 \quad 240.471$

$23.7815 \quad 268.864$

$28.1775 \quad 298.864$

$34.6061 \quad 362.273$

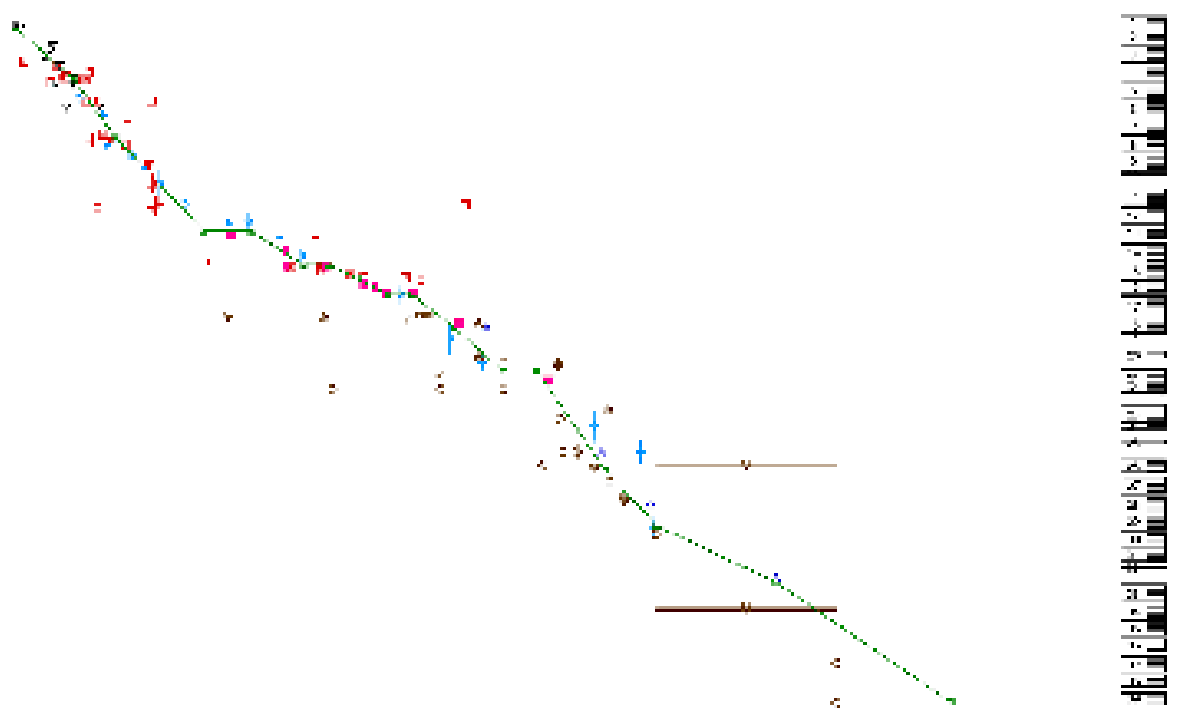

\section{|}

36619950710

AGE DEPTH

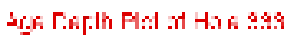

6

$31.917 \quad 360.643$

$37.3529 \quad 434.763$

$44.916 \quad 540.122$

$50.0683 \quad 589.127$

$51.25 \quad 598.928$

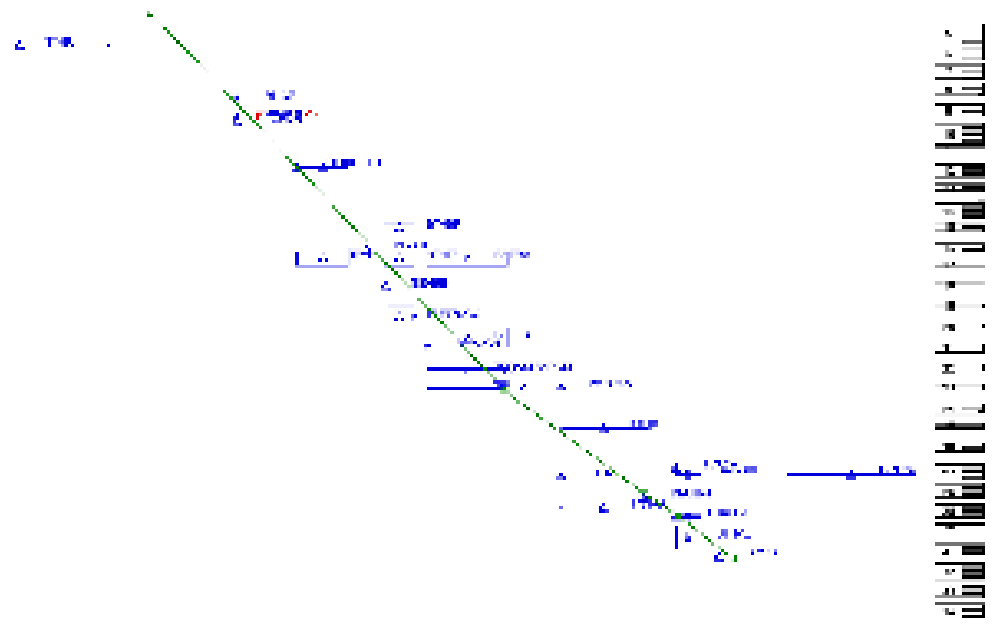

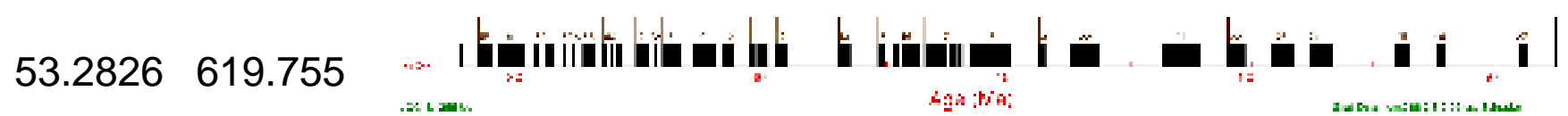

369A 19952407

AGE DEPTH

12

14.391131753 .0452

$14.7848705 \quad 104.126$ 
$15.6713946 \quad 133.595$

16.3542753143 .811

19.1687053143 .811

$21.0895673 \quad 158.35$

23.8

$26.9853 \quad 208.333$

$29.1597 \quad 283.712$

$33.0042 \quad 307.576$

$33.6345 \quad 331.439$

$40.2206 \quad 341.288$

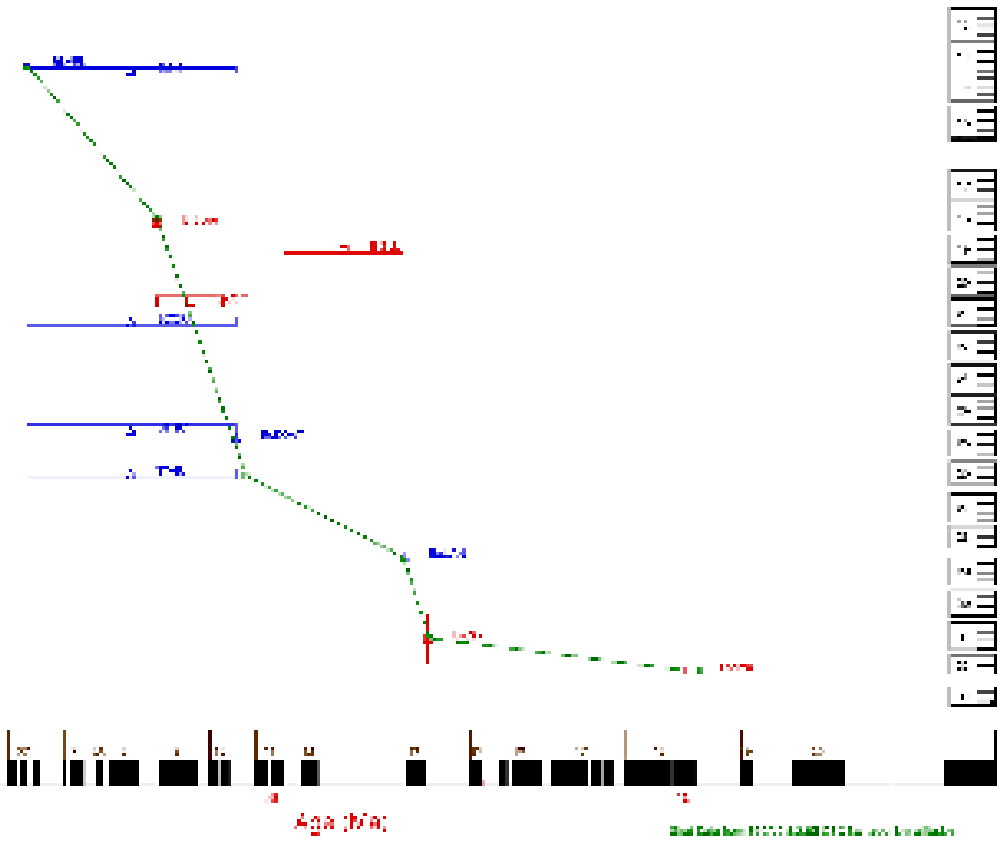

38619950710

AGE DEPTH

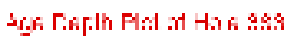

12

$29.8831 \quad 165.237$

$32.4336 \quad 238.744$

34.2402292 .956

$37.0563 \quad 315.926$

$43.0606 \quad 334.303$

44.5484346 .248

$47.3114 \quad 479.479$

50.6589529 .096

$53.475 \quad 579.632$

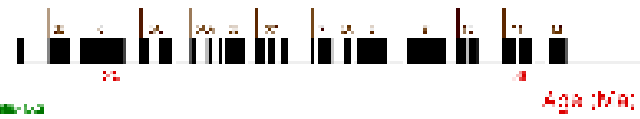

$56.1318 \quad 623.737$

$57.1945 \quad 623.737$

$61.2327 \quad 632.006$

\section{D 19950710}




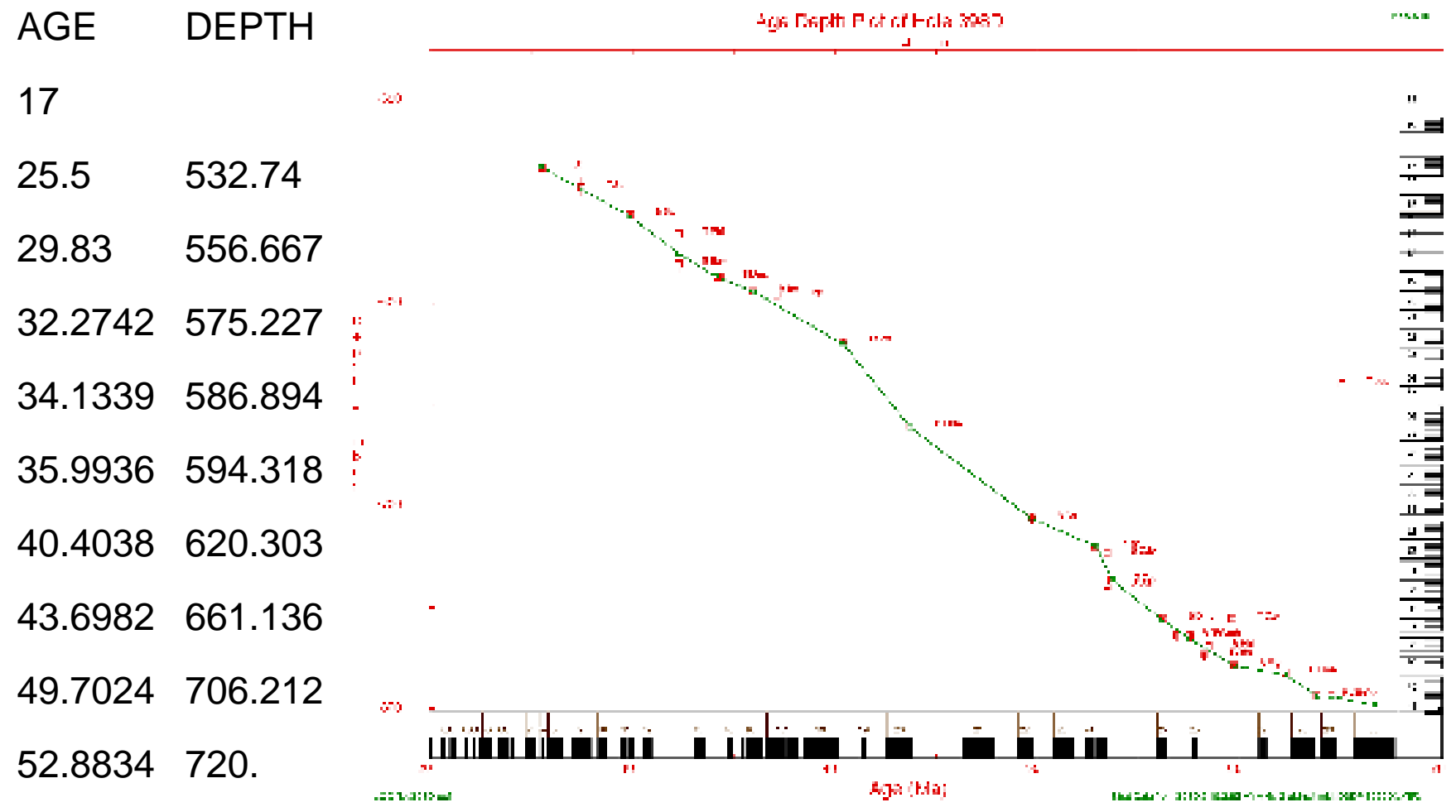

$53.645 \quad 736.667$

56.1318756 .061

$57.5053 \quad 765.667$

$59.6918 \quad 778.864$

62.1534783.

63.8363793 .712

64.4643793 .712

66.5994798 .485

Next Section... 
To download full-size diagrams, open the following directory and choose the file (named by hole number). File naming convention is $62 \mathrm{~A}$ _PICT.GIF (62A $=$ hole number).

DIRECTORY: adps app

\section{Holes 406-499}

\section{1}
AGE
DEPTH

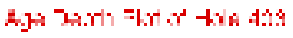

6

29.1498608 .636

$31.9554 \quad 672.273$

34.2827672 .273

$36.865 \quad 763.182$

$42.2848 \quad 763.182$

43.7

807.855

\section{8}
AGE
DEPTH

6

$1.57353 \quad 25.6667$

$3.28374 \quad 163.553$

11.9235163 .553

$12.9674 \quad 174.5$

$17.407 \quad 174.5$

$24.4846 \quad 326.493$
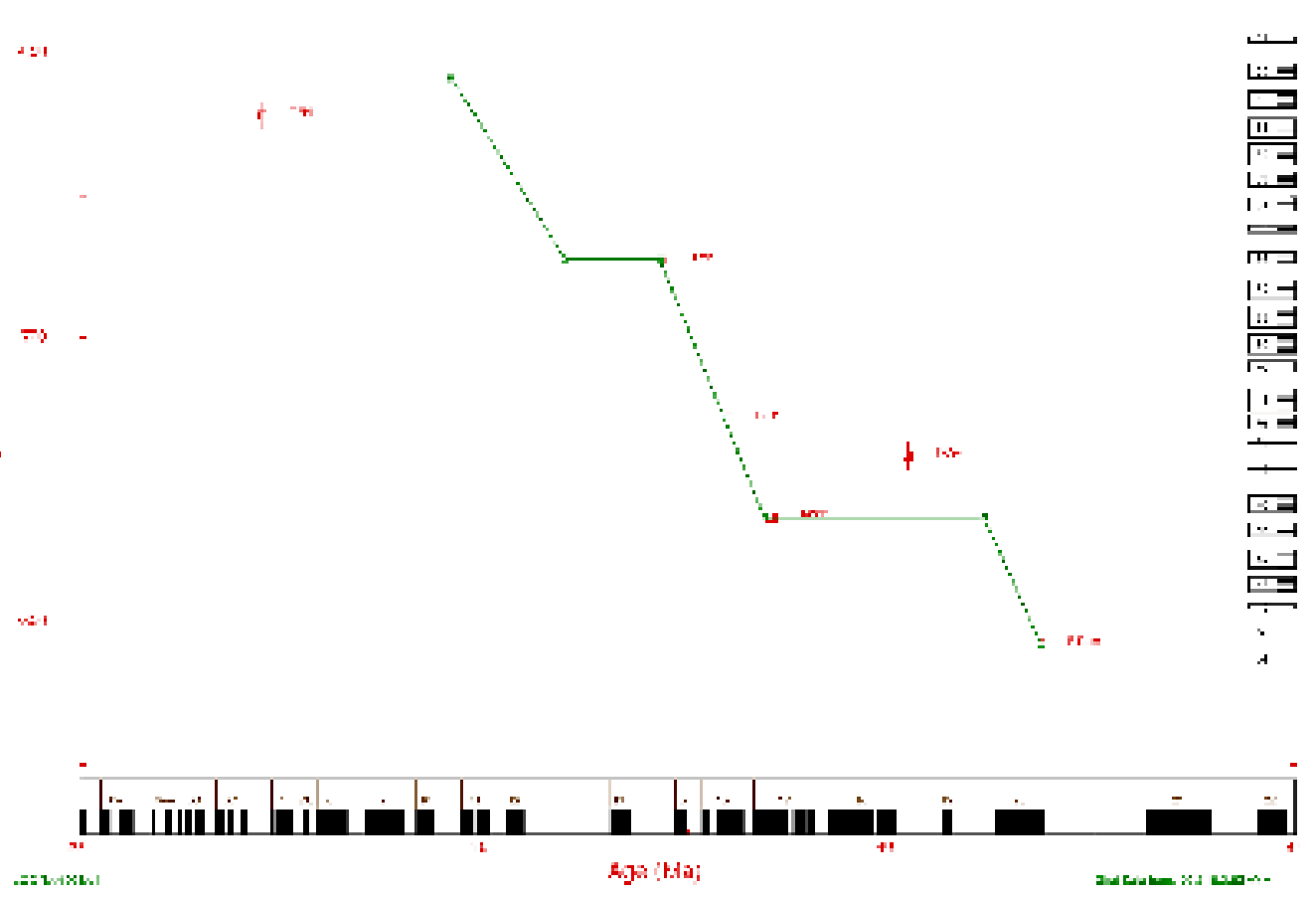


\section{5}

AGE DEPTH

9

$1.33936 \quad$ 785855

$1.66921 \quad 39.2927$

3.0839639 .2927

4.45873179 .961

9.45239179 .961

12.4265255 .436

$15.3676 \quad 316.692$

23.8014316 .692

$24.2046 \quad 335.56$

$\therefore$ ationse

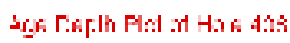

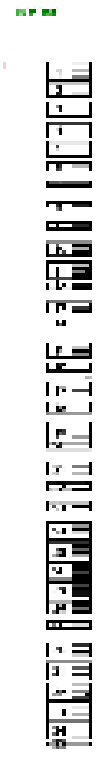

|

\section{8}

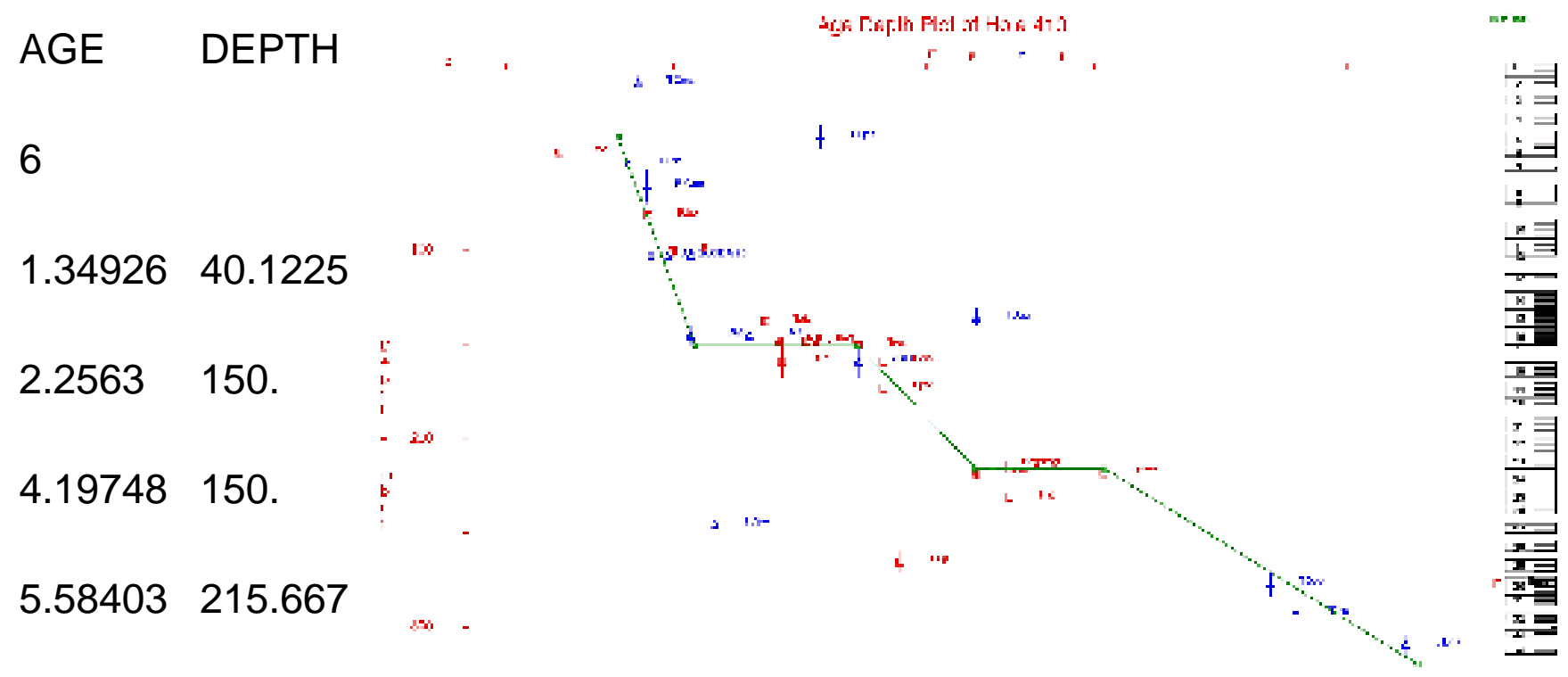

$7.1334 \quad 215.667$

$10.8477 \quad 319.755$

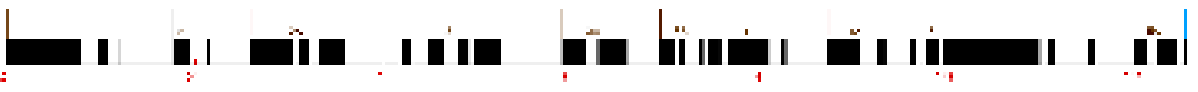
$x+2456$

Lin : $; i$ a:

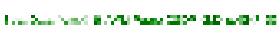

433A 19952507

AGE DEPTH 


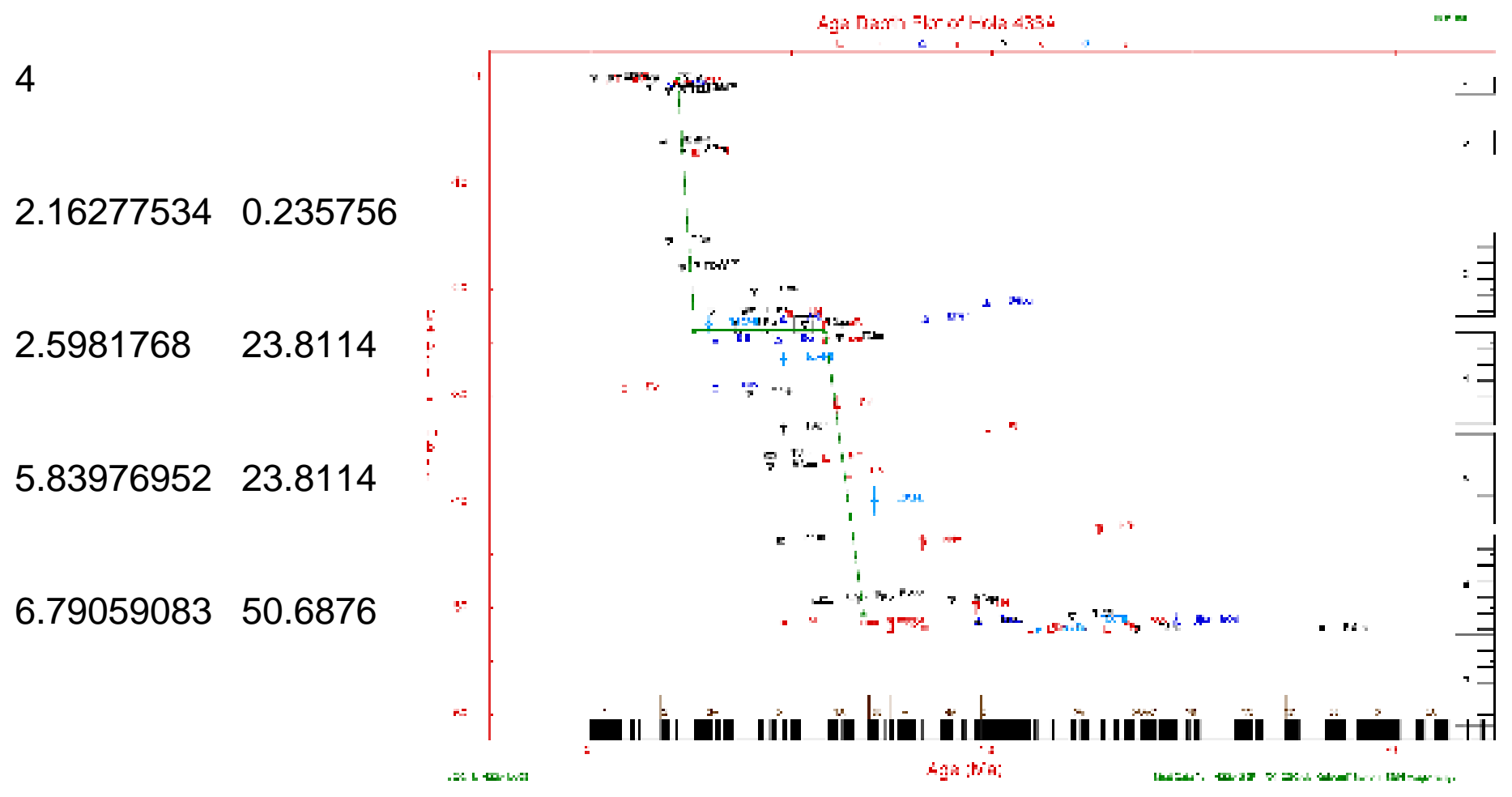

43619952507

AGE DEPTH

11

2.86E-06 $\quad 0.785854$

0.5135637533 .0059

1.7379235388 .0157

$2.11830588 \quad 110.685$

$2.9214148 \quad 158.743$

4.77656625191 .748

$5.79136621 \quad 247.544$

$7.15975577 \quad 247.544$

8.34119649310 .413

$12.1370338 \quad 310.413$

13.2941932346 .562

438A 19952507

AGE DEPTH

14 


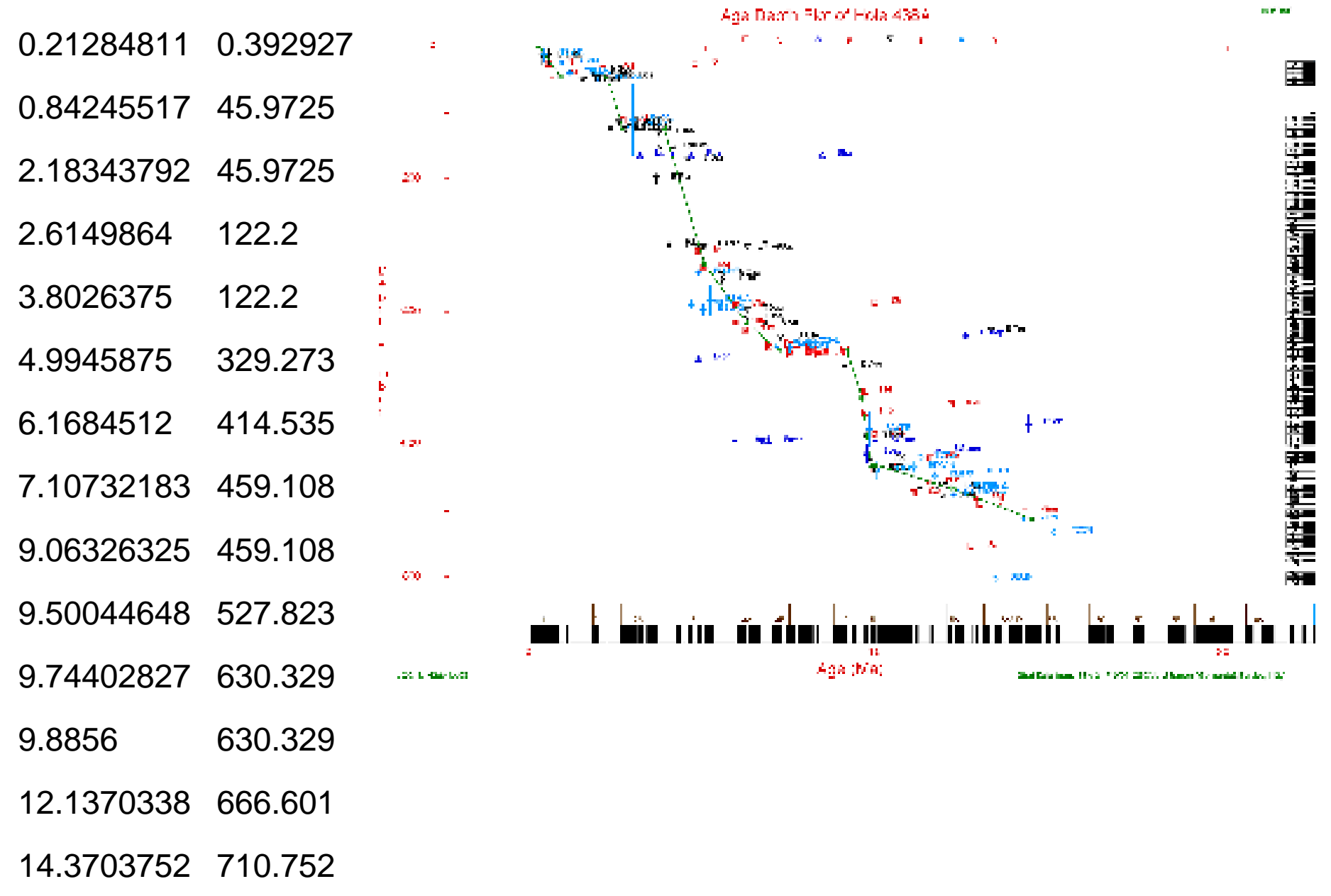

440B 19952507

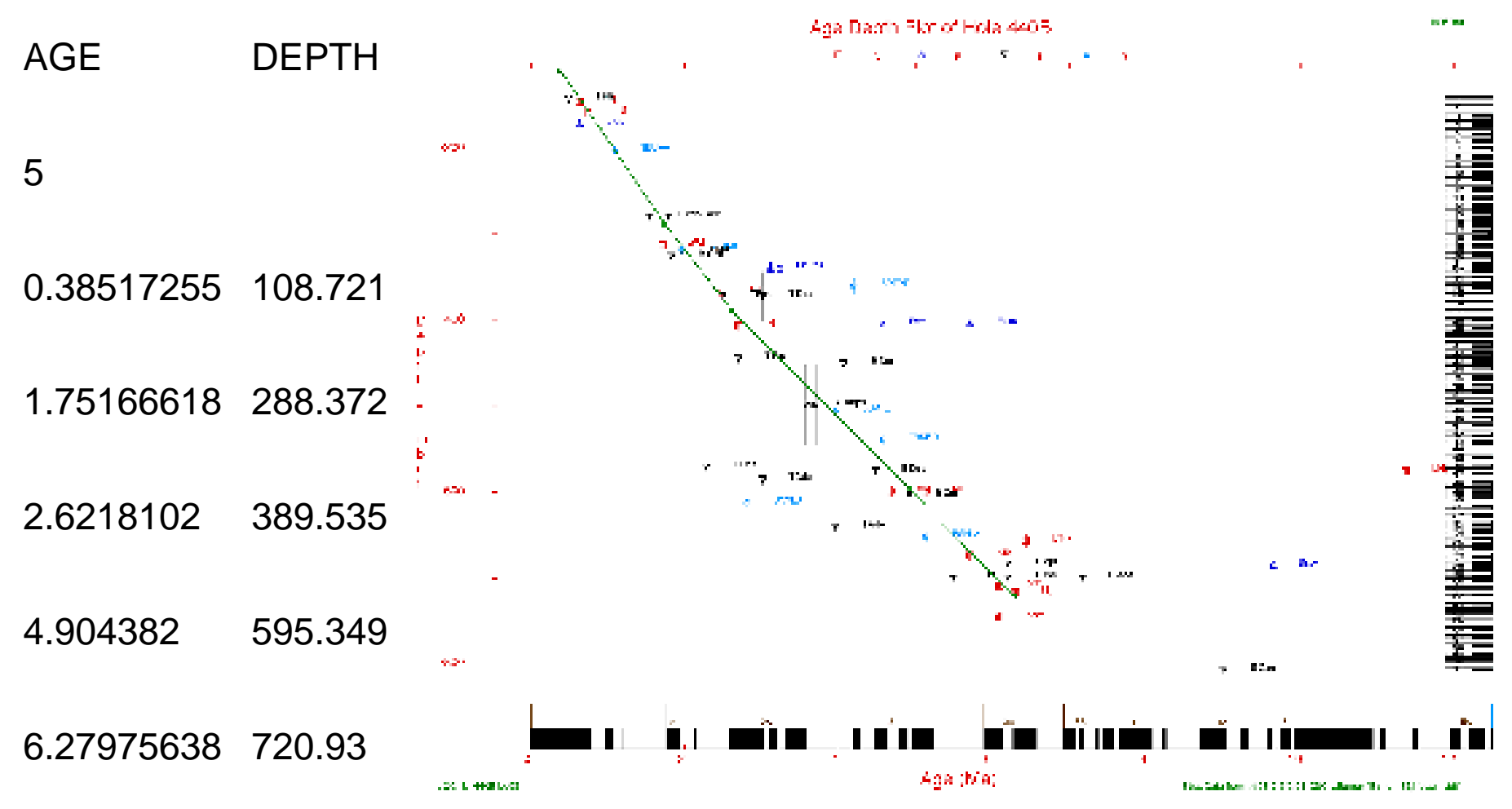

44519950808 


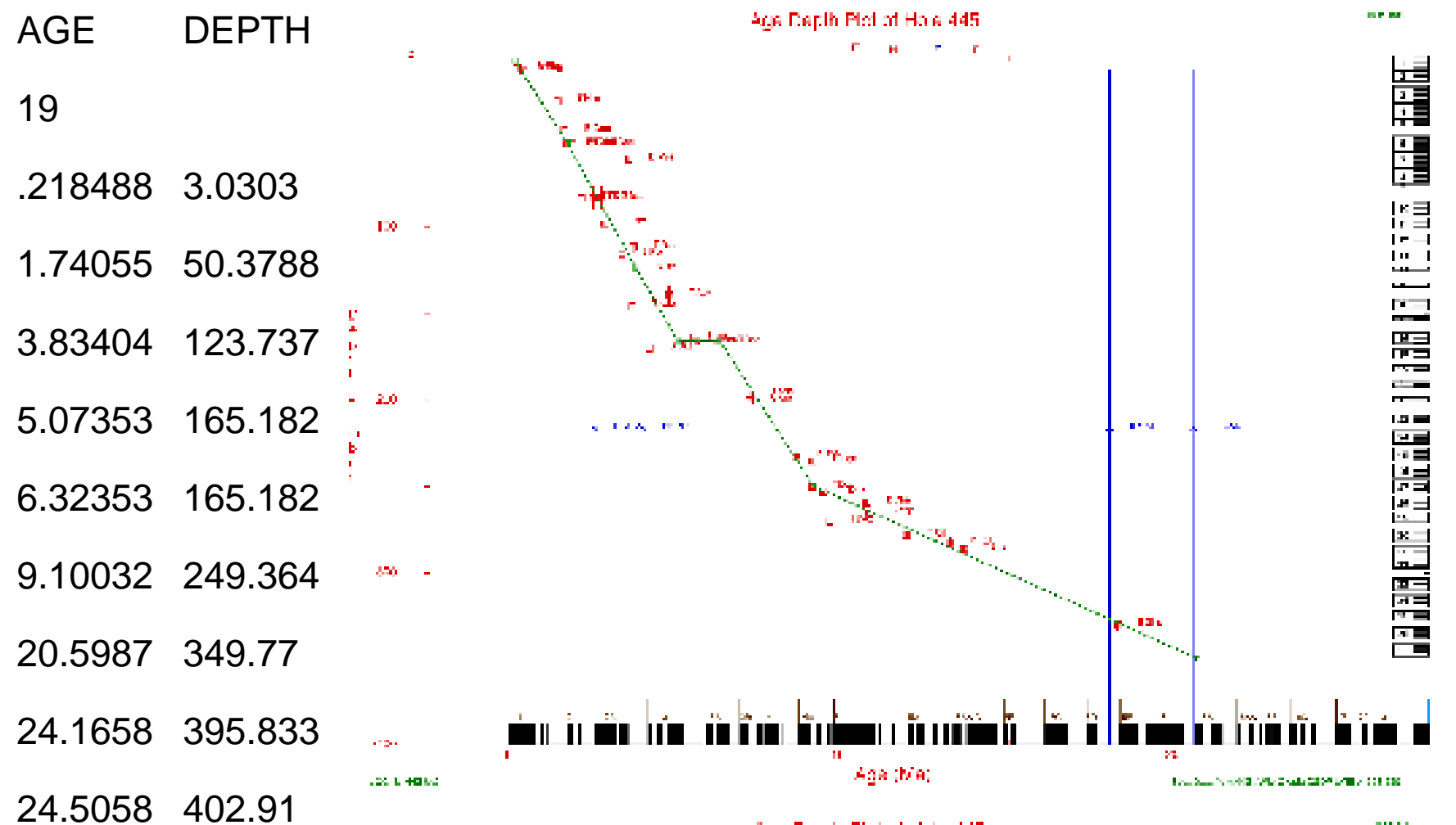

$24.5058 \quad 402.91$

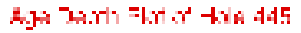

$25.526 \quad 423.333$

$27.3964 \quad 441.667$

29.8619484 .686

$32.5399 \quad 552.5$

34.3252552 .5

$37.0457 \quad 589.433$

$40.4463 \quad 614.242$

$43.6769 \quad 671.667$

$44.5696 \quad 671.667$

$53.4 \quad 832.42$

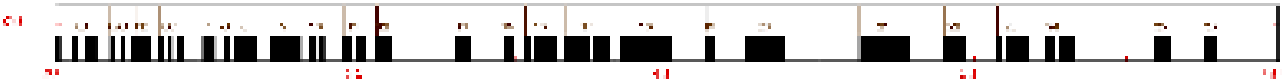
.ะ2

s.g. tha;

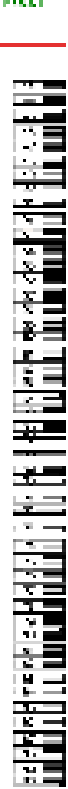

\section{1}

AGE DEPTH

8

$23.5137 \quad 43.6447$

$24.5116 \quad 76.5697$ 
$27.1113 \quad 102.603$

$27.479 \quad 111.026$

28.5032111 .026

$29.396 \quad 169.985$

$30.3151 \quad 169.985$

32.3

444.35

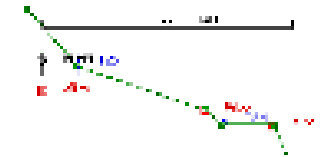

\section{5}

AGE DEPTH

11

8.39136e-2 .235756

1.21993

18.389

2.31911

18.389

3.4031

36.9352

7.41749

36.9352

9.53173

62.0498

11.4675

62.0498

14.5588

95.9091

17.8309

133.182

a.t."

ind

4 Then

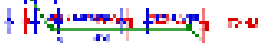

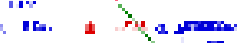

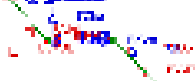

量

ons the

$+x_{0}$

ш

:

므

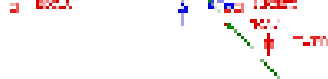

$\square$

u

-

$20.1842 \quad 133.182$

$22.7474 \quad 195.568$

\section{B 19950808}

AGE DEPTH 
9

.1008412 .33333

1.279419 .16666

$2.28466 \quad 64.8333$

9.1859364 .8333

9.81618178 .867

$14.5168 \quad 178.867$

$19.2143 \quad 278.182$

$23.687 \quad 436.447$

$32.9044 \quad 545.789$

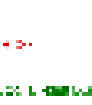

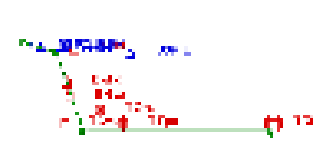

46219950711

AGE DEPTH

8

22.9832138 .636

$23.7868 \quad 172.045$

28.5

172.045

$29.6481 \quad 210.227$

$32.2952 \quad 289.242$

$34.1859 \quad 312.576$

$37.0693 \quad 340.682$

$44.1597 \quad 379.924$

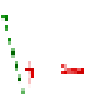

in toes on 70

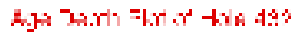

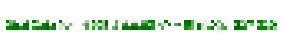

\section{5}

AGE DEPTH

$14.342376 \quad 589391$

$.534961 \quad 21.8075$ 
$1.27751 \quad 21.8075$

$3.24655 \quad 77.2102$

$4.18633 \quad 77.2102$

$4.58561 \quad 86.6405$

$5.61559 \quad 86.6405$

$6.36501 \quad 115.521$

$8.71009 \quad 115.521$

$9.26577 \quad 133.202$

$9.84911 \quad 133.202$

$12.3978 \quad 172.102$

$12.7088 \quad 186.693$

$17.563 \quad 406.667$

\section{A 19952507}

AGE DEPTH

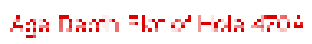

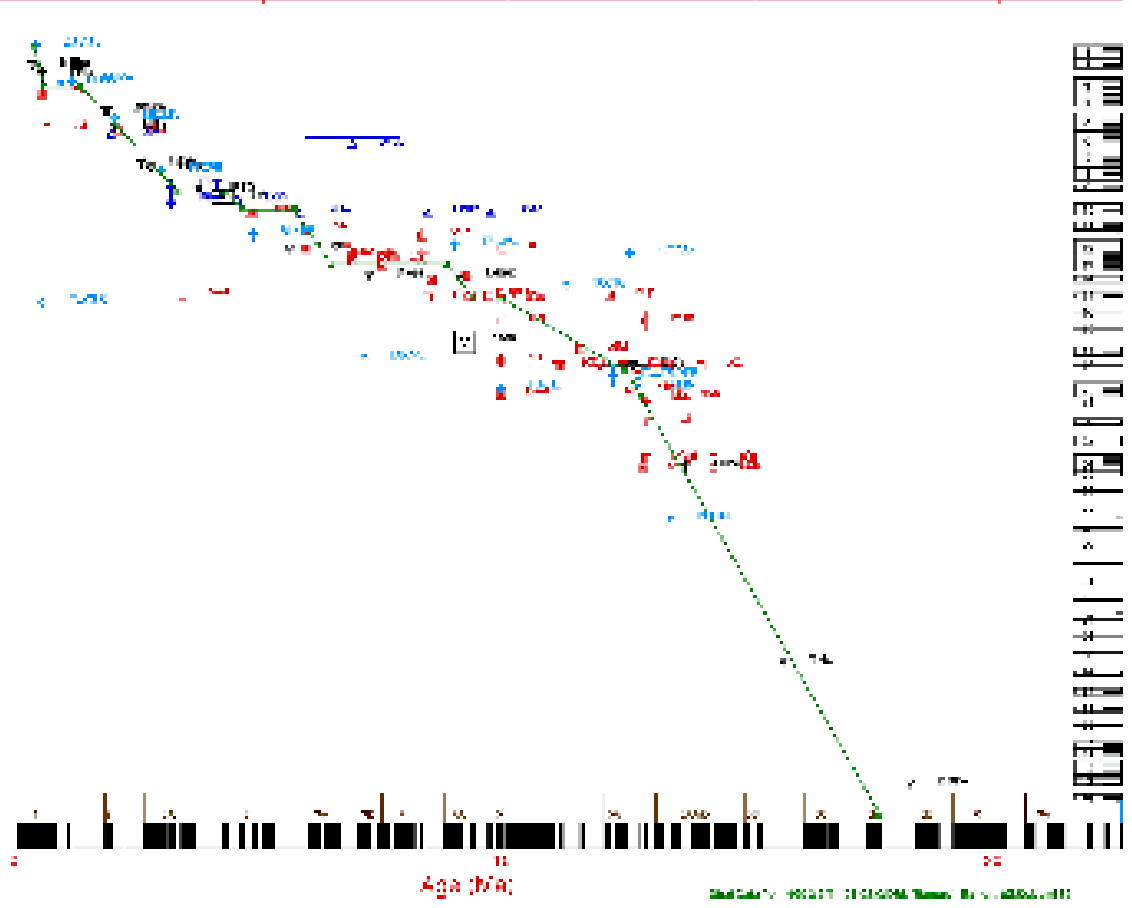

3

$4.958454 \quad 46.9548$

7.5985577172 .7701

$9.75045707 \quad 86.6798$

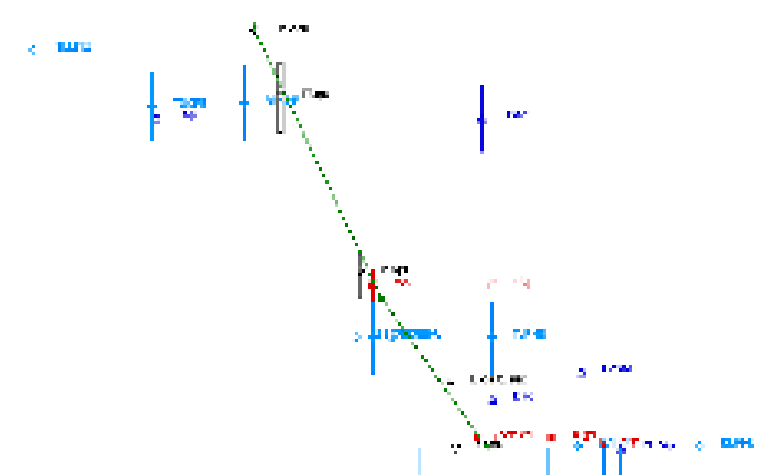

47019950804

AGE DEPTH

9 


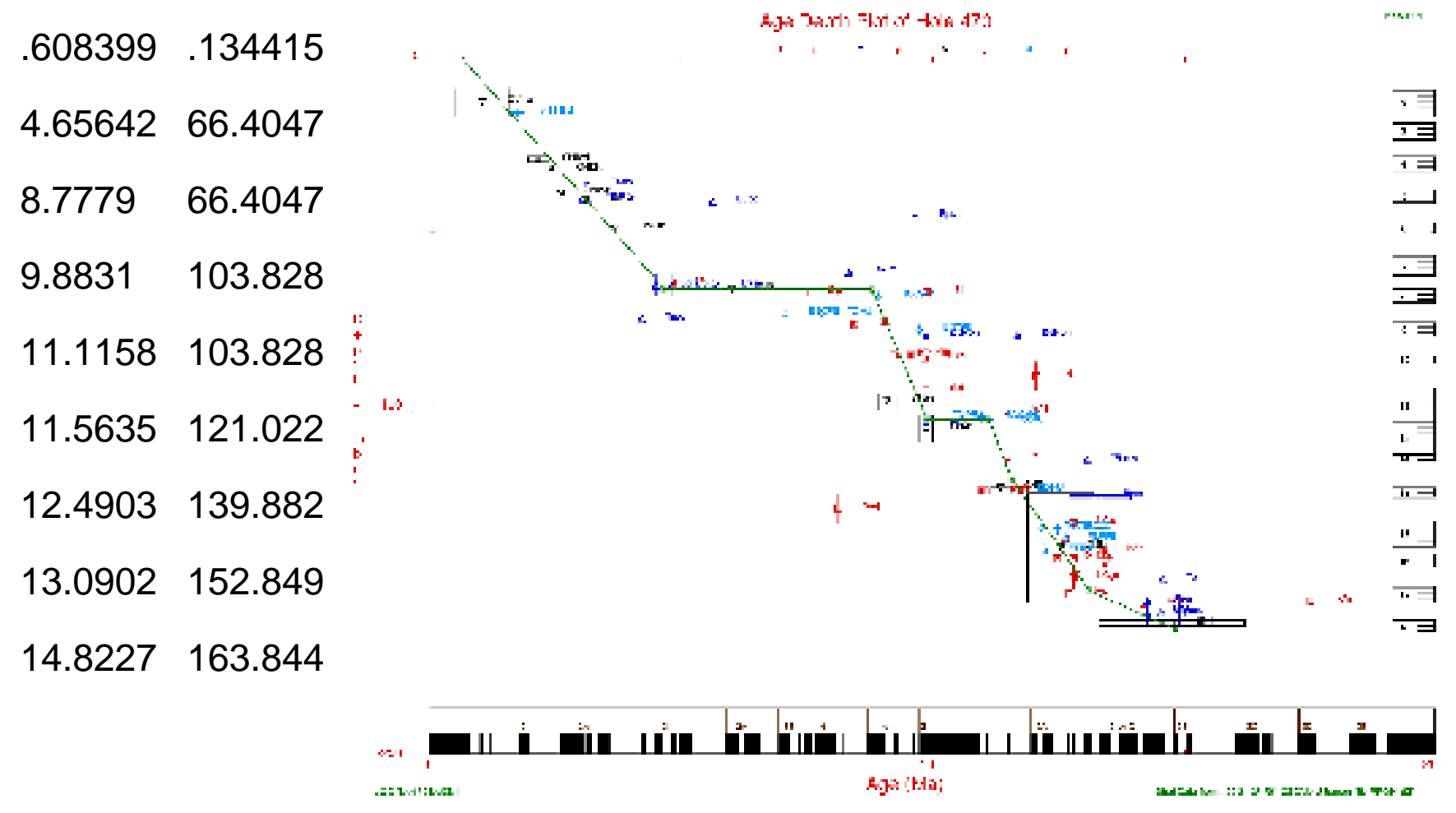

47219952507

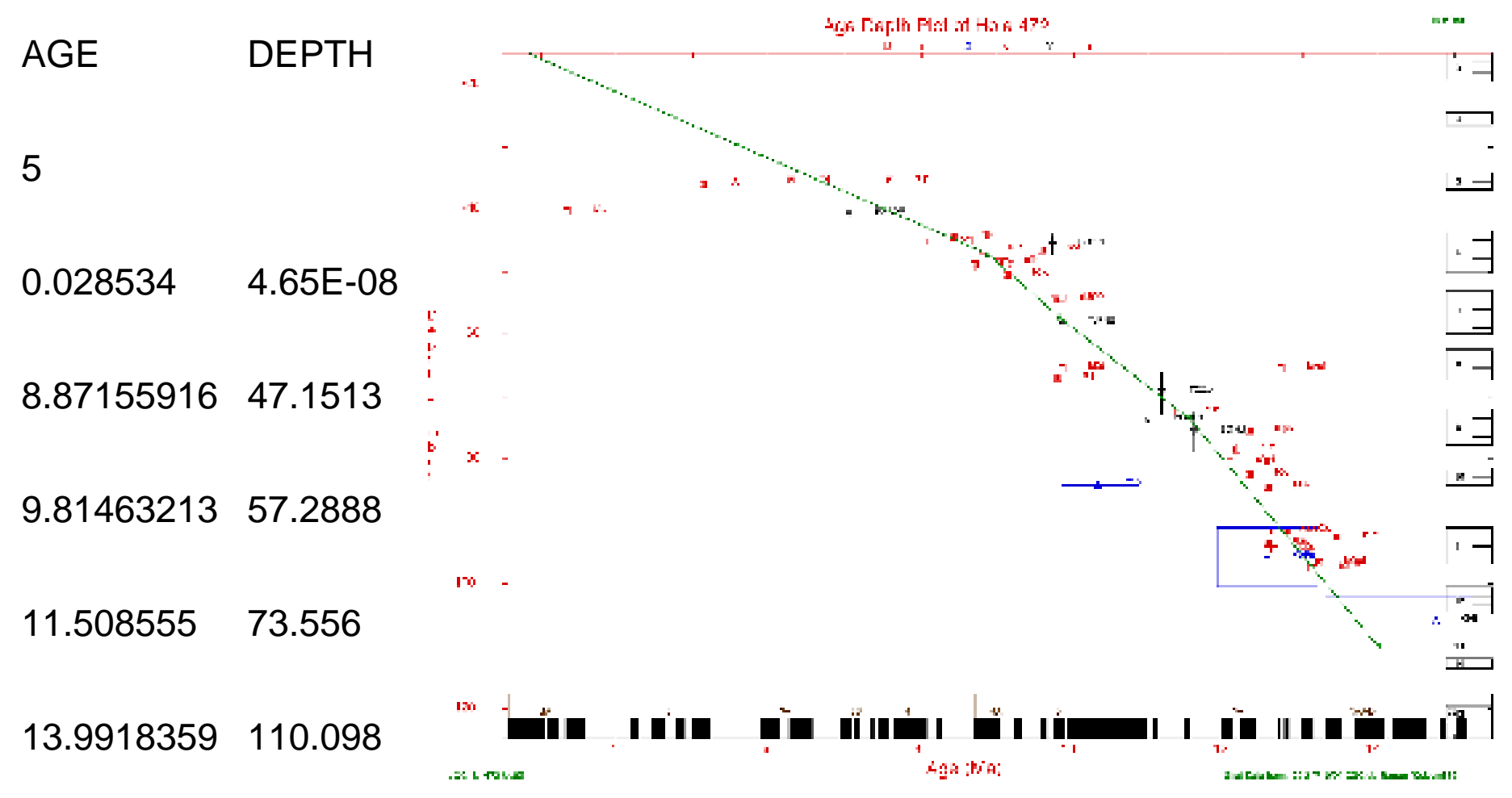

\section{7}

AGE DEPTH

6 


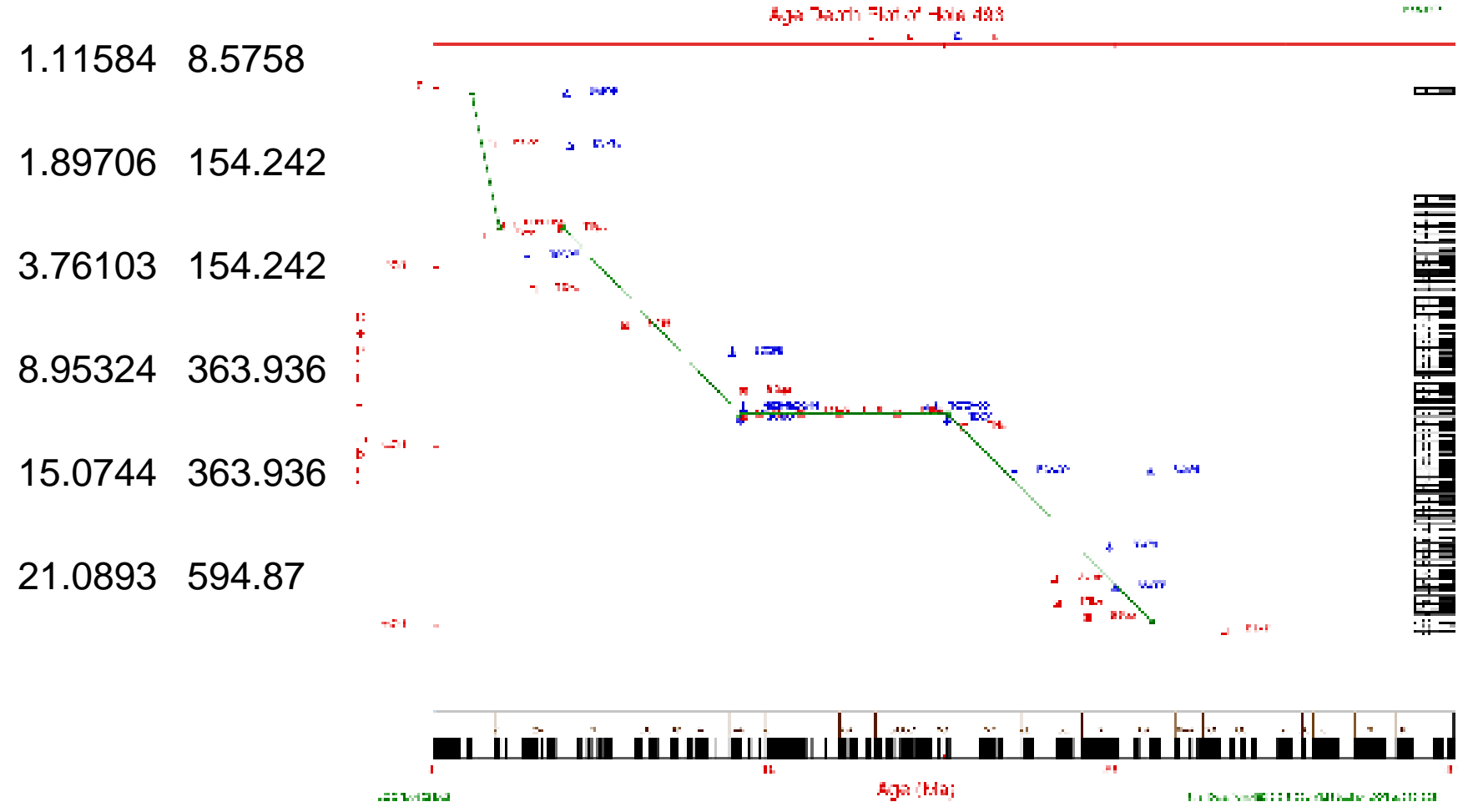

\section{5}

AGE DEPTH

12

4.28011e-2 .982318

$.956376 \quad 32.4165$

$2.65698 \quad 85.8871$

$9.03966 \quad 170.923$

$11.7965 \quad 170.923$

$12.425 \quad 188.409$

$14.1597 \quad 188.409$

$14.937 \quad 228.636$

$15.943 \quad 228.636$

. 3.

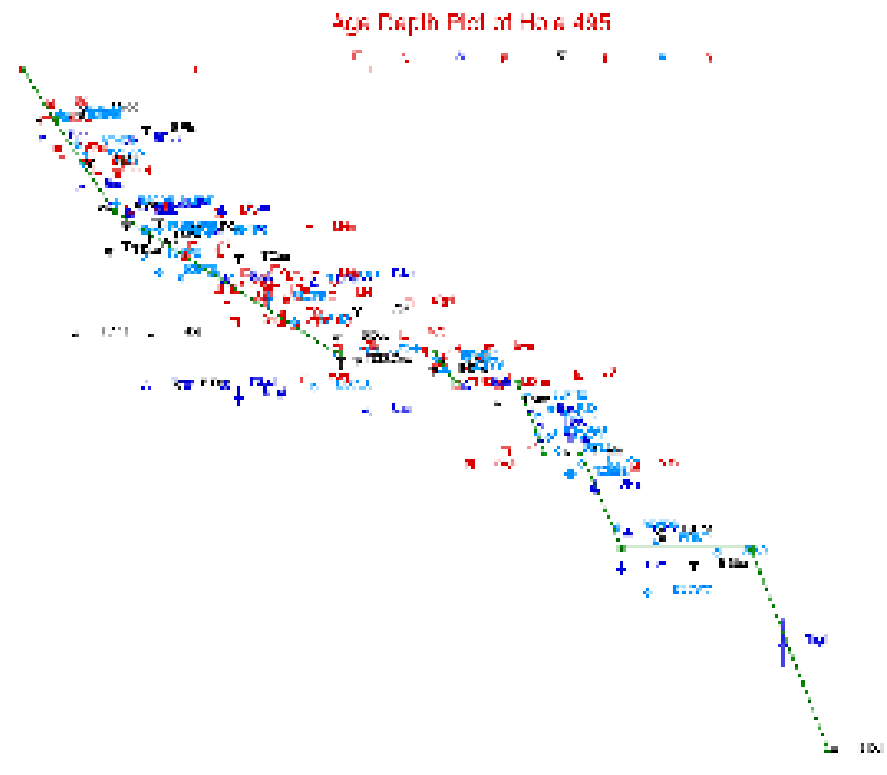

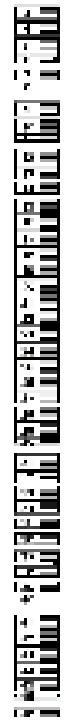

|

$17.1399 \quad 285.855$

$20.8085 \quad 285.855$

$23.0035 \quad 405.242$

\section{7}




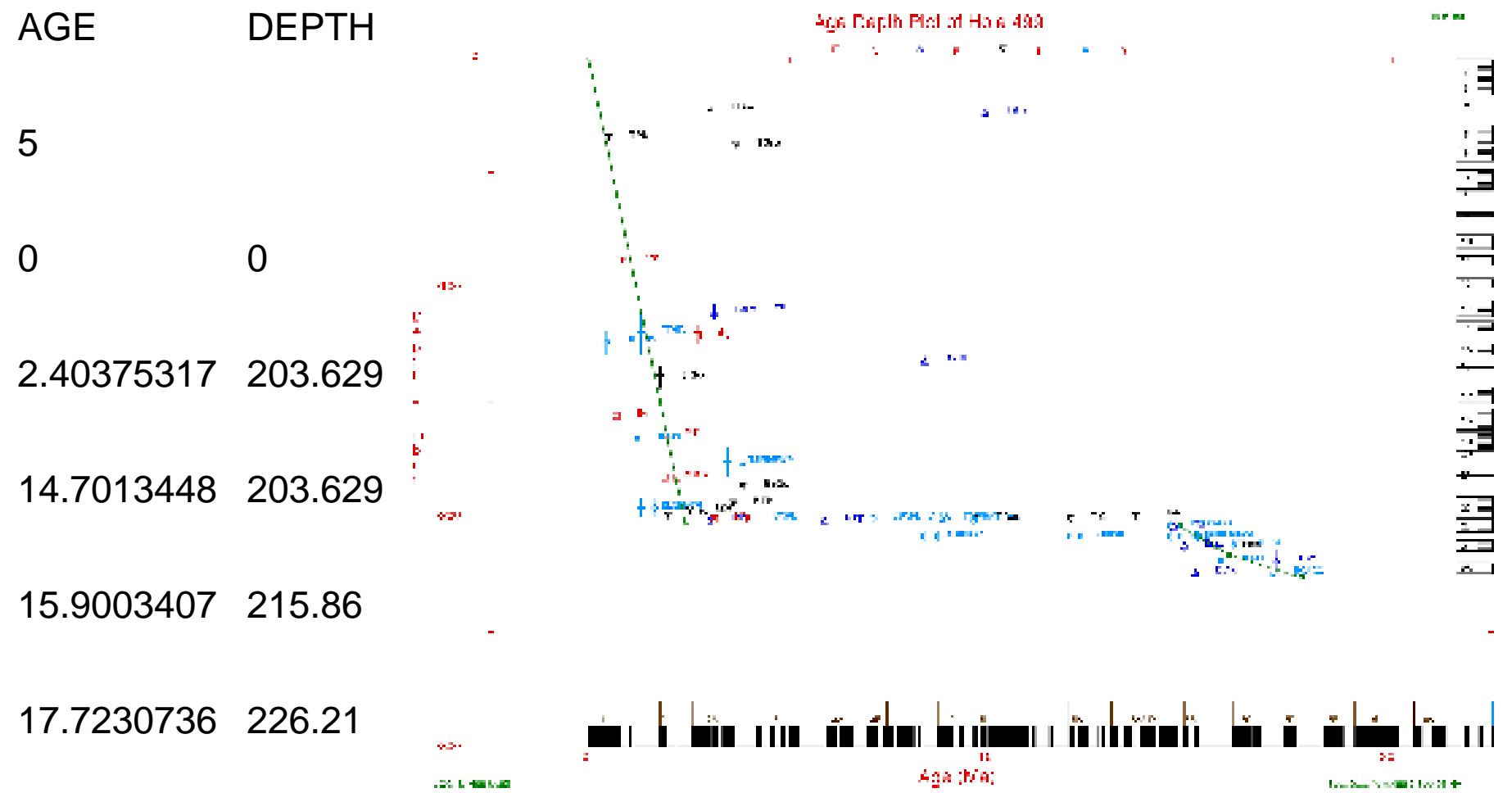

Next Section... 
To download full-size diagrams, open the following directory and choose the file (named by hole number). File naming convention is 62A_PICT.GIF (62A = hole number).

DIRECTORY: adps app

\section{Holes 572C-594}

572C 19952507

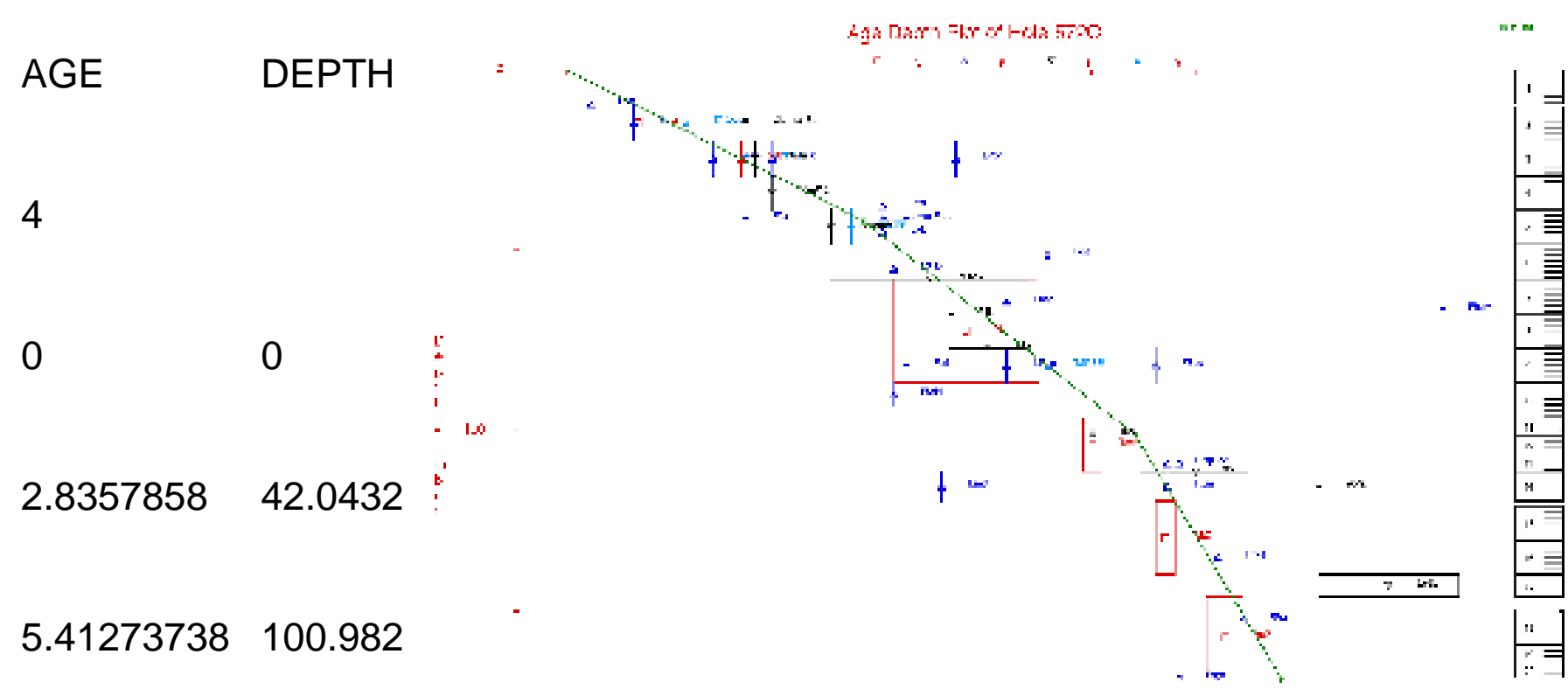

6.82603167169 .352

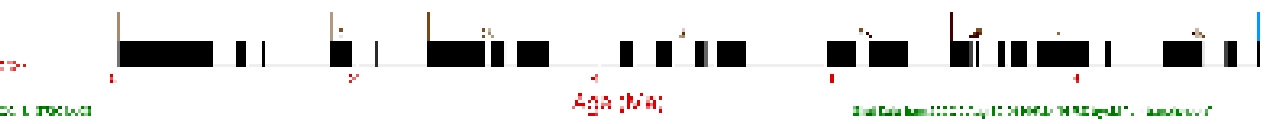

\section{D 19950803}

AGE DEPTH

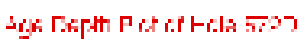

9

6.22868158 .939

9.50053270 .903

9.8831295 .406

10.882318 .07 .

$11.6033 \quad 341.257$

$12.4513 \quad 367.397$

$12.8473 \quad 386.027$

13.7633408 .841

15.0659456 .778

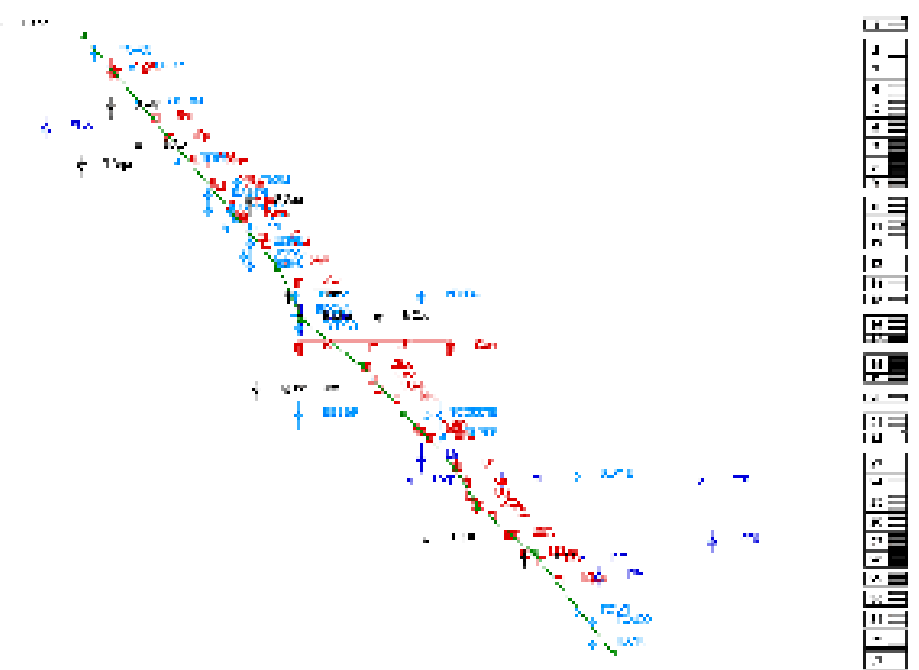




\section{A 19952507}

AGE DEPTH

11

0.05029568 1.4114E-08

$0.7771717 \quad 14.5753$

1.0550285716 .4931

1.1551529418 .2192

$1.606375 \quad 22.2358$

1.7726018225 .1761

1.9309281826 .6462

2.5720911434 .5205

$3.0416 \quad 40.8493$

$3.324159 \quad 44.3798$

$4.92924 \quad 57.8867$

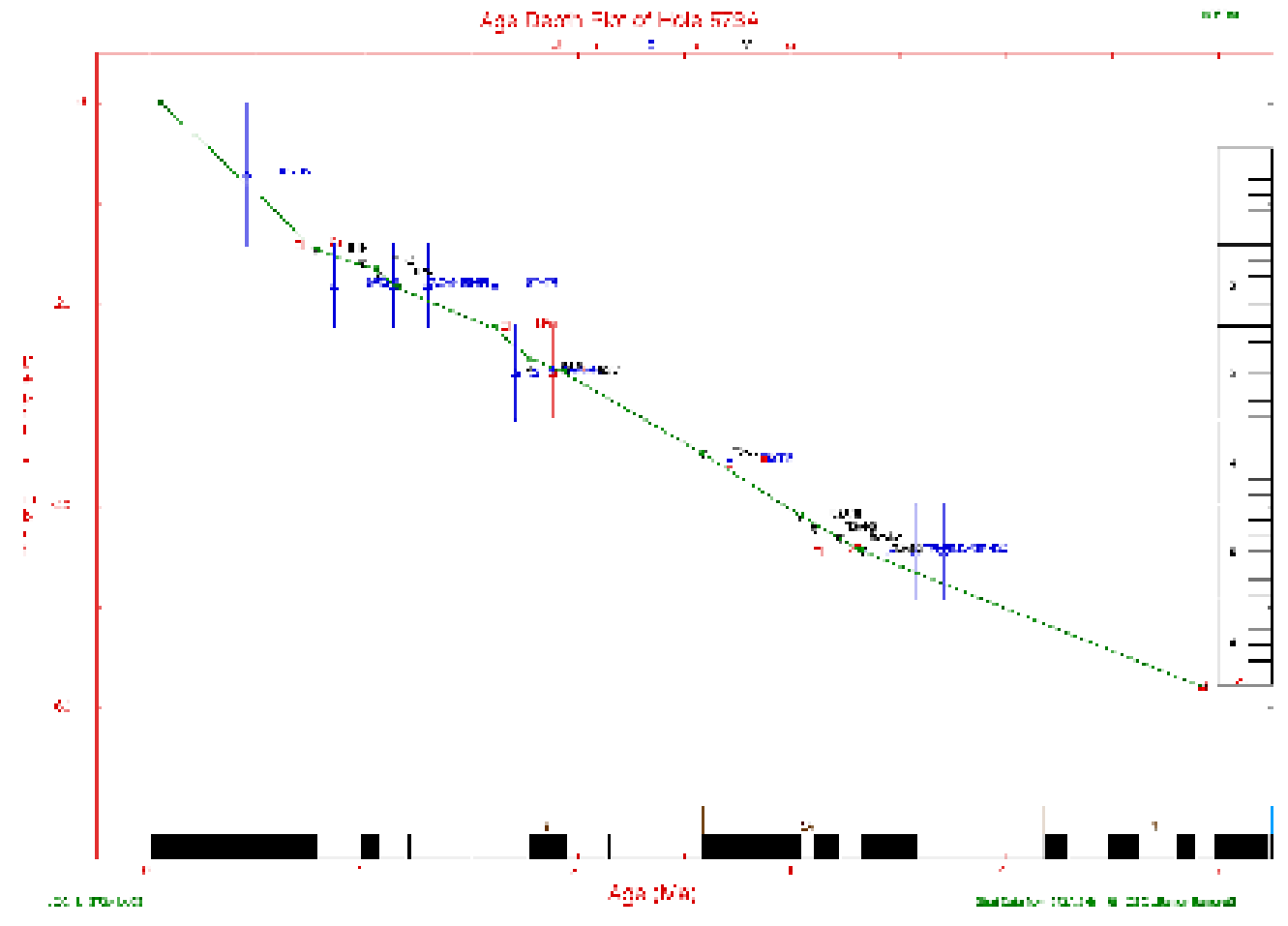

\section{B 19952407}

AGE DEPTH

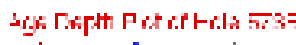

15

$8.4604102 \quad 147.32$

9.68035883168 .453

$9.83038587 \quad 168.453$

$9.87402667 \quad 186.371$

$11.6691908 \quad 186.371$

$12.4703315 \quad 210.26$

13.5554809210 .26

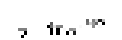
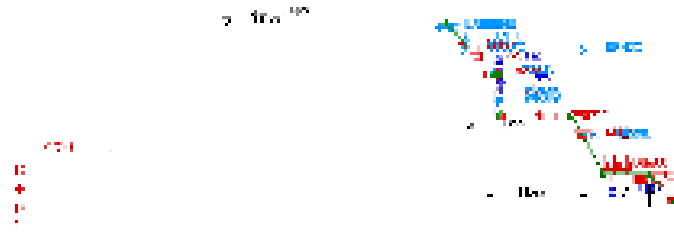

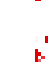

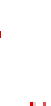

n: 1

$15.3774358 \quad 243.548$ 


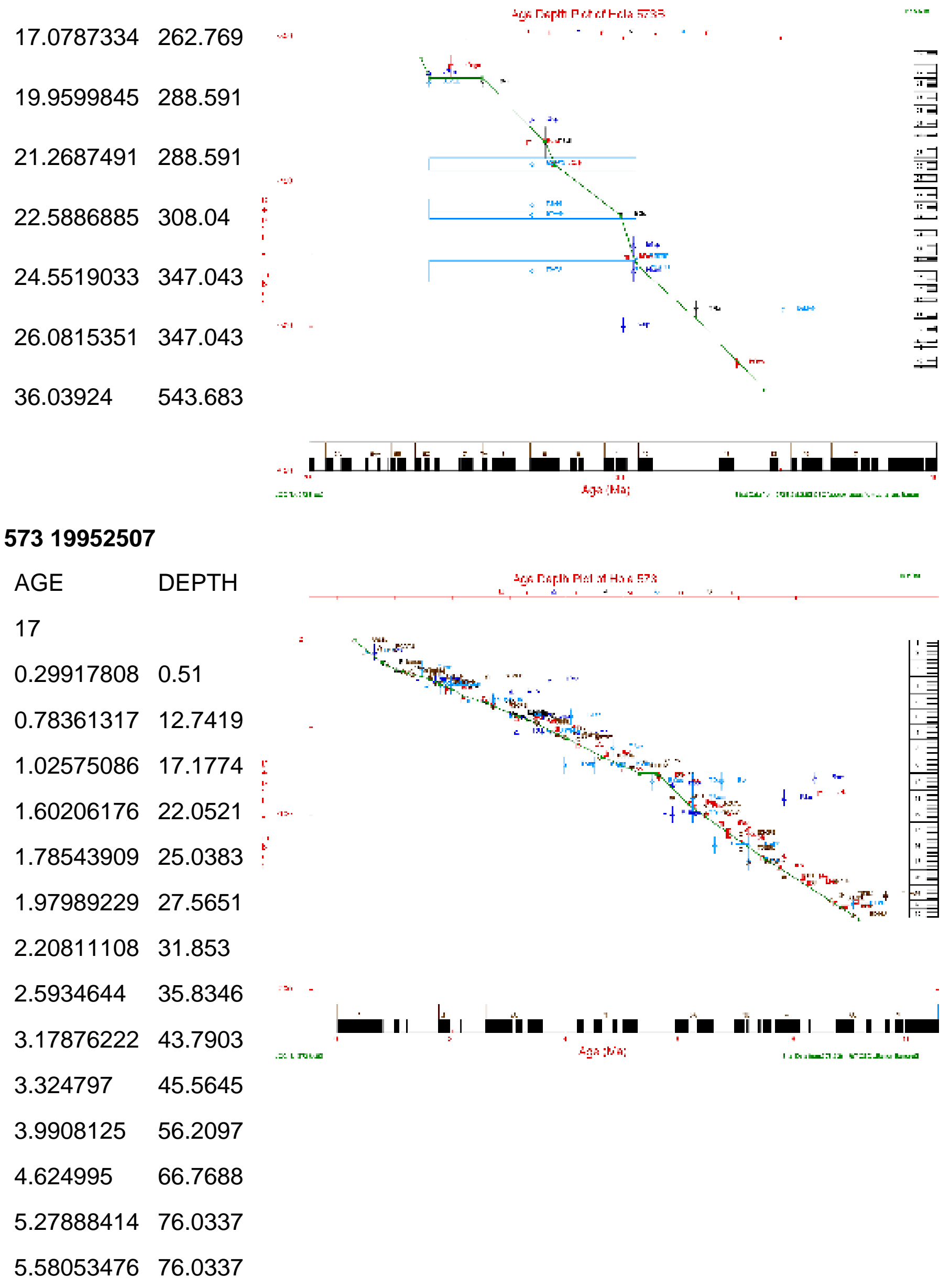


$6.115724 \quad 93.9516$

$7.459755 \quad 124.866$

9.12527575159 .812

\section{C 19950725}

AGE DEPTH

AGE 1.0

10

$16.1049 \quad 195.789$
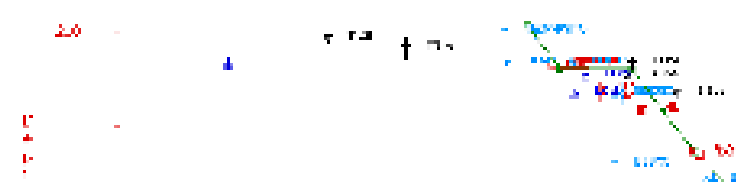

$16.7903 \quad 218.76$

18.2815218 .76

$18.9118 \quad 242.273$

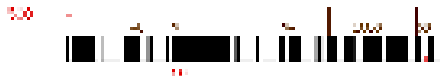
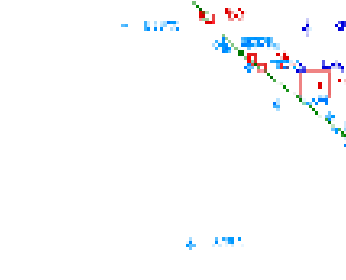

19.5991264 .012

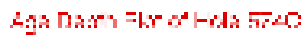

$20.362 \quad 284.227$

$22.5078 \quad 327.016$

$24.4247 \quad 385.835$

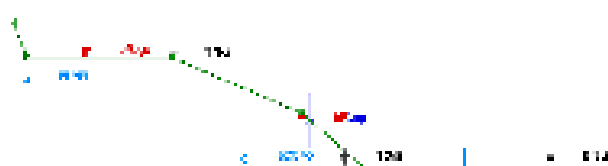

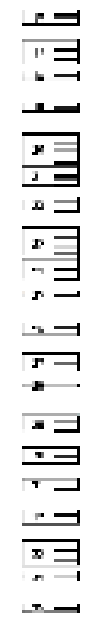

$28.5054 \quad 385.835$
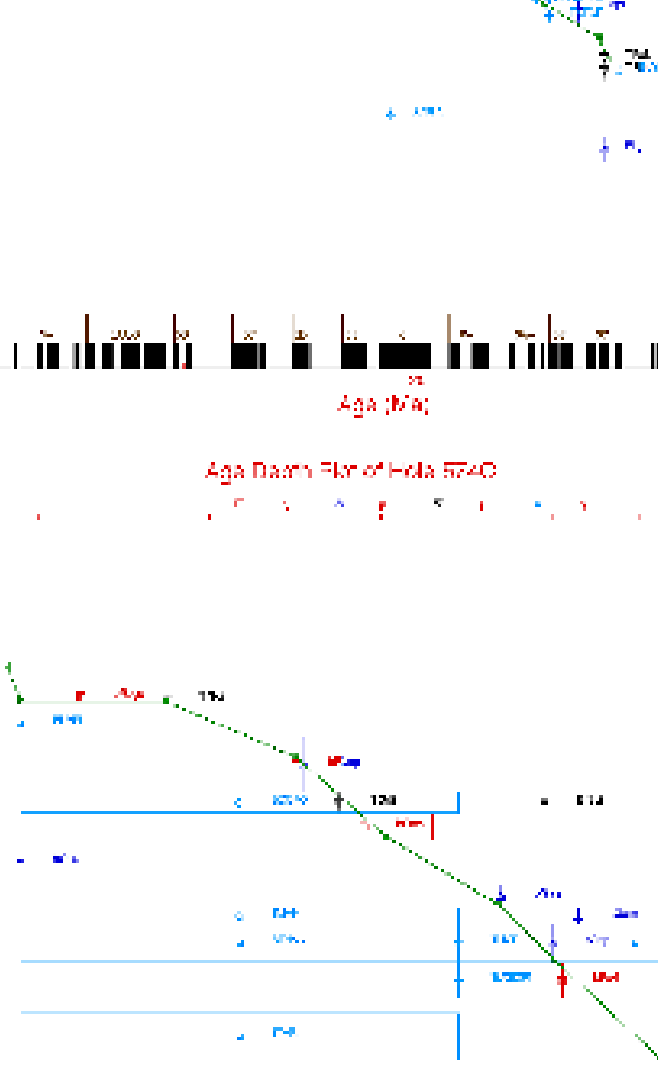

$\uparrow$.
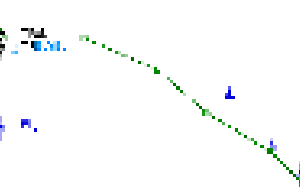

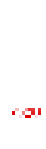

$34.3266 \quad 520.597$

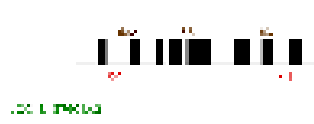

.

เ.

57419950725

AGE DEPTH 
15

.2350683 .445

$.295065 \quad 4.5023$

1.341114 .5023

$1.7856 \quad 7.81011$

$2.66708 \quad 12.0368$

3.5324218 .1048

$4.24741 \quad 25.6355$

$5.43856 \quad 35.4391$

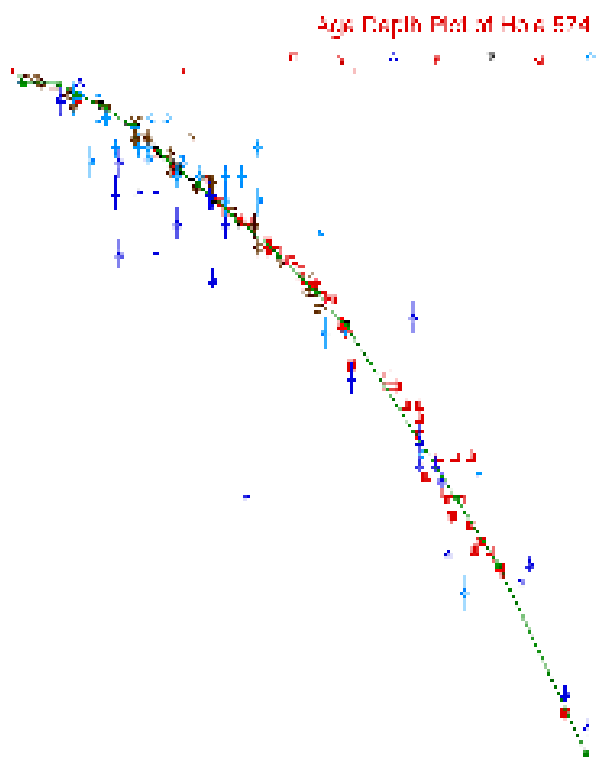

6.5632445 .8805

7.8107756 .6256

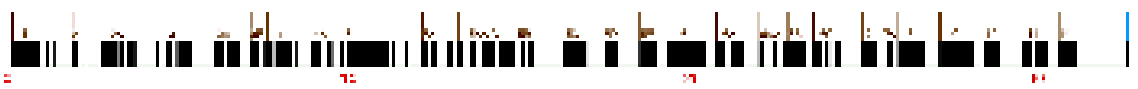

$8.90698 \quad 68.9522$

$9.73687 \quad 78.3333$

$12.91 \quad 130.2$

$14.1958 \quad 151.387$

$16.6846 \quad 207.504$

\section{7}

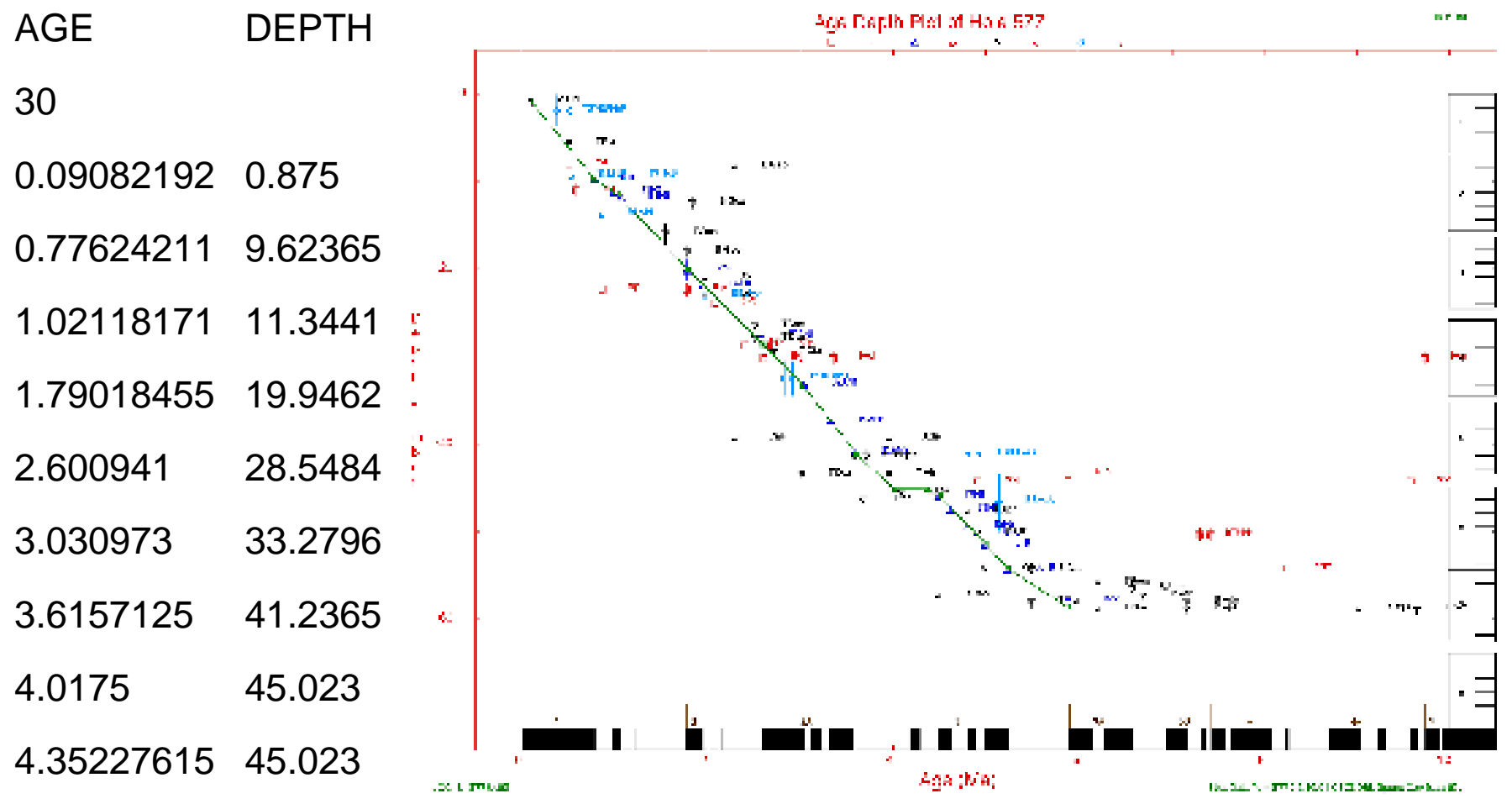




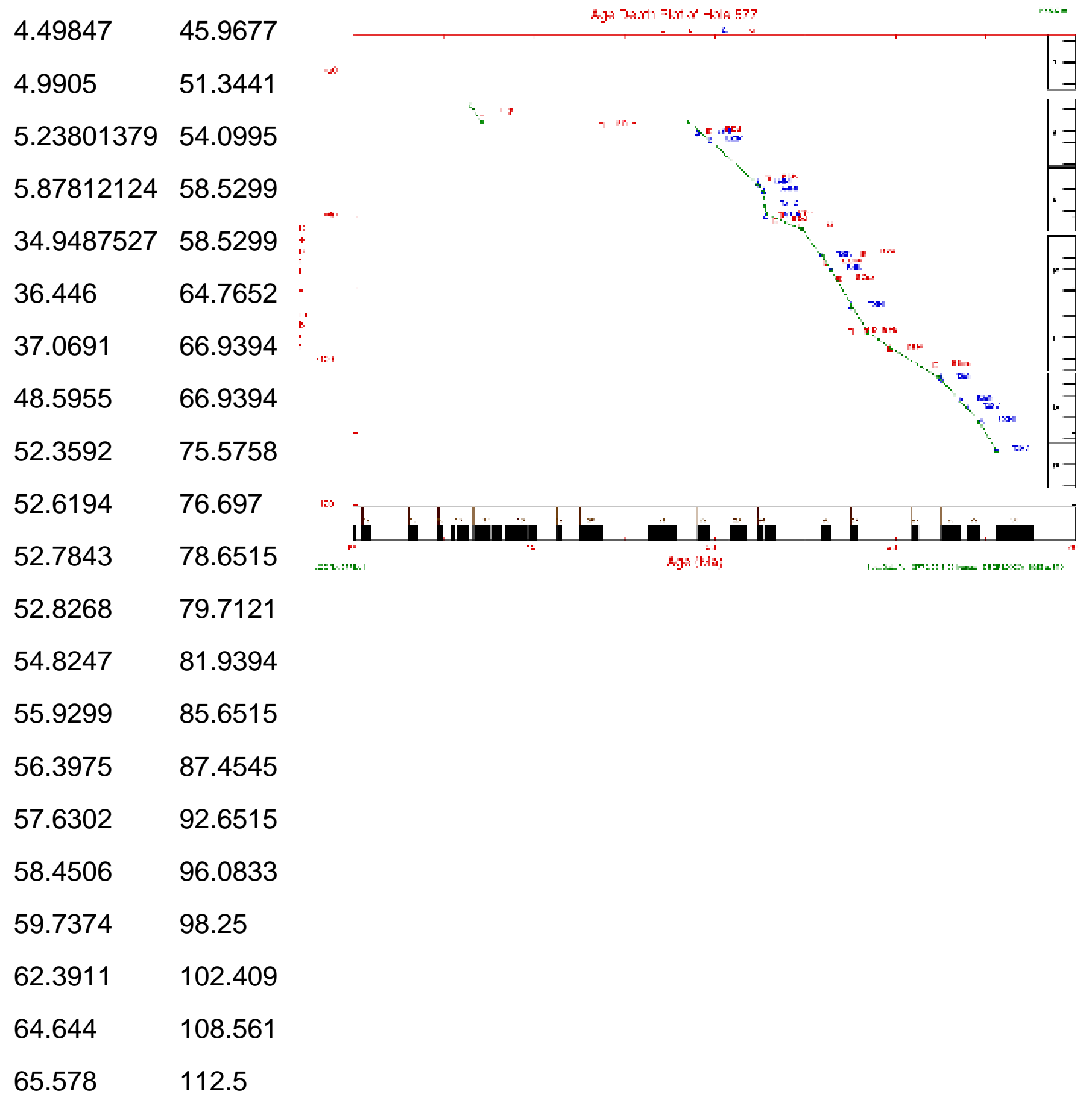

\section{7}

AGE DEPTH

12

$-0.0095231 \quad 2.8229 E-08$

$0.78635833 \quad 27.3813$

0.9936891432 .5268

1.5502823548 .147 
2.070734961 .6935

$2.8150594 \quad 78.1011$

$3.642725 \quad 88.6559$

5.83493834109 .709

6.61827383115 .957

$7.81642502 \quad 122.177$

12.3023485135 .618

15.155

144.91
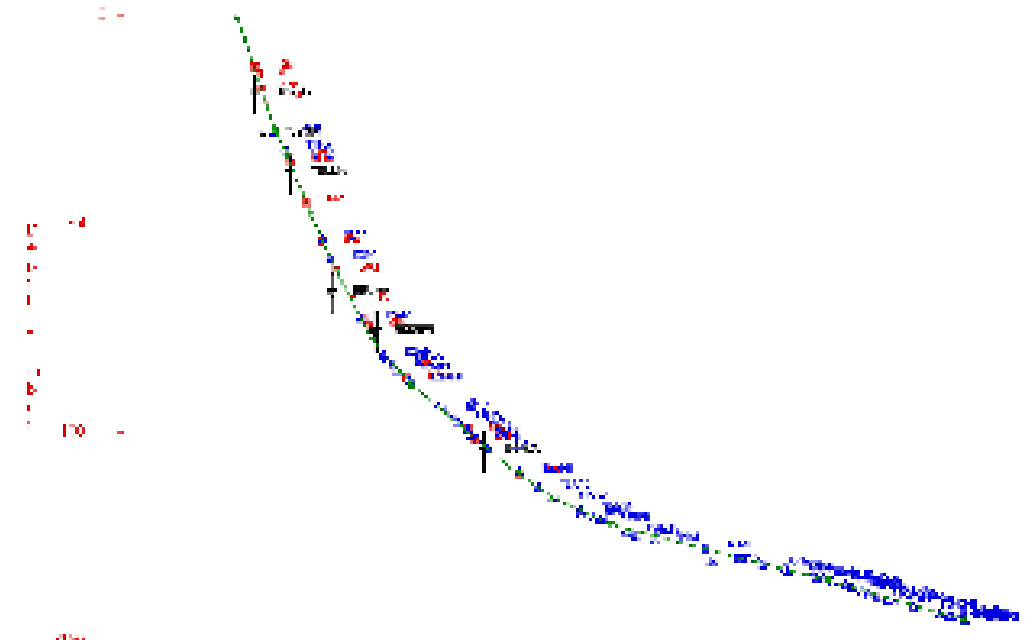

1.

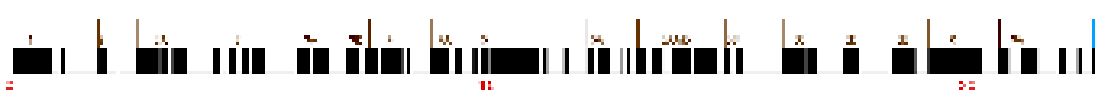

579A 19952507

AGE DEPTH

8

$-0.0071163$

0.134415

0.7785554

30.1075

1.0202948638 .9433

$1.77545727 \quad 61.8836$

$1.93129636 \quad 65.7427$

$2.5816528 \quad 87.9032$

3.12113444102 .688

$4.919385 \quad 149.786$

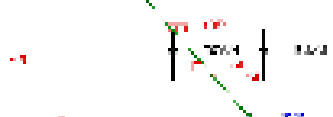

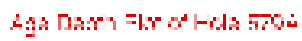

$m+n$

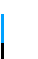




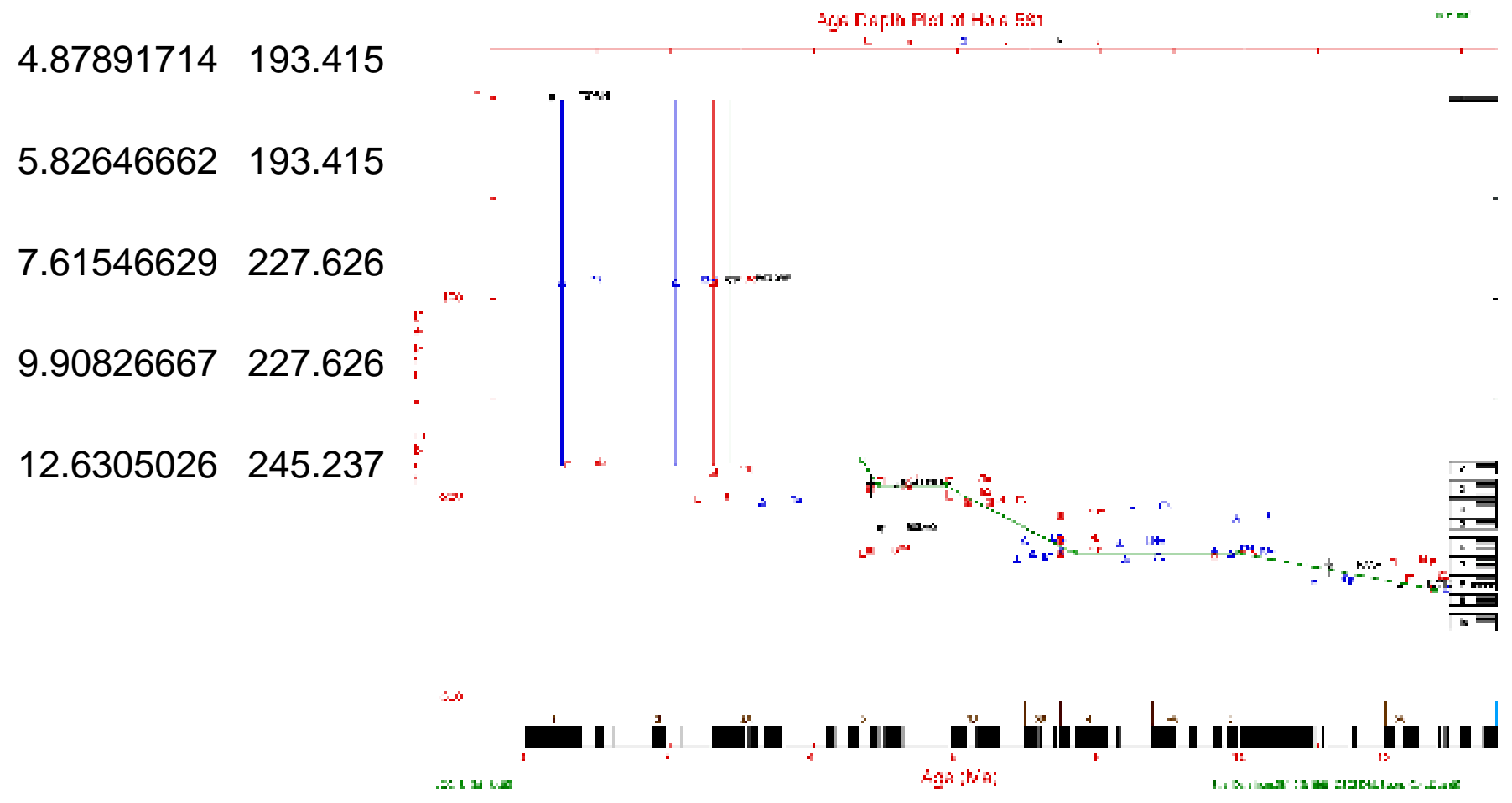

\section{B 19952507}

AGE DEPTH

4

$0.30229808 \quad 1.64384$

$2.655 \quad 164260$

$4.57751 \quad 127.397$

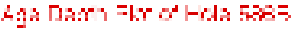

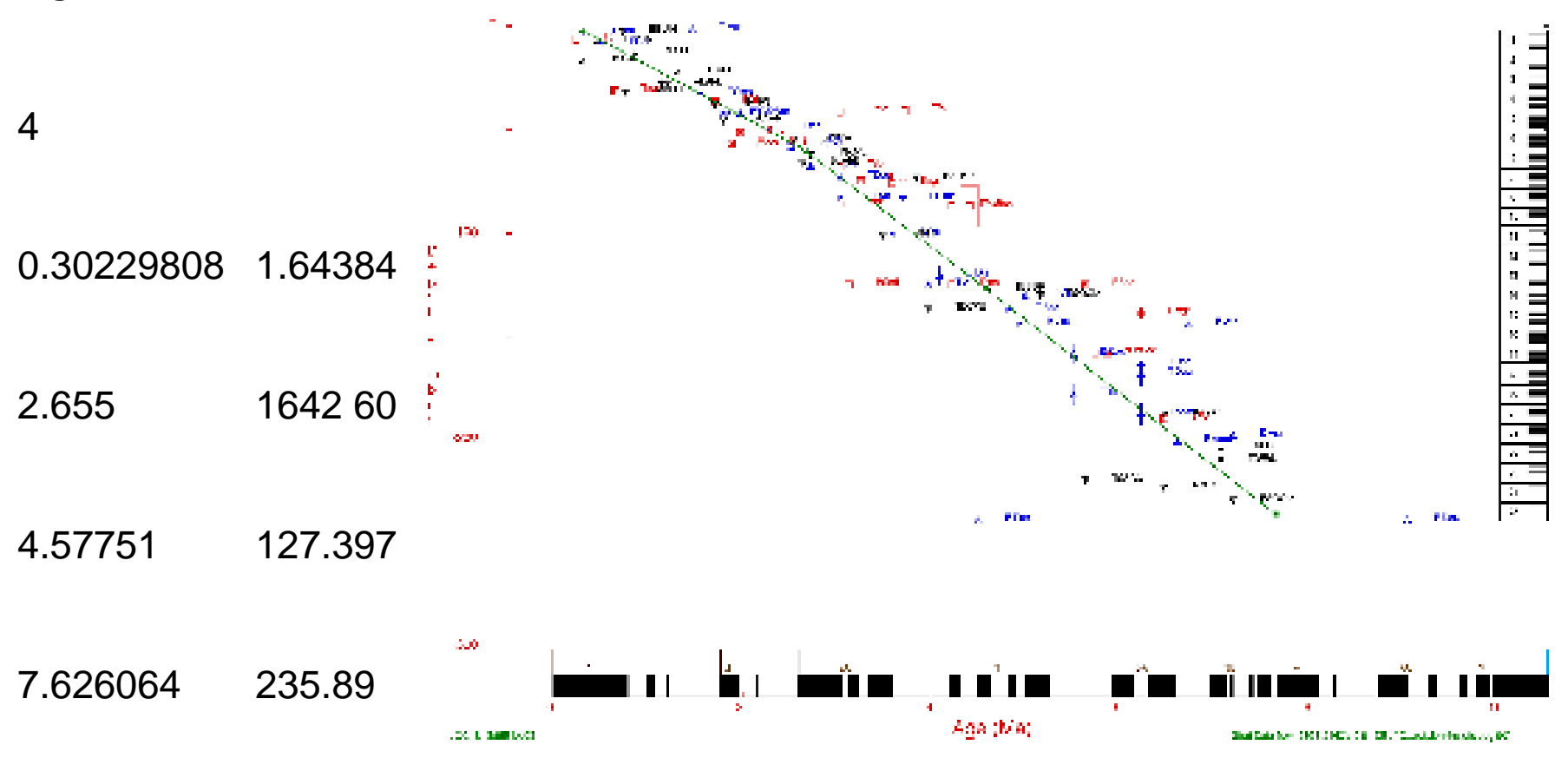

588A 19952407

AGE DEPTH

7

$9.8853 \quad 239.839$ 
$12.0394694 \quad 253.065$

$13.1073444 \quad 270.161$

$14.4181152 \quad 281.263$

$15.118095 \quad 294.892$

$16.049526 \quad 301.761$

$16.7227889 \quad 321.975$
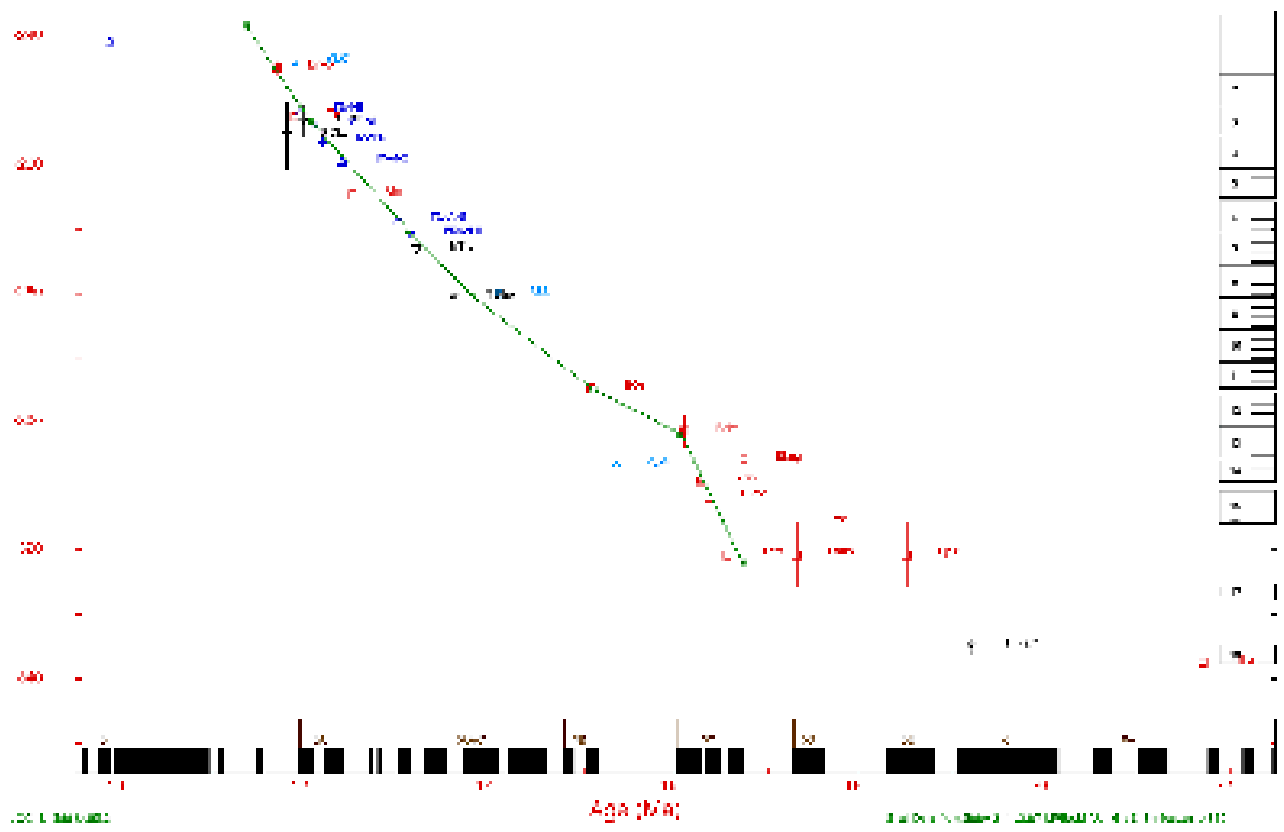

\section{C 19950802}

AGE DEPTH

9

$16.0858 \quad 322.258$

20

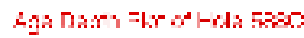

$m$

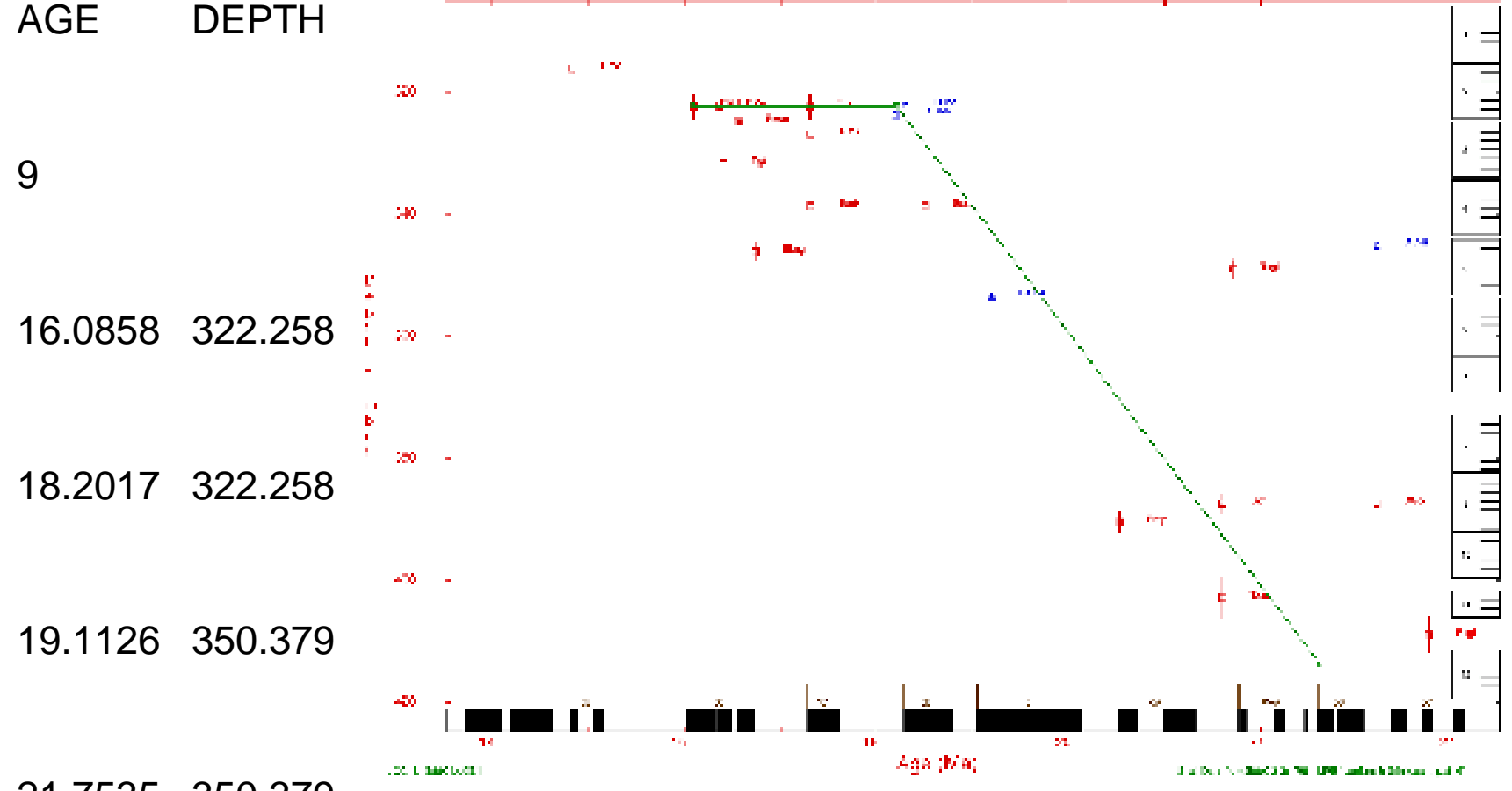

$21.7535 \quad 350.379$

$23.8363 \quad 409.091$

$27.0723 \quad 457.955$ 


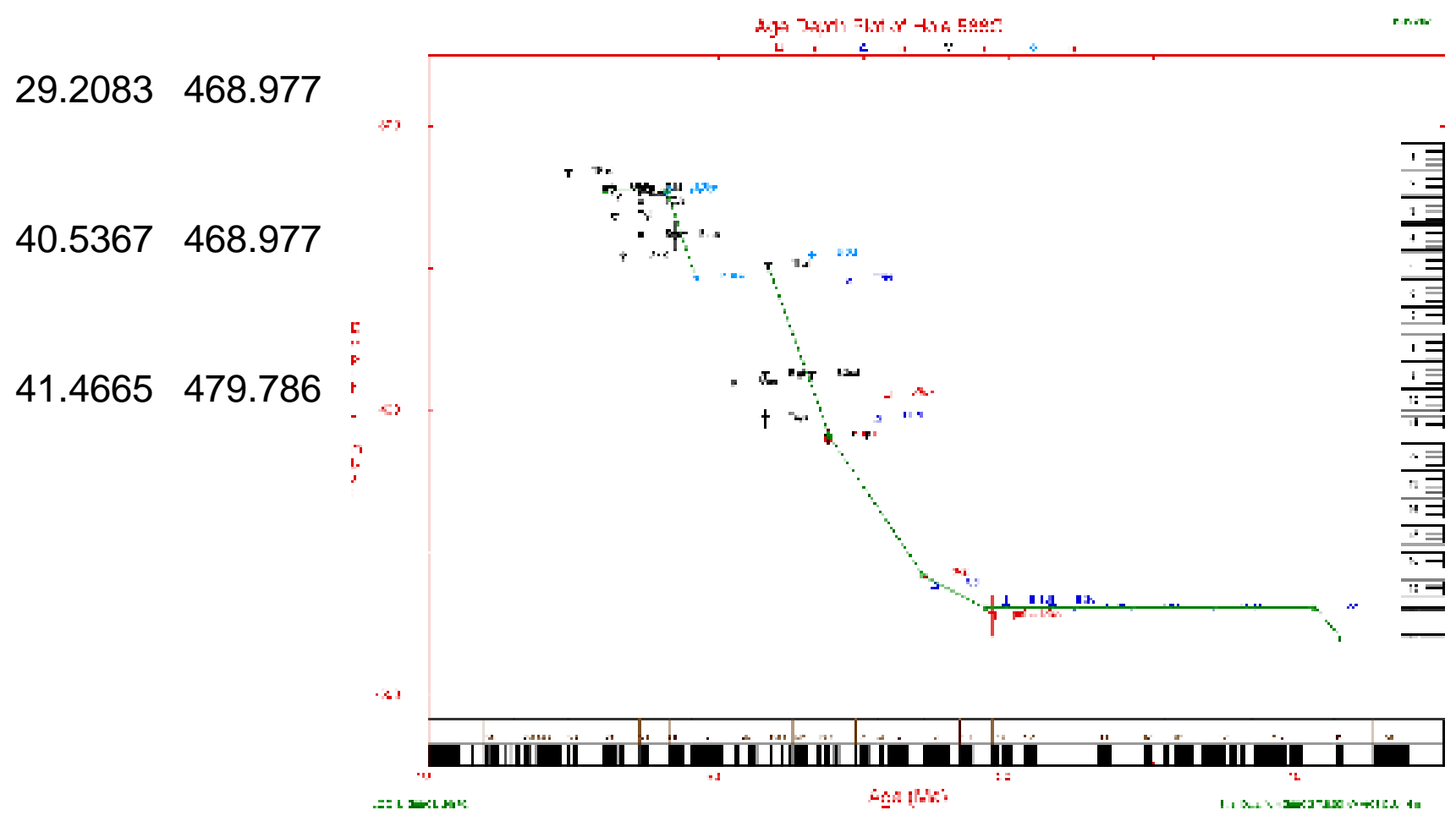

58819952507

$\begin{array}{ll}\text { AGE } & \text { DEPTH } \\ 22 & \\ 0.27136414 & 2.5876 E-08 \\ 0.77338603 & 10.4441 \\ 1.82999727 & 17.856 \\ 2.57403761 & 29.9847 \\ 3.0341758 & 38.4073 \\ 3.57639773 & 46.1562 \\ 4.18697889 & 79.3415 \\ 4.29672308 & 82.879 \\ 4.48159 & 86.0796 \\ 4.8 & 88.2695 \\ 4.924146 & 92.3124 \\ 5.2278125 & 96.3553 \\ 6.003971 & 124.579 \\ 6.61926783 & 144.355\end{array}$

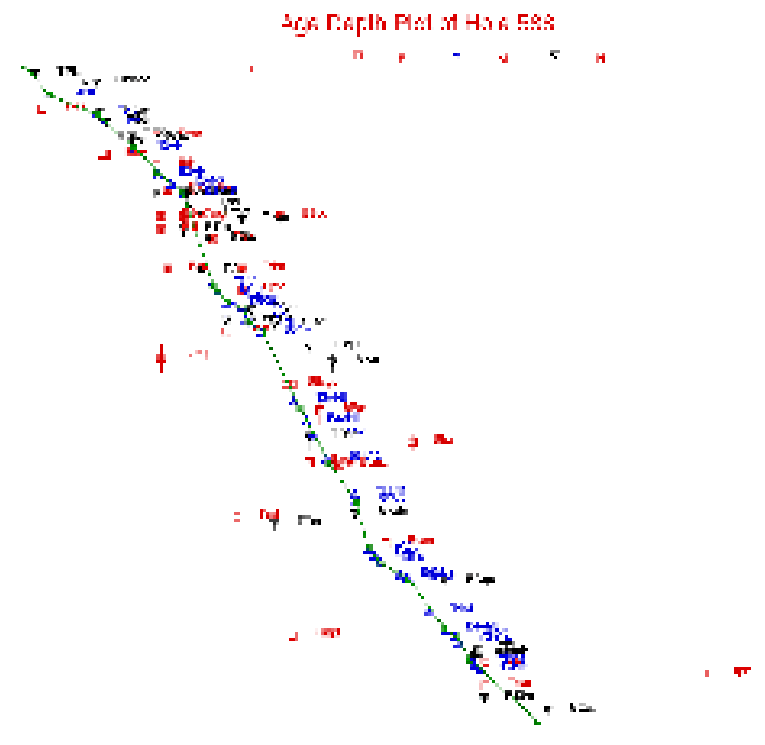


$7.16871308 \quad 158.576$

$7.4171053 \quad 174.885$

7.69418242181 .048

$8.27060278 \quad 186.371$

$9.02869 \quad 204.747$

9.24030467206 .585

9.56333029215 .773

10.9826883238 .441

590A 19952507

AGE DEPTH

9

1.1950014722 .043

1.7846781833 .3333

$2.57882893 \quad 47.4462$

$3.0362974 \quad 62.5$

3.3458522770 .0269

$3.5893375 \quad 81.3172$

$4.88739 \quad 196.102$

6.36707038196 .102

$6.9224615 \quad 280.779$

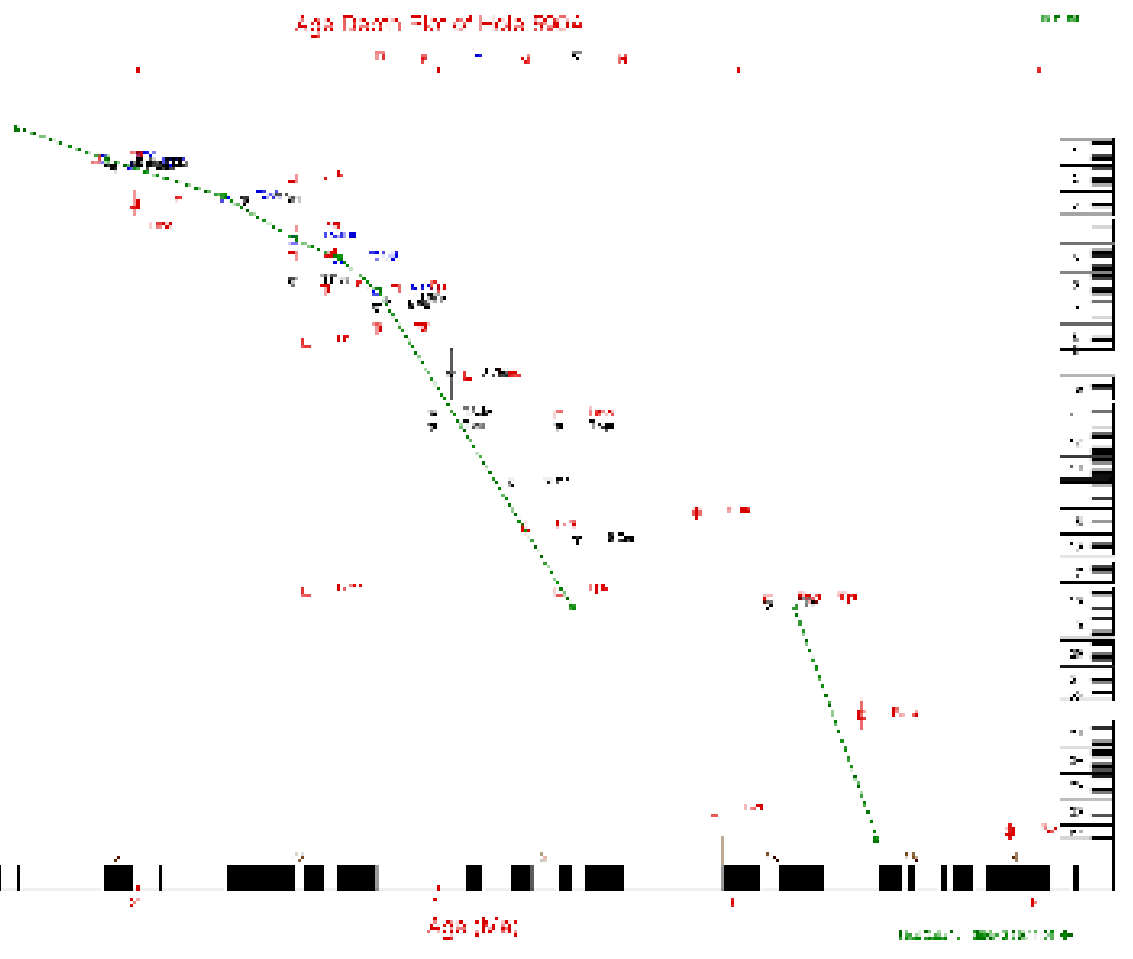

\section{B 19950803}

AGE DEPTH

12

.76809911 .5591

$1.75824 \quad 31.6667$

1.9536935 .8064

$2.57121 \quad 45.8602$

$3.03085 \quad 57.3925$ 


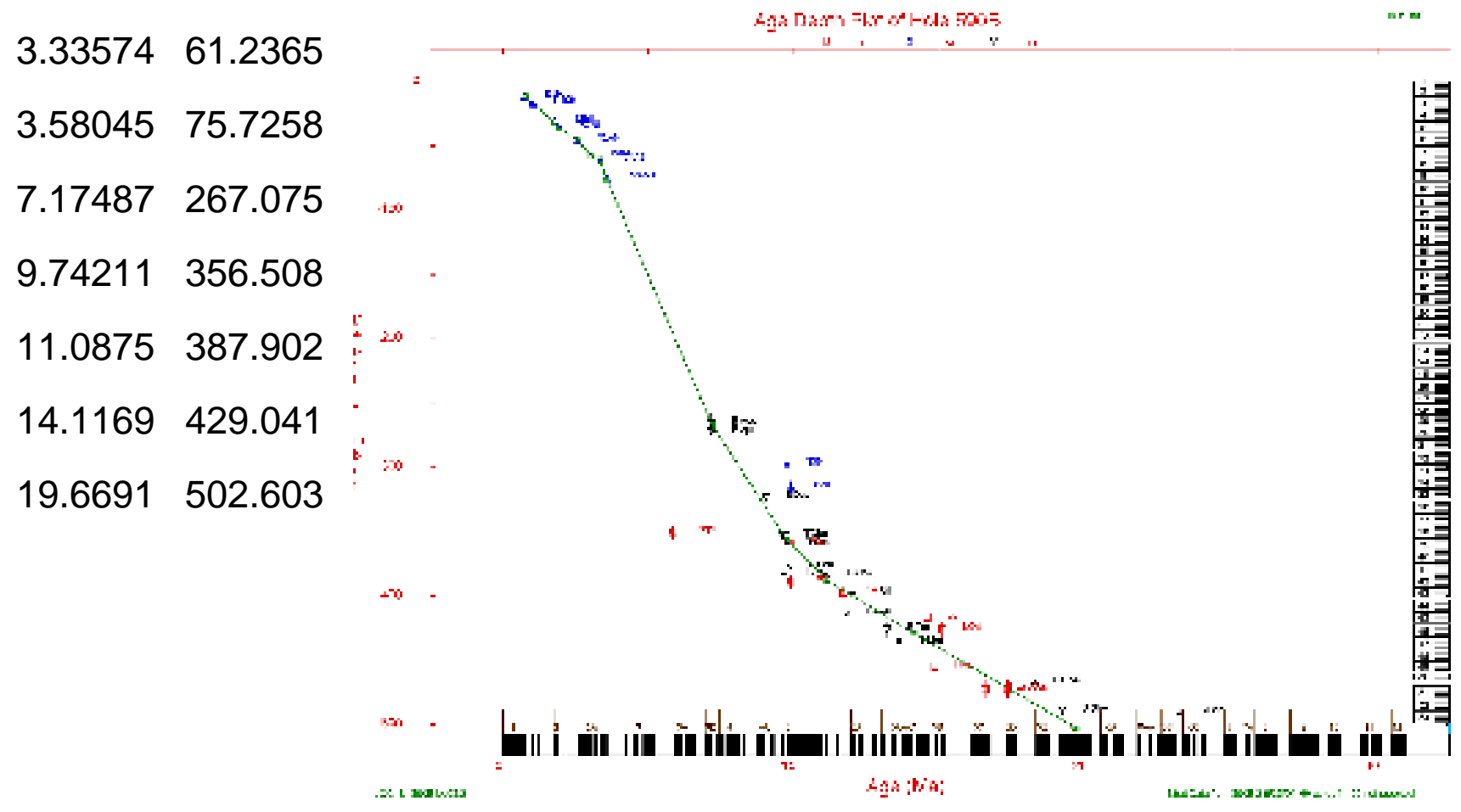

\section{7}

AGE DEPTH

16

$0.0779516 \quad 2.82259$

$0.29754436 \quad 3.89784$

0.778555416 .6667

$0.995248 \quad 23.3871$

1.0731880925 .4032

$1.77666818 \quad 44.8925$

1.9536897549 .5968

$2.5816528 \quad 67.0699$

3.04082

82.5269

$3.324797 \quad 89.2473$

3.5082727395 .7121

$3.7136375 \quad 117.917$

$4.58829 \quad 189.893$

7.68561484294 .793 
$9.78029667 \quad 358.346$

$14.8491822 \quad 449.464$

\section{5}

AGE DEPTH

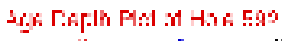

23

.1014521 .45161

$.777172 \quad 10.8602$

1.0861114 .086

$\begin{array}{ll}1.76671 & 18.9247\end{array}$

1.9476921 .8817

$2.58227 \quad 28.3333$

2.7386529 .589

3.5177343 .8356

3.5808847 .6882

$4.39367 \quad 86.5591$

4.68229108 .064

5.97639108 .064

6.33172134 .274

6.69506153 .763

8.34621153 .763

$9.18248 \quad 178.63$

9.75776207 .123

11.6334207 .123

$13.6187 \quad 253.864$

$16.5966 \quad 287.273$

$17.4002 \quad 302.273$

$30.3561 \quad 302.273$

$34.2536 \quad 352.545$ 
59319950802

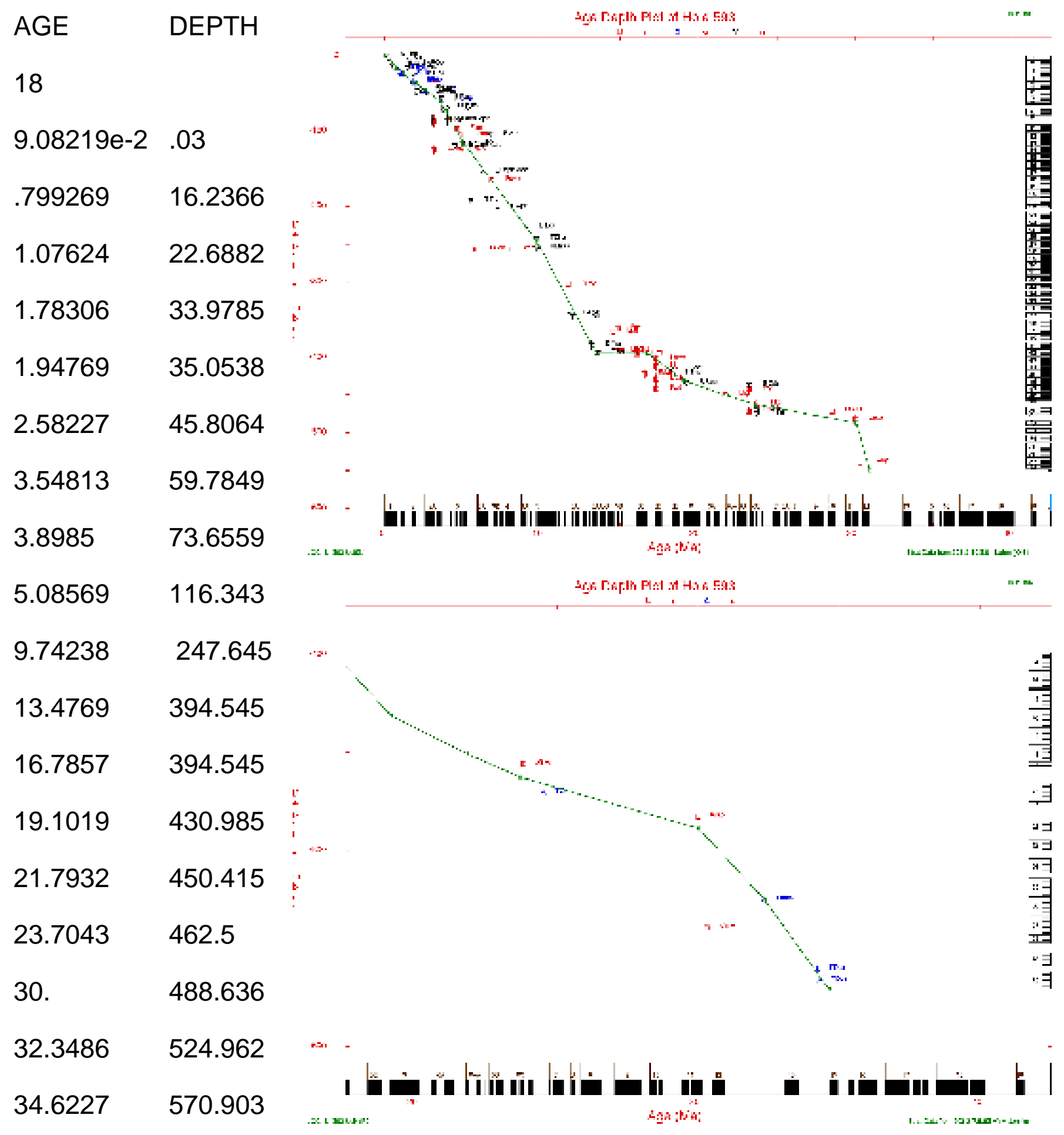

594A 19952507

AGE DEPTH

21

5.6594E-07 4.7047E-08

$0.45419721 \quad 43.951$ 
1.76051912104 .747

2.25941459104 .747

$2.7064498 \quad 127.565$

$3.268774 \quad 127.565$

3.6024875158 .652

4.79643375172 .818

$5.44970386 \quad 184.763$

$6.47276105 \quad 184.763$

7.59911086209 .265

8.48852682209 .265

8.95168155222 .818

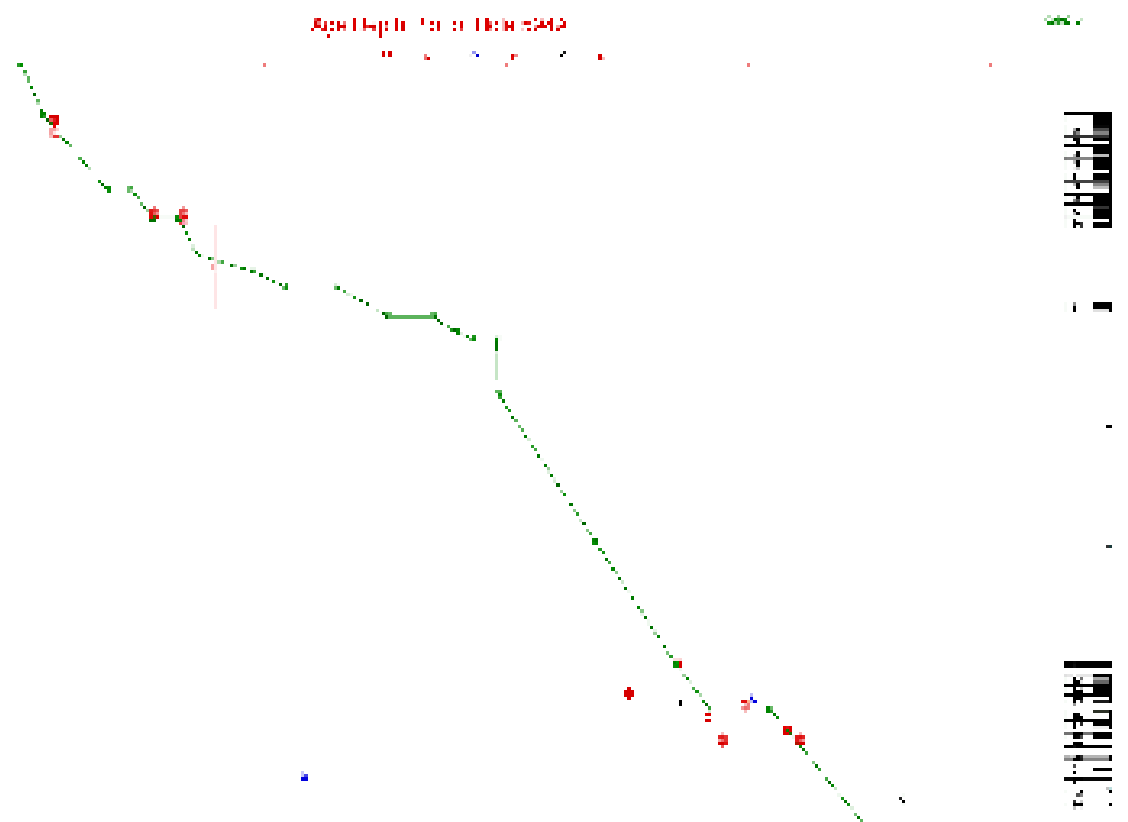

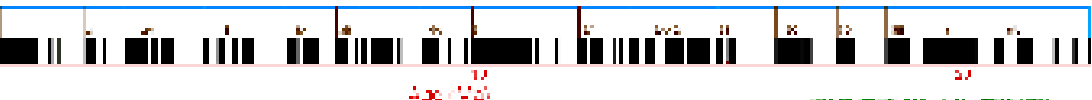

$9.31007238 \quad 227.412$

9.81005227227 .412

$9.84377733 \quad 273.354$

$11.8602283 \quad 395.559$

$13.522587 \quad 497.397$

14.2159278533 .844

15.4730108533 .844

$17.4801073 \quad 633.537$

59419950804

AGE DEPTH

17

5.6594e-7 $\quad 4.7047 \mathrm{e}-8$

$.339205 \quad 46.8606$

$1.76052 \quad 104.747$

$2.25941 \quad 104.747$

$2.63589 \quad 144.87$

$3.26877 \quad 144.87$ 
$3.60249 \quad 158.652$

$4.79643 \quad 172.818$

$5.4497 \quad 184.763$

$6.47276 \quad 184.763$

$7.59911 \quad 209.265$

$8.48853 \quad 209.265$

$8.95168 \quad 222.818$

$9.84378 \quad 273.354$

$11.7045 \quad 403.091$

$12.2902 \quad 440.276$

$13.454 \quad 493.874$ 493.874

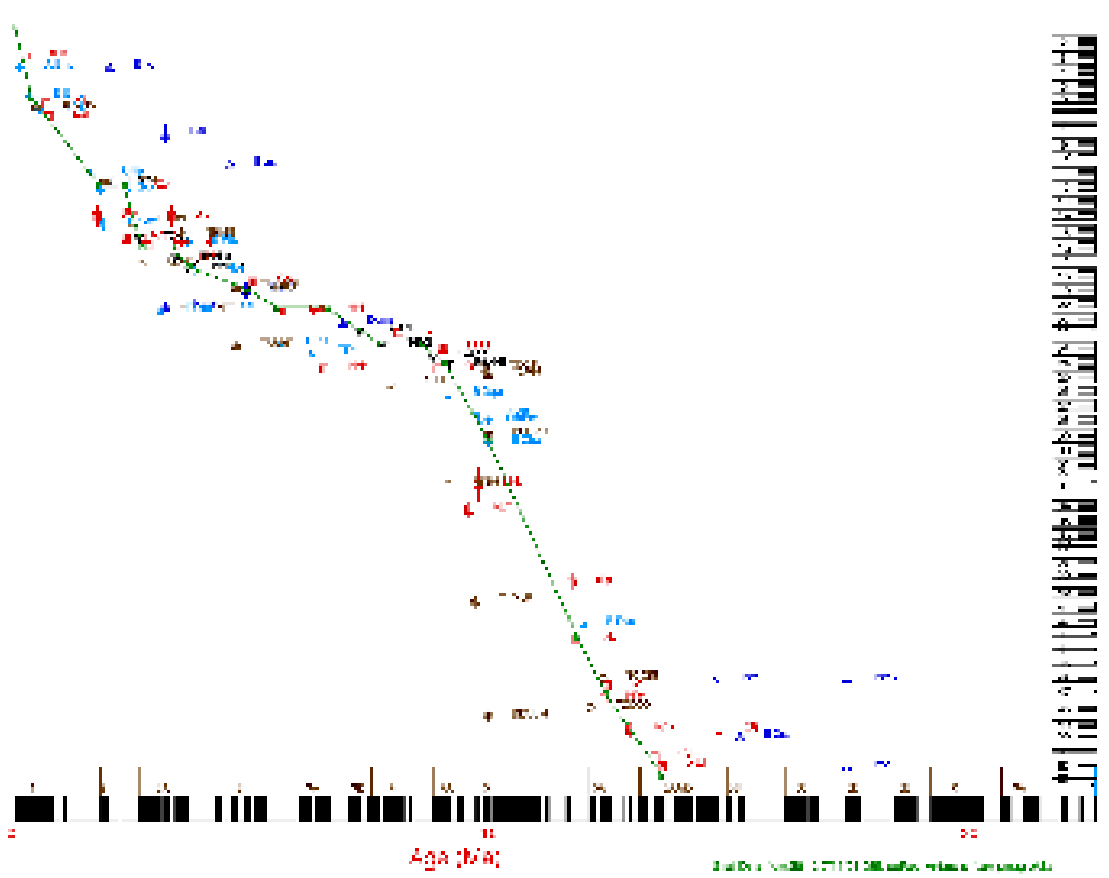

Next Section... 
To download full-size diagrams, open the following directory and choose the file (named by hole number). File naming convention is 62A_PICT.GIF (62A = hole number).

DIRECTORY: adps app

\section{Holes 603C-699A}

603C 19952507

AGE DEPTH

10

1.616730881 .22511

1.9515828542 .2665

2.5774385980 .245

$3.023374 \quad 115.773$

$3.294965 \quad 140.888$

$3.7374125 \quad 192.343$

$4.34467615 \quad 233.384$

4.69230375268 .952

$5.226125 \quad 312.5$

$6.021494 \quad 367.534$

\section{6}

AGE DEPTH

15

$1.5038 \quad 0$

$1.77882 \quad 17.3387$

1.9634935 .4839

2.3024169 .3548

$2.5227 \quad 70.5645$

2.5636181 .4516

3.0363115 .323

3.34352141 .935

$3.6962 \quad 195.161$
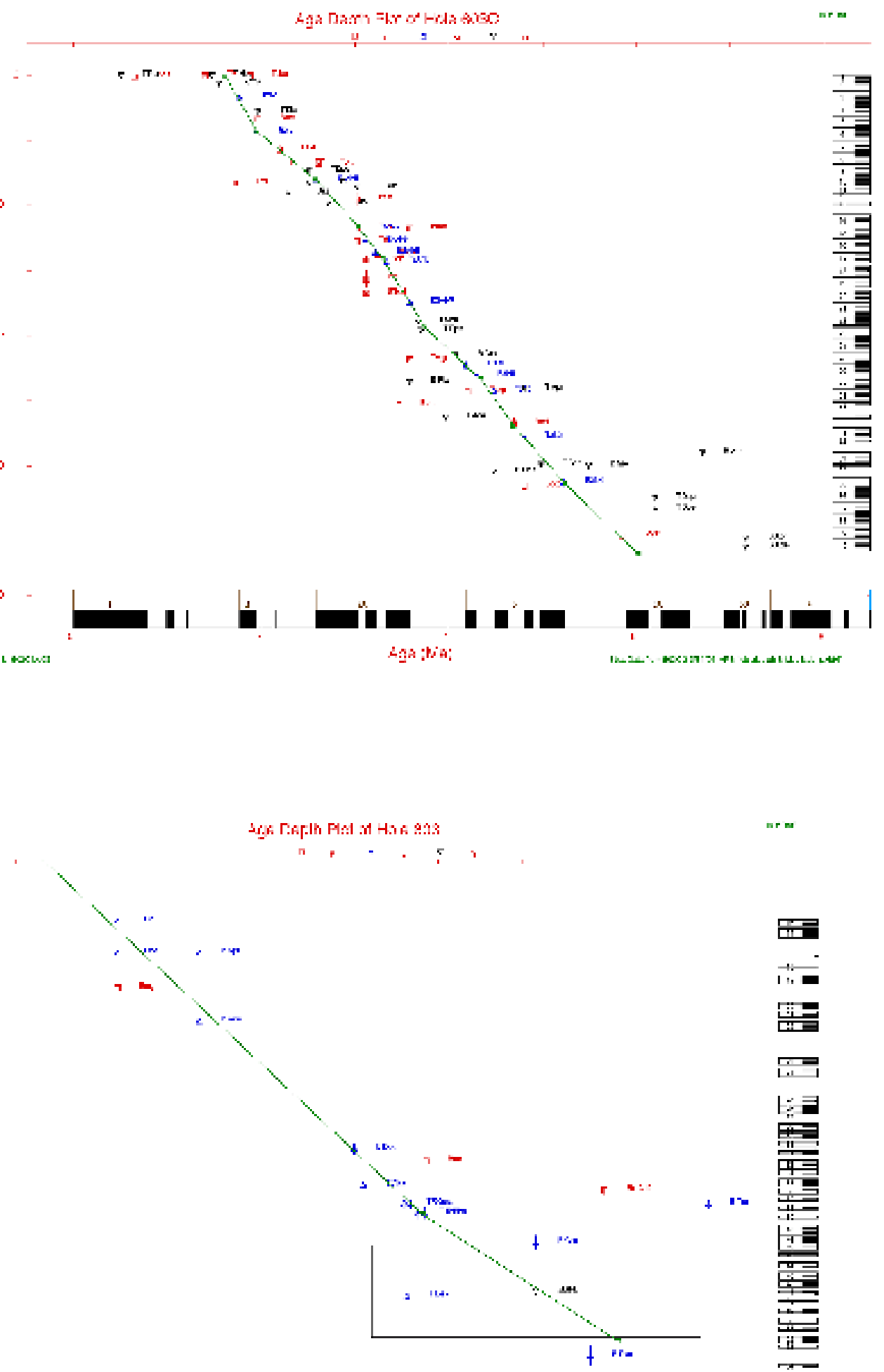

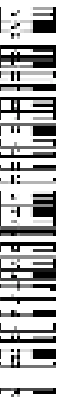


4.05271215 .726

4.49092239 .919

$4.81995 \quad 263.4$

5.28041296 .478

$9.81513 \quad 667.534$

$12.1318 \quad 798.775$

\section{8}

AGE DEPTH

9

$43.3794 \quad 240.429$

$50.5845 \quad 446.248$

$52.8445 \quad 537.879$

$54.8025 \quad 564.394$

$57.4874 \quad 622.833$

$59.6775 \quad 731.394$

62.2269731 .394

63.8025743 .682

$65.3046 \quad 765.742$

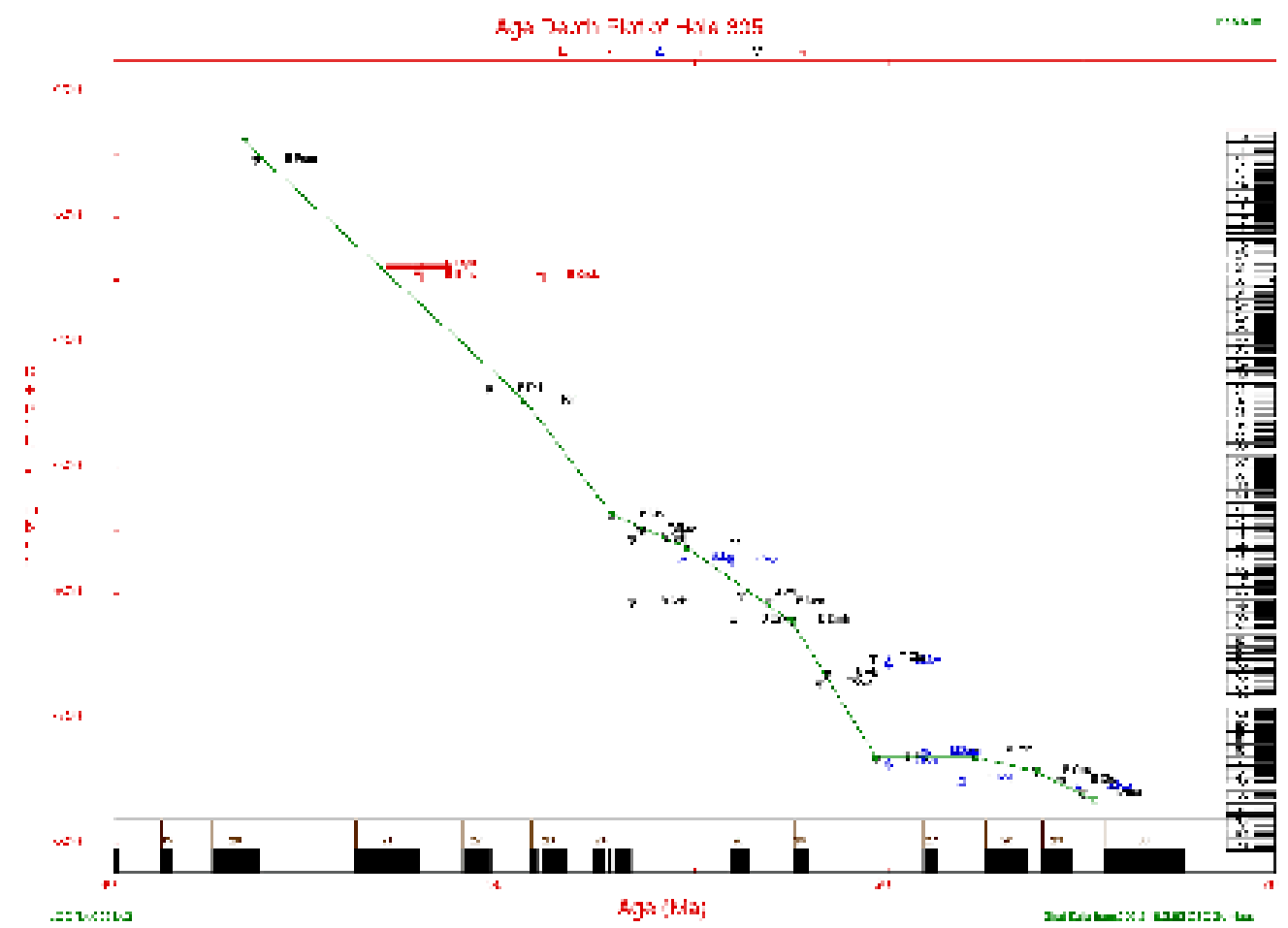

\section{7}

AGE DEPTH

15

$0 \quad 0$

$0.3232117 \quad 5.91397$

0.5114331810 .6183

0.7836143320 .0269

$0.9662945 \quad 23.3871$

1.0777679424 .0591

$1.762825 \quad 52.957$ 


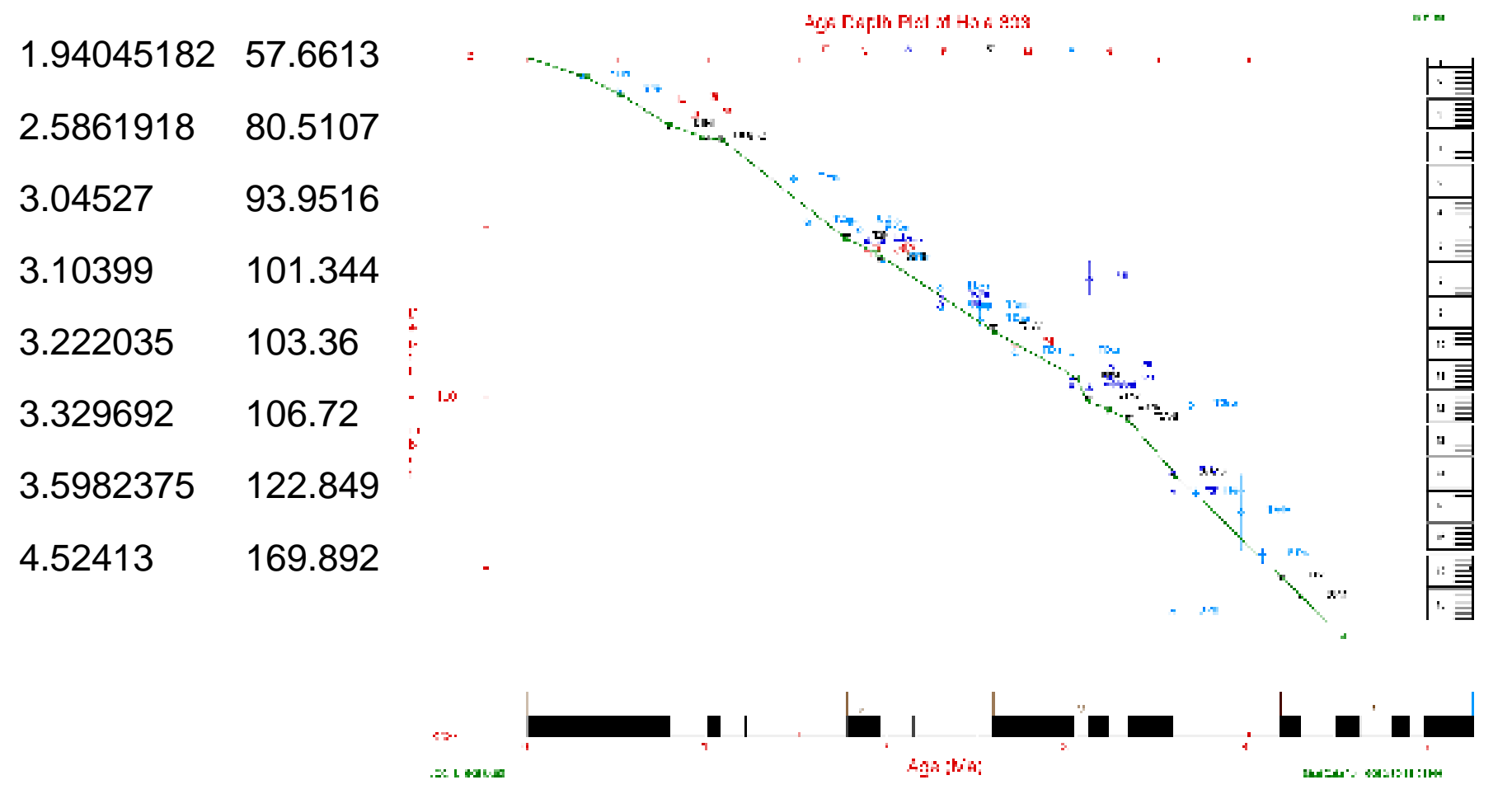

\section{7}

AGE DEPTH

19

$0.41637148 \quad 14.5161$

$0.77760658 \quad 34.2742$

$1.08509426 \quad 46.5054$

$1.762825 \quad 72.8494$

$2.57905353 \quad 109.504$

$3.0362974 \quad 127.419$

3.35394318138 .71

3.57870455145 .661

$4.19835778 \quad 176.344$

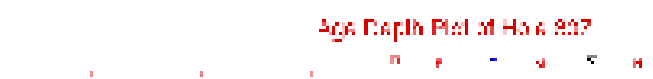

4.29730769180 .372

$4.48796 \quad 191.942$

$4.6131 \quad 194.22$

4.80438429202 .066

$4.900989 \quad 208.333$ 
$4.976319 \quad 210.744$

5.23312538223 .76

5.37928552238 .507

$5.9916185 \quad 238.507$

$6.7584515 \quad 279.764$

608A 19952507

AGE DEPTH

8

$0 \quad 0$

$0.7785554 \quad 18.0107$

$0.995248 \quad 21.371$

1.0796517622 .9862

$1.77002455 \quad 34.7741$

$2.730124 \quad 60.4126$

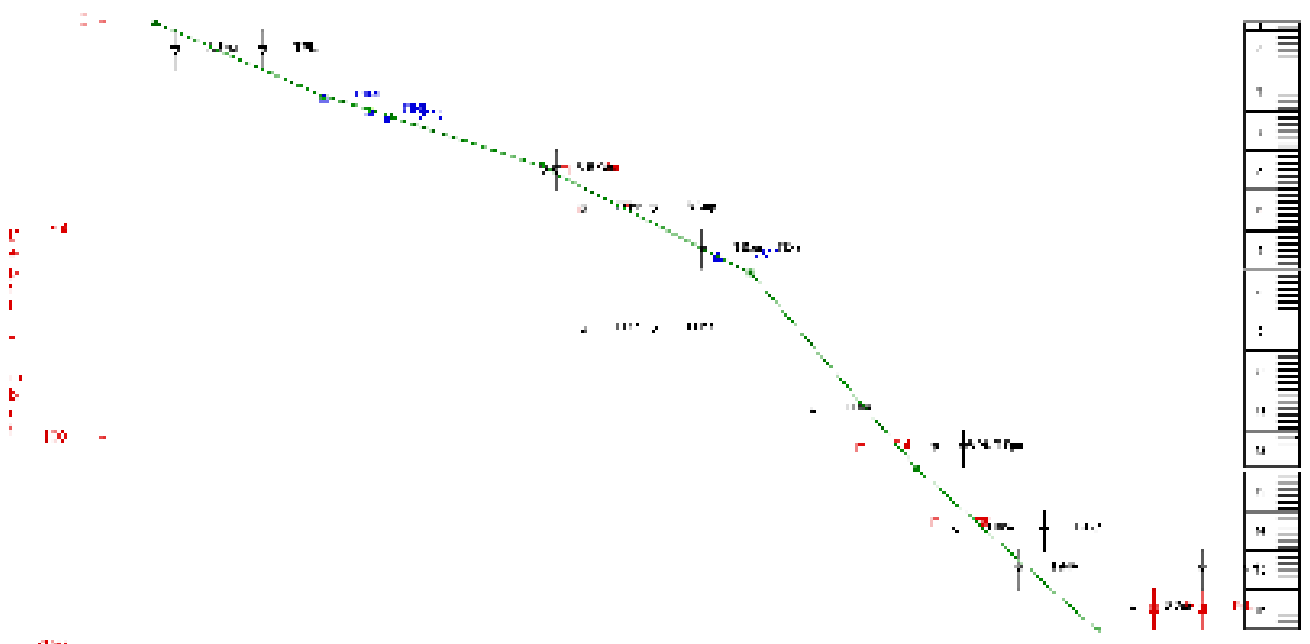

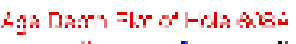

$3.48914773 \quad 107.269$

4.32025385146 .169

60819950802

AGE DEPTH

24

-7.1163e-3 . 134415

$1.07777 \quad 20.0269$

$1.76831 \quad 48.9247$

$1.94845 \quad 55.6451$

$2.59073 \quad 84.543$

$3.01543 \quad 92.6075$

$3.09687 \quad 101.344$

$3.586 \quad 110.081$ 


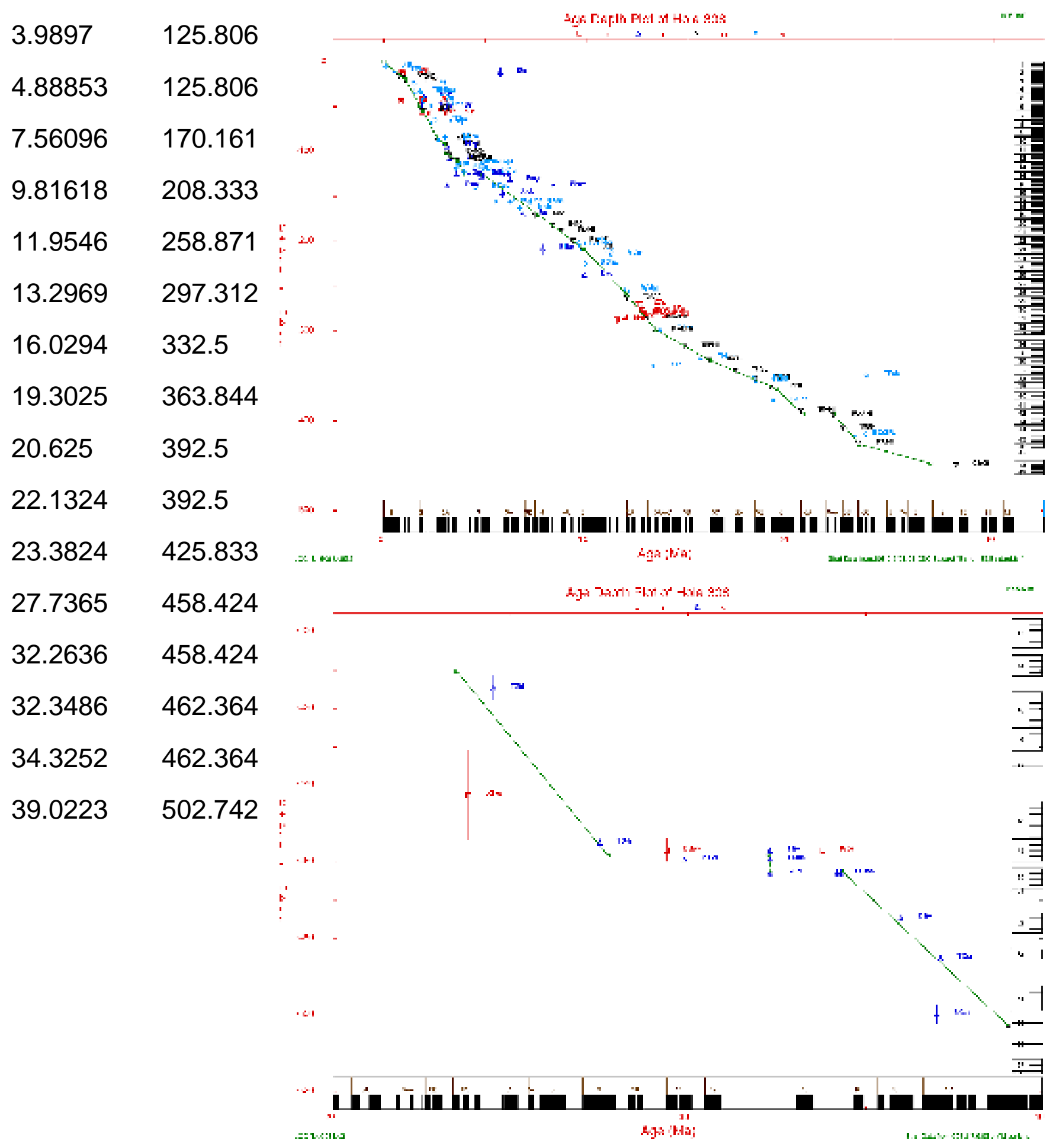

60919952507

AGE DEPTH

19

$0 \quad 0$

$0.78361317 \quad 43.9516$

0.9980537156 .8181 


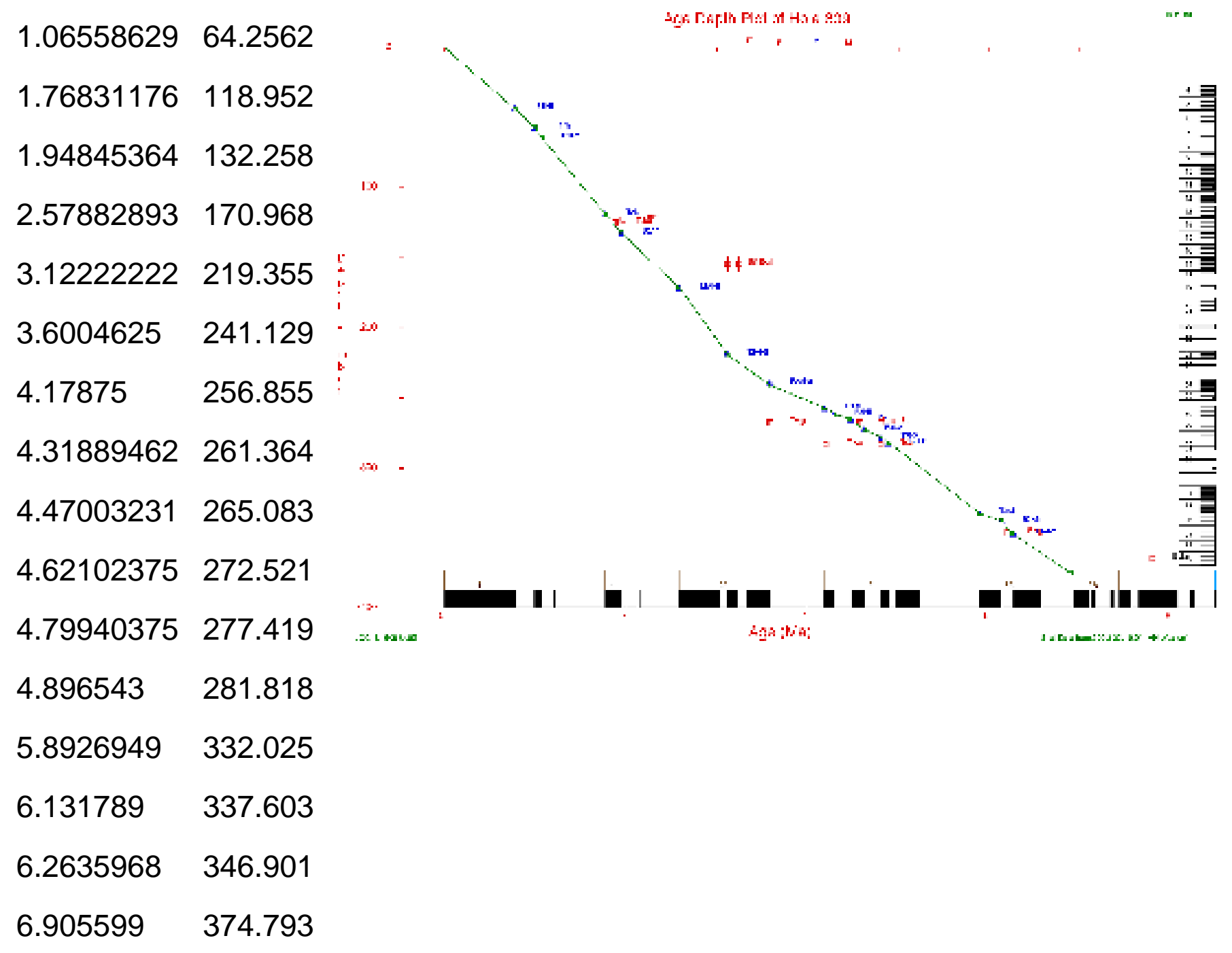

610A 19952507

AGE DEPTH

10

$\begin{array}{ll}7.1044 \mathrm{E}-07 & 9.6876 \mathrm{E}-08 \\ 0.78048067 & 42.7308 \\ 1.77002455 & 91.8467 \\ 1.96329378 & 100.196 \\ 2.5878952 & 127.701 \\ 3.04705 & \\ 151.747 & \end{array}$

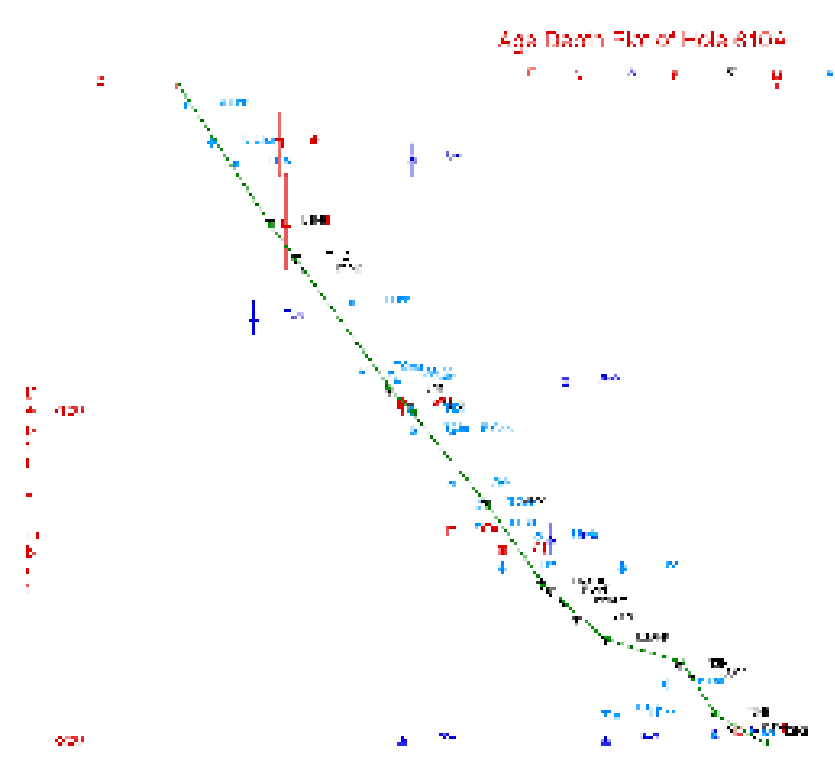

$3.5879625 \quad 168.959$

4.20923556175 .269

4.4921

191.398

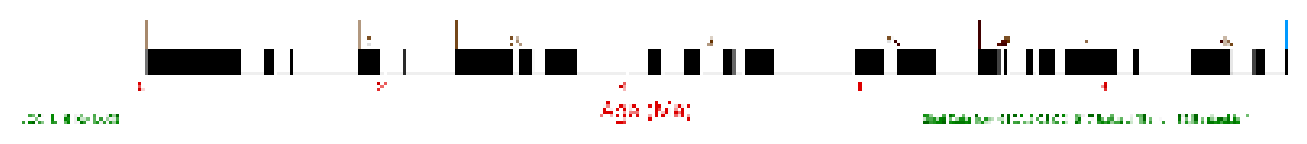


$4.894887 \quad 199.902$

61019952407

AGE DEPTH

14

7.1044E-07 9.6876E-08

$0.78048067 \quad 42.7308$

1.7700245591 .8467

1.96329378100 .196

$2.5878952 \quad 127.701$

$3.04705 \quad 151.747$

3.5879625168 .959

4.20923556175 .269

$4.4921 \quad 191.398$

$\cdots$

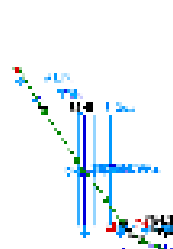

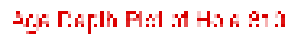

$4.77957 \quad 199.018$

16.7284281653 .831

17.3728691671 .12

18.2655609678 .978

$19.6353798 \quad 721.414$

\section{8}

AGE DEPTH

10

$22.423 \quad 119.142$

23.7832138 .285

33.4325138 .285

35.5579182 .695

$42.1041 \quad 182.695$

$44.6121 \quad 320.521$

$49.0755 \quad 320.521$ 
$50.4729 \quad 549.833$

66.1211549 .833

$68.406 \quad 566$

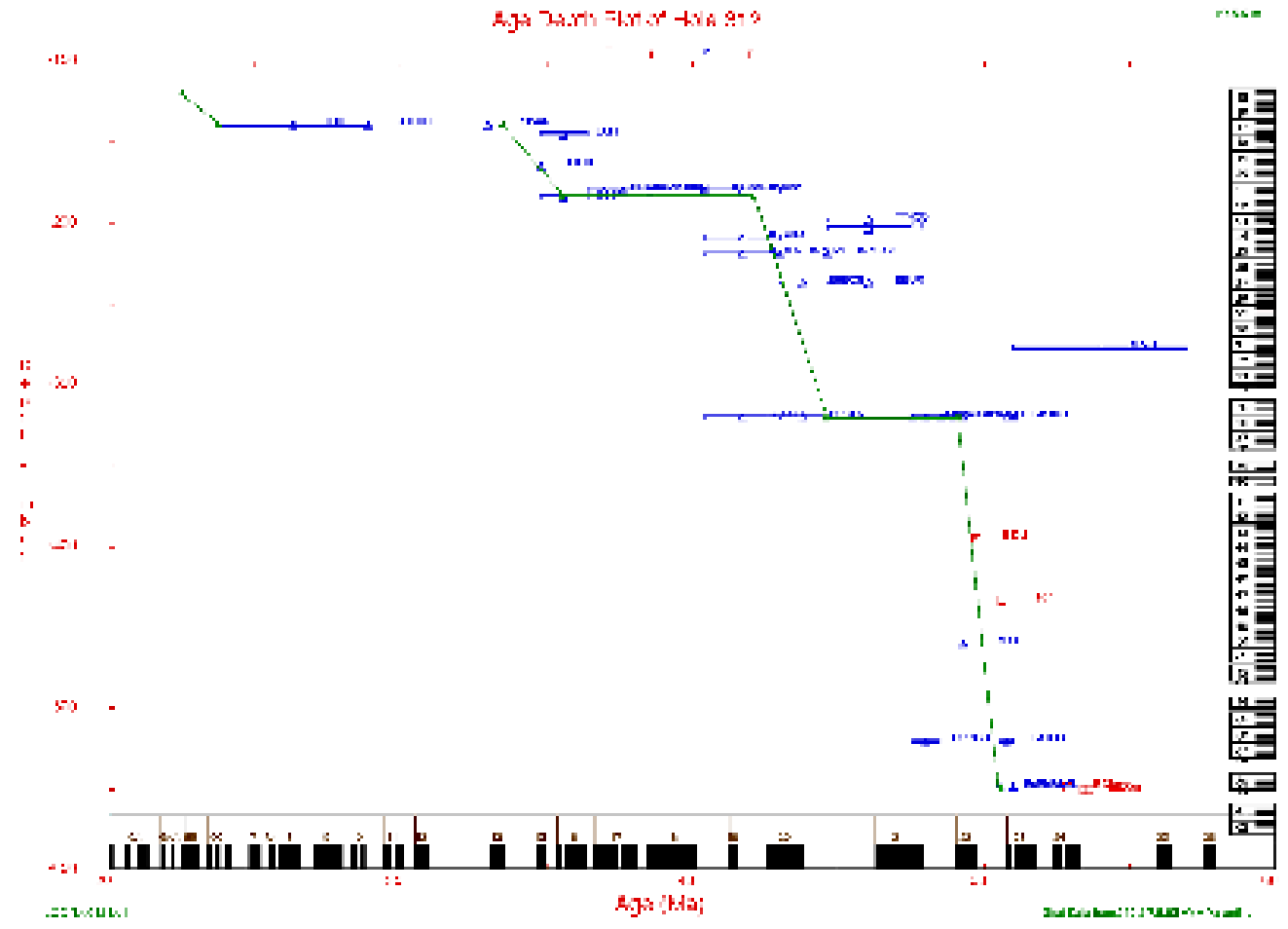

\section{A 19950718}

AGE DEPTH

13

23.7832120 .214

$24.5058 \quad 136.753$

$27.4814 \quad 136.753$

30.0319185 .452

$33.5175 \quad 255.283$

35.983436 .294

$36.0255 \quad 437.213$

37.0882437 .213

$38.0659 \quad 457.427$

$40.4038 \quad 457.427$

$\infty=1$
$\infty$
$\infty$
$\infty$

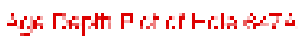

$41.2115 \quad 482.236$

$43.7194 \quad 609.035$

$53.5813 \quad 668.759$

\section{A 19950803}


AGE DEPTH

14

$-.008891 \quad .537641$

$.800717 \quad 22.9839$

$1.04983 \quad 32.3925$

2.6838375 .7576

3.71324110 .758

$4.81618 \quad 126.667$

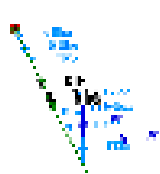

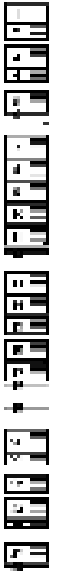

$6.17647 \quad 144.167$

$6.875 \quad 158.485$

$8.49265 \quad 159.015$

itin
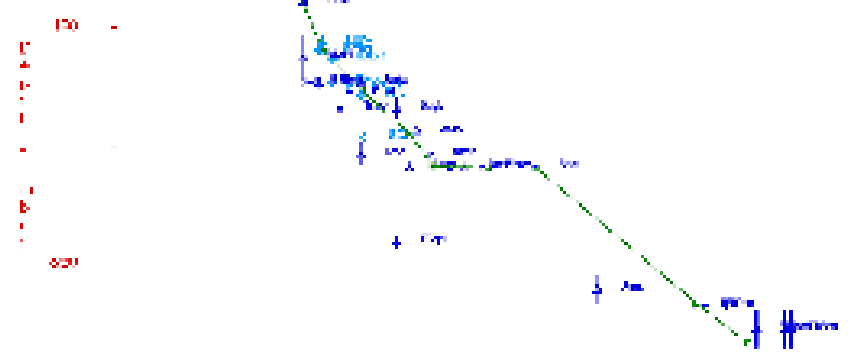

\section{|}

$9.88971 \quad 159.015$

$14.5588 \quad 215.758$

$16.0662 \quad 232.727$

$23.125 \quad 232.727$

$23.532 \quad 239.382$

\section{B 19950802}

AGE DEPTH

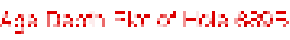

59

2.98552e-2 3.78784e-2

.169284

$5.79708 \mathrm{e}-2$

3.83359

$5.79708 \mathrm{e}-2$

4.2905

4.43182

4.47897

8.71212

4.62747

9.73485

4.79309

11.4394

$4.88448 \quad 11.8182$

4.98157

15.1894

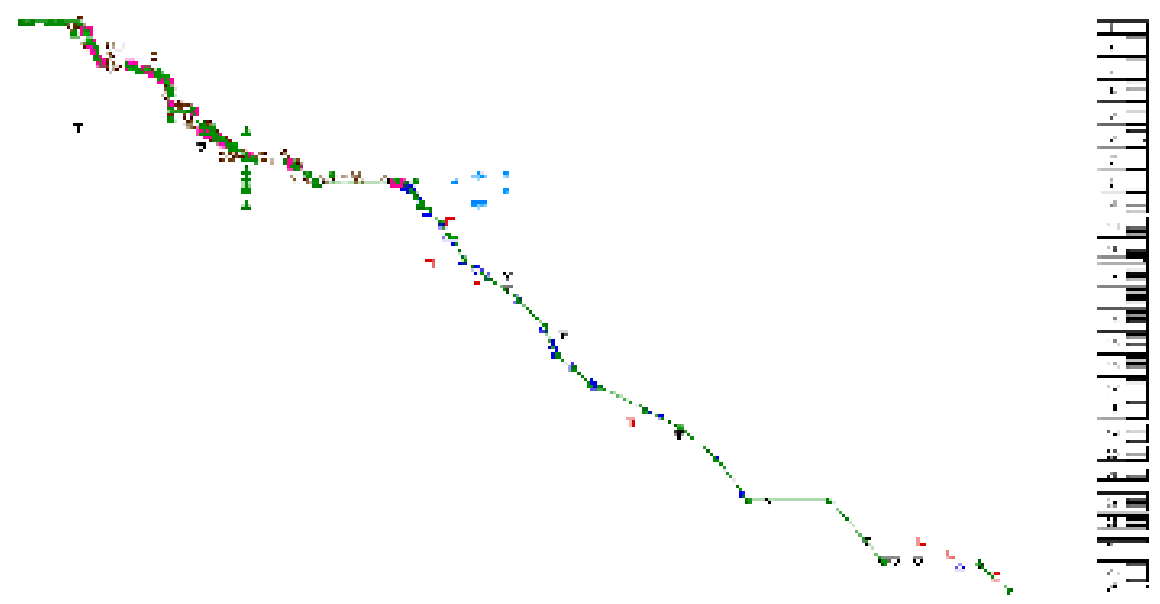


$5.31542 \quad 17.7795$

$7.09735 \quad 17.7795$

$7.16589 \quad 18.8208$

$7.42861 \quad 19.0046$

$8.26817 \quad 20.1685$

$8.70223 \quad 22.2511$

$9.31906 \quad 23.7825$

$9.5932 \quad 23.7825$

$9.73598 \quad 24.7014$

$9.83824 \quad 29.8333$

$9.88235 \quad 34.3333$

$9.88971 \quad 37.3333$

$11.3971 \quad 37.3333$

11.948546.

$12.83 \quad 48.55$

$13.01 \quad 48.8$

$13.2 \quad 49.55$

$13.46 \quad 50.77$

$13.69 \quad 51.8$

$14.08 \quad 52.27$

$14.2 \quad 52.55$

$15.1471 \quad 57.2727$

$15.7604 \quad 58.7862$

$17.7237 \quad 58.7862$

$18.2553 \quad 61.2273$

$19.5841 \quad 67.0455$

$24.8388 \quad 67.0455$

$25.625 \quad 68.7576$

$26.0063 \quad 70.3333$ 


\begin{tabular}{ll}
26.5609 & 76.0303 \\
27.0347 & 79.303 \\
27.9706 & 84.8788 \\
28.2941 & 89.8485 \\
28.7673 & 91.8182 \\
29.4034 & 100.273 \\
30.9286 & 106.818 \\
33.0712 & 116.818 \\
34.7184 & 128.182 \\
35.5898 & 139.667 \\
36.6844 & 145 \\
37.8534 & 152.273 \\
38.4378 & 153.182 \\
41.5728 & 162.727 \\
43.9107 & 170.909 \\
46.2487 & 183.182 \\
48.2511 & 201 \\
53.792 & 201 \\
57.3487 & 227 \\
63.6134 & 227 \\
65.8555 & 239.545 \\
\hline 3
\end{tabular}

690 B 19950802

AGE DEPTH

48

$\begin{array}{ll}0 & 0 \\ .172814 & 1.93308 \\ 2.41719 & 1.93308 \\ 2.59424 & 4.96212\end{array}$


$3.0283 \quad 6.59091$

3.119687 .00757

$4.18769 \quad 10.2651$

$4.2905 \quad 10.5303$

$4.48468 \quad 11.25$

4.6160411 .7803

4.9758618 .3333

5.2982919 .053

8.7079419 .053

9.0220720 .1136

$9.71198 \quad 22.0074$

9.9392529 .697

$11.662 \quad 29.697$

$12.1926 \quad 33.5606$

$13.4938 \quad 37.9545$

$15.1404 \quad 43.75$

$17.4219 \quad 43.75$

$17.6176 \quad 44.6212$

$17.8741 \quad 45.7576$

$18.2858 \quad 46.6288$

20.208250 .9697

$25.5768 \quad 50.9697$

$26.1594 \quad 56.9091$

$26.5592 \quad 60.25$

$27.0047 \quad 61.0985$

30.095673 .8897

$30.4727 \quad 80.9091$

30.998983 .8438

32.442291 .5454 
$36.3456 \quad 91.5454$

36.619796 .5682

37.615599 .4545

38.2742101 .553

$40.4107 \quad 101.553$

42.5389106 .273

43.6712118 .636

$47.2416 \quad 118.636$

$49.1711 \quad 131.7$

$\begin{array}{lll}51.6419 & 131.7\end{array}$

$52.678 \quad 139.74$

$52.8905 \quad 154.671$

$55.9724 \quad 185.299$

56.3975195 .635

58.1509216 .692

\section{A 19930913}

AGE DEPTH

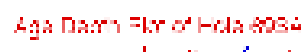

9

$2.12766 \mathrm{e}-6 \quad 7.14451 \mathrm{e}-8$

1.08396

29.1217

3.20935

29.1217

4.65462

104.006

8.20404

197.843

$10.1594 \quad 241.654$

$11.9235 \quad 263.944$

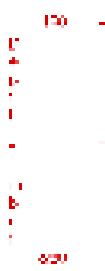

$25.1753 \quad 263.944$

$26.5994 \quad 278.867$

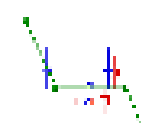

2
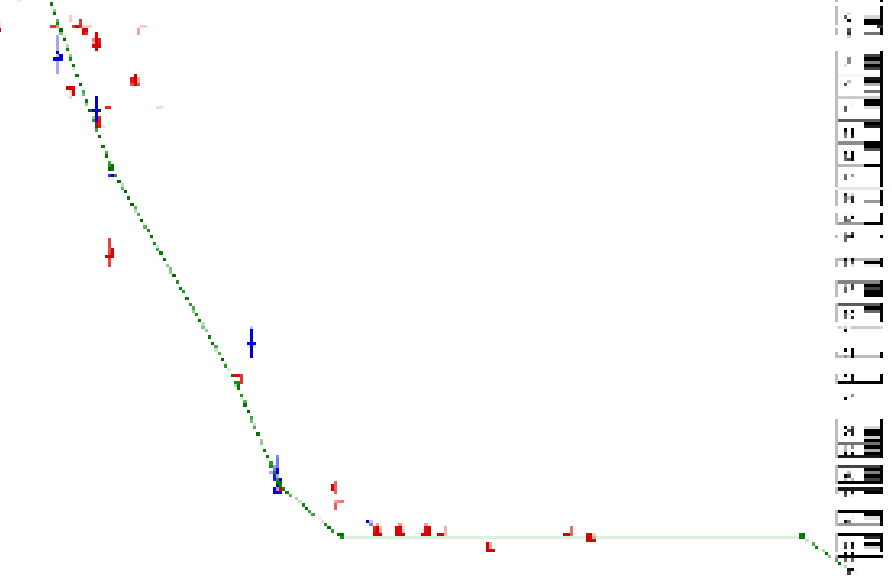

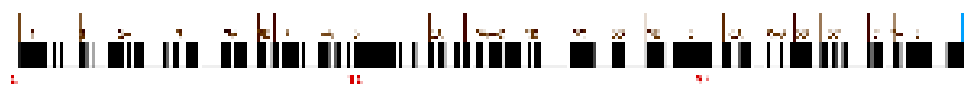
Las : is: 


\section{A 19950719}

AGE DEPTH

16

24.5

108.365

25.8449145

$27.067 \quad 167.5$

$28.7416 \quad 198.515$

$30.1488 \quad 216.667$

$32.8055 \quad 256.667$

$34.3996 \quad 328.333$

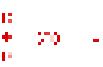

$35.9936 \quad 328.333$

37.0457351 .667

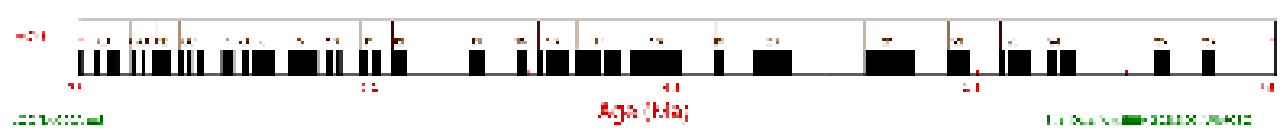

$40.3613 \quad 351.667$

41.0414396 .667

$46.2487 \quad 396.667$

$48.834 \quad 446.248$

49.9681470.

52.9012470.

$54.474 \quad 517.5$

Next Section... 
To download full-size diagrams, open the following directory and choose the file (named by hole number). File naming convention is 62A_PICT.GIF (62A = hole number). DIRECTORY: adps app

\section{Holes 700B-736A}

700B 19950719

AGE DEPTH

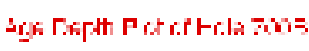

6

$20.3188 \quad 28.7902$

22.733658 .7424

$43.1137 \quad 58.7424$

$49.7556 \quad 167.228$

$57.6196 \quad 267.075$

6

$65.5898 \quad 342.42$

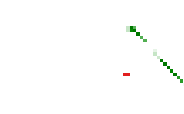

$4: 1$

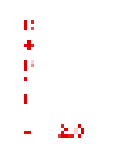

2

\section{b'}

-

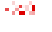

703A 19950719

AGE DEPTH

11

$24.1977 \quad 46.8606$

24.755653 .5988

28.262553 .5988

$28.7673 \quad 66.7687$

29.404978 .1818

30.122286 .3636

30.972495 .8652

$31.1583 \quad 97.5$

$32.1945 \quad 97.5$ 
$\begin{array}{ll}34.7184 & 131.087 \\ 40.8023 & 185.299\end{array}$

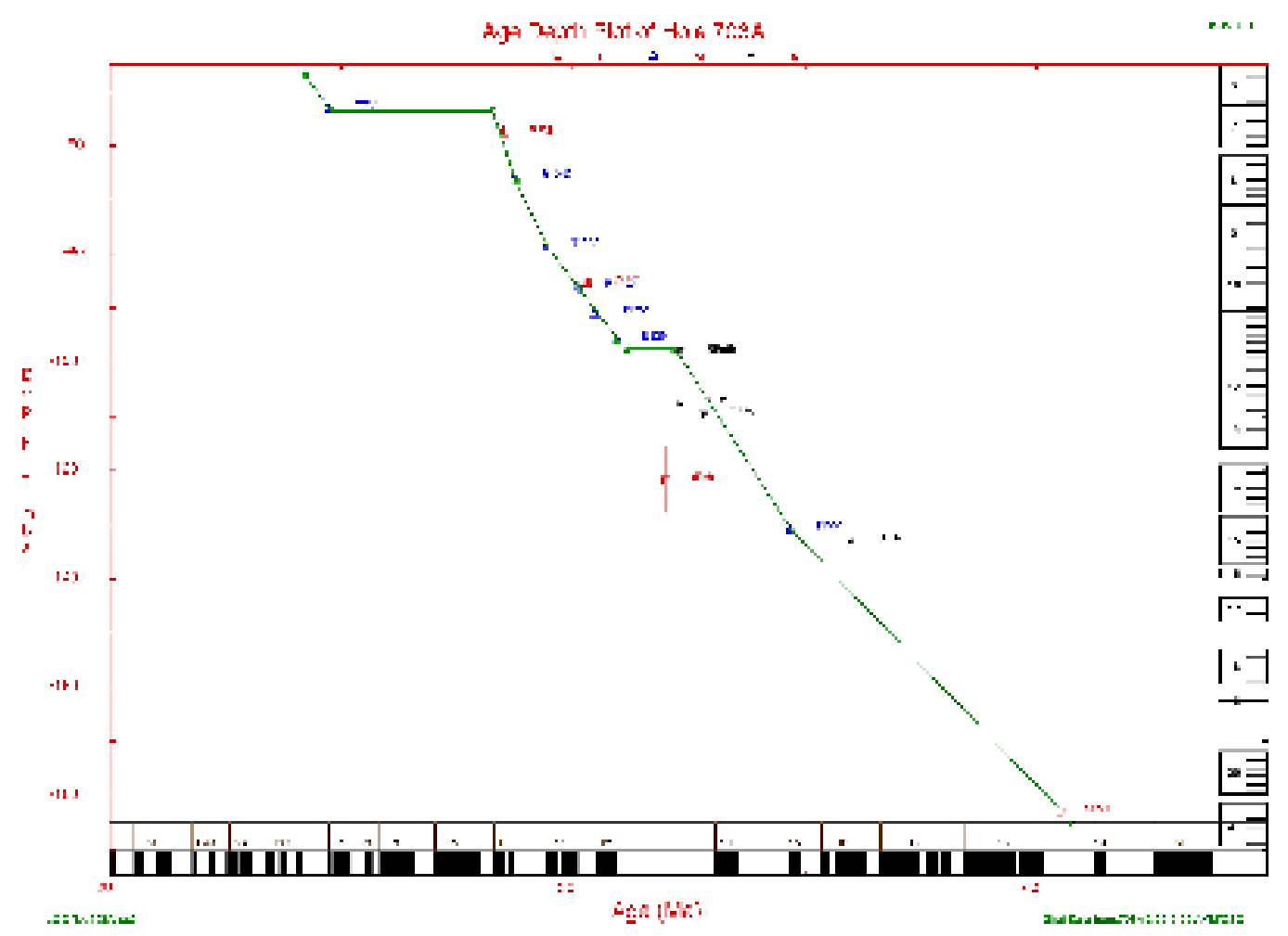

707A 19950720

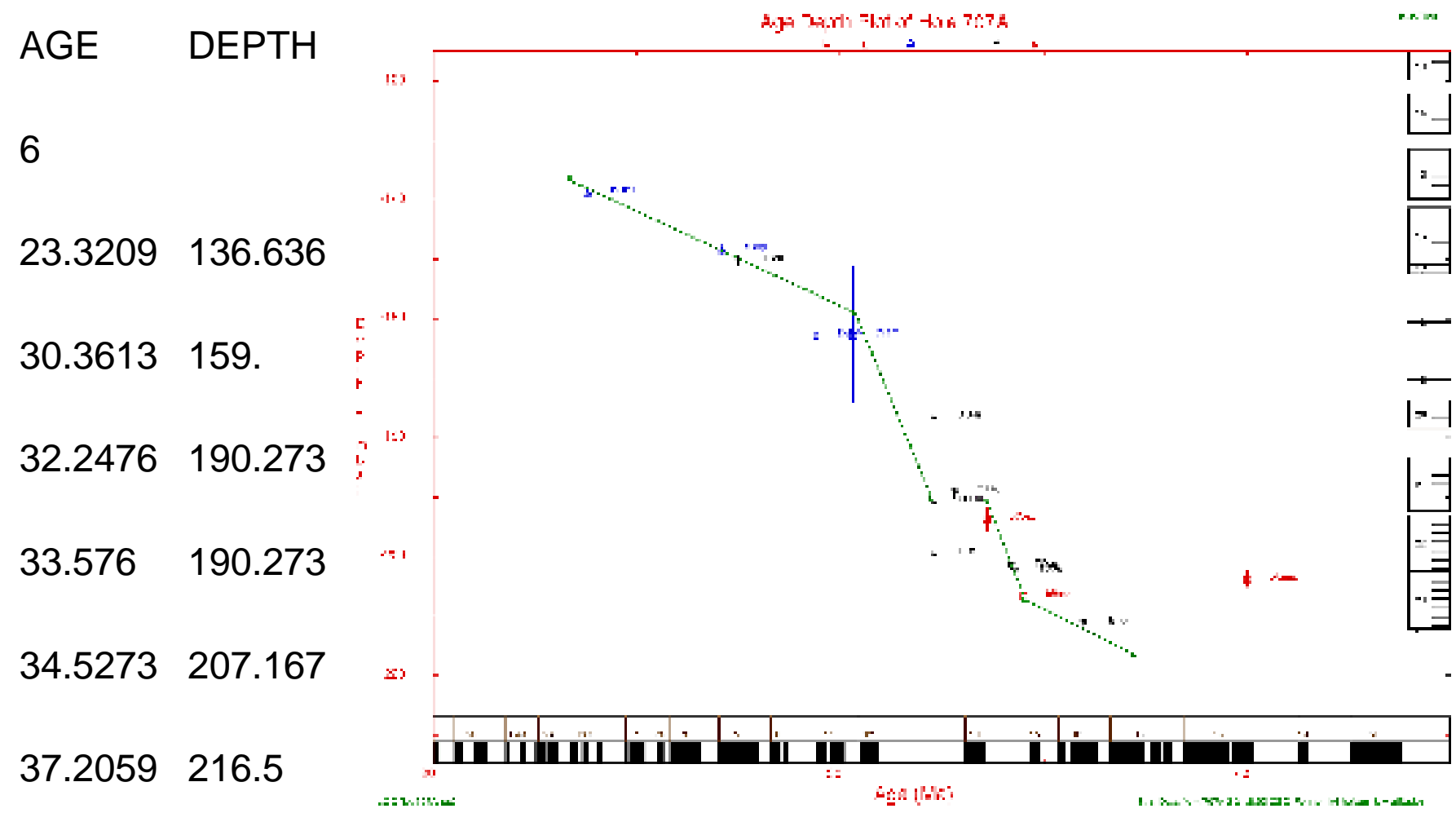

707C 19950720

AGE DEPTH

8 
$33.3794 \quad 195.833$

$40.4357 \quad 262.5$

$43.6451 \quad 262.5$

$53.661 \quad 320.455$

$58.1403 \quad 320.455$

$59.7715 \quad 367.727$

$64.9256 \quad 367.727$

66.0149373 .182

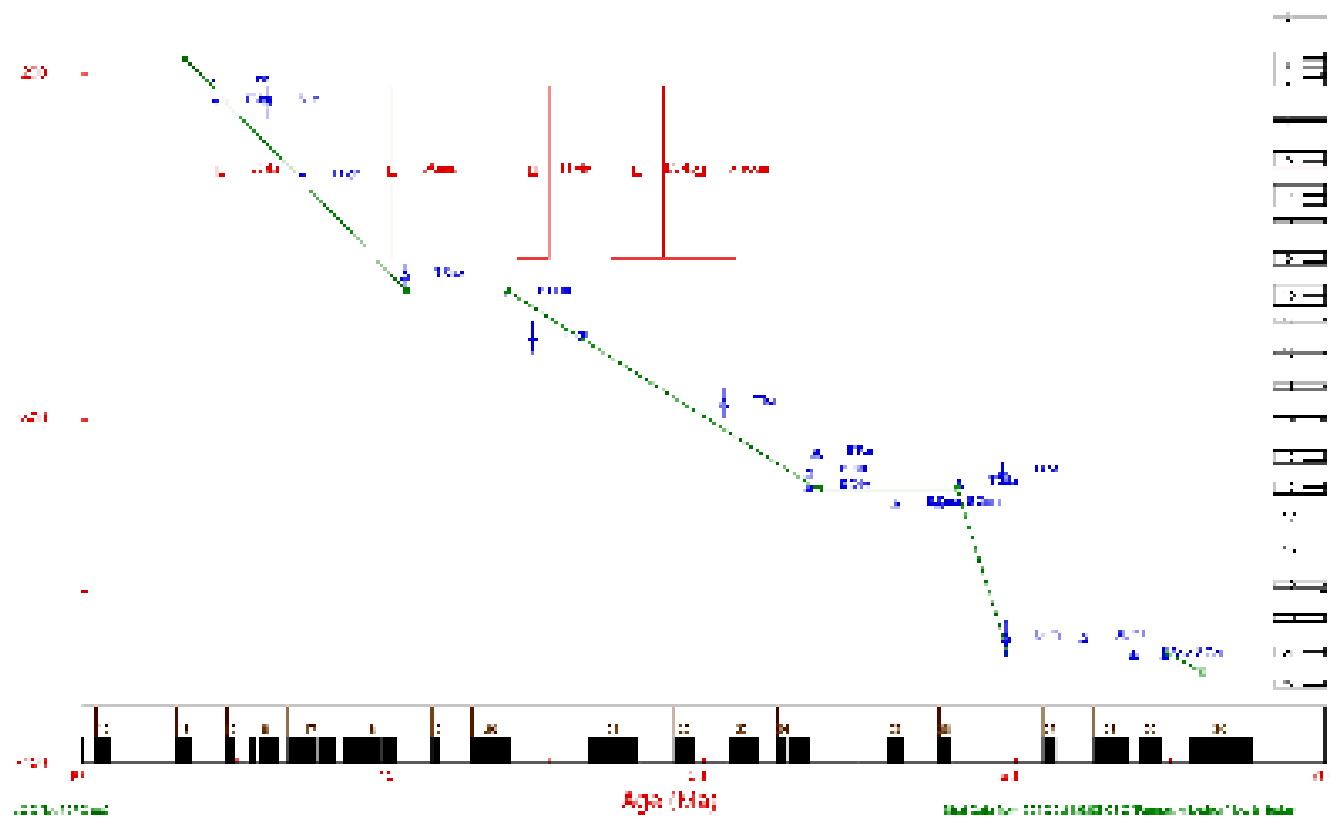

709A 19950803

AGE DEPTH

5

$.275 \quad 2.6$

1.9217120 .6989

$3.71324 \quad 34.5454$
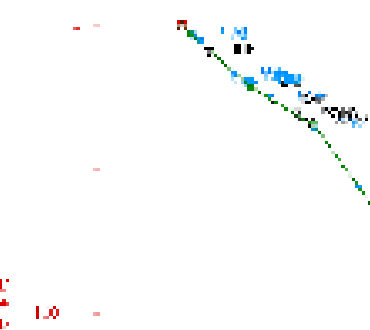

7.1691294 .0909

23.9706200.

\section{|}

709B 19950802

AGE DEPTH

11

$1.4958 \quad 15.5455$ 
$\begin{array}{ll}2.4916 & 24.0909 \\ 3.67647 & 33.9091 \\ 4.93698 & 54.2727 \\ 6.21008 & 62.4545 \\ 7.18067 & 91.3636 \\ 9.89496 & 113.409 \\ 11.1513 & 115.182 \\ 23.792 & 200.227 \\ 28.4958 & 220.955 \\ 30.4286 & 248.909\end{array}$

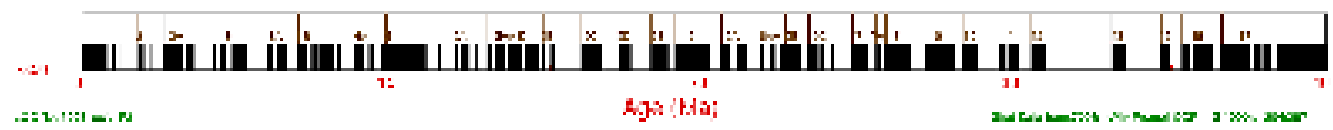

709C 19950720

AGE DEPTH

9

26.8571205 .667

33.021278 .333

$33.6134 \quad 278.333$

34.8361292.

36.0662292.

$37.0956 \quad 309.364$

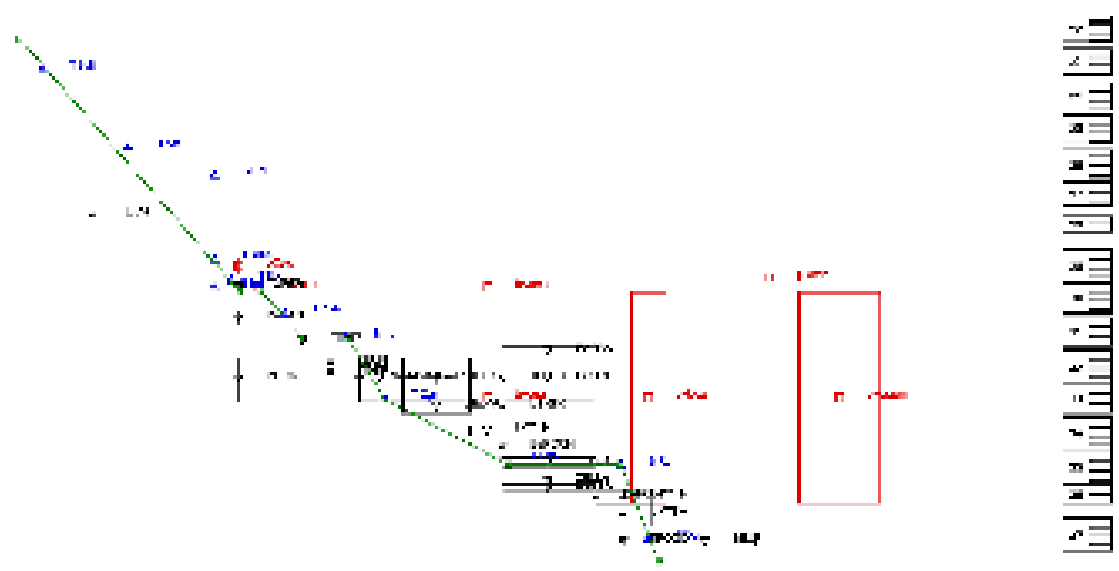

$40.562 \quad 328.273$

$43.7132 \quad 328.273$

$44.7794 \quad 356.439$ s. . |

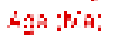

710 A 19950802

AGE DEPTH

23

.4149183. 
$1.80672 \quad 15.6667$

$4.30147 \quad 29.6667$

4.485333.

$4.6166 \quad 34.3333$

4.9842538.

$6.24475 \quad 49.6667$

6.5336252 .6667

$8.26681 \quad 66.3333$

$8.71324 \quad 74.3333$

$9.71114 \quad 80.5$

11.680793 .1667
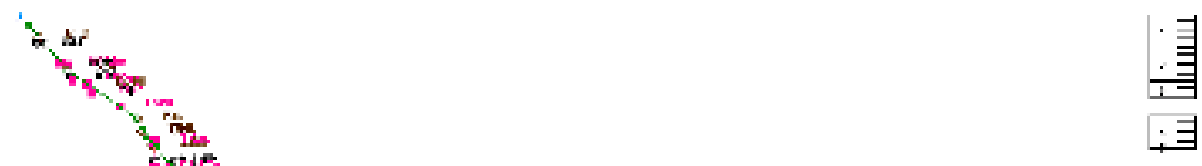

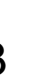

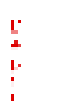

13.203893 .1667

14.175498 .8333

$14.8866 \quad 105.318$

$16.7647 \quad 111.864$

$20.105 \quad 118.273$

$22.4748 \quad 124.136$

23.7479143 .091

27.1092148 .712

28.5084193 .894

32.3025193 .894

32.7258195 .379

\section{B 19950803}

AGE DEPTH

16

$.28 \quad 2.45$

$1.60177 \quad 14.697$ 


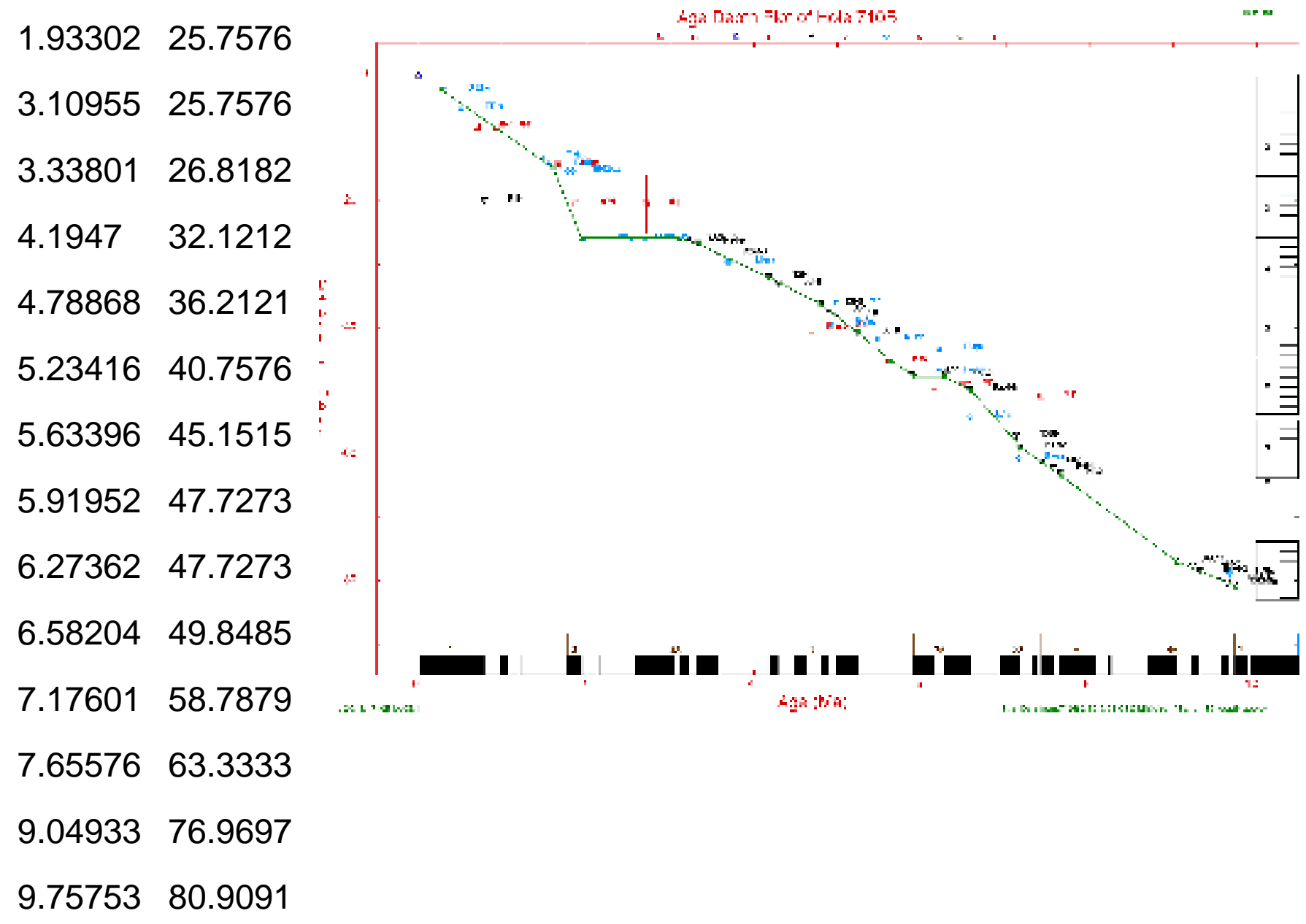

\section{A 19950720}

AGE DEPTH

10

$23.9426 \quad 85.5283$

$31.865 \quad 128.714$

$32.9748 \quad 153.682$

33.6504153 .682

$34.6546 \quad 163.936$

35.9936163 .936

$37.1376 \quad 176.97$

$40.3939 \quad 198.03$

$43.7553 \quad 198.03$

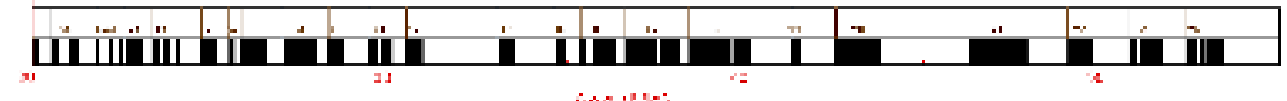

$45.2521 \quad 237.121$ 


\section{A 19950720}

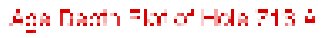

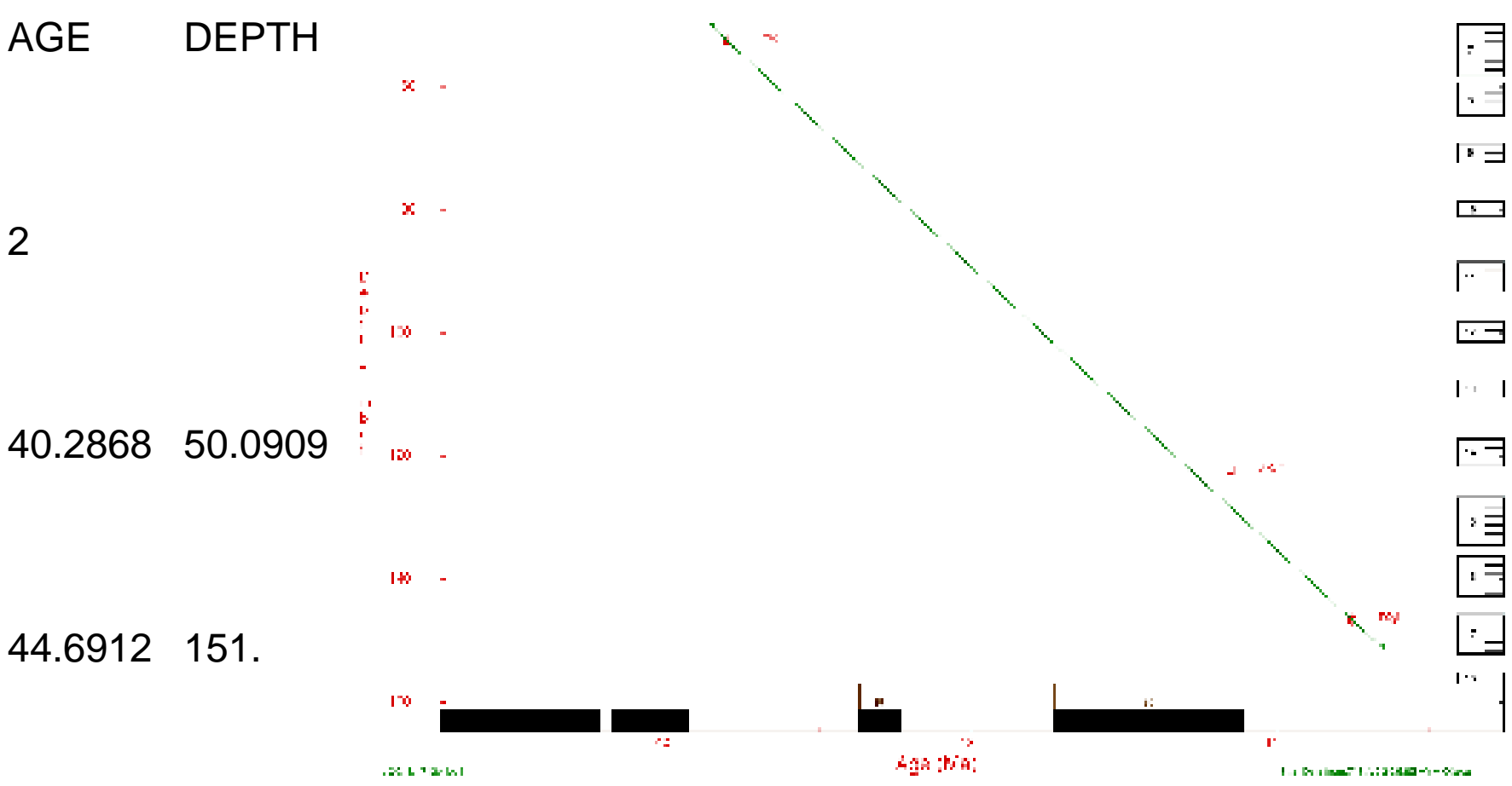

714A 19950720

AGE DEPTH

4

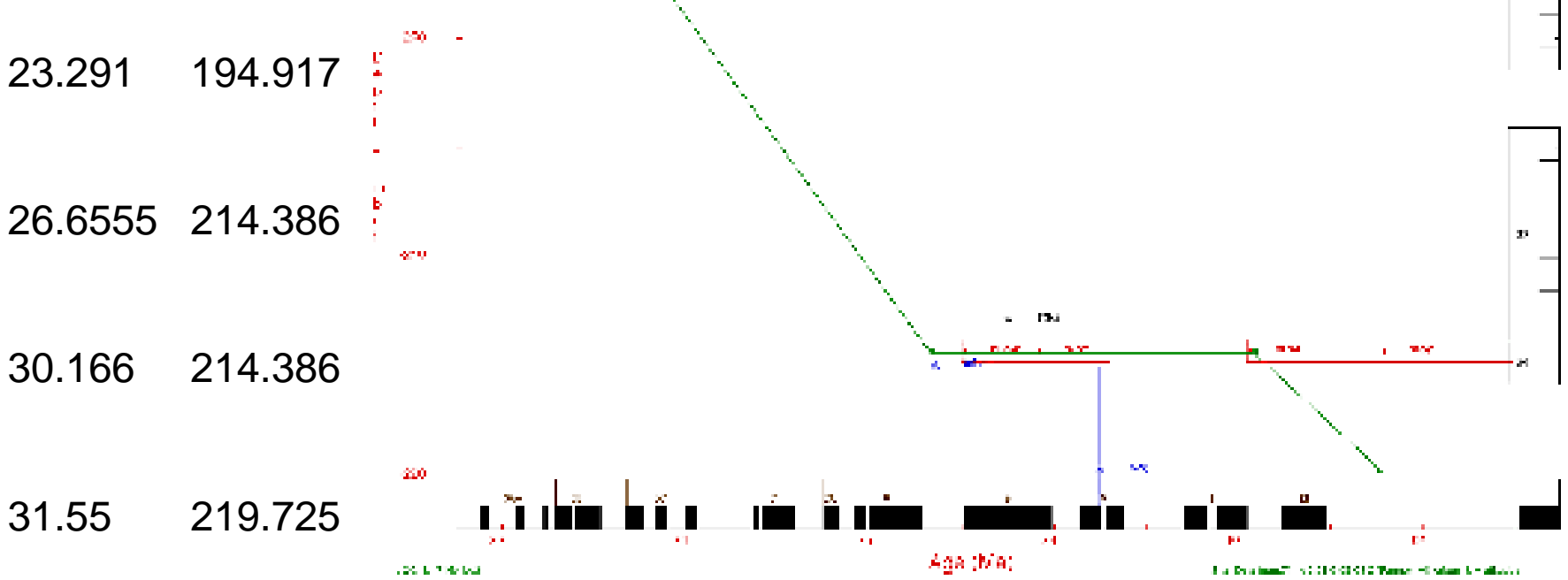

721A 19950729

AGE DEPTH 
4

.42393618 .7576

$1.06932 \quad 39.2424$

2.5885380 .0909

$2.84554 \quad 86.1515$

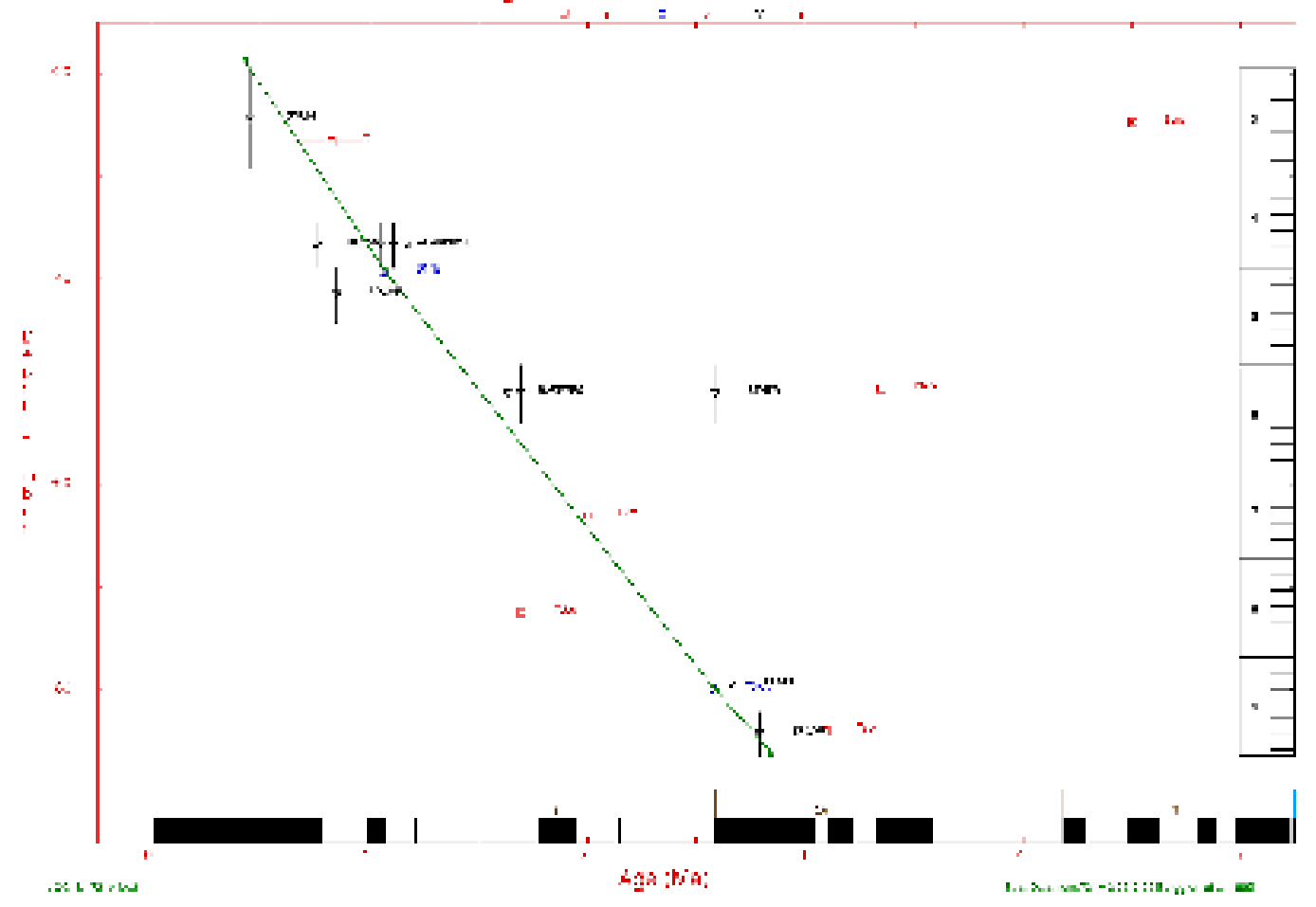

\section{B 19950731}

AGE DEPTH

9

1.8529478 .5606

in.

2.5929686 .3333

$3.59193 \quad 117.381$

4.48459137 .596

5.22848170 .061

$5.89496 \quad 207.427$

7.16177258 .333

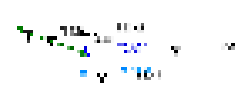

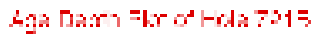

9.02941258 .333

$10.9671 \quad 315.85$
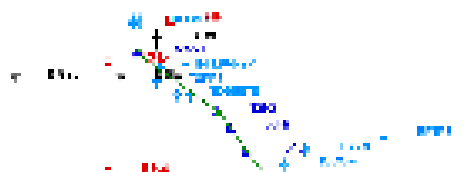

$\frac{1}{\vdots}$

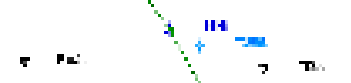

- 20
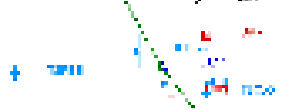

\section{A 19950731}

\section{AGE DEPTH}




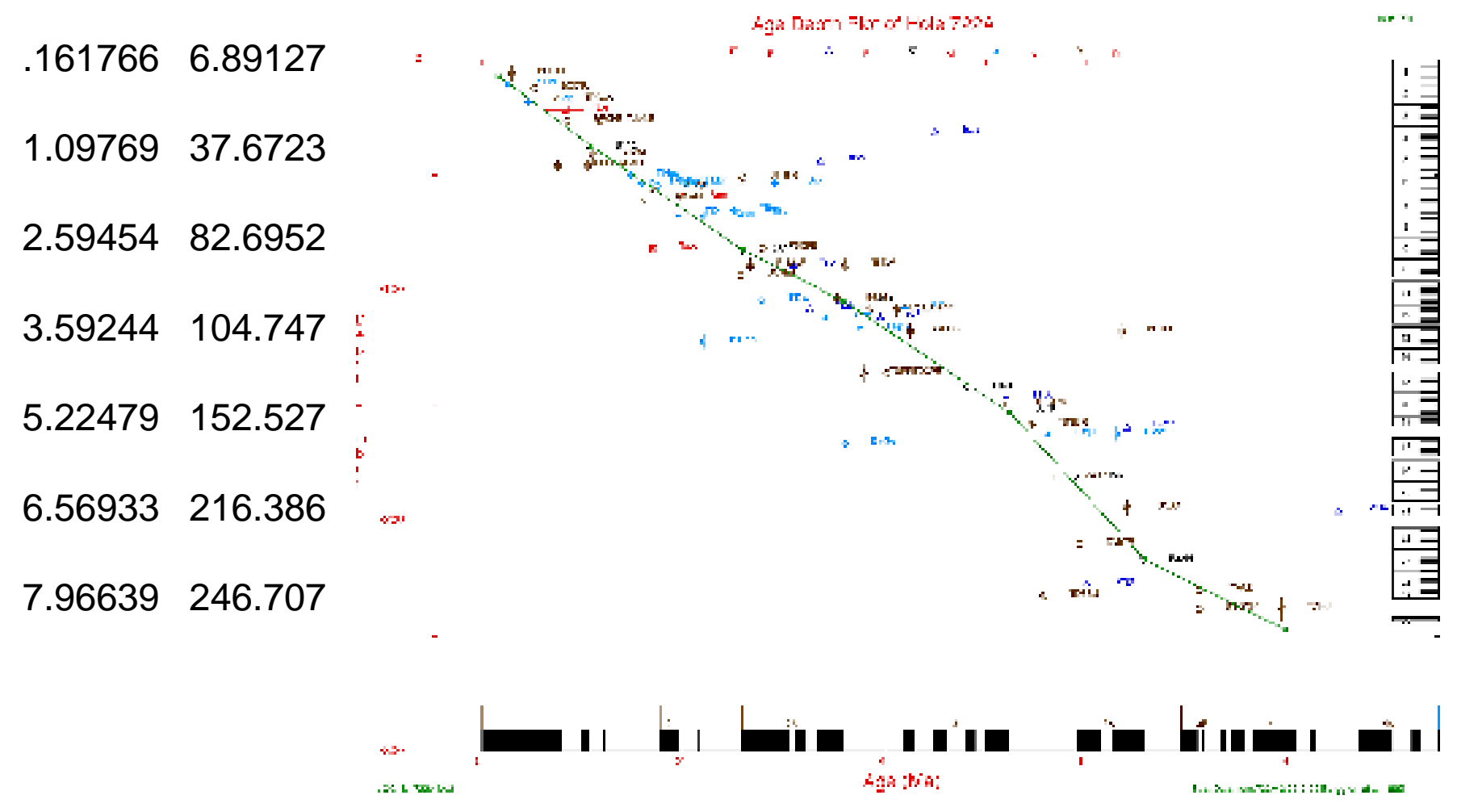

724B 19950729

AGE DEPTH

5

$.703257 \quad 60.4545$

$1.073 \quad 80.9091$

1.0

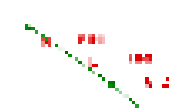

䁲

$1.47742 \quad 107.273$

$1.47742-107.273$

$1.95116 \quad 149.545$
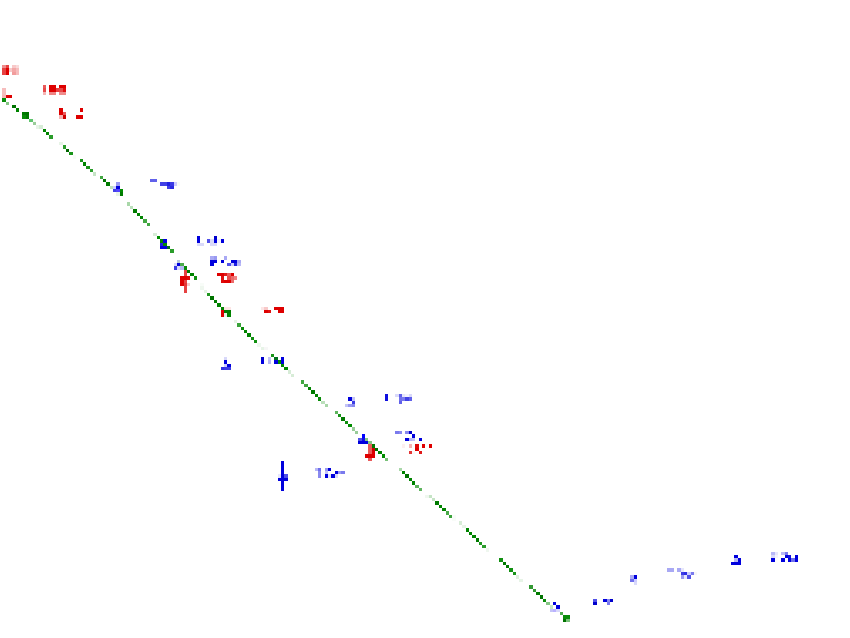

노

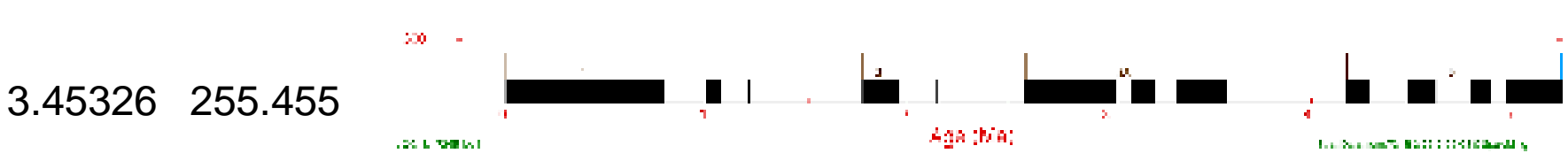

\section{A 19950729}
AGE
DEPTH

10

$8.40446 \mathrm{e}-3 \quad 1.83767$ 


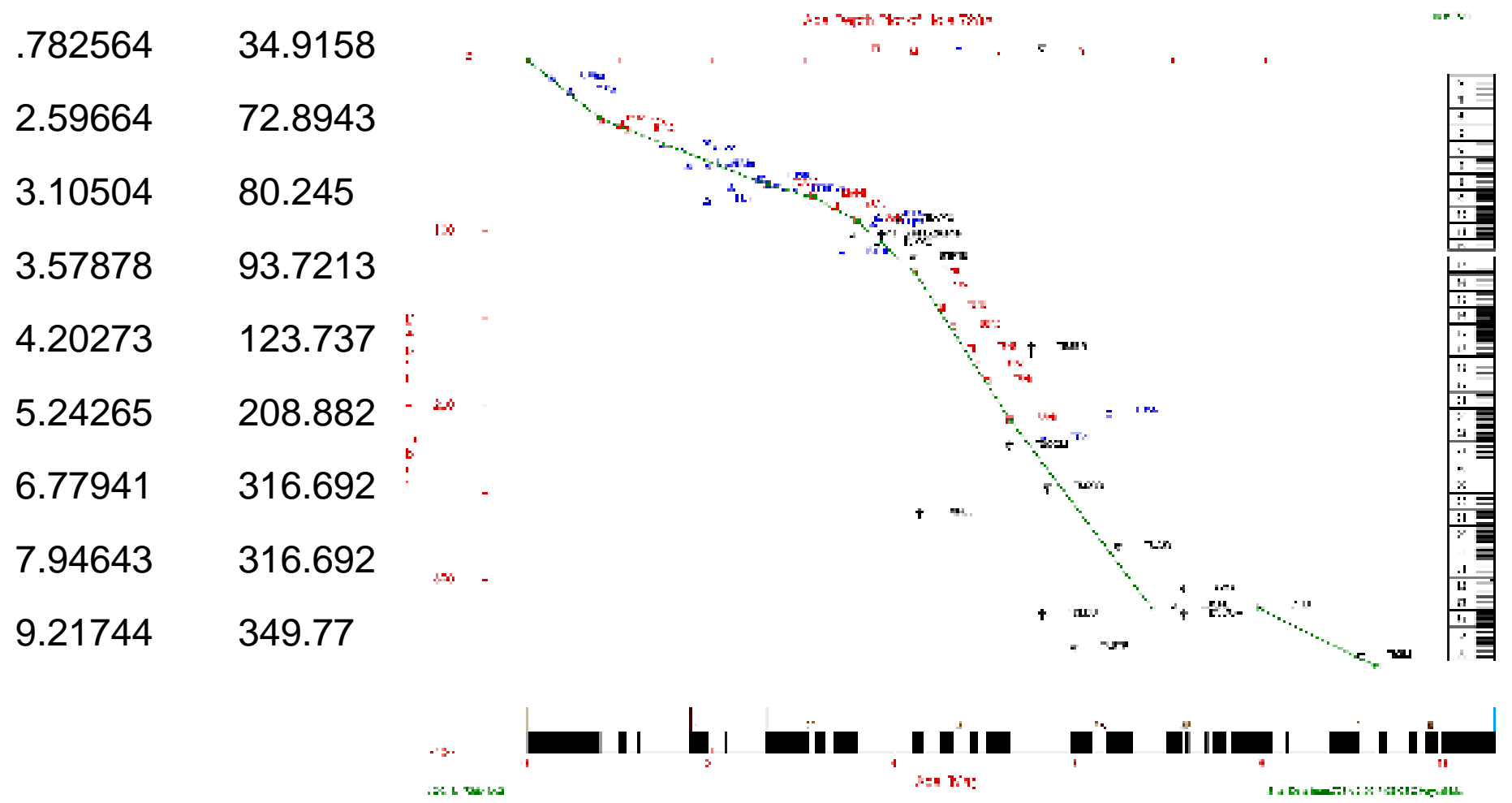

\section{A 19950731}

AGE DEPTH

8

.2247915 .51302

1.0294245 .9091

2.2794197 .0454

$5.55147 \quad 97.0454$

$9.01681 \quad 170.903$

9.85189245 .635

$11.25 \quad 245.635$

12.0221290

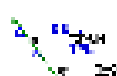

F,

P 3 in

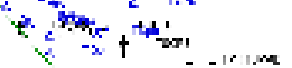

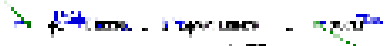

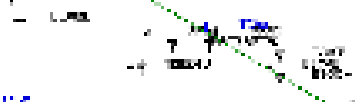

!

nomber

.

736A 19950730

AGE DEPTH 


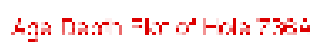

4

.1255265 .0536

$\begin{array}{lll}859244 & 39.9694 \\ 1.92227 & 150.23\end{array}$
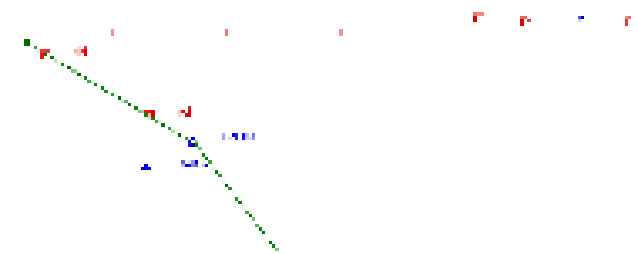

ב-

2.60399230 .168

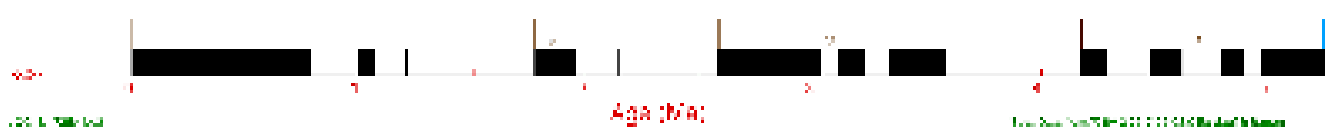

Next Section... 
To download full-size diagrams, open the following directory and choose the file (named by hole number). File naming convention is 62A_PICT.GIF (62A = hole number).

DIRECTORY: adps app

\section{Holes 737A-797B}

737A 19950730

AGE DEPTH

12

1.655462 .72728

1.956935 .83333

3.066185 .83333

3.3839321.

3.5861321.

$4.36607 \quad 65.5$

$4.61765 \quad 65.5$

4.8697596 .9697

6.07983131 .164

$7.60504 \quad 249.167$

10.6429249 .167

$10.7815 \quad 261.364$

\section{B 19950720}

AGE DEPTH

5

$24.0074 \quad 12.634$

24.509318 .5455

$32.825 \quad 18.5455$ 
$36.9607 \quad 70.8269$

47.8959211 .332
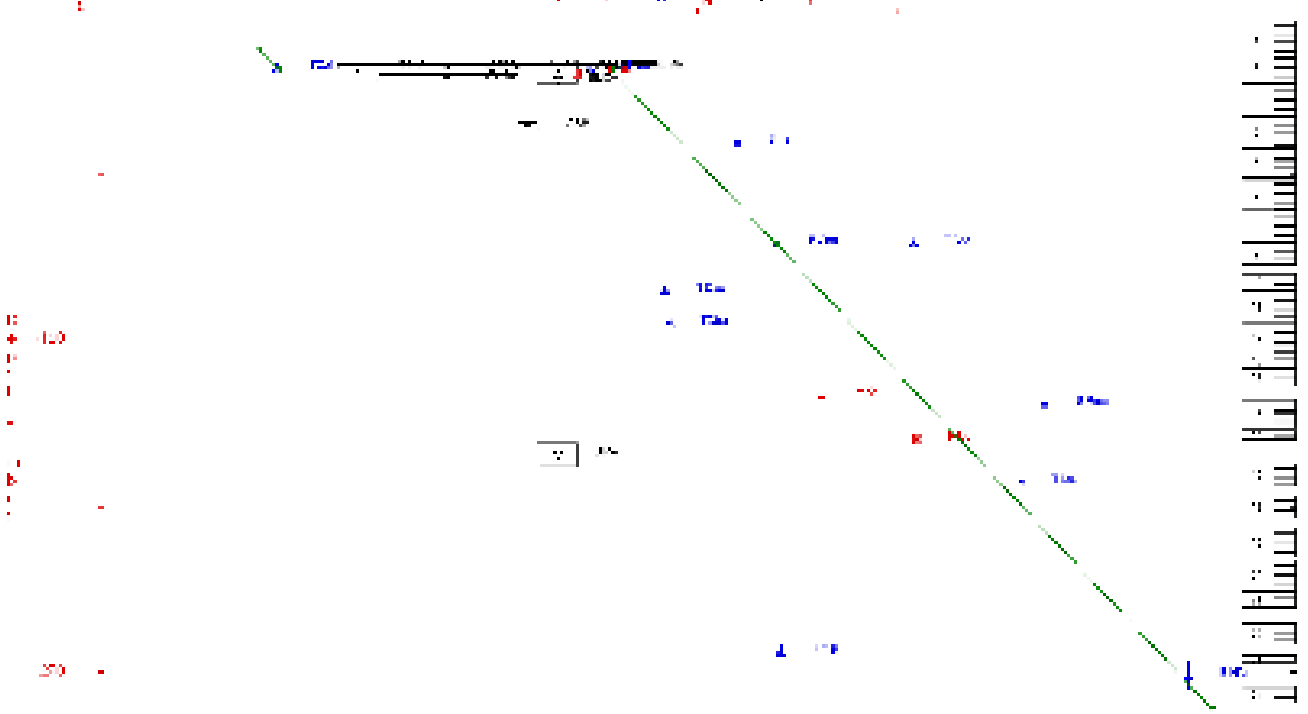

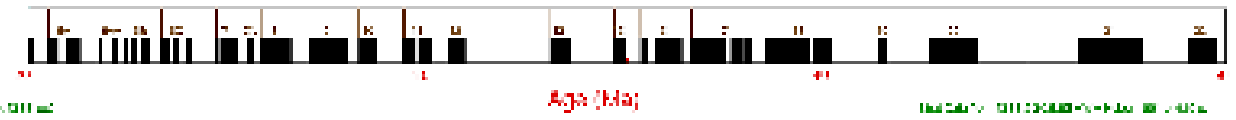 E2vall =}

\section{C 19950721}

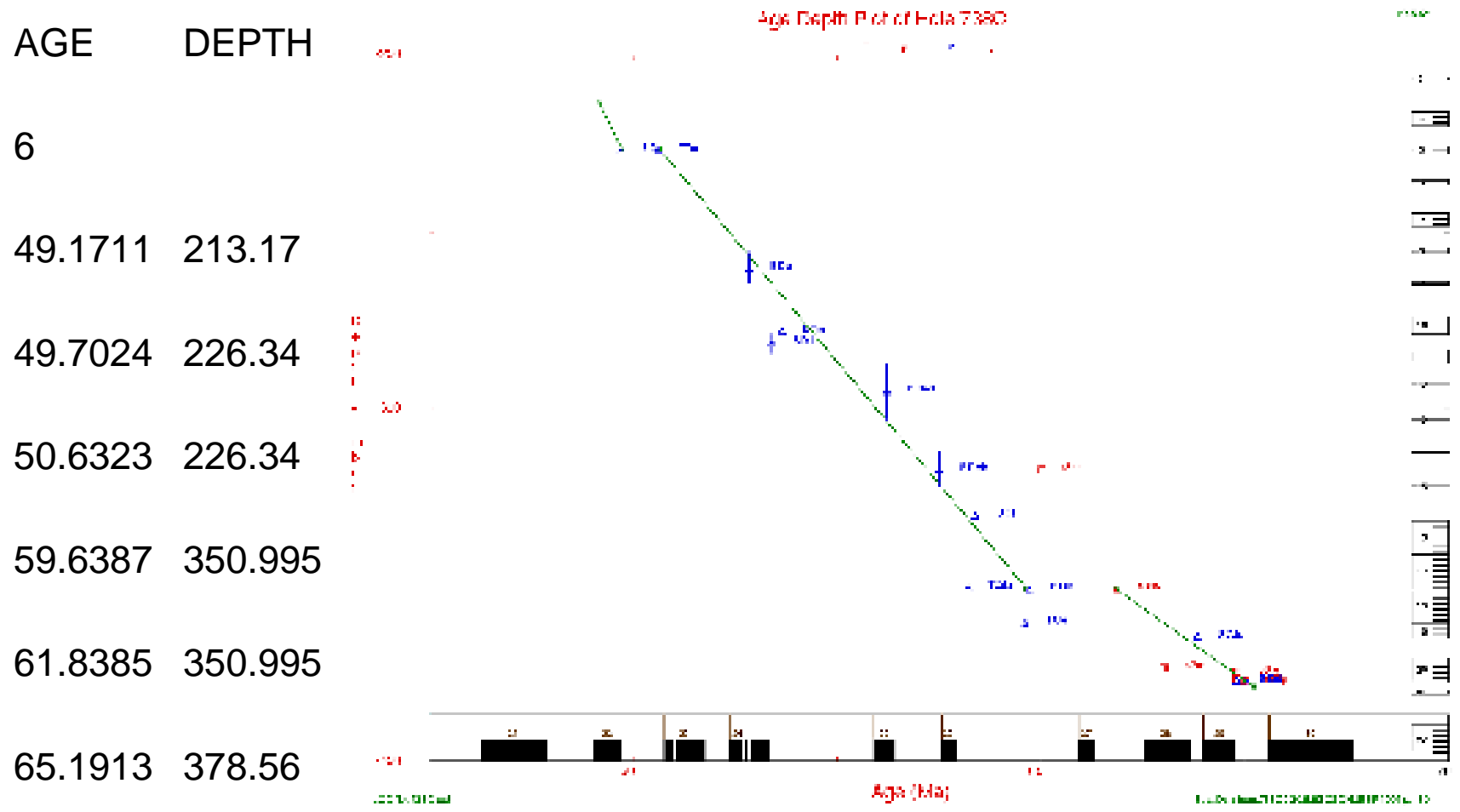

744A 19950730

AGE DEPTH

26

.9191212 .63636

2.5735315 .1818 
$3.5893 \quad 19.0455$

4.2975120 .0682

5.2912823 .0682

9.7118423 .0682

$9.92647 \quad 41.7273$

10.955941 .7273

14.816259 .9091

$16.0767 \quad 65.5454$

16.733265 .5454

17.647175 .1818

19.002183 .1212 $\therefore 24$ wew

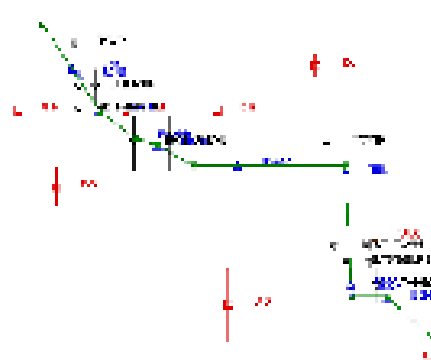

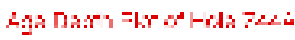

20.157692 .8182

$20.7878 \quad 96.4545$

$22.3634 \quad 96.4545$

$22.521 \quad 104.333$

24.2279104 .333

24.7269107 .606

27.0563115 .455

$27.4853 \quad 118.182$

30.3507118 .182

32.0085130 .758

33.0712138 .788

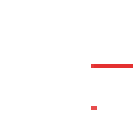

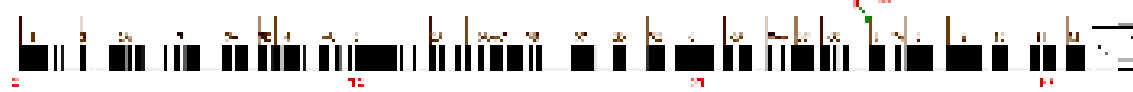

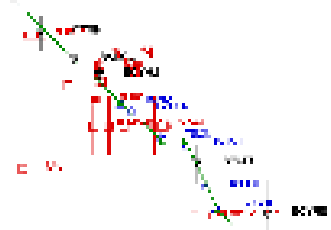

奉

$\cdot$

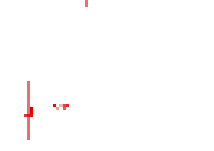

$=3 \mathrm{~m}$

当

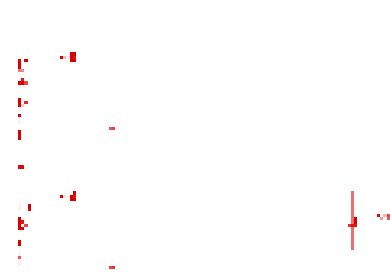

$\exists$

.13.

$+5$

$\rightarrow x+4$

-

تر

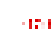

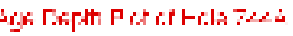

$\cdots$

35.3454162 .273

$36.153 \quad 171.212$

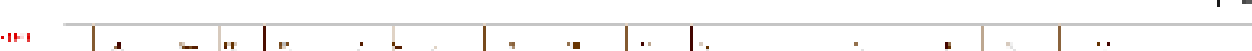

$1 \times 1$

.16.

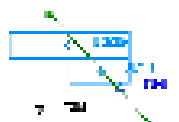

$+1$

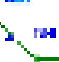

(x)
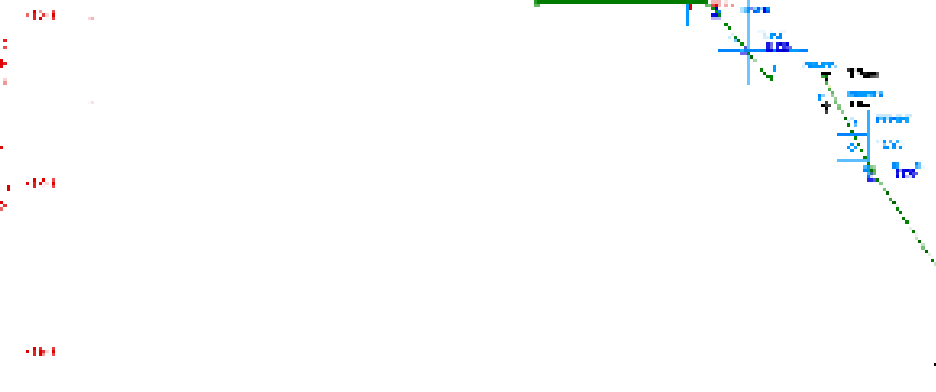

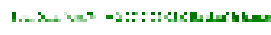

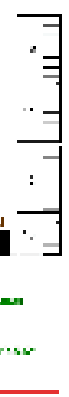

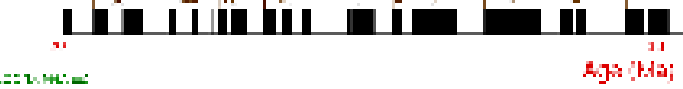

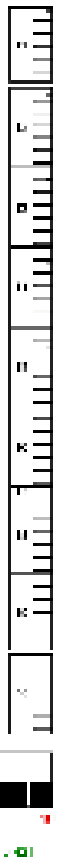

\section{B 19950730}

AGE DEPTH

12

$.182774 \quad 11.8683$ 
$.781514 \quad 42.4962$

$1.21219 \quad 57.8101$

1.7794193 .415

$1.95798 \quad 93.415$

$2.57773 \quad 112.94$

3.57563133 .997

4.46639148 .928

4.83613161 .945

$4.9958 \quad 179.939$

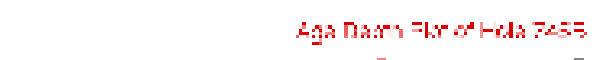

$\begin{array}{ll}5.81933 & 179.939 \\ 6.33824 & 210.184\end{array}$

$\begin{array}{ll}5.81933 & 179.939 \\ 6.33824 & 210.184\end{array}$
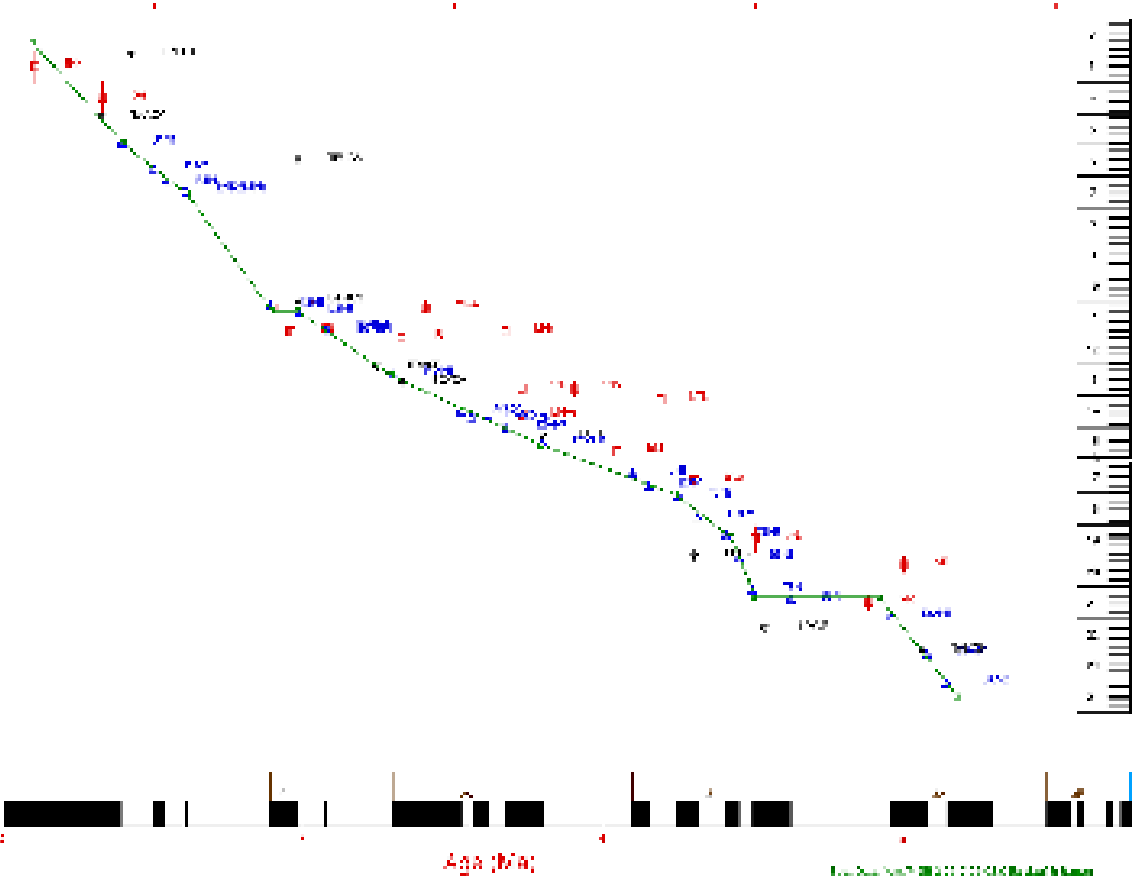

746A 19950730

AGE DEPTH

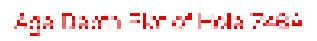

7

$6.41597 \quad 164.773$

$7.13866 \quad 181.364$

7.57563191 .591

$8.08298204 .773 \quad$ -

8.76891232 .045

$9.02101232 .045 \quad$.

$11.0042 \quad 270.455$

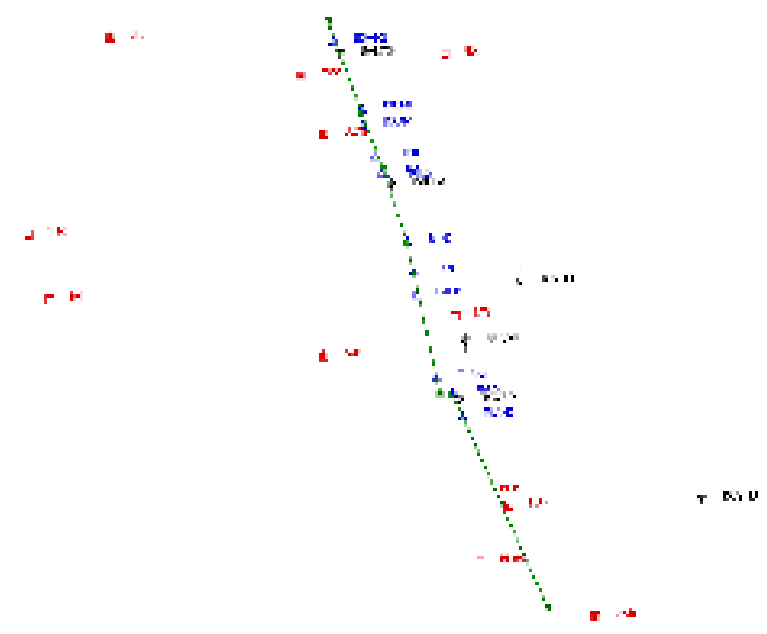

目

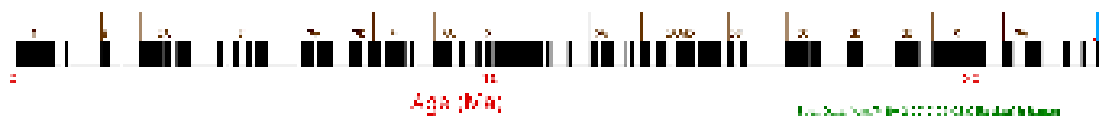

747A 19950801

AGE DEPTH

41

-3.27093e-2 9.09087e-2

$2.32165 \quad 21.2955$ 


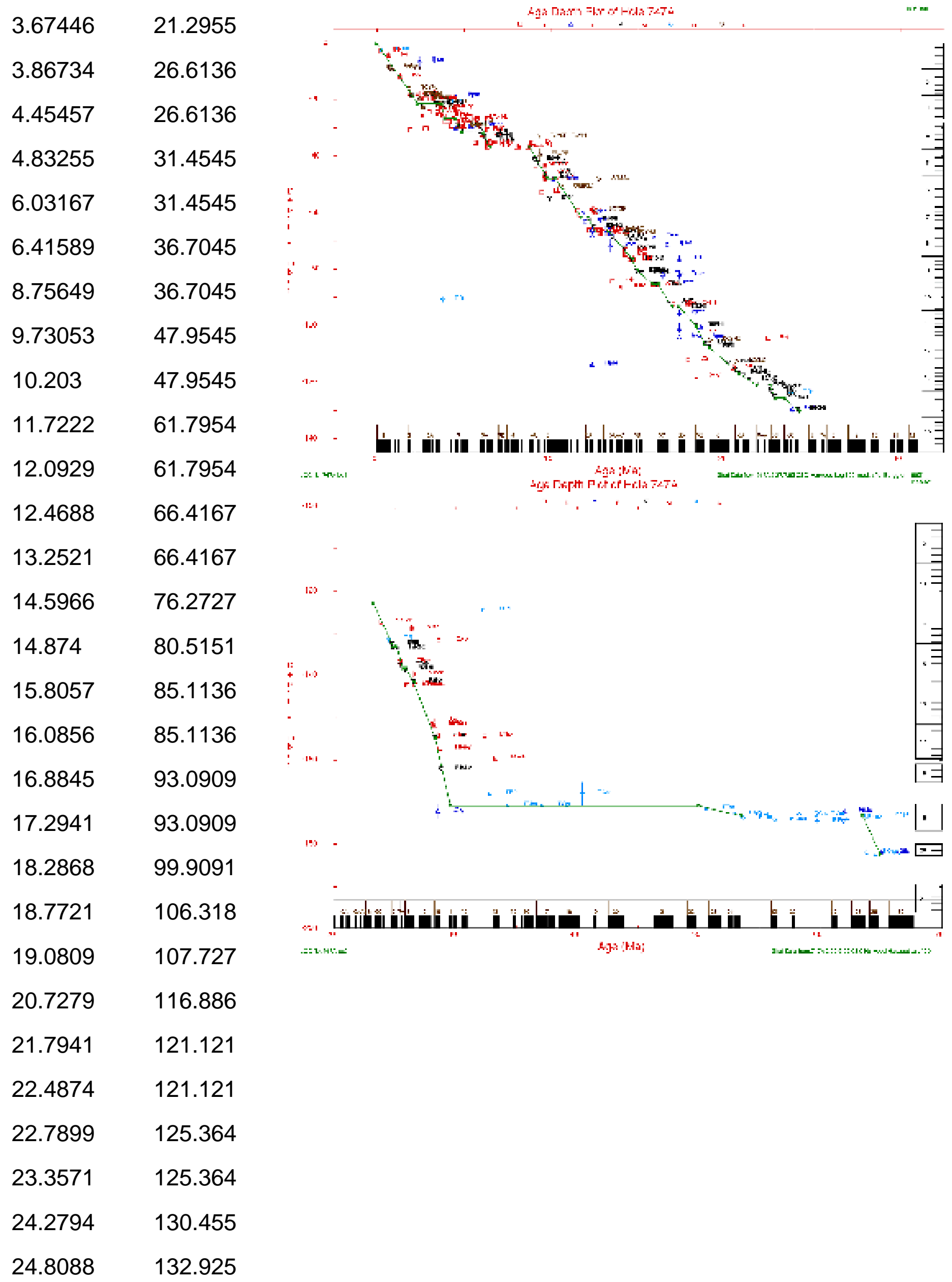




$\begin{array}{ll}25.1765 & 132.925 \\ 25.6282 & 138.285 \\ 25.8908 & 138.285 \\ 26.5525 & 141.654 \\ 28.2857 & 154.671 \\ 29.543 & 170.917 \\ 49.9628 & 170.917 \\ 53.3581 & 173.197 \\ 63.4006 & 173.197 \\ 64.8831 & 182.53\end{array}$

\section{C 19950721}
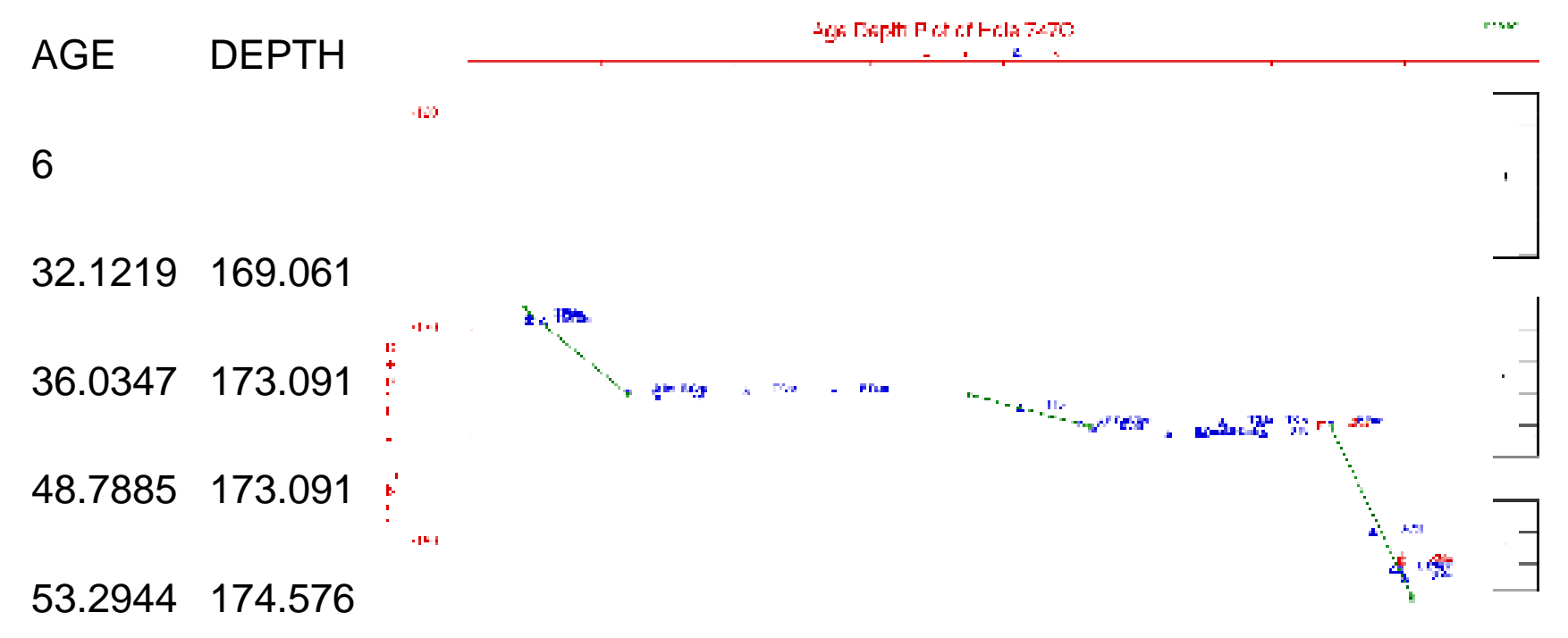

$62.2321 \quad 174.576$

65.2816182 .583

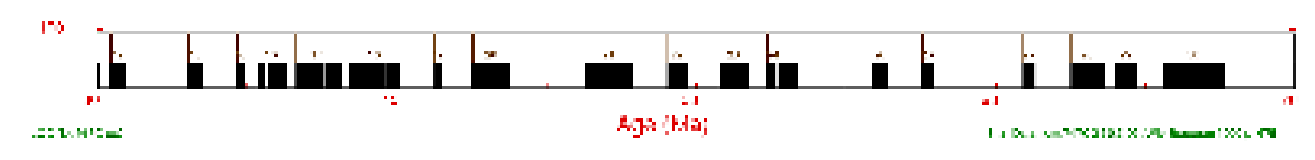

\section{B 19950801}

AGE DEPTH

27

.528038 209091

1.487542 .78939

$2.59554 \quad 2.78939$ 


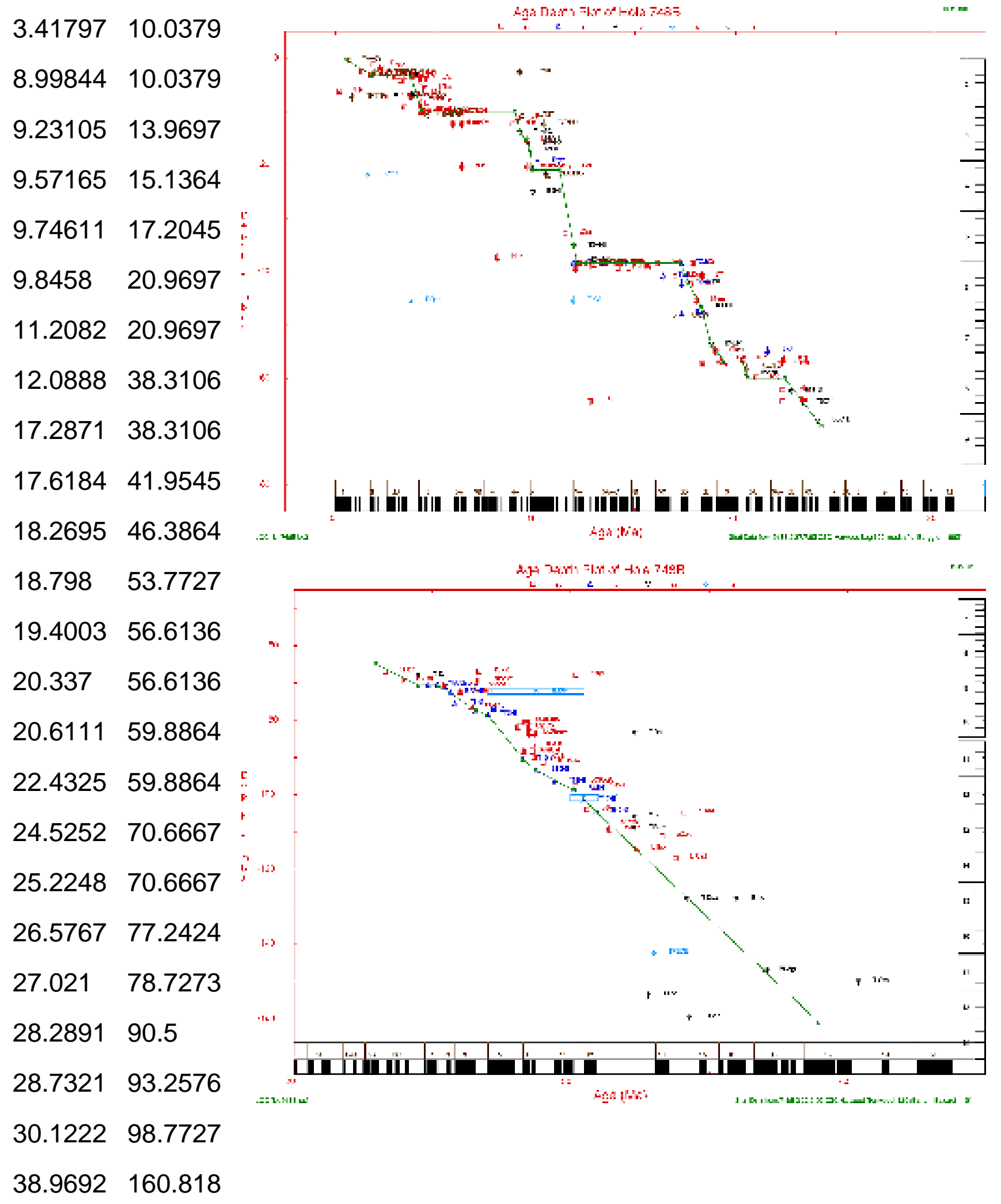

\section{C 19950723}

AGE DEPTH

8

$26.8704 \quad 176.187$ 


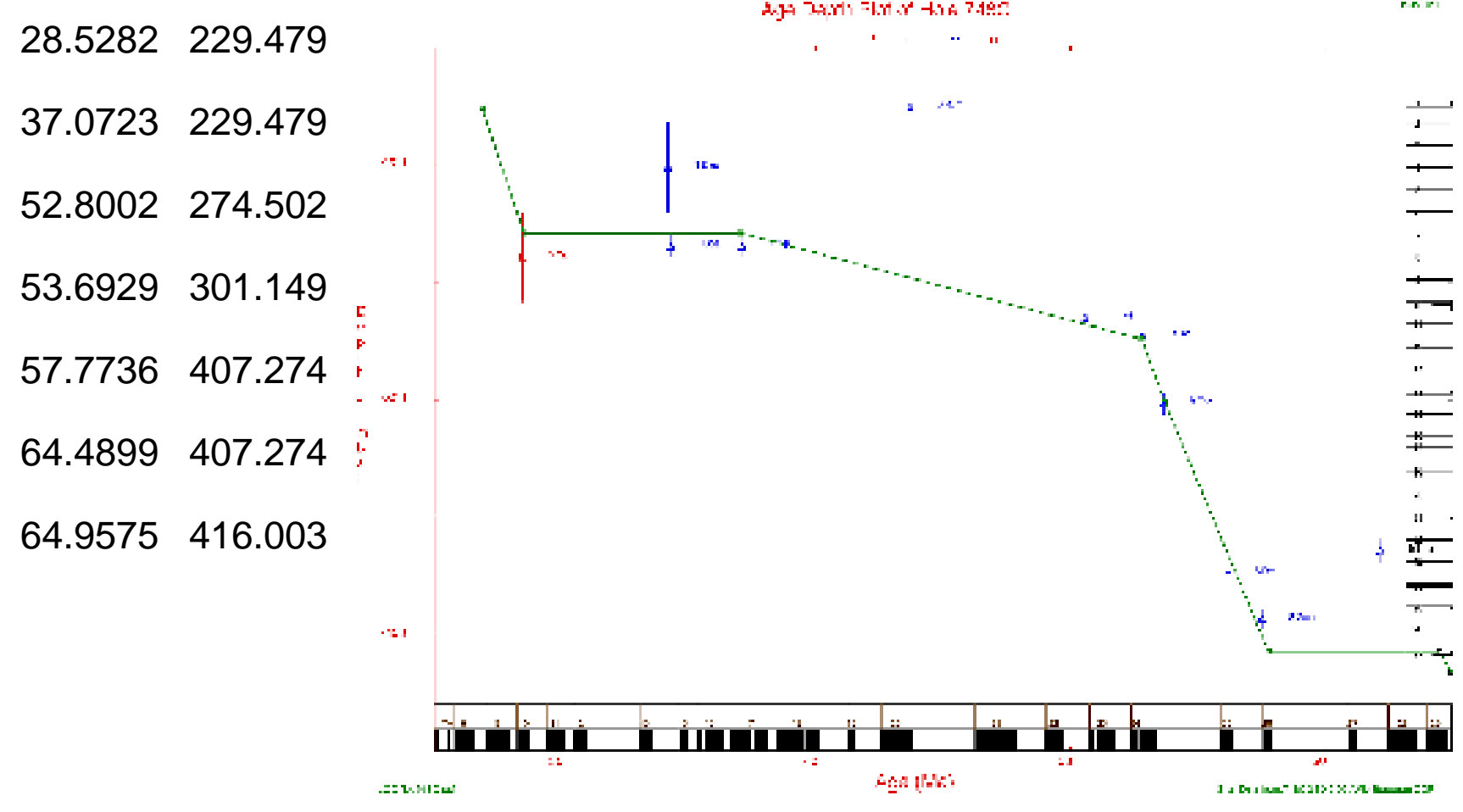

\section{B 19950723}

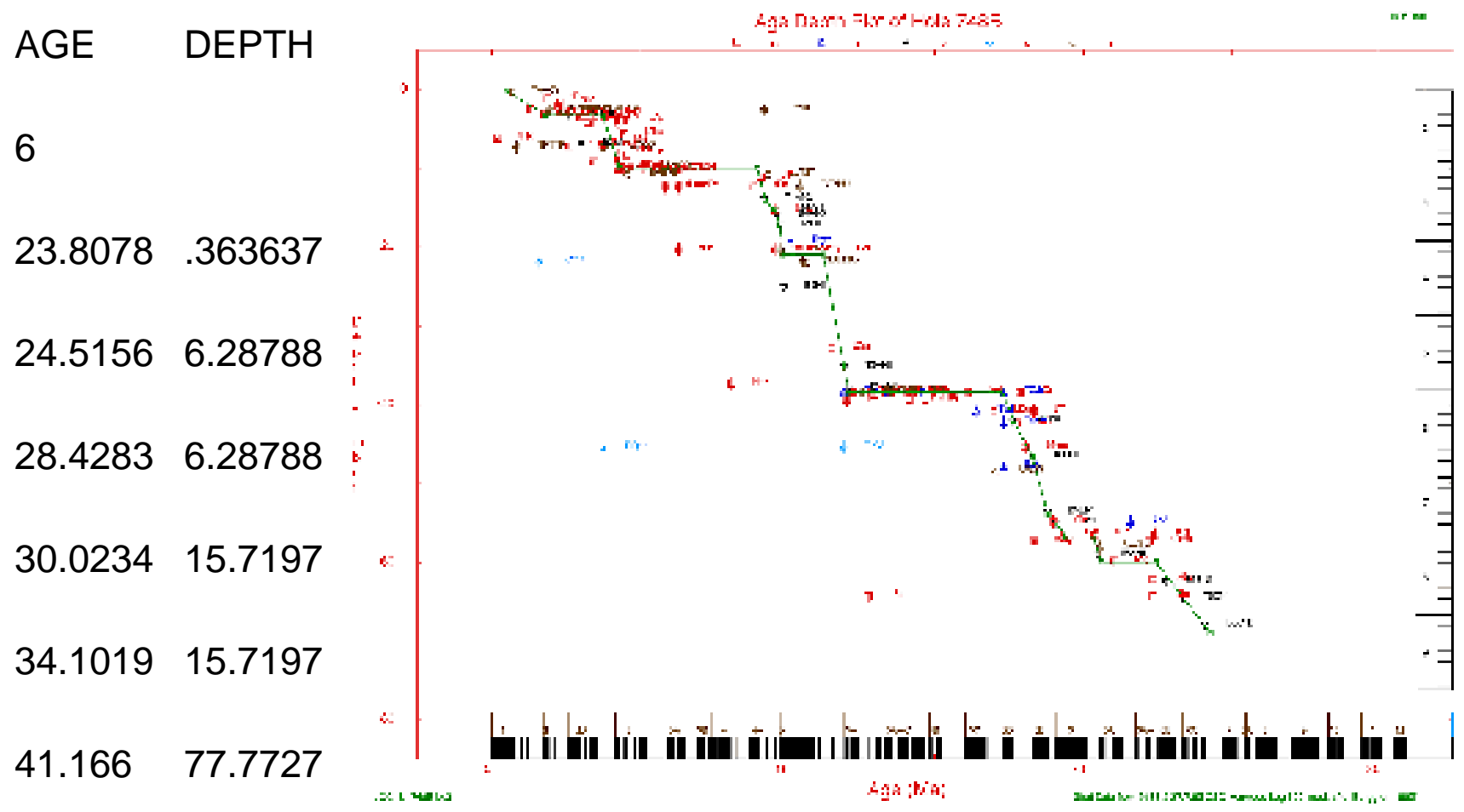

751A 19950801

AGE DEPTH

22

$2.54424 \mathrm{e}-2 \quad 8.33337 \mathrm{e}-2$

$.642265 \quad 1.75$ 


\begin{tabular}{ll}
1.69315 & 1.75 \\
2.01298 & 7.41667 \\
3.42437 & 7.41667 \\
4.81153 & 35.6667 \\
6.20509 & 35.6667 \\
6.6163 & 41.8333 \\
9.16355 & 41.8333 \\
9.32347 & 44.9167 \\
9.57477 & 44.9167 \\
10.2201 & 70.2727 \\
10.4989 & 70.2727 \\
12.2526 & 103.364 \\
12.9685 & 103.364 \\
13.74 & 109.833 \\
14.0063 & 109.833 \\
14.9963 & 131.333 \\
15.959 & 131.333 \\
17.2941 & 147.841 \\
18. & 147.841 \\
18.8655 & 159.848 \\
\hline 1
\end{tabular}
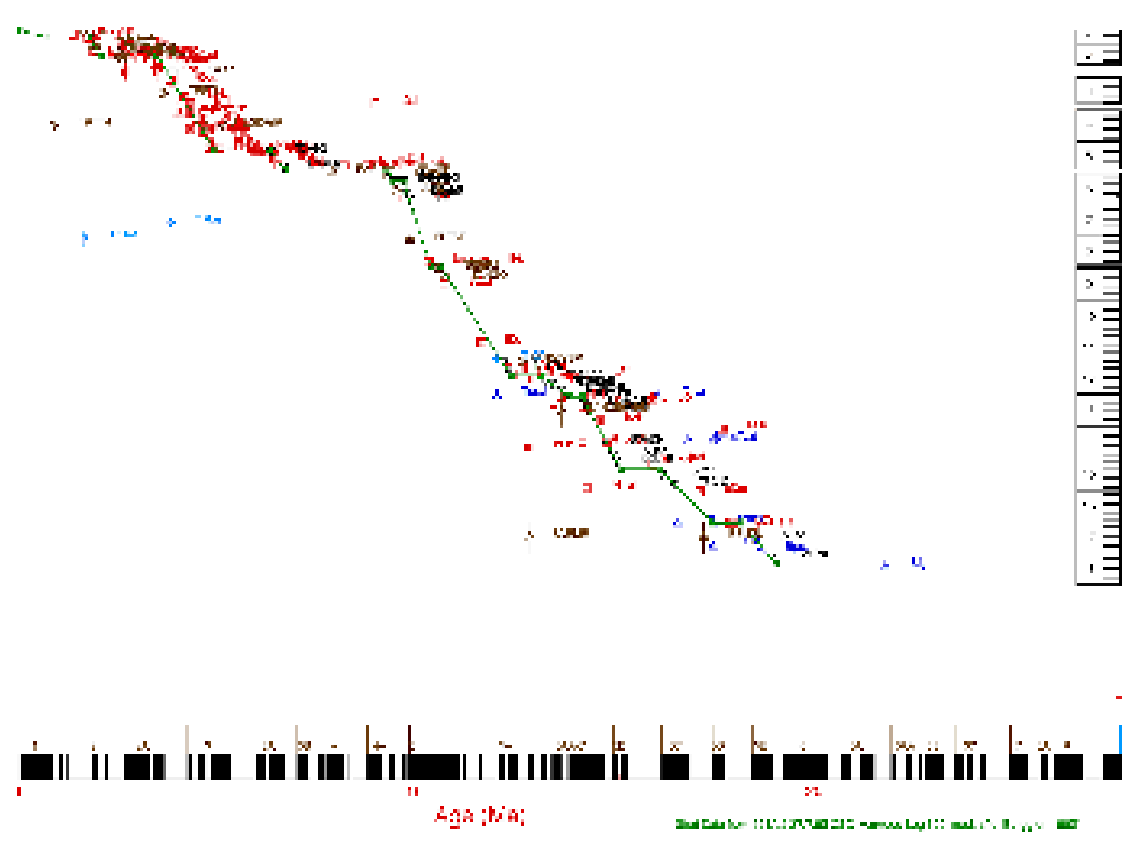

\section{B 19950731}

AGE DEPTH

14

3.67681e-2 .757579

$1.06618 \quad 13.4848$

$2.57353 \quad 37.7273$

$3.22269 \quad 51.2121$

$4.81092 \quad 84.9394$ 


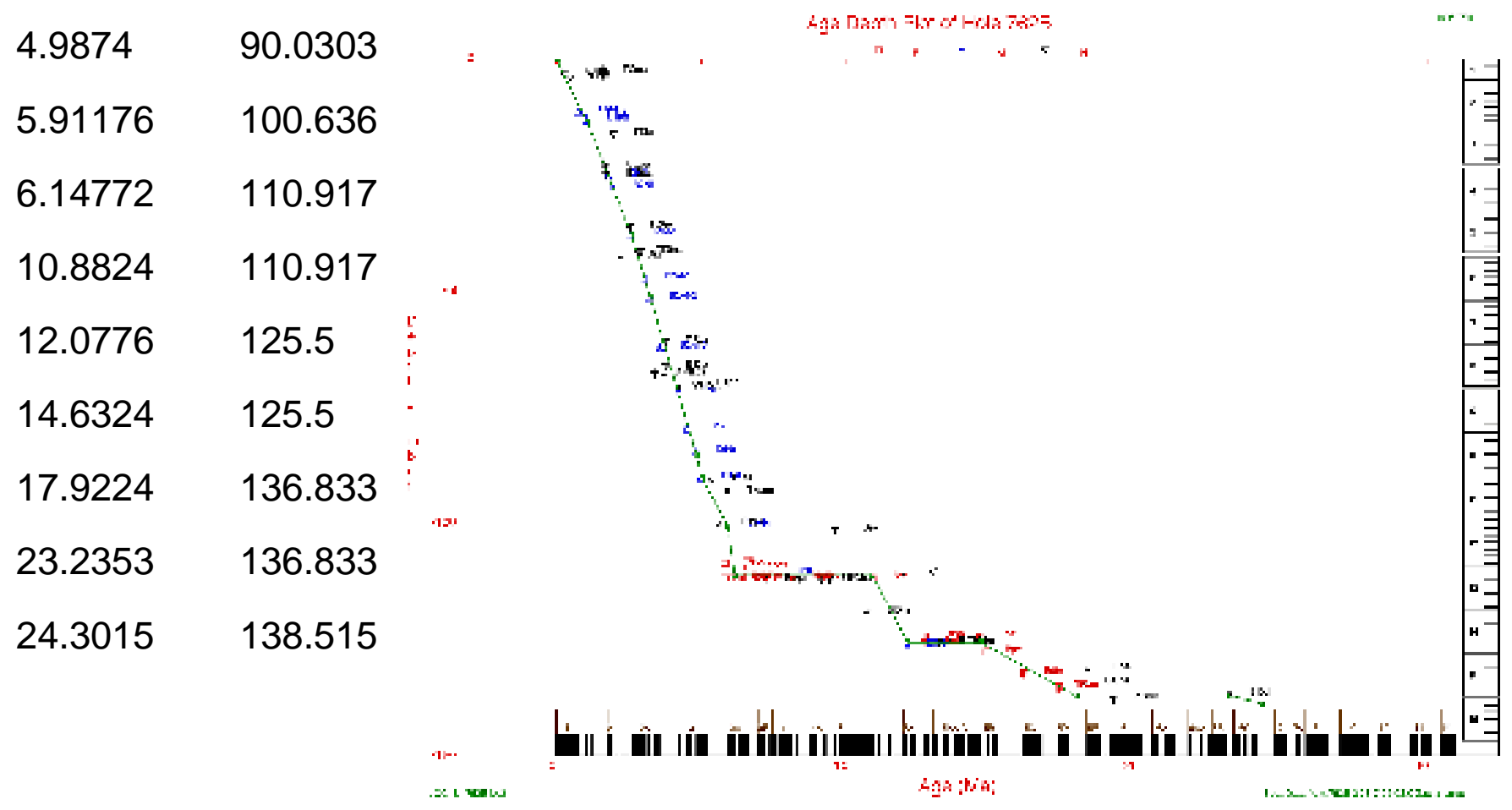

762C 19950723
AGE DEPTH

10

$33.8718 \quad 168.182$

37.0231263 .864

$40.458 \quad 277.727$

$43.7513 \quad 277.727$

$47.8108 \quad 330.475$

52.3592369 .525

$55.9013420 .455 \Leftrightarrow$

$61.3157 \quad 519.045$

$62.4076 \quad 519.045$

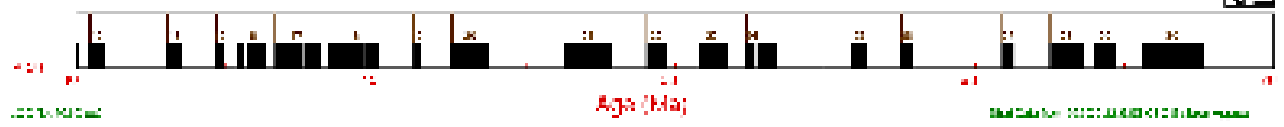

64.8514553 .273

\section{A 19950724}

\section{AGE DEPTH}


24.4328

83.

32.3109

94.8333

34.3277

94.8333

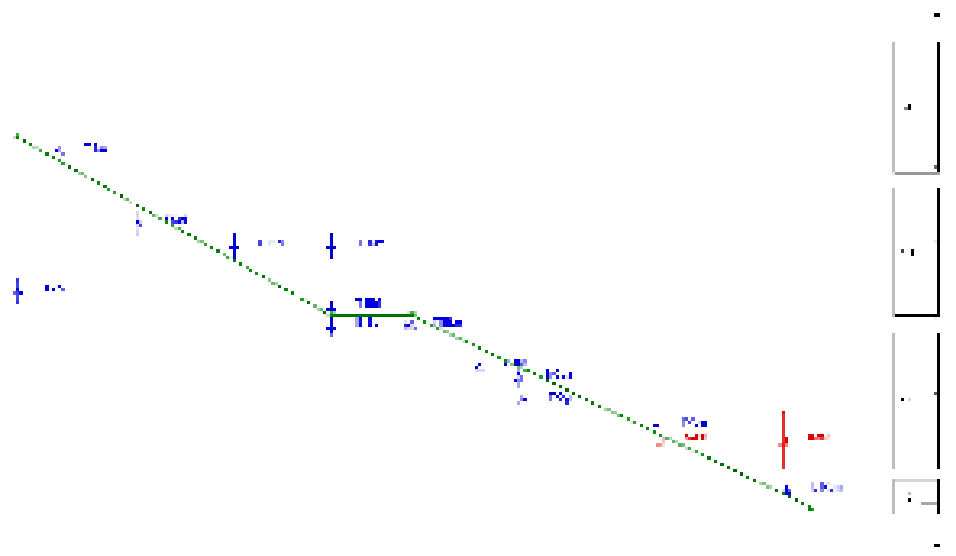

34.3277

44.3172

107.5

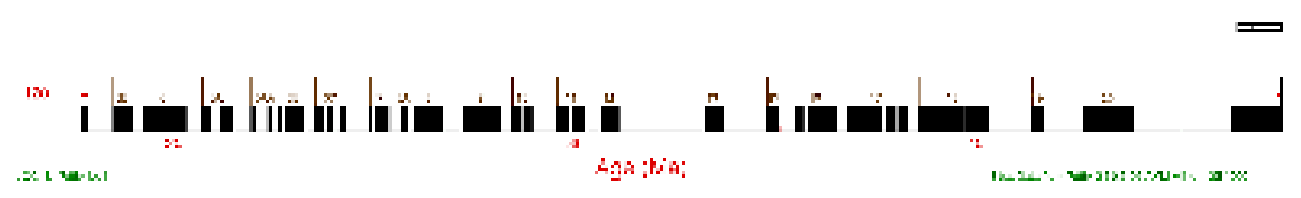

794A 19950731

AGE DEPTH

7

$.576156 \quad 17.7642$

$1.77101 \quad 54.5176$

$2.5835175 .6508 \cdot 1.0$

3.3345698 .928

$3.58036 \quad 107.81$

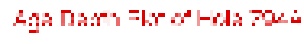

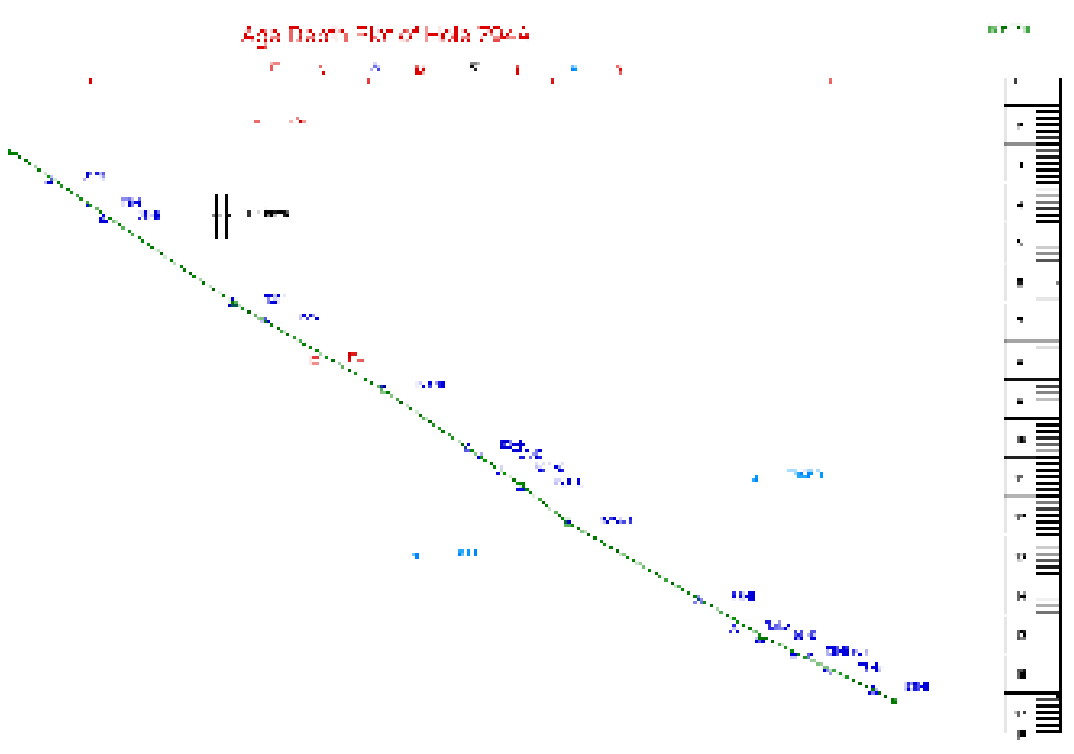

$4.63183 \quad 135.375$

$5.34191 \quad 150.995$

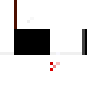

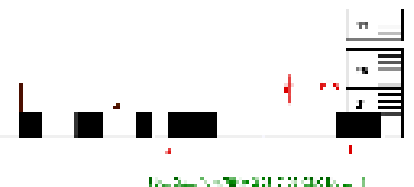

795A 19950731

AGE DEPTH

5 
$.229517 \quad 19.9081$

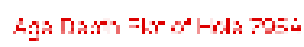

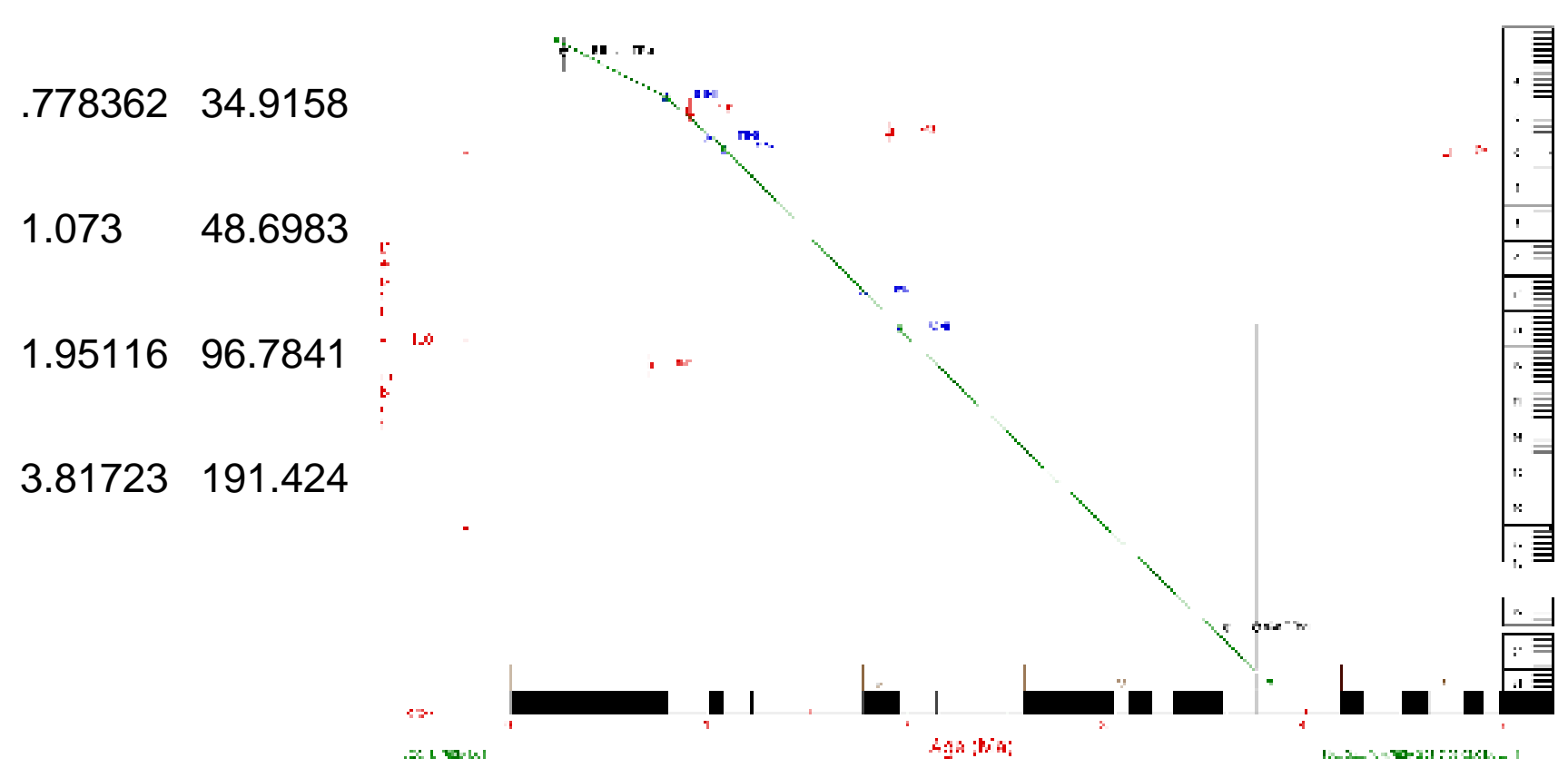

797B 19950731

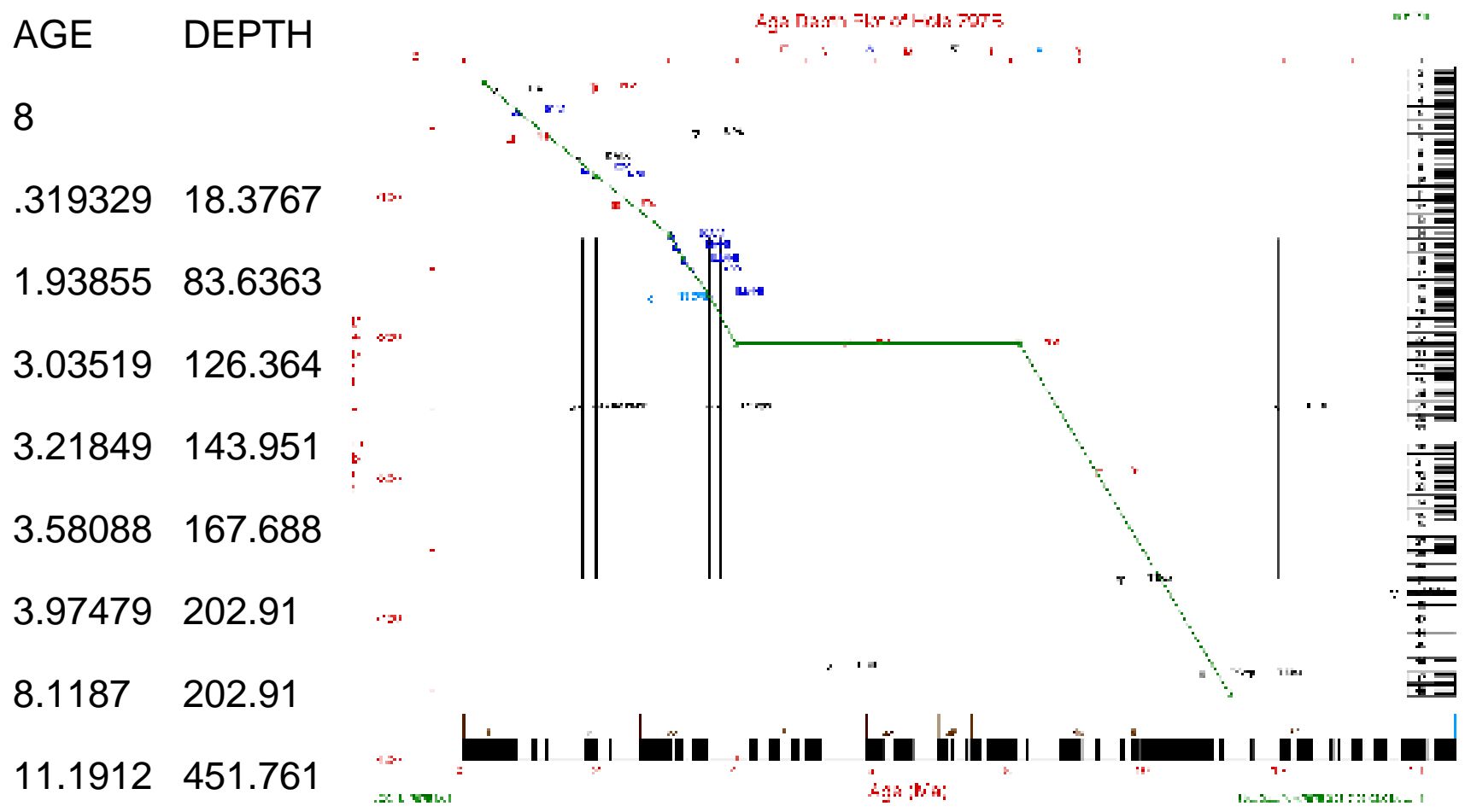

Next Section... 
To download full-size diagrams, open the following directory and choose the file (named by hole number). File naming convention is 62A_PICT.GIF (62A $=$ hole number).

DIRECTORY: adps app

\section{Holes 803B-841B}

803D 19950731

AGE DEPTH

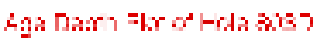

9

$-.0735261 .81819$

$1.95717 \quad 16.9545$

$4.56257 \quad 58.1364$

$5.59528 \quad 66.7273$

$9.15441 \quad 137.955$

$11.9485 \quad 219.773$

$13.6397 \quad 219.773$

$19.1764 \quad 253.139$

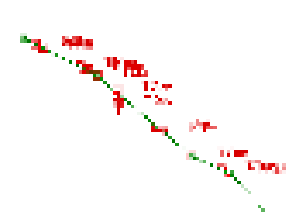

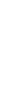

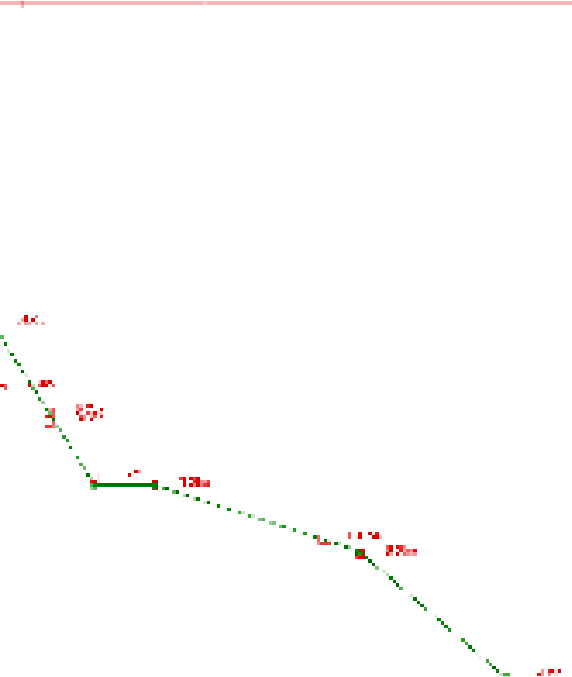

$23.1934317 .458 \quad \approx$ жsw

\section{B 19950731}

AGE DEPTH

8

$1.25 \quad 24.6554$

$3.75 \quad 94.3338$

$5.51471 \quad 161.868$

$8.63975 \quad 284.073$

$10.6748 \quad 365.682$

$13.1987 \quad 578.867$ 


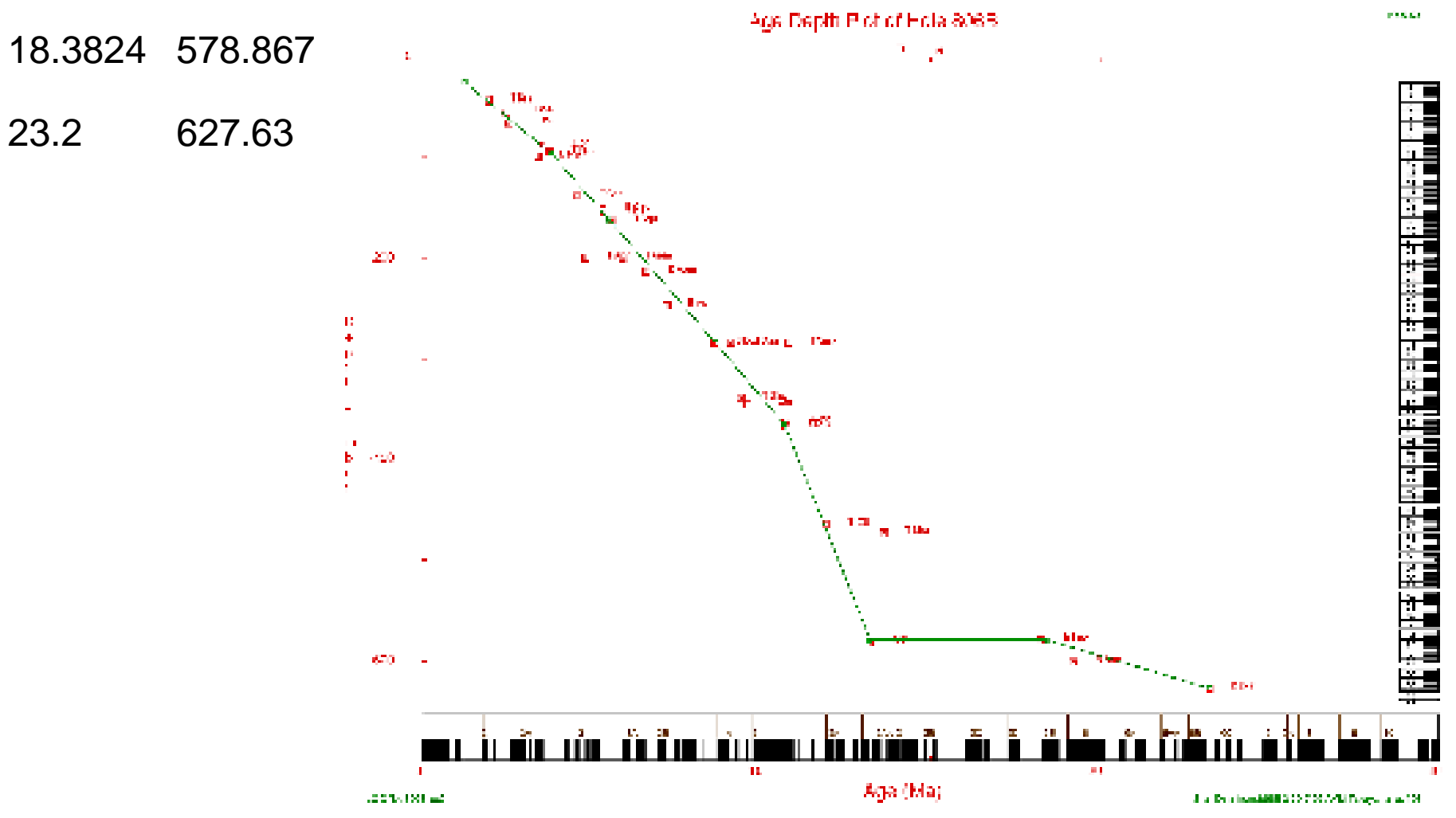

\section{C 19950807}

AGE DEPTH

24

$.212617 \quad 1.3712$

.77803818 .0758

.98364520 .6742

1.5911228 .4167

1.9556128 .4167

2.5817838 .

$3.04097 \quad 46.2727$

3.1108549 .1818

3.2198950 .8182

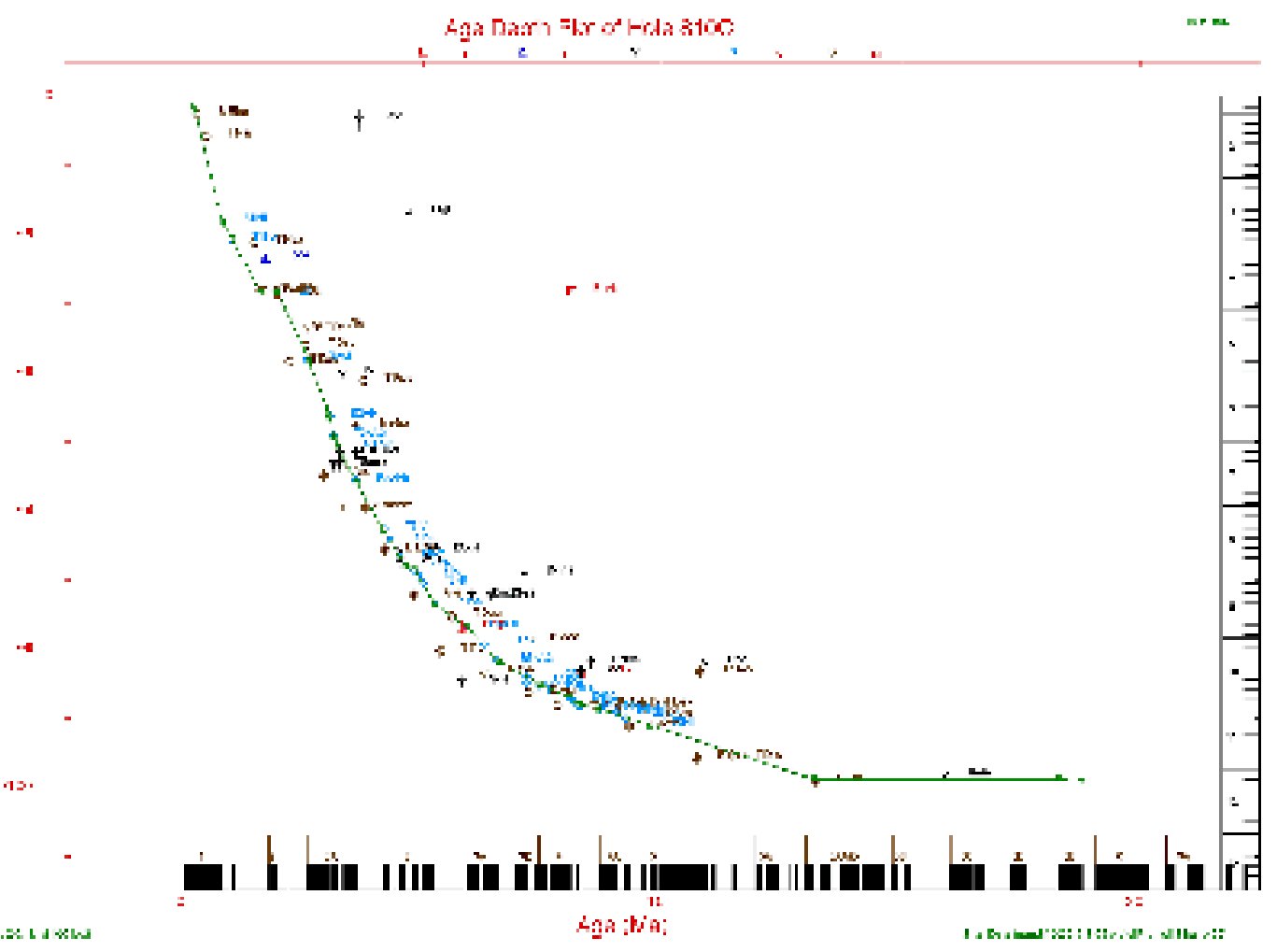

3.5924455 .9091

$4.17523 \quad 62.75$

$4.61656 \quad 67.8636$

4.7982968 .4773 
5.2468573 .5454

5.8995376 .8182

6.5537481 .7045

7.4322485 .0758

8.0677687 .197

8.2593588 .1818

8.6939388 .5606

9.7405590 .9697

13.151398 .8182

18.298398 .8182

18.744799 .1818

\section{A 19950731}

AGE DEPTH

8

.4042061 .13636

$1.58178 \quad 20.5$

1.6752325 .8182

1.9602825 .8182

3.0911246 .6818

3.7941284 .9158

$4.22584 \quad 315.833$

9.1

430.34
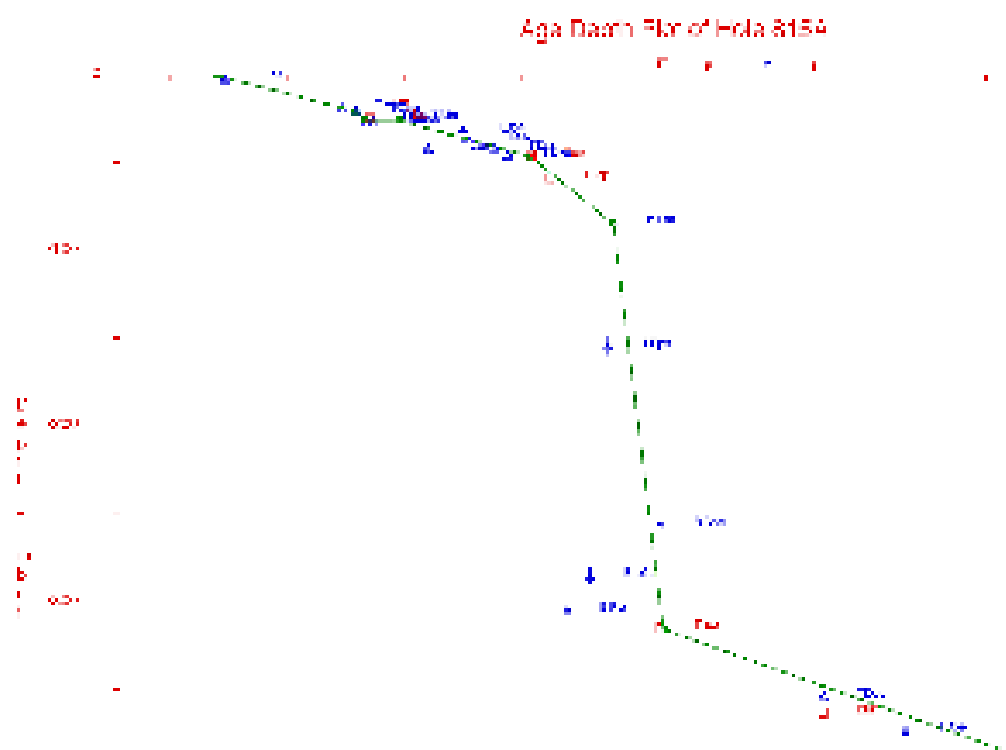

832B 19950801

AGE DEPTH

10 
$.257355 \quad 311.818$

1.96219707 .045

3.04622740 .227

3.59244748 .864

4.80252759 .773

5.24685767 .273

$5.89496 \quad 808.864$

12.2059969 .091

15.2784969 .091

16.5389985 .454

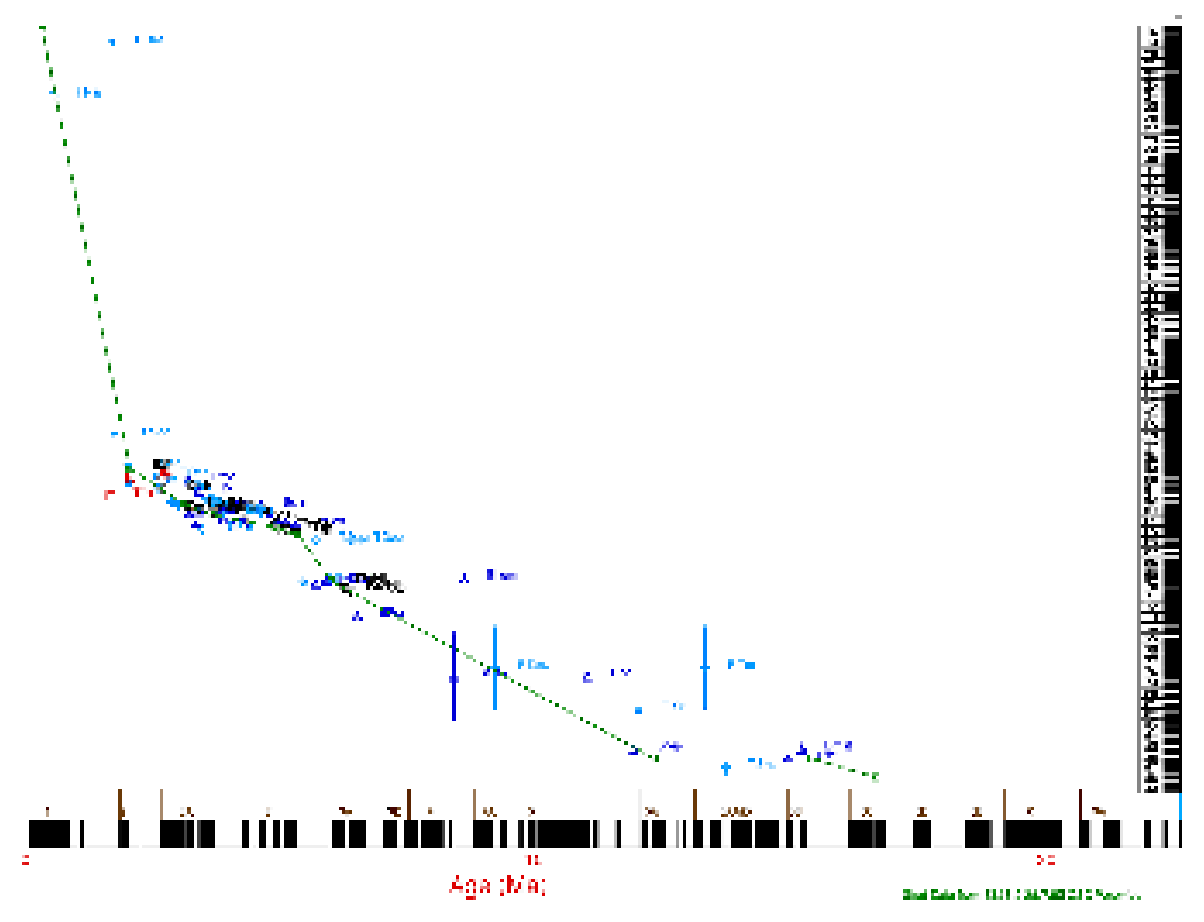

\section{B 19950802}

AGE DEPTH

14

.6785726 .83333

$2.58508 \quad 14.1667$

$4.16807 \quad 18.5$

$4.80357 \quad 22.1667$

4.9768924 .5

$5.21954 \quad 24.5$

$\begin{array}{lll}7.17227 & 45.1667\end{array}$

$9.92122 \quad 309.801$

$13.2721 \quad 464.165$

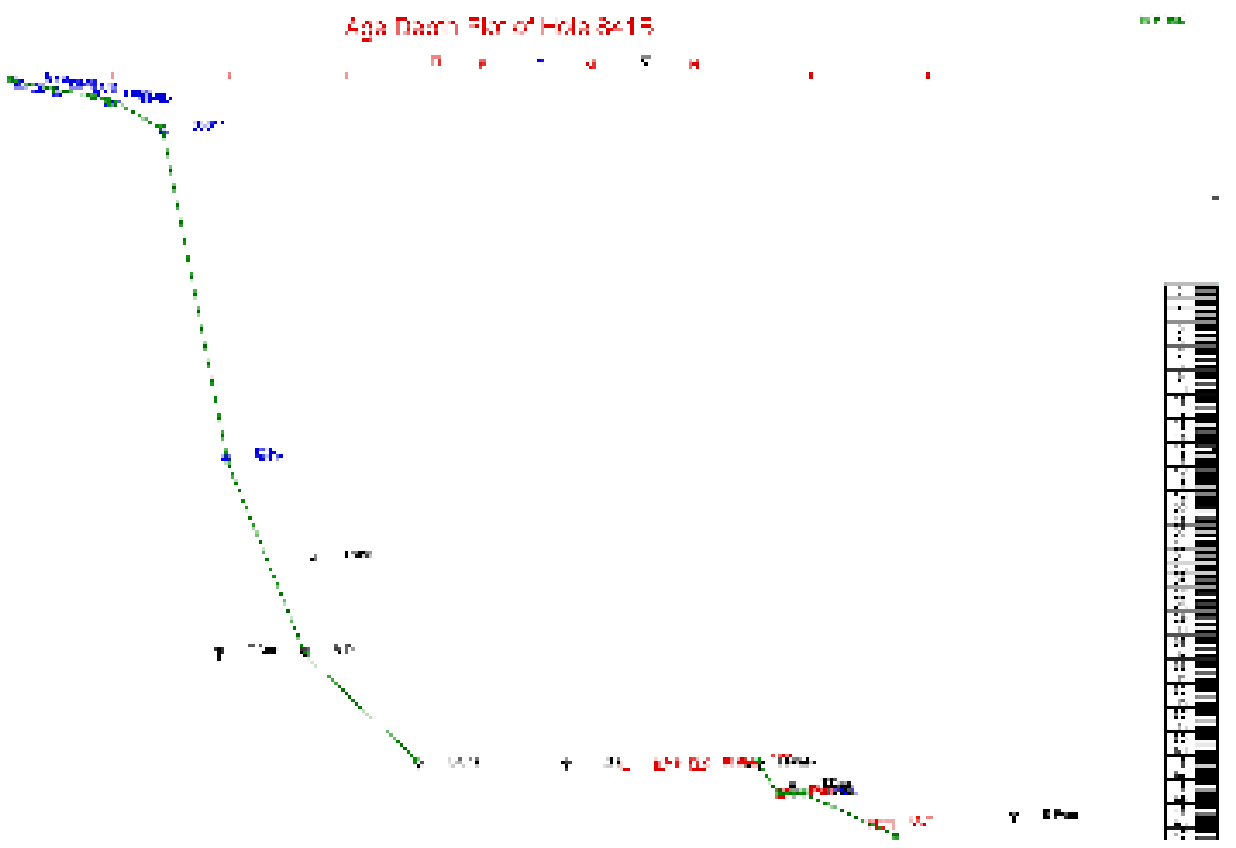

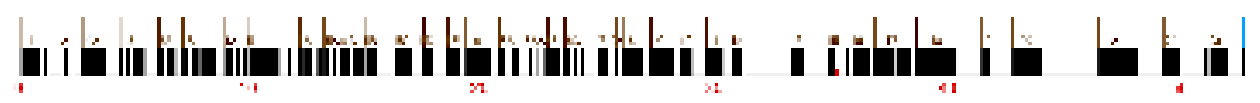

$18.1243 \quad 549.364$

$32.6621 \quad 549.364$

$33.5547 \quad 574.273$

34.7059574 .273 
Appendix A: Holes 803B-841B

$38.5767 \quad 607.81$ 